$$
\begin{gathered}
\text { UNIVERSIDADE DE SÃO PAULO } \\
\text { FACULDADE DE ECONOMIA, ADMINISTRAÇÃO E CONTABILIDADE } \\
\text { DEPARTAMENTO DE ADMINISTRAÇÃO } \\
\text { PROGRAMA DE PÓS-GRADUAÇÃO EM ADMINSTRAÇÃO }
\end{gathered}
$$

\title{
AVALIAÇÃO DE DESEMPENHO ORGANIZACIONAL DE COOPERATIVAS DE CRÉDITO: UMA ANÁLISE À LUZ DA TEORIA DA AGÊNCIA DOS PONTOS DE VISTA DE COOPERADOS, CONSELHEIROS E GERENTES
}

Elizabeth Wood Moçato de Oliveira Orientador: Prof. Dr. Hamilton Luiz Corrêa 
Prof. Dr. Vahan Agopyan

Reitor da Universidade de São Paulo

Prof. Dr. Fábio Frezatti

Diretor da Faculdade de Economia, Administração e Contabilidade

Prof. Dr. Moacir de Miranda Oliveira Júnior

Chefe do Departamento de Administração

Prof. Dr. Eduardo Kazuo Kayo

Coordenador do Programa de Pós-Graduação em Administração 
ELIZABETH WOOD MOÇATO DE OLIVEIRA

AVALIAÇÃO DE DESEMPENHO ORGANIZACIONAL DE

COOPERATIVAS DE CRÉDITO: UMA ANÁLISE À LUZ DA TEORIA DA AGÊNCIA DOS PONTOS DE VISTA DE COOPERADOS, CONSELHEIROS E GERENTES

Tese apresentada ao Programa de PósGraduação em Administração, da Faculdade de Economia, Administração e Contabilidade da Universidade de São Paulo como requisito parcial para a obtenção do título de Doutora em Ciências.

Orientador: Prof. Dr. Hamilton Luiz Corrêa

SÃO PAULO

2018 
FICHA CATALOGRÁFICA

Elaborada por Rafael Mielli Rodrigues - CRB-8/7286

Seção de Processamento Técnico do SBD/FEA/USP

Oliveira, Elizabeth Wood Moçatode

Avaliação de desempenho organizacional de cooperativas de crédito:

uma análise à luz da teoria da agência dos pontos de vista de cooperados,

conselheiros e gerentes / Elizabeth Wood Moçato de Oliveria. - São Paulo, 2018.

$323 \mathrm{p}$.

Tese (Doutorado) - Universidade de São Paulo, 2018.

Orientador: Hamilton Luiz Correa.

1. Avaliação de desempenho 2. Cooperativismo de crédito 3. Desempenho organizacional I. Universidade de São Paulo. Faculdade de Economia, Administração e Contabilidade. II. Título.

CDD -658.409 
Dedico este trabalho a minha mãe, que sempre me incentivou, orientou e investiu para que eu chegasse até aqui. 



\section{AGRADECIMENTOS}

Agradeço a Deus por ser meu amparo em todos os momentos, me sustentar e motivar. Agradeço a minha família por me dar condições de concluir mais essa etapa em minha vida.

Agradeço ao meu orientador, professor Dr. Hamilton Luiz Corrêa, por confiar em meu trabalho.

Aos membros da banca de qualificação, Dr. Flávio Hourneaux Junior e Dr. Júlio Araujo Carneiro da Cunha, pelas contribuições e direcionamentos, tão importantes para essa pesquisa.

Aos colegas de caminhada Dr. Lorimar Francisco Munaretto, Me. Rafael de Freitas Souza e Me. Willerson Lucas Campos Silva por todas as sugestões e contribuições. Agradeço a todos os participantes dessa pesquisa (cooperativas de crédito, conselheiros e cooperados), que disponibilizaram seu tempo para que ela pudesse ser realizada. 



\section{RESUMO}

OLIVEIRA, E. W. M. Avaliação de Desempenho Organizacional de Cooperativas de Crédito: uma análise à luz da teoria da agência dos pontos de vista de cooperados, conselheiros e gerentes. Tese de doutorado. Universidade de São Paulo, São Paulo, 2018.

O presente trabalho propôs-se a identificar indicadores de avaliação desempenho pertinentes a cooperativas de crédito; bem como compreender quais aspectos influenciam a avaliação de desempenho de cooperativas de crédito na visão de cada grupo envolvido, apontando as divergências e convergências de opiniões de agentes e principal, além de conhecer as variáveis determinadas como importantes para avaliar desempenho de cooperativas de crédito sob o ponto de vista dos envolvidos considerando seu perfil; verificar se os princípios do cooperativismo são tidos como importantes nesse processo; e sugerir um Modelo de Avaliação de Desempenho de Cooperativas de Crédito que diminua os conflitos de agência, relacionando a influência da Teoria da Agência com a gestão do desempenho de cooperativas de crédito. Para tanto, a pesquisa foi executada a partir de cinco etapas: a primeira consistiu na seleção de indicadores de Desempenho para Cooperativas de Crédito por intermédio da literatura, resultando em uma lista de 46 indicadores. A segunda foi a etapa de validação dos indicadores (validade de face e conteúdo e Delphi), cujo resultado foi a exclusão e inclusão de indicadores, resultando em um total de 53 indicadores. A terceira etapa identificou junto a cooperados, membros dos Conselhos Fiscal e Administrativo e gerentes quais dos indicadores validados eles julgavam pertinentes às cooperativas de crédito; quais aspectos influenciam na avaliação de desempenho de cooperativas de crédito na visão de cada grupo envolvido; quais as variáveis são tidas como importantes para avaliar desempenho de cooperativas de crédito sob o ponto de vista dos envolvidos considerando seu perfil; qual a influência da teoria da agência na gestão do desempenho de cooperativas de crédito; e se os princípios do cooperativismo são tidos como importantes quando se trata da avaliação de desempenho de cooperativas de crédito. $O$ resultado dessa etapa sugere que para a amostra participante existem divergências de opiniões em relação ao grau de importância de indicadores de desempenho, o que futuramente poderá gerar conflitos de agência. Por sua vez, a quarta etapa consistiu na entrevista com a equipe de planejamento de uma cooperativa singular a fim de conhecer o modelo de avaliação de desempenho utilizado pela mesma. O modelo, adaptado do Balanced Scorecard serviu, juntamente com as considerações das demais etapas dessa pesquisa como guia para a conclusão da quinta etapa do trabalho cujo objetivo foi propor um modelo de avaliação de desempenho para cooperativas de crédito que minimize os conflitos de agência. Esse modelo, formado por cinco módulos é pautado na idéia de que considerando os princípios do cooperativismo é possível reduzir os conflitos de agência de cooperativas de crédito.

Palavras-chave: Avaliação de Desempenho; Cooperativismo de Crédito; Desempenho Organizacional. 


\begin{abstract}
OLIVEIRA, E. W. M. Credit Unions' Organizational Performance Evaluation: an analysis in the light of agency theory from the points of view of cooperative members, advisors and managers. Doctoral dissertation. Universidade de São Paulo, São Paulo, 2018.
\end{abstract}

The present study intended to identify indicators of performance evaluation relevant to credit unions. Parallel to this objective, our work proposed to: understand which aspects influence credit unions' performance evaluation in the perspective of each group involved, pointing out divergences and convergences of agents opinions, as well as acknowledging the important variables to evaluate credit unions performance under the point of view of those involved according to their profile; verify if the principles of cooperativism are considered important in this process; suggest a Credit Union Performance Evaluation Model that can reduce agency conflicts by relating the influence of Theory of Agency to credit union performance management. In order to do so, the research was carried out in five stages: the first one consisted in the selection of Performance Indicators for Credit Unions through the literature, resulting in a list of 46 indicators. The second stage was the validation of the indicators (face, content and Delphi validity), whose result was the exclusion and inclusion of indicators, resulting in a total of 53 indicators. The third stage identified which of the validated indicators cooperative members, of the Fiscal Council, Administrative Council and managers judged as relevant to credit unions; which aspects influenced the performance evaluation of credit unions in the view of each group involved; what variables were considered important for evaluating the performance of credit unions from the point of view of those involved considering their profile; what was the influence of Theory of Agency on performance management of credit unions; and whether the principles of cooperativism were held to be important when it came to performance evaluation of credit unions. The result of this last stage suggests that for the participating sample there are divergences of opinions regarding the degree of importance of performance indicators, which in the future may lead to agency conflicts. On the other hand, the fourth stage consisted in interviews with the planning team of aspecific cooperative in order to know the model of performance evaluation used by them. The model, adapted from the Balanced Scorecard served, along with the considerations of the other stages of this research, as a guide to the conclusion of the fifth stage, whose objective was to propose a performance evaluation model for credit unions that minimizes agency conflicts. Composed of five modules, the proposed model is based on the idea that, considering the principles of cooperativism, it's possible to reduce the conflicts in credit union agencies.

Keywords: Performance Evaluation; Credit Cooperativism; Organizational Performance. 


\section{LISTA DE FIGURAS}

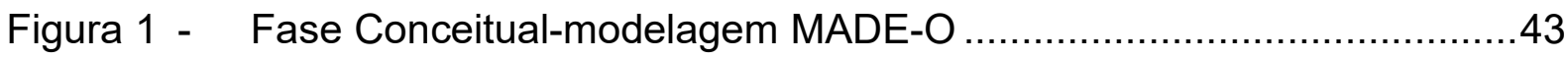

Figura 2 - Modelo de excelência da gestão PNQ ……...................................45

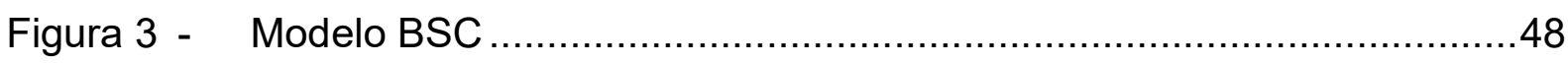

Figura 4 - Modelo Quantum de Avaliação de Desempenho ……………….......50

Figura 5 - Visual gráfico do modelo Skandia Navigator .......................................52

Figura 6 - Os princípios norteadores do modelo SIGMA ………......................54

Figura 7 - Modelo Integrated Performance Measurement System (IPMS) ...........56

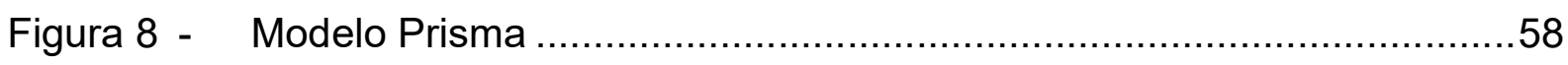

Figura 9 - Estrutura dos conteúdos do capítulo .............................................107

Figura 10 - Framework da pesquisa ............................................................109

Figura 11- Cerne do Modelo de Avaliação de Desempenho de Cooperativas de

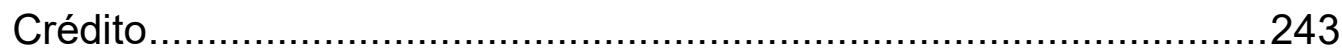

Figura 12 - O modelo de avaliação de Desempenho de Cooperativas de Crédito ...247 


\section{LISTA DE QUADROS}

Quadro 1 - Vantagens da avaliação de desempenho.....................................27

Quadro 2 - Vantagens e desvantagens dos sistemas de mensuração e dos

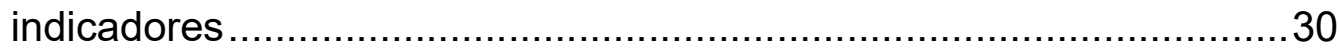

Quadro 3 - Etapas que devem estar compreendidas na elaboração de um sistema de mensuração ........................................................................... 36

Quadro 4 - Variáveis para mensuração e avaliação da organização .....................39

Quadro 5 - Matriz Quantum de medição de desempenho...................................49

Quadro 6 - Evolução dos Princípios Cooperativistas .....................................59

Quadro 7 - Relação das 10 maiores cooperativas financeiros do Brasil ...............63

Quadro 8 - Número de cooperativas por ramos ............................................65

Quadro 9 - Panorama do Sistema Cooperativo de Crédito Brasileiro ..................67

Quadro 10 - Estudos anteriores relacionados à Gestão do Desempenho de Cooperativas e Cooperativas de Crédito..........................................83

Quadro 11 - Área de atuação dos especialistas participantes do método Delphi .. 114

Quadro 12 - Indicadores finais de Avaliação de Desempenho de Cooperativas de Crédito

Quadro 13 - Objetivos da cooperativa e seus indicadores 


\section{LISTA DE TABELAS}

Tabela 1 - Números da amostra participante 120

Tabela 2 - Indicadores finais de Avaliação de Desempenho de Cooperativas de Crédito

Tabela 3 - Indicadores finais de Avaliação de Desempenho de Cooperativas de Crédito .139

Tabela 4 - Confiabilidade do instrumento de coleta de dados (Consistência Interna) 139

Tabela 5 - Estatística Descritiva do perfil das observações 140

Tabela 6 - Caracterização da amostra de conselheiros participantes

Tabela 7 - Caracterização da amostra de cooperados participantes

Tabela 8 - Caracterização da amostra de cooperados participantes 143

Tabela 9 - Pontuação atribuída pelos Conselheiros Fiscais em relação aos indicadores do módulo Financeiro

Tabela 10 - Pontuação atribuída pelos Conselheiros Fiscais em relação aos indicadores do módulo Associados

Tabela 11 - Pontuação atribuída pelos Conselheiros Fiscais em relação aos indicadores do módulo Processos Internos

Tabela 12 - Pontuação atribuída pelos Conselheiros Fiscais em relação aos indicadores do módulo Aprendizado e Crescimento

Tabela 13 - Pontuação atribuída pelos Conselheiros Fiscais em relação aos indicadores do módulo Pessoas e Inovação

Tabela 14 - Pontuação atribuída pelos Conselheiros Fiscais em relação aos indicadores do módulo Princípios Cooperativistas

Tabela 15 - Pontuação atribuída pelos Conselheiros Administrativos em relação aos indicadores do módulo Financeiro 151

Tabela 16 - Pontuação atribuída pelos Conselheiros Administrativos em relação aos indicadores do módulo Associados 152

Tabela 17 - Pontuação atribuída pelos Conselheiros Administrativos em relação aos indicadores do módulo Processos Internos. 154

Tabela 18 - Pontuação atribuída pelos Conselheiros Administrativos em relação aos indicadores do módulo Aprendizado e Crescimento 154 
Tabela 19 - Pontuação atribuída pelos Conselheiros Administrativos em relação aos indicadores do módulo Pessoas e Inovação

Tabela 20 - Pontuação atribuída pelos Conselheiros Administrativos em relação aos indicadores do módulo Princípios Cooperativistas 156

Tabela 21 - Pontuação atribuída pelos Cooperados em relação aos indicadores do módulo Financeiro

Tabela 22 - Pontuação atribuída pelos Cooperados em relação aos indicadores do módulo Associados

Tabela 23 - Pontuação atribuída pelos Cooperados em relação aos indicadores do módulo Processos Internos.

Tabela 24 - Pontuação atribuída pelos Cooperados em relação aos indicadores do módulo Aprendizado e Crescimento.

Tabela 25 - Pontuação atribuída pelos Cooperados em relação aos indicadores do módulo Pessoas e Inovação 163

Tabela 26 - Pontuação atribuída pelos Cooperados em relação aos indicadores do módulo Princípios Cooperativistas

Tabela 27 - Pontuação atribuída pelos Gerentes em relação aos indicadores do módulo Financeiro

Tabela 28 - Pontuação atribuída pelos Gerentes em relação aos indicadores do módulo Associados

Tabela 29 - Pontuação atribuída pelos Gerentes em relação aos indicadores do módulo Processos Internos

Tabela 30 - Pontuação atribuída pelos Gerentes em relação aos indicadores do módulo Aprendizado e Crescimento.

Tabela 31 - Pontuação atribuída pelos Gerentes em relação aos indicadores do módulo Pessoas e Inovação

Tabela 32 - Pontuação atribuída pelos Gerentes em relação aos indicadores do módulo Princípios Cooperativistas ....

Tabela 33 - Estatísticas dos grupos: categoria Financeiros

Tabela 34 - Estatísticas dos grupos: categoria Associado

Tabela 35 - Estatísticas dos grupos: categoria Processos Internos. 179

Tabela 36 - Estatísticas dos grupos: categoria Aprendizado e Crescimento.

Tabela 37 - Estatísticas dos grupos: categoria Pessoa e Inovação

Tabela 38 - Estatísticas dos grupos: categoria Princípios Cooperativistas 
Tabela 39 - Estatísticas do teste $\mathrm{H}$ de Kruskal-Wallis de amostras independentes 185

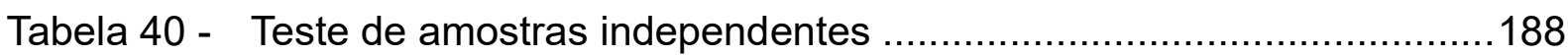

Tabela 41 - Bootstrap para Teste de amostras independentes ...........................188

Tabela 42 - Teste de amostras independentes ............................................190

Tabela 43 - Bootstrap para Teste de amostras independentes ...........................190

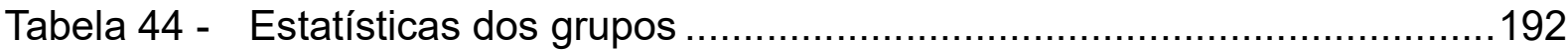

Tabela 45 - Teste de amostras independentes .............................................194

Tabela 46 - Bootstrap para Teste de amostras independentes …........................195

Tabela 47 - Estatísticas dos grupos: categoria Financeiro .................................203

Tabela 48 - Estatísticas dos grupos: categoria Associado ...................................205

Tabela 49 - Estatísticas dos grupos: categoria Processos Internos ......................206

Tabela 50 - Estatísticas dos grupos: categoria Aprendizado e Crescimento.........208

Tabela 51 - Estatísticas dos grupos: categoria Pessoa e Inovação .......................209

Tabela 52 - Estatísticas dos grupos: categoria Princípios Cooperativistas ...........211

Tabela 53 - Bootstrap para Teste de amostras independentes …......................212

Tabela 54 - Estatísticas Descritivas: Categoria das observações da amostra

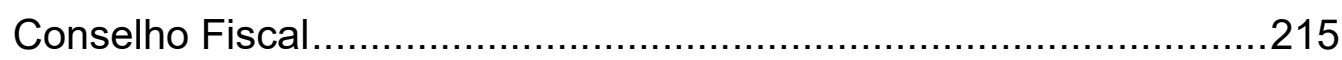

Tabela 55 - Estatísticas do teste $\mathrm{H}$ de Kruskal-Wallis de amostras independentes .216

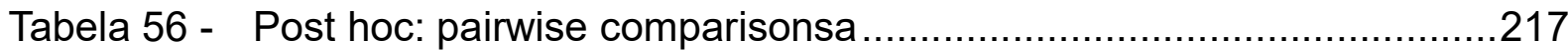

Tabela 57 - Médias de cada grupo por módulo ..............................................227

Tabela 58 - Médias para os indicadores onde houve convergência de opiniões

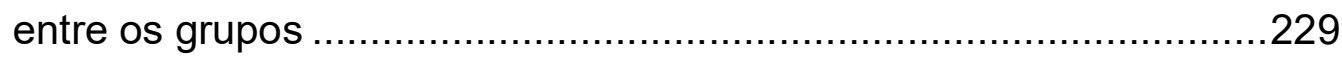

Tabela 59 - Estatísticas dos grupos: todas as categorias ..................................231 


\section{LISTA DE ABREVIATURAS E SIGLAS}

ANACOR - Análise de Correspondência

ANOVA - Análise de Variância

APO - Administração por Objetivos

BACEN - Banco Central do Brasil

BSC - Balanced Score Card

CAPES - Coordenação de Aperfeiçoamento de Pessoal de Nível Superior

$\mathrm{Cl}$ - $\quad$ Capital Intelectual

CNC - Conselho Nacional de Cooperativismo

CONFESOL - Confederação Nacional das Cooperativas Centrais de Crédito e

Economia Familiar e Solidária

CONSAD - Cooperativas possuem Conselho de Administração

COSIF - Plano Contábil do Sistema Financeiro

EVA - $\quad$ Economic Value Added

FNQ - $\quad$ Fundação Nacional da Qualidade

INCRA - Instituto Nacional de Colonização e Reforma Agrária

IPMS - INTEGRATED PERFormanCE MEASUREMENT SYSTEM

MADE-O - Método de Avaliação de Desempenho Global

MEG - Modelo de Excelência em Gestão

MQMD - Quantum de Medição de Desempenho

OCB - Organização das Cooperativas Brasileiras

PNQ - $\quad$ Prêmio Nacional da Qualidade

PP - Performance Prism

ROI - Retorno sobre investimento

SESCOOP - Serviço Nacional de Aprendizagem do Cooperativismo

SIGMA - Susteinability Integrated Guidelines for Management

SMART - Strategic Measurement Analysis and Reporting Technique

SNCC - Sistema Nacional de Crédito Cooperativo

TdB - Tableau de Bord

VE - Value Explorer 


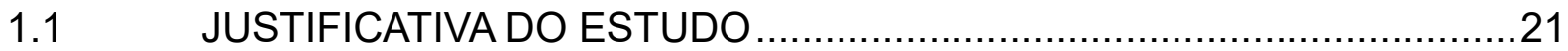

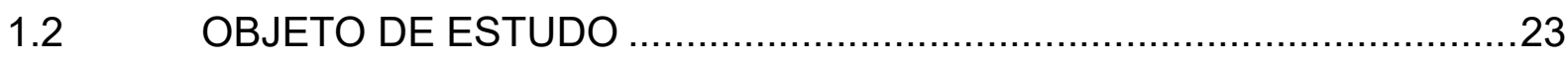

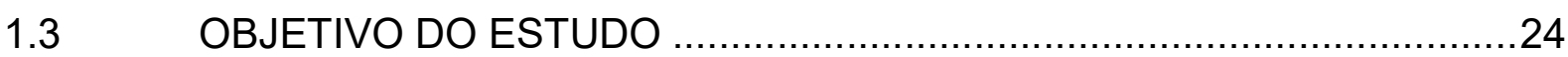

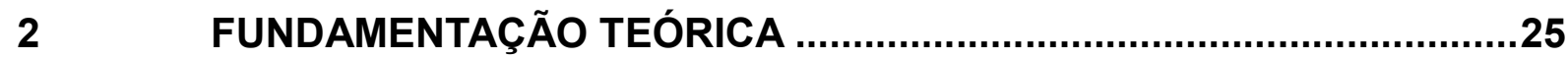

2.1 AVALIAÇÃO DE DESEMPENHO ORGANIZACIONAL …....................25

2.2 A CONSTRUÇÃO DE INDICADORES DE DESEMPENHO .....................31

2.3 PRINCIPAIS MODELOS DE AVALIAÇÃO DE DESEMPENHO .................37

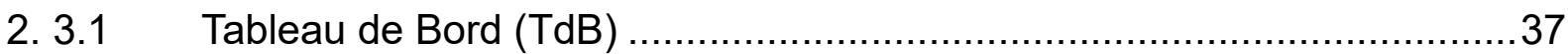

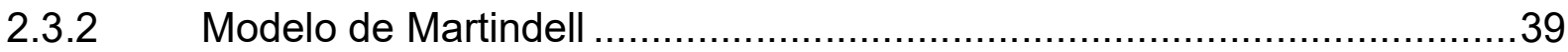

2.3.3 Modelo de Administração por Objetivos (APO) ………..........................40

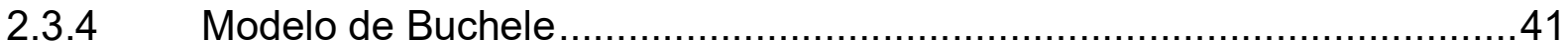

2.3.5 Método de Avaliação de Desempenho Global (MADE-O) …...................42

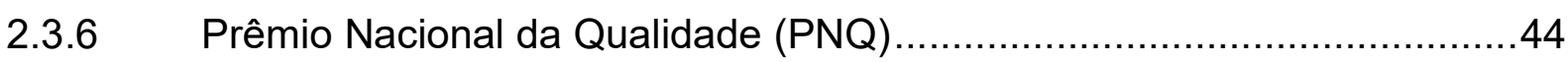

2.3.7 Strategic Measurement Analysis and Reporting Technique (SMART) ......46

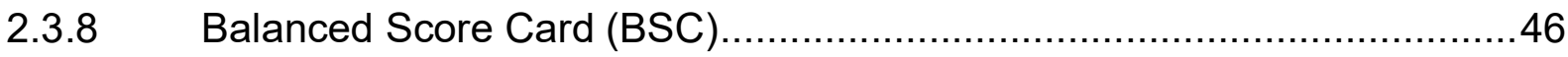

2.3.9 Quantum de Medição de Desempenho (MQMD) ………......................49

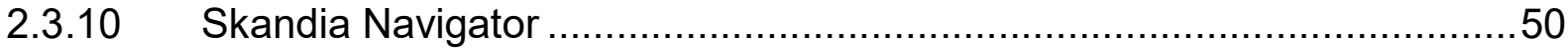

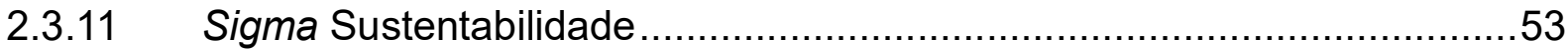

2.3.12 Integrated Performance Measurement System (IPMS) .........................55

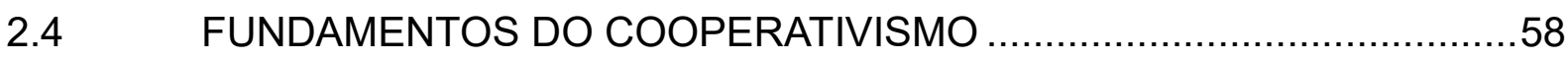

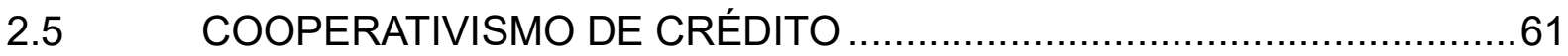

2.5.1 Cooperativas de Crédito no Brasil: histórico e dados gerais ....................63

2.6 PRINCÍPIOS COOPERATIVISTAS E AVALIAÇÃO DE DESEMPENHO DE COOPERATIVAS DE CRÉDITO: UMA DISCUSSSÃO SOBRE ASPECTOS RELEVANTES.

2.7 INDICADORES DE DESEMPENHO DE COOPERATIVAS DE CRÉDITO: A COMPOSIÇÃO DE UM REFERENCIAL PARA A PESQUISA ..................79

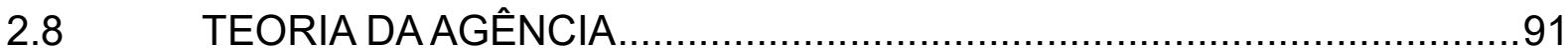

3 DESENVOLVIMENTO DO MODELO TEÓRICO E CONSTRUÇÃO DAS HIPÓTESES DE PESQUISA: COOPERATIVAS, CONFLITOS DE AGÊNCIA E A PERCEPÇÃO DE AVALIAÇÃO DE DESEMPENHO POR PARTE DE COOPERADOS, GERENTES E CONSELHEIROS ...................................97

4 PROCEDIMENTOS E ESCOLHAS METODOLÓGICAS ........................107

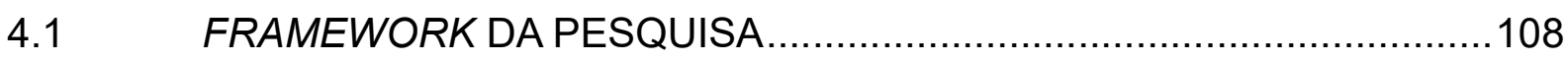

4.2 OBJETO DE ESTUDO E AMOSTRA …...........................................109 
4.3.1 Primeira etapa da pesquisa - Levantamento dos Indicadores de Avaliação de Desempenho de Cooperativas de Crédito com base no referencial teórico

4.3.2 Segunda etapa da pesquisa - Validação dos Indicadores de Avaliação de Desempenho de Cooperativas de Crédito

4.3.2.1 Delphi ...................................................................................... 113

4.3.2.2 Validação de Face e Conteúdo.................................................... 115

4.3.3 Terceira etapa da pesquisa - Coleta e análise estatística dos dados ....116

4.3.3.1 Universo de pesquisa ............................................................ 117

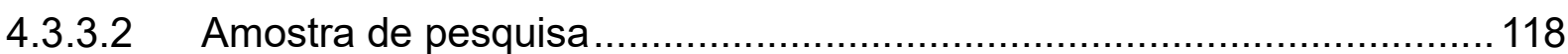

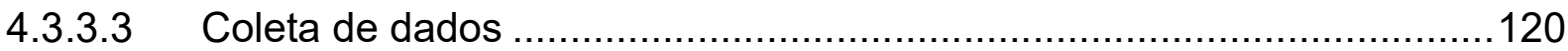

4.3.3.4 Tratamento e análise de dados .................................................... 122

4.3.4 Quarta etapa da pesquisa - Entrevista com cooperativa e análise documental ............................................................................... 124

4.3.4.1 Amostra participante..............................................................

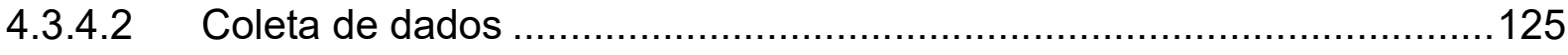

4.3.4.3 Análise dos dados ................................................................ 126

4.3.5 Quinta etapa da pesquisa - Proposição do Modelo de Avaliação de Desempenho de Cooperativas de Crédito.........................................126

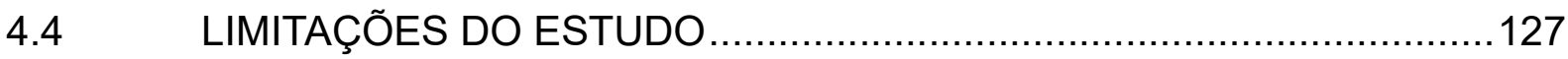

5 APRESENTAÇÃO E ANÁLISE DOS RESULTADOS ...........................129

5.1 LEVANTAMENTO DOS INDICADORES DE AVALIAÇÃO DE DESEMPENHO DE COOPERATIVA DE CRÉDITO COM BASE NO REFERENCIAL TEÓRICO .....................................................129

5.2 VALIDAÇÃO DOS INDICADORES DE AVALIAÇÃO DE DESEMPENHO 135

5.2.1 Resultados da metodologia Delphi .............................................. 135

5.2.2 Validação de face e conteúdo......................................................136

5.3 ANÁLISE ESTATÍSTICA DOS DADOS COLETADOS .........................137

5.3.1 Verificação da confiabilidade do instrumento ....................................138

5.3.2 Estatística descritiva do perfil das observações .................................140

5.3.2.1 Identificação dos conselheiros .................................................... 141

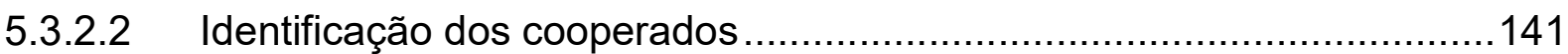

5.3.2.3 Identificação dos gerentes........................................................... 143

5.3.3 Estatística Descritiva Das Respostas ......................................... 144

5.3.3.1 Categoria das observações da amostra: conselheiros fiscais ................144

5.3.3.1.1 Módulo "Financeiro"................................................................ 144

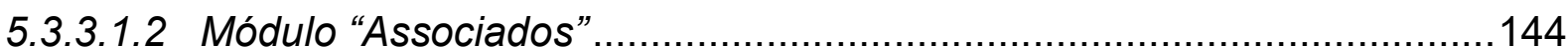




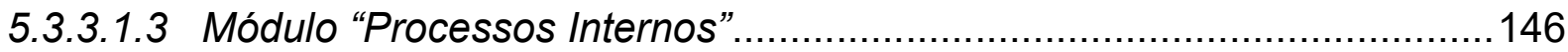

5.3.3.1.4 Módulo "Aprendizado e Crescimento" .................................................146

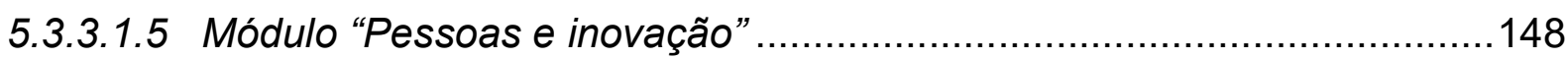

5.3.3.1.6 Módulo "Princípios Cooperativistas"................................................148

5.3.3.2 Categoria das observações da amostra: conselheiros administrativos

150

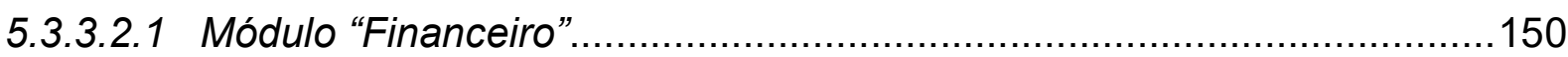

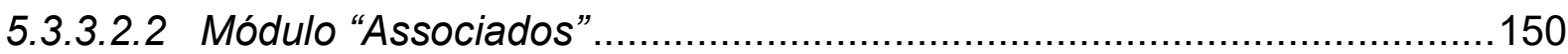

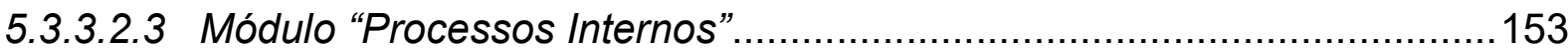

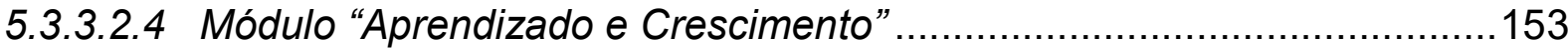

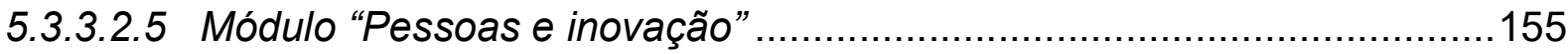

5.3.3.2.6 Módulo "Princípios Cooperativistas"...............................................155

5.3.3.3 Categoria das observações da amostra: cooperados .........................157

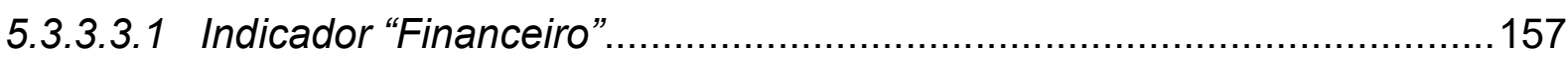

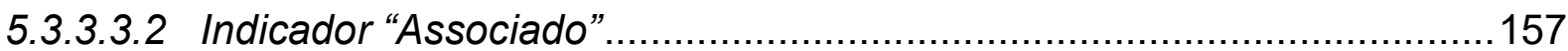

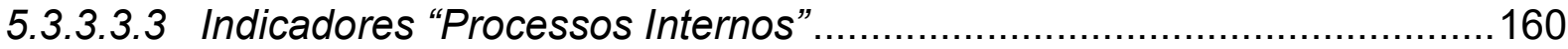

5.3.3.3.4 Indicadores "Aprendizado e Crescimento" ............................................160

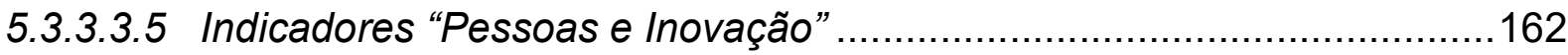

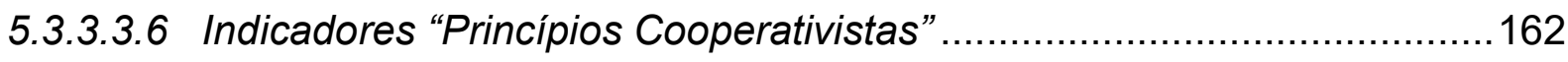

5.3.3.4 Categoria das observações da amostra: Gerentes ..............................165

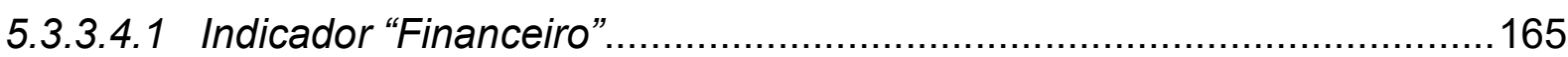

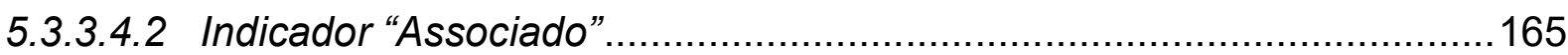

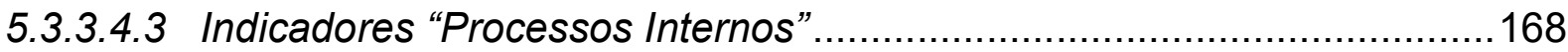

5.3.3.4.4 Indicadores "Aprendizado e Crescimento" ............................................168

5.3.3.4.5 Indicadores "Pessoas e Inovação" ....................................................170

5.3.3.4.6 Indicadores "Princípios Cooperativistas" ............................................170

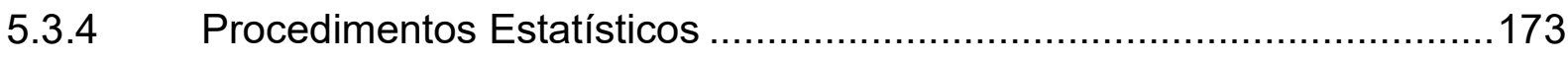

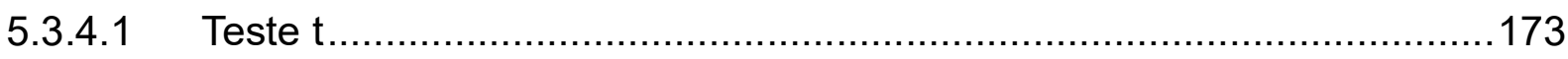

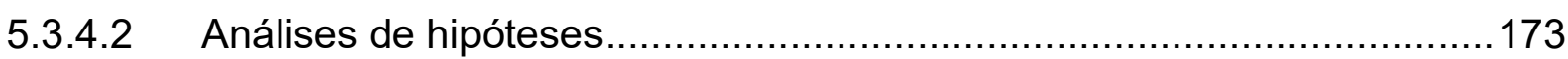

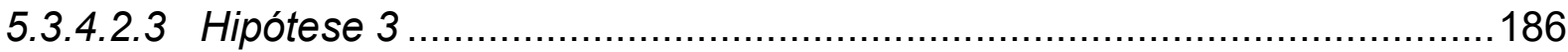

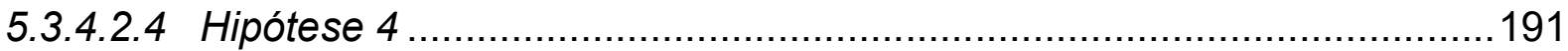

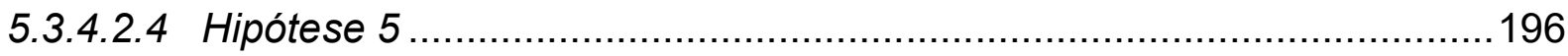

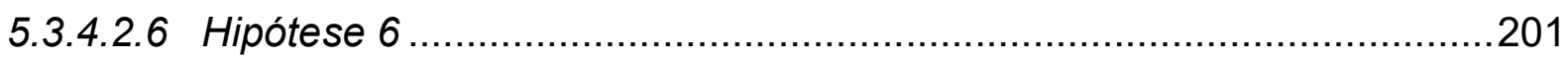

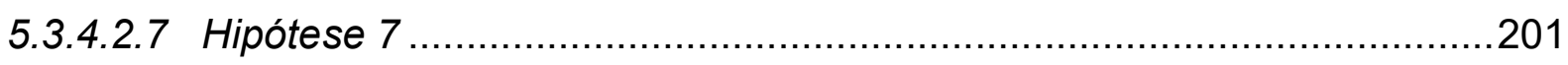

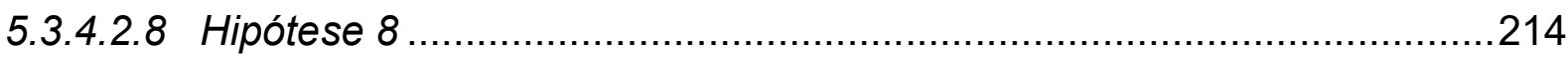

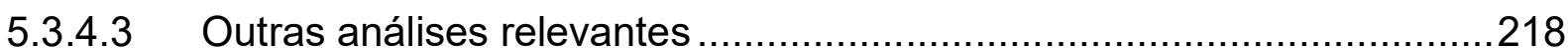


5.3.4.3.1 Variáveis determinadas como importantes para avaliar desempenho de cooperativas de crédito sob o ponto de vista dos envolvidos considerando seu perfil

5.3.4.3.2 Importância atribuída pelos diferentes grupos participantes da pesquisa para cada módulo

5.3.4.3.3 Convergências e divergências de opiniões entre agentes e principal ....228

5.3.4.3.4 Importância dada aos princípios do cooperativismo pelos grupos, quando se trata da avaliação de desempenho de cooperativas de crédito 236

5.4 ENTREVISTA COM COOPERATIVA E ANÁLISE DOCUMENTAL .236

5.5 A PROPOSIÇÃO DE UM MODELO DE AVALIAÇÃO DE DESEMPENHO PARA COOPERATIVAS DE CRÉDITO VISANDO A DIMINUIÇÃO DOS CONFLITOS DE AGÊNCIA 240

6 CONSIDERAÇÕES FINAIS .249

REFERÊNCIAS .259 APÊNDICES 




\section{INTRODUÇÃO}

\subsection{JUSTIFICATIVA DO ESTUDO}

Durante o X Congresso Nacional de Cooperativismo, organizado pela Organização das Cooperativas Brasileiras (OCB), ficou acordado que Sociedade Cooperativista é uma organização de, pelo menos, vinte (20) pessoas físicas unidas pela cooperação e ajuda mútua, gerida de forma democrática e participativa, com objetivos econômicos e sociais comuns e cujos aspectos legais e doutrinários são distintos de outras sociedades. Esse tipo de organização fundamenta-se nos princípios de Economia Solidária e se propõe a obter um desempenho econômico e eficiente através da qualidade e da confiabilidade dos serviços que presta a seus próprios associados e usuários.

Isso significa que cooperativas são instituições formadas por pessoas que tem uma mesma necessidade social e econômica, unidas a partir de princípios diferenciados, baseados em uma economia, denominada Solidária, que organiza a produção, consumo e distribuição de riquezas centrada na valorização do ser humano e não do capital.

Trata-se de uma maneira alternativa de organização, que surgiu na Inglaterra, em 1843, em reação às condições miseráveis e desumanas, unidas a escandalosos contrastes com a burguesia. Isso porque, após haver buscado em vão um remédio para sua situação em várias direções, agarrando-se a velhos regulamentos das corporações de ofício próprios da Idade Média e do início dos Tempos Modernos e Renascentistas, aderindo a elas ou deixando-se levar pelo desespero do motim, os trabalhadores compreenderam paulatinamente que era necessário uma profunda mudança da ordem social e que sua única arma - já que não possuíam capital, nem cultura nem a legalidade (tudo isso estava do outro lado) - residia na associação, graças à qual seu número podia transformar a debilidade em força (SCHNEIDER, 2001).

Devido à sua natureza originária, organizações cooperativistas nem sempre são geridas adequadamente, não considerando aspectos administrativos que podem melhorar seus rendimentos, como por exemplo, uma avaliação periódica de seu desempenho, visando identificar pontos a serem otimizados. 
Apesar dessa deficiência, as cooperativas de crédito são significativas para o crescimento econômico sustentável de vários países. Na Alemanha e Holanda, por exemplo, chegaram a responder por aproximadamente $40 \%$ do volume de crédito até o ano de 2010 (ALBUQUERQUE, 2010).

Já no Brasil, esse segmento tem grande potencial de crescimento. O governo brasileiro estimula a prática do cooperativismo, por esse oferecer crédito a baixo custo e agilidade. Em contrapartida, exige melhor qualificação e maior responsabilidade corporativa na gestão dessas instituições (ALBUQUERQUE, 2010).

Dessa forma, a cooperativa deixa de ser vista como uma simples associação mutualista para se transformar em uma complexa organização social, incorporando problemas da empresa capitalista moderna e segundo Pinho (1982) se desvirtuando de seus princípios básicos.

Esse processo, de profissionalização da gestão cooperativista, devido ao fato do crescimento do negócio, acaba por gerar um conflito de agência: de um lado, o cooperado, com seus interesses sócio-econômicos, e de outro lado os gestores da cooperativa, com interesses nem sempre alinhados aos princípios cooperativistas.

Esse fato é o que motiva essa pesquisa, ou seja, a necessidade de se profissionalizar cada vez mais a administração de instituições que trabalham com princípios de Economia Solidária, como é o caso das cooperativas de crédito, o que gera muitas vezes conflitos de interesse entre os grupos que se relacionam.

Em suma, a análise baseou-se na premissa de que a existência de separação entre a propriedade e o controle do capital conduz à presença de variáveis que representariam a possibilidade de surgimento de conflitos de interesses entre os participantes.

Sendo assim, tem-se a necessidade de conhecer qual a percepção de avaliação de desempenho de cada uma dessas figuras: o agente (profissional contratado para exercer determinada função - no caso gerentes e conselheiros administrativos e fiscais) e o principal (contratante - no caso o cooperado), a fim de identificar as variáveis tidas como fundamentais para avaliar uma cooperativa de crédito do ponto de vista dos referidos grupos, a fim de que essa possa balizar seu desempenho em indicadores que a levem a satisfazer as necessidades as quais se propôs. 
Com isso foi possível levantar as variáveis vistas como importantes para a Avaliação de Desempenho de Cooperativas de Crédito segundo a visão daqueles que administram a cooperativa (agente) e de seus cooperados (principal), a fim de analisar a percepção de desempenho de cooperativas de crédito sob a ótica da Teoria da Agência.

\subsection{OBJETO DE ESTUDO}

Dentre as intenções do trabalho está analisar a percepção de desempenho de cooperativas de crédito sob a ótica da Teoria da Agência, visto que esse tipo de organização tem partes envolvidas que podem ter interesses divergentes, e que por isso entendem que o desempenho adequado da instituição é dependente de aspectos nem sempre concordantes.

Considerando que é importante que agente e principal cuidem para que seus interesses e esforços sejam concentrados para o mesmo objetivo, esse trabalho se pautou, em um primeiro momento, em conhecer como cada uma dessas partes percebe o desempenho das cooperativas de crédito, bem como sua relação com os princípios e fundamentos cooperativistas, objetivo de formação de cooperativas.

Com isso, identificou-se indicadores de avaliação de desempenho pertinentes às cooperativas de crédito, considerando a percepção de agente e principal.

Com esses indicadores em mãos, e com base nas pesquisas empíricas realizadas, foi possível propor um modelo de Avaliação de Desempenho de Cooperativas de Crédito com vistas a minimizar os conflitos de agência.

Com isso, é possível auxiliar na definição do planejamento estratégico e na correção e adequação da gestão da instituição, visto que identificando tais indicadores de desempenho, esses poderão ser utilizados para medir o processo ou seus resultados, além de sinalizar possíveis desvios de rota nos planos traçados, bem como contribuindo para a melhoria na eficiência dos processos de trabalho.

Em suma, pretende-se ajudar os gestores de Cooperativas de Crédito a melhorar o desempenho das suas organizações, possibilitando maior chance de atendimento aos objetivos traçados no momento de fundação da cooperativa. 


\subsection{OBJETIVO DO ESTUDO}

\subsubsection{Objetivo Geral}

Analisar a percepção de desempenho de cooperativas de crédito sob a ótica da Teoria da Agência.

\subsubsection{Objetivos Específicos}

- Identificar indicadores de avaliação desempenho que sejam pertinentes a cooperativas de crédito;

- Compreender quais aspectos influenciam na avaliação de desempenho de cooperativas de crédito na visão de cada grupo envolvido;

- Relacionar as variáveis determinadas como importantes para avaliar desempenho de cooperativas de crédito sob o ponto de vista dos envolvidos considerando seu perfil;

- Verificar se os princípios do cooperativismo são tidos como importantes quando se trata da avaliação de desempenho de cooperativas de crédito.

- Apontar as divergências e convergências de opiniões de agentes e principal;

- Entender a influência da Teoria da Agência na gestão do desempenho de cooperativas de crédito;

- Sugerir um Modelo de Avaliação de Desempenho de Cooperativas de Crédito que diminua os conflitos de agência. 


\section{FUNDAMENTAÇÃO TEÓRICA}

\subsection{AVALIAÇÃO DE DESEMPENHO ORGANIZACIONAL}

O mundo globalizado e altamente competitivo no qual as organizações estão inseridas exige delas uma visão sistêmica, compreendendo a análise de variáveis como, a clareza na comunicação (a qual deve ser acessível e constantemente atualizada) e, a periodicidade das informações (SARUBBI, DIAS E CORRÊA, 2010). De acordo com Crandall (2002), não basta a intenção de se melhorar o desempenho, se faz necessária a mensuração do mesmo, ainda que esta seja complexa por ser difícil desenvolver mecanismos de medição que satisfação todos os stakeholders.

Para que as organizações tenham tal visão, se faz necessário o uso de ferramentas que auxiliem o processo de tomada de decisão que, de acordo com Corrêa (1986), não são representados apenas por instrumentos e sistemas de informações, mas também por métodos de avaliação que decodifiquem as informações coletadas. A referida junção de sistemas compreende a chamada Metodologia de Avaliação de Desempenho Organizacional.

Conforme apresentado por Kaplan e Norton (2004, p. 7) "os indicadores contábeis e financeiros tradicionais, como retorno sobre investimento e lucro por ação, às vezes emitem sinais enganosos para fins de melhoria contínua e inovação atividades exigidas pelo ambiente competitivo da atualidade". Desta forma, a fim de atender a atual dinâmica organizacional, os gestores têm buscado cada vez mais, modelos de mensuração do desempenho que vão além dos indicadores financeiros.

Uma correta mensuração e avaliação do desempenho organizacional permite aos gestores, além de comunicar a realidade empresarial aos stakeholders, conhecer melhor a empresa por meio da identificação, análise e eliminação das falhas, permitindo fornecimento de feedbacks positivos ou negativos de acordo com o desempenho mensurado (CORRÊA; HOURNEAUX, 2008).

$O$ acompanhamento do desempenho empresarial permite $O$ alcance dos objetivos estratégicos da empresa, pois é através dele que são feitas as avaliações e possíveis correções, com o intuito de garantir que o planejamento está sendo seguido (SERRA; TORRES; TORRES, 2009). 
Dentre as justificativas para se avaliar o desempenho organizacional, destacase a possibilidade de utilização de um sistema de avaliação de desempenho com o intuito de verificar relação entre o enfoque operacional e estratégico da empresa. Tal verificação permitirá aos gestores avaliar o alinhamento entre o planejado e o desenvolvido, monitorando o desenvolvimento das atividades empresariais de forma mensurável e com isso sendo capaz de propor melhorias para manter ou elevar os padrões de desempenho (CUNHA, 2011).

Além da clara importância de se usar indicadores e sistemas de avaliação de desempenho, em seu estudo, Cunha (2011) aponta variáveis complementares que auxiliam nessa justificativa, são elas: alterações na natureza do trabalho; aumento da relevância das certificações; aumento da competitividade; mudanças nas demandas externas; novas iniciativas de melhoria e produtividade das atividades empresariais; alterações nos papéis organizacionais e; surgimento de possibilidades advindas do uso da tecnologia de informação.

Basicamente serve para monitorar ou controlar atividades ou área da organização, a fim de estabelecer e garantir um foco de atuação da mesma, resultando em uma decisão estratégica baseada nos objetivos traçados e legitimando a organização perante o mercado (HOURNEAUX JR. ET AL., 2017).

Sink e Tuttle (1993), complementa essa idéia ao colocar que a utilização de instrumentos para avaliar o desempenho organizacional é a base para o alcance de flexibilidade ao identificar oportunidades e ameaças do ambiente externo à empresa, pois permite a antecipação destes. Ao avaliar, pode-se mensurar o desempenho financeiro, humano, mercadológico, comercial, dentre outros aspectos da instituição.

A preocupação com o desempenho se faz necessária, pois ela se reflete na tomada de decisão e na determinação e acompanhamento das estratégias empresarias. Diante de tal relevância, a administração deve ser focada nos indicadores de desempenho, tendo em vista que estes são considerados como o pulso da organização (PARMENTER, 1991).

Halachmi (2005, p. 503) afirma que "o simples fato de não se fazer medições leva a empresa a não melhorar, pois, medir leva ao entendimento, que leva ao controle, que, por sua vez, leva à melhoria".

O quadro 1 compila as vantagens da avaliação de desempenho, com base na ideia de Yokomizo (2009). 
Quadro 1 - Vantagens da avaliação de desempenho

\begin{tabular}{|c|c|}
\hline VANTAGEM & EVIDÊNCIA \\
\hline Abrangência & $\begin{array}{l}\text { Espera-se considerar a empresa como um todo, ter uma visão } \\
\text { sistêmica do negócio. }\end{array}$ \\
\hline Antecedência & $\begin{array}{l}\begin{array}{l}\text { Visa a previsão de situações de não conformidade, a fim de corrigir as } \\
\text { mesmas. }\end{array}\end{array}$ \\
\hline Causalidade & $\begin{array}{l}\text { Baseado no fato de que determinadas dimensões da empresa não } \\
\text { são explicadas em si mesmas, mas são diretamente causadas por } \\
\text { outras dimensões, tenta-se entender qual a relação de causalidade e } \\
\text { agir sobre tais dimensões. }\end{array}$ \\
\hline Comparabilidade & $\begin{array}{l}\text { Há a possibilidade de se fazer comparações de dimensões próximas } \\
\text { entre empresas diferentes. }\end{array}$ \\
\hline Perenidade & $\begin{array}{l}\text { Está relacionada a existência da empresa no longo prazo e está } \\
\text { intimamente ligada ao conceito de vantagem competitiva sustentável. }\end{array}$ \\
\hline
\end{tabular}

Fonte: elaborado pela autora baseado em Yokomizo (2009).

Ao analisar alguns modelos de avaliação de desempenho global tem-se que na era industrial, os indicadores contábeis e financeiros eram suficientes, pois a busca era por ganhos de escala. Contudo, a complexa realidade vivida pelas empresas na atualidade, requer habilidades e competências que não podem ser mensuradas com os referidos indicadores (KAPLAN e NORTON, 2004). Fazem-se necessários instrumentos que indiquem o desempenho e ao mesmo tempo gerem informações de avaliação da posição da empresa no mercado em que ela atua (ZILBER; FISCHMANN, 2002).

A credibilidade da administração, o foco em inovação da empresa, as visões estratégicas e a habilidade de atração de talentos, são exemplos de informações de desempenho não financeiras que são base para a maioria das decisões dos investidores. A justificativa para que dados não financeiros sejam tão relevantes é que fatores como inovação, produtividade, satisfação dos clientes, dentre outros, são os pilares do desempenho financeiro e não o inverso (ZILBER; FISCHMANN, 2002).

Para Corrêa (1986) são cinco as características que devem conter em um modelo de avaliação de desempenho organizacional para que este seja considerado completo, são elas: ser global, ou seja, deve conter todas as dimensões; histórico, conter vários anos; possibilitar o comparativo com outras empresas e setores; possuir uma relação de causa/efeito, ou seja, relacionar as áreas e; antecipação, focar nas causas e não apenas nos efeitos. 
Zilber e Fischmann (2002) apontam que um sistema de avaliação adequado e eficaz deve fazer a comparação entre o desempenho do negócio com outros em âmbito local, nacional ou ainda internacional; balancear medidas financeiras e não financeiras; fazer a identificação dos fatores críticos de sucesso e ligá-los aos objetivos estratégicos a fim de considerar que eles são a base para a construção do valor da empresa.

A avaliação do desempenho requer dos administradores uma compreensão multidisciplinar das suas funções, as quais compreendem a mensuração, a administração e o relato do desempenho em termos quantitativos. Frost (1999) relata a necessidade de suporte aos executivos, a fim de que esses entendam de forma completa como se quantifica e comunica o desempenho organizacional, pois com a demanda crescente e a conseqüente redução do tempo, se faz necessária a execução rápida e de baixo custo.

Para Sarubbi, Dias e Correa (2010), este processo de avaliação se dá em seqüência: mensuração, a qual é feita por meio dos indicadores mais adequados para a realidade empresarial; avaliação, onde se compara o resultado obtido com o desejado no momento do planejamento; diagnóstico, que consiste na análise dos motivos pelos quais ocorreram alterações em plano e realidade observada e; ação, onde há o processo de correção das falhas ou aproveitamento das ações quando estas são positivas.

Já Gallon, Ensslin e Ensslin (2011) compreendem a avaliação como um processo composto por três fases: (a) identificação dos aspectos que serão considerados na avaliação; (b) estabelecimento dos níveis de desempenho relativos a empresa em uma escala ordinal e; (c) identificação das diferenças de atratividades (mensuração) entre os níveis de desempenho, utilizando uma escala cardinal.

Independente do seqüenciamento adotado pela empresa, o fato é que é necessário realizar a mensuração do desempenho, a fim de não apenas identificar possíveis falhas, mas também com o intuito de conhecer as atividades desenvolvidas pela empresa que são agregadoras de valor ao produto e/ou serviço; permitir comparação entre o desempenho da empresa e de seus concorrentes e; possibilitar revisão das estratégias organizacionais.

Um dos instrumentos que viabilizam a mensuração de desempenho e visam auxiliar a definição do planejamento estratégico são os indicadores de desempenho, 
os quais permitem a verificação da propriedade da tomada de decisão e com isso a correção e a readequação do processo em curso (ZILBER; FISCHMANN, 2002).

Warrack, Sinha e Bawden (2001) apontam a utilidade dos indicadores de desempenho ao relatar que eles possibilitam a comparação dos resultados com padrões estabelecidos anteriormente; fazem a avaliação quantitativa do nível de desempenho de resultados almejados (quantitativos ou qualitativos) e; se caracterizam como um desafio permanente para a empresa.

A definição dos indicadores de desempenho, sejam eles financeiros ou não, tem que estar diretamente relacionada com a estratégia da empresa, a qual por sua vez deve ser firme e muito bem delineada (NIVEN, 2005). Tal relação entre indicadores e estratégia é entendida por Kaplan e Norton (2004) como sendo de causa e efeito, devendo permear todas as perspectivas do modelo de desempenho. Contudo, Zilber e Fischmann (2002) destacam que nem todas as medidas de desempenho necessárias configuram nos relatórios financeiros tradicionais.

Santos et al. (2011) afirmam que os indicadores do modelo utilizado pelas empresas são os meios pelos quais há a combinação a fim de mensurar o desempenho organizacional. Segundo os autores, o indicador de desempenho fornece a quantificação do desempenho e é uma representação da base utilizada para a mensuração, podendo estes ser qualitativos ou quantitativos, absolutos ou relativos, diretos ou indiretos.

Ao discutir indicadores de desempenho, Cunha (2011) apresenta uma classificação de cinco tipos de indicadores conforme descrito a seguir.

a) Indicadores estratégicos: são aqueles que informam o quão próximo ou não a organização está em relação ao seu objetivo;

b) Indicadores de produtividade: também chamado de indicador de eficiência, mensura a quantidade de recursos utilizados em relação aos outputs do processo;

c) Indicadores de qualidade: também chamado de indicador de eficácia, são os que relatam a satisfação dos clientes e as características do produto/serviço;

d) Indicadores de efetividade/impacto: apresentam as conseqüências advindas dos produtos/serviços e;

e) Indicadores de capacidade: informam a capacidade de um processo através dos outputs do mesmo por unidade de tempo. 
Uma relação entre as vantagens e desvantagens dos sistemas de mensuração e dos indicadores é apresentada no quadro 2.

Quadro 2 - Vantagens e desvantagens dos sistemas de mensuração e dos indicadores

\begin{tabular}{|c|c|}
\hline SISTEMA DE MENSURAÇÃO & INDICADORES \\
\hline \multicolumn{2}{|c|}{ VANTAGENS } \\
\hline Precisa ser construído adequadamente & Construção rápida \\
\hline Possibilita uma visão completa do objeto & Facilidade de operação \\
\hline \multicolumn{2}{|l|}{ Os dados podem ser divulgados } \\
\hline \multicolumn{2}{|l|}{ Os resultados servem de padrão } \\
\hline \multicolumn{2}{|l|}{$\begin{array}{l}\text { Os resultados podem servir de base para novas } \\
\text { medidas }\end{array}$} \\
\hline \multicolumn{2}{|l|}{ Pode ser aplicado a outros modelos de negócio } \\
\hline \multicolumn{2}{|l|}{ Transparente e auditável } \\
\hline \multicolumn{2}{|l|}{$\begin{array}{l}\text { Leva em consideração diferentes ângulos do } \\
\text { tema em estudo }\end{array}$} \\
\hline \multicolumn{2}{|c|}{ DESVANTAGENS } \\
\hline Demanda cuidado e tempo para ser construído & Uso específico \\
\hline A exigência de dados pode ser muito ampla & Não serve como padrão \\
\hline \multirow[t]{3}{*}{ A exigência de qualidade dos dados é restritiva } & Consideram um valor médio único \\
\hline & $\begin{array}{l}\text { Não podem ser agregados para valorizar objetos } \\
\text { complexos }\end{array}$ \\
\hline & Existe a possibilidade de duplicação \\
\hline
\end{tabular}

Fonte: Pike, Fernstrom e Roos (2005); Pace (2009).

Alguns dos problemas relacionados aos sistemas de mensuração de desempenho tradicionais são: maior enfoque no desempenho financeiro em detrimento do serviço ao cliente ou da qualidade; incompatibilidade entre padrões utilizados para formulação de planos e fixação de objetivos e os indicadores de desempenho observados; falta de flexibilidade para utilização das informações recebidas; foco na medição do controle em detrimento da valorização do aprimoramento e; ausência de diferenciação entre indicadores importantes, que por conta de sua complexidade acabam por serem apresentados em menor número e, aqueles indicadores que apresentam resultados triviais e que acabam por ser apresentados em grande quantidade (ZILBER; FISCHMANN, 2002).

Pace (2009) afirma que o desempenho mensurado através de um agrupamento qualquer de indicadores será sempre o reflexo de uma visão parcial e contextual da organização. Dessa forma, é levantada a questão da subjetividade dos resultados da mensuração, o que contraria a visão objetiva ressaltada por diferentes autores, 
devendo tais resultados estar abertos a discussão e se necessário, substituição a fim de eliminar o viés da definição dos indicadores.

\subsection{A CONSTRUÇÃO DE INDICADORES DE DESEMPENHO}

A um conjunto de dados ou informações, de preferência numérico, o qual representa um fenômeno específico e é utilizado para mensurar um processo ou os resultados deste, dá-se o nome de indicadores (MACEDO-SOARES; RATTON, 1999). Além da sinalização da realidade empresarial, a qual pode conter incoerências entre os resultados e o que havia sido planejado, os indicadores podem ainda atuar na prevenção de tais problemas, ao contribuir para a redução dos gastos e aumento da eficiência. Macedo-Soares e Ratton (1999, p. 48) definem o sistema de indicadores de desempenho como

um conjunto de pessoas, processos, métodos e ferramentas que, conjuntamente, geram, analisam, expõem, descrevem, avaliam e revisam dados e informações sobre as múltiplas dimensões do desempenho nos níveis individual, grupal, operacional e geral da organização, em seus diversos elementos constituintes.

Com o dever de sustentar um sistema de gestão que possibilite ao administrador avaliar o alinhamento entre o planejamento estratégico e os resultados, os indicadores de desempenho são o suporte para a gestão estratégica organizacional (CUNHA, 2011). Desta forma destaca-se a necessidade de uniformização na realização do processo de mensuração, compreendendo diferentes áreas e realidade da empresa, a fim de possibilitar a comparabilidade de diferentes aspectos avaliados.

A partir de tal importância é destacada a necessidade de ter atenção e procedimentos claros para se formular os indicadores, sendo que Cunha (2011) aponta que a melhor forma de se mensurar é aquela capaz de ser mais útil diante do que ela se propôs a fazer. Ou seja, se faz necessária a presença de medidas que representem de fato a realidade empresarial. A mensuração de muitos itens de pouca relevância para a tomada de decisão se configura apenas em aumento de custos para a empresa, pois não auxiliam a gerenciar e a monitorar a atividade empresarial.

Ressalta-se que os indicadores de desempenho também devem ser avaliados de forma constante, afinal eles devem refletir as mudanças ocorridas na organização, tendo em vista que a realidade empresarial vive em um ambiente complexo e altamente mutável. Em complemento, deve-se considerar a execução dos indicadores 
no momento da construção dos mesmos, pois além de factíveis (verificar a possibilidade de obtenção dos dados necessários) eles devem ser viáveis em termos de custo para a organização. O resumo desta ideia foi colocado por Hauser e Katz (1998), os quais consideram as boas medidas como sendo aquelas que balanceiam a dificuldade de obtenção dos dados com a efetividade, mantendo o foco nos pontos críticos da empresa.

Como já descrito, os indicadores de desempenho podem ser classificados em financeiros (mensuram de forma monetária aspectos organizacionais); ou nãofinanceiros (mensuram a operação da organização de outras formas, como por exemplo, a satisfação do consumidor, do funcionário, eficiência e produtividade, qualidade dos bens oferecidos, dentre outros).

Esses não são excludentes nem opostos, e sim complementares, visto que os não financeiros tem sido base para o alcance de melhores resultados monetários (CUNHA, 2011).

Pace (2009) lista quais seriam os atributos ideais para medidas de desempenho baseando-se em Jachson (1995), como descrito a seguir:

a) Clareza - medidas devem ser simples, bem definidas e de fácil compreensão.

b) Consistência - as definições utilizadas para produzir as medidas devem ser consistentes com unidades da organização.

c) Importância - as medidas relacionam-se com missão e objetivos e são capazes de comparar situações comparáveis.

d) Viabilidade - os objetivos estão baseados em expectativas realistas? Eles podem ser alcançados com ações razoáveis?

e) Limitação - concentrado em um número limitado de indicadores-chave (aqueles com maior probabilidade de retorno), ao longo do tempo e entre a sensibilidade a custos.

f) Comparabilidade - capacidade de informar os tomadores de decisão?

g) Controlabilidade - o desempenho só deve ser medido em relação às áreas sobre as quais se tem controle

h) Abrangência - as medidas refletem aspectos do comportamento considerados relevantes pelos tomadores de decisão 
i) Riscos contingentes - desempenho depende do ambiente em que a decisão é tomada. Esse ambiente compreende a estrutura da organização, o estilo da gestão, as incertezas e a complexidade do ambiente externo.

j) Oportunidade - as medidas podem ser preparadas e distribuídas com velocidade suficiente para serem úteis aos gerentes.

k) Não redundantes - cada medida deve ser capaz de contribuir com algo distinto.

Ao analisar as características necessárias para indicadores de organizações de saúde, Cunha (2011) compilou 6 variáveis, as quais, por serem amplas e ao mesmo tempo resumirem a ideia proposta por Pace (2009), além de serem cabíveis de aplicação na realidade de outras organizações serão listadas na seqüência:

a) Utilidade: diz respeito ao quão útil e aplicável os indicadores são tendo como base o propósito que eles foram pensados para atingir.

b) Confiabilidade: se refere a capacidade de se alcançar o mesmo resultado na maioria das vezes que é feita a aplicação em uma mesma população. Não se deve ter dúvidas quanto à forma de coleta, devendo a medida ser representativa aos conceitos que dão base a ela.

c) Direcionamento: diz respeito ao delineamento do objetivo do indicador, pois este deve ser bem específico e claro.

d) Comparabilidade: o indicador deve permitir a comparação do desempenho da empresa tanto com ela mesma, quanto com outras empresas do mesmo setor de atuação.

e) Interpretáveis: observa-se que além de representar um número mensurável, o indicador deve ser passível de interpretação, pois é nela que reside a subjetividade que pode ser o diferencial intangível para a organização.

f) Eficazes: se refere a intenção de fornecer a informação correta e que esta seja compreensível a fim de se alcançar o objetivo proposto com a mensuração.

Complementando a descrição e o entendimento da última variável proposta na compilação de Cunha (2011), ao analisar a eficácia de um sistema de mensuração de desempenho, Pace (2009) segue os pontos propostos por Kravchuck e Schack (1996), os quais listam 10 princípios para tal análise. A descrição de tais princípios está listada a seguir:

a) Formular de forma clara e coerente a missão, as estratégias e os objetivos; 
b) Desenvolver uma estratégia explicita de mensuração;

c) Envolver usuários-chave nas fases de desenho e de desenvolvimento;

d) Racionalizar a estrutura programática como forma preparatória a mensuração;

e) Desenvolver, na medida do necessário, múltiplos conjuntos de medidas para múltiplos usuários;

f) Levar em consideração durante o processo os clientes dos programas e dos sistemas;

g) Fornecer a cada usuário detalhes suficientes de modo a propiciar uma visão clara do desempenho;

h) Periodicamente rever e revisar o sistema de mensuração;

i) Levar em consideração as complexidades acima, abaixo e laterais da organização;

j) Evitar uma agregação excessiva das informações.

Para a construção de indicadores de desempenho, deve-se balancear a utilização dos diferentes tipos de medidas, pois tal mensuração pode ser deteriorada ou insuficiente a partir da escolha e uso de medidas qualitativas e quantitativas. É fato a dificuldade de se trabalhar com as medidas de desempenho, devendo então haver o controle constante de tais medidas.

Antes de se definir as etapas para a elaboração de um indicador de desempenho, cabe destacar alguns pressupostos que o sistema de mensuração deve conter. Baseado em Zilber e Fischmann (2002), primeiramente deve-se ter cuidado com os dados e informações que serão utilizadas, devendo estes serem consistentes e fidedignos, sem contar a necessidade de que estejam disponíveis dentro dos prazos estipulados a fim de permitir uma avaliação periódica. Se faz necessário o envolvimento de diferentes áreas da empresa, as quais devem estar treinadas e preparadas, desde a produção até o manuseio, disposição e utilização dos dados e informações.

Outro pressuposto é que os indicadores devem refletir os objetivos estratégicos da empresa, sendo que após a construção do sistema de indicadores/mensuração este será utilizado como base para a elaboração do planejamento estratégico da empresa. Além de representar relações matemáticas que possibilitem a análise de 
tendência, os indicadores devem refletir valores e variações reais do desempenho da empresa (ZILBER, FISCHMANN, 2002).

A fim de que os sistemas de mensuração de desempenho alcancem os resultados planejados, se faz necessário um processo periódico de desenvolvimento, gestão e avaliação. Segundo uma revisão de literatura feita por Pace (2009), a qual compilou e ordenou as ideias de Dixon, Nanni e Vollmann (1990) e Neely (1997) deve seguir etapas descritas no quadro 3. 
Quadro 3 - Etapas que devem estar compreendidas na elaboração de um sistema de mensuração

\begin{tabular}{|c|c|}
\hline ETAPA & DESCRIÇÃO \\
\hline Etapa 1 & $\begin{array}{c}\text { garantir o comprometimento da alta direção é essencial se a iniciativa de uso das } \\
\text { medidas for para toda a organização, pois sinaliza sua prioridade elevada e que } \\
\text { haverá recursos físicos e financeiros para tal. }\end{array}$ \\
\hline Etapa 2 & $\begin{array}{l}\text { selecionar departamentos, atividades e funções pode ocorrer de forma seletiva e } \\
\text { limitada de modo a criar credibilidade, permitir a coleta de informações de custos e de } \\
\text { benefícios e eliminar potenciais problemas previamente a uma implantação de maior } \\
\text { porte, iniciando por aqueles departamentos ou programas mais interessados. }\end{array}$ \\
\hline Etapa 3 & $\begin{array}{c}\text { atribuir responsabilidades de coordenação a profissionais ligados ao programa de } \\
\text { modo a dar maior credibilidade e responsabilidade. }\end{array}$ \\
\hline Etapa 4 & $\begin{array}{l}\text { rever e/ou identificar a missão, os objetivos e as metas são etapas do processo de } \\
\text { planejamento estratégico. }\end{array}$ \\
\hline Etapa 5 & $\begin{array}{l}\text { desenhar medidas que permitam acompanhar o progresso em direção aos objetivos e } \\
\text { às metas da organização, verificando as práticas de organizações semelhantes. }\end{array}$ \\
\hline Etapa 6 & $\begin{array}{c}\text { definir metas mensuráveis de desempenho fazendo uso de formas de benchmarking } \\
\text { baseadas em níveis ideais de desempenho. }\end{array}$ \\
\hline Etapa 7 & adotar procedimentos de coleta e mensuração de dados. \\
\hline Etapa 8 & $\begin{array}{c}\text { auditoria periódica dos dados sobre o desempenho de modo a evitar que eles se } \\
\text { tornem uma forma mais sofisticada de justificação da existência de um } \\
\text { programa/serviço. }\end{array}$ \\
\hline Etapa 9 & coletar e analisar informações sobre o desempenho. \\
\hline Etapa 10 & $\begin{array}{l}\text { adotar procedimentos de informação é a ligação necessária entre o desempenho e a } \\
\text { accountability. Obriga a disponibilização da informação em tempo hábil do } \\
\text { planejamento e do orçamento, cria incentivos para melhorias dos programas e ajuda } \\
\text { a construir apoio do ambiente externo. Ao se adotarem padrões de comunicação, } \\
\text { define-se quem deve receber a informação, com que freqüência e o que informar. }\end{array}$ \\
\hline Etapa 11 & $\begin{array}{l}\text { assegurar que exista uma ligação significativa entre a mensuração de desempenho e } \\
\text { os processos de tomada de decisões importantes para a organização. }\end{array}$ \\
\hline Etapa 12 & aperfeiçoar e rever de forma constante a mensuração de desempenho. \\
\hline
\end{tabular}

Fonte: PACE (2009)

A partir das etapas descritas no quadro 3, destaca-se alguns pontos relativos as peculiaridades das etapas. Na etapa 5 , ao se desenhar as medidas para acompanhamento do processo de ação previamente planejado, deve-se equilibrar medidas que enfatizem a qualidade e os impactos transformadores dos serviços, em detrimento de informações sobre inputs ou volumes. Já na etapa 7, algumas questões são colocadas por Pace (2009) a fim de que ao adotar os procedimentos sejam consideradas a necessidade de resposta para as seguintes perguntas: a) sobre informações necessárias - qual informação é necessária e com que freqüência? b) em relação aos métodos de coleta existentes - quais dados já são coletados? Em que grau eles atendem a nossas necessidades? Alguma coleta deve ser descontinuada? Qual nova informação é necessária? Quanto aos recursos disponíveis - quais os 
recursos disponíveis atualmente para coleta de dados? c) relativo às limitações quais limitações devem ser consideradas (fundos, tecnologia, privacidade)?

$\mathrm{Na}$ etapa 9 algumas questões devem ser respondidas diante da coleta e análise das informações. São elas: (a) os resultados esperados estão sendo alcançados? (b) Os dados de tendência mostram uma melhoria no desempenho ou há deterioração? (c) Como o desempenho se compara com os padrões, alvos ou desempenho de terceiros? (PACE, 2009). Por fim, Pace (2009) apresenta 11 questões que os gestores devem ter em mente a fim de aperfeiçoar e rever a mensuração do desempenho, são elas: (a) o que você espera que as medidas revelem? (b) as medidas estão cumprindo bem seu papel? (c) que problemas foram encontrados ao se tentar medir o desempenho? (d) são necessárias medidas adicionais? (d) algumas medidas são inúteis? (e) os dados são difíceis de serem obtidos? (f) muito caros de se obter? (g) os dados são difíceis de usar? (h) quais eventos no último exercício podem influenciar o desempenho corrente? (i) como podem ser melhorados os relatórios de desempenho? (j) quais mudanças devem ser implementadas na forma de coleta e análise e dos dados?

\subsection{PRINCIPAIS MODELOS DE AVALIAÇÃO DE DESEMPENHO}

\section{3.1 TABLEAU de Bord (TDB)}

O Tableau de Bord foi criado na França, na década de 30, por engenheiros que buscavam maior eficiência na produção (EPSTEIN; MANZONI, 1997). O TdB é considerado o primeiro modelo de avaliação de desempenho organizacional, e suas considerações são utilizadas ainda hoje, especialmente em organizações francesas (BOUGUIGNON ET AL., 2004).

O modelo faz uma metáfora com o painel de controle de um avião, no qual o piloto deve estar atento a vários comandos, assim como o gestor de uma instituição, que trabalha o tempo todo com muitos elementos. O TdB transforma a missão e visão do negócio em indicadores de desempenho (EPSTEIN; MANZONI, 1998).

Essa metodologia visa indicar ao gestor QUEM são os responsáveis por cada indicador; O QUÊ é relevante para a organização, ou seja, quais informações são necessárias; COMO proceder com tendências e acontecimentos não regulares; e 
QUANDO divulgar cada informação (LAUZEL, CIBERT; 1959 apud HOURNEAUX JR., 2005).

Rosa Jr. (2003) entende que o processo de desenvolvimento do Tableau de Bord deve ser realizado a partir das seguintes etapas:

$1^{\circ}$ : determinar os indicadores necessários e disponíveis, bem como quais serão utilizados;

$2^{\circ}$ : descrever o setor no qual se atua, e os objetivos e preocupações da gestão;

$3^{\circ}$ : preparar o projeto, no que tange ao seu contexto, pertinência, envergadura, escolha do setor alvo e da área piloro, recursos e responsabilidades;

$4^{\circ}$ : definir indicadores e seus parâmetros;

5\%: desenhar o Tableau de Bord, seus indicadores, visão, relatório e personalização;

$6^{\circ}$ : desenvolver um sistema de informatização de produção do Tableau de Bord e adaptá-lo aos sistemas existentes.

Basicamente, o Tableau de Bord é formado por indicadores derivados das diversas áreas da organização e do seu ambiente externo, com vistas a proporcionar ao gestor um controle das variáveis internas e externas (BOURGUIGNON ET AL, 2004; LEBAS, 1995).

Destaca-se que cada área ou departamento da organização pode ter seu próprio Tableau de Bord, com seus objetivos e indicadores próprios, porém sempre em consonância com os objetivos organizacionais. Dessa forma o modelo proporciona aos gestores uma visão global e simplificada de cada unidade organizacional, permitindo a tomada de decisão mais acertada já que informa o desempenho de cada unidade; além disso, faz com que cada departamento trabalhe em concordância com os objetivos da instituição. Trata-se de um modelo que permite certa descentralização, já que cada departamento pode trabalhar com seus próprios indicadores, mas sempre considerando a visão estratégica da organização (EPSTEIN; MANZONI, 1997).

$O \mathrm{TdB}$ tem grande ênfase financeira e seus indicadores não interagem muito entre si (KAPLAN; NORTON, 1997; BUSK ET AL, 2003), o que levou a sua baixa popularidade entre acadêmicos fora da França (BOURGUIGNON et al., 2004). Dentre as críticas ao modelo também estão: não parte de uma estratégia estabelecida, metas não são comparativas com outras empresas, foco operacional e não estratégico, visão limitada do todo (YOKOMIZO, 2009). 


\subsubsection{MODELO DE MARTINDELL}

O modelo de Martindell carrega o nome de seu proponente, Jackson Martindell, que em 1950, enquanto era presidente do American Institute of Management, descreve tal ferramenta com o intuito de promover uma análise completa das organizações. Segundo o autor, um modelo deve atender a cinco critérios: deve ser flexível, no que tange a sua aplicabilidade em qualquer tipo de administração e área de conhecimento; deve ser inteligível, quanto ao entendimento de questões organizacionais; deve permitir a comparação entre organizações (comparabilidade); deve possibilitar a mensurabilidade da qualidade da administração; e ter enfoque sistêmico, ou seja, deve considerar as inter-relações e a interdependência que ocorrem nas organizações (MARTINDELL, 1950).

O método prevê um quadro que propõe mensurar a pontuação de cada variável da organização, visando conhecer seu desempenho global, conforme o quadro 4 a seguir:

Quadro 4 - Variáveis para mensuração e avaliação da organização

\begin{tabular}{|c|c|}
\hline VARIÁVEIS & MÉDIA MÁXIMA \\
\hline Função econômica & 1.000 \\
\hline Estrutura organizacional & 500 \\
\hline Saúde dos Lucros & 600 \\
\hline Serviços para os acionistas & 700 \\
\hline Pesquisa e desenvolvimento & 800 \\
\hline Análise da diretoria & 800 \\
\hline Política fiscal & 1.000 \\
\hline Eficiência da produção & 1.100 \\
\hline Vigor das vendas & 1.300 \\
\hline Avaliação de executivos & 2.200 \\
\hline Total & $\mathbf{1 0 . 0 0 0}$ \\
\hline
\end{tabular}

Fonte: adaptado de Martindell (1950).

A fim de pontuar cada uma dessas variáveis, Martindell (1950) propõe mais de 300 perguntas. Segundo o autor do modelo, mensurar quantitativamente o desempenho de uma organização permite controlá-la de maneira mais efetiva, e aumentar as chances de realizar boa gestão. Tal modelo serve aos funcionários da organização e também aqueles que mantém relação com ela, como clientes, fornecedores, etc. 
O modelo de Martindell é pioneiro em estabelecer um enfoque quantitativo, e apresenta um avanço importante em relação ao modelo pioneiro, o Tableau de Bord: a abrangência de outras áreas, que não a financeira. Porém, é subjetivo em relação à atribuição de pontos a cada variável, o que dificulta a comparabilidade entre organizações, já que cada uma pode atribuir peso diferente a situações idênticas. Além disso, trata-se de uma opção que requer grande esforço para levantamento de informações (CORRÊA, 1986).

\subsubsection{MOdelo de AdMINISTRAÇÃo POR OBJetivos (APO)}

O Modelo de Administração por Objetivos (APO) foi criado por Peter Drucker, por volta de 1950, época em que a pressão econômica exigiu maior desempenho das organizações (LODI, 1974).

AAPO é descrita por Odiorne (1970), como sendo uma ferramenta que permite que gestores e subordinados identifiquem os objetivos organizacionais e responsabilidades de cada um nesse processo, ou seja, quais resultados cada um deve entregar. Dessa forma tem-se como controlar e guiar a organização bem como medir a entrega de cada funcionário, esperando-se assim controle e melhoria de desempenho, sendo essas as principais vantagens do modelo APO (DRUCKER, 1968).

Esse modelo auxilia no planejamento e controle das atividades organizacionais, e deve prezar, a priori, pelo estabelecimento de metas, depois pelo desenvolvimento de um plano de ação, uma revisão dos progressos e por ultimo a avaliação do desempenho (LODI, 1974).

Segundo Drucker (1968), não se deve colocar o lucro como principal objetivo da organização, pois o que realmente mantém a prosperidade da mesma é o equilíbrio entre suas áreas, bem como o equilíbrio entre objetivos de curto e longo prazo. Para ele, oito áreas-chave devem ser consideradas e mantidas em equilíbrio: posição no mercado, inovação, produtividade, recursos físicos e financeiros, rentabilidade, desenvolvimento dos gerentes, desempenho e desenvolvimento dos empregados e responsabilidade pública. 
Dentre as vantagens da APO está: as ações de todos os colaboradores estará sempre atrelada a algum objetivo específico, pode-se melhorar o desempenho individual e consequentemente global, motiva-se o funcionário (DAFT; MARCIC, 2004).

Quanto às desvantagens: não funciona bem em ambientes com mudanças constantes, com baixa relação entre empregado-empregador (DAFT; MARCIC, 2004).

\subsubsection{Modelo de BuChele}

Para Buchele (1962) conhecer apenas informações de caráter financeiro não era suficiente para orientar a organização. Por isso, na década de 70 , publica o livro Business Policy in Growing Firms, no qual descreve além do aspecto financeiro, outros que também são importantes para avaliar desempenho de organizações, como a coleta de informações adicionais, através, por exemplo, de entrevistas.

Para o autor, era imprescindível que médias e grandes organizações avaliassem além da questão financeira, a linha de produtos, bem como qual o posicionamento estratégico da organização no passado, no presente e no futuro; também deveria dar atenção aos diferentes departamentos, como os operacionais e de pesquisa e desenvolvimento, no que se refere a quesitos de engenharia, marketing, manufatura e outros; cuidar da alta administração, no que tange a identificar a capacidade da administração da cúpula, registrar aspectos da administração, e pensar na linha de sucessão; e sumarizar e avaliar a estratégia.

Segundo Buchele (1971), avaliar financeiramente a empresa permite conhecer índices vitais para a organização, porém focaliza somente o passado, e não o futuro, e revela apenas os sintomas de um possível problema, não suas causas. Já a análise departamental ajuda a ter uma idéia do todo, mas não permite uma integração das áreas. E a análise dos processos da alta cúpula, permite verificar o andamento do planejamento, controle, organização, assessoria e liderança, mas não permite a separação clara desses processos, e não integra a organização como um todo.

Nas colocações de Buchele fica clara a necessidade de se conhecer as perspectivas da empresa no passado, no presente e no futuro. Dessa forma é possível conhecer o desenvolvimento da organização ao longo do tempo, sua evolução ou reconhecer um possível retrocesso. 
Entre as vantagens do modelo de Buchele está a possibilidade da empresa se aperfeiçoar constantemente, bem como avaliar as ameaças e oportunidades e se preparar para elas, com inovação, desenvolvimento e novas estratégias administrativas.

Em relação às desvantagens tem-se: o modelo é simplificado, e não considera aspectos que são importantes, e também Buchele não deixa claro a forma como se deve implementá-lo (CORRÊA, 1986).

\subsubsection{Método de Avaliação de Desempenho Global (MADE-O)}

O Método de Avaliação de Desempenho Global (MADE-O) desenvolvido por Corrêa, em 1986, é baseado em duas vertentes, sendo elas abrangência e tempo. Em relação à abrangência, o autor advoga que um modelo deve necessariamente medir o desempenho em todas as áreas da empresa, ou seja, na área de recursos humanos, produção, finanças, entre outras. Já em relação ao tempo, o autor ressalta que a medição é válida para um determinado momento.

Para Corrêa (1986), o primeiro passo para se desenvolver um modelo de avaliação de desempenho organizacional é descrever a empresa, seu ambiente, sua cultura, missão, objetivos, estrutura, estratégia, bem como os eventos marcantes. Posteriormente deve-se definir os módulos que serão avaliados; esses serão apontados considerando as características da empresa. $O$ autor propõe a aplicação de dez módulos que podem ser utilizados em qualquer tipo de organização para a avaliação de desempenho de uma organização: Econômico-financeiro; Operacional; Recursos humanos; Satisfação dos usuários-clientes; Inovação tecnológica; Adaptação/ambiente; Avaliação técnica; Clima organizacional; Benefícios sociais e Potencialidade gerencial.

O terceiro passo é definir indicadores para cada módulo; esses tem o papel de trazer conceitos mensuráveis a cada módulo, permitindo que esses sejam medidos e consequentemente avaliados. Ressalta-se que esses indicadores são hierarquizados, de acordo com sua relevância para o respectivo módulo, facilitando a avaliação.

O próximo passo é definir padrões, ou seja, procura-se exemplos ótimos de indicadores, nacionais e internacionais, que serão tidos como padrão, para 
posteriormente serem comparados aos resultados obtidos (avaliação), finalizando o processo de desenvolvimento do modelo.

A figura 1 a seguir exprime o passo-a-passo para a criação de um Modelo de Avaliação do Desempenho Organizacional.

Figura 1 - Fase Conceitual-modelagem MADE-O

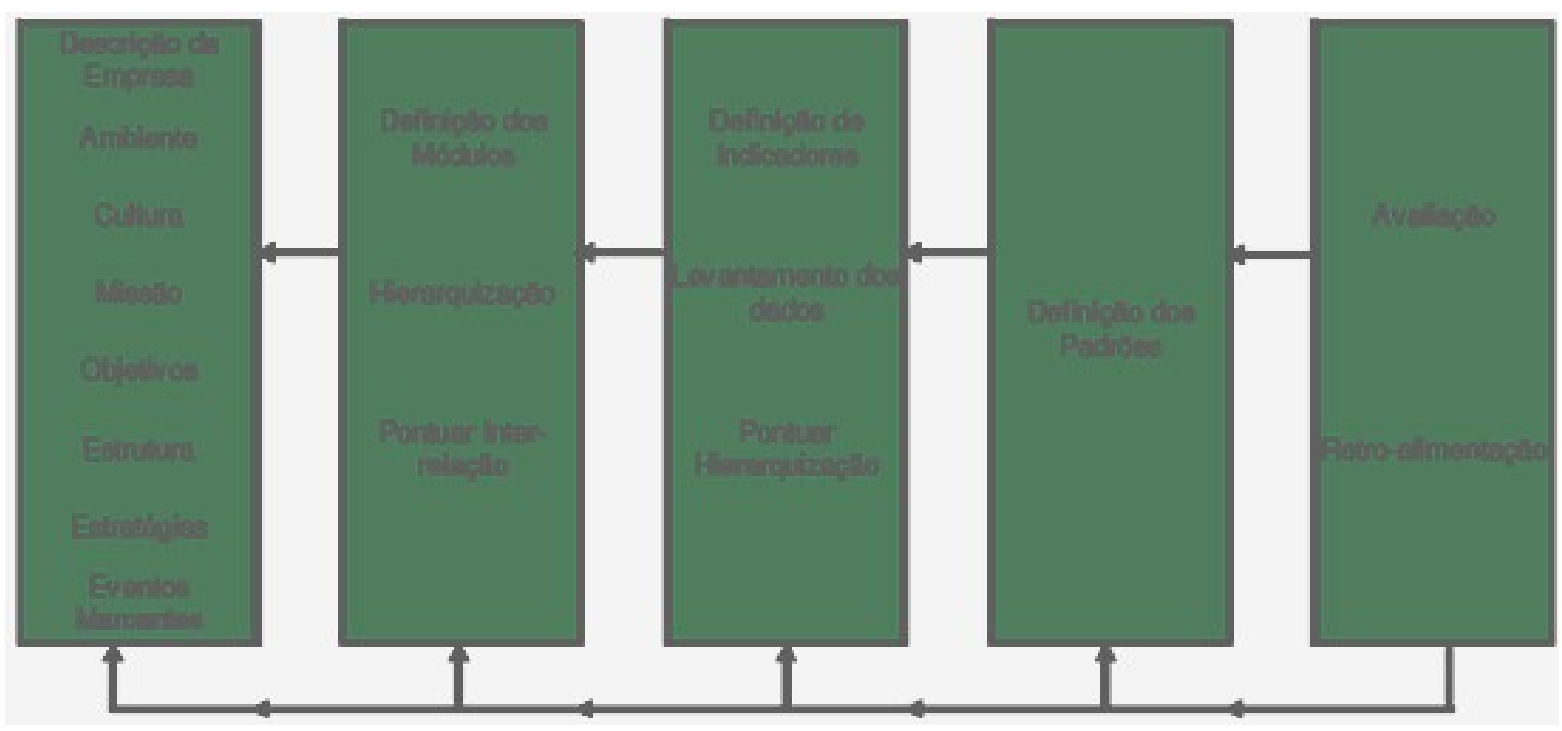

Fonte: Corrêa (1986)

Trata-se de um modelo versátil e aplicável a qualquer organização, indicando de modo sucinto e lógico o passo-a-passo da criação de um modelo de análise de desempenho que considera o ambiente externo e seus impactos na organização, bem como a finalidade da organização (se o objetivo é financeiro ou qualquer outro). Outros aspectos positivos do MADE-O são a sua abrangência e flexibilidade, pois esse pode ser adaptável a qualquer realidade. Além disso propõe uma matriz de responsabilidade que permite saber quem é responsável por qual atividade.

Cabe ressaltar que a flexibilidade que o modelo permite pode ser também um problema, visto que pode-se encontrar dificuldade no momento de definição de módulo e indicadores, bem como na hierarquização dos mesmos. Mais especificamente em relação a hierarquização dos indicadores, destaca-se que pode ocorrer a priorização de alguns indicadores, o que pode ser perigoso, para se alcançar o objetivo do modelo é essencial que todos os módulos sejam respeitados e idealmente hierarquizados. 


\subsubsection{Prêmio Nacional da Qualidade (PNQ)}

O Prêmio Nacional da Qualidade foi desenvolvido no Brasil pela Fundação Nacional da Qualidade (FNQ), no ano de 1991. Trata-se de um prêmio em nível nacional, muito semelhante ao Prêmio Europeu de Qualidade (1988), e fortemente baseado no Malcom Baldridge National Quality Award (1987) (FNQ, 2015).

O PNQ considera que contribui para o aumento da competitividade das empresas em 3 aspectos: auxilia a melhoria das prática de gestão, do desempenho e da capacitação das organizações; facilita a comunicação e o compartilhamento das melhores práticas entre todos os tipos de organizações; serve como modelo de referência para melhorar o atendimento e a aplicação das práticas de gestão.

A premiação visa gerar maior reconhecimento público à excelência da gestão das organizações com sede no Brasil; bem como estimular o desenvolvimento do país, além de promover a melhoria da qualidade da gestão e o aumento da competitividade das organizações. O ciclo de avaliação do PNQ reconhece as organizações referências em excelência da gestão no Brasil e é realizado anualmente (FNQ, 2015).

O PNQ conta com oito critérios de avaliação, sendo eles liderança, estratégia e planos, clientes, sociedade, informações e conhecimento, pessoas, processos e resultados, conforme figura 2 abaixo. Seu processo de implementação, também descrito pelo PNQ (2015), conta inicialmente com um diagnóstico. Nessa etapa a organização vai baixar um software chamado E-MEG que possibilita à organização ao responder algumas questões, conhecer o nível de maturidade de sua gestão. Essa fase é importante pois existem várias categorias de premiação, e a empresa deve conhecer em qual delas irá se inscrever. 
Figura 2 - Modelo de excelência da gestão PNQ

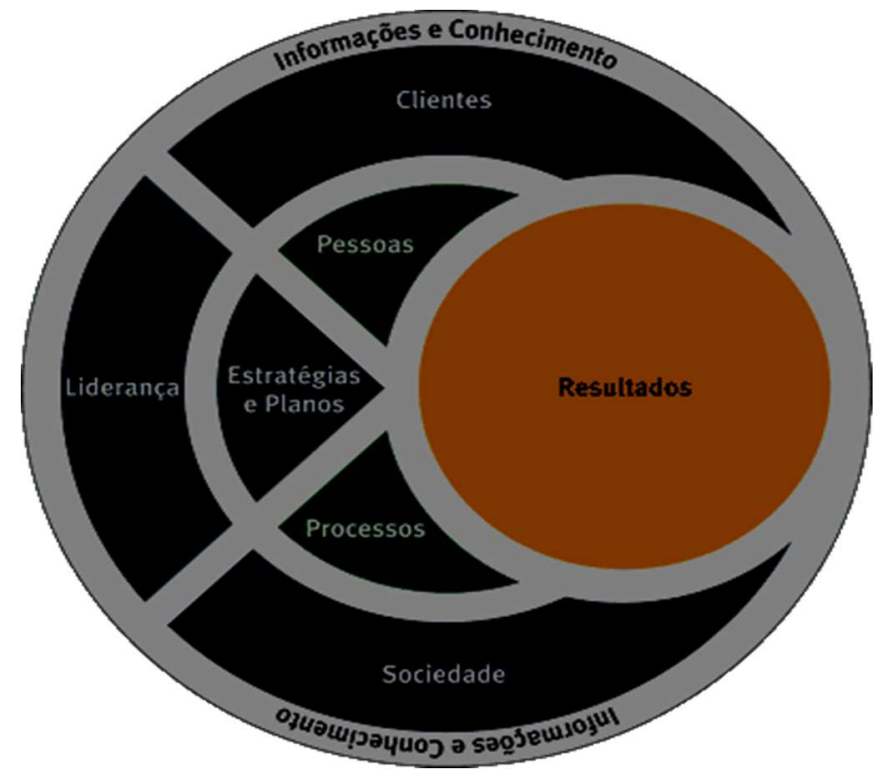

Fonte: FNQ (2015).

O próximo passo é se filiar a Fundação Nacional da Qualidade (FNQ), instituição responsável pelo Prêmio, bem como realizar curso de interpretação dos Critérios de Excelência (Setor de Qualidade) e estudar os Cadernos de Implementação, a fim de apresentar o programa aos participantes.

Na sequência é realizada a autoavaliação, na qual a organização reporta um relatório à $F N Q$, e essa por sua vez realiza a avaliação e premiação das melhores práticas.

O PNQ sobre críticas pelo fato de englobar critérios oriundos da escola da Administração da Qualidade Total, por não associar as práticas aos objetivos estratégicos da organização; não capturar dimensões de longo prazo e não considerar a criação de valor; e apresentar muitos indicadores (KAPLAN; NORTON, 1997; YENIYURT, 2003). 


\subsubsection{Strategic Measurement Analysis and Reporting Technique (SMART)}

O SMART foi desenvolvido pelo Wang Laboratories Inc., considerando o modelo proposto por Drucker, em 1954, denominado Modelo de Administração por Objetivos (APO). O SMART tem o intuito de proporcionar indicadores de desempenho que ajudassem no controle administrativo e consequentemente na boa gestão organizacional (CROSS; LYNCH, 1988).

Esse modelo também parte dos objetivos organizacionais, que devem ser ditados pela alta administração e transmitidos para todas as unidades do negócio, a fim de que sejam alcançados (KENNERLEY; NEELY, 2002). Se ttraduz na representação gráfica piramidal, composta por quatro níveis, que atentam para a qualidade, entrega, tempo de processo, custo, satisfação do consumidor, flexibilidade, produtividade, medidas de mercado, medidas financeiras e visão do negócio buscando que todas essas variáveis estejam condizentes com as medidas organizacionais, para que os objetivos sejam alcançados interna e externamente (CROSS; LYNCH, 1988).

Dentre as vantagens do modelo SMART está a capacidade de associar objetivos estratégicos a indicadores operacionais (GHALAYINI; NOBLE, 1996).

\subsubsection{Balanced Score CARd (BSC)}

O Balanced Score Card (BSC) é um conjunto balanceado de metas, indicadores, que representam a visão, estratégia organizacionais, e as transformam em metas com o objetivo de garantir o alcance das mesmas (KAPLAN, NORTON, 2000).

Antes ele era um modelo de mensuração de desempenho, depois foi considerado um sistema de comunicação e alinhamento estratégico, e atualmente é visto como sistema de gestão estratégica - isso seria uma estratégia de novo uso desse modelo.

Sua finalidade é comunicar, esclarecer, compartilhar as estratégias e avaliar o desempenho. Basicamente o BSC traduz a visão estratégica em objetivos e indicadores, pois "se não é possível medir, não é possível gerenciar". Em suma, tem 
o intuito de sair do abstrato, convertendo a estratégia em metas palpáveis (KAPLAN, NORTON, 2004).

As empresas podem adotar o BSC para buscar consenso com relação a estratégia; comunicar a estratégia a toda organização; alinhar as metas de cada área e pessoa ao objetivo maior; associar os objetivos estratégicos com metas de longo prazo e orçamentos anuais; identificar e alinhar as iniciativas estratégicas e realizar revisões estratégicas sistemáticas e periódicas.

O BSC trabalha sob quatro perspectivas, sendo elas: financeira, interna, cliente e aprendizado e crescimento. Cada uma delas possuem objetivos, indicadores, metas e ações.

A perspectiva financeira representa o potencial de crescimento, medindo os recursos necessários para desenvolver ou liberar novos produtos. Dentre os indicadores dessa perspectiva estão: ROI, EVA, visão dos acionistas, crescimento de receitas, margens operacionais, capital de giro, endividamento, entre outros.

A perspectiva dos interesses visa traduzir em objetivos e metas as expectativas do cliente, portanto, alguns de seus indicadores são: lealdade, pontualidade nas entregas, visão que eles tem da empresa, prazo, qualidade, desempenho, satisfação, retenção de clientes, vantagem pro cliente, entre outras.

Em relação aos processos internos, essa perspectiva visa a melhoria de processos internos. Nesse módulo os gestores identificam processos críticos que são indispensáveis para alcançar os objetivos da empresa, de seus acionistas e de seus clientes. Dentre os indicadores estão: custo, qualidade dos processo tempo de ciclo, inovação, serviços pós-venda, operações, entre outros.

A perspectiva de crescimento e aprendizado diz respeito às forças que vão mover a empresa no sentido de criar a infraestrutura que a empresa precisa para alcançar os objetivos definidos nas outras perspectivas. São indicadores desse módulo: competência dos funcionários, sugestões implementadas, receita por funcionário, grau de satisfação dos funcionários, criação de capital intelectual, infraestrutura necessária para produzir conhecimentos, motivação, desenvolvimento e engajamento. 
Figura 3 - Modelo BSC

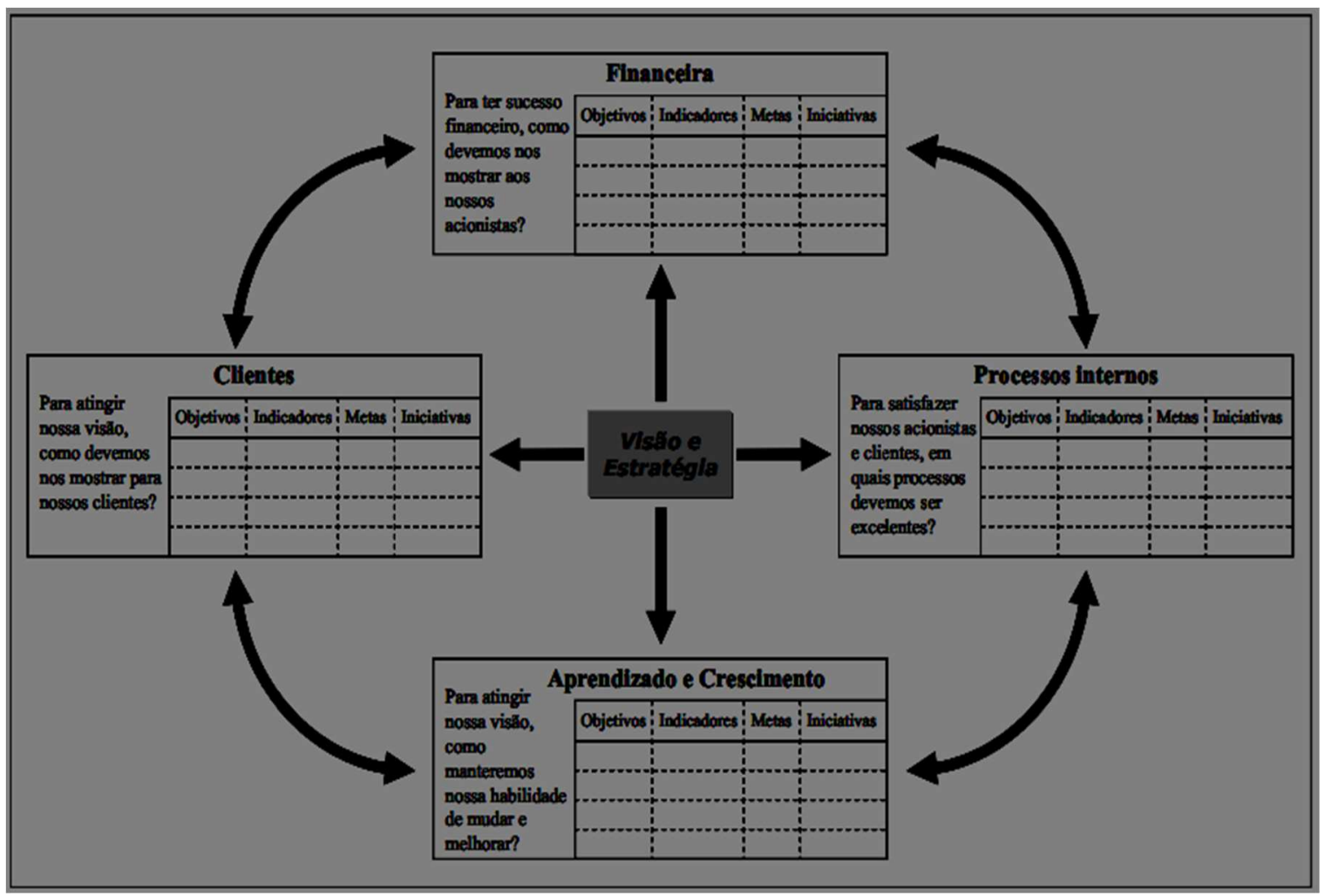

Fonte: Adaptado de Kaplan e Norton (1997, p. 72)

Destaca-se que não há limite de indicadores, porém deve-se cuidar para esses sejam possíveis de serem implementados. Cabe salientar ainda que cada empresa deve elaborar seus próprios indicadores, de acordo com sua estratégia.

Beber, Ribeiro e Kliemann Neto (2006) apontam como dificuldades na implementação do BSC a falta de comprometimento dos executivos e alta administração; falta da prática do aprendizado contínuo; falta de uma estratégia definida (ou bem comunicada); e também a utilização do BSC sem se basear na estratégia.

Dentre as críticas ao modelo estão: pouco foco no ambiente externo; necessidade de customização do BSC para atender os objetivos específicos dentro da realidade de cada empresa; e dificuldade de se definir os objetivos e indicadores não financeiros (MARINHO; SELIG, 2000).

Dentre os pontos favoráveis do BSC destaca-se que esse permite facilidade de implementação; tem amplo uso e disseminação; faz relação com a visão e a estratégia 
da empresa; e facilita a visualização e monitoramento que divulga os objetivos organizacionais (BEBER; RIBEIRO; KLIEMANN NETO, 2006).

\subsubsection{QuANTUM de MEdiçÃo de Desempenho (MQMD)}

Hronec, em seu livro Sinais Vitais, publicado na década de 1990, apresenta o Modelo Quantum de Medição de Desempenho (MQMD), baseado em três medidas de desempenho: custo, qualidade e tempo. O custo mede o lado econômico, a qualidade mede a excelência do produto ou serviço oferecido, e o tempo mede a excelência do processo (RESENDE, 2003; NETTO, 2007), conforme apresentado no quadro 5 abaixo, de Hronec (1994).

Quadro 5 - Matriz Quantum de medição de desempenho

\begin{tabular}{|c|c|c|c|}
\hline & Valor & \multicolumn{2}{|c|}{ Serviço } \\
\hline Níveis/medidas & Custo & Qualidade & Tempo \\
\hline Organização & $\begin{array}{l}\text { Financeiro } \\
\text { Operacional } \\
\text { Estratégico }\end{array}$ & $\begin{array}{c}\text { Empatia } \\
\text { Produtividade } \\
\text { Confiabilidade } \\
\text { Credibilidade } \\
\text { Competência }\end{array}$ & $\begin{array}{c}\text { Velocidade } \\
\text { Flexibilidade } \\
\text { Responsabilidade } \\
\text { Maleabilidade }\end{array}$ \\
\hline Processo & $\begin{array}{c}\text { Inputs } \\
\text { Atividades }\end{array}$ & $\begin{array}{l}\text { Conformidade } \\
\text { Produtividade }\end{array}$ & $\begin{array}{c}\text { Velocidade } \\
\text { Flexibilidade } \\
\text { Responsabilidade } \\
\text { Maleabilidade }\end{array}$ \\
\hline Pessoas & $\begin{array}{c}\text { Remuneração } \\
\text { Desenvolvimento } \\
\text { Motivação }\end{array}$ & $\begin{array}{l}\text { Confiabilidade } \\
\text { Credibilidade } \\
\text { Competência }\end{array}$ & $\begin{array}{c}\text { Responsabilidade } \\
\text { Maleabilidade }\end{array}$ \\
\hline
\end{tabular}

Fonte: Hronec (1994).

O MQMD busca avaliar o "valor" para o cliente, considerando o custo e a qualidade do produto ou serviço; e apresenta quatro elementos em sua estrutura: os elementos geradores são aqueles que possibilitam o desenvolvimento de uma estratégia voltada para a missão organizacional; os facilitadores são aqueles que oferecem apoio na implementação de medidas, no processo de mudança e na procura de melhores práticas; o processo consiste na definição de metas, monitoramento de atividades-chave, definição de medidas de processo e sua implementação; e melhoria contínua, que trata do feedback e ajustes de estratégia e medidas de desempenho (HRONEC, 1994). 
A figura 4 a seguir traz a representação gráfica do modelo Quantum:

Figura 4 - Modelo Quantum de Avaliação de Desempenho

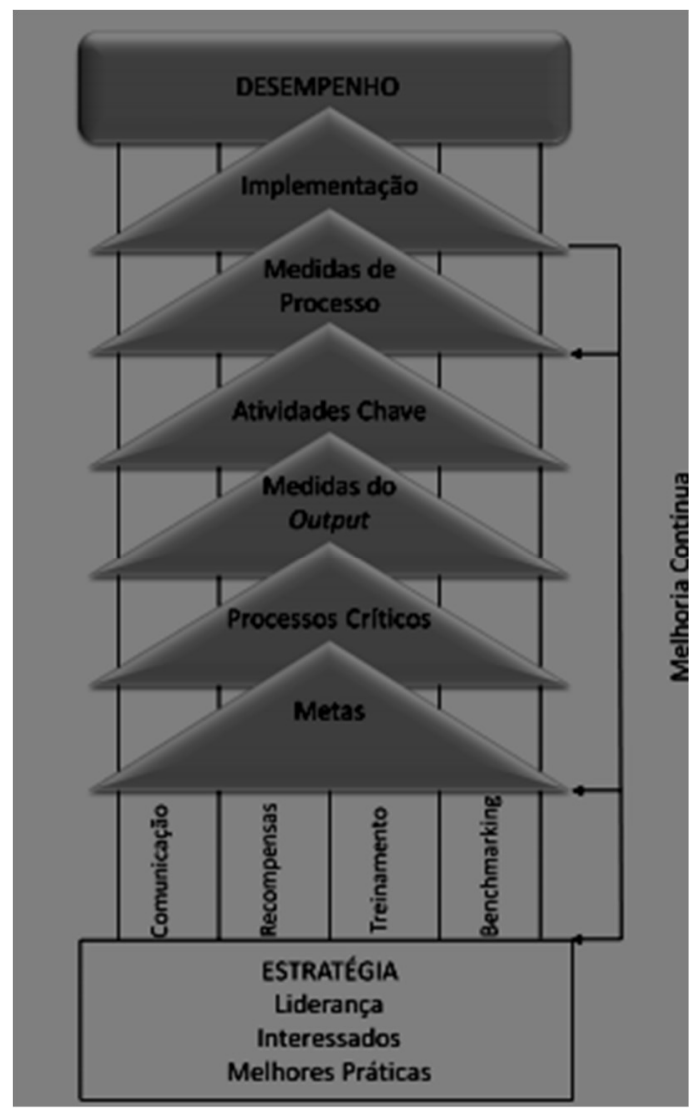

Fonte: adaptado de Hronec (1994).

Dentre as principais vantagens do MQMD, estão: suas medidas de desempenho contemplam os níveis organizacional, de processo e de pessoas; considera a satisfação os stakeholders; e proporciona feedback para melhoria contínua. Já em relação ás suas desvantagens: não integra áreas da organização; falta de agilidade para obtenção de informações, e falta de clareza dos indicadores (NETTO, 2007).

\subsubsection{SKANDIA NAVIGATOR}

Não se pode falar sobre o modelo de avaliação de desempenho Skandia Navigator, sem antes discorrer sobre o Capital Intelectual $(\mathrm{Cl})$. Segundo Edvinsson e Malone (1998) Cl designa de raízes ocultas do valor. Constitui-se de informações 
complementares e não subordinada às informações financeiras. É um capital não financeiro e representa a lacuna oculta entre o valor de mercado e o valor contábil.

É a composição de capital humano e o capital estrutural, de acordo com Edvinsson e Malone (1998, p. 10). A definição de Capital Humano, segundo os autores, é composta do conhecimento, da experiência, do poder de inovação e da habilidade dos funcionários de uma companhia para realizar as tarefas do dia-a-dia. Inclui também os valores, a cultura e filosofia da empresa. O capital humano não pode ser de propriedade da empresa. Stewart (1998) acrescenta que o capital intelectual é o responsável por proporcionar vantagem competitiva.

O Capital Estrutural são os equipamentos de informática, os softwares, o bancos de dados, as patentes, as marcas registradas e todo o resto da capacidade organizacional que apoia a produtividade dos funcionários, tudo que permanece no escritório quando os funcionários vão para casa. O capital estrutural também inclui o capital dos clientes, o relacionamento desenvolvido com os principais clientes. Ao contrário do capital humano, capital estrutural pode ser possuído e, portanto, negociado.

Reforçando o pensamento de Edvinsson e Malone (1998) citam que o capital estrutural pertence à empresa como um todo, podendo ser reproduzido e dividido.

O pioneiro a tratar sobre $\mathrm{Cl}$ foi Leif Edvinsson, que iniciou a criação do primeiro Relatório Anual de Capital Intelectual do Mundo em 1994, com informações financeiras e não financeiras restritas ao público interno, inspirando o desenvolvimento desde então em métricas do $\mathrm{Cl}$ (identificar, mensurar, monitorar e gerenciar os componentes do Cl). Já em 1995, a Skandia AFS, uma companhia de seguros e de serviços financeiros na Escandinávia, publicou o primeiro relatório balanceado ao público externo (visualizando o $\mathrm{Cl}$ ), apresentado como suplemento ao relatório financeiro, de acordo com o livro do Edvinsson e Malone (1998).

A institucionalização do $\mathrm{Cl}$ ocorreu em 1996 no Workshop on "The Reporting of Intangible Assets", na qual a recomendou-se a publicação de suplementos aos relatórios financeiros, indicando a capacidade de renovação e desenvolvimento das empresas, utilizando o modelo Skandia Navigator como benchmarking.

Em 1997, juntamente com Michael S. Malone, foi lançado um dos primeiros livros sobre o $\mathrm{Cl}$, em resposta às demandas da economia do conhecimento e a constatação do paradoxo do valor contábil das organizações em contraponto com o 
investimento em Cl. Podia-se comprovar que o valor de mercado de várias empresas era muito superior ao seu valor contábil, notou-se a necessidade de uma contabilidade do futuro, pois o modelo tradicional de contabilidade não tem conseguido acompanhar a revolução do mundo dos negócios.

O objetivo do trabalho com o $\mathrm{Cl}$ no modelo Skandia Navigator é o de visualizar e concretizar os ativos que impulsionam o desempenho, que criam pré-requisitos para competitividade no longo prazo. A partir dessa estratégia, pode-se determinar fatores de sucesso a serem maximizados (financeira, cliente, processo, renovação e desenvolvimento e, uma área compartilhada com as demais, a humana). Essa cinco áreas combinadas criaram o modelo holístico para o preparo de relatórios denominada de navegador, por isso o nome de Skandia Navigator.

Figura 5 - Visual gráfico do modelo Skandia Navigator

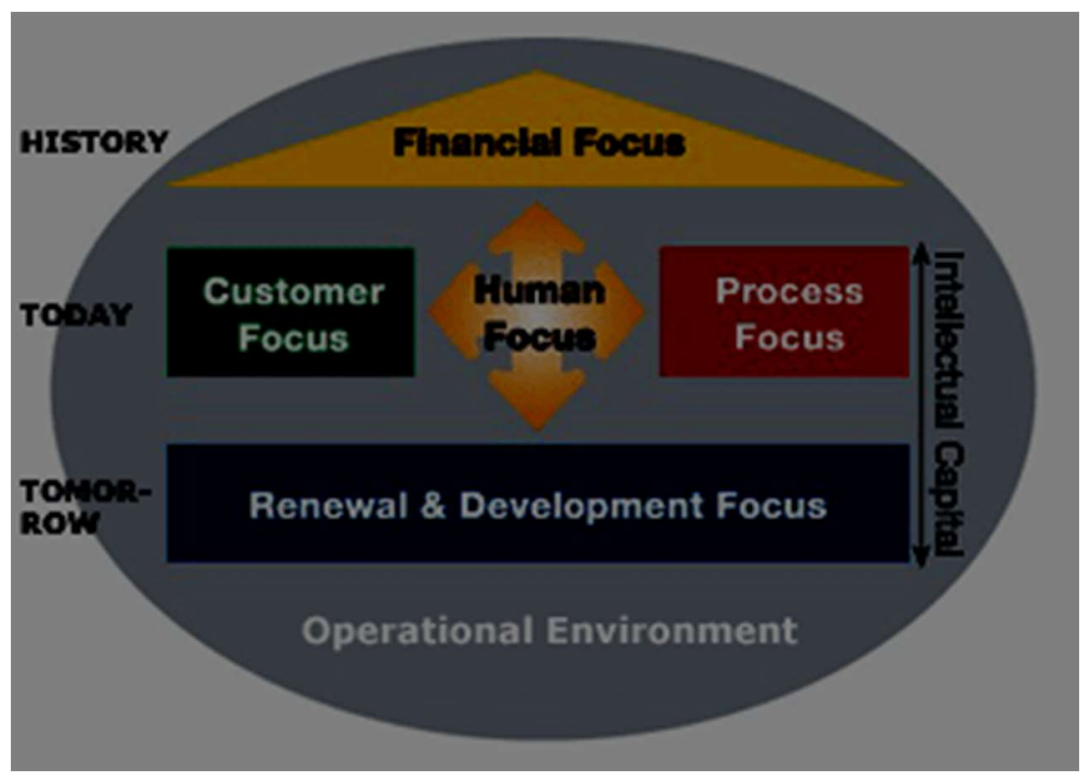

Fonte: Disponível em:

<http://www.valuebasedmanagement.net/methods_skandianavigator.html>.

Para facilitar a evolução do modelo dentro da organização, a empresa criou um guia em seis passos para a criação de $\mathrm{Cl}$, que são: 1) Missionária: conscientizando e compartilhando uma compreensão da busca de valores; 2) Avaliação: mensuração/métricas equilibradas para o desenvolvimento do navegador e publicação do primeiro suplemento de $\mathrm{Cl}$, incluindo a função de controller de $\mathrm{Cl}$, com a incumbência de alinhar a avaliação do $\mathrm{Cl}$ com o sistema contábil da empresa; 3) 
Liderança: entendimento do desenvolvimento dos diferentes componentes do $\mathrm{Cl}$ (humano e estrutural); 4) Tecnologia de informação: usar as TIC (Tecnologias de informação e comunicação) para identificar e dividir conhecimento de maneira eficaz; 5) Capitalização: criar mais valor financeiro das capacidades e ativos intangíveis; 6) Futuriza: criar o futuro e ter o conceito futuro como ativo. Foram necessários cinco anos para que este guia fosse elaborado.

\subsubsection{SIGMA SUSTENTABILIDADE}

A palavra SIGMA é um acrônimo que significa Susteinability Integrated Guidelines for Management. Trata-se de um modelo de avaliação de desempenho organizacional apresentado em 1999 pela British Standards Institution, cujo intuito é incorporar a sustentabilidade na gestão, realizando esforços no sentido de aprimorar a gestão socioambiental das organizações (GUIMARÃES, 2013).

Esse modelo é estruturado a partir do conceito de accountability, que remete à ideia de transparência, responsividade e conformidade; e baseia-se no princípio de gestão holística da empresa, considerando cinco diferentes tipos de capital que refletem na organização como um todo: humano, social, financeiro, manufaturado e natural.

Basicamente o SIGMA engloba aspectos ambientais, sociais e econômicos, advindos do conceito do Triple Bottom Line, de John Elkington, elaborado nos anos 90; e ainda acrescenta duas outras vertentes, relacionadas à aspectos financeiros e de infra-estrutura. Tudo isso com vistas a alcançar melhoria da performance por meio de ações e planejamentos alinhados à sustentabilidade.

O modelo SIGMA, representado pela figura 6 a seguir, é formado por cinco capitais, sendo eles: Capital Natural, representado por ecossistemas e recursos naturais; Capital Social, que diz respeito às relações e estruturas sociais; Capital Humano, que abrange aspectos como saúde, conhecimentos e motivações das pessoas que compõem a organização; Capital Manufaturado, que são os ativos fixos; e Capital Financeiro, representado pela riqueza dos demais capitais (GUIMARÃES, 2013). 
Figura 6 - Os princípios norteadores do modelo SIGMA

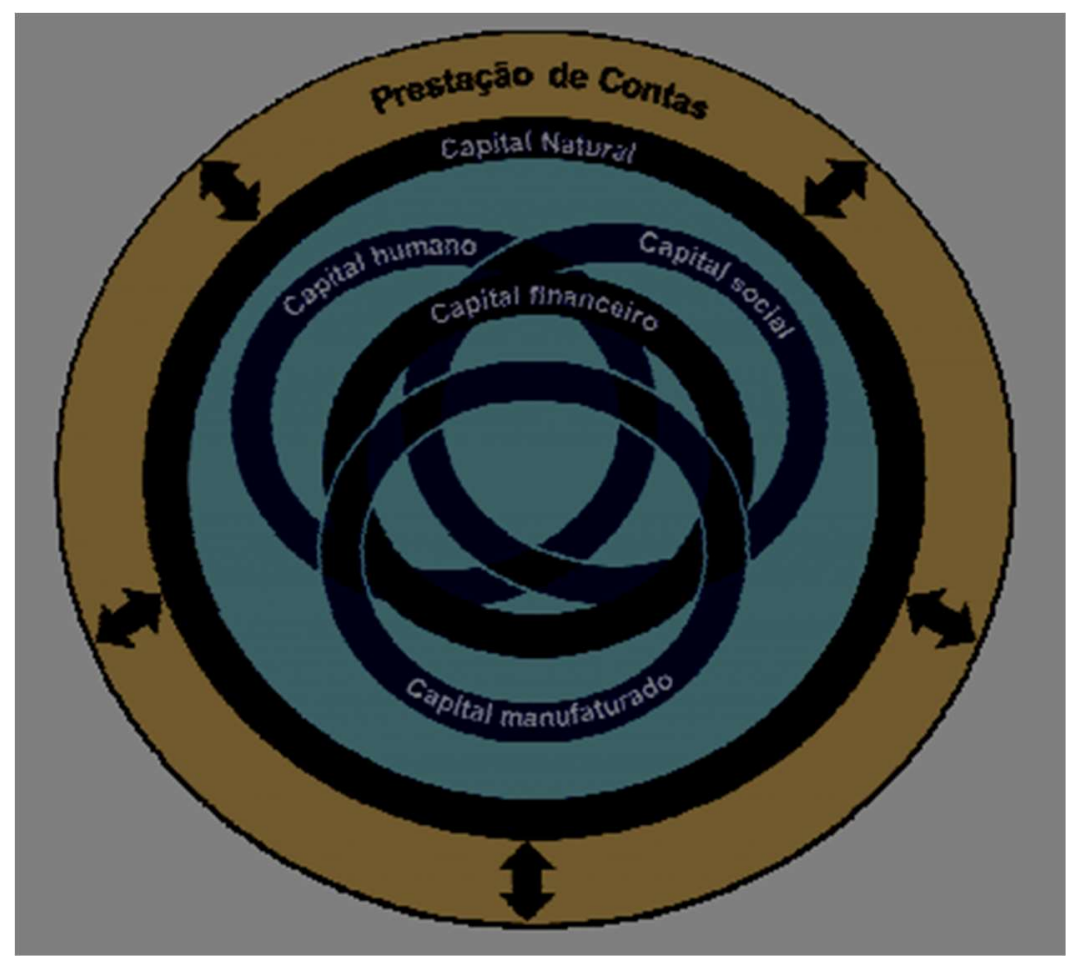

Fonte: Sigma Project (2003)

Segundo Guimarães (2013), o modelo não se destina para fins de certificação, mas acredita que auditoria é um importante componente da credibilidade.

Em relação a operacionalização do modelo, essa acontece em quatro etapas a fim de proporcionar seu gerenciamento: a primeira etapa diz respeito a liderança e visão, que representa o comprometimento da alta direção, revisão da missão, visão e princípios da organização, comunicação e treinamento e mudança de cultura (mudança rumo à sustentabilidade). A segunda etapa é o planejamento, na qual acontece a revisão da performance, a análise de adequação legal ou regulamentar, revisão de ações impactos e resultados e o planejamento estratégico e planejamento tático.

A próxima etapa é a entrega, representada pela mudança de administração que ocorre, implantação dos programas de gerenciamento, controles internos, e influência externa. E por fim, a quarta etapa, chamada monitoramento, visa revisar, mensurar, auditar, retro-alimentar o processo (GUIMARÃES, 2013). 
Apesar de sua proposta inovadora, visando integrar conceitos de sustentabilidade a gestão organizacional, o SIGMA possui número de publicações científicas limitado, além de não ser amplamente difundido em empresas, principalmente naquelas que não visualizam o capital natural como importante aspecto de sua atuação (GIÃO, GOMIDES, PICCHIONI, CORREAA, OLIVEIRA JUNIOR, 2010).

\subsubsection{Integrated Performance Measurement System (IPMS)}

O modelo Integrated Performance Measurement System (IPMS) foi proposto por Bititci et al. (1998a; 1998b), que entendem que as organizações têm quatro níveis de estrutura de controle que interagem entre si, são elas os negócios, as unidades de negócios, os processos de negócios e as atividades. Além disso, cada um desses níveis de estrutura deve considerar quatro elementos: os requerimentos dos stakeholders, monitoramento externo, objetivos e medidas de desempenho, conforme sugere a figura 7 abaixo proposta pelos autores: 
Figura 7 - Modelo Integrated Performance Measurement System (IPMS)

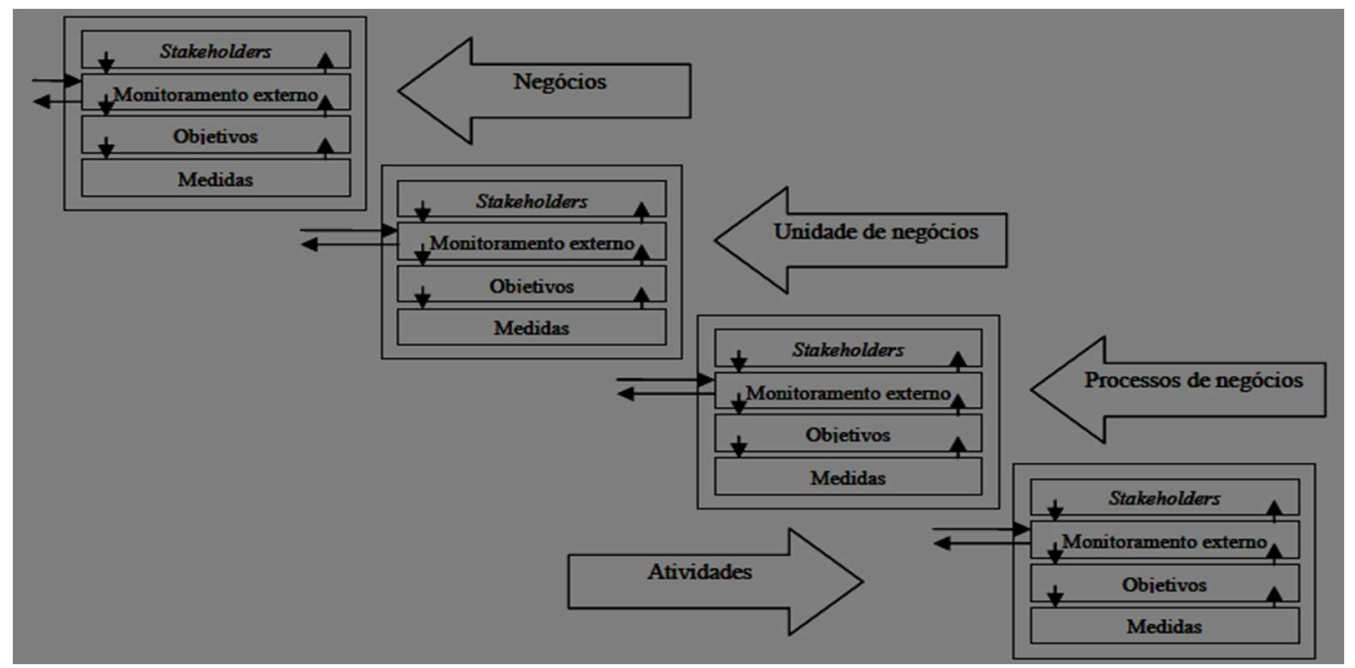

Fonte: Bititci et al. (1998a; 1998b).

Basicamente cada nível da estrutura deve reconhecer e entender o que querem os stakeholders; monitorar sua posisção frente aos concorrentes, bem como conhecer práticas benchmarking a fim de identificar necessidades de melhoria e desenvolvimento; estabelecer objetivos e metas; monitorar e rever os objetivos estabelecidos por meio de relatórios de desempenho; e transmitir esses objetivos para todos os níveis organizacionais (BITITCI ET AL., 1998b).

Dentre os pontos positivos do IPMS está: não envolve somente alta administração ao tratar de avaliação de desempenho; permite uma visão global do sistema; estabelece metas a partir das necessidades dos stakeholders e das práticas benchmarking, garantindo a consideração de aspectos externos a organização (CARNEIRO DA CUNHA, 2011).

Em relação aos aspectos negativos, Carneiro da Cunha (2011) coloca: pode existir dificuldade para operacionalizar o modelo; e o IPMS não considera a necessidade de avaliação constante da organização.

\subsubsection{Value Explorer (VE)}

Segundo Rocha (2012) o Value Explorer (VE) foi criado pela KPMG, ao identificar a grande necessidade de se gerir conhecimento, por isso trabaklha com a ideia de capital intectual. O VE basicamente pretende valorar financeiramente os recursos intangíveis, como ativos e doações, hablidades, conhecimento tácito, valores 
coletivos e normas, tecnologia e conhecimento explícito, processos básicos e de gestão (ANDRIESSEN; TISSEN, 2000).

Para tanto, inicialmente sugere que se identifique o capital intelectual, ao fazer uma lista das principais competências da organização; posteriormente deve-se avaliar o valor de cada competência, com o auxílio uma lista de verificação; depois faz-se uma avaliação do capital intectual através da atribuição de uma parcela dos ganhos esperados da organização; faz-se também uma lista de recomendações à gerência sobre como melhorar o valor do seu capital intelectual e por fim cria-se um relatório para gestão utilizando painel de valores (dashboard) (ROCHA, 2012).

O VE é bastante simples e prático, permite identificar as competências centrais da organização, direciona a tomada de decisão estratégica, prioriza ativos intangíveis, e utiliza linguagem compatível com termos financeiros. Dentre as dificuldades de utilização estão: dependência de dados subjetivos, e necessidade de análise detalhada dos valores coletados (NETTO, 2007).

\subsubsection{Performance Prism (PP)}

O modelo Prisma de Desempenho entende que um modelo de avaliação de desempenho deve buscar antes de mais nada entender o que se quer medir e qual a melhor forma de fazar isso (NEELY ET AL., 2000).

O Prisma considera cinco perspectivas: satisfação dos stakeholders, contribuição dos stakeholders, estratégias, processos e capacidades. Parte do princípio de que a organização deve satisfazer o stakeholder, podendo atender qualquer tipo de organização, mesmo aquelas sem fins lucrativos.

A figura 8 a seguir expressa graficamente o modelo: 
Figura 8 - Modelo Prisma

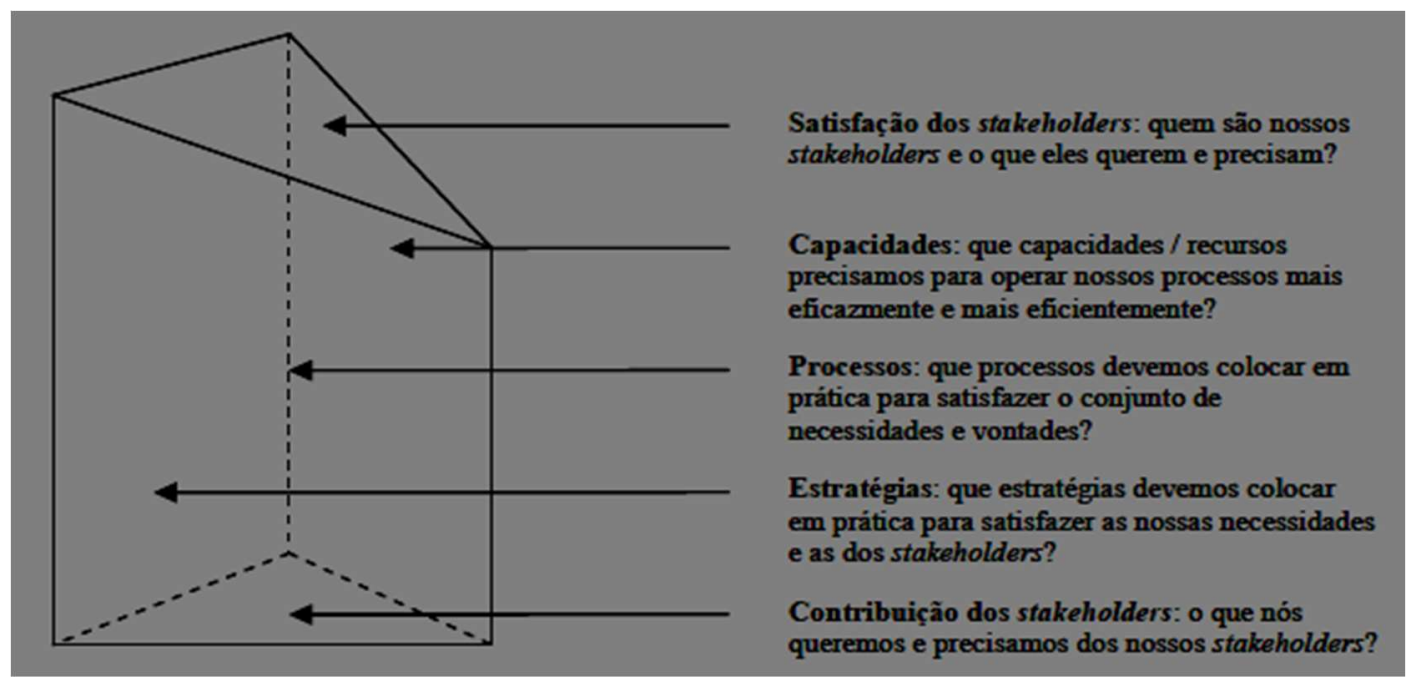

Fonte: Neely et al. (2001).

\subsection{FUNDAMENTOS DO COOPERATIVISMO}

Uma cooperativa é uma associação autônoma de pessoas, que se unem, voluntariamente, para satisfazer suas aspirações e necessidades econômicas, sociais e culturais comuns, através de uma empresa de propriedade coletiva, que é constituída para prestar serviços aos cooperados (PINHO, 1977).

Pinho (1977) destaca que as cooperativas são uma instituição sem fins lucrativos, cujas sobras líquidas retornam aos associados, proporcionalmente às suas operações realizadas com a cooperativa; regida pelo princípio da igualdade de direitos e obrigações dos cooperados, independente do número de cotas parte integralizadas pelo associado; sendo o cooperado usuário e empresário (dono da cooperativa) ao mesmo tempo.

Em linhas gerais, esse tipo de sociedade possui fins econômicos, mas não lucrativos, tem forma e natureza jurídica própria e é constituída para prestar serviços aos cooperados. Trata-se de uma instituição de dupla natureza, que preza por questões econômicas e sociais de seus cooperados, sendo esses donos e usuários da cooperativa concomitantemente.

Ao longo da história do cooperativismo, desde a primeira cooperativa reconhecida na literatura, Rochdale, passando pela criação em 1895 da Aliança Cooperativa Internacional, até a formação da Organização das Cooperativas 
Brasileiras, foram sendo alterados os princípios que regem a atuação das cooperativas (CANÇADO, 2004; SOUSA et al., 2014). O quadro 6 apresenta um resumo de tais princípios de forma cronológica, onde destacou-se os itens que se mantiveram no decorrer da evolução do tema.

Quadro 6 - Evolução dos Princípios Cooperativistas

\begin{tabular}{|c|c|c|c|}
\hline \multirow{2}{*}{$\begin{array}{l}\text { Estatuto de } 1844 \\
\text { (Rochdale }\end{array}$} & \multicolumn{3}{|c|}{ Congressos da Aliança Cooperativa Internacional } \\
\hline & 1937 (Paris) & 1966 (Viena) & 1995 (Manchester) \\
\hline 1. Adesão livre & $\begin{array}{l}\text { a) Princípios essenciais } \\
\text { de fidelidade aos pioneiros }\end{array}$ & $\begin{array}{l}\text { 1. Adesão livre (inclusive } \\
\text { neutralidade política, } \\
\text { religiosa, racial e social) }\end{array}$ & $\begin{array}{l}\text { 1. Adesão voluntária e } \\
\text { livre }\end{array}$ \\
\hline 2. Gestão democrática & 1. Adesão aberta & 2. Gestão democrática & 2. Gestão democrática \\
\hline $\begin{array}{l}\text { 3. Retorno Pro Rata das } \\
\text { operações }\end{array}$ & $\begin{array}{l}\text { 2. Controle ou gestão } \\
\text { democrática }\end{array}$ & $\begin{array}{l}\text { 3. Distribuição das } \\
\text { sobras: }\end{array}$ & $\begin{array}{c}\text { 3. Participação } \\
\text { econômica dos sócios }\end{array}$ \\
\hline $\begin{array}{l}\text { 4. Juro limitado ao capital } \\
\text { investido }\end{array}$ & $\begin{array}{l}\text { 3. Retorno Pro Rata das } \\
\text { operações }\end{array}$ & $\begin{array}{c}\text { a) Ao desenvolvimento da } \\
\text { cooperativa; }\end{array}$ & $\begin{array}{l}\text { 4. Autonomia e } \\
\text { independência }\end{array}$ \\
\hline 5. Vendas a dinheiro & $\begin{array}{l}\text { 4. Juros limitados ao } \\
\text { capital }\end{array}$ & b) Aos serviços comuns; & $\begin{array}{c}\text { 5. Educação, formação } \\
\text { e informação }\end{array}$ \\
\hline $\begin{array}{l}\text { 6. Educação dos } \\
\text { membros }\end{array}$ & $\begin{array}{l}\text { b) Métodos essenciais de } \\
\text { ação e organização }\end{array}$ & $\begin{array}{l}\text { c) Aos associados pro- } \\
\text { rata das operações }\end{array}$ & 6. Intercooperação \\
\hline \multirow[t]{3}{*}{ 7. Cooperativização global } & $\begin{array}{l}\text { 5. Compras e vendas à } \\
\text { vista }\end{array}$ & $\begin{array}{l}\text { 4. Taxa limitada de juros } \\
\text { ao capital social }\end{array}$ & $\begin{array}{l}\text { 7. Preocupação com a } \\
\text { comunidade }\end{array}$ \\
\hline & $\begin{array}{l}\text { 6. Promoção da } \\
\text { educação }\end{array}$ & $\begin{array}{l}\text { 5. Constituição de um } \\
\text { fundo para a educação } \\
\text { dos associados e do } \\
\text { público em geral }\end{array}$ & \\
\hline & $\begin{array}{l}\text { 7. Neutralidade política e } \\
\text { religiosa }\end{array}$ & $\begin{array}{c}\text { 7. Ativa cooperação entre } \\
\text { as cooperativas em âmbito } \\
\text { local, nacional e } \\
\text { internacional }\end{array}$ & \\
\hline
\end{tabular}

Fonte: Cançado (2004), grifo nosso.

No quadro 6 é possível verificar que apenas três dos princípios cooperativistas se mantiveram no decorrer do tempo, sendo uma marca da atuação das cooperativas, a adesão voluntária e livre, a promoção da educação e a gestão democrática. Esse último princípio caracteriza o fato de não haver um único chefe, mas sim um ambiente em que as decisões são tomadas em grupo, com base na visão da maioria dos membros (princípio de uma pessoa, um voto), em resumo, o grande diferencial da estrutura cooperativa é a necessidade de união de ideais e de esforços para o alcance de um bem comum.

Destaca-se que seu papel democrático que é frisado por Rodrigues (2004), porém em sentido macro, ao colocar que o cooperativismo tem uma função que 
transcende a tradicional função social e econômica. Ele tem também uma dimensão de caráter político, que é a defesa da democracia, o combate aos efeitos negativos da dubiedade econômica do liberalismo.

Isso porque, cooperativas são alternativas econômicas emancipatórias, cujos princípios não se baseiam na economia capitalista, pois tal sistema produz desigualdade de recursos e poder, relações de concorrência (baseadas no benefício pessoal e não na solidariedade), e exploração de recursos naturais de forma insustentável (SANTOS, 2002).

Portanto, ao contrário de empresas comuns inseridas no sistema capitalista, as cooperativas são alternativas baseadas na associação econômica entre iguais e na propriedade solidária. Trata-se de cooperação, mutualidade, autonomia, democracia participativa, igualdade, equidade e solidariedade. São estruturas que operam com princípios não capitalistas, porém estão inseridas no mercado global, com vistas a propiciar o crescimento econômico, a igualdade e ampliação da democracia.

É uma forma de desenvolvimento alternativo, baseado na igualdade $\mathrm{e}$ cidadania, que preza pela inclusão dos marginalizados na produção e nos seus resultados.

Propõe alternativas baseadas em iniciativas coletivas, geralmente plasmadas em empresas e organizações econômicas populares de propriedade e gestão solidária que tentam contrariar, por um lado, a separação entre capital e trabalho e, por outro, a necessidade de recorrer à ajuda estatal (SANTOS, 2008, p. 47-48).

O cooperativismo é considerado uma alternativa mais sustentável, igualitária e solidária para o desenvolvimento da economia e da sociedade em que vivemos, prezando pela economia da semiperiferia e da periferia, ao propor projetos de desenvolvimento comunitário e respeito pela diversidade. Sua implantação visa garantir que as minorias sejam incluídas no contexto econômico e social, e para que o sistema contemplasse a coletividade e não mais a individualidade, como vem fazendo o capitalismo, que não integra todos à economia (SINGER, 2002).

Sendo assim, surge como um meio de unir forças individuais para alcançar resultados coletivos, num ambiente econômico-social altamente competitivo (BECKER, 1996, p. 69).

No sentido de doutrina, o cooperativismo tem por objeto a correção do social pelo econômico através de associações de fim predominantemente econômico. De forma geral, as cooperativas são sociedades de pessoas organizadas em bases 
democráticas, que visam não só a suprir seus membros de bens e serviços como também a realizar determinados programas educativos e sociais (COSTA, 2007).

O desenvolvimento socioeconômico ocasionado pelas cooperativas, em especial no que diz respeito à diminuição da pobreza e geração de emprego, fez com que a Assembleia Geral da Organização das Nações Unidas (ONU) declarasse o ano de 2012 como Ano Internacional das Cooperativas.

Tal declaração visou estimular os governos a reconhecer as cooperativas como importantes agentes sociais e econômicos que colaboram para que sejam alcançadas as metas internacionais de desenvolvimento nas Metas do Milênio. Com isso a ONU fixa também como objetivo central o encorajamento dos governos para que estabeleçam políticas públicas e leis que favoreçam os empreendimentos de base cooperativistas, além de promover a formação das cooperativas através do incentivo a indivíduos e instituições (UNITED NATIONS, 2012).

O cooperativismo, no geral, é um sistema ainda pouco difundido quando comparado com o atual sistema vigente. Porém, muitas de suas práticas vêm logrando sucesso, e podem ser ainda melhor propagadas à medida que as pessoas conhecerem seus benefícios sistêmicos.

\subsection{COOPERATIVISMO DE CRÉDITO}

O fator determinante à formação de uma cooperativa de crédito é a capacidade de um grupo se reunir e passar a atuar financeiramente em conjunto. Esse grupo visa ter sucesso na intermediação financeira, considerando desde a alocação de recursos financeiros excedente, poupança, linhas de crédito, entre outras necessidades de seus cooperados (FAVALLI, 2010; BRESSAN, 2009).

Segundo Favalli (2010), outra característica (nem sempre necessária) da formação de cooperativas de crédito é a dificuldade dos agentes econômicos em obter financiamentos em bancos tradicionais, seja por sua região não ter agências bancárias ou até mesmo por conta dos serviços bancários serem de custo elevado. Portanto, a necessidade de acesso a serviços financeiros de menor custo é um dos principais determinantes para a formação de uma cooperativa de crédito. 
O cooperativismo de crédito se torna interessante já que proporciona serviços financeiros menos custosos e ainda traz a vantagem de no final do exercício contábil receber participação nas sobras da cooperativa, já que os cooperados são seus sócios.

Dessa maneira, o cooperativismo de crédito estimula a distribuição de renda, a transferência de recursos entre setores concentrados, até instituições financeiras menores, oferecendo um serviço financeiro de melhor qualidade e menor custo.

De acordo com o Sistema OCB (2015, p. 16) por conta da "grande interface com os produtores rurais e com municípios do interior do país, o cooperativismo de crédito possui fundamental importância para a inclusão financeira", refletindo em mais de $70 \%$ dos empréstimos feitos pelas cooperativas ser de valores menores a $\mathrm{R} \$ 5$ mil. Esse mercado atendido pelas cooperativas não é de interesse das grandes entidades financeiras, atribuindo a essas sociedades um relevante papel como agente de desenvolvimento social e econômico.

Os dados do Banco Central (BACEN) revelam que, em 31 de dezembro de 2016, existiam 1017 cooperativas singulares, 34 cooperativas centrais e 4 confederações, sendo que a maior parte delas eram ligadas aos sistemas SICOOB, SICREDI, UNICRED, e CONFESOL (BACEN, 2018).

Os dados obtidos através do convênio existente entre o Banco Central do Brasil e a OCB demonstram a representatividade do cooperativismo de crédito. Juntas as cooperativas administravam ativos totais da ordem de $\mathrm{R} \$ 296$ bilhões, sendo responsáveis por $3,57 \%$ no total de ativos do mercado financeiro brasileiro no ramo crédito, colocando as cooperativas de crédito na $6^{a}$ posição no ranking das maiores instituições financeiras do país. As operações de crédito totais atingiram quase $R \$ 109$ bilhões, representando $3,42 \%$ do total do SFN e os depósitos de $R \$ 142$ bilhões representavam $6,64 \%$ do total (PORTAL DO COOPERATIVISMO FINANCEIRO, 2018).

O convênio entre o BACEN e a OCB permitiu a divulgação de uma lista com as 100 maiores cooperativas financeiras do Brasil, com base dez/2014, as quais representam cerca de $60 \%$ dos ativos totais das cooperativas de crédito. No entanto, o quadro 7 traz as informações a respeito das 10 maiores cooperativas. Cabe destacar que metade dessas cooperativas estão localizadas na região sul do país, sendo 3 delas no Estado do Paraná. 
Quadro 7 - Relação das 10 maiores cooperativas financeiros do Brasil

\begin{tabular}{|c|c|c|c|c|c|c|c|c|c|c|}
\hline SIGLA & UF & Município & Ativos Totais & Rkg & $\begin{array}{l}\text { Operações } \\
\text { de Crédito }\end{array}$ & Rkg & $\begin{array}{c}\text { Total de } \\
\text { Depósitos }\end{array}$ & Rkg & $\begin{array}{c}\text { Patrimônio } \\
\text { Líquido }\end{array}$ & Rkg \\
\hline $\begin{array}{c}\text { SICOOB } \\
\text { CREDICITRUS }\end{array}$ & SP & Bebedouro & 3.528 .584 & 1 & 2.042 .444 & 1 & 1.308 .015 & 2 & 938.835 & 1 \\
\hline VIACREDI & SC & Blumenau & 2.484 .858 & 2 & 1.644 .836 & 2 & 1.788 .854 & 1 & 533.603 & 2 \\
\hline $\begin{array}{l}\text { SICOOB } \\
\text { COCRED }\end{array}$ & SP & Sertãozinho & 2.109 .270 & 3 & 1.254 .791 & 3 & 788.644 & 7 & 337.884 & 4 \\
\hline $\begin{array}{c}\text { SICREDI } \\
\text { OURO VERDE } \\
\text { MT } \\
\end{array}$ & MT & $\begin{array}{l}\text { Lucas do } \\
\text { Rio Verde }\end{array}$ & 1.594 .692 & 4 & 1.160 .349 & 4 & 513.306 & 18 & 301.861 & 6 \\
\hline $\begin{array}{c}\text { SICOOB } \\
\text { COOPERFOR } \\
\text { TE }\end{array}$ & DF & Brasília & 1.576 .703 & 5 & 1.139 .136 & 5 & 1.135 .619 & 3 & 363.210 & 3 \\
\hline CREDICOAMO & PR & $\begin{array}{l}\text { Campo } \\
\text { Mourão }\end{array}$ & 1.490 .179 & 6 & 794.590 & 7 & 467.233 & 22 & 299.710 & 7 \\
\hline $\begin{array}{c}\text { SICREDI } \\
\text { UNIÃO PR/SP }\end{array}$ & PR & Maringá & 1.482 .030 & 7 & 895.535 & 6 & 816.841 & 6 & 185.586 & 14 \\
\hline $\begin{array}{c}\text { SICREDI } \\
\text { PIONEIRA RS }\end{array}$ & RS & $\begin{array}{c}\text { Nova } \\
\text { Petropolis }\end{array}$ & 1.358 .975 & 8 & 617.741 & 13 & 1.018 .499 & 5 & 217.416 & 9 \\
\hline $\begin{array}{c}\text { SICOOB } \\
\text { CREDICOM }\end{array}$ & MG & $\begin{array}{c}\text { Belo } \\
\text { Horizonte }\end{array}$ & 1.254 .039 & 9 & 367.610 & 40 & 1.082 .358 & 4 & 129.981 & 32 \\
\hline $\begin{array}{c}\text { SICREDI } \\
\text { VANGUARDA } \\
\text { PR/SP }\end{array}$ & PR & Medianeira & 1.221 .087 & 10 & 786.749 & 8 & 709.302 & 10 & 182.282 & 16 \\
\hline Subtotal & & & 18.100 .417 & & 10.703 .781 & & 9.628 .671 & & 3.490 .368 & \\
\hline $\begin{array}{c}\text { Total das } \\
1.084 \\
\text { cooperativas } \\
\text { singulares }\end{array}$ & & & 110.555 .637 & & 66.911.358 & & 61.367 .012 & & 23.586.100 & \\
\hline $\begin{array}{c}\% \text { das } 10 \\
\text { maiores em } \\
\text { relação ao } \\
\text { total }\end{array}$ & & & $16,37 \%$ & & $16 \%$ & & $15,69 \%$ & & $14,80 \%$ & \\
\hline
\end{tabular}

Fonte: (PORTAL DO COOPERATIVISMO FINANCEIRO, 2015b)

Nota: Valores em R\$ mil / RKG = Ranking

aNão estão considerados as operações de crédito registradas no Ativo Compensado (BNDES, Finame) bNão estão consideradas as captações em Fundos de Investimento, Previdência, Poupança Rural e LCA

\subsubsection{CoOperativas De CRÉdito No BRASIL: HISTÓRICO E DADOS GERAIS ${ }^{1}$}

O cooperativismo de crédito iniciou no Brasil em 1902, no município de Nova Petrópolis, Rio Grande do Sul, com um grupo formado principalmente por produtores rurais. Essa primeira cooperativa ainda existe e atualmente se chama SICREDI

\footnotetext{
1 Destaca-se que todos os dados utilizados para contextualizar o universo dessa pesquisa foram retirados do site do Banco Central do Brasil, isso porque são os números oficiais e mais atualizados.
} 
Pioneira, atuando em vários municípios da Serra Gaúcha e sendo uma das maiores cooperativas de crédito do país (PAGNUSSATT, 2004).

Pagnussatt (2004) coloca que na década de 60 o cooperativismo de crédito expandiu consideravelmente devido ao aumento do número de instituições, especialmente na região Sul. Porém, na segunda metade da mesma década ocorre uma desestruturação no sistema, que resultou em uma nova ordem normativa.

O progresso das cooperativas de crédito é retomado nos anos 80 , nove anos após ser instituída nova lei para o segmento, que normatizou processos mais adequados as suas demandas, e principalmente quando se inicia o movimento de estruturação em associações e sistemas.

No ano de 2014 , o ramo crédito ficou em $3^{\circ}$ lugar em número de cooperativas (SISTEMA OCB, 2015). O quadro 8 apresenta o número de cooperativas no ano de 2014, segregando-os por ramo do cooperativismo brasileiro e fazendo o comparativo com outros anos. 
Quadro 8 - Número de cooperativas por ramos

\begin{tabular}{|c|c|c|c|c|c|c|c|c|}
\hline \multirow{2}{*}{ RAMO } & \multicolumn{6}{|c|}{ ANO } & \multicolumn{2}{|c|}{$\begin{array}{l}\text { VARIAÇÃO } \\
(2009-2014)\end{array}$} \\
\hline & 2009 & 2010 & 2011 & 2012 & 2013 & 2014 & $\mathbf{N}$ & $\%$ \\
\hline Agropecuário & 1.615 & 1.548 & 1.523 & 1.597 & 1.597 & 1.543 & -72 & $-4,46 \%$ \\
\hline Consumo & 128 & 120 & 123 & 122 & 122 & 124 & -4 & $-3,13 \%$ \\
\hline Crédito & 1.100 & 1.064 & 1.047 & 1.042 & 1.034 & 980 & -120 & $-10,91 \%$ \\
\hline Educacional & 304 & 302 & 294 & 300 & 300 & 282 & -22 & $-7,24 \%$ \\
\hline Especial & 15 & 9 & 12 & 6 & 6 & 9 & -6 & $-40,00 \%$ \\
\hline Habitacional & 253 & 242 & 226 & 220 & 220 & 283 & 30 & $11,86 \%$ \\
\hline Infraestrutura & 154 & 128 & 141 & 130 & 130 & 283 & 129 & $83,77 \%$ \\
\hline Mineral & 58 & 69 & 63 & 86 & 86 & 80 & 22 & $37,93 \%$ \\
\hline Produção & 226 & 235 & 243 & 253 & 253 & 268 & 42 & $18,58 \%$ \\
\hline Saúde & 871 & 852 & 846 & 849 & 849 & 818 & -53 & $-6,08 \%$ \\
\hline Trabalho & 1.408 & 1.024 & 966 & 977 & 977 & 877 & -531 & $-37,71 \%$ \\
\hline Turismo & 29 & 27 & 31 & 25 & 25 & 22 & -7 & $-24,14 \%$ \\
\hline Transporte & 1.100 & 1.015 & 1.088 & 1.228 & 1.228 & 1.164 & 64 & $5,82 \%$ \\
\hline TOTAL & 7.261 & 6.635 & 6.603 & 6.835 & 6.827 & 6.733 & & \\
\hline
\end{tabular}

Fonte: (PORTAL COOPERATIVISMO DO BRASIL, 2015; SESCOOP, 2012; SISTEMA OCB, 2015; VERBO COOPERAR, [C2016]).

Segundo dados da Organização das Cooperativas Brasileiras (2014), o ramo Crédito merece destaque, estando em primeiro lugar no ranking de cooperados. Em segundo lugar estavam as cooperativas de consumo, seguida pelas cooperativas agropecuárias e de infraestrutura. Esses quatro ramos juntos concentravam, no ano de 2014 cerca de 92\% dos cooperados (ORGANIZAÇÃO DAS COOPERATIVAS BRASILEIRAS, 2014).

Destaca-se que atualmente, segundo o documento "Panorama do Sistema Nacional de Crédito Cooperativo", expedido pelo Banco Central em 31 de dezembro de 2016, o Sistema Nacional de Crédito Cooperativo (SNCC) está estruturado em sistemas compostos por cooperativas singulares, cooperativas centrais ou federações de cooperativas e confederações de cooperativas.

No supracitado dia, existiam quatro confederações (Confederação Nacional das Cooperativas Centrais de Crédito e Economia Familiar e Solidária - Confesol, Confederação Nacional das Cooperativas do Sicoob, Confederação Interestadual das Cooperativas Ligadas ao Sicredi e Confederação Nacional das Cooperativas Centrais Unicred), 34 centrais e 1.017 singulares em atividade no país. Além disso, havia 
também dois bancos cooperativos (Banco Cooperativo do Brasil S.A. - Bancoob e Banco Cooperativo Sicredi S.A. - Bansicredi).

Além dos quatro sistemas de três níveis hierárquicos citados anteriormente, em 31 de dezembro de 2016, havia cinco sistemas de dois níveis hierárquicos em atividade, compostos por cooperativas centrais às quais estavam filiadas 47 singulares. Para fins de agregação de dados, essas singulares serão tratadas como pertencentes a um único sistema, denominado Centrais Independentes.

E também existiam 195 singulares não filiadas à central. Novamente, para fins de agregação de dados, essas singulares serão tratadas como pertencentes a um único sistema, denominado Singulares Independentes.

O gráfico 1 abaixo exprime a evolução do número de cooperativas de crédito singulares por sistema:

Gráfico 1 - Evolução do número de cooperativas de crédito singulares por sistema

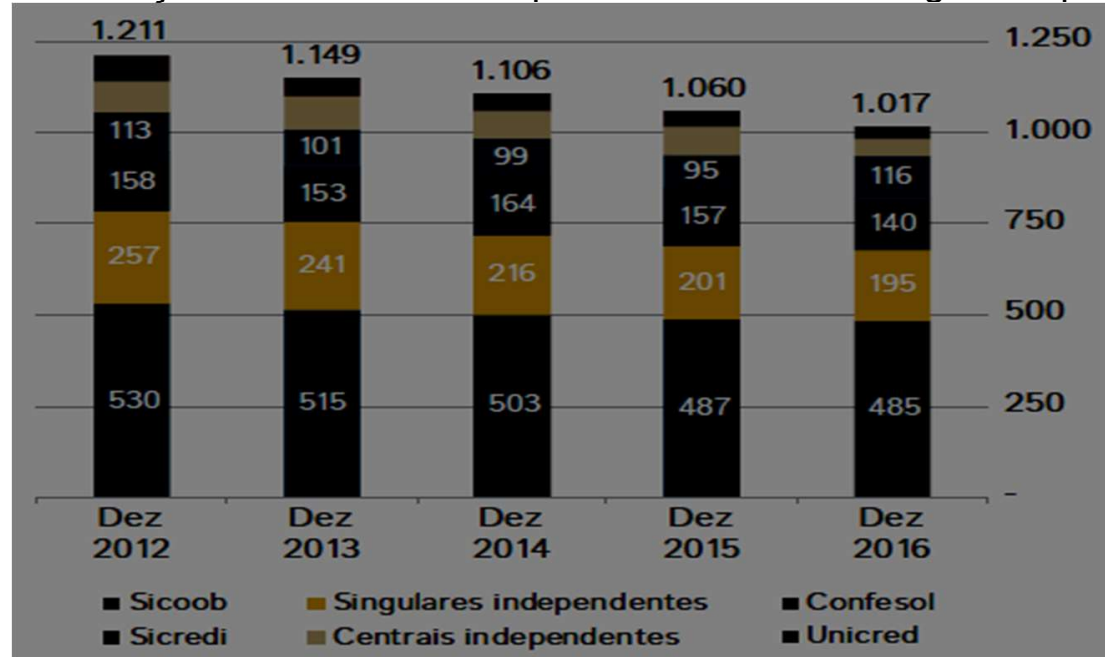

Fonte: Relatório Banco Central do Brasil (2016).

O número de pessoas físicas e jurídicas associadas a cooperativas de crédito é crescente e alcançou a marca de 8,9 milhões (BANCO CENTRAL DO BRASIL, 2016).

O gráfico 2 abaixo traz a evolução da quantidade de cooperados: 
Gráfico 2 - Evolução da quantidade de cooperados - Em milhões

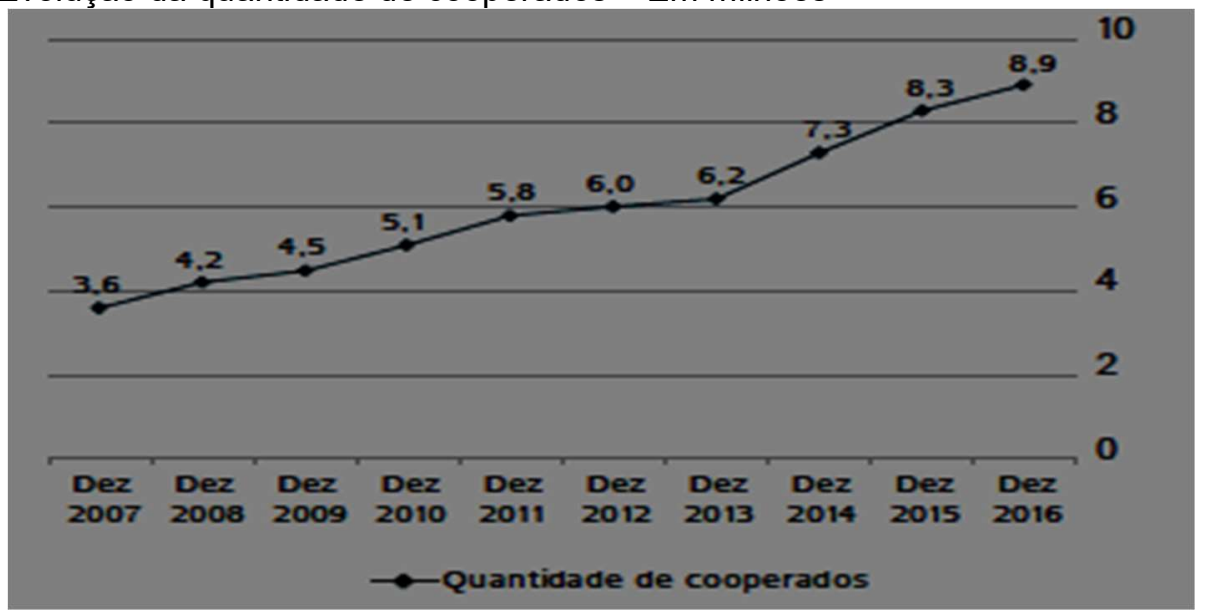

Fonte: Relatório Banco Central do Brasil (2016).

O quadro 9 abaixo buscou compilar os dados acima trazidos:

Quadro 9 - Panorama do Sistema Cooperativo de Crédito Brasileiro

\begin{tabular}{|c|c|c|c|c|c|}
\hline & CONFEDERAÇÕES & CENTRAIS & SINGULARES & $\begin{array}{l}\text { PONTOS DE } \\
\text { ATENDIMENTO }\end{array}$ & $\begin{array}{c}\text { NÚMERO } \\
\text { DE } \\
\text { ASSOCIADOS }\end{array}$ \\
\hline & CONFESOL & 4 & 140 & 541 & $467 \mathrm{mil}$ \\
\hline & SICOOB & 16 & 485 & $2,6 \mathrm{mil}$ & 4 milhões \\
\hline & SICREDI & 5 & 116 & 1587 & 3,7 milhões \\
\hline & UNICRED & 4 & 34 & 242 & 195.325 \\
\hline & & $\begin{array}{c}5 \\
\text { CENTRAIS } \\
\text { INDEPEN- } \\
\text { DENTES } \\
\end{array}$ & 47 & & \\
\hline & & & $\begin{array}{c}195 \\
\text { (SINGULARES } \\
\text { INDEPEN- } \\
\text { DENTES) } \\
\end{array}$ & & \\
\hline TOTAL: & 4 & 34 & 1017 & & 8,9 milhões \\
\hline
\end{tabular}

Fonte: autora com base nas informações do Banco Central do Brasil.

Destaca-se que todos os dados utilizados para contextualizar o universo dessa pesquisa foram retirados do site do Banco Central do Brasil, isso porque são os números oficiais e mais atualizados. Porém, o Banco Central não fornece o número de postos de atendimento e de associados das Centrais e Singulares Independentes, e os aqueles encontrados em outros sites estão desatualizados e conflitantes, por isso optou-se por não trabalhar com tais informações. 


\subsection{PRINCÍPIOS COOPERATIVISTAS E AVALIAÇÃO DE DESEMPENHO DE COOPERATIVAS DE CRÉDITO: UMA DISCUSSÃO SOBRE ASPECTOS RELEVANTES}

O destaque dado pela literatura acadêmica à relevância das medidas de desempenho se justifica pelo fato dessas se configurarem como ferramentas que traduzem a visão e a estratégia empresarial, ao comunicar os objetivos estratégicos e motivar o desempenho diante dos objetivos da organização (PACE, 2009).

Tal relevância é válida para a mensuração do desempenho de organizações de diferentes setores e características, como por exemplo, cooperativas. Nesse caso, a análise dessas instituições deve considerar a razão de ser das mesmas (pois as especificidades delas são fruto de seus princípios doutrinários) dentre outras variáveis peculiares a esse tipo de organização.

Vilela, Nagano e Merlo (2007) listam os objetivos básicos da avaliação das cooperativas como sendo: a identificação dos problemas que alteram o que havia sido planejado pela organização, com o intuito de corrigir e evitar que aconteça novamente; aproximar o máximo possível os resultados obtidos com os esperados; verificar se as estratégias e políticas se enquadram no contexto real que a empresa está inserida; verificar se a estrutura organizacional e processual da cooperativa é condizente com seus objetivos; criar condições para otimização dos processos diretivos e decisórios da cooperativa; propiciar um ambiente de relações interpessoais adequado e; fornecer informações gerenciais periódicas a fim de que haja agilidade na intervenção no desempenho da avaliação do modelo de gestão da cooperativa.

A maior parte dos trabalhos que se propõem a medir o desempenho de cooperativas se dedica a questões econômico-financeiras. Com algumas exceções que discutem que o desempenho da cooperativa não pode restringir-se a aspectos econômicos, mas deve também revelar o seu desempenho social, isso porque, em empreendimentos cooperativos há uma lógica diferente de funcionamento.

Lazzarini et al. (1999), por exemplo, atrelam o sucesso financeiro de cooperativas aos ganhos sociais ao concluírem que ao classificar as cooperativas através de variáveis econômicas, explica-se melhor seu desempenho do que ao se comparar com o uso de variáveis sociais. Dessa forma é reforçada pelos autores a importância de se acompanhar o desenvolvimento econômico das cooperativas, a fim 
de caracterizar o próprio desempenho social e, complementam ao sugerir o uso de variáveis operacionais de forma adicional as variáveis tradicionais.

Porém a ideia supracitada de utilização de indicadores econômicos em detrimentos dos sociais ainda não se configura como uma discussão fechada, pois autores divergem de opinião ao julgarem quais seriam os indicadores mais adequados. Existem correntes que defendem que devem ser incluídos os indicadores sociais, e outras que afirmam que para a realidade de cooperativas, o desempenho social é uma conseqüência do desempenho econômico, sugerindo a inclusão apenas de forma indireta do conteúdo dos indicadores sociais (MENEGÁRIO, 2000).

Um fato é comum às abordagens conhecidas: que o desempenho econômico deve ser mensurado. Em relação a isso, Bialoskorski Neto, Nagano e Moraes (2006) ressaltam a inadequação do uso de índices de avaliação econômica de forma comparativa para organizações com e sem fins lucrativos, pois tais índices devem considerar e se ajustar à realidade e a estrutura de capital de cada organização.

Contudo, os referidos autores afirmam que a análise tradicional (por exemplo, Kanitz, Retorno do investimento, Retorno dos ativos, dentre outros) utilizada para avaliar o desempenho financeiro ainda é tida como um padrão ao se mensurar o desempenho de cooperativas.

Em relação a essa ideia, Barros e Moraes (2015, p. 4) também corroboram:

... a avaliação do desempenho das cooperativas de crédito não deve se basear apenas nos mesmos indicadores tradicionalmente utilizados na avaliação de bancos, já que estas não são voltadas para a maximização de valor para o investidor com base no investimento e sim para a maximização de valor para o cooperado.

Fica claro que se faz necessária a consideração de aspectos inerentes às cooperativas na composição de índices para a mensuração do desempenho das mesmas. Lembrando que as cooperativas não possuem fins lucrativos, ou seja, não objetivam o lucro e a remuneração do capital dos associados, portanto, os índices voltados a elas devem considerar indicadores de produtividade ou ainda de serviços fornecidos aos cooperados (SANTOS, 1986).

O fato de não ter a finalidade de lucro, possibilita a cooperativa oferecer produtos e serviços ao melhor preço possível ao associado ou ainda no melhor nível em termos de qualidade de produtos e serviços. A partir daí não estariam sendo gerados resultados para a cooperativa, mas sim diretamente nas atividades 
econômicas dos seus associados. Sendo assim, a evolução da atividade econômica dos cooperados e a organização do quadro social são importantes padrões de desempenho e eficiência (MEURER; MARCON, 2007).

Portanto, entende-se aqui, que além de indicadores financeiros, deve-se utilizar outras dimensões para análise do desempenho de cooperativas de crédito, como por exemplo, indicadores que delimitem o grau de atendimento da estratégia proposta, visando conhecer as atividades desenvolvidas e o quanto elas agregam valor ao produto/serviço ofertado, ou seja, conhecer o quanto o enfoque estratégico está alinhado ao enfoque operacional.

Nesse sentido, existe a necessidade de monitorar o desempenho econômico e financeiro de cooperativas, a fim de manter a sobrevivência dessas organizações que possuem como ponto crítico a maximização de resultados financeiros aos associados; e além dos indicadores tradicionalmente utilizados, se faz necessária a adição de indicadores sociais na análise de desempenho (BIALOSKORSKI NETO, 2005; SANTOS, 1986), bem como demais indicadores pertinentes a esse tipo de organização.

Nesse sentido, autores como Oliveira Junior (1996), apontam para a necessidade de se avaliar o desempenho de cooperativas a partir de outros indicadores, que não só financeiros, ao colocar que os conjuntos de fatores econômico-financeiros e socioeconômicos são interdependes e o equilíbrio no seu desenvolvimento é que definirá a eficiência global das cooperativas.

Pinho (1986) também coloca que se os administradores de cooperativas priorizarem aspectos associativos correrão o risco de encontrar problemas na gestão financeira e ao mesmo tempo, se considerarem apenas aspectos empresariais, poderão se distanciar dos cooperados e da sua finalidade social. Portanto, a autora salienta a importância de se mensurar atividade social e econômico-financeira concomitantemente.

Para Muccillo Netto (1993), Farias (1998) e Catelli et al. (1999), avaliar desempenho significa avaliar ou mensurar a contribuição, ou o resultado, trazidos à determinada instituição pelos seus centros de responsabilidade, ou seja, avaliar ou mensurar a contribuição das diferentes áreas para formação do resultado global.

Em específico, para instituições financeiras, Muccillo Netto (1993) destaca que avaliar desempenho significa essencialmente avaliar pessoas, gestores, que 
administram unidades ou centros de responsabilidade, bem como mensurar a importância dos produtos oferecidos ao mercado, com objetivo de observar qual deles proporciona maior ou menor contribuição.

Além disso, segundo a Organização das Cooperativas Brasileiras (OCB), os valores de ajuda mútua, responsabilidade, democracia, igualdade, equidade, solidariedade, a crença na honestidade, transparência, responsabilidade social e preocupação com seu semelhante são norteadores do cooperativismo (OCB, 2006), e, portanto, basilares na definição de seu modelo de gestão e em suas práticas organizacionais. Tais valores se chocam com as premissas do indivíduo egoísta e orientado à maximização de interesses particulares (FONTES FILHO VENTURA; OLIVEIRA, 2008).

São inúmeros autores que discutem acerca do desvirtuamento de cooperativas em relação aos princípios intrínsecos a esse tipo de instituição. Entre eles estão Curi (2005), Pinho (1982), Costa (2007), Domingues (2002), Birschall (1997), Fergunson (1991), Kotz (2007), Cançado, Souza e Pereira (2015), Monteiro et al. (2010), Bertuol, Cançadio e Souza (2012), Crúzio (1999), Oliveira Junior (1991), entre tantos outros.

Tal temática emerge da constatação de que o espírito cooperativista está cada vez mais longe de suas raízes, resultando em cooperativas consideradas de fachada por se comportarem como empresas privadas (COSTA, 2007).

Costa (2007) entende que apesar de terem se passado mais de 170 anos da criação da primeira cooperativa (chamada Sociedade dos Probos Pioneiros de Rochdale - localizada na Inglaterra), o fenômeno cooperativista ainda é pouco estudado, o que gera grandes confusões teóricas e conceituais, resultando no desvirtuamento da prática cooperativista.

Para Pinho (1982), tal desvirtuamento acontece devido a problemas resultantes da própria evolução da cooperativa, que deixou de ser uma simples associação mutualista para se transformar em uma complexa organização social. Em outras palavras, a cooperativa incorpora todos os problemas da empresa capitalista moderna. Assim, do ponto de vista socioeconômico, a cooperativa se modernizou desvirtuandose dos seus princípios básicos.

Essa instituição, que deveria ter a finalidade de unir pessoas com objetivos sociais e econômicos comuns, a partir da cooperação e ajuda mútua, com base em uma gestão democrática, participativa e fundamentada na economia solidária ( $X$ 
Congresso Nacional de Cooperativismo - OCB, 1988), passa a ser pautada no espírito de lucratividade, desviando-se dos seus fins sociais, tratando cooperados como sócios e desconsiderando os fins para os quais foi constituída (CURI, 2005). Para Pinho (1982) trata-se de um "Cooperativismo sem Rochdale" na acepção doutrinária que utiliza cooperativa como técnica empresarial.

$\mathrm{Em}$ se tratando do cooperativismo brasileiro, esse presta serviços aos associados em função de seus estabelecimentos individuais, de maneira isolada. Portanto, há um desvirtuamento de sua essência, do seu caráter libertário, da filosofia de interesse coletivo, caracterizando um descaminho no momento da importação do modelo europeu de cooperativismo, não refletindo seu conceito original (PONTES, 2004).

Isso porque, no Brasil, o cooperativismo nasceu dos anseios da alta sociedade, e não da baixa, ou seja, foram as elites políticas e econômicas, principalmente do setor agrícola, unidas ao governo (com um discurso desenvolvimentista), que encabeçaram tal ideia (PEREIRA; SOUZA, 2013).

Nesse sentido, o cooperativismo brasileiro é evidenciado como sendo a expressão da lógica da produção capitalista, já que busca a partir de políticas públicas estatais, beneficiar grandes empreendimentos, seguindo os interesses do capital (GONÇALVES, 2006).

Trata-se assim de um capitalismo disfarçado, buscando tão somente benefícios financeiros, desconsiderando a essência do cooperativismo, seu ideário libertador, de superação das péssimas condições de trabalho às quais os empregados estavam submetidos.

Pereira e Souza (2013) corroboram com essa idéia ao colocar que muitas vezes as pessoas se associam as cooperativas com o intuito de conseguir incentivos fiscais, além de usufruírem da estrutura da mesma para se capitalizar e montar sua própria estrutura produtiva, caracterizando o espírito capitalista individualista. Nesse sentido, a cooperativa, pautada na ideologia da relação fraternal, passa a se resumir a interesses financeiros, contribuindo unicamente para a manutenção do atual estado das coisas (GOLÇALVES, 2006).

Além desse problema, há outro que causa o desvirtuamento de cooperativas: igualar um empreendimento cooperativista a uma empresa mercantil, considerando 
que o primeiro deve aplicar técnicas gerenciais similares às aplicadas pelo segundo, é desvirtuar o cooperativismo, contribuindo para uma farsa (NASCIMENTO, 2000). Crúzio (1999, p. 40) alerta:

Se, por um lado, a empresa e a cooperativa diferem internamente, por outro, se assemelham com relação à disputa do lucro de dentro para fora da organização, isto é, se igualam pela forma de concorrer no mercado externo. Neste sentido transformam insumos em bens e serviços finais para o consumo ou em capitais. Igualmente, é o processo decisório que transforma os recursos dos acionistas (empresa) ou dos associados (cooperativa) em ativos permanentes, tais como prédios, máquinas, equipamentos etc. Ademais, tanto na cooperativa quanto na empresa, produzir implica requisitos básicos, tais como máquinas e equipamentos, na estrutura de processo. Envolve ainda a estrutura comercial, que fornecerá condições para realizar os desembolsos necessários à contratação da mão-de-obra, à aquisição de matéria-prima, à manutenção dos prédios e do maquinário etc., desde que a estrutura de processo forneça os meios à produção. Desta forma, pode-se afirmar que essas organizações têm a singularidade da função empresarial em torno do ativo permanente, isto é, têm a mesma finalidade com relação à produção de mercadorias ou à prestação de serviços, para gerar um certo grau de rentabilidade, que remunere satisfatoriamente o capital dos cooperados ou dos empresários, empregado na sua instalação. Por isto, quanto mais alto seja o nível desta remuneração, tanto mais se justifica o investimento em capital produtivo ou em prestação de serviços. Em torno destas similaridades organizacionais é correto dizer que, de dentro para fora da associação, a administração da cooperativa deve exercer e aprimorar a função empresarial, isto é, fazer com que o sistema insumos-cooperativaprodutos ou serviços funcione com a maior utilização dos meios de produção dos associados, a fim de alcançar o melhor nível de produção e produtividade. Nível de produção considerado como mensuração do volume a produzir ou de serviços a prestar, em determinado período de tempo. Produtividade considerada como produzir ou prestar serviços cada vez mais e melhor, em cada vez menos tempo. Para tanto, é necessário que a administração da cooperativa dedique esforços gerenciais de forma que os resultados dos processos produtivos ou da prestação de serviços sejam uma agregação significativa de valor, isto é, quanto maior o valor do produto ou do serviço para terceiros tanto maior será o seu preço de mercado. Igualmente, pela relação, quanto menor for o custo que a cooperativa obtiver na tarefa de agregar valor, tanto maior será sua taxa de valor agregado.

Portanto, de um lado tem-se as cooperativas, cuja proposta original é combater a exclusão social, trazendo emancipação socioeconômica a seu associado, ao eliminar atravessadores e humanizar relações de comércio e trabalho. De outro lado, tem-se a necessidade de gerar excedente, e conseqüentemente gerir tal instituição para que alcance seus objetivos. (BERTUOL, CANÇADO E SOUZA, 2012).

Essa dicotomia representada pela competitividade e respeito à doutrina foi bastaste frisada no primeiro International Summit of Cooperatives, realizado em Quebéc no Canadá em 2012. O que se sabe é que existe uma tensão entre o capitalismo, que prioriza o lucro, e a existência de organizações sociais, que priorizam pessoas. Esse primeiro, colocando em cheque as práticas e conceitos que circundam o efetivo cumprimento dos princípios cooperativistas (MONTEIRO ET AL., 2010).

Fica clara a preocupação de que o empreendimento cooperativo é preso, há um dilema estrutural: corre o risco de fracassar já que sua estrutura democrática o torna lento na tomada de decisões, e porque o princípio doutrinário "singularidade do 
voto" o impede de alcançar um bom nível de capitalização para se expandir, visto que independentemente da parcela de capital social adquirida pelo associado este tem direito há apenas um voto em assembleias. E para expandir suas operações é necessário crescente investimento, o que torna necessário apelar para investidores externos, desvirtuando-o de seus princípios (BIRSCHALL, 1997; FERGUNSON, 1991).

Além disso, os autores colocam que os preços e condutas de empresas cooperativistas não serão diferentes das firmas de capital, pois apresentam custos de transação elevados, estando, portanto, em desvantagem competitiva.

Bialoskorski Neto (2006) ressalta que os princípios doutrinários cooperativistas influenciam diretamente no sucesso dessa instituição, já que o princípio da democracia exige altos custos de transação nas tomadas de decisão por meio de assembleias gerais; o princípio da igualdade, no qual cada homem tem direito a apenas um voto, desestimula a participação junto à cooperativa; e o princípio da solidariedade, do retorno pro rata das operações e da não existência de lucro, impossibilitam uma delimitação clara dos direitos de propriedade, aumentando custos de agência e transação.

Oliveira Junior (1991) apregoa que para conseguir a agilidade capaz de acompanhar o mercado, as cooperativas precisam de executivos capacitados e que formem uma equipe capaz de desenvolver essa organização de maneira competitiva.

Porém, isso causará uma aproximação ainda maior da cooperativa com empresas mercantis, sendo necessária uma adequada gestão dos princípios cooperativistas, para que não sejam desvalorizados em detrimento de objetivos econômicos.

Uma coisa é clara, empreendimentos cooperativos são organizações diferentes das empresas mercantis, quanto aos seus objetivos, por isso devem ser geridos também de maneira diferente, visando respeitar os princípios cooperativistas, bem como impulsionar competitivamente a instituição.

A problemática do desvirtuamento dos princípios cooperativistas só será resolvida, segundo Jaeger (2005) depois que o aparato legal cooperativista Ihe der meios de manter o equilíbrio diante do binômio coletivo-individual, num ambiente de forças competitivas. 
Kotz (2007) vê que o equilíbrio é a palavra-chave que possibilita estágio contínuo e ascendente de crescimento, tanto financeiro quanto social, do empreendimento cooperativo.

Isso porque, se as decisões da cooperativa só priorizarem o interesse do cooperado, esta poderá ter problemas de caixa, já que provavelmente estará praticando preços acima do mercado, o que afetará sua saúde financeira e contribuirá para fragilizar o empreendimento no futuro (KOTZ, 2007).

Ao mesmo tempo, se os interesses da cooperativa prevalecerem sobre os dos associados, essas passam a atuar como empresas mercantis, e invertem sua prioridade, já que se manter no mercado passa a ser mais importante do que gerar emancipação social e econômica ao seu cooperado. Dessa forma iguala-se a empresas convencionais, e perde sua razão de existir (KOTZ, 2007).

Portanto, o ideal é que haja um equilíbrio entre os interesses do empreendimento cooperativo e do empreendedor cooperativo, visto que o primeiro foi criado para atender as necessidades econômicas e sociais do segundo, e não deve perder tal foco, pois caso isso aconteça há caracterização de desvirtuamento do empreendimento cooperativo.

É importante ressaltar, que as cooperativas brasileiras são instituições inseridas no sistema capitalista de produção, e que precisam sobreviver em consonância com ele, devendo ser economicamente eficientes para continuar atuando no mercado e poder trazer benefícios para seus associados (BIRCK, 2005). Sendo assim, precisam ser competitivas tanto quanto um empreendimento convencional.

Portanto, o ideal é que sejam eficientes quanto ao seu objetivo (que é emancipar social e economicamente seu cooperado), e ao mesmo tempo competitivas em um mercado capitalista, necessitando utilizar estratégias como: enxugar custos, buscar escala de produção, compatibilizar agilidade na tomada de decisões democráticas, buscar a modernidade na gestão, ser inovadoras e compatibilizar atividades. Ao conseguirem responder as problemáticas organizacionais e de gestão, poderão ao mesmo tempo aproveitar oportunidades empresariais que se abrem no mercado, para que assim cresçam e permaneçam atingindo sua finalidade socioeconômica. 
Resumidamente, um empreendimento cooperativo deve permanecer vigilante quanto ao seu desempenho social, político, educacional e financeiro, pois assim poderá atingir sua finalidade, satisfazendo cooperados e mantendo-se competitivo.

Suas direções devem assumir o desafio de administrar a instituição sob essa ótica, pois quando valoriza-se apenas o aspecto econômico da organização, afastase da sua característica principal, tornando-a uma empresa mercantil. Portanto, é imprescindível que os dirigentes conheçam e respeitem a filosofia cooperativista, não se afastando de seus princípios e diferenciando a cooperativa de uma empresa convencional (OLIVEIRA, 2007).

Dessa forma, poderão ser competitivos e eficientes, inserindo-se cada vez mais no mercado, sem desconsiderar seus princípios e valores doutrinários (solidariedade, democracia, participação, transparência e distribuição justa de resultados).

Por outro lado, apesar de estarem pautadas em princípios cooperativistas e serem regidas por leis específicas, as cooperativas são instituições que estão inseridas no mercado capitalista, e para atenderem seus objetivos emancipatórios precisam competir nesse mercado. Esse fato, a torna, muito próxima de empresas convencionais, necessitando assim de sustentabilidade política, bem como eficiência e aprimoramento administrativo, para entregar bons resultados, como qualquer outra empresa.

Sendo assim, considerando a literatura pesquisada, vê-se que Cooperativas, sejam elas de Crédito ou não, tem um objetivo especial: proporcionar bem estar social e econômico aos seus associados, emancipando-os frente a um sistema capitalista excludente. Portanto, fica claro que essa base, que justifica seu aparecimento e manutenção, deve ser considerada.

Identificar a relevância atual dessa temática dentro das Cooperativas de Crédito é uma das preocupações desse trabalho, visto que há muitas discussões sobre o desvirtuamento dos princípios cooperativistas e do consequente não atendimento das necessidades socioeconômicas de seus associados. Isso porque, na tentativa de sobreviver à competição de mercado travada com empresas capitalistas, o cooperativismo passou a lançar mão dos mesmos métodos organizacionais e operacionais de que se valiam as demais empresas, visando alcançar eficiência econômica. Isso resultou em uma transformação das estruturas das cooperativas, que 
muitas vezes inviabilizou os princípios de participação efetiva e de controle democrático (LOUREIRO, 1981).

Considerando todas as discussões teóricas até o momento, entende-se que as cooperativas são organizações que não possuem um dono com interesse capitalista puro, visando tão somente a remuneração de seu investimento. Seu processo econômico é mais complexo, visto que seus investimentos, estratégias e táticas empresariais tem como referencial sua clientela primária e fundamental que é o associado (OLIVEIRA, 1996).

Portanto, as decisões nas cooperativas compreendem um universo analítico mais amplo que o das demais empresas, pois o que está em jogo não é a capacidade de acumulação, crescimento da empresa e conseqüente remuneração do capital investido, mas a capacidade de acumulação e crescimento dos associados, enquanto unidades produtivas e a remuneração de seu trabalho.

Originalmente a preocupação central da cooperativa de crédito é satisfazer as necessidades econômicas, e consequentemente social, cultural de seu associado. Por essa razão, o cliente, aqui representado pelo cooperado, é a razão de existir da cooperativa.

Sendo assim, é necessário entender quão bem a cooperativa de crédito preenche as necessidades dos seus consumidores via oferecimento de serviços. Para tanto, deve-se preocupar-se em identificar necessidades dos associados via indicadores como: relacionamento com clientes, número de associados, volume de consumo, número de reclamações, nível de satisfação, consumo médio, índice de retenção de cooperados.

Além de se preocupar com a satisfação das necessidades do cooperado, é importante ressaltar que Cooperativas de Crédito são instituições ligadas ao Banco Central do Brasil, é ele que coordena e monitora as cooperativas de crédito brasileiras, e considera que dentre os propósitos dessas, está a necessidade de contribuir para o desenvolvimento da economia local, e promover a intermediação entre a poupança e as demandas por serviços financeiros de uma mesma região.

Por isso, é papel das cooperativas de crédito ajudar a corrigir desigualdades regionais sem a dependência direta do poder público. Nesse contexto é que o crescimento do setor cooperativista de crédito é considerado prioritário pelo Governo. 
Esse cenário permite a associação de empreendedores de micro e pequenas empresas a cooperativas de crédito, facilitando o acesso dessas empresas a linhas de crédito em condições compatíveis com a sua realidade, fortalecendo as pequenas e médias empresas, o setor agrícola e do trabalhador que não tem acesso a crédito a juros mais acessíveis.

Cooperativas de crédito mais eficientes desempenham melhor seu papel socioeconômico, o que acontece pela desintermediação financeira, que resulta em taxas de captação e empréstimos diferenciadas, gerando mais oportunidades para a circulação de recursos e, consequentemente, o desenvolvimento local, já que depositantes e tomadores de empréstimos normalmente pertencem à mesma localidade (FERREIRA; GONÇALVES; BRAGA, 2007).

Portanto, em relação ao seu desempenho, as cooperativas de crédito brasileiras também devem considerar: desenvolver projetos sociais, melhoria da qualidade de vida da população autóctone, desenvolvimento de atividades econômicas na região.

Ainda, segundo as discussões teóricas até o momento, destaca-se que ser eficiente é uma exigência da atividade que as Cooperativas de Crédito desenvolvem. A intermediação financeira tem como matéria-prima o dinheiro, depósitos efetuados pelos cooperados e ao mesmo tempo repassados como produto final, a partir de empréstimos a outros cooperados. Esta atividade é muito sensível e não aceita a má gestão. Uma cooperativa que apresenta um bom desempenho econômico, no sentido dinâmico, refere-se a conseguir resultados positivos, ou melhor dizendo, obter sobras as quais refletirão positivamente no patrimônio líquido. Ao mesmo tempo, consegue um bom desempenho financeiro que, no sentido dinâmico, refere-se à variação de caixa que estaticamente representará o saldo de caixa no balanço patrimonial.

Uma cooperativa de crédito com as características citadas acima dificilmente estará insolvente, apresentando um patrimônio líquido, negativo ou com o valor dos ativos menor que o valor de mercado do passivo. As cooperativas de crédito, atuando em um mercado altamente competitivo e por questão de princípio; não podem atuar como os bancos buscando sempre a maior lucratividade possível para a sua manutenção e crescimento. Elas devem atender às necessidades dos cooperados, e ao mesmo tempo garantir o seu desenvolvimento. 
Estando no mesmo ambiente que os bancos, as cooperativas de crédito, devem obedecer às mesmas condições que os bancos obedecem na gestão de fundos que, segundo Silva (1998, p.589) são três, segurança, liquidez e estabilidade.

Na prioridade da administração dos fundos, um banco deve enfocar primeiramente a liquidez, visando ao atendimento às necessidades previsíveis de recursos para atendimento dos saques de seus clientes (por conta dos depósitos), bem como as solicitações de empréstimos. O segundo objetivo é a segurança. Desse modo, o banco deve evitar riscos indevidos e que ameacem os depósitos a ele confiado. Operações de créditos imprudentes poderão prejudicar a reputação do banco e levá-lo à quebra. O terceiro objetivo é a lucratividade que também não pode ser negligenciada.

As cooperativas de crédito não devem negligenciar nenhum destes objetivos já que a sua estabilidade no mercado depende diretamente de seu desempenho, já a terceira condição, porém deve ser buscada com moderação para não desviarem do seu objetivo central que é atender as necessidades financeiras de seus cooperados a um custo menor que o de mercado.

Portanto, visando avaliar a saúde financeira da cooperativa, deve-se considerar: capitalização, imobilização, capital de giro, alavancagem, encaixe, cobertura voluntária, liquidez geral, volume de crédito em relação ao patrimônio líquido, despesas de pessoal, despesas administrativas, despesas totais, geração de renda, aplicações totais, captações totais, receita operacional, ativo real, passivo real, aplicação total e captação total (BRESSAN ET AL., 2011; QUIROGA, BRESSAN E BRAGA, 2005).

Para que tudo isso seja possível é importante que a cooperativa pense adequadamente seus processos, ou seja, sua capacidade operacional, o que envolve melhoria da cadeia de processos internos visando maior eficiência e eficácia, bem como valorize e respeite princípios cooperativistas, e mantenha sempre em pauta os objetivos fundamentais do surgimento de uma cooperativa.

\subsection{INDICADORES DE DESEMPENHO DE COOPERATIVAS DE CRÉDITO: A COMPOSIÇÃO DE UM REFERENCIAL PARA A PESQUISA}

A avaliação de desempenho do cooperativismo de crédito tem sido estudada de diversas formas até o momento. Quando procuramos por "avaliação de desempenho de cooperativas de crédito" no Portal de Periódicos CAPES, encontramos 61 (sessenta e um) trabalhos. 
Esses trabalhos foram analisados com vistas a levantar indicadores de desempenho que vem sendo utilizados na academia para avaliar desempenho de cooperativas de crédito. Os indicadores levantados fizeram parte da coleta de dados empíricos.

Porém, dentre os 61 (sessenta e um) trabalhos analisados, apenas 1 (um) trata de indicadores de desempenho global, os demais, são especificamente voltados a análises de desempenho econômico-financeiras. Esse trabalho, elaborado por Porto (2002), está descrito, no quadro 10 abaixo.

Considerando um dos objetivos desse trabalho, que é identificar indicadores de avaliação desempenho que sejam pertinentes as cooperativas de crédito, sabe-se, conforme discutido em capítulos anteriores, que apenas indicadores econômicofinanceiros não bastam, sendo necessário desdobrar as perspectivas/dimensões e complementar o quadro de indicadores.

Autores como Oliveira Junior (1996), apontam para a necessidade de se avaliar o desempenho de cooperativas a partir de outros indicadores, que não só financeiros, ao colocar que os conjuntos de fatores econômico-financeiros e socioeconômicos são interdependes e o equilíbrio no seu desenvolvimento é que definirá a eficiência global das cooperativas.

Pinho (1986) também coloca que se os administradores de cooperativas priorizarem aspectos associativos correrão o risco de encontrar problemas na gestão financeira e ao mesmo tempo, se considerarem apenas aspectos empresariais, poderão se distanciar dos cooperados e da sua finalidade social. Portanto, a autora salienta a importância de se mensurar atividade social e econômico-financeira concomitantemente.

Em relação a essa ideia, Barros e Moraes (2015, p. 4) também corroboram:

... a avaliação do desempenho das cooperativas de crédito não deve se basear apenas nos mesmos indicadores tradicionalmente utilizados na avaliação de bancos, já que estas não são voltadas para a maximização de valor para o investidor com base no investimento e sim para a maximização de valor para o cooperado.

Portanto, tem-se o desafio de aperfeiçoar o conjunto de indicadores de forma a construir um quadro mais completo deles, que contemple a instituição de maneira global, visto que uma cooperativa de crédito, embora tenha a atividade principal voltada a questões econômico-financeiras, é uma instituição complexa, que demanda outras vertentes de análise, quando se trata do seu desempenho global. 
Destaca-se que ainda assim, optou-se por analisar os trabalhos que contemplam exclusivamente questões econômico-financeiras, pra que dêem suporte no momento de construir os indicadores dessa perspectiva, como os trabalhos de Bortoluzzi et al. (2011), Ferreira, Gonçalves e Braga (2007) e Bressan, Braga e Bressan (2003), Yamada e Bialoskorski Neto (2010), bem como as exigências do Banco Central do Brasil - BACEN, que regulamenta o cooperativismo de crédito brasileiro.

Para identificar outros indicadores, que não se limitem a aspectos financeiros, fez-se uma pesquisa no Google Acadêmico, utilizando a mesma referência de busca anterior: "avaliação de desempenho de cooperativas de crédito", e depois de analisados cerca de 50 (cinquenta) trabalhos, ainda deparava-se com a mesma problemática, ou seja, os trabalhos encontrados são voltados especialmente a análises financeiras, com exceção do trabalho de Hubner et al. (2012), cujo objetivo é propor um conjunto de fatores que podem se constituir em indicadores de desempenho sob a perspectiva do BSC em uma cooperativa de crédito; e Barros e Moraes (2015) que investigam desempenho financeiro e operacional, porém, esse último voltado apenas à prestação de serviços, desconsiderando o aspecto global da organização cooperativista.

Além desses trabalhos, voltados às cooperativas de crédito, optou-se por investigar sobre indicadores de desempenho de cooperativas de modo geral. Os trabalhos aqui analisados foram referenciados por outros já descritos anteriormente ou foram buscados em ferramentas de pesquisa a partir das palavras-chave: "avaliação de desempenho de cooperativas".

Com esta nova busca, obteve-se acesso ao trabalho de Bialoskorski Neto, Nagano e Moraes (2006), "Utilização de redes neurais artificiais para avaliação socioeconômica: uma aplicação em cooperativas", que se preocupa em mensurar o desempenho socioeconômico de cooperativas agropecuárias. Os indicadores apurados pelos autores estão dispostos no quadro 10 a seguir.

O trabalho de Menegário (2000) intitulado "Emprego de indicadores sócioeconômicos na avaliação financeira de cooperativas agropecuárias", traz a discussão da importância de aplicação de indicadores sociais para balizar o desempenho de cooperativas, visto que essas são organizações de "prestação de serviços, onde o 
dono é também usuário, o que torna o seu sucesso econômico dependente do seu sucesso social (MENEGÁRIO, 2000, p. 3).

O autor entende como indicadores socioeconômicos, aqueles que refletem o desempenho social da empresa cooperativa, ou seja, que estão relacionados a princípios doutrinários do cooperativismo e a características peculiares das cooperativas.

Sendo assim, Menegário (2000) lista como indicadores socioeconômicos para cooperativas: o nível de participação dos associados (medido pela relação "cooperados ativos/número total de associados" ou "cooperados presentes nas Assembleias Gerais Ordinárias/número total de associados"); sobras ou faturamento por cooperado; capital integralizado por associado; crescimento do quadro social ou do nível de participação (participação efetiva do cooperado na tomada de decisão por meio de votação em Assembleias); e eficiência dos serviços prestados (medido através da relação "número de funcionários do corpo de assistência técnica/cooperado ou pelo grau de diversificação das atividades da cooperativa).

Outro trabalho identificado como pertinente no que tange a elencar indicadores de desempenho de cooperativas é a tese de Munaretto (2013), que traz um conjunto de indicadores de avaliação de desempenho para cooperativas de eletrificação. Mais informações sobre esse e os demais trabalhos e seus indicadores estão dispostos no quadro 10.

Destaca-se que dentre as fontes pesquisadas foi possível levantar: 215 indicadores denominados Econômico/Financeiros; 6 indicadores denominados Cliente; 10 indicadores denominados Processos Internos; 7 indicadores denominados Aprendizado e Crescimento; 25 indicadores denominados Sociais; 5 indicadores denominados Sócio-econômicos; 12 indicadores denominados Eficiência Operacional; 5 indicadores denominados Pessoas e Inovação; 7 indicadores denominados Qualidade Técnica e Comercial; 4 indicadores denominados Satisfação do Consumidor; 5 indicadores denominados Relacionamento com Associados; 2 indicadores denominados Benefícios Sociais e Ambientais. 
Quadro 10 - Estudos anteriores relacionados à Gestão do Desempenho de Cooperativas e Cooperativas de Crédito

REFERÊNCIA: PORTO, Wellington Silva. Avaliação de Desempenho de Cooperativas de Crédito Rural Baseada no uso do Balanced Scorecard. Florianópolis, 2002. 80f. Dissertação (Mestrado em Engenharia de Produção) - Programa de Pós-graduação em Engenharia de Produção. UFSC, 2002.

\section{Objetivo do estudo}

\section{Propor um modelo de}

avaliação de desempenho

empresarial voltado para

cooperativas de crédito rural,

que possibilite a conciliação

dos objetivos estratégico-

empresariais e os objetivos

sociais, atendendo às

necessidades comuns dos

cooperantes, e, ao mesmo

tempo, utilizando seu

potencial frente ao mercado,

visando o sucesso das

atividades produtivas

individuais, com enfoque no

Balanced Scorecard.

\section{PERSPECTIVA FINANCEIRA:}

Percentual de vendas das novas aplicações; Taxa de Redução do custo por transação; Retorno sobre o Capital

Empregado; Aumento das vendas nos segmentos-chave; Percentual de transações em seus vários canais; Valor

Econômico Agregado

\section{PERSPECTIVA DO CLIENTE:}

Captação de cooperantes; Retenção de cooperantes; Satisfação de cooperantes (Conforto do ambiente; tempo de espera até o atendimento; Burocracia do atendimento; Qualidade do atendimento; Produtos e serviços oferecidos (qualidade e diversidade); Custo dos produtos e serviços; Estacionamento; Unificação ou concentração dos assuntos a serem resolvidos; Opções de serviços pela Internet; Segurança do prédio; Segurança das transações; Serviço "Call center"; Qualidade do atendimento; Custo dos produtos e serviços; Unificação ou concentração dos assuntos a serem resolvidos; Segurança das transações; Tempo de espera até o atendimento).

\section{PERSPECTIVA DOS PROCESSOS INTERNOS:}

Lucratividade por segmento-salvo; Percentual de receita gerada por novos produtos; Percentual de transações realizadas através dos diversos canais (caixas eletrônicos, caixas convencionais, ou auxiliadas por computador)

PERSPECTIVA DE APRENDIZADO E CRESCIMENTO:

Melhorias das capacidades dos funcionários; Melhorias dos sistemas de informação; Motivação para agir no melhor interesse da empresa 
REFERÉNCIA: BORTOLUZZI, S. C.; ENSSLIN, S. R.; LYRIO, M. V. L.; ENSSLIN, L. Avaliação de desempenho econômico-financeiro: uma proposta de integração de indicadores contábeis tradicionais por meio da Metodologia Multicritério de Apoio à Decisão Construtivista (MCDA-C). Revista Alcance - Eletrônica, Vol. 18 - n. 2 - p. 200-218 / abr-jun 2011.

\begin{tabular}{|c|c|}
\hline Objetivo do estudo & Indicadores de desempenho \\
\hline $\begin{array}{l}\text { Propor um modelo para } \\
\text { Avaliação de Desempenho } \\
\text { econômico-financeiro, } \\
\text { considerando os indicadores } \\
\text { contábeis tradicionais e } \\
\text { buscando integrá-los, com } \\
\text { base nas percepções do } \\
\text { decisor, para possibilitar } \\
\text { uma avaliação global do } \\
\text { desempenho econômico- } \\
\text { financeiro da organização. }\end{array}$ & $\begin{array}{l}\text { INDICADORES FINANCEIROS: } \\
\text { Rentabilidade do patrimônio líquido; Imobilização do patrimônio líquido; Liquidez corrente; Participação de capital de } \\
\text { terceiros; Rentabilidade sobre o ativo; Margem líquida; Liquidez geral; Valor patrimonial da ação; Lucro por ação; } \\
\text { LAJIR por ação; Fluxo de caixa por ação; LAJIDA por ação; Fluxo de caixa operacional sobre o Passivo Circulante; } \\
\text { Giro da capital circulante; Grau do endividamento financeiro; Margem bruta; Resultado econômico; Retorno sobre o } \\
\text { investimento; Economic Value Added (EVA); Market Value Added (MVA); Margem Operacional; EBITDA (Earnings } \\
\text { Before Interest, Taxes, Depreciation and Amortization); Fluxo de Caixa Operacional }\end{array}$ \\
\hline \multicolumn{2}{|c|}{$\begin{array}{l}\text { REFERÊNCIA: FERREIRA, M. A. M.; GONÇALVES, R. M. L.; BRAGA, M. J. Investigação do desempenho das cooperativas de crédito de Minas } \\
\text { Gerais por meio da DEA. Economia Aplicada, São Paulo, v. 11, n. 3, p. 425-445, Jul-Set. } 2007 .\end{array}$} \\
\hline Objetivo do estudo & Indicadores de desempenho \\
\hline $\begin{array}{l}\text { Buscou investigar o } \\
\text { desempenho das } \\
\text { Cooperativas de Economia e } \\
\text { Crédito Mútuo de Minas } \\
\text { Gerais, fundamentando-se } \\
\text { no conceito de eficiência e } \\
\text { considerando o seu papel de } \\
\text { instituições de } \\
\text { desintermediação financeira } \\
\text { entre os seus membros } \\
\text { associados. }\end{array}$ & $\begin{array}{l}\text { INDICADORES FINANCEIROS } \\
\text { Capitalização; Imobilização; Capital em giro; Alavancagem; Cobertura voluntária; Liquidez geral; Volume de crédito; } \\
\text { Despesa com Pessoal; Despesa Administrativa; Despesa total; Geração de rendas; Crescimento aplicações totais; } \\
\text { Crescimento captações totais; Crescimento receita operacional }\end{array}$ \\
\hline
\end{tabular}


REFERÊNCIA: BRESSAN, V. G. F.; BRAGA, M. J.; BRESSAN, A. A. Avaliação financeira das cooperativas de crédito rural do estado de Minas Gerais. O.R. \& A. Revista de Administração da UFLA - v.5 - n.2 - julho/dezembro 2003.

\begin{tabular}{|c|c|}
\hline Objetivo do estudo & Indicadores de desempenho \\
\hline $\begin{array}{l}\text { Este artigo apresenta uma } \\
\text { análise financeira das } \\
\text { cooperativas de crédito rural } \\
\text { no estado de Minas Gerais, } \\
\text { no período de } 1998 \text { a } 2001 .\end{array}$ & $\begin{array}{l}\text { INDICADORES FINANCEIROS } \\
\text { 1. Estrutura; Capitalização; Imobilização; Capital de giro; Alavancagem; Solvência; Encaixe; Cobertura voluntária; } \\
\text { Liquidez geral; Volume de crédito em relação ao patrimônio líquido; Despesa; Despesa de pessoal; Despesa } \\
\text { administrativa; Despesa total; Rentabilidade; Geração de renda; Crescimento; Aplicações totais; Captações totais; } \\
\text { Receita operacional; Ativo real; Passivo real. }\end{array}$ \\
\hline \multicolumn{2}{|c|}{$\begin{array}{l}\text { REFERÊNCIA: HUBNER, B. T.; TIECKER, S. S.; UTZIG, M. J. S.; MAGRO, C. B. D.; DITTADI, J. R.; LAVARDA, C. E. F. Proposta de Indicadores } \\
\text { de Performance sob a Perspectiva do Balanced Scorecard: O Caso de uma Cooperativa de Crédito. Revista Catarinense da Ciência Contábil - } \\
\text { CRCSC - Florianópolis, v. 11, n. 31, p. 9-22, dez./mar. } 2012\end{array}$} \\
\hline Objetivo do estudo & Indicadores de desempenho \\
\hline $\begin{array}{l}\text { O estudo teve por objetivo } \\
\text { propor um conjunto de } \\
\text { fatores que podem se } \\
\text { constituir em indicadores de } \\
\text { desempenho sob a } \\
\text { perspectiva do BSC em uma } \\
\text { cooperativa de crédito. }\end{array}$ & $\begin{array}{l}\text { PERSPECTIVA DE APRENDIZAGEM E CRESCIMENTO } \\
\text { Qualidade do atendimento; Motivação do colaborador em desempenhar sua função; Conhecimento do colaborador } \\
\text { para dar informações corretas; Nivel de rotatividade } \\
\text { PERSPECTIVA DOS CLIENTES } \\
\text { Qualidade do atendimento; Satisfação do cliente ( cortesia no atendimento em geral; consulta aos clientes; qualidade } \\
\text { na prestação do atendimento; acessibilidade à informação; tempo de atendimento no caixa; qualidade da informação } \\
\text { disponibilizada; custos dos produtos e serviços; diversidade dos produtos e serviços; atendimento telefônico; } \\
\text { burocracia no atendimento; serviço da carteira de crédito; satisfação com o desempenho da organização; tempo de } \\
\text { espera na fila; qualidade na prestação de serviço de caixa; segurança nas transações via internet; atendimento por } \\
\text { meios eletrônicos; estacionamento); Atendimento on line } \\
\text { PERSPECTIVA FINANCEIRA: } \\
\text { Endividamento; Capacidade de cada setor de gerar recursos financeiros; Nível de comprometimento da receita; } \\
\text { Equilíbrio do orçamento (receitas maiores que despesas); Volume de receitas } \\
\text { PERSPECTIVA DE PROCESSOS INTERNOS }\end{array}$ \\
\hline
\end{tabular}




\begin{tabular}{|c|c|}
\hline & $\begin{array}{l}\text { Modo e velocidade na concepção de novos produtos e serviços; Demanda de produtos e serviços na cooperativa; } \\
\text { Volume de produtos oferecidos e com demanda satisfatória; Projetos sociais desenvolvidos; Nível de transparência; } \\
\text { Quantidade de estagiários; Número de eventos que os colaboradores participam }\end{array}$ \\
\hline \multicolumn{2}{|c|}{$\begin{array}{l}\text { REFERÊNCIA: BIALOSKORSKI NETO, S.; NAGANO, M. S.; MORAES, M. B. C. Utilização de redes neurais artificiais para avaliação } \\
\text { socioeconômica: uma aplicação em cooperativas. R.Adm., São Paulo, v.41, n.1, p.59-68, jan./fev./mar. } 2006\end{array}$} \\
\hline Objetivo do estudo & Indicadores de desempenho \\
\hline $\begin{array}{l}\text { Apresenta e discute a } \\
\text { utilização de Redes Neurais } \\
\text { Artificiais (RNA) para a } \\
\text { mensuração do } \\
\text { desempenho } \\
\text { socioeconômico aplicado em } \\
\text { cooperativas agropecuárias. }\end{array}$ & 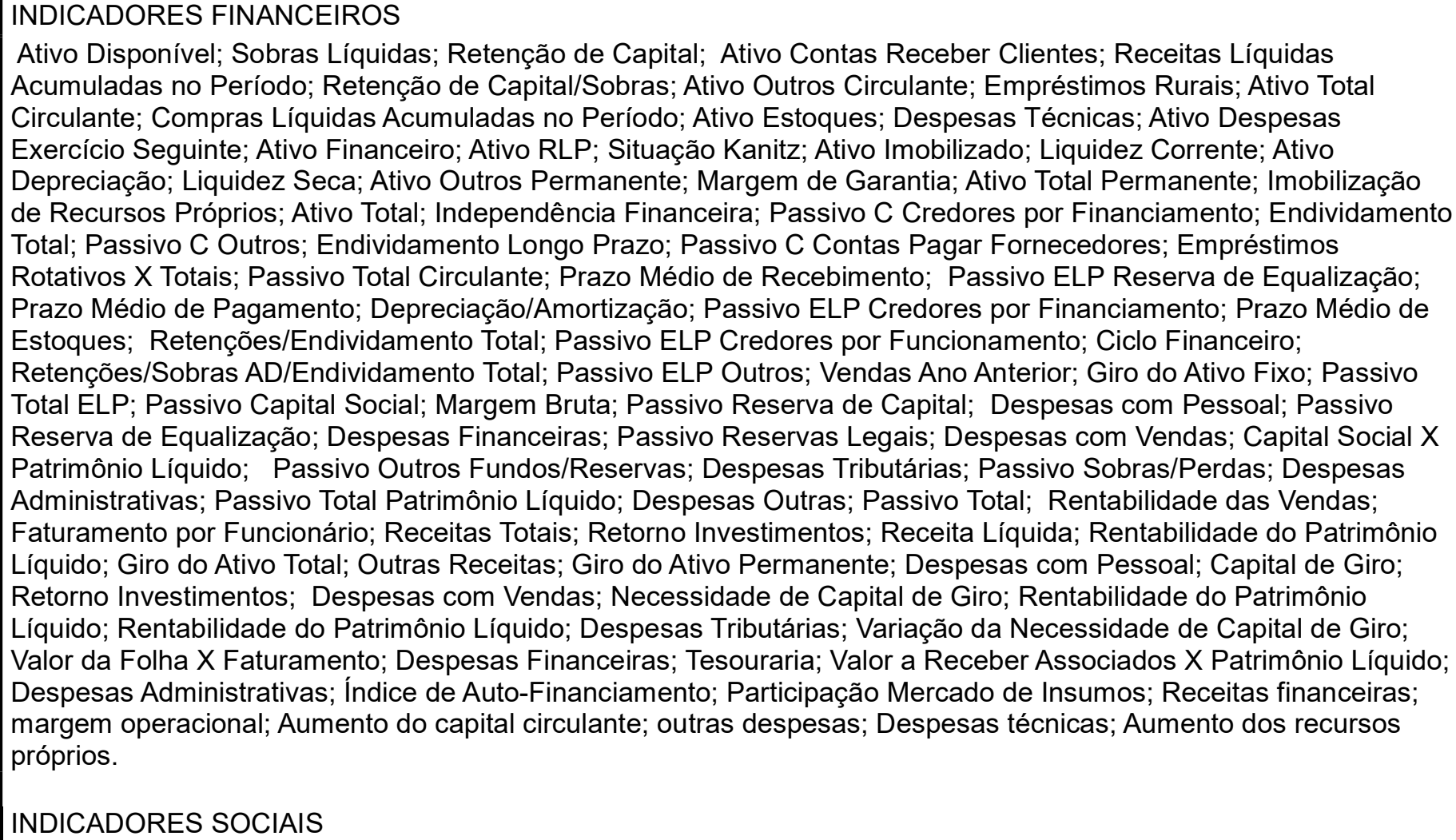 \\
\hline
\end{tabular}




\begin{tabular}{|c|c|}
\hline & $\begin{array}{l}\text { Número Associados Atual; Número Associados Anterior; Associados em Assembleia Geral Ordinária (AGO); } \\
\text { Associados em Comitês; Número Associados Ativos; Número Funcionários; Número Funcionários Demitidos; } \\
\text { Número Técnicos; Número Produtores Ação; Produção Área/Ação; Recebimento Físico; Valor da Folha de } \\
\text { Pagamento; Valor a Receber Associados; Mercado de Insumos; Fornecimento de Insumos; Crescimento das } \\
\text { Vendas; Faturamento por Associado; Crescimento do Quadro Social; Participação Social; Capital Social por } \\
\text { Associado; Associados Ativos X Associados Total; Participação nas Assembleias; Representação Social e Política; } \\
\text { Associados X Funcionários; Associados X Técnicos; Participação de Mercado. }\end{array}$ \\
\hline \multicolumn{2}{|c|}{$\begin{array}{l}\text { REFERÊNCIA: MENGÁRIO, A. H. Emprego de indicadores sócio-econômicos na avaliação financeira de cooperativas agropecuárias. Dissertação } \\
\text { (mestrado) da Escola Superior de Agricultura Luiz de Queiroz. Piracicaba, 2000. } 121 \text { p. }\end{array}$} \\
\hline Objetivo do estudo & \begin{tabular}{|c|} 
Indicadores de desempenho \\
\end{tabular} \\
\hline $\begin{array}{l}\text { Avaliar a influência de } \\
\text { indicadores sócio- } \\
\text { econômicos na situação } \\
\text { financeira, particularmente } \\
\text { na previsão de } \\
\text { inadimplência junto ao } \\
\text { sistema financeiro, das } \\
\text { cooperativas agropecuárias } \\
\text { do Estado do Paraná. }\end{array}$ & $\begin{array}{l}\text { INDICADORES SÓCIO-ECONÔMICOS } \\
\text { 1.Nível de participação dos associados (medido pela relação "cooperados ativos/número total de associados" ou } \\
\text { "cooperados presentes nas Assembleias Gerais Ordinárias/número total de associados"); Sobras ou faturamento por } \\
\text { cooperado; Capital integralizado por associado; Crescimento do quadro social ou do nível de participação } \\
\text { (participação efetiva do cooperado na tomada de decisão - por meio de votação em Assembleias); Eficiência dos } \\
\text { serviços prestados (medido através da relação "número de funcionários do corpo de assistência técnica/cooperado } \\
\text { ou pelo grau de diversificação das atividades da cooperativa). }\end{array}$ \\
\hline \multicolumn{2}{|c|}{$\begin{array}{l}\text { REFERÊNCIA: MUNARETTO, L. F. Avaliação de desempenho organizacional em cooperativas de eletrificação: um estudo sobre o uso de } \\
\text { indicadores de desempenho. Tese (doutorado) - Universidade de São Paulo. São Paulo, 2013, } 293 \text { p. }\end{array}$} \\
\hline Objetivo do estudo & Indicadores de desempenho \\
\hline $\begin{array}{l}\text { O estudo apresentou os } \\
\text { objetivos de desenvolver } \\
\text { lista de indicadores para } \\
\text { compor modelo de avaliação } \\
\text { de desempenho para as } \\
\text { CEs e após verificar sobre o } \\
\text { uso e finalidade dos } \\
\text { indicadores CEs, na }\end{array}$ & $\begin{array}{l}\text { INDICADORES ECONÔMICO-FINANCEIROS } \\
\text { Percentual das despesas operacionais em relação às vendas de energia; Índice de endividamento; Liquidez } \\
\text { corrente; EBITDA; Margem Líquida; Percentual do faturamento investido no sistema elétrico de geração e } \\
\text { distribuição; Investimento na construção de novas redes; Valor adicionado da cooperativa; Retorno do patrimônio } \\
\text { líquido (rentabilidade). } \\
\text { INDICADORES DE EFICIÊNCIA OPERACIONAL }\end{array}$ \\
\hline
\end{tabular}




\begin{tabular}{|c|c|}
\hline $\begin{array}{l}\text { seqüência foi verificado } \\
\text { sobre a existência de } \\
\text { correlação (associação) dos } \\
\text { indicadores com as } \\
\text { finalidades de tomada de } \\
\text { decisão estratégica, } \\
\text { monitoramento e controle, } \\
\text { educação e aprendizagem, } \\
\text { legitimidade e comunicação } \\
\text { externa, e por fim foi } \\
\text { verificado sobre as } \\
\text { finalidades mais relevantes } \\
\text { no uso de indicadores nas } \\
\text { CEs. }\end{array}$ & $\begin{array}{l}\text { Custo médio do kWh. De energia adquirida; Custo médio do kWh. De energia faturada; Energia faturada em kWh; } \\
\text { Energia adquirida em kWh; Percentual de energia com fugas e perdas; Horas extras (trabalho extraordinário); Custo } \\
\text { e despesas por consumidor de energia; Gastos com frota de veículos por Km rodados; Percentual de queima de } \\
\text { transformadores - PQT. } \\
\text { INDICADORES DE PESSOAS E INOVAÇÃO } \\
\text { Nível de satisfação dos colaboradores; Percentual de colaboradores com cursos de especialização, mestrado e } \\
\text { doutorado; Percentual de faturamento gasto em treinamento; Giro dos colaboradores (turnover); Número de } \\
\text { acidentes de trabalho; } \\
\text { INDICADORES DE QUALIDADE TÉCNICA E COMERCIAL } \\
\text { FEC (freqüência equivalente de interrupção por unidade consumidora); DEC (duração equivalente de interrupção por } \\
\text { unidade consumidora); DIC (duração de interrupção individual por unidade consumidora); FIC (freqüência de } \\
\text { interrupção individual por unidade consumidora); DMIC (duração máxima de interrupção contínua por unidade } \\
\text { consumidora); DER - duração equivalente de reclamação (insatisfação do consumidor); FER - freqüência } \\
\text { equivalente de reclamação (insatisfação do consumidor). } \\
\text { INDICADORES DE SATISFAÇÃO DO CONSUMIDOR } \\
\text { Índice de satisfação dos consumidores de energia; Valor de venda médio por consumidor; Quantidade de kWh. } \\
\text { Faturado/número de consumidores; Número de reclamações recebidas de clientes. } \\
\text { INDICADORES DE RELACIONAMENTO COM ASSOCIADOS } \\
\text { Número de sócios que ingressaram na cooperativa de eletrificação; Participação em reuniões dos associados } \\
\text { (Assembleia Geral dos Sócios); Gastos com a formação do quadro social (FATES); Faturamento com associados; } \\
\text { Distribuição de sobras do exercício. }\end{array}$ \\
\hline
\end{tabular}




\begin{tabular}{|c|c|}
\hline \multicolumn{2}{|c|}{$\begin{array}{l}\text { REFERÊNCIA: YAMADA, C. Y.; BIALOSKORSKI NETO, S. Indicadores e Avaliação de Desempenho de Cooperativas de Crédito Rural. XVIII } \\
\text { SIICUSP, São Paulo, } 2010 .\end{array}$} \\
\hline Objetivo do estudo & Indicadores de desempenho \\
\hline $\begin{array}{l}\text { O objetivo desse trabalho é } \\
\text { estudar os indicadores e a } \\
\text { avaliação de desempenho } \\
\text { das cooperativas de crédito } \\
\text { rural e, especificamente, } \\
\text { discutir se a identificação } \\
\text { entre os indicadores } \\
\text { financeiros disponíveis para } \\
\text { análise de instituições } \\
\text { financeiras são consistentes } \\
\text { para a realização de tal } \\
\text { análise nas cooperativas de } \\
\text { crédito rural. }\end{array}$ & $\begin{array}{l}\text { INDICADORES FINANCEIROS } \\
\text { Independência Financeira - medida por Margem Financeira e Retorno sobre investimentos; Margem financeira; } \\
\text { Índice de Eficiência Operacional; Rentabilidade Financeira - englobou Custo de Capitação e Relação } \\
\text { Capital/Depositante. }\end{array}$ \\
\hline \multicolumn{2}{|r|}{ REFERÊNCIA: OCFD } \\
\hline Objetivo do estudo & Indicadores de desempenho \\
\hline $\begin{array}{l}\text { Principais indicadores } \\
\text { financeiros listados no Plano } \\
\text { Contábil do Sistema } \\
\text { Financeiro (COSIF) }\end{array}$ & $\begin{array}{l}\text { INDICADORES DE LIQUIDEZ } \\
\text { Liquidez Geral (LG) - Mede o grau de liquidez mediante confronto entre o ativo circulante e realizável em longo prazo } \\
\text { com o passivo circulante e exigivel em longo prazo; Liquidez Imediata (LM) - Mede o grau de liquidez mediante; } \\
\text { Confronto entre os ativos de maior grau de realização em relação aos depósitos. } \\
\text { ESTRUTURA DE CAPITAL } \\
\text { Composição de créditos (CAC) - Indica a relação entre as operações de crédito e as captações. Das operações de } \\
\text { crédito estão deduzidos os créditos em liquidação; Nível de inadimplemento (NID) - Demonstra o grau de risco das } \\
\text { operações de crédito, mediante confronto entre as operações de crédito em liquidação e as operações de crédito; } \\
\text { Comprometimento patrimonial (COMP) - Revela os recursos próprios aplicados em ativos de menor conversibilidade. }\end{array}$ \\
\hline
\end{tabular}




\begin{tabular}{|c|c|}
\hline & $\begin{array}{l}\text { Geração de receita (GER) - Mede o grau de geração de receitas oriundas do ativo total, mediante confronto entre as } \\
\text { receitas totais e os ativos totais; Rentabilidade financeira (REF) - Demonstra o retorno proporcionado pelas } \\
\text { aplicações financeiras, mediante confronto entre as receitas das aplicações financeiras e as aplicações financeiras; } \\
\text { Receitas dos créditos (REC) - Demonstra o retorno proporcionado pelas operações de crédito, mediante confronto } \\
\text { entre as receitas de operações de crédito e as operações de crédito; } \\
\text { DESEMPENHO DA CAPTAÇÃo } \\
\text { Custo da captação (CCP) - Indica o custo incorrido nas captações, mediante confronto entre as despesas de } \\
\text { captações e as captações totais remuneradas; Retorno da captação (RCP) - Estabelece a relação entre as despesas } \\
\text { de captação e as receitas das operações de crédito. } \\
\text { COMPORTAMENTO DA GESTÃO } \\
\text { Custo da gestão (CGE) - Indica a participação das despesas administrativas nas despesas totais; Receitas e } \\
\text { despesas (RED) - Revela o desequilíbrio financeiro. }\end{array}$ \\
\hline \multicolumn{2}{|c|}{$\begin{array}{l}\text { REFERÊNCIA: BARROS, M. G.; MOARES; M. B. C. Análise dos Determinantes de Desempenho em Cooperativas de Crédito no Brasil: Um Estudo } \\
\text { com Base no Desempenho Financeiro e Operacional em Benefício ao Cooperado. XV Congresso USP de Controladoria e Contabilidade. São } \\
\text { Paulo: julho, 2015. }\end{array}$} \\
\hline Objetivo do estudo & Indicadores de desempenho \\
\hline $\begin{array}{l}\text { O trabalho buscou investigar } \\
\text { os determinantes do } \\
\text { desempenho das } \\
\text { Cooperativas de Crédito } \\
\text { brasileiras considerando sua } \\
\text { finalidade principal de } \\
\text { beneficiar os cooperados. }\end{array}$ & $\begin{array}{l}\text { INDICADORES FINANCEIROS: } \\
\text { Alavancagem; Exigibilidades Tributárias e Trabalhistas; Rentabilidade do Patrimônio Líquido Final; Rentabilidade do } \\
\text { Patrimônio Líquido Ajustado; Rentabilidade da Atividade Bancária; Rentabilidade da Atividade Bancária; } \\
\text { Rentabilidade do Crédito; Eficiência Operacional; Margem Bruta, Margem Liquida; Créditos Não Problemáticos, } \\
\text { Provisionamento; Spread; Liquidez Geral; Despesas Administrativas pela Receita Total; Despesa Administrativa pelo } \\
\text { Ativo Total; Descasamento Ativo; Operações de Crédito pelo Ativo Total; Custos Administrativos pelas Receitas; } \\
\text { Sobras pelo Ativo Total; Sobras pela Receita Total; Despesas Administrativas pelos Depósitos; Participação da } \\
\text { Receita de Intermediação na Receita Total. } \\
\text { INDICADORES OPERACIONAIS: } \\
\text { Participação da Receita de Interm. Receita Total (receita de Intermediação Financeira/receita total); Despesas } \\
\text { Administrativas pelos Depósitos (despesas administrativas/depósitos); Volume de Sobras pelo Ativo Total (sobras } \\
\text { líquidas/ativo total) }\end{array}$ \\
\hline
\end{tabular}

Fonte: elaborado pela autora. 


\subsection{TEORIA DA AGÊNCIA}

A teoria dos custos da agência passa a ser desenvolvida com maior ênfase a partir do artigo de Jensen e Meckling (1976), quando os autores dão novo enfoque aos estudos sobre relacionamentos de agência, ao acrescentarem aspectos comportamentais.

Essa área está atrelada ao estudo da Governança Corporativa, e advém das relações sociais e econômicas geradas pela necessidade de contratação de terceiros para a produção (FAVALLI, 2010). Ou seja, estuda a relação entre "agente" (profissional contratado) e "principal" (contratante).

A existência de "agente" e "principal" se dá pelo fato de que as operações das instituições estão cada dia mais complexas, necessitando então a contratação de profissionais especialistas em determinados setores, visando crescimento e o desenvolvimento patrimonial da instituição (ARRUDA; MADRUGA; FREITAS JUNIOR, 2008).

No início do século passado, os chamados conflitos ou custos de agência, não eram tão relevantes, pois a propriedade e o controle das grandes empresas estavam nas mãos dos indivíduos chamados de "capitães da indústria". A crise econômica de 1929 , que acarretou grandes perdas para investidores, e o surgimento das grandes corporações levaram à desconcentração da propriedade e à criação de um novo modelo de controle empresarial, em que o principal, o titular da propriedade, delega ao agente o poder de decisão sobre essa propriedade (PRATT; ZECKHAUSER, 1985).

Portanto, esse contexto está diretamente ligado ao processo histórico evolutivo das corporações durante o século passado e mais fortemente nos dias atuais, com o movimento de internacionalização da estrutura de propriedade das organizações, dispersão do número de acionistas, pulverização da propriedade e a ocorrência de maior rotatividade da propriedade acionária com a negociação das ações nas bolsas de valores (ANDRADE; ROSSETTI, 2007).

Nesse cenário, a estrutura institucional deixa de ser centrada em uma pessoa ou em um pequeno grupo e passa a ser composta por diversos acionistas. Altera-se também a gerência dos negócios, que deixa de ser conduzida pelo proprietário, que antes era o gerente ou principal executivo, e passa a ser a conduzida por funcionários contratados para esse fim, havendo uma separação entre os acionistas (donos do 
capital) e os administradores (que gerenciam o capital do acionista) (MARTIN ET AL., 2004).

Porém, o proprietário e contratado tem interesses distintos, fazendo surgir os conflitos de agência, pois, se ambas as partes de tal relação são maximizadoras de utilidade, há boa motivação para acreditar que o agente nem sempre agirá de acordo com os melhores interesses do principal (JENSEN, MECKLING, 1976; COSTAMARQUES E CONDE, 2000; GODOY E MARCON, 2006). Segundo Morgan (2002), na prática, os agentes se preocupam com a própria riqueza, com os benefícios indiretos, com a segurança no emprego, e com aspectos extra-organização.

Nesse sentido, a teoria da agência estuda as relações entre os participantes de um sistema, em que propriedade e controle são designados a pessoas diferentes, gerando conflitos de interesse entre os indivíduos (ARRUDA, MADRUGA, FREITAS JUNIOR; 2008).

Isso porque, conforme observa Fontes Filho (2003) existem interesses distintos entre principal e agente. A separação entre propriedade e gestão, embora efetiva para assegurar o investimento do proprietário em novos negócios e agregar capital de outros sócios para a sua expansão, introduz problemas de relacionamento entre proprietários e gestores. O gestor ou agente, dotado de interesses individuais, pode não perseguir os objetivos dispostos pelos proprietários, o principal, ou não empregar todo o esforço necessário para a condução do negócio.

Basicamente, esses conflitos de interesses acontecem, pois nenhum indivíduo deseja maximizar uma função que não seja a sua, já que seus comportamentos serão sempre condizentes com suas preferências e objetivos, ou seja, a hipótese fundamental dessa teoria é que as pessoas têm interesses diferentes e cada uma busca maximizar seus próprios objetivos.

Dentre os conflitos de interesse, Eggertsson (1995) destaca: a) assimetria de informação - o agente dispõe de mais informação sobre os detalhes das tarefas a executar do que o proprietário, o que lhe permite obter vantagens; b) os interesses das partes envolvidas (proprietário e agente) não coincidem e, muitas vezes, podem entrar em conflito e c) a existência de comportamentos e oportunistas por parte dos agentes conduz a custos mais elevados para o proprietário.

Portanto, dizer que o agente sempre age em benefício do principal é "simplista e esconde vieses de comportamento do administrador que podem prejudicar a 
empresa... é impossível assegurar que o agente tome decisão ótima do ponto de vista do principal" (KAIO; FAMÁ, 1997, p. 2-3).

Segundo Mendes (2001), é essencial pensar que o "principal” irá perder parte de sua riqueza e, deverá extrair do "agente" o melhor desempenho possível, já que deixará de obter o máximo para obter o possível, devido à participação de um administrador profissional.

Portanto, sempre irá existir uma perda residual por parte do principal. Essa perda é referente a cada unidade monetária equivalente de redução no bem-estar do principal em função das divergências existentes que, por sua vez, não conduzem àquelas decisões que maximizariam esse bem-estar. Sempre que um indivíduo depende da ação de outro, um relacionamento de agência surge (PRATT; ZECKHAUSER, 1985).

Salienta-se, que os conflitos de agência não são exclusivos de relações empresariais, aplicando-se também a qualquer situação onde alguém detém a propriedade e delega poderes a outra parte. Tal sentimento de insegurança e desconfiança, pode se instalar em qualquer tipo de instituição em que exista agente e principal (NASCIMENTO; BIANCHI, 2005).

Segundo os autores, essa apreensão gera a necessidade de se criar mecanismos que revistam as operações da organização com a segurança necessária para que a integridade de seus resultados seja preservada e as transações que os formam sejam conduzidas com eficácia e transparência. Essa preocupação incentiva a adoção de uma estratégia para o comportamento administrativo que considere um alinhamento entre os objetivos do principal e do agente.

Em suma, a teoria da agência se preocupa em resolver problemas causados pelo fato de o desejo ou objetivo do principal e do agente serem conflitantes, já que os mesmos apresentam diferenças quanto às suas preferências, bem como pela dificuldade do principal monitorar o comportamento do agente. Portanto, o foco dessa teoria está em determinar um contrato mais eficiente entre agente e principal, considerando as pessoas, a organização e a informação (CLARK, 2004).

Os conflitos de agências não são facilmente eliminados, já que não existe contrato completo, que abranja todas as condições e respostas às mudanças, e nem agente perfeito, já que o interesse próprio se sobrepõe aos interesses de terceiros (JENSEN; MECKLING, 1976). 
Visando reduzir o conflito de agência, as relações entre os proprietários e agentes podem ser reguladas por contratos formais ou informais. A relação é considerada formal, ou explícita, quando é expressa por meio de contratos que determinam os direitos e os deveres principais e acessórios, assinados por ambas as partes. A relação é dita implícita, ou informal, quando as relações não são orientadas por contratos, mas por usos e costumes que vão sustentar e dar legitimidade às ações dos proprietários e agentes (SILVA, 2011).

$\mathrm{Na}$ tentativa de encontrar uma solução otimizada para eliminar, ou pelo menos reduzir uma eventual distância existente entre o que o principal espera e o que efetivamente é realizado pelo agente, ocorrem alguns custos, chamados de custos de agência. Considerando-se a relação entre os proprietários e o agente, esses custos podem ser despesas de criação e estruturação de contratos, despesas de monitoramento, contratação de seguros contra perdas decorrentes de má administração, ou planos de incentivos para melhorar o desempenho da administração. Esses incentivos podem ser remunerações, bonificações ou concessão de ações associadas ao desempenho do administrador (SILVA, 2011).

Jensen e Meckling (1976) também enumeram como custos de agência: despesas com o monitoramento pelo principal para limitar atividades aberrantes do agente, visando acompanhar se o mesmo atua para defender os interesses do principal; despesas com bonding para garantir que o agente não irá tomar certas decisões que prejudiquem o principal ou para garantir que o principal será compensado caso o agente tome essas ações; perda residual (residual loss) que corresponde à diminuição da riqueza do principal devido a divergências entre as decisões dos agentes e as decisões que iriam maximizar a riqueza do principal.

Portanto, os custos de agência são a soma dos: custos de criação e estruturação de contratos entre o principal e o agente; gastos de monitoramento das atividades dos gestores pelo principal; gastos promovidos pelo próprio agente para mostrar ao principal que seus atos não serão prejudiciais ao mesmo; e perdas residuais (JENSEN; MECKLING, 1976).

Segundo Segatto-Mendes e Carvalho Rocha (2005), o principal também pode procurar meios de entusiasmar o agente à tomada de decisões que resultariam em aspectos positivos ao principal, o que também representa um custo de agência. 
Percebe-se, dessa forma, que os conflitos de interesse conduzem à existência de custos, que envolvem tanto custos de oportunidade (relativos às perdas devido à aplicação de recursos em determinado fim e não em outro que geraria maiores rendimentos) quanto gastos para monitoramento do comportamento dos administradores, com a finalidade de incentivá-los a buscar a maximização da riqueza do acionista e protegê-lo de ações inadequadas dos administradores.

Portanto, o foco de análise da Teoria da Agência está no comportamento oportunista do agente, bem como na sugestão de mecanismos que asseguram a construção de um contrato o mais eficiente possível na solução dos problemas derivados da relação entre principal e agente (MARTINEZ, 1998).

De forma geral, a Teoria da Agência tem sido de grande valia no entendimento das diversas relações entre principal e agente, em diversos setores no ambiente organizacional, e busca estabelecer e identificar os incentivos que levam o agente a, de uma maneira geral, executar o que dele se espera, de forma a atender aos interesses do principal, visando reduzir os conflitos mencionados. 


\section{DESENVOLVIMENTO DO MODELO TEÓRICO E CONSTRUÇÃO DAS HIPÓTESES DE PESQUISA: COOPERATIVAS, CONFLITOS DE AGÊNCIA E A PERCEPÇÃO DE AVALIAÇÃO DE DESEMPENHO POR PARTE DE COOPERADOS, GERENTES E CONSELHEIROS}

Os conflitos de agência em cooperativas podem surgir pelo fato de essas serem organizações complexas, nas quais as funções de decisão são separadas das funções de assumir o risco residual, que é o risco da diferença entre entradas estatísticas de recursos e pagamentos prometidos pelos agentes.

Bialoskorski Neto, Barroso e Rezende (2008), entendem que um conflito de agência surge nas cooperativas brasileiras pelo fato de os resultados (sobras) serem distribuídos aos associados proporcionalmente às operações de cada um deles e, não, aos gestores a título de participação.

Já para Branch e Baker (2000), o principal conflito de agência em sociedades cooperativas acontece por não haver uma separação clara entre os proprietários (associados) e os tomadores de decisão (gestores) da cooperativa.

Em se tratando de cooperativas, destaca-se que os direitos de propriedade nesse tipo de organização são confusos, visto que as quotas-parte não são negociáveis em mercado, o poder de decisão é igualitário e o direito sobre os resultados do empreendimento não é transparente. Essas características geram uma série de dificuldades na gestão dessas instituições e favorecem o surgimento de conflitos entre os membros que assumem cargos de direção na cooperativa e os demais cooperados (SILVA; SOUSA; LEITE, 2011).

Eles também surgem porque os direitos de retornos não são negociáveis e reembolsáveis, o que deixa os associados ausentes de informações de mercado que poderiam favorecer suas decisões. Além disso, o corpo de administradores é constituído quase que exclusivamente de cooperados que, com freqüência, não têm informações específicas da organização para uma tomada de decisões efetiva, prejudicando, especialmente, as decisões de longo prazo (COOK ET AL., 2004).

Para Zylbersztajn (2002), o duplo papel do cooperado, sendo, ao mesmo tempo, proprietário e usuário, é o responsável por grande parte dos problemas de gestão que as cooperativas enfrentam, pois gera problemas relacionados a não separação entre propriedade e controle, causando perda de eficiência gerencial da cooperativa, especialmente em organizações com elevado grau de complexidade. 
Ou seja, na nomenclatura da teoria da agência, o cooperado será, simultaneamente, agente e principal da mesma relação contratual. Essa relação, para Bialoskorski Neto (1994), pode levar a uma situação de ineficiência para a cooperativa, uma vez que, nas assembleias gerais e nos momentos de definições econômicas na cooperativa, esse cooperado - agente - pode fixar, como principal da relação contratual, sua própria remuneração ou suas margens de custos. Também são possíveis o aparecimento e o incremento das remunerações não pecuniárias para o grupo de cooperados que procede à gestão da empresa, principalmente no conselho de administração e no conselho fiscal.

Portanto, não há separação efetiva entre propriedade e controle nas cooperativas, o que pode se transformar em um problema grave de conflito de agência, que será semelhante àquele observado entre os acionistas minoritários e os acionistas controladores, já que os ocupantes dos cargos nos conselhos da cooperativa, embora não detenham maior participação na propriedade da mesma, terão maior participação no seu controle e poderão obter e manter vantagens pessoais (SILVA; SOUSA; LEITE, 2011).

As cooperativas também podem apresentar diferentes conflitos associados ao direito de propriedade, conforme apontados por Cook (1995) e Cook et al. (2004): o problema free-rider (ocorre quando os direitos de propriedade são não negociáveis, inseguros ou não atribuídos, e os atores, membros ou não, usam um recurso para seu benefício individual ou quando os novos membros obtêm os mesmos direitos de cota ou sobre os resíduos que os antigos membros, e são intitulados com o mesmo pagamento por cota). Tal comportamento foi observado por Padula e Araújo (2008) que verificaram um baixo envolvimento dos associados em uma cooperativa de trabalho de médicos caracterizado pelo baixo índice de participação desses nas assembleias gerais extraordinárias e ordinárias da cooperativa.

Além do efeito free-rider, ou efeito carona, o autor aponta outros como:

- o problema de horizonte, que surge pela restrição à transferibilidade do direito sobre os resíduos, restringindo a liquidez a um mercado secundário para a transferência de tais direitos, e criando um ambiente de desestímulo ao investimento dos membros;

- o problema de portfólio, que ocorre quando os membros das cooperativas, diante da falta de transferibilidade, liquidez e mecanismos para a transferência dos 
resíduos, não são capazes de ajustar sua carteira de ativos para igualar suas preferências de risco pessoais e podem tentar encorajar os tomadores de decisão das cooperativas a rearranjar em suas carteiras, mesmo que a redução do risco implique em uma redução do retorno;

- o problema de controle que é associado aos custos de agência que surgem da tentativa de prevenir a divergência de interesses entre os membros e seu corpo de diretores (principal) e gerentes (agente);

- e o problema de custos de influência que decorre das atividades de influência que surgem em organizações quando suas decisões afetam a distribuição de valores ou outros benefícios entre os membros ou grupos constituintes da organização - os grupos ou indivíduos afetados, para alcançar seus próprios interesses, tentam influenciar as decisões em seu benefício.

Esse último problema ocorre porque, embora vários assuntos - como fusão, incorporação, fixação do valor dos honorários e gratificações - tenham que ser submetidos à votação na assembleia, muitas decisões são tomadas exclusivamente pelo conselho de administração, e devem estar comprometidas com a ideologia cooperativa, além de buscar colocar em prática os valores cooperativos e atender aos interesses coletivos (SILVA; SOUSA; LEITE, 2011).

Segundo os autores, as possibilidades de se fazer cumprir esses objetivos são poucas, podendo ser apontados os seguintes problemas principais: os membros que fazem parte do conselho administrativo são, geralmente, poucos, favorecendo a concentração do poder de decisão nas mãos desses membros; como apenas cooperados podem concorrer às eleições para membros do conselho, nem sempre eles estarão preparados para exercer funções administrativas; a renovação obrigatória do conselho de administração é de, no mínimo, um terço dos membros por eleição, tornando possível que alguns deles se perpetuem na direção da cooperativa.

Embora isso favoreça a profissionalização desses membros, também favorece uma imposição de sua visão pessoal sobre a cooperativa; quando a cooperativa opta por criar órgãos administrativos, com a contratação de gerentes independentes, geralmente, esses gerentes estão subordinados ao conselho administrativo, invertendo uma situação comum em empresas privadas - em vez de o gerente exercer as funções administrativas e ser fiscalizado pelo conselho, ele está, hierarquicamente, 
abaixo desse conselho, sendo subordinado às suas decisões, dificultando a profissionalização da gestão (SILVA; SOUSA; LEITE, 2011).

Esses conflitos ainda são agravados pelo fato de o ambiente institucional criado pela legislação e pela estrutura doutrinária, de acordo com Bialoskorski Neto (1994), comprometer os custos de transação e de agenciamento, e, por último, a eficiência da cooperativa.

O fato de as organizações cooperativas necessitarem de um processo de legitimação das decisões nas assembleias gerais e nos conselhos, nos quais, devido ao princípio de democracia e igualdade, são definidos os rumos do empreendimento, faz com que todas as decisões estratégicas de importância e de longo prazo, nessas sociedades, sejam custosas e lentas. Isso pode ocasionar altos custos de transação e de agenciamento no processo de adaptação da cooperativa às modificações no mercado e no ambiente institucional.

Além dessas dificuldades enfrentadas pelas cooperativas, com relação ao seu conselho administrativo, há ainda outras, provenientes da dificuldade de operação do conselho fiscal, que é o órgão responsável pela fiscalização do conselho administrativo: as atribuições desse conselho são limitadas, visto que eles são formados, ao menos no Brasil, unicamente por cooperados que, muitas vezes, não estão capacitados para essa função.

Embora não sejam permitidos membros no conselho fiscal que tenham relações de parentesco com os membros do conselho administrativo, muitas vezes eles podem ter laços de amizade, sendo os membros do conselho fiscal coniventes com as decisões do conselho administrativo; os pareceres do conselho fiscal são, geralmente, associados aos resultados obrigatoriamente apresentados pelo conselho administrativo, que são anuais, fazendo com que, muitas vezes, o conselho fiscal não exerça, efetivamente, sua função fiscalizadora (SILVA; SOUSA; LEITE, 2011).

Portanto, entende-se que entre cooperado e conselho administrativo pode surgir a maior divergência de interesses: os cooperados defendendo seus interesses coletivos e o conselho de administração defendendo seus interesses individuais. E também entre os cooperados e o conselho fiscal, visto que esse conselho age, muitas vezes, em seu próprio interesse, não cumprindo suas efetivas funções de fiscalizar as atividades do conselho administrativo e de prestar contas aos cooperados. Essa 
situação torna-se ainda mais grave quando o conselho de administração fornece informações incompletas, exercendo certa dominação sobre o conselho fiscal.

Sendo assim, formula-se a primeira hipótese dessa pesquisa:

H1: Existem conflitos de interesse entre os grupos de cooperados e o conselho de administração em relação à Avaliação de Desempenho.

Pode ainda surgir, também, conflito de agência entre os cooperados e o gerente, ou gerentes, que exerçam atividades administrativas dentro da cooperativa. Esse conflito pode ocorrer pelo fato de os gerentes tenderem a agir em prol dos interesses dos membros do conselho administrativo, ao qual são subordinados, e não no interesse dos cooperados (CUEVAS; FISCHER, 2006).

Propõe-se aqui mais um hipótese de pesquisa:

H2: Existem conflitos de interesse entre os grupos de cooperados e os gerentes em relação à Avaliação de Desempenho, visto que os gerentes tendem a agir conforme os interesses do Conselho Administrativo e não conforme o interesse dos cooperados.

Segundo Soares e Ventura (2008), o fato de a cooperativa ser administrada pelos associados eliminaria, em teoria, os problemas de agência entre associados e gestores. Isso porque o gestor seria, ao mesmo tempo, o principal e o agente. No entanto, grupos de associados podem não ter os mesmos objetivos e interesses, o que pode comprometer as estratégias da cooperativa.

Nesse sentido, Birchall e Simmons (2004) observam que na prática, quando o número de associados aumenta, há uma tendência de que o controle seja cedido a um grupo de gestores, o que gera problemas clássicos de governança.

Ademais, cabe ressaltar que os gestores de cooperativas de crédito são cooperados eleitos em assembleia geral, segundo critérios que, não necessariamente, estariam ligados aos requisitos relacionados com as atribuições dos cargos. Nesse ambiente, os gestores são levados a representar grupos dentro da cooperativa, acabando por potencializar os conflitos de agência (LIMA, 2014). 
Cuevas e Fischer (2006) entendem que são dois os conflitos de agência que dominam as cooperativas de crédito: o supracitado conflito entre os associados e gestores e o conflito entre os associados com perfil tomador de recursos e os com perfil poupador.

Em suma, podem surgir conflitos até mesmo entre os próprios cooperados, devido aos diferentes perfis. Westley e Branch (2000) observam que há uma tendência dos tomadores de empréstimo dominarem a direção da cooperativa de crédito e a administrarem de acordo com o interesse desse grupo. O tema foi também estudado por Bressan, Braga e Bressan (2012) nas cooperativas de crédito filiadas ao SICOOB Crediminas, no qual concluíram sobre dominação não muito intensificada por parte dos tomadores de empréstimo.

Esse fenômeno faz com que as pessoas procurem a associação à cooperativa de crédito com o intuito principal de tomar empréstimos mais baratos e não para depositar recursos, o que cria condições que potencializam o aumento da inadimplência.

Segundo Amess e Howcroft (2001), em cooperativas de crédito, os investidores são também clientes. Além disso, nesse tipo de organização, muitas vezes o espírito cooperativista rivaliza com posturas oportunistas do quadro social. Enquanto há os que se associam por acreditar nos ideais cooperativos, e há aqueles que seguem uma lógica utilitarista e pragmática, associando-se pelo menor custo de suas operações ou pela dificuldade que têm em conseguir satisfazer suas necessidades financeiras em outro local. Como conseqüência, a construção da confiança depende do ethos criado na cooperativa, em torno de um espírito associativo (FONTES FILHO ET AL., 2008).

Nesse sentido, Branch e Baker (2000) observam que as diferentes visões dos associados em relação à cooperativa gerarão diferentes formas de comportamento. Aqueles cooperados que se associarem com o objetivo de depositar suas economias focarão a segurança da instituição e o adequado nível de remuneração de seus depósitos, com preocupação a respeito dos custos das transações. Dessa forma, apoiarão também a melhoria de sua estrutura, o que, entre outros critérios, inclui a profissionalização da gerência.

Por outro lado, os que se associam com o objetivo de obter empréstimos estabelecerão baixas taxas para os empréstimos e depósitos e terão um 
comportamento mais indulgente em relação à concessão do crédito e à inadimplência. Além disso, serão mais agressivos em relação à mobilização de depósitos e menos preocupados com a profissionalização da administração.

Corroboram também com essa discussão Bressan, Braga e Bressan (2012) ao afirmarem que os associados com perfil aplicador de recursos querem receber as mais altas taxas de juros, enquanto os tomadores querem minimizar as taxas de juros sobre os empréstimos. A cooperativa de crédito não pode simultaneamente maximizar as taxas de juros pagas aos depositantes e minimizar as taxas de juros pagas pelos tomadores. Com isso, pode-se desenvolver um conflito entre esses dois tipos de associados (PATIN; McNIEL, 1991).

Considerando essas discussões, formulam-se mais duas hipóteses de pesquisa:

H3: Os tomadores de empréstimos terão comportamento mais indulgente em relação à inadimplência. Além disso, serão menos preocupados com a profissionalização da administração.

H4: Aqueles cooperados que se associarem com o objetivo de depositar suas economias focarão a segurança da instituição e o adequado nível de remuneração de seus depósitos, com preocupação a respeito dos custos das transações. Dessa forma, apoiarão também a melhoria de sua estrutura, o que, entre outros critérios, inclui a profissionalização da gerência.

Sendo assim, as estruturas de governança tendem a ser relativamente piores quanto mais heterogêneo for o grupo de associados (BECHT ET AL., 2002).

Sabe-se que a governança corporativa presente nas organizações cooperativas é dificultada pelas características desse tipo de organização, conforme apontado por Williamson (1988): a propriedade das organizações cooperativas costuma estar fragmentada, não havendo concentração, o que faz com que não existam atores, como os acionistas majoritários de companhias privadas, que se comprometam com o desempenho organizacional e com o monitoramento de sua administração. 
O autor também coloca que pela pulverização da propriedade da organização cooperativa, não há atores que busquem maximizar o seu valor, visto que os cooperados possuem pequenas participações, muitas vezes se interessando de forma mais intensa nos serviços oferecidos pelas cooperativas do que no valor dessa organização; as prioridades dos cooperados refletem mais fortemente seus interesses pessoais do que os interesses coletivos da cooperativa, fazendo com que prevaleça o oportunismo, no lugar da cooperação; como os cooperados possuem pequena participação na organização cooperativa e, na maioria das vezes, focam mais seus negócios individuais, eles não se comprometem com a avaliação dos riscos assumidos pela cooperativa, assim como não se sentem responsáveis pelos resultados obtidos, principalmente os negativos.

Propõe-se aqui a quinta e sexta hipóteses de pesquisa:

H5: Devido ao perfil dos associados, há conflitos de interesse dentro do próprio grupo de associados.

H6: Existe a tendência dos cooperados priorizarem seus benefícios individuais e não coletivos nas Cooperativas de Crédito.

Entre os fatores que podem favorecer a redução do conflito de agência é uma melhoria na governança das cooperativas (COOK ET AL., 2004). A adoção das boas práticas de governança corporativa pode auxiliar na redução dos conflitos de agência nas organizações cooperativas, principalmente aquela observada entre o conselho de administração e os demais cooperados - proprietários da cooperativa.

Todos os cooperados devem ser responsáveis pela gestão estratégica da organização, e não apenas aqueles que fazem parte dos conselhos ou exercem outros cargos na cooperativa. Participar efetivamente da organização cooperativa pode fazer com que os cooperados exerçam papel fiscalizador, avaliando se as decisões tomadas pelos conselhos são de interesse de toda a cooperativa (SILVA; SOUSA; LEITE, 2011).

Dessa forma, exige-se do conselho de administração a maior transparência possível, para que o conselho fiscal possa exercer plenamente sua função de fiscalização. $O$ conselho de administração deve ser o responsável pelas deliberações 
estratégicas da cooperativa, pela definição de políticas e pela prestação de contas aos cooperados. Suas funções devem ser independentes das funções executivas, assim como seus membros devem ser independentes, evitando que sejam influenciados pelos gestores responsáveis pela execução. As decisões desse conselho devem visar sempre o interesse coletivo, e nunca os interesses individuais, e essas decisões devem ser disponibilizadas a todos, de maneira fundamentada e transparente (SILVA; SOUSA; LEITE, 2011).

Em relação ao conselho de administração, Costa e Bialoskorski Neto (2004) propõem averiguar a qualificação dos principais executivos, se existe profissionalização, o número de mandatos cumpridos pelos gestores, o nível de conhecimento dos gestores sobre suas funções entre outros aspectos.

Ainda, o conselho fiscal, ciente das decisões tomadas pelo conselho administrativo e da fundamentação dessas decisões, deve buscar prestar contas aos cooperados, das mais diversas atividades e demonstrações realizadas pelo conselho administrativo. Essas informações devem ter um fluxo constante e serem as mais precisas e completas possíveis. Suas funções incluem um controle do estado patrimonial e contábil da cooperativa, assim como das atividades realizadas pela Cooperativa, buscando contribuir na correção de falhas e irregularidades. Ele é um dos responsáveis por legitimar a ação do conselho de administração, por emitir pareceres sobre suas decisões (HANSMANN, 1999).

Insere-se mais uma hipótese de pesquisa:

H7: Há conflitos de interesses entre os membros do Conselho Fiscal e Administrativo em relação à Avaliação do Desempenho da Cooperativa de Crédito.

Em suma, a equidade entre todos os membros da cooperativa também é considerada fundamental, pois, só assim, é possível que se evitem ações oportunistas e favorecimento de cooperados, sejam ou não membros dos conselhos. As decisões dos gestores devem sempre visar o interesse coletivo, e nunca os interesses individuais, próprios ou não. De maneira similar, as decisões estratégicas por parte do Conselho Administrativo e suas demais deliberações devem atender às necessidades e objetivar os ganhos de todos os cooperados. E, por fim, a ação fiscalizadora do 
Conselho Fiscal deve buscar instruir os gestores, de modo que eles ajam em prol dos interesses coletivos (COOK ET AL., 2004; BIALOSKORSKI NETO, 1998; MACHADO FILHO ET AL., 2004; KARANTININIS, 2003; POWEL, 1990).

Para Westley e Branch (2000), a resolução desse conflito de agência depende de definições claras das responsabilidades de cada um dos envolvidos na gestão da cooperativa. Essas definições deveriam constar explicitamente em seu estatuto social por meio da utilização dos seguintes princípios: definição clara das alçadas de decisão; de critérios técnicos mínimos para que um associado possa ser eleito para os órgãos de administração; das atribuições do comitê de supervisão (auditoria interna) que deve funcionar sem interferência; da política e critérios utilizados na concessão do crédito; da responsabilidade da direção em relação às operações e ao funcionamento da cooperativa de crédito em geral; de códigos de ética e de controles dos empréstimos realizados para membros da administração; e previsão de rotação de cargos entre os membros da administração.

Já para Branch e Baker (2000), os conflitos de agência nas cooperativas de crédito podem ser superados a partir de regras de governança bem definidas, controles internos eficazes, adequação dos serviços prestados, adoção de regulamentações prudenciais e supervisão externa.

Além disso, valores como ajuda mútua, responsabilidade, democracia, igualdade, equidade, solidariedade, a crença na honestidade, transparência, responsabilidade social e preocupação com o semelhante são segundo a Organização das Cooperativas Brasileiras (2016) norteadores do cooperativismo, e, portanto, necessários para a preservação da identidade organizacional, e, ao mesmo tempo, promovem cooperativas sólidas, competitivas, transparentes e confiáveis.

Com isso, é estabelecida a oitava hipótese do trabalho:

H8: Se os gestores das cooperativas de crédito tentam assegurar os princípios e valores cooperativos, então os gestores enfatizam a livre e aberta adesão dos membros, o caráter democrático da gestão e do controle cooperativos, a autonomia e a independência, a responsabilidade social e a preservação da identidade organizacional. 


\section{PROCEDIMENTOS E ESCOLHAS METODOLÓGICAS}

Este capítulo é destinado a apresentar os procedimentos metodológicos utilizados para alcançar os objetivos propostos por essa pesquisa. Sendo assim, apresenta um framework da investigação, o objeto de estudo, delineamento das etapas da pesquisa - considerando os métodos utilizados, maneira de aplicação, validação, universo, amostra, coleta, tratamento e análise de dados, e as limitações do estudo.

Para melhor compreensão, a figura 9 apresenta a estrutura dos conteúdos desse capítulo.

Figura 9 - Estrutura dos conteúdos do capítulo

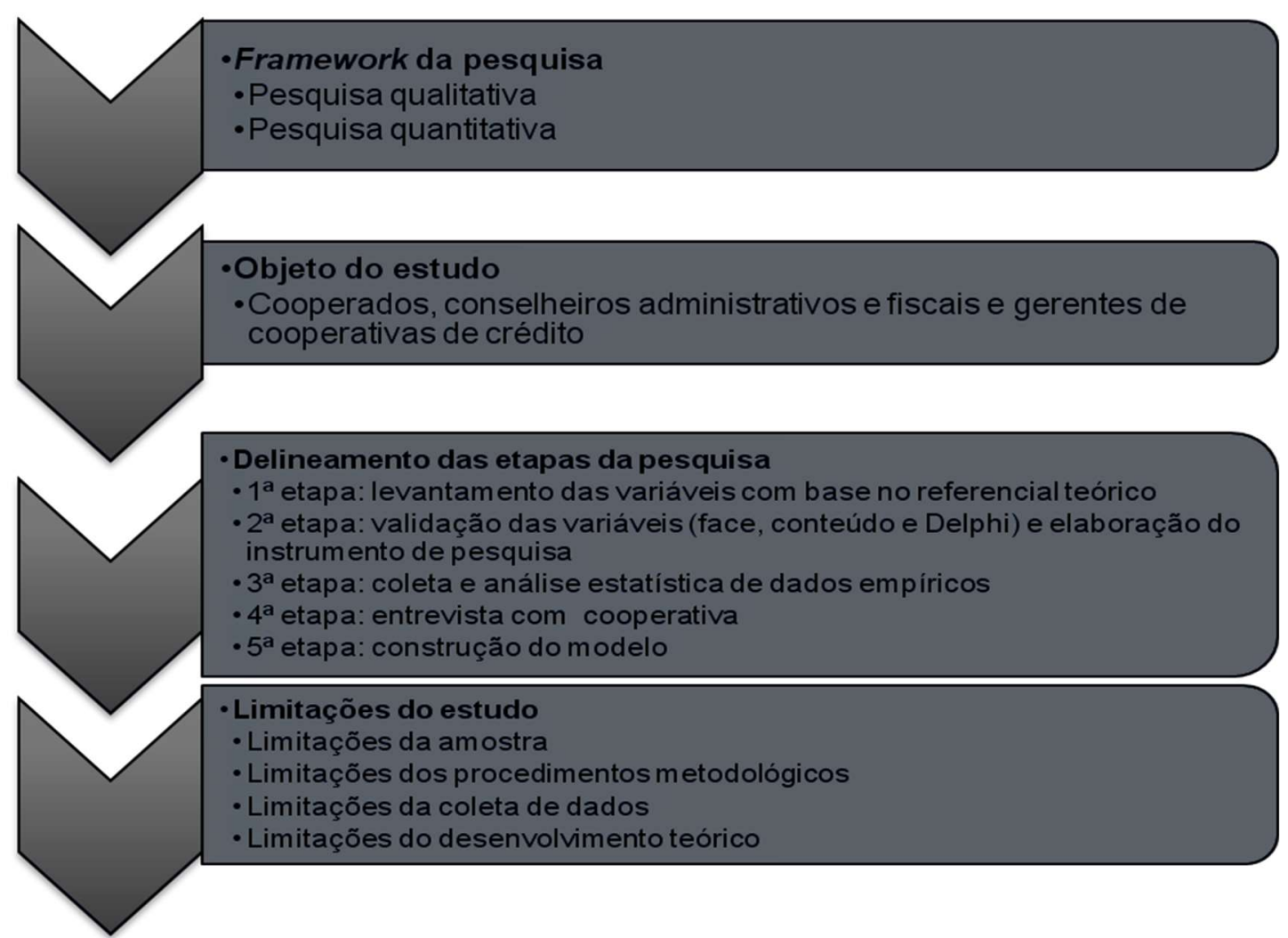

Fonte: própria autora. 


\subsection{FRAMEWORK DA PESQUISA}

A parte inicial desta pesquisa constituiu-se da elaboração do projeto de pesquisa, que contemplou a definição do tema, os objetivos, a revisão bibliográfica, a abordagem conceitual e delineamento metodológico utilizado.

Em sua fase inicial a pesquisa assume um caráter qualitativo com a revisão teórica dos conceitos pertinentes a investigação e a confecção da lista de indicadores de desempenho de Cooperativas de Crédito.

Essa primeira fase deu suporte teórico para o desenvolvimento e seleção final (validação) de um conjunto de indicadores de desempenho de Cooperativas de Crédito, e configurou-se como uma etapa de natureza qualitativa e quali-quantitativa.

Após a validação dos indicadores de desempenho a pesquisa assume um caráter quantitativo, e seus objetivos nessa fase passam a ser compreender quais aspectos influenciam na avaliação de desempenho de cooperativas de crédito na visão de cada grupo envolvido; relacionar as variáveis determinadas como importantes para avaliar desempenho de cooperativas de crédito sob o ponto de vista dos envolvidos considerando seu perfil; entender a influência da teoria da agência na gestão do desempenho de cooperativas de crédito; e verificar se os princípios do cooperativismo são tidos como importantes quando se trata da avaliação de desempenho de cooperativas de crédito.

Após essa fase, a pesquisa assume novamente um caráter qualitativo, no momento em que é realizada a entrevista com uma cooperativa singular a fim de conhecer como se dá o seu processo atual de avaliação do desempenho. Na seqüência, a partir de todos os dados coletados pela pesquisa, em uma etapa também qualitativa, propõe-se um modelo de avaliação de desempenho que diminua os conflitos de agência em cooperativas de crédito.

Sendo assim, esse estudo assume um caráter qualitativo em sua fase inicial, de enunciação e validação, e caráter quantitativo na sua segunda etapa empírica, tratamento metodológico este que tem sido tendência em estudos da área de Administração de Desempenho (THORPE; BEASLEY,2004); e volta a assumir caráter qualitativo.

A figura 10 a seguir o framework da pesquisa. 
Figura 10 - Framework da pesquisa

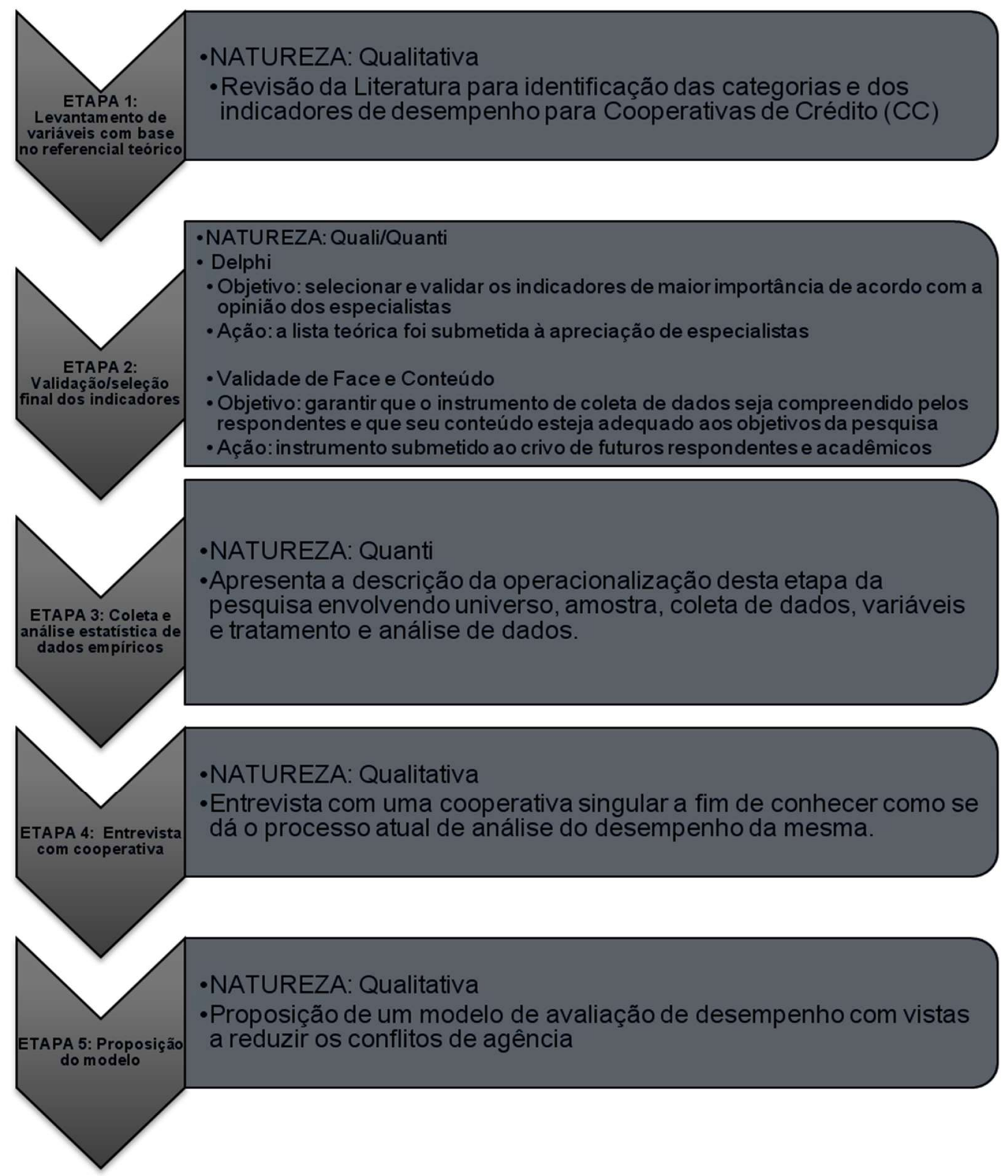

Fonte: própria autora.

\subsection{OBJETO DE ESTUDO E AMOSTRA}

O objeto de estudo desta pesquisa são os Cooperados, Gerentes e Conselheiros Administrativos e Fiscais de Cooperativas de Crédito brasileiras, ramo este que merece destaque quando se fala de cooperativismo, visto que de acordo com a Organização das Cooperativas Brasileiras (2015) é o que conta com o maior número de cooperados no Brasil. 


\subsection{DELINEAMENTO DAS ETAPAS DA PESQUISA}

A presente pesquisa foi executada a partir de cinco etapas: a primeira consistiu na seleção de indicadores de Desempenho para Cooperativas de Crédito por intermédio da literatura; a segunda foi a etapa de validação dos indicadores; e terceira etapa identificou junto a cooperados, membros dos Conselhos Fiscal e Administrativo e gerentes quais dos indicadores validados eles julgavam pertinentes às cooperativas de crédito; quais aspectos influenciam na avaliação de desempenho de cooperativas de crédito na visão de cada grupo envolvido; quais as variáveis são tidas como importantes para avaliar desempenho de cooperativas de crédito sob o ponto de vista dos envolvidos considerando seu perfil; qual a influência da teoria da agência na gestão do desempenho de cooperativas de crédito; e se os princípios do cooperativismo são tidos como importantes quando se trata da avaliação de desempenho de cooperativas de crédito.

Por sua vez, a quarta etapa consistiu na entrevista com a equipe de planejamento de uma cooperativa singular a fim de conhecer o modelo de avaliação de desempenho utilizado pela mesma. E por fim, com os dados provenientes das etapas anteriores, foi possível concluir a quinta etapa do trabalho cujo objetivo foi propor um modelo de avaliação de desempenho para cooperativas de crédito que minimize os conflitos de agência.

A seguir cada etapa será descrita mais detalhadamente.

\subsubsection{Primeira etapa da Pesquisa - LeVantamento dos Indicadores de AValiação de Desempenho de Cooperativas de Crédito com base no Referencial TEÓRICO}

Essa primeira etapa foi realizada com base no referencial teórico. A princípio, foi procurado por "avaliação de desempenho de cooperativas de crédito" no Portal de Periódicos CAPES, e encontrados 61 (sessenta e um) trabalhos. Esses trabalhos foram aqui analisados com vistas a levantar indicadores de desempenho que vem sendo utilizados na academia para avaliar desempenho de cooperativas de crédito. Os indicadores levantados farão parte da coleta de dados empíricos. 
Porém, dentre os 61 (sessenta e um) trabalhos analisados, apenas 1 (um), o de Porto (2002), trata de indicadores que vão além da perspectiva financeira, mas especificamente, trabalha com o BSC; os demais, são especificamente voltados a análises de desempenho econômico-financeiras.

Considerando um dos objetivos desse trabalho, que é identificar indicadores de avaliação desempenho que sejam pertinentes as cooperativas de crédito, e conforme as discussões teóricas expostas, vê-se que apenas indicadores econômicofinanceiros não bastam, sendo necessário desdobrar as perspectivas/dimensões e complementar o quadro de indicadores.

Portanto, tem-se o desafio de aperfeiçoar o conjunto de indicadores de forma a construir um quadro mais completo deles, que contemple a instituição de maneira global, visto que uma cooperativa de crédito, embora tenha a atividade principal voltada a questões econômico-financeiras, é uma instituição complexa, que demanda outras vertentes de análise, quando se trata do seu desempenho global.

Destaca-se que ainda assim, optou-se por analisar os trabalhos que contemplam exclusivamente questões econômico-financeiras, pra que dêem suporte no momento de construir os indicadores dessa perspectiva, como os trabalhos de Bortoluzzi et al. (2011), Ferreira, Gonçalves e Braga (2007) e Bressan, Braga e Bressan (2003), Yamada e Bialoskorski Neto (2010), bem como as exigências do Banco Central do Brasil (BACEN), que regulamenta o cooperativismo de crédito brasileiro.

Para identificar outros indicadores, que não se limitem a aspectos financeiros, fez-se uma pesquisa no Google Acadêmico, utilizando a mesma referência de busca anterior: "avaliação de desempenho de cooperativas de crédito", e depois de analisados cerca de 50 (cinqüenta) trabalhos, ainda deparava-se com a mesma problemática, ou seja, os trabalhos encontrados são voltados especialmente a análises financeiras, com exceção dos trabalhos de Hubner et al. (2012), cujo objetivo é propor um conjunto de fatores que podem se constituir em indicadores de desempenho sob a perspectiva do BSC em uma cooperativa de crédito; e Barros e Moraes (2015) que investigam desempenho financeiro e operacional, porém, esse último voltado apenas à prestação de serviços, desconsiderando o aspecto global da organização cooperativista. 
Além desses trabalhos, voltados às cooperativas de crédito, optou-se por investigar sobre indicadores de desempenho de cooperativas de modo geral. Os trabalhos aqui analisados foram referenciados por outros já descritos anteriormente ou foram buscados em ferramentas de pesquisa a partir das palavras-chave: "avaliação de desempenho de cooperativas".

Com esta nova busca, obteve-se acesso aos trabalhos de Bialoskorski Neto, Nagano e Moraes (2006), Menegário (2000) e Munaretto (2013).

Destaca-se que dentre as fontes pesquisadas foi possível levantar: 215 indicadores denominados Econômico/Financeiros; 6 indicadores denominados Cliente; 10 indicadores denominados Processos Internos; 7 indicadores denominados Aprendizado e Crescimento; 25 indicadores denominados Sociais; 5 indicadores denominados Sócio-econômicos; 12 indicadores denominados Eficiência Operacional; 5 indicadores denominados Pessoas e Inovação; 7 indicadores denominados Qualidade Técnica e Comercial; 4 indicadores denominados Satisfação do Consumidor; 5 indicadores denominados Relacionamento com Associados; 2 indicadores denominados Benefícios Sociais e Ambientais.

Para chegar à lista de indicadores que serão utilizados na pesquisa, fez-se uma varredura naqueles repetidos, os que englobavam outros e os que eram específicos de cooperativas de outros ramos.

Destaca-se, que no caso de indicadores financeiros, cujo número era muito grande, optou-se por priorizar aqueles que se repetiam nos trabalhos de dois ou mais autores, bem como os que tinham medida expressa ou eram passíveis de medição, e que não fossem muito detalhados, como por exemplo, margem bruta, margem operacional e margem líquida; liquidez corrente, liquidez geral e liquidez seca; optando-se por uma forma somente, sem variações.

Optou-se ainda por não trabalhar com todos os módulos disponíveis na literatura, visto que vários deles eram bastante próximos e puderam ser distribuídos nos demais módulos, como é o caso do "Social", tão relevante quando se trata de uma cooperativa, cujos elementos foram realocados. Destaca-se ainda que o módulo "Clientes" foi ajustado para "Associados" devido a natureza da atividade ser cooperativista.

Com isso obteve-se a lista de 46 indicadores que foram submetidos à metodologia Delphi, e à validação de face e conteúdo, para posteriormente serem 
avaliados por cooperados, membros de Conselho Fiscal e Administrativo e gerentes de Cooperativas de Crédito.

\subsubsection{SEgunda etAPA DA PESQUISA - VALIDAÇÃo dos Indicadores de AVALIAÇÃo de Desempenho de CoOperativas de Crédito}

Essa etapa da pesquisa teve como objetivo submeter a lista de indicadores ao crivo da metodologia Delphi e realizar a Validação de Face e Conteúdo do Instrumento de Pesquisa. Descreve-se a seguir esses procedimentos.

\subsubsection{DELPHI}

A lista de indicadores coletados por meio do referencial teórico foi submetida ao crivo da metodologia Delphi, com o objetivo de validar no campo qualquer levantamento teórico para descartar a possibilidade de esse estar imerso em preceitos e subjetividade do indivíduo-pesquisador (CUNHA, 2011).

O método Delphi teve como objetivo conhecer a opinião de especialistas sobre um determinado assunto, promovendo feedback controlado acerca das opiniões colocadas (MEYRICK, 2003). Destaca-se que os participantes dessa etapa foram pessoas distintas da validação de face e conteúdo.

O Delphi é um método capaz de coletar sistematicamente a opinião de especialistas sobre determinada questão, visando a validade de pesquisas científicas. Trata-se de uma espécie de comunicação estruturada, na qual faz-se feedback das contribuições de conhecimentos individuais, visando garantir o anonimato dos respondentes, avaliação e revisão dos seus pontos de vista (LINSTONE; TUROFF, 1975).

Segundo Munaretto, Corrêa e Cunha (2013), o método Delphi favorece o anonimato dos respondentes, a representação estatística dos resultados, a reflexão e consequentemente respostas mais elaboradas.

Esse método pode ser utilizado em diferentes áreas do conhecimento, e segundo Vergara (2008) não existe uma quantidade ideal de participantes desse método, já que essa quantidade depende do escopo de pesquisa e da quantidade de especialistas disponíveis para participar. Apesar disso, o autor coloca que o método normalmente utiliza em torno de 10 a 30 especialistas. 
Sackman (1975) define que o Delphi pode ser realizado por meio de questionário do tipo "papel e lápis", devendo ser aplicado por correio, em uma entrevista pessoal, em uma sessão interativa ou on line, sendo a técnica básica de apresentação e coleta de dados o questionário formal e estruturado com uma série de itens, utilizando uma escala semelhante, qualitativa ou quantitativa, dependendo dos objetivos do estudo.

Na presente pesquisa o Delphi foi realizado com dez especialistas, que foram selecionados por conveniência considerando sua experiência em Cooperativismo de Crédito. O quadro 11 a seguir traz a área de atuação de cada um deles.

Quadro 11 - Área de atuação dos especialistas participantes do método Delphi

\begin{tabular}{|c|c|}
\hline Respondente & Área de atuação \\
\hline Respondente 1 & $\begin{array}{c}\text { Docente do curso técnico em cooperativismo, ministrando aulas de Introdução ao } \\
\text { Cooperativismo e Legislação Cooperativista. }\end{array}$ \\
\hline Respondente 2 & $\begin{array}{c}3 \text { anos na área comercial de uma cooperativa de crédito, gerenciando diferentes tipos de } \\
\text { carteira de diferentes segmentos de renda. }\end{array}$ \\
\hline Respondente 3 & Trainee por 1 ano em uma Cooperativa de Crédito. Funcionário efetivo por 8 meses. \\
\hline Respondente 4 & $\begin{array}{c}\text { Docente de Administração, tendo ministrado aulas do componente curricular Fundamentos } \\
\text { do Cooperativismo. Com experiência de dois anos com o cooperativismo da região central } \\
\text { do Estado do Paraná, atuando com os vários segmentos cooperativistas da referida região. } \\
\text { Atualmente, coordena projeto de Desenvolvimento de Pequenas Cooperativas } \\
\text { Agroindustriais. }\end{array}$ \\
\hline Respondente 5 & Analista de negócios em cooperativa de crédito há 5 anos. \\
\hline Respondente 6 & $\begin{array}{c}\text { Funcionário de uma cooperativa de crédito por } 8 \text { anos, onde exerceu os cargos de Trainee, } \\
\text { Assistente de Negócios e Gerente de Negócios. }\end{array}$ \\
\hline Respondente 7 & $\begin{array}{c}\text { Experiência como Trainee por } 1 \text { ano em uma Cooperativa de Crédito. Possui treinamentos e } \\
\text { acompanhamentos com gerente geral das unidades, se especializando em rotatividade e } \\
\text { atendimento ao cooperado. }\end{array}$ \\
\hline Respondente 8 & $\begin{array}{l}\text { Docente de Administração com ênfase em Cooperativismo tendo ministrado disciplinas } \\
\text { como: Fundamentos do Cooperativismo e Legislação Cooperativista. }\end{array}$ \\
\hline Respondente 9 & Docente do curso técnico de Cooperativismo. \\
\hline Respondente 10 & $\begin{array}{l}\text { Profissional da área de educação que trabalha com profissionais de nível gerencial de } \\
\text { entidade de treinamento de cooperativas. Dessa forma, teve contato com os principais } \\
\text { desafios e características de todos os tipos de cooperativas - inclusive de crédito. }\end{array}$ \\
\hline
\end{tabular}

Fonte: autora.

A abordagem dos especialistas participantes do Delphi foi realizada via e-mail, devido à facilidade de acesso aos respondentes por esse meio e também por ser uma abordagem aceita no meio acadêmico e utilizada nos estudos acerca de Administração do Desempenho, como por exemplo, nos trabalhos de Cunha (2011) e Munaretto (2013), bem como por ser de fácil administração, baixos custos, rápida captação e análise de dados (HAIR JR ET AL., 2005).

A técnica Delphi foi aplicada aos especialistas participantes por intermédio de um instrumento de pesquisa (apêndice 1), que contemplava três partes: a primeira onde os participantes descreviam sua experiência profissional com Cooperativas de 
Crédito/Cooperativismo, a fim de certificar que eles realmente eram especialistas no assunto.

A segunda parte continha um quadro com os indicadores coletados na pesquisa bibliográfica, no qual os especialistas, considerando uma escala likert de cinco pontos assinalavam com "x" o grau de importância de cada indicador para avaliar o desempenho de Cooperativas de Crédito - sendo o indicador classificado como "cinco" extremamente importante e aquele classificado como "um" não é importante.

E a última seção do instrumento de pesquisa continha um espaço para o participante inserir os indicadores que julgava importantes para avaliar o desempenho de Cooperativas de Crédito e que não estavam contemplados no quadro.

A fim de concretizar os objetivos da Delphi, considerou-se manter em pauta apenas com os indicadores que a maioria dos especialistas (sendo, portanto, pelo menos seis dos dez participantes) classificaram de grau de importância quatro ou cinco, ou seja, muito importante ou extremamente importante. E também os indicadores que os especialistas consideram relevantes e que não estavam previamente contemplados no quadro.

\subsubsection{VALIDAÇÃo de FAce E CONTEÚDo}

Após a submissão dos indicadores de avaliação de desempenho de cooperativas de crédito aos especialistas, o novo instrumento de coleta de dados (apêndice 2) foi submetido à validade de face e conteúdo, com vistas a compreender se o constructo mede o que deve medir (HAIR JR ET AL., 2005), sendo essa a única maneira de avaliar possíveis problemas que o instrumento de coleta de dados pode vir a ter, bem como assegurar maior adequação das respostas aos objetivos do estudo (PRESSER ET AL., 2004; GIL, 2006; FORSYTH ET AL., 2004).

Mais especificamente, a validade de face busca garantir que o instrumento seja adequadamente compreendido pelos respondentes, para que não comprometa a obtenção correta dos dados. E a validade de conteúdo visa verificar se o conteúdo do instrumento está adequado aos objetivos da pesquisa, ou seja, se ele contempla todos os elementos que deveria contemplar para que as perguntas de pesquisa sejam respondidas. 
Para tanto, foi utilizada uma ficha de avaliação, elaborada com base em Munaretto (2013), que integra o apêndice 2, visando conhecer a dificuldade de leitura, compreensão das questões, tempo adequado para respondê-lo, presença de erros tipográficos, apresentação adequada, clareza nas questões, repetição de indicadores e sugestão de inclusão ou exclusão de indicadores.

Essa ficha de avaliação foi respondida por 10 (dez) pessoas, sendo 3 (três) acadêmicos e 7 (sete) participantes do estudo (associados de cooperativa de crédito), visto que Cunha (2011), salienta a importância de se realizar pré-teste com o público participante da amostra.

Tanto a ficha de avaliação, quanto o instrumento de coleta de dados foram enviados por e-mail aos acadêmicos, e foram impressos e entregues aos cooperados indicados pela gerência de uma Cooperativa de Crédito participante do estudo escolhida por conveniência.

Destaca-se que os acadêmicos participantes dessa etapa tiveram acesso ao trabalho, a fim de conhecer seus objetivos, e os cooperados no ato do recebimento dos questionários foram contextualizados a respeito da pesquisa. Dessa forma acadêmicos e cooperados puderam ter mais embasamento para se posicionarem adequadamente.

\subsubsection{Terceira etapa da PESQUisa - Coleta e ANÁlise estatística dos dados}

Essa etapa se propôs a identificar junto a cooperados, membros dos Conselhos Fiscal e Administrativo e gerentes quais dos indicadores validados eles julgavam pertinentes às cooperativas de crédito; quais aspectos influenciam na avaliação de desempenho de cooperativas de crédito na visão de cada grupo envolvido; quais as variáveis são tidas como importantes para avaliar desempenho de cooperativas de crédito sob o ponto de vista dos envolvidos considerando seu perfil; qual a influência da teoria da agência na gestão do desempenho de cooperativas de crédito; e se os princípios do cooperativismo são tidos como importantes quando se trata da avaliação de desempenho de cooperativas de crédito.

A seguir descreve-se o universo de pesquisa, amostra participante, processo de coleta, tratamento e análise de dados. 


\subsubsection{UNIVERSO DE PESQUISA}

O universo da pesquisa é representado pelo total de indivíduos que possuem as mesmas características para o determinado estudo (MARCONI; LAKATOS, 2003). Considera-se aqui quatro públicos de interesse da pesquisa: associados, gerentes e membros dos Conselhos Administrativo e Fiscal de cooperativas de crédito.

É importante ressaltar que todos os dados utilizados para contextualizar o universo dessa pesquisa foram retirados do site do Banco Central do Brasil, isso porque são os números oficiais e mais atualizados. Porém, o Banco Central não fornece o número de gerentes e conselheiros de cooperativas de crédito, conforme discutido a seguir.

Em relação ao número de pessoas físicas e jurídicas associadas a cooperativas de crédito, temos a marca de 8,9 milhões (BANCO CENTRAL DO BRASIL, 2016).

Como já dito, infelizmente não encontrou-se fonte confiável que traga o número de gerentes e conselheiros administrativos de todas as cooperativas de crédito brasileiras. E não foi possível a pesquisadora estimar tal número porque a dinâmica de gerência de cada uma é diferente, variando a quantidade de membros. Por exemplo, segundo o Portal do Cooperativismo Financeiro (2018), 72\% das Cooperativas possuem Conselho de Administração (CONSAD), o restante possui apenas Diretoria. Portanto, considerando isso e a quantidade de cooperativas de crédito existentes no país, torna-se inviável o levantamento desse dado.

Diferentemente do que acontece com o Conselho Administrativo, a legislação cooperativista prevê o número de membros no Conselho Fiscal, sendo esse formado por 3 (três) membros efetivos e 3 (três) suplentes.

Considerando o documento "Panorama do Sistema Nacional de Crédito Cooperativo", expedido pelo Banco Central em 31 de dezembro de 2016, o Sistema Nacional de Crédito Cooperativo (SNCC) contava, no referido dia, com 34 cooperativas de crédito centrais e 1.017 singulares em atividade no país. Nessa data o Sistema Nacional de Crédito Cooperativo contava com quatro sistemas de três níveis hierárquicos (ou seja, com confederação, centrais e singulares), e ainda haviam cinco sistemas de dois níveis hierárquicos em atividade, compostos por cooperativas centrais às quais estavam filiadas 47 singulares, denominadas Centrais 
Independentes. Também na mesma data, existiam 195 singulares não filiadas à central, denominadas Singulares Independentes (vide quadro 9).

Sendo assim, é plausível considerar que no Brasil existam cerca de 3051 conselheiros fiscais de cooperativas singulares, 102 de cooperativas centrais, e 12 de confederações, totalizando 3165 conselheiros fiscais em exercício efetivo. Destacase que esses números foram previstos pela pesquisadora com base na legislação cooperativista, e não estão disponíveis em fontes oficiais.

\subsubsection{AMOSTRA DE PESQUISA}

A amostra é uma parcela convenientemente selecionada do universo (população); é um subconjunto do universo (MARCONI; LAKATOS, 2003).

A princípio, para definir a amostra participante desse estudo, optou-se por contatar as 10 maiores cooperativas financeiras do Brasil (no que tange a sua movimentação financeira), retratadas no quadro 7 desse trabalho, a fim de convidálas a participar do estudo, a saber: Sicoob Credicitrus, Viacredi, Sicoob Cocred, Sicredi Ouro Verde MT, Sicoob Cooperforte, Credicoamo, Sicredi União PR/SP, Sicredi Pioneira RS, Sicredi Credibom e Sicredi Vanguarda PR/SP.

Dessas, apenas quatro se propuseram a participar da pesquisa, sendo elas: Viacredi, Sicredi Ouro Verde MT, Sicredi União PR/SP e Sicredi Pioneira RS.

Diante desse cenário, de baixa participação das maiores cooperativas, e considerando a necessidade de grande número de respondentes, optou-se por ampliar a amostra do estudo.

Para tanto, pautou-se na interpretação da Organização das Cooperativas Brasileiras (OCB), que basicamente divide o segmento de cooperativismo de crédito do Brasil em cinco blocos: três são representados pelos sistemas Sicredi, Sicoob e Unicred e os outros dois por cooperativas de crédito independentes e de Economia Solidária.

Os sistemas Sicredi e Sicoob atuam com diversas linhas de crédito voltadas para o desenvolvimento dos vários setores da economia, mais especialmente o setor primário. Por sua vez, o Unicred é formado por cooperativas de crédito voltadas para o nicho de profissionais da saúde, atuando em grande parte do país. 
Considerando a representatividade das Cooperativas Sicoob e Sicredi e também o fato delas atenderem diferentes públicos, o que não é o caso da cooperativa Unicred, essas foram escolhidas de forma intencional para serem contatas e convidadas a participar da etapa empírica da investigação. Mais especificamente, optou-se por contatar as Centrais Sicredi PR/SP/RJ e Sicoob SC/RS, escolhidas por representarem os Estados que concentram maior número de associados a Cooperativas de Crédito, condizente $38 \%$ do total de cooperados (VERBO COOPERAR, 2016).

Porém, a Central Sicoob SC/RS que não se interessou em participar da pesquisa. Portanto, a nova amostra foi escolhida por conveniência, considerando a representatividade do Sistema Sicredi e abertura de uma das Centrais para participar da pesquisa.

Destaca-se que o sistema Sicredi, originário da região Sul, atua em grande parte do país, sendo o primeiro a constituir um banco cooperativo, o Bansicredi. Tratase da cooperativa de crédito pioneira no país, fundada pelo Padre Theodor Amstad, em 1902, em Nova Petrópolis, Rio Grande do Sul.

Atualmente conta com cinco cooperativas centrais (Central Sicredi Sul/Sudeste, Central Sicredi PR/ SP/ RJ, Central Sicredi Centro Norte e Central Sicredi Brasil Central, Central Sicredi Norte/Nordeste), e uma confederação, constituída pela união das cinco centrais (SICREDI, 2018).

Mais especificamente, a Central Sicredi PR/SP/RJ, participante desse estudo, administra atualmente 31 Cooperativas Singulares em 435 municípios, com 547 agências e aproximadamente 1,1 milhões de associados (SICREDI, 2018).

A Central Sicredi PR/SP/RJ conta com 15 (quinze) membros do Conselho Administrativo, 3 (três) membros efetivos e 3 (três) suplentes no Conselho Fiscal.

Participaram deste estudo membros dos Conselhos Fiscal e Administrativo das referidas cooperativas, bem como gerentes e cooperados das referidas cooperativas. A tabela 1 abaixo expressa os números da amostra participante, com as informações pertinentes ao objeto de estudo: 
Tabela 1 - Números da amostra participante

\begin{tabular}{|c|c|c|c|c|}
\hline Cooperativa & $\begin{array}{c}\text { Número } \\
\text { de } \\
\text { associados }\end{array}$ & $\begin{array}{l}\text { Conselheiros } \\
\text { Fiscais }\end{array}$ & $\begin{array}{l}\text { Conselheiros } \\
\text { Administrativos }\end{array}$ & Gerentes \\
\hline $\begin{array}{c}\text { Central Sicredi } \\
\text { PR/SP/RJ }\end{array}$ & 1.100 .000 & $\begin{array}{c}3 \text { efetivos } \\
\text { e } 3 \text { suplentes }\end{array}$ & 15 & $\begin{array}{c}\text { há somente } \\
\text { diretores de área }\end{array}$ \\
\hline Viacredi & 450.000 & $\begin{array}{c}3 \text { efetivos } \\
\text { e } 3 \text { suplentes }\end{array}$ & 6 & 13 \\
\hline $\begin{array}{l}\text { Sicredi Ouro } \\
\text { Verde MT }\end{array}$ & 60.000 & $\begin{array}{c}3 \text { efetivos } \\
\text { e } 3 \text { suplentes }\end{array}$ & 12 & 42 \\
\hline $\begin{array}{c}\text { Sicredi } \\
\text { União PR/SP }\end{array}$ & 160.000 & $\begin{array}{c}3 \text { efetivos } \\
\text { e } 3 \text { suplentes }\end{array}$ & 11 & 78 \\
\hline $\begin{array}{c}\text { Sicredi } \\
\text { Pioneira RS }\end{array}$ & 118.308 & $\begin{array}{c}3 \text { efetivos } \\
\text { e } 3 \text { suplentes }\end{array}$ & 14 & 48 \\
\hline TOTAL & 1.888 .308 & 30 & 58 & 181 \\
\hline
\end{tabular}

Fonte: elaborado pela autora com base nos sites das respectivas cooperativas, site do Banco Central e em contato telefônico com as cooperativas participantes.

A Central Sicredi PR/SP/RJ optou por não divulgar o número de gerentes e conselheiros administrativos e fiscais de suas 31 cooperativas singulares afiliadas, mas se comprometeu a enviar para seus responsáveis o convite para a pesquisa, bem como os links dos questionários para a participação de seus membros.

Cabe salientar que não há possibilidade de garantir que os questionários foram enviados a todos os participantes da amostra, visto que a autora não teve acesso a essas pessoas, já que enviou aos responsáveis os links da pesquisa para que eles repassassem ao público pertinente.

Embora não possa ser confirmado esse envio, acredita-se que ele foi realizado pois a pesquisadora recebeu 28 questionários respondidos membros dos Conselhos Fiscal (sendo 25 válidos), 36 do Conselho Administrativo (sendo 28 válidos), 129 questionários de gerentes (sendo 93 válidos) e 246 de cooperados (sendo 152 válidos). Destaca-se que entende-se por questionário válido aquele que é completamente respondido.

\subsubsection{COLETA DE DADOS}

Os dados foram coletados por meio de uma pesquisa do tipo Survey, que utiliza um único instrumento de coleta de dados (normalmente um questionário), visando ter 
acesso a informações de uma amostra de tamanho significativo, para posteriormente realizar análises e conclusões sobre os dados coletados (BERTO; NAKANO, 2000; GIL, 2010).

Mais especificamente, fez-se principalmente uso do Survey online (exceto no caso do público cooperados), visto que esse permite alcançar várias pessoas com características comuns em um curto espaço de tempo; facilita que o respondente expresse determinadas opiniões que não faria pessoalmente (sensação de anonimato); possibilita a realização de análises preliminares dos dados antes de acabar a sua coleta; elimina erros de transcrição; evita despesas com a aquisição de equipamentos de gravação; poupa custo com viagens, telefone e transcrição dos dados; permite entrevistar mais de um participante de cada vez; possibilita que os participantes escolham o ambiente para responder às perguntas (casa ou escritório, por exemplo) e administrem seu tempo para responder a pesquisa, pelo fato de as respostas serem melhor pensadas antes de serem respondidas (EVANS; MATHUR, 2005; MEHO, 2006).

Forza (2002) classifica a pesquisa Survey em três tipos: o exploratório é útil nos estágios iniciais de uma pesquisa sobre o fenômeno, a fim de adquirir uma visão inicial da temática e fornecer base para um Survey mais detalhado; o descritivo objetiva entender a relevância de certo fenômeno, descrevendo sua distribuição na população, sem a intenção de desenvolver teoria, mas sim fornecer subsídios para construção de teorias ou seu refinamento, e o confirmatório que ocorre quando o conhecimento sobre um fenômeno já foi desenvolvido teoricamente usando conceitos bem definidos (constructos), modelos e proposições. Assim, caracterizam-se como teste de teorias ou como explanatórias.

O Survey aqui desenvolvido tem características exploratórias, visto que os constructos abordados (Avaliação de Desempenho, Teoria da Agência e Cooperativismo de Crédito), quando trabalhados em conjunto, ainda são temas pouco abordados na literatura, necessitando a construção de novas relações e teoria.

A fim de distribuir os instrumentos de coleta de dados ao público de interesse, elaborou-se três questionários na plataforma Qualtrics, um voltado a Membros dos Conselhos Administrativo e Fiscal, o outro a Gerentes de Cooperativas de Crédito e o terceiro a Cooperados. Destaca-se que os três questionários são de igual conteúdo, 
no que tange aos indicadores de Avaliação de Desempenho, o que altera é a apenas a parte inicial deles, destinada a caracterização do respondente.

Os links da pesquisa foram repassados aos responsáveis para enviar aos gerentes e conselheiros via e-mail.

Destaca-se que as cooperativas não têm o hábito de se comunicarem com seus cooperados via e-mail, e por isso não puderam repassar os questionários a esse

público de forma eletrônica, portanto, algumas agências disponibilizaram o questionário impresso aos cooperados para que respondessem, outras repassaram informalmente, por meios digitais (e-mail e whatsapp), o questionário para cooperados com os quais tinham uma relação pessoal mais próxima. E principalmente foram recolhidos questionários respondidos por cooperados em assembleias nas quais a pesquisadora esteve presente.

\subsubsection{TRATAMENTO E ANÁLISE DE DADOS}

Para o teste das hipóteses foram empregadas técnicas de estatística descritiva, a saber: teste t para amostras independentes, teste t para amostras dependentes, teste de Mann-Whitney e teste de Kruskal-Wallis.

$\mathrm{O}$ teste $t$-Student ou somente teste té um teste de hipótese que usa conceitos estatísticos para rejeitar ou não uma hipótese nula quando a estatística de teste $(t)$ segue uma distribuição $t$-Student (BOLFARINE; SANDOVAL, 2000), visando avaliar as diferenças entre as médias de dois grupos.

Essa técnica é utilizada quando a estatística de teste segue uma distribuição normal, mas a variância da população é desconhecida. Nesse caso, é usada a variância amostral e, com esse ajuste, a estatística de teste passa a seguir uma distribuição $t$-Student.

Dois tipos de teste $t$ foram usados a saber: teste $t$ para amostras independentes, usado quando existem duas condições experimentais e diferentes participantes foram designados para cada condição; e teste t para amostras dependentes, usado quando existem duas condições experimentais e os mesmos participantes tomaram parte em ambas as condições (FIELD, 2009). 
Por não atender algumas suposições necessárias para desenvolver testes paramétricos como ANOVA, utilizou-se de testes não paramétricos, como os já citados testes de Mann-Whitney e de Kruskal-Wallis.

De acordo com Siebert e Siebert (2017) a escolha de métodos não paramétricos se apóiam nas limitações dos dados por não atenderem aos pressupostos dos métodos paramétricos ou ainda quando as amostras são pequenas. Principalmente amostras compostas por 30 casos ou menos devem sempre utilizar procedimentos não paramétricos (MATHEWS, 2010; RYAN, 2013).

Além de depender de poucas ou quase nenhuma suposição sobre a forma ou parâmetros da distribuição da população, uma importante vantagem dos procedimentos não paramétricos é poder ser aplicados utilizando dados nominais e ordinais, não ficando dependentes apenas das variáveis de intervalo e razão (SIEBERT; SIEBERT, 2017).

Quando a intenção é determinar se há diferenças entre dois grupos em uma variável dependente contínua ou ordinal, é utilizado o teste de Mann-Whitney. Esse teste é apresentado como uma versão não-paramétrica equivalente ao o teste $t$ de amostras independentes (FIELD, 2013, p.480).

No caso de buscar determinar se existe uma diferença entre observações pareadas ou combinadas, ou seja, quando os dados são provenientes dos mesmos participantes, será utilizado o teste dos postos com sinais de Wilcoxon. Este teste pode ser considerado como o equivalente não paramétrico ao teste t de amostras pareadas. Os participantes são os mesmos indivíduos testados em duas ocasiões ou sob duas condições diferentes na mesma variável dependente.

No entanto, quando a intenção foi determinar se existem diferenças estatisticamente significativas entre dois ou mais grupos de uma variável independente em uma variável dependente contínua ou ordinal, será utilizado o teste $\mathrm{H}$ de Kruskal-Wallis. Esse teste é considerado como uma alternativa não-paramétrica para a ANOVA independente de um fator (FAN; ZHANG; ZHANG, 2011).

Após a realização da análise de variância, foi necessário usar testes post hoc para identificar quais pares de médias de tratamentos diferem significativamente entre si. 


\subsubsection{QUARTA ETAPA DA PESQUISA - ENTREVISTA COM COOPERATIVA E ANÁLISE DOCUMENTAL}

Visando atender um dos objetivos específicos desse trabalho, que é sugerir um modelo de avaliação de desempenho que reduza os conflitos de agência, optou-se por conhecer como se dá o processo de avaliação de desempenho de uma das cooperativas singulares participantes do estudo.

\subsubsection{AMOSTRA PARTICIPANTE}

Foi escolhida uma das cooperativas singulares participantes do estudo, que conta atualmente com 78 pontos de atendimento e aproximadamente 160 mil cooperados.

A escolha dessa unidade de análise foi selecionada propositalmente com o intuito de ajudar o pesquisador a atender o problema e a questão de pesquisa (CRESWELL, 2007). Tal escolha foi intencional, considerando que no contato inicial a cooperativa entrevistada se colocou a disposição para apresentar sua metodologia de avaliação de desempenho atual. 


\subsubsection{COLETA DE DADOS}

Esse processo se deu por meio de uma entrevista via Shype com o Gestor de Planejamento Estratégico da cooperativa, responsável pelo planejamento financeiro e por verificar os indicadores estratégicos e comunicá-los aos envolvidos (diretoria executiva e setores).

Para tanto foi utilizado um instrumento semi-estruturado de coleta de dados, disponível no apêndice 6, visando fomentar a interação com o entrevistado. Dentre as questões abordadas estavam: como é feito o processo de avaliação de desempenho da cooperativa, se utilizam algum modelo como base para o processo, quais indicadores são considerados, como e por quem foram construídos, quem é a equipe responsável por esse processo, se os princípios cooperativistas são considerados no processo de avaliação, se é estabelecido peso para módulos e indicadores, e se a metodologia utilizada é a mesma de outras cooperativas do sistema.

Cannel e Kahn (1974) destacam que pesquisas semi-estruturadas, pedem uma composição de roteiro com tópicos gerais selecionados e elaborados. Trata-se de definir núcleos de interesse do pesquisador, que têm vínculo com a realidade sob estudo; existindo assim uma direção, ainda que não de forma totalmente declarada, para o conteúdo que vai ser obtido nas entrevistas (QUEIROZ, 1987).

Esse formato pede também uma formulação flexível das questões, cuja sequência e minúcia ficarão por conta do discurso dos sujeitos e da dinâmica que flui naturalmente no momento em que entrevistador e entrevistado se defrontam e partilham uma conversa permeada de perguntas abertas (ALVES; SILVA, 1992).

Destaca-se que os dados da entrevista foram gravados e transcritos para facilitar a análise dos mesmos.

Visando complementar o entendimento sobre o modelo utilizado pela cooperativa para avaliar o seu desempenho, foi compartilhado com a pesquisadora o documento que compila o Planejamento Estratégico da mesma, o qual contém informações como: a ideologia estratégica da cooperativa; análise SWOT; mapa estratégico (modelo), indicadores e metas, iniciativas, ações e projetos. Com esse documento foi possível acessar todos os módulos e indicadores trabalhados pela cooperativa em seu modelo de avaliação de desempenho. 
Este meio de coleta de dados tem, segundo Creswell (2007, p. 192) as seguintes vantagens: "pode ser acessado em um momento conveniente para o pesquisador (...) representa dados refletidos, aos quais os participantes dedicaram atenção para compilar (...) economiza tempo do pesquisador e despesas com transcrição". Porém, por outro lado, te limitações como leitura ótica desse documento pode ser equivocada; o material pode ser incompleto, não autêntico ou impreciso.

Salienta-se acreditar ser importante a triangulação de métodos visando reduzir as inconsistências e contradições da pesquisa ao passo que ajuda evidenciar constatações coletadas na entrevista.

\subsubsection{ANÁLISE DOS DADOS}

A análise de dados foi realizada a partir de três guias mestras, conforme proposta por Alves e Silva (1992): foram consideradas as questões advindas do problema de pesquisa (o que ele indaga, o que quer saber); formulou-se a abordagem conceitual adotada (gerando pólos específicos de interesse); e considerou-se a realidade sob estudo (que exige um "espaço" para mostrar suas evidências e consistências).

Portanto, considerou-se a necessidade de se conhecer com se dá o processo de avaliação de desempenho da cooperativa, e a partir disso extraiu -se dos dados levantados as respostas para as perguntas formuladas.

\subsubsection{Quinta etapa da Pesquisa - Proposição do Modelo de AValiação de Desempenho de CoOperativas de Crédito}

A proposição de um Modelo de Avaliação de Desempenho de Cooperativas de Crédito que reduzisse os conflitos de agência foi realizada com base nas etapas anteriores da pesquisa.

Utilizou-se para tanto os dados resultantes do levantamento empírico no qual constatou-se quais elementos são tidos como relevantes para avaliação de desempenho de cooperativas de crédito com base na visão de cooperados, conselheiros e gerentes; bem como dados da entrevista realizada com a cooperativa e elementos salientados pela literatura. 


\subsection{LIMITAÇÕES DO ESTUDO}

Entre as limitações desse estudo está o tamanho da amostra participante da etapa empírica, que não permite que se faça generalização dos resultados obtidos para todas as Cooperativas de Crédito brasileiras. Ainda em relação à amostra, destaca-se que o número de Conselheiros participantes foi abaixo do esperado, especialmente conselheiros fiscais, provavelmente pelo fato de a quantidade de conselheiros que a amostra escolhida possuía ser pequena, e nem todos, apesar de convidados, se disponibilizarem a participar.

Salienta-se também que os indicadores de avaliação de desempenho utilizados nesse estudo não representam globalmente as organizações cooperativas de crédito, visto que são um recorte dos principais trabalhos da área, que por suas limitações também não conseguem especificar todas as variáveis representativas desse universo. Porém, caso fosse possível levantar todas essas variáveis, inviabilizaria o presente estudo, visto que não seria concebível coletar as opiniões dos grupos envolvidos com cooperativas de crédito acerca de todos os indicadores, pois a lista seria muito extensa. 


\section{APRESENTAÇÃO E ANÁLISE dOS RESULTADOS}

\subsection{LEVANTAMENTO DOS INDICADORES DE AVALIAÇÃO DE DESEMPENHO DE COOPERATIVA DE CRÉDITO COM BASE NO REFERENCIAL TEÓRICO}

Após a pesquisa por indicadores de desempenho de cooperativas de crédito e cooperativas de maneira geral, foi possível levantar:

- 215 indicadores denominados Econômico/Financeiros;

- 6 indicadores denominados Cliente;

- 10 indicadores denominados Processos Internos;

- 7 indicadores denominados Aprendizado e Crescimento;

- 25 indicadores denominados Sociais;

- 5 indicadores denominados Socioeconômicos;

- 12 indicadores denominados Eficiência Operacional;

- 5 indicadores denominados Pessoas e Inovação;

- 7 indicadores denominados Qualidade Técnica e Comercial;

- 4 indicadores denominados Satisfação do Consumidor;

- 5 indicadores denominados Relacionamento com Associados;

- 2 indicadores denominados Benefícios Sociais e Ambientais.

Para chegar à lista de indicadores que foram utilizados na pesquisa, fez-se uma varredura naqueles repetidos, os que englobavam outros e os que eram específicos de cooperativas de outros ramos.

Destaca-se, que no caso de indicadores financeiros, cujo número era muito grande, optou-se por priorizar aqueles que se repetiam nos trabalhos de dois ou mais autores, bem como os que tinham medida expressa ou eram passíveis de medição, e que não fossem muito detalhados, como por exemplo, margem bruta, margem operacional e margem líquida; liquidez corrente, liquidez geral e liquidez seca; optando-se por uma forma somente, sem variações.

Optou-se ainda por não trabalhar com todos os módulos disponíveis na literatura, visto que vários deles eram bastante próximos e puderam ser distribuídos nos demais módulos, como é o caso do "Social", tão relevante quando se trata de uma cooperativa, cujos elementos foram realocados nos demais nos módulos. Destaca-se 
ainda que ajustou-se o módulo "Clientes" para "Associados", pois entende-se ser mais apropriado, visto que se trata de um público com características diferentes de clientes.

Com isso obteve-se a lista de 46 indicadores que foram levados à apreciação de especialistas por intermédio do método Delphi e posteriormente à validação de face e conteúdo, para mais tarde serem avaliados por cooperados, membros de Conselho Fiscal e Administrativo e gerentes de Cooperativas de Crédito.

Esses estão apresentados no quadro 12 a seguir, bem como sua fórmula de cálculo e autores que as utilizam como indicadores de desempenho de cooperativa. 
Quadro 12 - Indicadores finais de Avaliação de Desempenho de Cooperativas de Crédito

\begin{tabular}{|c|c|c|c|}
\hline $\begin{array}{l}\text { Tipo de } \\
\text { indicador }\end{array}$ & Indicador & Fórmula para cálculo & Autores \\
\hline \multirow[t]{10}{*}{ Financeiro } & Crescimento das Vendas & $\begin{array}{c}\text { valor presente de vendas subtraído pelo valor passado / } \\
\text { valor passado }\end{array}$ & $\begin{array}{c}\text { BIALOSKORSKI NETO, NAGANO e MORAES } \\
\text { (2006);PORTO (2002) }\end{array}$ \\
\hline & Retorno sobre o Investimento & $\begin{array}{l}\text { ganho obtido subtraído do valor do investimento / valor do } \\
\text { investimento }\end{array}$ & $\begin{array}{c}\text { PORTO (2002); BORTOLUZZI et al. (2011); } \\
\text { BIALOSKORSKI NETO, NAGANO e MORAES } \\
(2006)\end{array}$ \\
\hline & Valor Econômico Agregado & $\begin{array}{l}\text { resultado operacional líquido subtraído (investimento total } \\
\text { multiplicado pelo custo médio ponderado de capital) }\end{array}$ & Porto (2002); BORTOLUZZI et al. (2011) \\
\hline & Rentabilidade do patrimônio líquido & Lucro líquido anual / Patrimônio Líquido x 100 & $\begin{array}{c}\text { BORTOLUZZI et al. (2011); } \\
\text { BRESSAN, BRAGA e BRESSAN (2003); } \\
\text { BIALOSKORSKI NETO, NAGANO e MORAES } \\
\text { (2006); YAMADA e BIALOSKORSKI NETO } \\
\text { (2010); BARROS; MORAES (2015) }\end{array}$ \\
\hline & Imobilização do patrimônio líquido & ativo permanente/patrimônio líquido & $\begin{array}{l}\text { BORTOLUZZI et al. (2011); FERREIRA, } \\
\text { GONÇALVES e BRAGA(2007); BRESSAN, } \\
\text { BRAGA e BRESSAN (2003); BIALOSKORSKI } \\
\text { NETO, NAGANO e MORAES (2006) }\end{array}$ \\
\hline & Liquidez corrente & Ativo Circulante / Passivo Circulante. & $\begin{array}{l}\text { BORTOLUZZI et al. (2011); BIALOSKORSKI } \\
\text { NETO, NAGANO e MORAES (2006) }\end{array}$ \\
\hline & Capital em giro & (patrimônio líquido - ativo permanente)/patrimônio líquido & $\begin{array}{l}\text { FERREIRA, GONÇALVES e BRAGA(2007); } \\
\text { BRESSAN, BRAGA e BRESSAN (2003) }\end{array}$ \\
\hline & Grau do endividamento financeiro & $\begin{array}{c}\text { O quanto de dinheiro de terceiros a cooperativa usa em } \\
\text { suas operações }\end{array}$ & $\begin{array}{c}\text { BORTOLUZZI et al. (2011); HUBNER et al } \\
\text { (2012); BIALOSKORSKI NETO, NAGANO e } \\
\text { MORAES (2006) }\end{array}$ \\
\hline & Margem bruta & Lucro bruto/receita total $\times 100$ & $\begin{array}{c}\text { BORTOLUZZI et al. (2011); } \\
\text { BIALOSKORSKI NETO, NAGANO e MORAES } \\
\text { (2006); YAMADA e BIALOSKORSKI NETO } \\
\text { (2010); BARROS, MORAES (2015) }\end{array}$ \\
\hline & Resultado econômico & é o prejuízo ou sobras total da cooperativa & $\begin{array}{l}\text { BORTOLUZZI et al. (2011); BIALOSKORSKI } \\
\text { NETO, NAGANO e MORAES (2006) }\end{array}$ \\
\hline
\end{tabular}




\begin{tabular}{|c|c|c|c|}
\hline & Capitalização & patrimônio líquido/passivo real & $\begin{array}{c}\text { FERREIRA, GONÇALVES e BRAGA(2007); } \\
\text { BRESSAN, BRAGA e BRESSAN (2003); } \\
\text { BORTOLUZZI et al. (2011) }\end{array}$ \\
\hline & Alavancagem & captação total/patrimônio líquido & $\begin{array}{c}\text { FERREIRA, GONÇALVES e BRAGA(2007); } \\
\text { BRESSAN, BRAGA e BRESSAN (2003); } \\
\text { BARROS, MORAES (2015) }\end{array}$ \\
\hline & Cobertura voluntária & disponibilidades/passivo real & $\begin{array}{l}\text { FERREIRA, GONÇALVES e BRAGA (2007); } \\
\text { BRESSAN, BRAGA e BRESSAN (2003) }\end{array}$ \\
\hline & Volume de crédito & operações de crédito/patrimônio líquido & $\begin{array}{l}\text { FERREIRA, GONÇALVES e BRAGA(2007); } \\
\text { BRESSAN, BRAGA e BRESSAN (2003) }\end{array}$ \\
\hline & Geração de rendas & receita operacional/(ativo real - ativo permanente) & $\begin{array}{l}\text { FERREIRA, GONÇALVES e BRAGA(2007); } \\
\text { BRESSAN, BRAGA e BRESSAN (2003) }\end{array}$ \\
\hline & Crescimento aplicações totais & $\begin{array}{l}\text { aplicação total do último período/aplicação total do período } \\
\text { anterior }\end{array}$ & $\begin{array}{l}\text { FERREIRA, GONÇALVES e BRAGA(2007); } \\
\text { BRESSAN, BRAGA e BRESSAN (2003) }\end{array}$ \\
\hline & Crescimento captações totais & $\begin{array}{l}\text { captação total do último período/captação total do período } \\
\text { anterior }\end{array}$ & $\begin{array}{l}\text { FERREIRA, GONÇALVES e BRAGA(2007); } \\
\text { BRESSAN, BRAGA e BRESSAN (2003); OCDF }\end{array}$ \\
\hline & Crescimento receita operacional & receita operacional do último período/ receita operacional & $\begin{array}{c}\text { FERREIRA, GONÇALVES e BRAGA (2007); } \\
\text { BRESSAN, BRAGA e BRESSAN (2003); } \\
\text { HUBNER et al. (2012) }\end{array}$ \\
\hline & Equilíbrio do orçamento & receitas maiores que despesas & HUBNER et al. (2012); OCDF \\
\hline & Independência Financeira & $\begin{array}{c}\text { medida por Margem Financeira e Retorno sobre } \\
\text { investimentos }\end{array}$ & $\begin{array}{c}\text { BIALOSKORSKI NETO, NAGANO e MORAES } \\
\text { (2006); } \\
\text { YAMADA e BIALOSKORSKI NETO (2010) }\end{array}$ \\
\hline & Faturamento por Funcionário & faturamento dividido pelo total de funcionários & $\begin{array}{c}\text { BIALOSKORSKI NETO, NAGANO e MORAES } \\
\text { (2006); MUNARETTO (2013) }\end{array}$ \\
\hline & Nível de inadimplemento (NID) & $\begin{array}{l}\text { Demonstra o grau de risco das operações de crédito, } \\
\text { mediante confronto entre as operações de crédito em } \\
\text { liquidação e as operações de crédito }\end{array}$ & OCDF; BARROS, MORAES (2015) \\
\hline & Receitas dos créditos (REC) & $\begin{array}{l}\text { Demonstra o retorno proporcionado pelas operações de } \\
\text { crédito, mediante confronto entre as receitas de operações } \\
\text { de crédito e as operações de crédito }\end{array}$ & OCDF; BARROS, MORAES (2015) \\
\hline
\end{tabular}




\begin{tabular}{|c|c|c|c|}
\hline \multirow[t]{6}{*}{ Associados } & Retenção de cooperantes & $\begin{array}{l}\text { Número de associados atual subtraído pelo número anterior } \\
\text { de cooperantes }\end{array}$ & $\begin{array}{c}\text { PORTO (2002); BIALOSKORSKI NETO, } \\
\text { NAGANO e MORAES (2006) }\end{array}$ \\
\hline & Satisfação de cooperantes & $\begin{array}{l}\text { Conforto do ambiente; tempo de espera até o atendimento; } \\
\text { Burocracia do atendimento; Qualidade do atendimento; } \\
\text { Produtos e serviços oferecidos (qualidade e diversidade); } \\
\text { Custo dos produtos e serviços; Estacionamento; Unificação } \\
\text { ou concentração dos assuntos a serem resolvidos; Opções } \\
\text { de serviços pela Internet; Segurança do prédio; Segurança } \\
\text { das transaçães; Serviço "Call center"; Qualidade do } \\
\text { atendimento; Custo dos produtos e serviços; Unificação ou } \\
\text { concentraçãa dos assuntos a serem resolvidos; Segurança } \\
\text { das transações; Tempo de espera até o atendimento }\end{array}$ & $\begin{array}{c}\text { PORTO (2002); HUBNER et al (2012); } \\
\text { BIALOSKORSKI NETO, NAGANO e MORAES } \\
\text { (2006);MENGÁRIO (2000);BARROS, MORAES } \\
\text { (2015) }\end{array}$ \\
\hline & $\begin{array}{l}\text { Associados em Assembleia Geral } \\
\text { Ordinária (AGO) }\end{array}$ & número de associados participantes das $\mathrm{AGO}$ & $\begin{array}{c}\text { BIALOSKORSKI NETO, NAGANO e MORAES } \\
\text { (2006); MUNARETTO (2013); } \\
\text { MENEGÁRIO (2000) }\end{array}$ \\
\hline & Número Associados Ativos & cooperados ativos/número total de associados & $\begin{array}{c}\text { BIALOSKORSKI NETO, NAGANO e MORAES } \\
\text { (2006); MENGÁRIO (2000) }\end{array}$ \\
\hline & Sobras ou faturamento por cooperado & $\begin{array}{l}\text { valor das sobras distribuídas dividido pelo faturamento } \\
\text { multiplicados por } 100\end{array}$ & $\begin{array}{c}\text { MENGÁRIO (2000); MUNARETTO (2013); } \\
\text { BIALOSKORSKI NETO, NAGANO e } \\
\text { MORAES (2006) }\end{array}$ \\
\hline & Capital integralizado por associado & Valor médio integralizado por cada associado & MUNARETTO (2013) \\
\hline \multirow{6}{*}{$\begin{array}{c}\text { Processos } \\
\text { internos }\end{array}$} & Lucratividade por segmento-alvo & percentual de sobras de cada segmento & PORTO (2002) \\
\hline & $\begin{array}{l}\text { Percentual de transações realizadas } \\
\text { através dos diversos canais }\end{array}$ & $\begin{array}{c}\text { Percentual de transações realizadas através dos diversos } \\
\text { canais (caixas eletrônicos, caixas convencionais, ou } \\
\text { auxiliadas por computador) }\end{array}$ & PORTO (2002) \\
\hline & Projetos sociais desenvolvidos & número de projetos sociais desenvolvidos & HUBNER et al. (2012) \\
\hline & Percentual de trabalho extraordinário & $\begin{array}{l}\text { quantidade de horas extras realizadas dividida pela } \\
\text { quantidade de horas totais multiplicados por } 100\end{array}$ & MUNARETTO (2013) \\
\hline & $\begin{array}{l}\text { Número de consumidores por ponto } \\
\text { de atendimento próprio }\end{array}$ & $\begin{array}{l}\text { número de consumidores de dividido pelo número de pontos } \\
\text { de atendimento }\end{array}$ & MUNARETTO (2013) \\
\hline & Desenvolvimento sustentável & $\begin{array}{l}\text { Atenção ao capital humano envolvido, à sustentabilidade } \\
\text { econômica do negócio e preservação do meio ambiente }\end{array}$ & HUBNER et al. (2012) \\
\hline
\end{tabular}




\begin{tabular}{|c|c|c|c|}
\hline & $\begin{array}{l}\text { Volume de produtos oferecidos e com } \\
\text { demanda satisfatória }\end{array}$ & $\begin{array}{l}\text { Quantidade de produtos oferecidos e com demanda } \\
\text { satisfatória }\end{array}$ & HUBNER et al. (2012) \\
\hline & Quantidade de estagiários & Número de estagiários & HUBNER et al. (2012) \\
\hline \multirow[t]{3}{*}{$\begin{array}{l}\text { Aprendizado e } \\
\text { Crescimento }\end{array}$} & $\begin{array}{l}\text { Melhorias das capacidades dos } \\
\text { funcionários (conhecimento do } \\
\text { colaborador para dar as informações } \\
\text { corretas) }\end{array}$ & $\begin{array}{l}\text { número de cursos de capacitação aplicados aos } \\
\text { funcionários }\end{array}$ & PORTO (2002); HUBNER et al (2012) \\
\hline & Nível de rotatividade & $\begin{array}{c}\text { (número de admissões somados ao número de } \\
\text { desligamentos) dividido por dois e dividido pelo número } \\
\text { total de funcionários }\end{array}$ & HUBNER et al. (2012) \\
\hline & $\begin{array}{l}\text { Motivação para agir no melhor } \\
\text { interesse da cooperativa }\end{array}$ & Pesquisas motivacionais & PORTO (2002); HUBNER et al. (2012) \\
\hline \multirow[t]{6}{*}{$\begin{array}{l}\text { Pessoas e } \\
\text { inovação }\end{array}$} & Idade média dos colaboradores & $\begin{array}{c}\text { somatório das idades dos colaboradores dividido pelo } \\
\text { número de colaboradores }\end{array}$ & MUNARETTO (2013) \\
\hline & Profissionalização da Administração & $\begin{array}{l}\text { Número de treinamentos, cursos, eventos que os } \\
\text { funcionários e gestores participam }\end{array}$ & PORTO (2002); HUBNER et al. (2012) \\
\hline & Melhoria constante da estrutura & $\begin{array}{l}\text { Melhorias em sistemas de informação, concepção de novos } \\
\text { produtos e serviços }\end{array}$ & PORTO (2002); HUBNER et al. (2012) \\
\hline & Nível de satisfação dos colaboradores & Pesquisa de satisfação com os funcionários & MUNARETTO (2013 \\
\hline & $\begin{array}{c}\text { Percentual de colaboradores com } \\
\text { cursos de especialização, mestrado e } \\
\text { doutorado }\end{array}$ & $\begin{array}{c}\text { Quantidade de especialistas, mestres e doutores dividida } \\
\text { pelo total de funcionários } \times 100\end{array}$ & MUNARETTO (2013) \\
\hline & Número de acidentes de trabalho & somatório dos acidentes de trabalho no período & MUNARETTO (2013) \\
\hline
\end{tabular}

Fonte: autora 


\subsection{VALIDAÇÃO DOS INDICADORES DE AVALIAÇÃO DE DESEMPENHO}

\subsubsection{Resultados da metodologia DelPhi}

O método Delphi gerou a exclusão dos seguintes indicadores do módulo "Financeiro": valor econômico agregado, imobilização do patrimônio líquido, liquidez corrente, alavancagem, cobertura voluntária, volume de crédito, crescimento receita operacional, independência financeira, faturamento por funcionário, receitas dos créditos (REC). Sendo assim, tal módulo passa a ser representado por um total de 13 indicadores.

No módulo "Associados" excluiu o indicador capital integralizado por associado, e incluiu relevância do associado na tomada de decisão; totalizando 6 indicadores nesse módulo.

No módulo "Processos Internos" foram excluídas nessa fase 3 indicadores, a saber: número de consumidores por ponto de atendimento, volume dos produtos oferecidos com demanda satisfatória e quantidade de estagiários; totalizando 5 indicadores no referido módulo.

O modulo "Aprendizado e Crescimento" manteve-se com todos os indicadores.

No módulo "Pessoas e Inovação", foram excluídos os indicadores: percentual de colaboradores com cursos de especialização, mestrado e doutorado, número de acidentes de trabalho e idade média dos colaboradores. Dessa forma, o módulo passou a conter 3 indicadores.

Sendo assim, o instrumento final de coleta de dados, após o crivo da validade de face e conteúdo e método Delphi passou a conter:

- 13 indicadores no módulo "Financeiro";

- 6 indicadores no módulo "Associados";

- 5 indicadores no módulo "Processos Internos";

- 3 indicadores no módulo "Aprendizado e Crescimento";

- 3 indicadores no módulo "Pessoas e Inovação";

A nova lista de indicadores, após a metodologia Delphi está disposta no apêndice 2, documento este que foi enviado aos participantes da validade de face e conteúdo. 


\subsubsection{VALIDAÇÃo de FACE E CONTEÚDO}

Como já mencionado, o questionário contendo os indicadores de avaliação de desempenho de cooperativas de crédito foi submetido à análise de dez pessoas a fim de verificar se o instrumento é de fácil compreensão e se está adequado aos objetivos da pesquisa.

Nessa etapa, os acadêmicos participantes, que conheciam previamente os objetivos da pesquisa e as hipóteses a serem testadas, sugeriram incluir no módulo "Associados" indicadores que exprimissem ganhos individuais de cooperados, a fim de atender aos objetivos da pesquisa, como: menor custo das transações, ganhos financeiros de cada cooperado individualmente, ganhos financeiros de todos os cooperados (enquanto grupo), emancipação social e econômica do associado, educação, formação e informação do cooperado e realização pessoal dos cooperados.

No mesmo sentido, sugeriram incluir no módulo "Processos Internos" os seguintes indicadores: nível de transparência, perpetuação da instituição e preservação da identidade organizacional.

Sugeriram ainda substituir o indicador "Nível de satisfação dos colaboradores" por outros indicadores equivalentes a esse e que fossem mais interessantes para o teste das hipóteses da pesquisa, como: segurança no emprego para os trabalhadores da cooperativa, pagamento de bons salários aos funcionários da cooperativa, benefícios extra para bons funcionários, respeito às opiniões dos trabalhadores, respeito às opiniões dos trabalhadores, ambiente ético e que valoriza o capital humano e condições de trabalho adequadas.

Nas suas discussões sugeriram ainda incluir o módulo "Princípios Cooperativistas", com os seguintes indicadores: cumpre os princípios cooperativistas, democracia e igualdade, solidariedade, valores de ajuda mútua, autonomia e independência, adesão livre e voluntária, preocupação com a comunidade, geração de empregos, combate a exclusão social.

Destaca-se que os participantes da validade de face e conteúdo avaliaram o instrumento de coleta de dados como sem dificuldade de leitura, compreensão e erros tipográficos, bem como entenderam que o conteúdo final, o tamanho da letra e as questões são adequadas. 
Sendo assim, o novo instrumento de coleta de dados foi reformulado, e adequado aos públicos participantes da etapa empírica dessa investigação. Os instrumentos de coleta de dados estão dispostos nos apêndices 3,4 e 5 , sendo voltados a Cooperados, Gerentes e Conselheiros, respectivamente.

\subsection{ANÁLISE ESTATÍSTICA DOS DADOS COLETADOS}

O processo de coleta de dados foi realizado em cerca de dois meses, visto que a maior parte das cooperativas convidadas a participar do estudo demandaram de reunião com os responsáveis para apresentar o teor dos dados e posteriormente decidir se participariam ou não da pesquisa. Após a confirmação das participantes, as mesmas dispararam e-mails com os links do questionário para os públicos-alvo da investigação. Destaca-se que foi necessário entrar em contato novamente com as participantes solicitando que reforçassem o convite a responder o questionário devido a baixa adesão de participação. Após essa intervenção foi possível coletar mais questionários respondidos.

A tabela 2 demonstra a quantidade de respostas obtidas na pesquisa.

Tabela 2 - Indicadores finais de Avaliação de Desempenho de Cooperativas de Crédito

\begin{tabular}{|c|c|c|c|}
\hline & & \multicolumn{2}{|c|}{$\%$ válidos do total } \\
\hline $\begin{array}{l}\text { ( = ) Instrumentos (questionários) } \\
\text { recebidos }\end{array}$ & 439 & $100 \%$ & \\
\hline Conselheiros & 64 & $14,60 \%$ & \\
\hline Cooperados & 246 & $56 \%$ & \\
\hline Gerentes & 129 & $29,40 \%$ & \\
\hline $\begin{array}{l}\text { ( - ) Instrumentos (questionários) } \\
\text { incompletos }\end{array}$ & 141 & $100 \%$ & \\
\hline Conselheiros & 8 & $7,80 \%$ & \\
\hline Cooperados & 3 & $66,70 \%$ & \\
\hline Gerentes & 94 & $25,50 \%$ & \\
\hline $\begin{array}{c}\text { ( = ) Instrumentos (questionários) } \\
\text { válidos }\end{array}$ & 298 & $100 \%$ & $67,90 \%$ \\
\hline Conselheiros & 53 & $17,80 \%$ & $82,80 \%$ \\
\hline Cooperados & 152 & $51 \%$ & $61,80 \%$ \\
\hline Gerentes & 93 & $31,20 \%$ & $67,90 \%$ \\
\hline
\end{tabular}

Fonte: autora.

Após finalizar o prazo de retorno dos instrumentos, foram recebidos 439 instrumentos de pesquisa (questionários). Destes, foram eliminados 141 que 
apresentavam respostas incompletas. Assim, a amostra atingiu o número de 298 instrumentos de coleta de dados completos (válidos), o que representa quase $68 \%$ dos questionários recebidos.

Após a tabulação dos dados dos questionários válidos, eles foram transferidos para o IBM ${ }^{\circledR} S P S S^{\circledR}$ StatisticsVersion23 para a realização das análises.

\subsubsection{VERIFICAÇÃO DA CONFIABILIDADE DO INSTRUMENTO}

Para Hourneaux Junior (2010), a confiabilidade de um instrumento refere-se à precisão com que um conceito é mensurado por esse instrumento, possibilitando a repetição desse instrumento em outras ocasiões, com a obtenção dos mesmos resultados.

A confiabilidade (consistência interna) dos instrumentos de coleta de dados foi realizada por meio da aplicação da estatística alfa de Cronbach, para cada uma das variáveis (67 variáveis/indicadores) e pelo alfa geral (alfa total - conjunto de todas as variáveis/indicadores).

Segundo Trochim (2003), a consistência interna refere-se ao grau com que os itens do questionário estão correlacionados entre si e com o resultado geral da pesquisa, o que representa uma mensuração de confiabilidade do mesmo. Para Souza (2011), a determinação do coeficiente de alfa de Cronbach é o mais apropriado para escalas com mais de duas categorias, aplicando-se a variáveis ordinais ou contínuas.

Diferentes autores recomendam que um bom nível de consistência interna se refere a um valor de 0,7 ou mais, quando mais altos os valores do alfa de Cronbach são melhores (DEVILLIS, 2003; KLINE, 2005; HAIR JR ET AL, 2005). Foram considerados os mesmos parâmetros descritos pelos autores Hill e Hill (2000), sendo aceitável um coeficiente alfa de 0,70 (HAIR JR. et al, 2005) (tabela 3). 
Tabela 3 - Indicadores finais de Avaliação de Desempenho de Cooperativas de Crédito

\begin{tabular}{cc}
\hline Variação do coeficiente de alfa & Intensidade de associação \\
\hline$<0,6$ & Baixa \\
$0,60 a<0,7$ & Moderada \\
$0,7 \mathrm{a}<0,8$ & Boa \\
$0,8 \mathrm{a}<0,9$ & Muito Boa \\
0,9 & Excelente \\
\hline
\end{tabular}

Fonte: Hair, Jr. et al (2005, p. 200)

A tabela 4 apresenta o alfa de Cronbach ( $\alpha$ ) geral da escala e também os valores para as escalas de cada uma das categorias. Juntamente com os valores do o alfa de Cronbach é apresentada a quantidade de itens da escala de cada categoria e ao final o total da escala.

Tabela 4 - Confiabilidade do instrumento de coleta de dados (Consistência Interna)

\begin{tabular}{ccc}
\hline & Estatísticas de confiabilidade \\
\hline Grupo de Variáveis & Alfa de Cronbach & N de itens \\
Fin & 0,932 & 13 \\
Ass & 0,845 & 12 \\
Pro & 0,85 & 8 \\
Apr & 0,644 & 3 \\
Pes & 0,831 & 8 \\
Pri & 0,907 & 9 \\
GERAL (Coeficiente Geral) & $\mathbf{0 , 9 6 2}$ & $\mathbf{5 3}$ \\
\hline
\end{tabular}

Fonte: autora.

O alfa de Cronbach ( $\alpha$ ) geral dessa escala é 0,962 (tabela 4), o que indica um alto nível de consistência interna para a escala, sendo considerado excelente de acordo com os critérios da tabela 3. As escalas de cada umas das categorias também apresentam valores do alfa de Cronbach acima de 0,7, indicando bons níveis de consistência interna, exceto a categoria "aprendizado e crescimento" $(0,644)$ (tabela 4), no entanto, ao retirar as variáveis dessa categoria da escala, o valor do alfa de Cronbach da escala cai, por isso optou-se por manter as variáveis (apêndice 7).

Também, foram realizados os cálculos para todas as variáveis (indicadores) individualmente, com o objetivo de se verificar sobre a necessidade de exclusão de alguma delas, caso os resultados melhorassem o coeficiente geral. Porém, nos 
cálculos individuais não houve variação significativa em relação ao coeficiente geral. Desta forma, não foi necessário excluir nenhuma variável (indicador). Os valores dos coeficientes alfa de cada uma das variáveis estão apresentados no Apêndice 7 .

\subsubsection{Estatística DESCRITIVA DO PERFIL DAS OBSERVAÇÕES}

No total foram coletados 53 questionários válidos respondidos por Conselheiros, 152 por Cooperados e 93 por gerentes, totalizando 298 questionários válidos.

Destaca-se que a faixa etária da maioria dos respondentes está entre 25 e 35 anos e a maior parte dos respondentes possui curso de especialização, conforme tabela 5 .

Tabela 5 - Estatística Descritiva do perfil das observações

\begin{tabular}{llccc}
\hline Identificação & Frequência & Percentual & $\begin{array}{c}\text { Porcentagem } \\
\text { acumulada }\end{array}$ \\
\hline Categoria das & Conselheiros & 53 & 17,8 & 17,8 \\
observações & Cooperados & 152 & 51 & 68,8 \\
& Gerentes & 93 & 31,2 & 100 \\
& Total & $\mathbf{2 9 8}$ & $\mathbf{1 0 0}$ & \\
\hline Idade & $18-24$ anos & 40 & 13,4 & 13,4 \\
& $25-35$ anos & 117 & 39,3 & 52,7 \\
& $36-50$ anos & 92 & 30,9 & 83,6 \\
& acima de 51 anos & 49 & 16,4 & 100 \\
\hline Escolaridade & Total & $\mathbf{2 9 8}$ & $\mathbf{1 0 0}$ & \\
& Fundamental & 2 & 0,7 & 0,7 \\
& incompleto & & & \\
& Fundamental completo & 2 & 0,7 & 1,3 \\
& Médio incompleto & 2 & 0,7 & 2 \\
& Médio completo & 13 & 4,4 & 6,4 \\
& Superior incompleto & 45 & 15,1 & 21,5 \\
& Superior completo & 73 & 24,5 & 46 \\
& Especialização & 145 & 48,7 & 94,6 \\
& Mestrado ou doutorado & 16 & 5,4 & 100 \\
& Total & $\mathbf{2 9 8}$ & $\mathbf{1 0 0}$ & \\
\cline { 2 - 4 } & & &
\end{tabular}

Fonte: autora. 


\subsubsection{IDENTIFICAÇÃO DOS CONSELHEIROS}

Foram recolhidos 25 questionários válidos de Conselheiros Fiscais e 28 de Conselheiros Administrativos, a maior parte dos respondentes tem mais de 51 anos $(64,2 \%)$, possuem curso de especialização $(49,1 \%)$ e estão no cargo a 2 mandatos $(49,1 \%)$, conforme a tabela 6 .

Tabela 6 - Caracterização da amostra de conselheiros participantes

\begin{tabular}{|c|c|c|c|c|}
\hline \multicolumn{2}{|c|}{ Identificação } & Freqüência & Porcentual & $\begin{array}{l}\text { Porcentagem } \\
\text { acumulada }\end{array}$ \\
\hline \multirow{3}{*}{$\begin{array}{l}\text { A qual Conselho } \\
\text { pertencem }\end{array}$} & Fiscal & 25 & 47,2 & 47,2 \\
\hline & Administrativo & 28 & 52,8 & 100,0 \\
\hline & Total & 53 & 100,0 & \\
\hline \multirow{4}{*}{ Faixa etária } & $25-35$ anos & 10 & 18,9 & 18,9 \\
\hline & $36-50$ anos & 9 & 17,0 & 35,8 \\
\hline & acima de 51 anos & 34 & 64,2 & 100,0 \\
\hline & Total & 53 & 100,0 & \\
\hline \multirow{6}{*}{ Escolaridade } & Médio completo & 2 & 3,8 & 3,8 \\
\hline & Superior incompleto & 2 & 3,8 & 7,5 \\
\hline & Superior completo & 18 & 34,0 & 41,5 \\
\hline & Especialização & 26 & 49,1 & 90,6 \\
\hline & Mestrado ou doutorado & 5 & 9,4 & 100,0 \\
\hline & Total & 53 & 100,0 & \\
\hline \multirow{5}{*}{$\begin{array}{l}\text { Número de } \\
\text { mandatos }\end{array}$} & 1 mandato & 23 & 43,4 & 43,4 \\
\hline & 2 mandatos & 26 & 49,1 & 92,5 \\
\hline & 3 mandatos & 1 & 1,9 & 94,3 \\
\hline & 4 ou mais mandatos & 3 & 5,7 & 100,0 \\
\hline & Total & 53 & 100,0 & \\
\hline
\end{tabular}

Fonte: autora.

\subsubsection{IDENTIFICAÇÃO DOS COOPERADOS}

Em relação ao perfil de cooperados da amostra participante salienta-se que a maioria possui conta de pessoa física (92,1\% dos respondentes), tem entre 25 e 35 anos (44,7\%), possuem curso de especialização (30,3\%), são associados a mais de 5 anos (32,3\%), possuem renda familiar superior à $R \$ 7.632,00 \quad(29,6 \%$ dos respondentes) e nunca participaram de assembleias (46,1\%), conforme a tabela 7 . 
Tabela 7 - Caracterização da amostra de cooperados participantes

\begin{tabular}{|c|c|c|c|c|}
\hline \multicolumn{2}{|c|}{ Identificação } & \multirow{2}{*}{$\begin{array}{r}\text { Frequência } \\
140\end{array}$} & \multirow{2}{*}{$\begin{array}{r}\text { Porcentual } \\
92,1\end{array}$} & \multirow{2}{*}{$\begin{array}{r}\begin{array}{c}\text { Porcentagem } \\
\text { acumulada }\end{array} \\
92,1\end{array}$} \\
\hline Tipo de conta & Pessoa Física & & & \\
\hline & Pessoa Jurídica & 12 & 7,9 & 100,0 \\
\hline & Total & 152 & 100,0 & \\
\hline \multirow[t]{5}{*}{ Faixa etária } & 18-24 anos & 39 & 25,7 & 25,7 \\
\hline & $25-35$ anos & 68 & 44,7 & 70,4 \\
\hline & $36-50$ anos & 33 & 21,7 & 92,1 \\
\hline & acima de 51 anos & 12 & 7,9 & 100,0 \\
\hline & Total & 152 & 100,0 & \\
\hline \multirow[t]{9}{*}{$\overline{\text { Escolaridade }}$} & Fundamental incompleto & 2 & 1,3 & 1,3 \\
\hline & Fundamental completo & 2 & 1,3 & 2,6 \\
\hline & Médio incompleto & 2 & 1,3 & 3,9 \\
\hline & Médio completo & 11 & 7,2 & 11,2 \\
\hline & Superior incompleto & 41 & 27,0 & 38,2 \\
\hline & Superior completo & 39 & 25,7 & 63,8 \\
\hline & Especialização & 46 & 30,3 & 94,1 \\
\hline & Mestrado ou doutorado & 9 & 5,9 & 100,0 \\
\hline & Total & 152 & 100,0 & \\
\hline \multirow{5}{*}{$\begin{array}{l}\text { Tempo de } \\
\text { associados }\end{array}$} & menos de 1 ano & 30 & 19,7 & 19,7 \\
\hline & entre 1 e 2 anos & 40 & 26,3 & 46,1 \\
\hline & entre 3 e 4 anos & 33 & 21,7 & 67,8 \\
\hline & mais de 5 anos & 49 & 32,2 & 100,0 \\
\hline & Total & 152 & 100,0 & \\
\hline \multirow[t]{7}{*}{ Renda familiar } & Até $\mathrm{R} \$ 954$ & 3 & 2,0 & 2,0 \\
\hline & $\mathrm{R} \$ 954$ a $\mathrm{R} \$ 1.908,00$ & 18 & 11,8 & 13,8 \\
\hline & $\mathrm{R} \$ 1.908$ a $\mathrm{R} \$ 3.816$ & 36 & 23,7 & 37,5 \\
\hline & $\mathrm{R} \$ 3.816$ a $\mathrm{R} \$ 5.724$ & 31 & 20,4 & 57,9 \\
\hline & $\mathrm{R} \$ 5.724$ a $\mathrm{R} \$ 7.632$ & 19 & 12,5 & 70,4 \\
\hline & mais de $R \$ 7.632$ & 45 & 29,6 & 100,0 \\
\hline & Total & 152 & 100,0 & \\
\hline \multirow{7}{*}{$\begin{array}{l}\text { Número de } \\
\text { assembleias }\end{array}$} & nunca participei & 70 & 46,1 & 46,1 \\
\hline & 1 assembleia & 13 & 8,6 & 54,6 \\
\hline & 2 assembleias & 26 & 17,1 & 71,7 \\
\hline & 3 assembleias & 15 & 9,9 & 81,6 \\
\hline & 4 assembleias & 12 & 7,9 & 89,5 \\
\hline & mais de 5 assembleias & 16 & 10,5 & 100,0 \\
\hline & Total & 152 & 100,0 & \\
\hline
\end{tabular}

Fonte: autora. 


\subsubsection{IDENTIFICAÇÃO DOS GERENTES}

Em relação aos gerentes participantes da amostra dessa pesquisa destaca-se que $53,8 \%$ deles tem entre 36 e 50 anos, $78,5 \%$ possuem curso de especialização, $59,1 \%$ deles são gerentes a mais de 5 anos e $88,2 \%$ são gerentes gerais. A Tabela 8 apresenta as estatísticas relacionados ao perfil dos gerentes.

Tabela 8 - Caracterização da amostra de cooperados participantes

\begin{tabular}{|c|c|c|c|c|}
\hline \multicolumn{2}{|c|}{ Identificação } & \multirow{2}{*}{$\begin{array}{r}\text { Frequência } \\
1\end{array}$} & \multirow{2}{*}{$\begin{array}{r}\text { Porcentual } \\
1,1\end{array}$} & \multirow{2}{*}{$\begin{array}{l}\begin{array}{l}\text { Porcentagem } \\
\text { acumulada }\end{array} \\
1,1\end{array}$} \\
\hline$\overline{\text { Faixa etária }}$ & $18-24$ anos & & & \\
\hline & 25-35 anos & 39 & 41,9 & 43,0 \\
\hline & $36-50$ anos & 50 & 53,8 & 96,8 \\
\hline & acima de 51 anos & 3 & 3,2 & 100,0 \\
\hline & Total & 93 & 100,0 & \\
\hline \multirow[t]{5}{*}{ Escolaridade } & Superior incompleto & 2 & 2,2 & 2,2 \\
\hline & Superior completo & 16 & 17,2 & 19,4 \\
\hline & Especialização & 73 & 78,5 & 97,8 \\
\hline & Mestrado ou doutorado & 2 & 2,2 & 100,0 \\
\hline & Total & 93 & 100,0 & \\
\hline Tempo que & menos de 1 ano & 13 & 14,0 & 14,0 \\
\hline exercem função & entre 1 e 2 anos & 7 & 7,5 & 21,5 \\
\hline \multirow[t]{3}{*}{ de gerência } & entre 3 e 4 anos & 18 & 19,4 & 40,9 \\
\hline & mais de 5 anos & 55 & 59,1 & 100,0 \\
\hline & Total & 93 & 100,0 & \\
\hline Gerência a qual & Pessoa Física & 8 & 8,6 & 8,6 \\
\hline \multirow[t]{3}{*}{ pertence } & Pessoa Jurídica & 3 & 3,2 & 11,8 \\
\hline & Geral & 82 & 88,2 & 100,0 \\
\hline & Total & 93 & 100,0 & \\
\hline
\end{tabular}

Fonte: autora. 


\subsubsection{Estatística Descritiva Das Respostas}

\subsubsection{CATEGORIA DAS OBSERVAÇÕES DA AMOSTRA: CONSELHEIROS FISCAIS}

\subsection{MÓDULO "FINANCEIRO"}

A pontuação atribuída pelos Conselheiros Fiscais em relação aos indicadores do módulo Financeiro, bem como suas estatísticas constam na tabela 9. Em suma, todos os constructos desse módulo foram muito bem avaliados por esse público. Os mais bem avaliados de acordo com o grau de importância percebida foram: Crescimento das Aplicações totais (com 162 pontos e 6,48 de média), Nível de inadimplemento (162 pontos e 6,48 de média) e Rentabilidade do patrimônio líquido (159 pontos e 6,36 de média). Os fatores que alcançaram menor pontuação foram Margem bruta, com 143 pontos e 5,72 de média, e Retorno sobre o investimento (144 pontos e 5,76 de média).

\subsection{MÓDULO “ASSOCIADOS”}

A pontuação atribuída pelos Conselheiros Fiscais em relação aos indicadores do módulo "Associados", bem como suas estatísticas constam na tabela 10. Em suma, todos os constructos desse módulo foram muito bem avaliados por esse público. Os mais bem avaliados de acordo com o grau de importância percebida foram: Número de associados ativos (166 pontos e 6,64 de média) e Satisfação de cooperantes (com 162 pontos e 6,48 de média).

Os fatores que alcançaram menor pontuação foram Ganhos financeiros de cada cooperado individualmente (com 140 pontos e 5,60 de média), e Emancipação social e econômica do associado (com 144 pontos e 5,76 de média). 
Tabela 9 - Pontuação atribuída pelos Conselheiros Fiscais em relação aos indicadores do módulo Financeiro

\begin{tabular}{|c|c|c|c|c|c|c|c|c|c|c|c|}
\hline & \multirow[b]{2}{*}{ Soma } & \multirow{2}{*}{$\begin{array}{c}\text { Escore } \\
(175=100 \%)\end{array}$} & \multirow[b]{2}{*}{ Média } & \multirow[b]{2}{*}{ Mediana } & \multirow[b]{2}{*}{ Moda } & \multirow{2}{*}{$\begin{array}{l}\text { Desvio } \\
\text { Padrão }\end{array}$} & \multirow[b]{2}{*}{ Mínimo } & \multirow[b]{2}{*}{ Máximo } & \multicolumn{3}{|c|}{ Percentis } \\
\hline & & & & & & & & & 25 & 50 & 75 \\
\hline (Fin1) Crescimento das vendas & 153 & $87,43 \%$ & 6,12 & 6,00 & 6 & ,332 & 6 & 7 & 6,00 & 6,00 & 6,00 \\
\hline (Fin2) Retorno sobre o investimento & 144 & $82,29 \%$ & 5,76 & 6,00 & 6 & ,831 & 4 & 7 & 5,50 & 6,00 & 6,00 \\
\hline (Fin3) Rentabilidade do patrimônio líquido & 159 & $90,86 \%$ & 6,36 & 6,00 & 6 & ,490 & 6 & 7 & 6,00 & 6,00 & 7,00 \\
\hline (Fin4) Capital em giro & 150 & $85,71 \%$ & 6,00 & 6,00 & 6 &, 500 & 5 & 7 & 6,00 & 6,00 & 6,00 \\
\hline (Fin5) Grau do endividamento financeiro & 149 & $85,14 \%$ & 5,96 & 6,00 & 6 & ,889 & 4 & 7 & 5,50 & 6,00 & 7,00 \\
\hline (Fin6) Margem bruta & 143 & $81,71 \%$ & 5,72 & 6,00 & 6 & ,843 & 4 & 7 & 5,00 & 6,00 & 6,00 \\
\hline (Fin7) Resultado econômico & 159 & $90,86 \%$ & 6,36 & 6,00 & 6 & ,490 & 6 & 7 & 6,00 & 6,00 & 7,00 \\
\hline (Fin8) Capitalização & 154 & $88,00 \%$ & 6,16 & 6,00 & 6 & 624 & 5 & 7 & 6,00 & 6,00 & 7,00 \\
\hline (Fin9) Geração de rendas & 150 & $85,71 \%$ & 6,00 & 6,00 & 6 & 1,000 & 4 & 7 & 5,50 & 6,00 & 7,00 \\
\hline (Fin10) Crescimento aplicações totais & 162 & $92,57 \%$ & 6,48 & 7,00 & 7 &, 714 & 5 & 7 & 6,00 & 7,00 & 7,00 \\
\hline (Fin11) Crescimento captações totais & 150 & $85,71 \%$ & 6,00 & 6,00 & 6 &, 500 & 5 & 7 & 6,00 & 6,00 & 6,00 \\
\hline (Fin12) Equilíbrio do orçamento & 150 & $85,71 \%$ & 6,00 & 6,00 & 6 & 1,000 & 4 & 7 & 5,50 & 6,00 & 7,00 \\
\hline (Fin13) Nível de inadimplemento (NID) & 162 & $92,57 \%$ & 6,48 & 6,00 & 6 &, 510 & 6 & 7 & 6,00 & 6,00 & 7,00 \\
\hline
\end{tabular}

Fonte: autora.

Tabela 10 - Pontuação atribuída pelos Conselheiros Fiscais em relação aos indicadores do módulo Associados

\begin{tabular}{|c|c|c|c|c|c|c|c|c|c|c|c|}
\hline & \multicolumn{3}{|c|}{ Escore } & \multicolumn{5}{|c|}{ Desvio } & \multicolumn{3}{|c|}{ Percentis } \\
\hline & Soma & $(175=100 \%)$ & Média & Mediana & Moda & Padrão & Mínimo & Máximo & 25 & 50 & 75 \\
\hline (Ass1) Retenção de cooperantes & 153 & $87,43 \%$ & 6,12 & 6,00 & 6 &, 600 & 5 & 7 & 6,00 & 6,00 & 6,50 \\
\hline (Ass2) Satisfação de cooperantes & 162 & $92,57 \%$ & 6,48 & 6,00 & 6 &, 510 & 6 & 7 & 6,00 & 6,00 & 7,00 \\
\hline (Ass3) Menor custo das transações & 156 & $89,14 \%$ & 6,24 & 6,00 & 6 & ,436 & 6 & 7 & 6,00 & 6,00 & 6,50 \\
\hline (Ass4) Ganhos financeiros de cada cooperado individualmente & 140 & $80,00 \%$ & 5,60 & 6,00 & 6 & ,707 & 4 & 6 & 5,00 & 6,00 & 6,00 \\
\hline $\begin{array}{l}\text { (Ass5) Ganhos financeiros de todos os cooperados (enquanto } \\
\text { grupo) }\end{array}$ & 157 & $89.71 \%$ & 6,28 & 6,00 & 6 & 678 & 5 & 7 & 6,00 & 6,00 & 7,00 \\
\hline (Ass6) Emancipação social e econômica do associado & 144 & $82,29 \%$ & 5,76 & 6,00 & 6 & ,831 & 4 & 7 & 5,50 & 6,00 & 6,00 \\
\hline (Ass7) Educação, formação e informação ao cooperado & 160 & $91,43 \%$ & 6,40 & 6,00 & 6 &, 500 & 6 & 7 & 6,00 & 6,00 & 7,00 \\
\hline (Ass8) Realização pessoal dos cooperados & 150 & $85,71 \%$ & 6,00 & 6,00 & 6 & ,707 & 5 & 7 & 5,50 & 6,00 & 6,50 \\
\hline (Ass9) Associados em Assembleia Geral Ordinária & 153 & $87,43 \%$ & 6,12 & 6,00 & 6 & 971 & 4 & 7 & 6,00 & 6,00 & 7,00 \\
\hline (Ass10) Número associados ativos & 166 & $94,86 \%$ & 6,64 & 7,00 & 7 & ,490 & 6 & 7 & 6,00 & 7,00 & 7,00 \\
\hline (Ass11) Sobras ou faturamento por cooperado & 157 & $89,71 \%$ & 6,28 & 6,00 & 6 & 678 & 5 & 7 & 6,00 & 6,00 & 7,00 \\
\hline (Ass12) Relevância do associado na tomada de decisão & 153 & $87,43 \%$ & 6,12 & 6,00 & 7 & 1,054 & 4 & 7 & 5,50 & 6,00 & 7,00 \\
\hline
\end{tabular}

Fonte: autora. 


\subsection{MÓDULO "PROCESSOS INTERNOS"}

A pontuação atribuída pelos Conselheiros Fiscais em relação aos indicadores do módulo "Processos Internos", bem como suas estatísticas constam na tabela 11. Em suma, todos os constructos desse módulo foram muito bem avaliados por esse público. Os mais bem avaliados de acordo com o grau de importância percebida foram: Nível de transparência (172 pontos e 6,88 de média) e Desenvolvimento Sustentável (com 163 pontos e 6,52 de média). O fator que alcançou menor pontuação foi Percentual de trabalho extraordinário (com 129 pontos e 5,16 de média).

\subsection{MÓDULO "APRENDIZADO E CRESCIMENTO"}

A pontuação atribuída pelos Conselheiros Fiscais em relação aos indicadores do módulo "Aprendizado e Crescimento", bem como suas estatísticas constam na tabela 12.

Em suma, o constructo mais bem avaliado por esse público participante da amostra, de acordo com o grau de importância percebido por eles, é: Melhoria das capacidades dos funcionários, com 154 pontos e 6,16 de média.

Os fatores que alcançaram menor pontuação foram Motivação para agir no melhor interesse da cooperativa (com 150 pontos e 6 de média) e Nível de rotatividade (com 150 pontos e 6 de média). 
Tabela 11 - Pontuação atribuída pelos Conselheiros Fiscais em relação aos indicadores do módulo Processos Internos

\begin{tabular}{|c|c|c|c|c|c|c|c|c|c|c|c|}
\hline & \multirow[b]{2}{*}{ Soma } & \multicolumn{2}{|l|}{ Escore } & \multirow[b]{2}{*}{ Mediana } & \multirow[b]{2}{*}{ Moda } & \multirow{2}{*}{$\begin{array}{l}\text { Desvio } \\
\text { Padrão }\end{array}$} & \multirow[b]{2}{*}{ Mínimo } & \multirow[b]{2}{*}{ Máximo } & \multicolumn{2}{|c|}{ Percentis } & \multirow[b]{2}{*}{75} \\
\hline & & $(175=100 \%)$ & Média & & & & & & 25 & 50 & \\
\hline (Pro1) Lucratividade por segmento-alvo & 138 & $78,86 \%$ & 5,52 & 6,00 & 6 & ,714 & 4 & 6 & 5,00 & 6,00 & 6,00 \\
\hline $\begin{array}{l}\text { (Pro2) Percentual de transações realizadas } \\
\text { através dos diversos canais }\end{array}$ & 138 & $78,86 \%$ & 5,52 & 6,00 & 6 & ,714 & 4 & 6 & 5,00 & 6,00 & 6,00 \\
\hline (Pro3) Projetos sociais desenvolvidos & 154 & $88,00 \%$ & 6,16 & 6,00 & 7 & ,800 & 5 & 7 & 5,50 & 6,00 & 7,00 \\
\hline (Pro4) Percentual de trabalho extraordinário & 129 & $73,71 \%$ & 5,16 & 5,00 & 6 & ,800 & 4 & 6 & 4,50 & 5,00 & 6,00 \\
\hline (Pro5) Desenvolvimento sustentável & 163 & $93,14 \%$ & 6,52 & 7,00 & 7 & ,714 & 5 & 7 & 6,00 & 7,00 & 7,00 \\
\hline (Pro6) Nível de Transparência & 172 & $98,29 \%$ & 6,88 & 7,00 & 7 & ,332 & 6 & 7 & 7,00 & 7,00 & 7,00 \\
\hline (Pro7) Perpetuação da instituição & 159 & $90,86 \%$ & 6,36 & 6,00 & 7 & ,700 & 5 & 7 & 6,00 & 6,00 & 7,00 \\
\hline (Pro8) Preservação da identidade organizacional & 159 & $90,86 \%$ & 6,36 & 6,00 & 7 &, 700 & 5 & 7 & 6,00 & 6,00 & 7,00 \\
\hline
\end{tabular}

Fonte: autora.

Tabela 12 - Pontuação atribuída pelos Conselheiros Fiscais em relação aos indicadores do módulo Aprendizado e Crescimento

\begin{tabular}{|c|c|c|c|c|c|c|c|c|c|c|c|}
\hline & \multicolumn{3}{|c|}{ Escore } & \multirow[b]{2}{*}{ Mediana } & \multirow[b]{2}{*}{ Moda } & \multirow{2}{*}{$\begin{array}{l}\text { Desvio } \\
\text { Padrão }\end{array}$} & \multirow{2}{*}{ Mínimo } & \multirow[b]{2}{*}{ Máximo } & \multicolumn{3}{|c|}{ Percentis } \\
\hline & Soma & $(175=100 \%)$ & Média & & & & & & 25 & 50 & 75 \\
\hline (Apr1) Melhorias das capacidades dos funcionários & 154 & $88,00 \%$ & 6,16 & 6,00 & 7 & ,800 & 5 & 7 & 5,50 & 6,00 & 7,00 \\
\hline (Apr2) Nível de rotatividade & 150 & $85,71 \%$ & 6,00 & 6,00 & 6 & 1,000 & 4 & 7 & 5,50 & 6,00 & 7,00 \\
\hline (Apr3) Motivação para agir no melhor interesse da cooperativa & 150 & $85,71 \%$ & 6,00 & 6,00 & 6 & ,707 & 5 & 7 & 5,50 & 6,00 & 6,50 \\
\hline
\end{tabular}

Fonte: autora. 


\subsection{Módulo "PESSOAS E INOVAÇão"}

A pontuação atribuída pelos Conselheiros Fiscais em relação aos indicadores do módulo "Pessoas e Inovação", bem como suas estatísticas constam na tabela 13.

Em suma, o constructo mais bem avaliado por esse público participante da amostra, de acordo com o grau de importância percebido por eles, é: Profissionalização da administração (com 173 pontos e 6,92 de média), Condições de trabalho adequadas (com 159 pontos e 6,28 de média) e Ambiente de trabalho ético e que valoriza o capital humano (com 157 pontos e 6,28 de média).

Os fatores que alcançaram menor pontuação foram Melhoria constante da estrutura da cooperativa (com 141 pontos e 5,64 de média), Segurança no emprego para os trabalhadores da cooperativa e Benefícios extra para bons funcionários, igualmente com 144 pontos e 5,76 de média.

\subsection{MÓdULO "PRINCÍPIOS COOPERATIVISTAS"}

A pontuação atribuída pelos Conselheiros Fiscais em relação aos indicadores do módulo "Princípios Cooperativistas", bem como suas estatísticas constam na tabela 14.

Em suma, os constructos mais bem avaliados por esse público participante da amostra, de acordo com o grau de importância percebido por eles, são: Cumpre princípios cooperativistas (com 172 pontos e 6,88 de média), Democracia e igualdade (com 166 pontos e 6,64 de média), Adesão livre e voluntária (com 166 pontos e 6,64 de média). O fator que alcançou menor pontuação foi e Autonomia e independência (com 148 pontos e 5,92 de média). 
Tabela 13 - Pontuação atribuída pelos Conselheiros Fiscais em relação aos indicadores do módulo Pessoas e Inovação

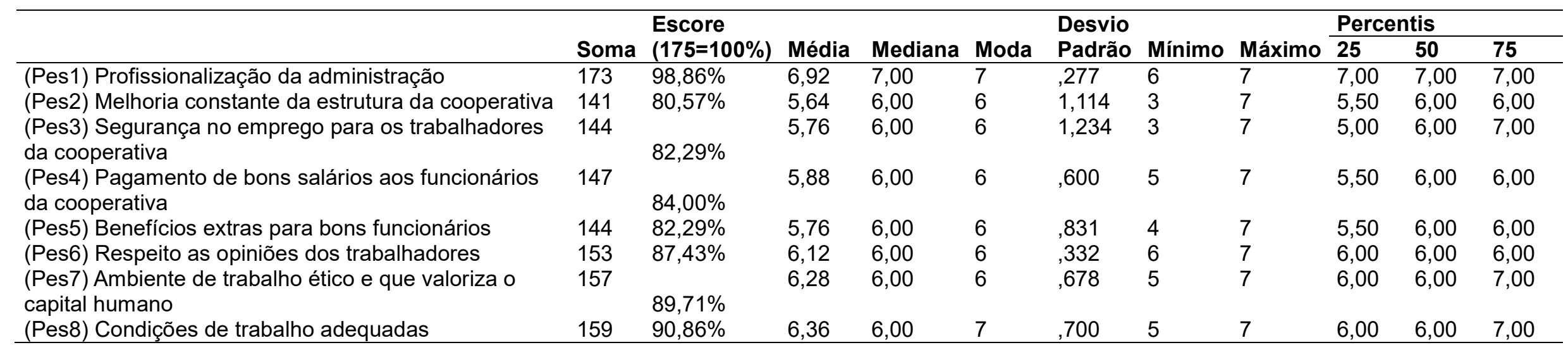

Fonte: autora.

Tabela 14 - Pontuação atribuída pelos Conselheiros Fiscais em relação aos indicadores do módulo Princípios Cooperativistas

\begin{tabular}{|c|c|c|c|c|c|c|c|c|c|c|c|}
\hline & \multicolumn{3}{|c|}{ Escore } & \multirow[b]{2}{*}{ Mediana } & \multirow[b]{2}{*}{ Moda } & \multirow{2}{*}{$\begin{array}{l}\text { Desvio } \\
\text { Padrão }\end{array}$} & \multirow[b]{2}{*}{ Mínimo } & \multirow[b]{2}{*}{ Máximo } & \multicolumn{2}{|c|}{ Percentis } & \multirow[b]{2}{*}{75} \\
\hline & Soma & $(175=100 \%)$ & Média & & & & & & 25 & 50 & \\
\hline (Pri1) Cumpre princípios cooperativistas & 172 & $98,29 \%$ & 6,88 & 7,00 & 7 & ,332 & 6 & 7 & 7,00 & 7,00 & 7,00 \\
\hline (Pri2) Democracia e igualdade & 166 & $94,86 \%$ & 6,64 & 7,00 & 7 &, 700 & 5 & 7 & 6,50 & 7,00 & 7,00 \\
\hline (Pri3) Solidariedade & 160 & $91,43 \%$ & 6,40 & 7,00 & 7 & ,866 & 5 & 7 & 5,50 & 7,00 & 7,00 \\
\hline $\begin{array}{l}\text { (Pri4) Valores de ajuda mútua (preocupação com o } \\
\text { semelhante) }\end{array}$ & 150 & $85,71 \%$ & 6,00 & 6,00 & 6 & ,707 & 5 & 7 & 5,50 & 6,00 & 6,50 \\
\hline (Pri5) Autonomia e a independência & 148 & $84,57 \%$ & 5,92 & 6,00 & 7 & 1,077 & 4 & 7 & 5,00 & 6,00 & 7,00 \\
\hline (Pri6) Adesão livre e voluntária & 166 & $94,86 \%$ & 6,64 & 7,00 & 7 &, 700 & 5 & 7 & 6,50 & 7,00 & 7,00 \\
\hline (Pri7) Preocupação com a comunidade & 158 & $90,29 \%$ & 6,32 & 6,00 & $6^{b}$ & 690 & 5 & 7 & 6,00 & 6,00 & 7,00 \\
\hline (Pri8) Geração de empregos & 150 & $85,71 \%$ & 6,00 & 6,00 & 6 & ,707 & 5 & 7 & 5,50 & 6,00 & 6,50 \\
\hline (Pri9) Combate a exclusão social & 150 & $85,71 \%$ & 6,00 & 6,00 & 6 & 1,000 & 4 & 7 & 5,50 & 6,00 & 7,00 \\
\hline
\end{tabular}

b. Ha várias modas. O menor valor é mostrado

Fonte: autora. 


\subsection{MÓDULO "FINANCEIRO"}

A pontuação atribuída pelos Conselheiros Administrativos em relação aos indicadores do módulo Financeiro, bem como suas estatísticas constam na tabela 15.

Em suma, os constructos mais bem avaliados por esse público participante da amostra, de acordo com o grau de importância percebido por eles, são: Nível de inadimplemento (190 pontos e 6,79 de média), Resultado econômico (187 pontos e 6,68 de média).

Os fatores que alcançaram menor pontuação foram Crescimento das captações totais (com 167 pontos e 5,94 de média) e Margem Bruta (com 170 pontos e 6,07 de média).

\subsection{MÓDULO "AsSOCIADOS"}

A pontuação atribuída pelos Conselheiros Administrativos em relação aos indicadores do módulo "Associados", bem como suas estatísticas constam na tabela 16.

Em suma, os constructos mais bem avaliados por esse público participante da amostra, de acordo com o grau de importância percebido por eles, são: Número de associados ativos (com 185 pontos e 6,61 de média), e Satisfação de cooperantes (com 183 pontos e 6,54 de média). O fator que alcançou menor pontuação foi Realização pessoal dos cooperados com 158 pontos e 5,64 de média. 
Tabela 15 - Pontuação atribuída pelos Conselheiros Administrativos em relação aos indicadores do módulo Financeiro

\begin{tabular}{|c|c|c|c|c|c|c|c|c|c|c|c|}
\hline & \multicolumn{3}{|c|}{ Escores } & \multicolumn{5}{|c|}{ Desvio } & \multicolumn{3}{|c|}{ Percentis } \\
\hline & Soma & $(196=100 \%)$ & Média & Mediana & Moda & Padrão & Mínimo & Máximo & 25 & 50 & 75 \\
\hline (Fin1) Crescimento das vendas & 182 & $92,86 \%$ & 6,50 & 7,00 & 7 &, 577 & 5 & 7 & 6,00 & 7,00 & 7,00 \\
\hline (Fin2) Retorno sobre o investimento & 185 & $94,39 \%$ & 6,61 & 7,00 & 7 &, 567 & 5 & 7 & 6,00 & 7,00 & 7,00 \\
\hline (Fin3) Rentabilidade do patrimônio líquido & 181 & $92,35 \%$ & 6,46 & 7,00 & 7 & 1,036 & 2 & 7 & 6,00 & 7,00 & 7,00 \\
\hline (Fin4) Capital em giro & 177 & $90,31 \%$ & 6,32 & 7,00 & 7 & ,863 & 4 & 7 & 6,00 & 7,00 & 7,00 \\
\hline (Fin5) Grau do endividamento financeiro & 175 & $89,29 \%$ & 6,25 & 6,00 & 6 & 645 & 5 & 7 & 6,00 & 6,00 & 7,00 \\
\hline (Fin6) Margem bruta & 170 & $86,73 \%$ & 6,07 & 6,00 & 6 & ,716 & 5 & 7 & 6,00 & 6,00 & 7,00 \\
\hline (Fin7) Resultado econômico & 187 & $95,41 \%$ & 6,68 & 7,00 & 7 & ,476 & 6 & 7 & 6,00 & 7,00 & 7,00 \\
\hline (Fin8) Capitalização & 176 & $89,80 \%$ & 6,29 & 6,00 & 6 & 659 & 5 & 7 & 6,00 & 6,00 & 7,00 \\
\hline (Fin9) Geração de rendas & 175 & $89,29 \%$ & 6,25 & 6,00 & 6 & ,701 & 5 & 7 & 6,00 & 6,00 & 7,00 \\
\hline (Fin10) Crescimento aplicações totais & 167 & $85,20 \%$ & 5,96 & 6,00 & 6 & ,744 & 5 & 7 & 5,00 & 6,00 & 6,75 \\
\hline (Fin11) Crescimento captações totais & 174 & $88,78 \%$ & 6,21 & 6,00 & 7 & ,787 & 5 & 7 & 6,00 & 6,00 & 7,00 \\
\hline (Fin12) Equilíbrio do orçamento & 182 & $92,86 \%$ & 6,50 & 7,00 & 7 & ,694 & 5 & 7 & 6,00 & 7,00 & 7,00 \\
\hline (Fin13) Nível de inadimplemento (NID) & 190 & $96,94 \%$ & 6,79 & 7,00 & 7 &, 418 & 6 & 7 & 7,00 & 7,00 & 7,00 \\
\hline
\end{tabular}

Fonte: autora. 
Tabela 16 - Pontuação atribuída pelos Conselheiros Administrativos em relação aos indicadores do módulo Associados

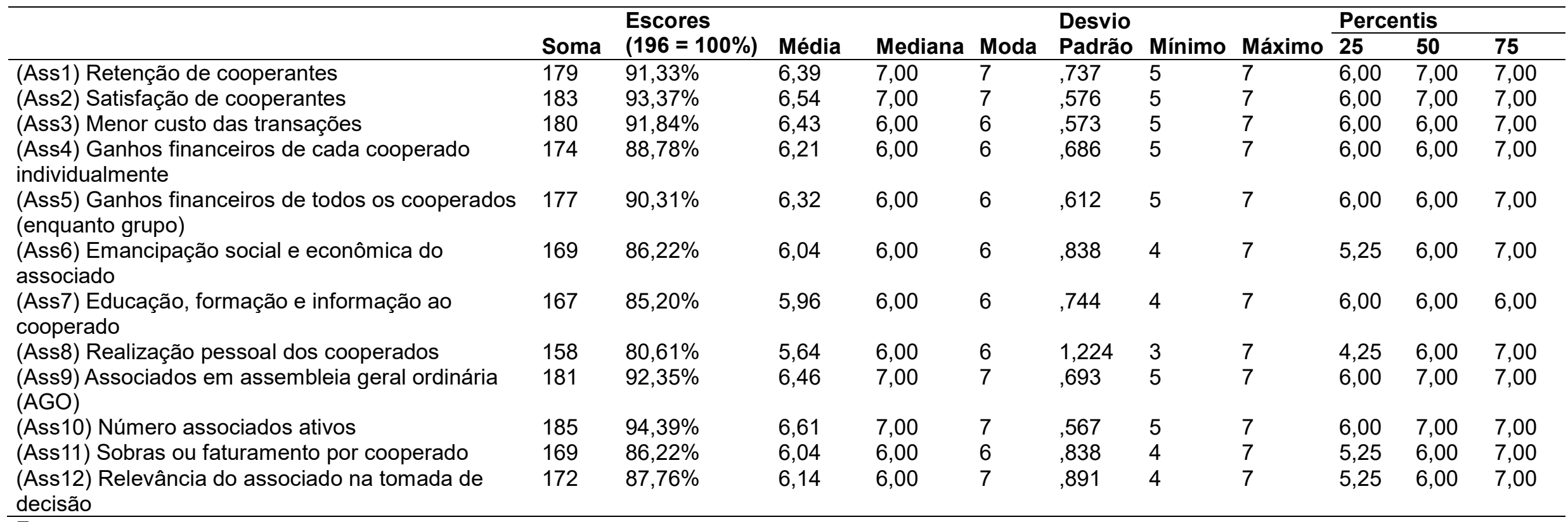

Fonte: autora. 


\subsection{MÓDULO “PROCESSOS INTERNOS"}

A pontuação atribuída pelos Conselheiros administrativos em relação aos indicadores do módulo "Processos Internos", bem como suas estatísticas constam na tabela 17.

Em suma, os constructos mais bem avaliados por esse público participante da amostra, de acordo com o grau de importância percebido por eles, são: Nível de transparência (192 pontos e 6,86 de média), e Perpetuação da instituição (189 pontos e 6,75 de média). $O$ fator que alcançou menor pontuação foi Percentual de trabalho extraordinário (com 133 pontos e 4,75 de média).

\subsection{MÓDULO "APRENDIZADO E CRESCIMENTO"}

A pontuação atribuída pelos Conselheiros Administrativos em relação aos indicadores do módulo "Aprendizado e Crescimento", bem como suas estatísticas constam na tabela 18.

Em suma, os constructos mais bem avaliados por esse público participante da amostra, de acordo com o grau de importância percebido por eles, são: Melhoria nas capacidades dos funcionários (com 187 pontos e 6,68 de média). O fator que alcançou menor pontuação foi Nível de rotatividade (com 161 pontos e 5,75 de média). 
Tabela 17 - Pontuação atribuída pelos Conselheiros Administrativos em relação aos indicadores do módulo Processos Internos

\begin{tabular}{|c|c|c|c|c|c|c|c|c|c|c|c|}
\hline & \multirow[b]{2}{*}{ Soma } & \multirow{2}{*}{$\begin{array}{l}\text { Escores } \\
(196=100 \%)\end{array}$} & \multirow[b]{2}{*}{ Média } & \multirow[b]{2}{*}{ Mediana } & \multirow[b]{2}{*}{ Moda } & \multirow{2}{*}{$\begin{array}{l}\text { Desvio } \\
\text { Padrão }\end{array}$} & \multirow[b]{2}{*}{ Mínimo } & \multirow[b]{2}{*}{ Máximo } & \multicolumn{3}{|c|}{ Percentis } \\
\hline & & & & & & & & & 25 & 50 & 75 \\
\hline (Pro1) Lucratividade por segmento-alvo & 160 & $81,63 \%$ & 5,71 & 6,00 & 6 &, 810 & 4 & 7 & 5,00 & 6,00 & 6,00 \\
\hline $\begin{array}{l}\text { (Pro2) Percentual de transações realizadas } \\
\text { através dos diversos canais }\end{array}$ & 158 & $80,61 \%$ & 5,64 & 6,00 & 6 & 1,224 & 1 & 7 & 5,00 & 6,00 & 6,00 \\
\hline (Pro3) Projetos sociais desenvolvidos & 168 & $85,71 \%$ & 6,00 & 6,00 & 6 & ,861 & 4 & 7 & 6,00 & 6,00 & 6,75 \\
\hline (Pro4) Percentual de trabalho extraordinário & 133 & $67,86 \%$ & 4,75 & 5,00 & 5 & 1,404 & 1 & 7 & 4,00 & 5,00 & 6,00 \\
\hline (Pro5) Desenvolvimento sustentável & 170 & $86,73 \%$ & 6,07 & 6,00 & 6 & 858 & 4 & 7 & 6,00 & 6,00 & 7,00 \\
\hline (Pro6) Nível de Transparência & 192 & $97,96 \%$ & 6,86 & 7,00 & 7 & ,356 & 6 & 7 & 7,00 & 7,00 & 7,00 \\
\hline (Pro7) Perpetuação da instituição & 189 & $96,43 \%$ & 6,75 & 7,00 & 7 & ,441 & 6 & 7 & 6,25 & 7,00 & 7,00 \\
\hline (Pro8) Preservação da identidade organizacional & 178 & $90,82 \%$ & 6,36 & 6,00 & 6 & 678 & 4 & 7 & 6,00 & 6,00 & 7,00 \\
\hline
\end{tabular}

Fonte: autora.

Tabela 18 - Pontuação atribuída pelos Conselheiros Administrativos em relação aos indicadores do módulo Aprendizado e Crescimento

\begin{tabular}{|c|c|c|c|c|c|c|c|c|c|c|c|}
\hline & \multirow[t]{2}{*}{ Soma } & \multirow{2}{*}{$\begin{array}{l}\text { Escores } \\
(196=100 \%)\end{array}$} & \multirow[t]{2}{*}{ Média } & \multirow[t]{2}{*}{ Mediana } & \multirow[t]{2}{*}{ Moda } & \multirow{2}{*}{$\begin{array}{l}\text { Desvio } \\
\text { Padrão }\end{array}$} & \multirow[t]{2}{*}{ Mínimo } & \multirow[t]{2}{*}{ Máximo } & \multicolumn{3}{|c|}{ Percentis } \\
\hline & & & & & & & & & 25 & 50 & 75 \\
\hline (Apr1) Melhorias das capacidades dos funcionários & 187 & $95,41 \%$ & 6,68 & 7,00 & 7 &, 548 & 5 & 7 & 6,00 & 7,00 & 7,00 \\
\hline (Apr2) Nível de rotatividade & 161 & $82,14 \%$ & 5,75 & 6,00 & 6 & ,585 & 4 & 7 & 5,25 & 6,00 & 6,00 \\
\hline $\begin{array}{l}\text { (Apr3) Motivação para agir no melhor interesse da } \\
\text { cooperativa }\end{array}$ & 174 & $88,78 \%$ & 6,21 & 6,00 & 6 & 630, & 5 & 7 & 6,00 & 6,00 & 7,00 \\
\hline
\end{tabular}

cooperativa 


\subsection{MódULO "PESSOAS E INOVAÇÃO"}

A pontuação atribuída pelos Conselheiros Administrativos em relação aos indicadores do módulo "Pessoas e Inovação", bem como suas estatísticas constam na tabela 19.

Em suma, os constructos mais bem avaliados por esse público participante da amostra, de acordo com o grau de importância percebido por eles, são: Profissionalização da administração (com 190 pontos e 6,79 de média) e Ambiente de trabalho ético e que valoriza o capital humano (com 179 pontos e 6,39 de média).

Os fatores que alcançaram menor pontuação foram Benefícios extra para bons funcionários, com 153 pontos e 5,46 de média e Segurança no emprego para os trabalhadores da cooperativa, com 160 pontos e 5,71 de média.

\subsection{MÓDULO "PRINCIPIOS COOPERATIVISTAS"}

A pontuação atribuída pelos Conselheiros Administrativos em relação aos indicadores do módulo "Princípios Cooperativistas", bem como suas estatísticas constam na tabela 20.

Em suma, os constructos mais bem avaliados por esse público participante da amostra, de acordo com o grau de importância percebido por eles, são: Cumpre princípios cooperativistas (com 184 pontos e 6,57 de média), e Democracia e igualdade (com 176 pontos e 6,29 de média). Os fatores que alcançaram menor pontuação foram Valores de ajuda mútua (preocupação com o semelhante) e Geração de empregos, ambos com 163 pontos e 5,82 de média. 
Tabela 19 - Pontuação atribuída pelos Conselheiros Administrativos em relação aos indicadores do módulo Pessoas e Inovação

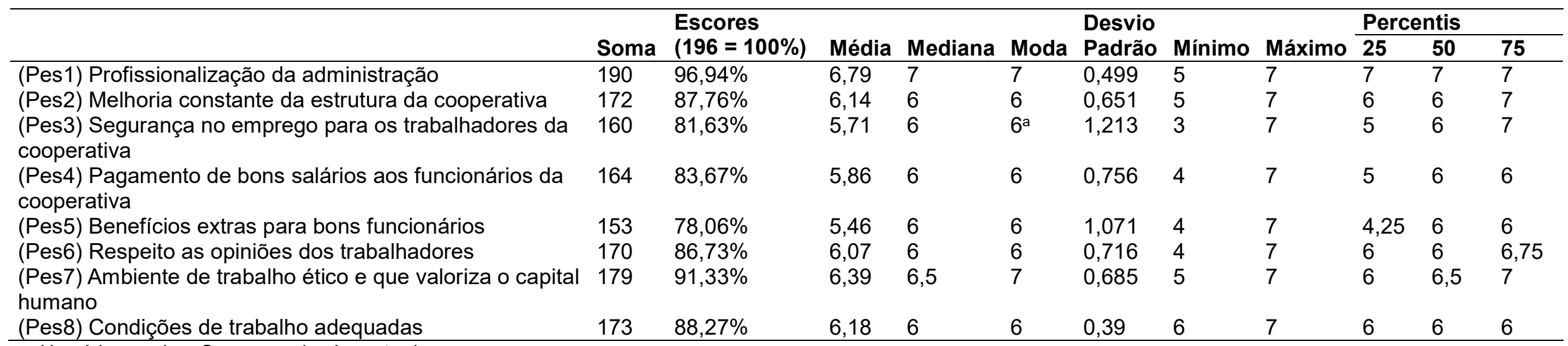

(Pes8) Condições de trabalho adequadas

$17388,27 \%$

6,186

Fonte: autora.

Tabela 20 - Pontuação atribuída pelos Conselheiros Administrativos em relação aos indicadores do módulo Princípios Cooperativistas

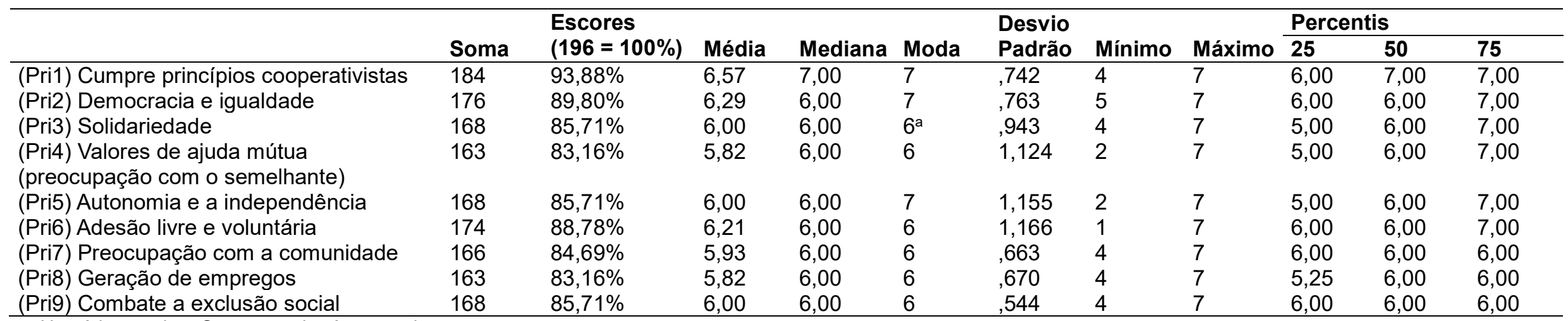

a. Ha várias modas. O menor valor é mostrado

Fonte: autora. 


\subsubsection{CATEGORIA DAS OBSERVAÇÕES DA AMOSTRA: COOPERADOS}

\subsection{INDICADOR "FINANCEIRO"}

A pontuação atribuída pelos Cooperados em relação aos indicadores do módulo "Financeiro", bem como suas estatísticas constam na tabela 21. Em suma, os constructos mais bem avaliados pelos Cooperados participantes da amostra, de acordo com o grau de importância percebido por eles, são: "Equilíbrio do orçamento" com 919 pontos e 6,05 de média; "Nível de inadimplemento", com 909 pontos e média 5,98; e "Retorno sobre o investimento" com 908 pontos e 5,97 de média.

Os fatores que alcançaram menor pontuação foram "Crescimento das aplicações totais" com 796 pontos e 5,24 de média; "Capitalização" com 809 pontos e 5,32 de média; e "Crescimento das vendas" com 817 pontos e 5,38 de média.

\subsection{INDICADOR "ASSOCIADO"}

A pontuação atribuída pelos Cooperados em relação aos indicadores do módulo "Associados", bem como suas estatísticas constam na tabela 22. Em suma, os constructos mais bem avaliados pelos Cooperados participantes da amostra, de acordo com o grau de importância percebido por eles, são: "Educação, formação e informação do associado" com 934 pontos e 6,14 de média; e "Menor custo das transações", com 928 pontos e média 6,11.

Os fatores que alcançaram menor pontuação foram "Associados em Assembleia Geral Ordinária" com 701 pontos e 4,61 de média; "Retenção de cooperados" com 787 pontos e 5,18 de média; e "Número de associados ativos" com 798 pontos e 5,25 de média. 
Tabela 21 - Pontuação atribuída pelos Cooperados em relação aos indicadores do módulo Financeiro

\begin{tabular}{|c|c|c|c|c|c|c|c|c|c|c|c|}
\hline \multicolumn{9}{|c|}{ Escore (\%) } & \multicolumn{3}{|c|}{ Percentis } \\
\hline & & $(1064=$ & & & & Desvio & & & & & \\
\hline & Soma & 100) & Média & Mediana & Moda & Padrão & Mín & Máx & 25 & 50 & 75 \\
\hline (Fin1) Crescimento das Vendas & 817 & $76,79 \%$ & 5,38 & 6,00 & 6 & 1,336 & 1 & 7 & 4,00 & 6,00 & 6,00 \\
\hline (Fin2) Retorno Sobre o Investimento & 908 & $85,34 \%$ & 5,97 & 6,00 & 6 & 1,098 & 1 & 7 & 6,00 & 6,00 & 7,00 \\
\hline (Fin3) Rentabilidade do Patrimônio Líquido & 888 & $83,46 \%$ & 5,84 & 6,00 & 7 & 1,267 & 1 & 7 & 5,00 & 6,00 & 7,00 \\
\hline (Fin4) Capital em Giro & 859 & $80,73 \%$ & 5,65 & 6,00 & 6 & 1,241 & 1 & 7 & 5,00 & 6,00 & 7,00 \\
\hline (Fin5) Grau do Endividamento Financeiro & 847 & $79,61 \%$ & 5,57 & 6,00 & 6 & 1,310 & 1 & 7 & 5,00 & 6,00 & 6,00 \\
\hline (Fin6) Margem Bruta & 837 & $78,67 \%$ & 5,51 & 6,00 & 6 & 1,424 & 1 & 7 & 5,00 & 6,00 & 7,00 \\
\hline (Fin7) Resultado Econômico & 891 & $83,74 \%$ & 5,86 & 6,00 & 7 & 1,256 & 1 & 7 & 5,00 & 6,00 & 7,00 \\
\hline (Fin8) Capitalização & 809 & $76,03 \%$ & 5,32 & 6,00 & 6 & 1,350 & 1 & 7 & 4,00 & 6,00 & 6,00 \\
\hline (Fin9) Geração de Rendas & 853 & $80,17 \%$ & 5,61 & 6,00 & 6 & 1,271 & 1 & 7 & 5,00 & 6,00 & 6,75 \\
\hline (Fin10) Crescimento Aplicações Totais & 821 & $77,16 \%$ & 5,40 & 6,00 & 6 & 1,324 & 1 & 7 & 5,00 & 6,00 & 6,00 \\
\hline (Fin11) Crescimento Captações Totais & 796 & $74,81 \%$ & 5,24 & 6,00 & 6 & 1,316 & 1 & 7 & 4,00 & 6,00 & 6,00 \\
\hline (Fin12) Equilíbrio do Orçamento & 919 & $86,37 \%$ & 6,05 & 6,00 & 7 & 1,231 & 1 & 7 & 6,00 & 6,00 & 7,00 \\
\hline (Fin13) Nível de Inadimplemento (NID) & 909 & $85,43 \%$ & 5,98 & 6,00 & 7 & 1,242 & 1 & 7 & 5,00 & 6,00 & 7,00 \\
\hline
\end{tabular}

Fonte: autora. 
Tabela 22 - Pontuação atribuída pelos Cooperados em relação aos indicadores do módulo Associados

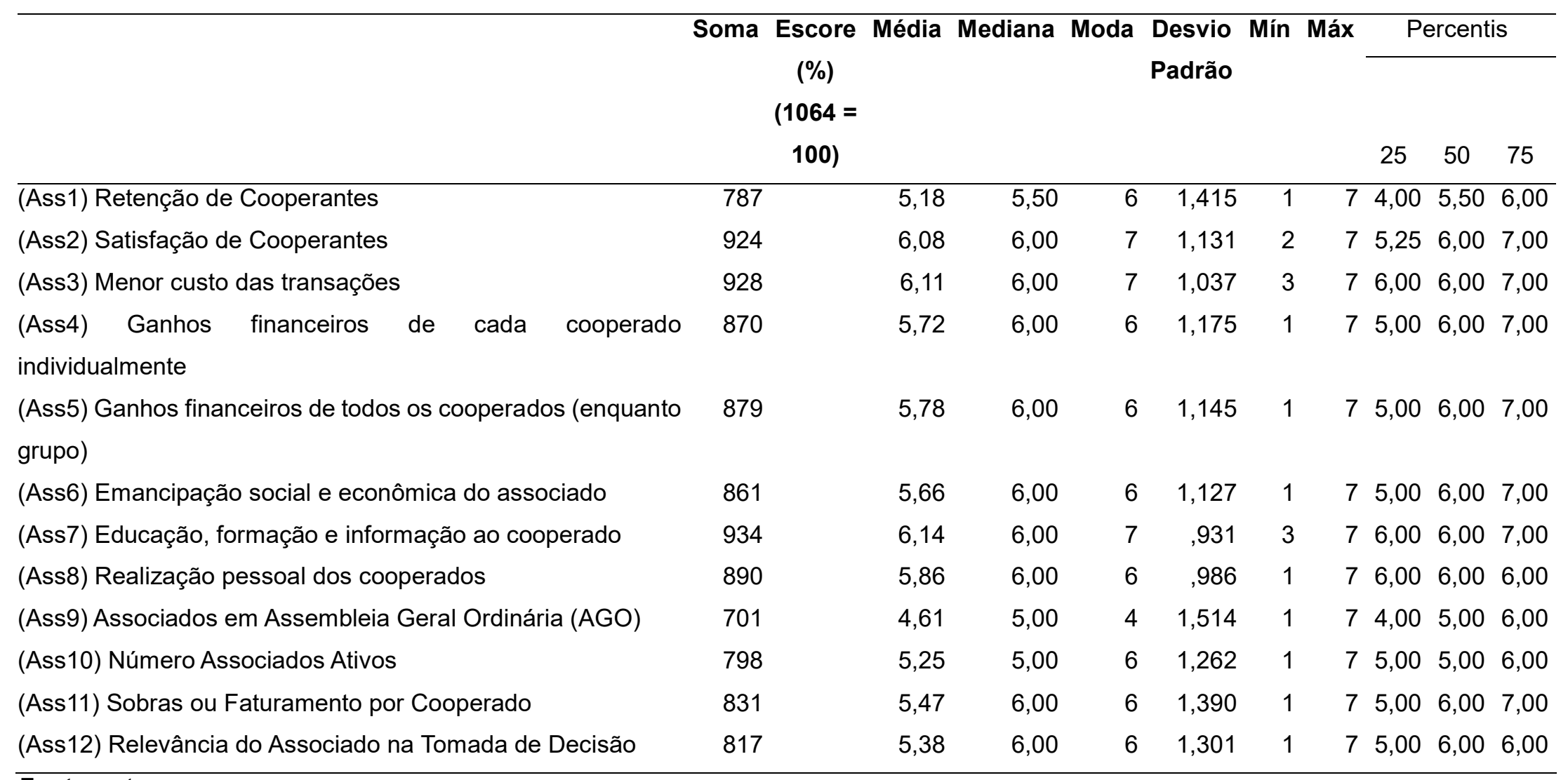

Fonte: autora. 


\subsection{INDICADORES "PROCESSOS INTERNOS"}

A pontuação atribuída pelos Cooperados em relação aos indicadores do módulo "Processos Internos", bem como suas estatísticas constam na tabela 23. Em suma, os constructos mais bem avaliados pelos Cooperados participantes da amostra, de acordo com o grau de importância percebido por eles, são: "Nível de transparência" com 999 pontos e 6,67 de média; "Preservação da identidade organizacional", com 862 pontos e média 5,67; e "Perpetuação da instituição" com 854 pontos e 5,62 de média.

Os fatores que alcançaram menor pontuação foram "Percentual de trabalho extraordinário" com 685 pontos e 4,51 de média; "Percentual de transações realizados nos diversos canais" com 761 pontos e 5,01 de média; e "Projetos sociais desenvolvidos" com 777 pontos e 5,11 de média.

\subsection{INDICADORES "APRENDIZADO E CRESCIMENTO"}

A pontuação atribuída pelos Cooperados em relação aos indicadores do módulo "Aprendizado e Crescimento", bem como suas estatísticas constam na tabela 24. Em suma, o constructo mais bem avaliado pelos Cooperados participantes da amostra, de acordo com o grau de importância percebido por eles, é: "Melhoria nas capacidades dos funcionários" com 863 pontos e 5,68 de média.

O fator que alcançou menor pontuação foi "Nível de rotatividade" com 773 pontos e 5,09 de média. 
Tabela 23 - Pontuação atribuída pelos Cooperados em relação aos indicadores do módulo Processos Internos

\begin{tabular}{|c|c|c|c|c|c|c|c|c|c|c|c|}
\hline & \multirow{2}{*}{\multicolumn{3}{|c|}{$\begin{array}{c}\text { Escore } \\
(\%) \\
(1064=\end{array}$}} & \multirow[b]{3}{*}{ Mediana } & \multirow[b]{3}{*}{ Moda } & \multirow[b]{2}{*}{ Desvio } & \multirow[b]{3}{*}{ Mín } & \multirow[b]{3}{*}{ Máx } & \multicolumn{3}{|c|}{ Percentis } \\
\hline & & & & & & & & & & & \\
\hline & Soma & 100) & Média & & & Padrão & & & 25 & 50 & 75 \\
\hline (Pro1) Lucratividade por Segmento-Alvo & 797 & & 5,24 & 5,00 & 6 & 1,367 & 1 & 7 & 4,25 & 5,00 & 6,00 \\
\hline $\begin{array}{l}\text { (Pro2) Percentual de Transações Realizadas Através dos } \\
\text { Diversos Canais }\end{array}$ & 761 & & 5,01 & 5,00 & 5 & 1,476 & 1 & 7 & 4,00 & 5,00 & 6,00 \\
\hline (Pro3) Projetos Sociais Desenvolvidos & 777 & & 5,11 & 5,00 & 6 & 1,568 & 1 & 7 & 4,00 & 5,00 & 6,00 \\
\hline (Pro4) Percentual de Trabalho Extraordinário & 685 & & 4,51 & 5,00 & 4 & 1,644 & 1 & 7 & 4,00 & 5,00 & 6,00 \\
\hline (Pro5) Desenvolvimento Sustentável & 829 & & 5,45 & 6,00 & 7 & 1,491 & 1 & 7 & 5,00 & 6,00 & 7,00 \\
\hline (Pro6) Nível de Transparência & 999 & & 6,57 & 7,00 & 7 & ,706 & 4 & 7 & 6,00 & 7,00 & 7,00 \\
\hline (Pro7) Perpetuação da instituição & 854 & & 5,62 & 6,00 & 6 & 1,207 & 1 & 7 & 5,00 & 6,00 & 7,00 \\
\hline (Pro8) Preservação da identidade organizacional & 862 & & 5,67 & 6,00 & 6 & 1,195 & 1 & 7 & 5,00 & 6,00 & 6,00 \\
\hline
\end{tabular}

Fonte: autora.

Tabela 24 - Pontuação atribuída pelos Cooperados em relação aos indicadores do módulo Aprendizado e Crescimento

\begin{tabular}{|c|c|c|c|c|c|c|c|c|c|c|c|}
\hline & \multirow{2}{*}{\multicolumn{3}{|c|}{$\begin{array}{c}\text { Escore } \\
(\%) \\
(1064=\end{array}$}} & \multirow[b]{3}{*}{ Mediana } & \multirow[b]{3}{*}{ Moda } & \multirow[b]{2}{*}{ Desvio } & \multirow[b]{3}{*}{ Mín } & \multirow[b]{3}{*}{ Máx } & \multicolumn{3}{|c|}{ Percentis } \\
\hline & & & & & & & & & & & \\
\hline & Soma & 100) & Média & & & Padrão & & & 25 & 50 & 75 \\
\hline (Apr1) Melhorias das Capacidades dos Funcionários & 863 & & 5,68 & 6,00 & 7 & 1,259 & 1 & 7 & 5,00 & 6,00 & 7,00 \\
\hline (Apr2) Nível de Rotatividade & 773 & & 5,09 & 5,00 & 6 & 1,409 & 1 & 7 & 4,00 & 5,00 & 6,00 \\
\hline $\begin{array}{l}\text { (Apr3) Motivação para agir no melhor interesse da } \\
\text { cooperativa }\end{array}$ & 874 & & 5,75 & 6,00 & 6 & 1,031 & 1 & 7 & 5,00 & 6,00 & 6,00 \\
\hline
\end{tabular}

Fonte: autora. 


\subsection{INDICADORES "PESSOAS E INOVAÇÃO"}

A pontuação atribuída pelos Cooperados em relação aos indicadores do módulo "Pessoas e Inovação", bem como suas estatísticas constam na tabela 25. Em suma, os constructos mais bem avaliados pelos Cooperados participantes da amostra, de acordo com o grau de importância percebido por eles, são: "Condições de trabalho adequadas" com 964 pontos e 6,34 de média; "Profissionalização da administração", com 956 pontos e 6,29 de média; e "Ambiente ético e que valoriza o capital humano", com 930 pontos e 6,12 de média.

Os fatores que alcançaram menor pontuação foram "Benefícios extra para os bons funcionários" com 868 pontos e 5,71 de média; "Segurança no emprego", com 896 pontos e 5,89 de média; e "Pagamentos de bons salários aos funcionários" com 897 pontos e 5,9 de média.

\subsection{INDICADORES "PRINCÍPIOS COOPERATIVISTAS"}

A pontuação atribuída pelos Cooperados em relação aos indicadores do módulo "Princípios Cooperativistas", bem como suas estatísticas constam na tabela 26. Em suma, os constructos mais bem avaliados pelos Cooperados participantes da amostra, de acordo com o grau de importância percebido por eles, são: "Geração de empregos" com 915 pontos e 6,02 de média; "Democracia e igualdade", com 891 pontos e 5,86 de média; e "Combate a exclusão social", com 876 pontos e 5,76 de média.

Os fatores que alcançaram menor pontuação foram "Cumpre os princípios cooperativistas" com 834 pontos e 5,49 de média; "Preocupação com a comunidade", com 847 pontos e 5,57 de média; e "Solidariedade" com 848 pontos e 5,58 de média. 
Tabela 25 - Pontuação atribuída pelos Cooperados em relação aos indicadores do módulo Pessoas e Inovação

\begin{tabular}{|c|c|c|c|c|c|c|c|c|c|c|c|}
\hline & \multirow{2}{*}{\multicolumn{3}{|c|}{$\begin{array}{c}\text { Escore } \\
(\%) \\
(1064=\end{array}$}} & \multirow[b]{3}{*}{ Mediana } & \multirow[b]{3}{*}{ Moda } & \multirow[b]{2}{*}{ Desvio } & \multirow[b]{3}{*}{ Mín } & \multirow[b]{3}{*}{ Máx } & \multicolumn{3}{|c|}{ Percentis } \\
\hline & & & & & & & & & & & \\
\hline & Soma & 100) & Média & & & Padrão & & & 25 & 50 & 75 \\
\hline (Pes1) Profissionalização da administração & 956 & & 6,29 & 7,00 & 7 & ,925 & 2 & 7 & 6,00 & 7,00 & 7,00 \\
\hline (Pes2) Melhoria constante da estrutura da cooperativa & 897 & & 5,90 & 6,00 & 7 & 1,060 & 3 & 7 & 5,00 & 6,00 & 7,00 \\
\hline $\begin{array}{l}\text { (Pes3) Segurança no emprego para os trabalhadores da } \\
\text { cooperativa }\end{array}$ & 896 & & 5,89 & 6,00 & 6 & 1,158 & 2 & 7 & 5,00 & 6,00 & 7,00 \\
\hline $\begin{array}{l}\text { (Pes4) Pagamento de bons salários aos funcionários da } \\
\text { cooperativa }\end{array}$ & 897 & & 5,90 & 6,00 & 6 & 1,047 & 2 & 7 & 5,00 & 6,00 & 7,00 \\
\hline (Pes5) Benefícios extras para bons funcionários & 868 & & 5,71 & 6,00 & 6 & 1,007 & 3 & 7 & 5,00 & 6,00 & 6,00 \\
\hline (Pes6) Respeito as opiniões dos trabalhadores & 902 & & 5,93 & 6,00 & 6 & ,954 & 3 & 7 & 5,25 & 6,00 & 7,00 \\
\hline $\begin{array}{l}\text { (Pes7) Ambiente de trabalho ético e que valoriza o capital } \\
\text { humano }\end{array}$ & 930 & & 6,12 & 6,00 & 7 & 1,067 & 2 & 7 & 6,00 & 6,00 & 7,00 \\
\hline (Pes8) Condições de trabalho adequadas & 964 & & 6,34 & 7,00 & 7 & ,862 & 3 & 7 & 6,00 & 7,00 & 7,00 \\
\hline
\end{tabular}

Fonte: autora. 
Tabela 26 - Pontuação atribuída pelos Cooperados em relação aos indicadores do módulo Princípios Cooperativistas

Escore (\%) Desvio Percentis

Soma $(1064=100)$ Média Mediana Moda Padrão Mín Máx $25 \quad 50 \quad 75$

\begin{tabular}{|c|c|c|c|c|c|c|c|c|c|c|}
\hline Princípios & 834 & 5,49 & 6,00 & 6 & 1,496 & 1 & 7 & 5,00 & 6,00 & 7,00 \\
\hline (Pri2) Democracia e igualdade & 891 & 5,86 & 6,00 & 7 & 1,207 & 1 & 7 & 5,00 & 6,00 & 7,00 \\
\hline (Pri3) Solidariedade & 848 & 5,58 & 6,00 & 6 & 1,315 & 1 & 7 & 5,00 & 6,00 & 7,00 \\
\hline (Pri4) Valores de ajuda mútua & 858 & 5,64 & 6,00 & 6 & 1,159 & 1 & 7 & 5,00 & 6,00 & 6,00 \\
\hline (Pri7) Preocupação com a comunidade & 847 & 5,57 & 6,00 & 6 & 1,274 & 1 & 7 & 5,00 & 6,00 & 6,75 \\
\hline (Pri8) Geração de empregos & 915 & 6,02 & 6,00 & 7 & 1,058 & 2 & 7 & 5,00 & 6,00 & 7,00 \\
\hline (Pri9) Combate a exclusão social & 876 & 5,76 & 6,00 & 6 & 1,172 & 1 & 7 & 5,00 & 6,00 & 7,00 \\
\hline
\end{tabular}

Fonte: autora. 


\subsubsection{CATEGORIA DAS OBSERVAÇÕES DA AMOSTRA: GERENTES}

\subsection{INDICADOR "FINANCEIRO"}

A pontuação atribuída pelos Gerentes em relação aos indicadores do módulo "Financeiro", bem como suas estatísticas constam na tabela 27. Em suma, os constructos mais bem avaliados pelos Gerentes participantes da amostra, de acordo com o grau de importância percebido por eles, são: "Rentabilidade do Patrimônio Líquido" com 598 pontos e 6,43 de média; "Resultado Econômico", com 618 pontos e 6,65 de média; "Equilíbrio do Orçamento", com 613 pontos e 6,59 de média; e "Nível de Inadimplemento (NID)", com 635 pontos e 6,83 de média.

Os fatores que alcançaram menor pontuação foram "Margem bruta" com 550 pontos e 5,91 de média; "Geração de rendas", com 567 pontos e 6,1 de média.

\subsection{INDICADOR "ASSOCIADO"}

A pontuação atribuída pelos Gerentes em relação aos indicadores do módulo "Associado", bem como suas estatísticas constam na tabela 28. Em suma, os constructos mais bem avaliados pelos Gerentes participantes da amostra, de acordo com o grau de importância percebido por eles, são: "Satisfação de cooperantes", com 632 pontos e 6,8 de média; "Educação, formação e informação ao cooperado" com 619 pontos e 6,66 de média; "Retenção de cooperantes" com 616 pontos e 6,62 de média; e "Número de associados ativos" com 608 pontos e 6,54 de média.

O fator que alcançou menor pontuação foi "Ganhos financeiros de cada cooperado individualmente" com 524 pontos e 5,63 de média. 
Tabela 27 - Pontuação atribuída pelos Gerentes em relação aos indicadores do módulo Financeiro

\begin{tabular}{|c|c|c|c|c|c|c|c|c|c|c|c|}
\hline & \multicolumn{3}{|c|}{ Escore (\%) } & \multicolumn{5}{|c|}{ Desvio } & \multicolumn{3}{|c|}{ Percentis } \\
\hline & Soma & $(651=100)$ & Média & Mediana & Moda & Padrão & Mín & Máx & 25 & 50 & 75 \\
\hline (Fin1) Crescimento das Vendas & 573 & $88,02 \%$ & 6,16 & 6,00 & 6 & ,696 & 3 & 7 & 6,00 & 6,00 & 7,00 \\
\hline (Fin2) Retorno Sobre o Investimento & 568 & $87,25 \%$ & 6,11 & 6,00 & 6 & 650 & 5 & 7 & 6,00 & 6,00 & 7,00 \\
\hline (Fin3) Rentabilidade do Patrimônio Líquido & 598 & $91,86 \%$ & 6,43 & 7,00 & 7 & ,826 & 3 & 7 & 6,00 & 7,00 & 7,00 \\
\hline (Fin4) Capital em Giro & 583 & $89,55 \%$ & 6,27 & 6,00 & 6 & ,768 & 3 & 7 & 6,00 & 6,00 & 7,00 \\
\hline (Fin5) Grau do Endividamento Financeiro & 572 & $87,86 \%$ & 6,15 & 6,00 & 6 &, 884 & 2 & 7 & 6,00 & 6,00 & 7,00 \\
\hline (Fin6) Margem Bruta & 550 & $84,49 \%$ & 5,91 & 6,00 & 6 & ,843 & 3 & 7 & 5,00 & 6,00 & 6,00 \\
\hline (Fin7) Resultado Econômico & 618 & $94,93 \%$ & 6,65 & 7,00 & 7 &, 583 & 4 & 7 & 6,00 & 7,00 & 7,00 \\
\hline (Fin8) Capitalização & 578 & $88,79 \%$ & 6,22 & 6,00 & 6 &, 735 & 4 & 7 & 6,00 & 6,00 & 7,00 \\
\hline (Fin9) Geração de Rendas & 567 & $87,10 \%$ & 6,10 & 6,00 & 6 & ,677 & 4 & 7 & 6,00 & 6,00 & 7,00 \\
\hline (Fin10) Crescimento Aplicações Totais & 582 & $89,40 \%$ & 6,26 & 6,00 & 6 & 674 & 4 & 7 & 6,00 & 6,00 & 7,00 \\
\hline (Fin11) Crescimento Captações Totais & 588 & $90,32 \%$ & 6,32 & 6,00 & 6 & ,628 & 5 & 7 & 6,00 & 6,00 & 7,00 \\
\hline (Fin12) Equilíbrio do Orçamento & 613 & $94,16 \%$ & 6,59 & 7,00 & 7 &, 612 & 4 & 7 & 6,00 & 7,00 & 7,00 \\
\hline (Fin13) Nível de Inadimplemento (NID) & 635 & $97,54 \%$ & 6,83 & 7,00 & 7 & ,407 & 5 & 7 & 7,00 & 7,00 & 7,00 \\
\hline
\end{tabular}

Fonte: autora. 
Tabela 28 - Pontuação atribuída pelos Gerentes em relação aos indicadores do módulo Associados

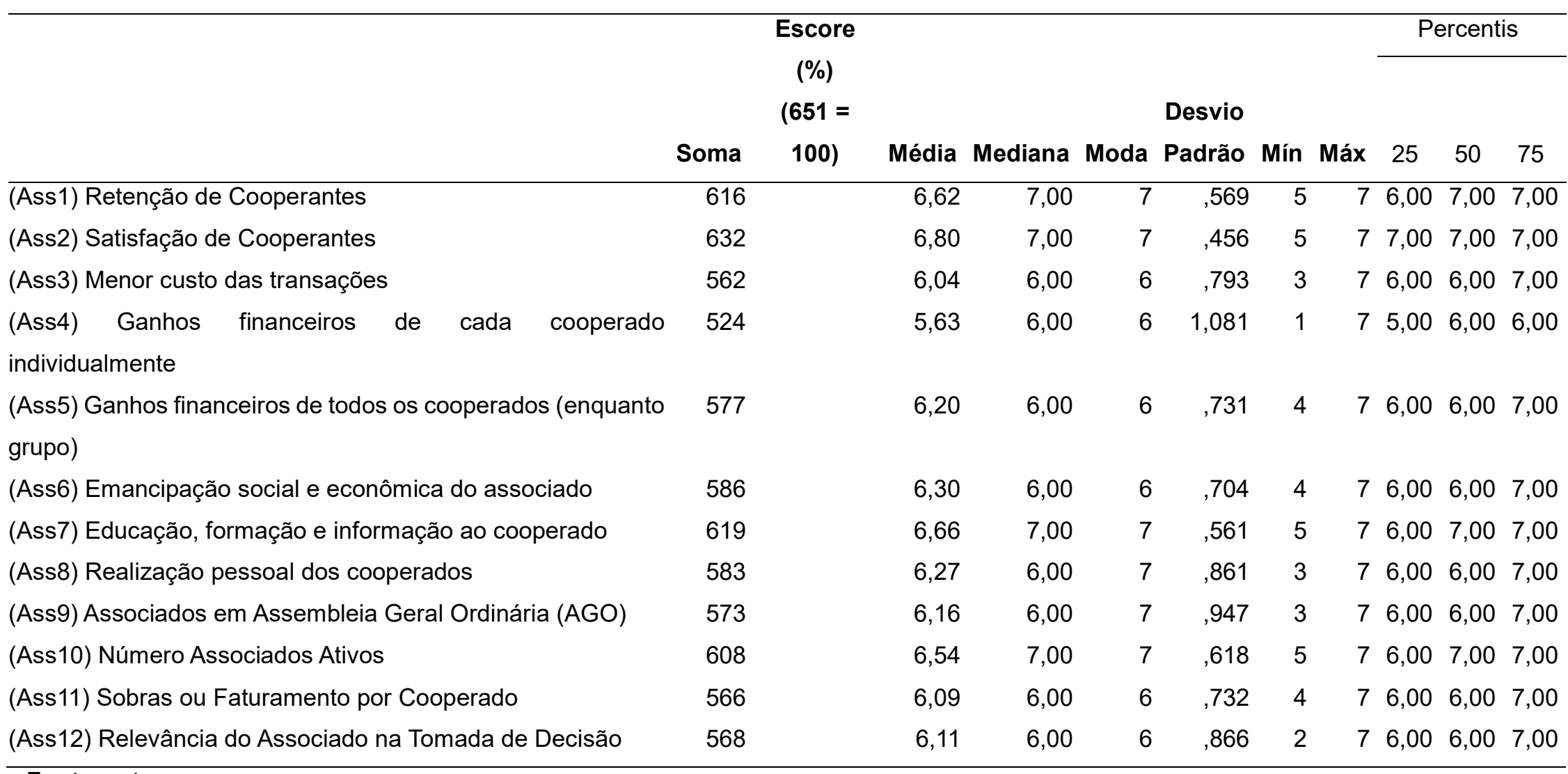

Fonte: autora. 


\subsection{INDICADORES "PROCESSOS INTERNOS"}

A pontuação atribuída pelos Gerentes em relação aos indicadores do módulo "Processos Internos", bem como suas estatísticas constam na tabela 29. Em suma, os constructos mais bem avaliados pelos Gerentes participantes da amostra, de acordo com o grau de importância percebido por eles, são: "Nível de transparência" com 642 pontos e 6,90 de média; e "Perpetuação da instituição" com 624 pontos e 6,71 de média.

Os fatores que alcançaram menor pontuação foram "Percentual de trabalho extraordinário" com 514 pontos e 5,53 de média; e "Lucratividade por segmento-alvo", com 536 pontos e 5.76 de média.

\subsection{INDICADORES "APRENDIZADO E CRESCIMENTO"}

A pontuação atribuída pelos Gerentes em relação aos indicadores do módulo "Aprendizado e Crescimento", bem como suas estatísticas constam na tabela 30. Em suma, o constructo mais bem avaliado pelos Gerentes participantes da amostra, de acordo com o grau de importância percebido por eles, é: "Melhoria das capacidades dos funcionários" com 624 pontos e 6,71 de média.

O fator que alcançou menor pontuação foi "Nível de rotatividade" com 580 pontos e 6,24 de média. 
Tabela 29 - Pontuação atribuída pelos Gerentes em relação aos indicadores do módulo Processos Internos

\begin{tabular}{|c|c|c|c|c|c|c|c|c|c|c|c|}
\hline & & \multirow{2}{*}{$\begin{array}{c}\text { Escore } \\
(\%) \\
(651= \\
100)\end{array}$} & \multirow[b]{2}{*}{ Média } & \multirow[b]{2}{*}{ Mediana } & \multirow[b]{2}{*}{ Moda } & \multirow[b]{2}{*}{$\begin{array}{l}\text { Desvio } \\
\text { Padrão }\end{array}$} & \multirow[b]{2}{*}{ Mín } & \multirow[b]{2}{*}{ Máx } & \multicolumn{3}{|c|}{ Percentis } \\
\hline & Soma & & & & & & & & 25 & 50 & 75 \\
\hline (Pro1) Lucratividade por Segmento-Alvo & 536 & & 5,76 & 6,00 & 6 & ,937 & 2 & 7 & 5,00 & 6,00 & 6,00 \\
\hline $\begin{array}{l}\text { (Pro2) Percentual de Transações Realizadas Através dos } \\
\text { Diversos Canais }\end{array}$ & 560 & & 6,02 & 6,00 & 6 & ,737 & 4 & 7 & 6,00 & 6,00 & 7,00 \\
\hline (Pro3) Projetos Sociais Desenvolvidos & 594 & & 6,39 & 6,00 & 7 & ,643 & 5 & 7 & 6,00 & 6,00 & 7,00 \\
\hline (Pro4) Percentual de Trabalho Extraordinário & 514 & & 5,53 & 6,00 & 6 & 1,049 & 3 & 7 & 5,00 & 6,00 & 6,00 \\
\hline (Pro6) Nível de Transparência & 642 & & 6,90 & 7,00 & 7 & ,297 & 6 & 7 & 7,00 & 7,00 & 7,00 \\
\hline (Pro7) Perpetuação da instituição & 624 & & 6,71 & 7,00 & 7 & 618 & 3 & 7 & 7,00 & 7,00 & 7,00 \\
\hline (Pro8) Preservação da identidade organizacional & 612 & & 6,58 & 7,00 & 7 &, 596 & 5 & 7 & 6,00 & 7,00 & 7,00 \\
\hline
\end{tabular}

Fonte: autora.

Tabela 30 - Pontuação atribuída pelos Gerentes em relação aos indicadores do módulo Aprendizado e Crescimento

\begin{tabular}{|c|c|c|c|c|c|c|c|c|c|c|}
\hline & \multicolumn{2}{|l|}{ Escore (\%) } & \multirow[b]{2}{*}{ Mediana } & \multicolumn{3}{|c|}{ Desvio } & \multirow[b]{2}{*}{ Máx } & \multicolumn{3}{|c|}{ Percentis } \\
\hline & Soma $(651=100)$ & Média & & Moda & Padrão & Mín & & 25 & 50 & 75 \\
\hline (Apr1) Melhorias das capacidades dos funcionários & 624 & 6,71 & 7,00 & 7 &, 502 & 5 & 7 & 6,00 & 7,00 & 7,00 \\
\hline (Apr2) Nível de rotatividade & 580 & 6,24 & 6,00 & 6 & ,799 & 3 & 7 & 6,00 & 6,00 & 7,00 \\
\hline (Apr3) Motivação para agir no melhor interesse da & 585 & 6,29 & 6,00 & 7 & 904 & 1 & 7 & 6,00 & 6,00 & 7,00 \\
\hline
\end{tabular}

erativa

Fonte: autora. 


\subsection{INDICADORES "PESSOAS E INOVAÇÃO"}

A pontuação atribuída pelos Gerentes em relação aos indicadores do módulo "Pessoas e Inovação", bem como suas estatísticas constam na tabela 31. Em suma, os constructos mais bem avaliados pelos Gerentes participantes da amostra, de acordo com o grau de importância percebido por eles, são: "Profissionalização da administração" e "Ambiente de trabalho ético e que valoriza o capital humano", ambos com 621 pontos e 6,68 de média; e "Condições de trabalho adequadas", com 617 pontos e 6,63 de média.

O fator que alcançou menor pontuação foi "Benefícios extras para os bons funcionários" com 536 pontos e 5,76 de média.

\subsection{INDICADORES "PRINCÍPIOS COOPERATIVISTAS"}

A pontuação atribuída pelos Gerentes em relação aos indicadores do módulo "Princípios cooperativistas", bem como suas estatísticas constam na tabela 32. Em suma, todos os constructos foram muito bem avaliados. Os mais bem avaliados pelos Gerentes participantes da amostra, de acordo com o grau de importância percebido por eles, são: "Cumpre os princípios cooperativistas", com 628 pontos e 6,75 de média e "Ambiente Preocupação com a comunidade", com 621 pontos e 6,68 de média.

Os fatores que alcançaram menor pontuação foram "Solidariedade" com 589 pontos e 6,33 de média e "Combate a exclusão social" com 593 pontos e 6,38 de média. 
Tabela 31 - Pontuação atribuída pelos Gerentes em relação aos indicadores do módulo Pessoas e Inovação

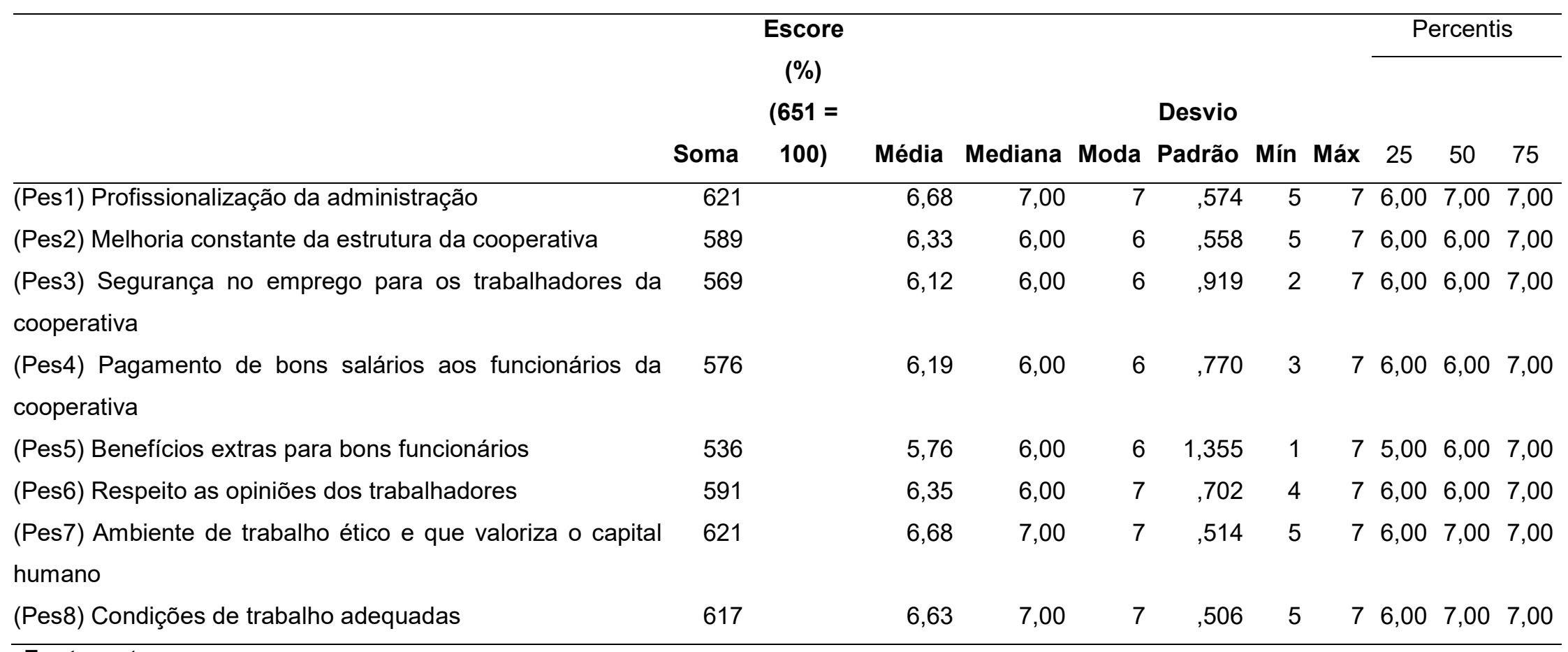

Fonte: autora. 
Tabela 32 - Pontuação atribuída pelos Gerentes em relação aos indicadores do módulo Princípios Cooperativistas

\begin{tabular}{|c|c|c|c|c|c|c|c|c|c|c|c|}
\hline & \multicolumn{3}{|c|}{ Escore (\%) } & \multicolumn{5}{|c|}{ Desvio } & \multicolumn{3}{|c|}{ Percentis } \\
\hline & Soma & $(651=100)$ & Média & Mediana & Moda & Padrão & Mín & Máx & 25 & 50 & 75 \\
\hline (Pri1) Cumpre Princípios Cooperativistas & 628 & & 6,75 & 7,00 & 7 & ,503 & 5 & 7 & 7,00 & 7,00 & 7,00 \\
\hline (Pri2) Democracia e igualdade & 606 & & 6,52 & 7,00 & 7 & 619 & 5 & 7 & 6,00 & 7,00 & 7,00 \\
\hline (Pri3) Solidariedade & 589 & & 6,33 & 6,00 & 7 &, 727 & 4 & 7 & 6,00 & 6,00 & 7,00 \\
\hline (Pri4) Valores de ajuda mútua & 603 & & 6,48 & 7,00 & 7 & ,669 & 5 & 7 & 6,00 & 7,00 & 7,00 \\
\hline (Pri5) Autonomia e a independência & 599 & & 6,44 & 7,00 & 7 & ,650 & 5 & 7 & 6,00 & 7,00 & 7,00 \\
\hline (Pri6) Adesão livre e voluntária & 613 & & 6,59 & 7,00 & 7 & ,647 & 4 & 7 & 6,00 & 7,00 & 7,00 \\
\hline (Pri7) Preocupação com a comunidade & 621 & & 6,68 & 7,00 & 7 &, 555 & 5 & 7 & 6,00 & 7,00 & 7,00 \\
\hline (Pri8) Geração de empregos & 601 & & 6,46 & 7,00 & 7 & ,669 & 5 & 7 & 6,00 & 7,00 & 7,00 \\
\hline (Pri9) Combate a exclusão social & 593 & & 6,38 & 7,00 & 7 & ,721 & 4 & 7 & 6,00 & 7,00 & 7,00 \\
\hline
\end{tabular}

Fonte: autora. 


\subsubsection{Procedimentos Estatísticos}

\subsubsection{TESTE $T$}

Ao analisar os dados utilizando o teste t é necessário verificar se os esses têm as condições necessárias para serem analisados por meio do referido teste. $O$ teste $t$ de amostras independentes pressupõem que os dados da sua variável dependente sejam de populações aproximadamente normalmente distribuídas para cada grupo da variável independente.

No entanto, o teste t de amostras independentes é considerado "robusto" para violações da normalidade quando os tamanhos das amostras são iguais ou quase iguais, os tamanhos das amostras são bastante grandes (25 a 30) e os testes são de duas caudas em vez de unicaudal (KANG; HARRING, 2012; LAERD STATISTICS, 2015; SAWILOWSKY; BLAIR, 1992). Isso significa que alguma violação dessa suposição pode ser tolerada e o teste ainda fornecerá resultados válidos.

Adicionalmente, o teste $t$ também assume que existe a homogeneidade da variância, ou seja, que a variância em cada grupo de sua variável independente seja igual. No entanto, se o tamanho da amostra em cada grupo for semelhante, a violação dessa suposição nem sempre é muito grave, caso contrário o teste t de amostras independentes é sensível à violação dessa suposição.

\subsubsection{ANÁLISES DE HIPÓTESES}

O nível de significância $(\alpha)$ dos testes de hipóteses foi fixado em 0,05. O coeficiente de confiança de 95\% (1- $\alpha$ ) significa que foi aceita nessa pesquisa no máximo uma probabilidade de $5 \%$ de se cometer um erro do Tipo I. Para o tipo de pesquisa social aplicada e para esse assunto, tais parâmetros são aceitáveis e atendem às necessidades do trabalho.

\subsection{Hipótese 1}

A fim de testar a hipótese 1: Existem conflitos de interesse entre os grupos de cooperados e o conselho de administração em relação a Avaliação de Desempenho, um teste $t$ de amostras independentes foi executado para determinar 
em quais indicadores de cada uma das categorias os "Cooperados" e "Conselho Administrativo" apresentam níveis de percepção de importância diferentes. O bootstrapping foi empregado para gerar intervalos de confiança para a diferença entre as médias, sendo cada intervalo de confiança baseado em 10000 amostras de bootstrapping.

Investigou-se a normalidade da distribuição para cada um dos grupos por meio do teste de Kolmogorov-Smirnov. Os resultados demonstram que os dados de cada grupo não são distribuídos normalmente $(p<0,05)$. Contudo, como a amostra total é composta por 152 observações, o teste t de amostras independentes é considerado "robusto" para violações da normalidade (KANG; HARRING, 2012; LAERD STATISTICS, 2015; SAWILOWSKY; BLAIR, 1992). A homogeneidade das variâncias foi testada utilizando o teste de Levene. Caso a homogeneidade das variâncias for violada, então foi utilizado o Teste t de Welch, que se mostra mais robusto quando há a violação da homogeneidade das variâncias somado a expressiva diferença no tamanho das amostras (tamanhos de grupo desiguais) (HOWELL, 2012; KOHR; GAMES, 1974).

Em relação aos indicadores do módulo Financeiro, de acordo com os resultados do teste Levene apenas Fin2, Fin3, Fin4 e Fin12 (Retorno sobre o investimento, Rentabilidade do patrimônio líquido, Capital em giro e Equilíbrio do orçamento), apresentaram homogeneidade das variâncias ( $p>0,05)$. Para os demais indicadores, a homogeneidade das variâncias foi violada $(p<0,05)$, assim os resultados para o Teste t de Welch são encontrados nas linhas "Variâncias iguais não assumidas" (tabela 33).

Por fim, não houve uma diferença estatisticamente significativa entre Conselho Administrativo (média $=6,50$, erro padrão de média $=0,131$ ) e Cooperados (média $=$ 6,05 , erro padrão de média $=0,100$ ) apenas para o indicador Fin12 (Equilíbrio do orçamento). Esta diferença de 0,454 (Percentil 95\%, IC [0,129, 0,773]) não se mostrou estatisticamente significativa $(t(178)=1,894, p=0,060)$.

Para os demais indicadores houve diferença estatisticamente significativa entre os grupos Conselho Administrativo e Cooperados $(p<0,05)$. A estatística t, os graus de liberdade e o valor da significância, juntamente com a diferença média e o intervalo de confiança estimados pelo bootstraping estão na relatados na tabela 33.

Acerca dos indicadores da categoria Associado, os resultados do teste Levene apenas o indicador Ass12 (Relevância do associado na tomada de decisão) 
apresentou homogeneidade das variâncias $(p>0,05)$. Para os demais indicadores, a homogeneidade das variâncias foi violada $(p<0,05)$, assim os resultados para o Teste t de Welch são encontrados nas linhas "Variâncias iguais não assumidas" (tabela 34).

Por fim, não houve uma diferença estatisticamente significativa entre Conselho Administrativo e Cooperados apenas para os indicadores Ass7 e Ass8 (Educação, formação e informação ao cooperado e Realização pessoal dos cooperados). As diferenças entre os grupos não se mostraram estatisticamente significativa, pois $p>0,05$.

Para os demais indicadores houve diferença estatisticamente significativa entre os grupos Conselho Administrativo e Cooperados $(p<0,05)$. A estatística $t$, os graus de liberdade e o valor da significância, juntamente a diferença média e o intervalo de confiança estimados pelo bootstraping estão na relatados na tabela 34 . 
Tabela 33 - Estatísticas dos grupos: categoria Financeiros

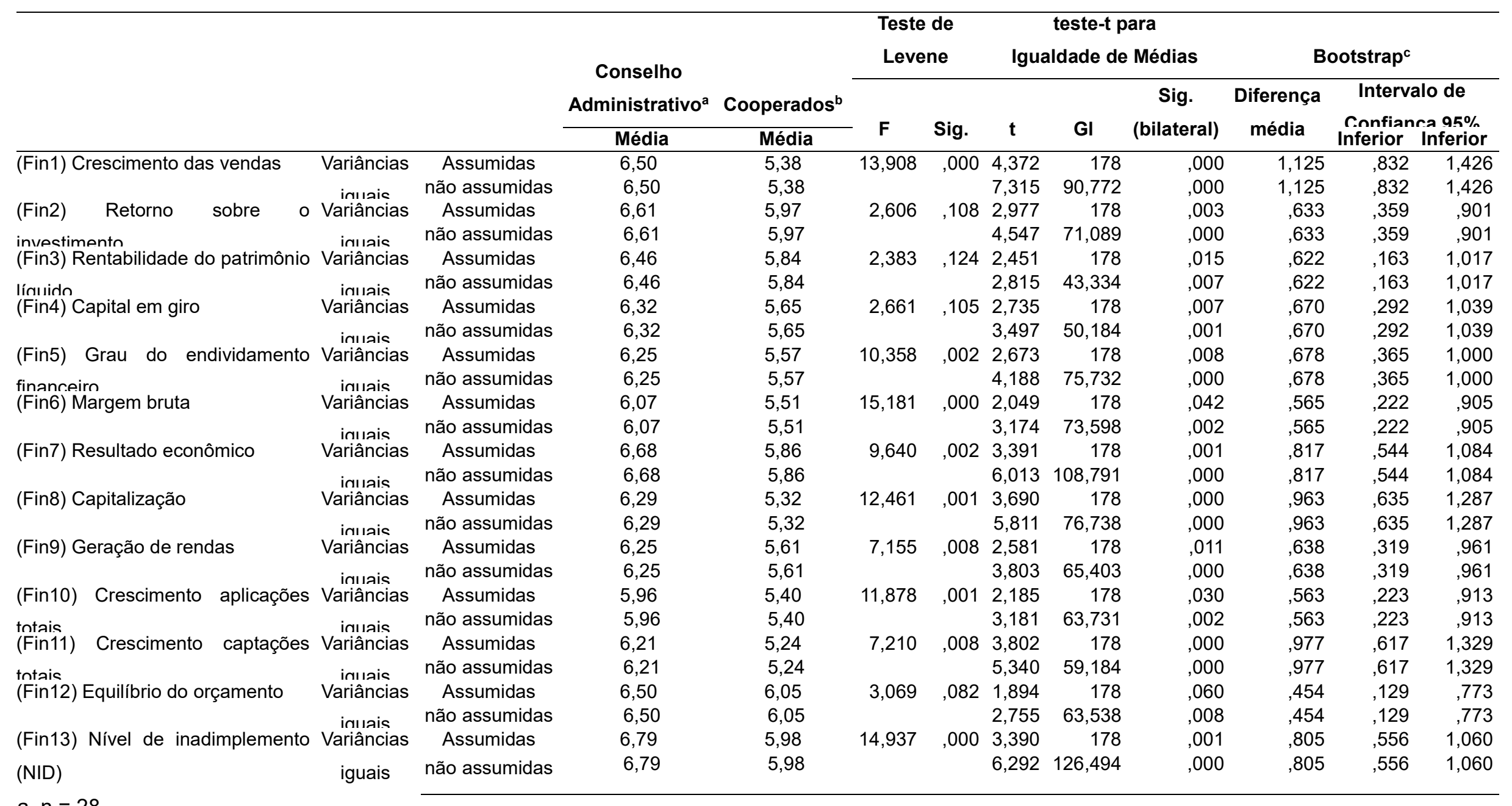

a. $\mathrm{n}=28$

$n=15$

c. A menos que indicado de outra maneira, os resultados da bootstrap são baseados em 10000 amostras bootstrap Fonte: autora. 
Tabela 34 - Estatísticas dos grupos: categoria Associado

\begin{tabular}{|c|c|c|c|c|c|c|c|c|c|c|c|c|}
\hline & & & \multirow{3}{*}{$\begin{array}{c}\text { Conselho } \\
\text { Administrativo }\end{array}$} & \multirow[b]{3}{*}{ Cooperados $^{b}$} & \multirow{2}{*}{\multicolumn{2}{|c|}{$\begin{array}{l}\text { Teste de } \\
\text { Levene }\end{array}$}} & \multicolumn{3}{|c|}{ teste-t para } & \multirow{2}{*}{\multicolumn{3}{|c|}{ Bootstrapc }} \\
\hline & & & & & & & \multirow[b]{3}{*}{$\mathbf{T}$} & dade de & Médias & & & \\
\hline & & & & & \multirow[b]{2}{*}{$\mathbf{F}$} & \multirow[b]{2}{*}{ Sig. } & & \multirow[b]{2}{*}{ GI } & \multirow{2}{*}{$\begin{array}{c}\text { Sig. } \\
\text { (bilateral) }\end{array}$} & \multirow{2}{*}{$\begin{array}{l}\text { Diferença } \\
\text { média }\end{array}$} & \multirow{2}{*}{\multicolumn{2}{|c|}{$\begin{array}{l}\text { Intervalo de } \\
\text { Connfianca } 95 \% \\
\text { Inferior Inferior }\end{array}$}} \\
\hline & & & Média & Média & & & & & & & & \\
\hline \multirow[t]{2}{*}{ (Ass1) Retenção de cooperantes } & Variâncias & Assumidas & 6,39 & 5,18 & 8,411 & ,004 & 4,429 & 178 &, 000 & 1,215 & ,866 & 1,560 \\
\hline & iguais & não assumidas & 6,39 & 5,18 & & & 6,732 & 70,259 &, 000 & 1,215 & ,866 & 1,560 \\
\hline \multirow[t]{2}{*}{ (Ass2) Satisfação de cooperantes } & Variâncias & Assumidas & 6,54 & 6,08 & 5,612 & ,019 & 2,085 & 178 & 039 & ,457 & 178 &, 732 \\
\hline & iguais & não assumidas & 6,54 & 6,08 & & & 3,208 & 72,379 &, 002 & ,457 & 178 &, 732 \\
\hline (Ass3) Menor & Variâncias & assumidas & 6,43 & 6,11 & 5,303 & ,022 & 1,603 & 178 & 111 & ,323 &, 050 &, 599 \\
\hline transações & iguais & não assumidas & 6,43 & 6,11 & & & 2,359 & 65,187 & 021 &, 323 &, 050 &, 599 \\
\hline (Ass4) Ganhos financeiros de & Variâncias & assumidas & 6,21 & 5,72 & 7,822 &, 006 & 2,140 & 178 & 034 & ,491 & 169 &, 806 \\
\hline cada cooperado individualmente & iguais & não assumidas & 6,21 & 5,72 & & & 3,049 & 60,852 &, 003 & ,491 & 169 & ,806 \\
\hline (Ass5) Ganhos financeiros de & Variâncias & assumidas & 6,32 & 5,78 & 7,451 & ,007 & 2,423 & 178 & 016 &, 539 & ,251 & ,829 \\
\hline \multirow{3}{*}{$\begin{array}{l}\text { todos os cooperados (enquanto } \\
\text { (Ass6) Emancipação social e } \\
\text { econômica do associado }\end{array}$} & iguais & não assumidas & 6,32 & 5,78 & & & 3,632 & 67,986 & 001 &, 539 & ,251 & ,829 \\
\hline & Variâncias & assumidas & 6,04 & 5,66 & 5,268 & ,023 & 1,659 & 178 & ,099 & ,371 & 014 & ,728 \\
\hline & iguais & não assumidas & 6,04 & 5,66 & & & 2,030 & 47,062 &, 048 & ,371 & ,014 & ,728 \\
\hline \multirow{2}{*}{$\begin{array}{l}\text { (Ass7) Educação, formação e } \\
\text { informacão ao cooperado }\end{array}$} & Variâncias & assumidas & 5,96 & 6,14 & 5,781 & ,017 &,- 970 & 178 & ,334 &,- 180 &,- 497 &, 125 \\
\hline & iguais & não assumidas & 5,96 & 6,14 & & & $-1,130$ & 44,133 & ,265 &,- 180 &,- 497 & 125 \\
\hline \multirow{6}{*}{$\begin{array}{l}\text { (Ass8) Realização pessoal dos } \\
\text { cooperados } \\
\text { (Ass9) Associados em assembleia } \\
\text { geral ordinária (AGO) } \\
\text { (Ass10) Número associados ativos }\end{array}$} & Variâncias & assumidas & 5,64 & 5,86 & 5,903 & ,016 & $-1,007$ & 178 & ,315 &,- 212 &,- 696 & ,252 \\
\hline & iguais & não assumidas & 5,64 & 5,86 & & &,- 868 & 33,759 & ,391 &,- 212 &,- 696 & ,252 \\
\hline & Variâncias & assumidas & 6,46 & 4,61 & 10,538 & ,001 & 6,342 & 178 &, 000 & 1,852 & 1,497 & 2,197 \\
\hline & iguais & não assumidas & 6,46 & 4,61 & & & 10,319 & 83,778 &, 000 & 1,852 & 1,497 & 2,197 \\
\hline & Variâncias & assumidas & 6,61 & 5,25 & 10,905 & ,001 & 5,578 & 178 &, 000 & 1,357 & 1,069 & 1,636 \\
\hline & iguais & não assumidas & 6,61 & 5,25 & & & 9,159 & 85,977 &, 000 & 1,357 & 1,069 & 1,636 \\
\hline \multirow{4}{*}{$\begin{array}{l}\text { (Ass11) Sobras ou faturamento } \\
\text { por cooperado } \\
\text { (Ass12) Relevância do associado } \\
\text { na tomada de decisão }\end{array}$} & Variâncias & assumidas & 6,04 & 5,47 & 11,309 & ,001 & 2,092 & 178 & ,038 &, 569 &, 174 &, 945 \\
\hline & iguais & não assumidas & 6,04 & 5,47 & & & 2,925 & 58,616 &, 005 &, 569 & ,174 &, 945 \\
\hline & Variâncias & assumidas & 6,14 & 5,38 & 2,474 & 118 & 2,993 & 178 & 003 & 768 & 380 & 1,158 \\
\hline & iguais & não assumidas & 6,14 & 5,38 & & & 3,864 & 50,979 &, 000 & ,768 & ,380 & 1,158 \\
\hline
\end{tabular}

a. $n=28$

b. $n=152$

c. A menos que indicado de outra maneira, os resultados da bootstrap são baseados em 10000 amostras bootstrap

Fonte: autora. 
Na categoria Processos Internos, segundo os resultados do teste Levene, apenas os indicadores Pro2 e Pro4 (Percentual de transações realizadas através dos diversos canais e Percentual de trabalho extraordinário) apresentaram homogeneidade das variâncias $(p>0,05)$. Para as demais variáveis, a homogeneidade das variâncias foi violada, assim os resultados para o Teste $t$ de Welch são encontrados nas linhas "Variâncias iguais não assumidas" (tabela 35).

Por fim, não houve uma diferença estatisticamente significativa entre Conselho Administrativo (média $=4,75$, erro padrão de média $=0,265$ ) e Cooperados (média $=$ 4,51 , erro padrão de média $=0,133$ ) apenas para o indicador Pro4 (Percentual de trabalho extraordinário). Esta diferença de 0,243 (Percentil 95\%, IC [-0,355, 0,804]) não se mostrou estatisticamente significativa ( $(178)=0,735, p=0,463)$.

Para os demais indicadores houve diferença estatisticamente significativa entre os grupos Conselho Administrativo e Cooperados $(p<0,05)$. A estatística $t$, os graus de liberdade e o valor da significância, juntamente a diferença média e o intervalo de confiança estimados pelo bootstraping estão na relatados na tabela 35.

Em relação aos indicadores da categoria Aprendizado e Crescimento, de acordo com os resultados do teste Levene, a homogeneidade das variâncias foi violada para todos os indicadores $(p<0,05)$, assim os resultados para o Teste $t$ de Welch são encontrados nas linhas "Variâncias iguais não assumidas" (tabela 36).

Para todos os indicadores desta categoria houve diferença estatisticamente significativa entre os grupos Conselho Administrativo e Cooperados $(p<0,05)$. A estatística $t$, os graus de liberdade e o valor da significância, juntamente a diferença média e o intervalo de confiança estimados pelo bootstraping estão na relatados na tabela 36 . 
Tabela 35 - Estatísticas dos grupos: categoria Processos Internos

\begin{tabular}{|c|c|c|c|c|c|c|c|c|c|c|c|c|}
\hline & & & \multirow{3}{*}{$\begin{array}{c}\text { Conselho } \\
\text { Administrativo }^{\mathrm{a}}\end{array}$} & \multirow{3}{*}{$\frac{\text { Cooperados }^{b}}{\text { Média }}$} & \multicolumn{2}{|c|}{$\begin{array}{l}\text { Teste de } \\
\text { Levene }\end{array}$} & \multicolumn{3}{|c|}{$\begin{array}{c}\text { teste-t para } \\
\text { Igualdade de Médias }\end{array}$} & \multicolumn{3}{|c|}{ Bootstrap ${ }^{c}$} \\
\hline & & & & & \multirow[b]{2}{*}{$\mathbf{F}$} & \multirow[b]{2}{*}{ Sig. } & \multirow[b]{2}{*}{$\mathbf{t}$} & \multirow[b]{2}{*}{ GI } & \multirow{2}{*}{$\begin{array}{l}\text { Sig. } \\
\text { (bilateral) }\end{array}$} & \multirow{2}{*}{$\begin{array}{l}\text { Diferença } \\
\text { média }\end{array}$} & \multicolumn{2}{|c|}{$\begin{array}{c}\text { Intervalo de } \\
\text { Confiança } 95 \%\end{array}$} \\
\hline & & & & & & & & & & & Inferior & Inferior \\
\hline $\begin{array}{ll}\text { (Pro1) } & \text { Lucratividade }\end{array}$ & Variâncias & assumidas & 5,71 & 5,24 & 6,879 &, 009 & 1,765 & 178 & , 079 & ,471 & ,094 &, 830 \\
\hline segmento-alvo & iguais & não assumidas & 5,71 & 5,24 & & & 2,491 & 59,798 &, 016 & ,471 & ,094 & ,830 \\
\hline (Pro2) Percentual de transações & Variâncias & assumidas & 5,64 & 5,01 & 1,486 & ,225 & 2,148 & 178 &, 033 & ,636 & ,081 & 1,100 \\
\hline realizadas através dos diversos & iguais & não assumidas & 5,64 & 5,01 & & & 2,443 & 42,863 & 019 & ,636 & 081 & 1,100 \\
\hline (Pro3) Projetos sociais & Variâncias & assumidas & 6,00 & 5,11 & 15,022 &, 000 & 2,914 & 178 &, 004 & ,888 & ,473 & 1,279 \\
\hline desenvolvidos & iguais & não assumidas & 6,00 & 5,11 & & & 4,302 & 65,700 &, 000 & ,888 & ,473 & 1,279 \\
\hline (Pro4) Percentual de trabalho & Variâncias & assumidas & 4,75 & 4,51 & 1,984 & 161 &, 735 & 178 & ,463 & 243 &,- 355 & ,804 \\
\hline extraordinário & iguais & não assumidas & 4,75 & 4,51 & & & ,820 & 41,871 &, 417 & ,243 &,- 355 & ,804 \\
\hline Desenvolvimento & Variâncias & assumidas & 6,07 & 5,45 & 12,792 &, 000 & 2,125 & 178 & ,035 & ,617 & ,205 & 1,000 \\
\hline sustentável & iguais & não assumidas & 6,07 & 5,45 & & & 3,054 & 62,002 &, 003 & 617 & 205 & 1,000 \\
\hline (Pro6) Nível de Transparência & Variâncias & assumidas & 6,86 & 6,57 & 18,199 &, 000 & 2,083 & 178 & 039 & ,285 & ,101 & ,452 \\
\hline & iguais & não assumidas & 6,86 & 6,57 & & & 3,222 & 73,269 &, 002 & ,285 & ,101 & ,452 \\
\hline (Pro7) Perpetuação da instituição & Variâncias & assumidas & 6,75 & 5,62 & 22,586 &, 000 & 4,893 & 178 &, 000 & 1,132 & ,882 & 1,383 \\
\hline & iguais & não assumidas & 6,75 & 5,62 & & & 8,803 & 114,059 &, 000 & 1,132 & ,882 & 1,383 \\
\hline (Pro8) Preservação da identidade & Variâncias & assumidas & 6,36 & 5,67 & 6,064 & ,015 & 2,948 & 178 &, 004 &, 686 & ,362 & ,991 \\
\hline organizacional & iguais & não assumidas & 6,36 & 5,67 & & & 4,269 & 62,984 &, 000 & 686 & ,362 & ,991 \\
\hline
\end{tabular}

a. $n=28$; b. $n=152$; c. A menos que indicado de outra maneira, os resultados da bootstrap são baseados em 10000 amostras bootstrap. Fonte: autora.

Tabela 36 - Estatísticas dos grupos: categoria Aprendizado e Crescimento

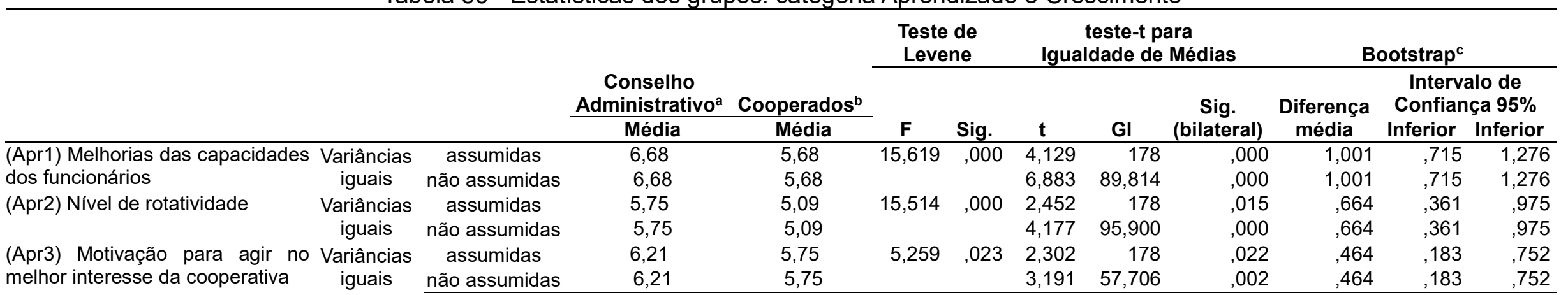

a. $n=28$; b. $n=152$; c. A menos que indicado de outra maneira, os resultados da bootstrap são baseados em 10000 amostras bootstrap

Fonte: autora. 
Já os indicadores da categoria Pessoas e Inovação quando reportados ao teste Levene, demonstraram que a homogeneidade das variâncias foi violada nos indicadores Pes1, Pes2 e Pes8 (Profissionalização da administração, Melhoria constante da estrutura da cooperativa, e Condições de trabalho adequadas) $(p<0,05)$, assim os resultados para o Teste t de Welch são encontrados nas linhas "Variâncias iguais não assumidas". Os demais indicadores não violam a homogeneidade das variâncias $(p>0,05)$ (tabela 37$)$.

Por fim, houve uma diferença estatisticamente significativa entre Conselho Administrativo (média $=6,79$, erro padrão de média $=0,94$ ) e Cooperados (média $=$ 6,29 , erro padrão de média $=0,075$ ) apenas para o indicador Pes1 (Profissionalização da administração). Esta diferença de 0,496 (Percentil 95\%, IC [0,256, 0,719]) se mostrou estatisticamente significativa $(t(67,264)=4,119, p=0,000)$.

Para os demais indicadores não houve diferença estatisticamente significativa entre os grupos Conselho Administrativo e Cooperados ( $p>0,05)$. A estatística $t$, os graus de liberdade e o valor da significância, juntamente a diferença média e o intervalo de confiança estimados pelo bootstraping estão na relatados na tabela 37.

De acordo com os resultados do teste Levene os indicadores Pri2, Pri4, Pri5 e Pri6 (Democracia e igualdade/Valores de ajuda mútua (preocupação com o semelhante)/Autonomia e a independência/Adesão livre e voluntária), da categoria Princípios Cooperativistas, apresentaram homogeneidade das variâncias $(p>0,05)$. Para os demais indicadores, a homogeneidade das variâncias foi violada, assim os resultados para o Teste $t$ de Welch são encontrados nas linhas "Variâncias iguais não assumidas".

Por fim, não houve uma diferença estatisticamente significativa entre Conselho Administrativo e Cooperados para os indicadores Pri2, Pri4, Pri5, Pri8 e Pri9 (Democracia e igualdade/Valores de ajuda mútua (preocupação com o semelhante)/Autonomia e a independência/Geração de empregos/Combate a exclusão social). As diferenças entre os grupos não se mostraram estatisticamente significativa, pois $p>0,05$. Para os demais indicadores (Pri1, Pri3, Pri6 e Pri7 - Cumpre princípios cooperativistas/Solidariedade/Adesão livre e voluntária/Preocupação com a comunidade) houve diferença estatisticamente significativa entre os grupos Conselho Administrativo e Cooperados $(p<0,05)$. 
Tabela 37 - Estatísticas dos grupos: categoria Pessoa e Inovação

\begin{tabular}{|c|c|c|c|c|c|c|c|c|c|c|c|}
\hline & & \multirow[b]{2}{*}{$\begin{array}{c}\begin{array}{c}\text { Conselho } \\
\text { Administrativo }^{a}\end{array} \\
\text { Média }\end{array}$} & \multirow[b]{2}{*}{$\frac{\text { Cooperados }^{b}}{\text { Média }}$} & \multicolumn{2}{|c|}{$\begin{array}{l}\text { Teste de } \\
\text { Levene }\end{array}$} & \multicolumn{3}{|c|}{$\begin{array}{c}\text { teste-t para } \\
\text { Igualdade de Médias }\end{array}$} & \multicolumn{3}{|c|}{ Bootstrap } \\
\hline & & & & $\mathbf{F}$ & Sig. & $\mathbf{t}$ & gl & $\begin{array}{c}\text { Sig. } \\
\text { (bilateral) }\end{array}$ & $\begin{array}{l}\text { Diferença } \\
\text { média }\end{array}$ & $\begin{array}{r}\text { Interva } \\
\text { Confianc } \\
\text { Inferior } \\
\end{array}$ & $\begin{array}{l}\text { alo de } \\
\text { ça } 95 \% \\
\text { Inferior }\end{array}$ \\
\hline (Pes1) Profissionalização da Variâncias & assumidas & 6,79 & 6,29 & 12,680 &, 000 & 2,761 & 178 & ,006 & ,496 & ,256 & ,719 \\
\hline administração iguais & não & 6,79 & 6,29 & & & 4,119 & 67,264 & 000 & ,496 & ,256 & ,719 \\
\hline (Pes2) Melhoria constante Variâncias & assumidas & 6,14 & 5,90 & 7,928 & ,005 & 1,165 & 178 & ,246 & ,242 &,- 052 &, 535 \\
\hline da estrutura da cooperativa iguais & não & 6,14 & 5,90 & & & 1,610 & 57,379 & 113 & ,242 &,- 052 &, 535 \\
\hline (Pes3) Segurança no Variâncias & assumidas & 5,71 & 5,89 & ,925 & ,338 &,- 752 & 178 & ,453 &,- 180 &,- 674 & ,290 \\
\hline emprego para os iguais & não & 5,71 & 5,89 & & &,- 729 & 36,637 & ,471 &,- 180 &,- 674 & ,290 \\
\hline (Pes4) Pagamento de bons Variâncias & assumidas & 5,86 & 5,90 & 2,400 &, 123 &,- 213 & 178 & ,832 &,- 044 &,- 375 & 276 \\
\hline salários aos funcionários da iguais & não & 5,86 & 5,90 & & &,- 266 & 48,373 & ,792 &,- 044 &,- 375 & ,276 \\
\hline (Pes5) Benefícios extras Variâncias & assumidas & 5,46 & 5,71 & 1,202 & ,274 & - & 178 & 241 &,- 246 &,- 680 & 181 \\
\hline para bons funcionários iguais & não & 5,46 & 5,71 & & & - & 36,349 & 267 &,- 246 &,- 680 & 181 \\
\hline (Pes6) Respeito as opiniões Variâncias & assumidas & 6,07 & 5,93 & 2,973 & ,086 & ,724 & 178 & 470 &, 137 &,- 173 & ,438 \\
\hline dos trabalhadores iguais & não & 6,07 & 5,93 & & & ,880 & 46,618 & ,383 & 137 &,- 173 & ,438 \\
\hline (Pes7) Ambiente de trabalho Variâncias & assumidas & 6,39 & 6,12 & 2,772 & ,098 & 1,311 & 178 & 192 & ,274 &,- 041 &, 577 \\
\hline ético e que valoriza o capital iguais & não & 6,39 & 6,12 & & & 1,762 & 54,550 & 084 & ,274 &,- 041 &, 577 \\
\hline (Pes8) Condições de Variâncias & assumidas & 6,18 & 6,34 & 19,560 & ,000 &,- 984 & 178 & ,327 &,- 164 &,- 357 & 044 \\
\hline trabalho adequadas & não & 6,18 & 6,34 & & & & 85,132 & ,111 &,- 164 &,- 357 & ,044 \\
\hline
\end{tabular}

a. $n=28$

b. $n=152$

c. A menos que indicado de outra maneira, os resultados da bootstrap são baseados em 10000 amostras bootstrap

Fonte: autora. 
Tabela 38 - Estatísticas dos grupos: categoria Princípios Cooperativistas

\begin{tabular}{|c|c|c|c|c|c|c|c|c|c|c|c|c|}
\hline & & & \multirow[b]{2}{*}{$\begin{array}{c}\text { Conselho } \\
\text { Administrativo }^{\mathrm{a}} \\
\text { Média }\end{array}$} & \multirow[b]{2}{*}{$\frac{\text { Cooperados }^{b}}{\text { Média }}$} & \multicolumn{2}{|c|}{$\begin{array}{l}\text { Teste de } \\
\text { Levene }\end{array}$} & \multicolumn{3}{|c|}{$\begin{array}{c}\text { teste-t para } \\
\text { Igualdade de Médias }\end{array}$} & \multicolumn{3}{|c|}{ Bootstrapc } \\
\hline & & & & & $\mathbf{F}$ & Sig. & $\mathbf{t}$ & gl & $\begin{array}{c}\text { Sig. } \\
\text { (bilateral) }\end{array}$ & $\begin{array}{l}\text { Diferença } \\
\text { média }\end{array}$ & $\begin{array}{l}\text { Interva } \\
\text { Confian } \\
\text { Inferior }\end{array}$ & $\begin{array}{l}\text { alo de } \\
\text { ça } 95 \% \\
\text { Inferior }\end{array}$ \\
\hline (Pri1) Cumpre & Variâncias & assumidas & 6,57 & 5,49 & 12,413 &, 001 & 3,746 & 178 & ,000 & 1,085 &, 700 & 1,436 \\
\hline cooperativistas & iguais & não & 6,57 & 5,49 & & & 5,850 & 75,083 &, 000 & 1,085 & ,700 & 1,436 \\
\hline $\begin{array}{l}\text { (Pri2) Democracia e } \\
\text { igualdade }\end{array}$ & $\begin{array}{l}\text { Variâncias } \\
\text { iguais }\end{array}$ & $\begin{array}{l}\text { assumidas } \\
\text { não }\end{array}$ & $\begin{array}{l}6,29 \\
6,29\end{array}$ & $\begin{array}{r}5,86 \\
5,86\end{array}$ & 2,983 &, 086 & $\begin{array}{l}1,791 \\
2,432\end{array}$ & $\begin{array}{r}178 \\
55,545\end{array}$ & $\begin{array}{l}075 \\
, 018\end{array}$ & $\begin{array}{l}, 424 \\
, 424\end{array}$ & $\begin{array}{l}, 078 \\
, 078\end{array}$ & $\begin{array}{l}, 762 \\
, 762\end{array}$ \\
\hline (Pri3) Solidariedade & $\begin{array}{l}\text { Variâncias } \\
\text { iguais }\end{array}$ & $\begin{array}{l}\text { assumidas } \\
\text { não }\end{array}$ & $\begin{array}{l}6,00 \\
6,00\end{array}$ & $\begin{array}{r}5,58 \\
5,58\end{array}$ & 5,502 & ,020 & $\begin{array}{l}1,618 \\
2,028\end{array}$ & $\begin{array}{r}178 \\
48,695\end{array}$ & $\begin{array}{l}, 107 \\
, 048\end{array}$ & $\begin{array}{l}, 421 \\
, 421\end{array}$ & $\begin{array}{l}, 003 \\
, 003\end{array}$ & $\begin{array}{l}, 818 \\
, 818\end{array}$ \\
\hline (Pri4) Valores de ajuda & Variâncias & assumidas & 5,82 & 5,64 & ,414 &, 521 &, 745 & 178 & 457 & 177 &,- 301 & 609 \\
\hline mútua (preocupação com o & iguais & não & 5,82 & 5,64 & & & ,761 & 38,349 &, 451 & 177 &,- 301 & ,609 \\
\hline (Pri5) Autonomia e a & Variâncias & assumidas & 6,00 & 5,81 & ,277 &, 599 & ,890 & 178 & ,375 & ,191 &,- 291 & 620 \\
\hline independência & iguais & não & 6,00 & 5,81 & & & ,817 & 35,210 & ,419 &, 191 &,- 291 &, 620 \\
\hline (Pri6) Adesão & Variâncias & assumidas & 6,21 & 5,59 & 3,347 & ,069 & 2,620 & 178 & 010 & 622 & 100 & 1,027 \\
\hline voluntária & iguais & não & 6,21 & 5,59 & & & 2,599 & 37,382 & 013 &, 622 &, 100 & 1,027 \\
\hline (Pri7) Preocupação com a & Variâncias & assumidas & 5,93 & 5,57 & 17,343 & ,000 & 1,441 & 178 &, 151 &, 356 &, 039 &, 666 \\
\hline comunidade & iguais & não & 5,93 & 5,57 & & & 2,194 & 70,464 & 032 & ,356 & ,039 & 666 \\
\hline (Pri8) Geração de empregos & Variâncias & assumidas & 5,82 & 6,02 & 4,856 & ,029 &,- 956 & $\begin{array}{r}178 \\
55429\end{array}$ & 340 & $\begin{array}{l}-, 198 \\
-198\end{array}$ &,- 499 & 099 \\
\hline $\begin{array}{l}\text { (Pri9) Combate a exclusão } \\
\text { social }\end{array}$ & $\begin{array}{l}\text { Variâncias } \\
\text { iquais }\end{array}$ & $\begin{array}{l}\text { assumidas } \\
\text { não }\end{array}$ & $\begin{array}{l}6,00 \\
6,00\end{array}$ & $\begin{array}{l}5,76 \\
5,76\end{array}$ & 22,729 & ,000 & $\begin{array}{l}1,047 \\
1,691\end{array}$ & $\begin{array}{r}178 \\
82,116\end{array}$ & ,297 & $\begin{array}{l}\text {,237 } \\
\text {,237 }\end{array}$ & $\begin{array}{l}-, 044 \\
-, 044\end{array}$ & $\begin{array}{l}, 510 \\
, 510\end{array}$ \\
\hline
\end{tabular}

a. $\mathrm{n}=28$

b. $n=152$

c. A menos que indicado de outra maneira, os resultados da bootstrap são baseados em 10000 amostras bootstrap

Fonte: autora. 
Com o objetivo de investigar se os membros do Conselho Administrativo percebem maior importância nas diferentes categorias dos indicadores de desempenho em relação aos Cooperados, aplicou-se 0 teste $t$ de amostras independentes para as médias.

Inicialmente buscou-se investigar se os dados são normalmente distribuídos para cada um dos grupos. Considerando os valores obtidos, a maioria dos dados não são distribuídos normalmente, conforme avaliado pelo teste de Kolmogorov-Smirnov $(p<0,05)$.

De acordo com os resultados do teste Levene a homogeneidade das variâncias foi violada $(p<0,05)$ para as categorias de indicadores Financeiro (Fin), Associado (Ass), Processos Internos (Pro) e Aprendizado e Crescimento (Apr), assim os resultados para o Teste t de Welch são encontrados nas linhas "Variâncias iguais não assumidas". Já as categorias de indicadores Pessoas e Inovação (Pes) e Princípios Cooperativistas (Pri) apresentaram homogeneidade das variâncias $(p>0,05)$.

Por fim, não houve uma diferença estatisticamente significativa entre Conselho Administrativo (média $=6,075$, erro padrão de média $=0,1051$ ) e Cooperados (média $=6,011$, erro padrão de média $=0,560)$ apenas para a categoria de indicadores Pessoas e Inovação (Pes). Esta diferença de 0,064 (Percentil 95\%, IC [-0,164, 0,300]) não se mostrou estatisticamente significativa $(t(44,609)=0,543, p=0,590)$.

Para as demais categorias de indicadores houve diferença estatisticamente significativa entre os grupos Conselho Administrativo e Cooperados $(p<0,05)$.

Portanto, conclui-se que com exceção do módulo Pessoas e Inovação, todos os demais possuem diferenças estatísticas significativas em relação à opinião dos grupos em análise.

Mais especificamente, no módulo "Financeiro" as opiniões coincidem em apenas um indicador, no módulo "Associados" coincidem em dois indicadores, no módulo "Processos internos" em apenas um indicador, no módulo "Aprendizado e Crescimento" as opiniões não coincidem em nenhum dos indicadores, em "Pessoas e inovação", as opiniões coincidem em quase todos os indicadores (apenas um que não), e no módulo "Princípios cooperativistas" coincidem em cinco indicadores.

Sendo assim, é possível reconhecer que na amostra pesquisada os Cooperados e Conselheiros Administrativos divergem de opinião no que tange ao grau de importância da maior parte dos indicadores, mais especificamente em 37 dos 53 indicadores apresentados. 
Portanto, pode-se dizer que existem conflitos de opiniões entre os grupos de Cooperados e Conselheiros Administrativos, no que tange a Avaliação de Desempenho de cooperativas de Crédito, o que pode levar a conflitos de interesse, confirmando a hipótese 1.

\subsection{Hipótese 2}

A fim de testar a hipótese 2: Existem conflitos de interesse entre os grupos de cooperados e os gerentes em relação à Avaliação de Desempenho, visto que os gerentes tendem a agir conforme os interesses do Conselho Administrativo e não conforme o interesse dos cooperados, procedeu-se um teste $\mathrm{H}$ de KruskalWallis para determinar se haviam diferenças nos escores da importância atribuída aos diferentes indicadores de desempenho para cooperativas de crédito entre os grupos "Conselheiros Administrativos", "Cooperados" e "Gerentes".

Inicialmente verificou-se que as distribuições dos escores não foram semelhantes para todos os grupos, conforme avaliado pela inspeção visual dos boxplots. As diferenças não foram estatisticamente significativas $(p>0,05)$ nas variáveis Margem bruta (Fin6), Geração de rendas (Fin9), Menor custo das transações (Ass3), Ganhos financeiros de cada cooperado individualmente (Ass4), Segurança no emprego para os trabalhadores da cooperativa (Pes3), Pagamento de bons salários aos funcionários da cooperativa (Pes4) e Benefícios extras para bons funcionários (Pes5) (conforme valores de $X^{2}(k-1)$ e p-valor apresentados na tabela 39 ).

No entanto, as classificações médias dos escores foram estatisticamente significativamente diferentes $(p<0,05)$ entre os grupos para as demais variáveis (conforme valores de $\mathrm{X}^{2}(\mathrm{k}-1)$ e $\mathrm{p}$-valor apresentados na tabela 39 ), indicando que a distribuição de pelo menos um grupo é diferente da distribuição de outro grupo. 
Tabela 39 - Estatísticas do teste H de Kruskal-Wallis de amostras independentes

\begin{tabular}{|c|c|c|c|c|c|c|c|c|c|c|}
\hline \multicolumn{11}{|c|}{ Comparações $^{c}$} \\
\hline & & & & & Coop & Coop & Coop & Confis & & Gere \\
\hline & $\mathrm{n}$ & $\begin{array}{l}\text { Estatística } \\
\text { de teste }\left(x^{2}\right)\end{array}$ & G.L. ${ }^{a}$ & Sig. ${ }^{b}$ & $\begin{array}{c}x \\
\text { Gere }\end{array}$ & $\begin{array}{c}x \\
\text { ConAdm }\end{array}$ & $\begin{array}{c}x \\
\text { ConFis }\end{array}$ & $\begin{array}{c}x \\
\text { ConAdm }\end{array}$ & $\begin{array}{c}x \\
\text { ConAdm }\end{array}$ & $\begin{array}{c}\mathbf{X} \\
\text { ConFiscal }\end{array}$ \\
\hline Fin1 & 298 & 40,527 & 3 & 0,000 & 0,000 & 0,000 & & & & \\
\hline Fin2 & 298 & 16,581 & 3 & 0,001 & & 0,005 & & 0,001 & 0,006 & \\
\hline Fin3 & 298 & 20,82 & 3 & 0,000 & 0,000 & 0,011 & & & & \\
\hline Fin4 & 298 & 21,69 & 3 & 0,000 & 0,000 & 0,013 & & & & \\
\hline Fin5 & 298 & 15,475 & 3 & 0,001 & 0,002 & & & & & \\
\hline Fin6 & 298 & 4,549 & 3 & 0,208 & & & & & & \\
\hline Fin7 & 298 & 39,384 & 3 & 0,000 & 0,000 & 0,001 & & & & \\
\hline Fin8 & 298 & 39,299 & 3 & 0,000 & 0,000 & 0,001 & 0,019 & & & \\
\hline Fin9 & 298 & 11,295 & 3 & 0,010 & & & & & & \\
\hline Fin10 & 298 & 39,99 & 3 & 0,000 & 0,000 & & 0,000 & & & \\
\hline Fin11 & 298 & 56,74 & 3 & 0,000 & 0,000 & 0,000 & & & & \\
\hline Fin12 & 298 & 16,356 & 3 & 0,001 & 0,002 & & & & & 0,029 \\
\hline Fin13 & 298 & 48,53 & 3 & 0,000 & 0,000 & 0,001 & & & & 0,047 \\
\hline Ass1 & 298 & 93,546 & 3 & 0,000 & 0,000 & 0,000 & 0,028 & & & 0,037 \\
\hline Ass2 & 298 & 35,451 & 3 & 0,000 & 0,000 & & & & & \\
\hline Ass3 & 298 & 5,076 & 3 & 0,166 & & & & & & \\
\hline Ass4 & 298 & 7,846 & 3 & 0,049 & & & & & & \\
\hline Ass5 & 298 & 11,622 & 3 & 0,009 & 0,046 & & & & & \\
\hline Ass6 & 298 & 22,459 & 3 & 0,000 & 0,000 & & & & & \\
\hline Ass7 & 298 & 28,903 & 3 & 0,000 & 0,000 & & & & 0,000 & \\
\hline Ass8 & 298 & 15,298 & 3 & 0,002 & 0,002 & & & & 0,040 & \\
\hline Ass9 & 298 & 95,304 & 3 & 0,000 & 0,000 & 0,000 & 0,000 & & & \\
\hline Ass 10 & 298 & 104,972 & 3 & 0,000 & 0,000 & 0,000 & 0,000 & & & \\
\hline Ass11 & 298 & 15,706 & 3 & 0,001 & 0,010 & & 0,022 & & & \\
\hline Ass12 & 298 & 30,74 & 3 & 0,000 & 0,000 & 0,009 & 0,009 & & & \\
\hline Pro1 & 298 & 9,482 & 3 & 0,024 & 0,018 & & & & & \\
\hline Pro2 & 298 & 37,497 & 3 & 0,000 & 0,000 & & & & & \\
\hline Pro3 & 298 & 54,377 & 3 & 0,000 & 0,000 & 0,037 & 0,007 & & & \\
\hline Pro4 & 298 & 26,606 & 3 & 0,000 & 0,000 & & & & & \\
\hline Pro5 & 298 & 62,827 & 3 & 0,000 & 0,000 & & 0,000 & & 0,012 & \\
\hline Pro6 & 298 & 21,528 & 3 & 0,000 & 0,000 & & & & & \\
\hline Pro7 & 298 & 78,933 & 3 & 0,000 & 0,000 & 0,000 & 0,032 & & & \\
\hline Pro8 & 298 & 51,31 & 3 & 0,000 & 0,000 & 0,016 & 0,023 & & & \\
\hline Apr1 & 298 & 62,246 & 3 & 0,000 & 0,000 & 0,000 & & & & 0,024 \\
\hline Apr2 & 298 & 54,725 & 3 & 0,000 & 0,000 & & 0,005 & & & \\
\hline Apr3 & 298 & 22,759 & 3 & 0,000 & 0,000 & & & & & \\
\hline Pes1 & 298 & 27,607 & 3 & 0,000 & 0,002 & 0,009 & 0,000 & & & \\
\hline Pes2 & 298 & 12,552 & 3 & 0,006 & 0,019 & & & & & 0,023 \\
\hline Pes3 & 298 & 3,213 & 3 & 0,360 & & & & & & \\
\hline Pes4 & 298 & 8,28 & 3 & 0,041 & & & & & & \\
\hline Pes5 & 298 & 4,56 & 3 & 0,207 & & & & & & \\
\hline Pes6 & 298 & 13,753 & 3 & 0,000 & 0,002 & & & & & \\
\hline Pes7 & 298 & 19,772 & 3 & 0,003 & 0,000 & & & & & \\
\hline Pes8 & 298 & 15,759 & 3 & 0,001 & & & & & 0,001 & \\
\hline Pri1 & 298 & 85,524 & 3 & 0,000 & 0,000 & 0,000 & 0,000 & & & \\
\hline Pri2 & 298 & 26,25 & 3 & 0,000 & 0,000 & & 0,001 & & & \\
\hline Pri3 & 298 & 26,089 & 3 & 0,000 & 0,000 & & 0,005 & & & \\
\hline Pri4 & 298 & 39,845 & 3 & 0,000 & 0,000 & & & & 0,012 & 0,042 \\
\hline Pri5 & 298 & 24,687 & 3 & 0,000 & 0,000 & & & & & \\
\hline Pri6 & 298 & 67,7 & 3 & 0,000 & 0,000 & 0,014 & 0,000 & & & \\
\hline Pri7 & 298 & 67,759 & 3 & 0,000 & 0,000 & & 0,035 & & 0,000 & \\
\hline Pri8 & 298 & 20,604 & 3 & 0,000 & 0,006 & & & & 0,001 & 0,039 \\
\hline Pri9 & 298 & 20,146 & 3 & 0,000 & 0,000 & & & & & \\
\hline
\end{tabular}

${ }^{a}$ Graus de Liberdade

bSignificância Assintótica (teste bilateral)

c Resultado do teste Pairwise Comparisons assinalando as comparações que se apresentaram diferença estatisticamente significativas ao nível de $5 \%$.

Fonte: autora. 
Para descobrir quais grupos são diferentes de quais outros grupos foi executado um teste post hoc. No caso do teste de Kruskal-Wallis, foram executadas e interpretadas todas as comparações emparelhadas usando o procedimento de Dunn (1964) com um ajuste de Bonferroni.

Esta análise post hoc revelou diferenças estatisticamente significativas nos escores entre os grupos Gerente e Cooperados em 44 dos 46 indicadores que apresentaram haver diferença entre grupos, sendo que apenas os indicadores Retorno sobre o investimento e Condições de trabalho adequadas não apresentaram diferença nas respostas. Já, em relação ao grupo de Conselheiros Administrativos, o grupo Gerentes revelou diferenças estatisticamente significativas nos escores em 8 dos 46 indicadores.

Sendo assim, entende-se que a opinião dos Gerentes está mais próxima das respostas dos Conselheiros Administrativos, confirmando-se a hipótese 2 de que cooperados e gerentes tem opinião mais distante a respeito de avaliação de desempenho e que gerentes tem opiniões mais próximas dos conselheiros administrativos do que dos cooperados, o que pode em algum momento ocasionar conflitos de interesse.

\subsection{HIPÓTESE 3}

A fim de testar a hipótese 3: Os tomadores de empréstimos terão comportamento mais indulgente em relação à inadimplência. Além disso, serão menos preocupados com a profissionalização da administração, estabeleceu-se inicialmente que os tomadores de empréstimos são mais tolerantes em relação à inadimplência e por isso dão menos importância ao indicador "Nível de Inadimplemento", e são menos preocupados com a profissionalização da administração, por isso dão menos importância ao indicador "Profissionalização da Administração".

Inicialmente, com o objetivo de investigar se os "Tomadores de Empréstimos" ( média $=5,885$, desvio padrão $=1,275$, erro padrão da média 0,250 ) atribuem menor importância ao indicador Nível de Inadimplemento do que os "Não Tomadores de Empréstimos" (média $=6,000$, desvio padrão $=1,239$, erro padrão da média 0,110 ), aplicou-se o teste $\mathrm{t}$ para as médias dos dois grupos. Conforme avaliado pelo teste de Kolmogorov-Smirnov os dados não são distribuídos normalmente $(p<0,05)$. No 
entanto, como a amostra total é composta por 152 observações, o teste t de amostras independentes é considerado "robusto" para violações da normalidade (KANG; HARRING, 2012; LAERD STATISTICS, 2015; SAWILOWSKY; BLAIR, 1992). De acordo com o teste Levene (tabela 40), não se pode rejeitar a hipótese de igualdade entre as variâncias dos grupos "Tomadores de Empréstimos" e "Não Tomadores de Empréstimos" para a variável "Nível de Inadimplemento (NID)" ( $p=0,628)$. O que se permite concluir que há homogeneidade das variâncias, podendo proceder com 0 Teste t.

Por fim, pode-se dizer que não houve uma diferença estatisticamente significativa $(t(150)=0,430, p=0,668)$ entre as médias dos grupos "Tomadores de Empréstimos" e "Não Tomadores de Empréstimos" para a variável "Nível de Inadimplemento (NID)". Os resultados discutidos encontram-se nas tabelas 40 e 41 . 
Tabela 40 - Teste de amostras independentes

\begin{tabular}{|c|c|c|c|c|c|c|c|c|c|c|}
\hline & & \multicolumn{2}{|c|}{$\begin{array}{c}\text { Teste de Levene para } \\
\text { igualdade de } \\
\text { variâncias } \\
\end{array}$} & \multicolumn{7}{|c|}{ teste-t para Igualdade de Médias } \\
\hline & & \multirow[t]{2}{*}{ 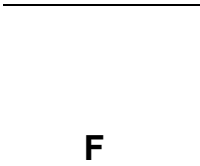 } & \multirow[b]{2}{*}{ Sig. } & \multirow[b]{2}{*}{$\mathbf{t}$} & \multirow[b]{2}{*}{ gl } & \multirow{2}{*}{$\begin{array}{c}\text { Sig. } \\
\text { (bilateral) }\end{array}$} & \multirow{2}{*}{$\begin{array}{l}\text { Diferença } \\
\text { média }\end{array}$} & \multirow{2}{*}{$\begin{array}{l}\text { Erro } \\
\text { padrão da } \\
\text { diferença }\end{array}$} & \multicolumn{2}{|c|}{$\begin{array}{c}95 \% \text { Intervalo de } \\
\text { Confiança da } \\
\text { Diferença }\end{array}$} \\
\hline & & & & & & & & & Inferior & Superior \\
\hline (Fin13) Nível & de Variâncias iguais assumidas & ,236 & ,628 & ,430 & 150 & ,668 & ,115 & ,268 &,- 415 & ,645 \\
\hline $\begin{array}{l}\text { inadimplemento } \\
\text { (NID) }\end{array}$ & $\begin{array}{l}\begin{array}{l}\text { Variâncias iguais não } \\
\text { assumidas }\end{array} \\
\end{array}$ & & & ,422 & 35,426 & ,676 & 115 &, 273 &,- 439 & ,670 \\
\hline
\end{tabular}

Fonte: autora.

Tabela 41 - Bootstrap para Teste de amostras independentes

\begin{tabular}{|c|c|c|c|c|c|}
\hline & \multirow[b]{3}{*}{ Diferença média } & \multicolumn{4}{|c|}{ Bootstrap $^{\mathbf{a}}$} \\
\hline & & \multirow[b]{2}{*}{ Viés } & \multirow[b]{2}{*}{ Erro Erro } & \multicolumn{2}{|c|}{ Intervalo de Confiança 95\% } \\
\hline & & & & Inferior & Superior \\
\hline $\begin{array}{l}\text { (Fin13) Nível de inadimplemento Variâncias iguais assumidas } \\
\end{array}$ & 115 & ,003 & 273 &,- 400 & ,675 \\
\hline (NID) Variâncias iguais não assumidas &, 115 & ,003 & ,273 &,- 400 & 675 \\
\hline
\end{tabular}

a. A menos que indicado de outra maneira, os resultados da bootstrap são baseados em 10000 amostras bootstrap

Fonte: autora. 
Com o objetivo de investigar se os "Tomadores de Empréstimos" (média = 6,462, desvio padrão $=0,963$, erro padrão da média $=0,86$ ) percebem maior importância no indicador Profissionalização da Administração do que os "Não Tomadores de Empréstimos" (média $=6,254$, desvio padrão $=0,706$, erro padrão da média $=0,138$ ), aplicou-se o teste t entre as médias do indicador "Profissionalização da Administração" para os dois grupos.

Conforme avaliado pelo teste Kolmogorov-Smirnov, os dados não são distribuídos normalmente $(p<0,05)$. No entanto, como a amostra total é composta por 152 observações, o teste t de amostras independentes é considerado "robusto" para violações da normalidade (KANG; HARRING, 2012; LAERD STATISTICS, 2015; SAWILOWSKY; BLAIR, 1992). De acordo com o teste de Levene (tabela 42) não se pode rejeitar a hipótese de igualdade entre as variâncias dos grupos "Tomadores de Empréstimos" e "Não Tomadores de Empréstimos" para a variável "Profissionalização da Administração" ( $p=0,254)$. O que se permite concluir que há homogeneidade das variâncias, podendo proceder com o Teste t.

Por fim, pode-se dizer que não houve uma diferença estatisticamente significativa $(t(150)=-1,042, p=0,299)$ entre as médias dos grupos "Tomadores de Empréstimos" e "Não Tomadores de Empréstimos" para a variável "Profissionalização da Administração". Os valores apresentados podem ser visualizados nas tabelas 42 e 43. 
Tabela 42 - Teste de amostras independentes

\begin{tabular}{|c|c|c|c|c|c|c|c|c|c|c|}
\hline & & \multicolumn{4}{|c|}{$\begin{array}{l}\text { Teste de Levene } \\
\text { para igualdade de } \\
\text { variâncias }\end{array}$} & \multicolumn{4}{|c|}{ teste-t para Igualdade de Médias } & \\
\hline & & \multirow[b]{2}{*}{$\mathbf{F}$} & \multirow[b]{2}{*}{ Sig. } & \multirow[b]{2}{*}{$\mathbf{t}$} & \multirow[b]{2}{*}{ gl } & \multirow{2}{*}{$\begin{array}{l}\text { Sig. } \\
\text { (bilateral) }\end{array}$} & \multirow{2}{*}{$\begin{array}{c}\text { Diferença } \\
\text { média }\end{array}$} & \multirow{2}{*}{$\begin{array}{c}\text { Erro } \\
\text { padrão da } \\
\text { diferença }\end{array}$} & \multicolumn{2}{|c|}{$\begin{array}{c}95 \% \text { Intervalo de } \\
\text { Confiança da Diferença }\end{array}$} \\
\hline & & & & & & & & & Inferior & Superior \\
\hline (Pes1) & Variâncias iguais assumidas & 1,313 & ,254 & $-1,042$ & 150 & 299 &,- 208 & ,199 &,- 601 & ,186 \\
\hline $\begin{array}{l}\text { Profissionalização } \\
\text { administração }\end{array}$ & $\begin{array}{l}\text { da Variâncias iguais não } \\
\text { assumidas }\end{array}$ & & & $-1,274$ & 46,499 & ,209 &,- 208 & 163 &,- 535 & 120 \\
\hline
\end{tabular}

Tabela 43 - Bootstrap para Teste de amostras independentes

\begin{tabular}{|c|c|c|c|c|c|}
\hline & \multirow[b]{3}{*}{ Diferença média } & \multicolumn{4}{|c|}{ Bootstrap $^{a}$} \\
\hline & & \multirow[b]{2}{*}{ Viés } & \multirow[b]{2}{*}{ Erro Erro } & \multicolumn{2}{|c|}{ Intervalo de Confiança 95\% } \\
\hline & & & & Inferior & Superior \\
\hline da Variâncias iguais assumidas &,- 208 & ,001 & ,162 &,- 515 & ,121 \\
\hline Variâncias iguais não assumidas &,- 208 &, 001 & ,162 &,- 515 &, 121 \\
\hline
\end{tabular}

a. A menos que indicado de outra maneira, os resultados da bootstrap são baseados em 10000 amostras bootstrap

Fonte: autora. 
Portanto, conclui-se que para a presente amostra, não houve divergência significativa em relação ao grau de importância dado por "tomadores de empréstimos" e "não tomadores de empréstimos" no que tange aos indicadores Nível de inadimplemento e Profissionalização da Administração.

Nesse caso, considerando a amostra do presente trabalho, rejeita-se a hipótese H3, de que tomadores de empréstimos terão comportamento mais indulgente em relação à inadimplência e serão menos preocupados com a profissionalização da administração.

\subsection{HIPÓTESE 4}

Com o objetivo de testar a hipótese 4: Aqueles cooperados que se associarem com o objetivo de depositar suas economias focarão a segurança da instituição e o adequado nível de remuneração de seus depósitos, com preocupação a respeito dos custos das transações. Dessa forma, apoiarão também a melhoria de sua estrutura, o que, entre outros critérios, inclui a profissionalização da gerência, estabeleceu-se inicialmente que os que depositam suas economias são aqueles que utilizam os serviços de investimentos, e dão maior importância aos indicadores: Retorno sobre o investimento, Melhorias das capacidades dos funcionários, Menor custo das transações, Ganhos financeiros de cada cooperado individualmente, Profissionalização da administração, Melhoria constante da estrutura da cooperativa, e Perpetuação da instituição.

Com o objetivo de investigar se os "Cooperados que utilizam os serviços de investimento" percebem maior importância nos indicadores supracitados do que os "Cooperados que não utilizam os serviços de investimento", aplicou-se o teste t entre as médias, conforme valores das médias apresentadas na tabela 44 . Os testes executados utilizando reamostragem bootstrap com 10000 de amostra. 
Tabela 44 - Estatísticas dos grupos

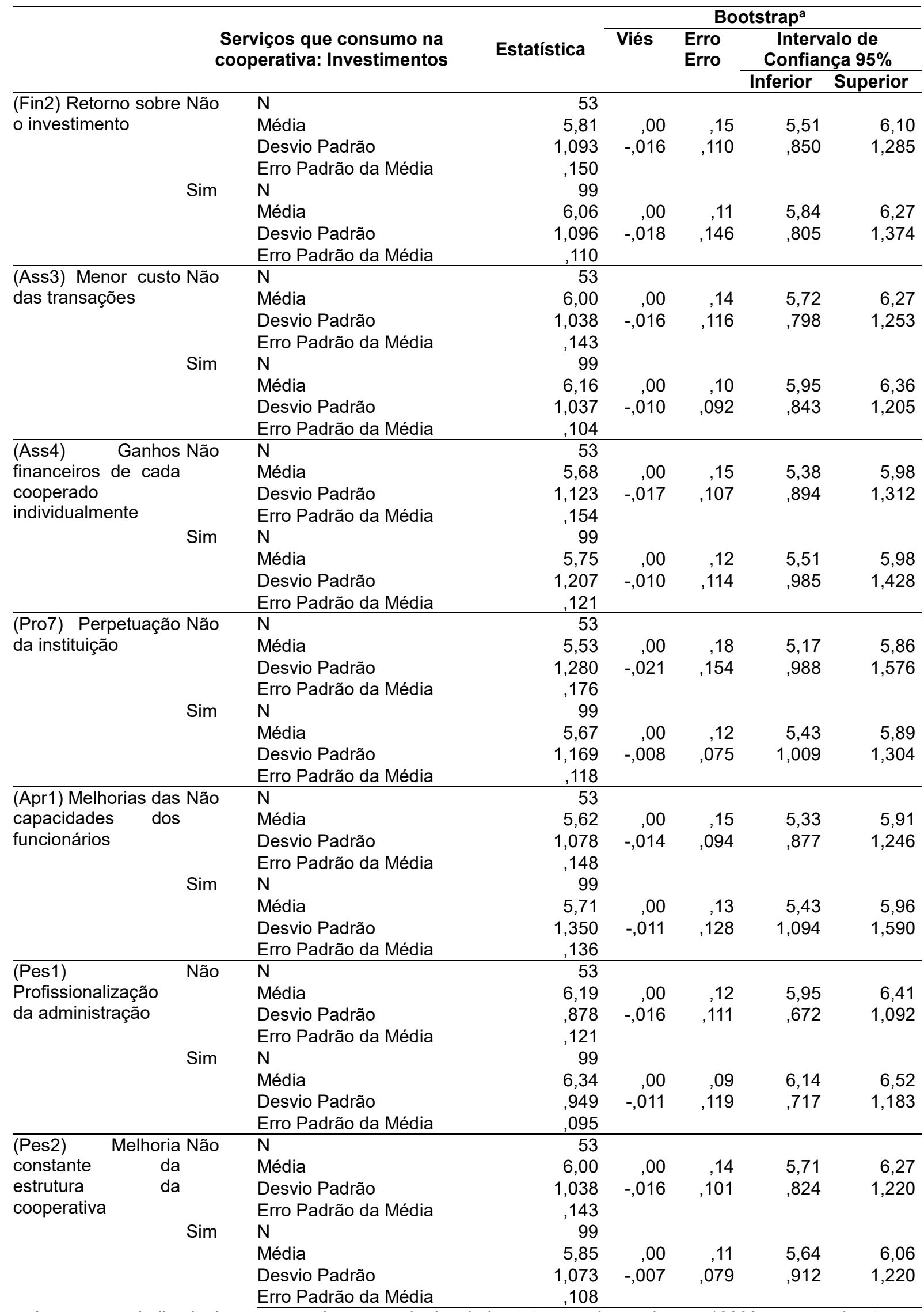

a. A menos que indicado de outra maneira, os resultados da bootstrap são baseados em 10000 amostras bootstrap Fonte: autora. 
Inicialmente buscou-se investigar se os dados são normalmente distribuídos para cada um dos grupos. Os dados não são distribuídos normalmente, conforme avaliado pelo teste de Kolmogorov-Smirnov $(p<0,05)$. No entanto, como a amostra total é composta por 152 observações, o teste $\mathrm{t}$ de amostras independentes é considerado "robusto" para violações da normalidade (KANG; HARRING, 2012; LAERD STATISTICS, 2015; SAWILOWSKY; BLAIR, 1992).

Em um segundo momento, buscou-se testar a homogeneidade das variâncias em cada grupo. Considerando os valores do teste Levene, não se pode rejeitar a hipótese de igualdade entre as variâncias dos grupos para todos as variáveis $(p>0,05)$. O que se permite concluir que há homogeneidade das variâncias, podendo proceder com o Teste t para todos os indicadores.

O nível de significância encontrado pelo teste t para os indicadores analisados (conforme resultados apresentados na tabela 45) foi superior ao nível alfa estabelecido $(p>0,05)$. Por isso, não se pode rejeitar a hipótese de igualdade entre as médias dos grupos "Cooperados que utilizam os serviços de investimento" e "Cooperados que não utilizam os serviços de investimento" para os indicadores testados, logo não houve uma diferença estatisticamente significativa entre as médias dos grupos. O erro padrão e o intervalo de confiança estimados pelo bootstrap estão apresentadas na tabela 46 .

Portanto, conclui-se que para a presente amostra, não houve divergência significativa em relação ao grau de importância dado por "Cooperados que utilizam os serviços de investimento" e "Cooperados que não utilizam os serviços de investimento" no que tange aos indicadores Retorno sobre o investimento, Melhorias das capacidades dos funcionários, Menor custo das transações, Ganhos financeiros de cada cooperado individualmente, Profissionalização da administração, Melhoria constante da estrutura da cooperativa, e Perpetuação da instituição.

Nesse caso, considerando a amostra do presente trabalho, rejeita-se a hipótese $\mathrm{H} 4$, de que os cooperados que se associarem com o objetivo de depositar suas economias irão focar na segurança da instituição e no adequado nível de remuneração de seus depósitos, com preocupação a respeito dos custos das transações; bem como apoiarão também a melhoria de sua estrutura, o que, entre outros critérios, inclui a profissionalização da gerência. 
Tabela 45 - Teste de amostras independentes

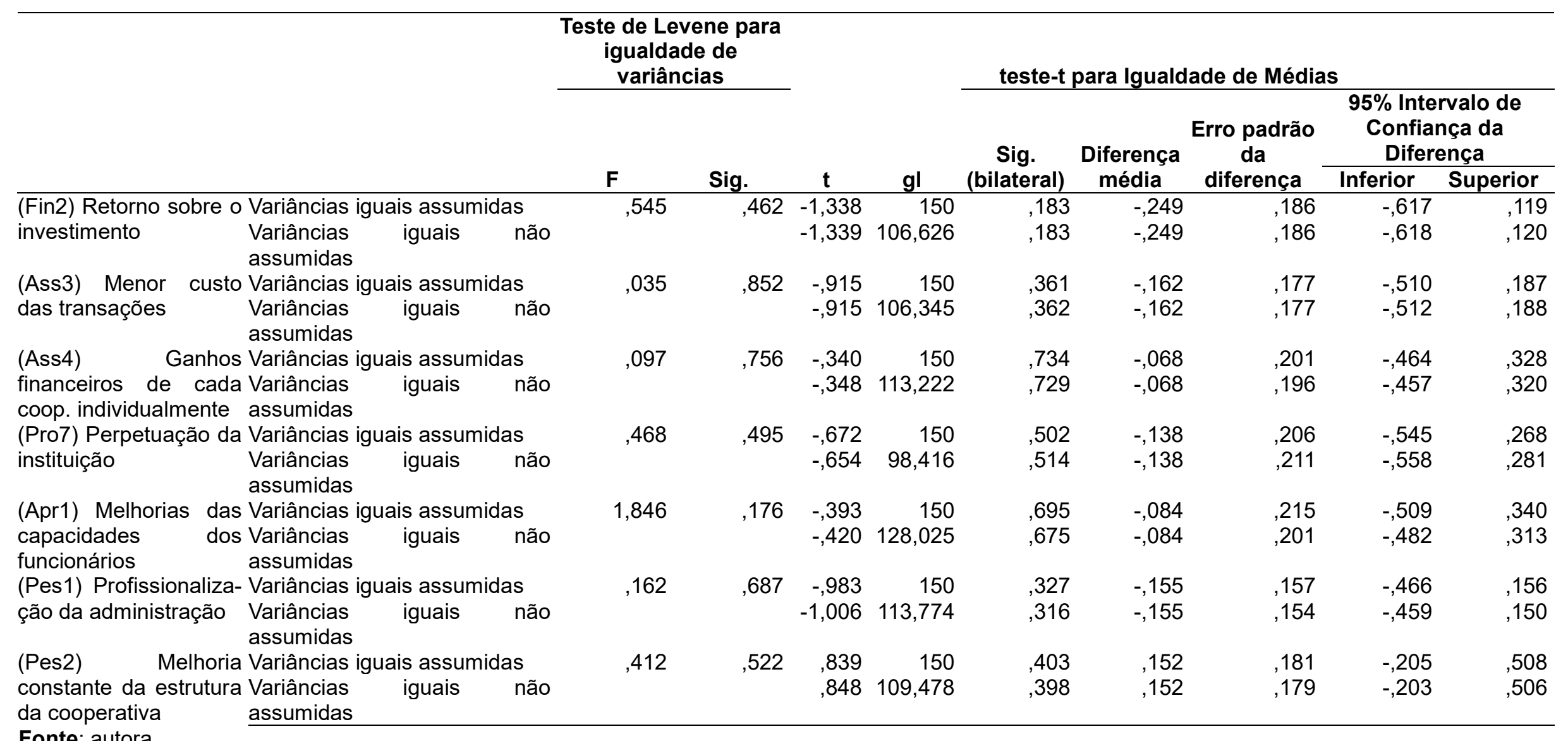

Fonte: autora. 
Tabela 46 - Bootstrap para Teste de amostras independentes

\begin{tabular}{|c|c|c|c|c|c|}
\hline & \multirow[b]{3}{*}{ Diferença média } & \multirow[b]{3}{*}{ Viés } & \multicolumn{3}{|c|}{ Bootstrap $^{a}$} \\
\hline & & & \multirow[b]{2}{*}{ Erro padrão } & \multicolumn{2}{|c|}{ Intervalo de Confiança $95 \%$} \\
\hline & & & & Inferior & Superior \\
\hline o Variâncias iguais assumidas &,- 249 &,- 001 & 188 &,- 612 & 117 \\
\hline Variâncias iguais não assumidas &,- 249 &,- 001 & 188 &,- 612 & 117 \\
\hline custo $\quad$ das Variâncias iguais assumidas &,- 162 & ,002 & 176 &,- 512 & 186 \\
\hline Variâncias iguais não assumidas &,- 162 & ,002 & 176 &,- 512 & 186 \\
\hline (Ass4) Ganhos financeiros de Variâncias iguais assumidas &,- 068 & ,003 & , 195 &,- 438 & ,314 \\
\hline cada cooperado individualmente Variâncias iguais não assumidas &,- 068 & ,003 & ,195 &,- 438 & ,314 \\
\hline (Pro7) Perpetuação da instituição Variâncias iguais assumidas &,- 138 & ,001 & ,210 &,- 563 & ,269 \\
\hline Variâncias iguais não assumidas &,- 138 & ,001 & 210 &,- 563 & ,269 \\
\hline (Apr1) Melhorias das capacidades Variâncias iguais assumidas &,- 084 & 005 & 199 &,- 470 & 317 \\
\hline dos funcionários $\quad$ Variâncias iguais não assumidas &,- 084 & ,005 & 199 &,- 470 & ,317 \\
\hline da Variâncias iguais assumidas &,- 155 & 001 & 152 &,- 453 & 144 \\
\hline Variâncias iguais não assumidas &,- 155 & ,001 & 152 &,- 453 & 144 \\
\hline (Pes2) Melhoria constante da Variâncias iguais assumidas &, 152 & ,002 & 178 &,- 206 & ,495 \\
\hline estrutura da cooperativa $\quad \underline{\text { Variâncias iguais não assumidas }}$ & ,152 &, 002 & ,178 &,- 206 & ,495 \\
\hline
\end{tabular}

a. A menos que indicado de outra maneira, os resultados da bootstrap são baseados em 10000 amostras bootstrap

Fonte: autora. 


\subsection{HIPÓTESE 5}

A fim de testar a hipótese 5: Devido ao perfil dos associados, há conflitos de interesse dentro do próprio grupo de associados, foi realizado um teste $\mathrm{H}$ de Kruskal-Wallis, conduzido para determinar se haviam diferenças nos escores da importância atribuída aos diferentes indicadores entre os níveis das variáveis que caracterizam o perfil dos cooperados. Pode-se considerar que as distribuições dos escores não foram semelhantes para todos os grupos, conforme avaliado pela inspeção visual dos boxplots.

Para descobrir quais grupos são diferentes de quais outros grupos foi executado um teste post hoc. No caso do teste de Kruskal-Wallis, foram executadas e interpretadas todas as comparações emparelhadas usando o procedimento de Dunn (1964) com um ajuste de Bonferroni. Valores de $p$ ajustados são apresentados. Os valores são postos médios, a menos que seja indicado o contrário.

A primeira variável de perfil analisada foram os níveis de idade dos cooperados. As diferenças nas classificações médias dos escores foram estatisticamente significantes $(p<0,05)$ apenas para os indicadores Fin4 $\left(X^{2}(3)=7,920, p=0,048\right)$, Ass7 $\left(X^{2}(3)=8,037, p=0,045\right)$, Ass9 $\left(X^{2}(3)=11,817, p=0,008\right)$, Ass11 $\left(X^{2}(3)=7,983, p=0,046\right)$, Pro2 $\left(X^{2}(3)=10,476, p=0,015\right)$, Pro3 $\left(X^{2}(3)=11,098, p=0,011\right)$, Pri1 $\left(X^{2}(3)=8,459\right.$, $p=0,048)$, Pri3 $\left(X^{2}(3)=10,171, p=0,037\right)$ e Pri7 $\left(X^{2}(3)=10,016, p=0,018\right)$. Para as demais variáveis as diferenças não foram estatisticamente significativas $(p>0,05)$ entre os diferentes níveis de idade dos cooperados.

A análise post hoc revelou diferenças estatisticamente significativas nos escores dos seguintes indicadores:

- Fin4 entre os grupos "18 a 24 anos" (postos médios = 65,04) e "acima de 51 anos" (postos médios = 102,17) $(p=0,046)$;

- Ass7 entre os grupos "18 a 24 anos" (postos médios = 87,74) e "acima de 51 anos" (postos médios $=49,83)(p=0,032)$;

- Ass9 entre os grupos "25 a 35 anos" (postos médios = 67,61) e "acima de 51 anos" (postos médios $=108,58)(p=0,013)$;

- Ass11 entre os grupos "25 a 35 anos" (postos médios = 71,24) e "acima de 51 anos" (postos médios $=107,25)(p=0,043)$; 
- Pro2 entre os grupos "25 a 35 anos" (postos médios = 5,136) e "36 a 50 anos" $(M=5,869)(p=0,009)$;

- Pro3 entre os grupos "25 a 35 anos" (postos médios = 64,21) e "36 a 50 anos" $(M=88,32)(p=0,050)$;

- Pri1 entre os grupos "25 a 35 anos" (postos médios $=67,91$ ) e "acima de 51 anos" (postos médios $=104,62)(p=0,036)$;

- Pri3 entre os grupos "25 a 35 anos" (postos médios = 66,99) e "36 a 50 anos" (postos médios $=94,59)(p=0,013)$.

- Pri7 entre os grupos "25 a 35 anos" (postos médios $=67,99$ ) e "acima de 51 anos" (postos médios $=106,71)(p=0,021)$;

É interessante notar que a faixa etária de menor idade, considera menos importante o indicador Fin4 (Capital em giro) do que a faixa etária mais alta participantes da pesquisa; e mais importante o indicador Ass7 (Educação, formação e informação ao cooperado).

Por sua vez, os participantes de idade entre 25 e 35 anos dão menor importância aos indicadores Ass9 (Associados em assembleia geral ordinária (AGO) e Ass11 (Sobras ou faturamento por cooperado) do que os de idade acima de 51 anos.

Os grupos de pessoas de 25 a 25 anos classificaram com menor grau de importância os indicadores Pro2 (Percentual de transações realizadas através dos diversos canais) e Pro3 (Projetos sociais desenvolvidos) do que os participantes com idade entre 36 e 50 anos.

Os participantes com idade entre 25 e 35 anos atribuíram menor grau de importância aos indicadores Pri1 (Cumpre princípios cooperativistas) e Pri7 (Preocupação com a comunidade) do que aqueles com idade acima de 51 anos.

Os participantes entre 25 e 35 anos consideram menos importante o indicador Pro3 (Solidariedade) do que os participantes com idade entre 36 e 50 anos.

Dessa forma, percebe-se que os participantes que se encaixam nas faixas etárias de menor idade têm tendência de classificar os indicadores com menor grau de importância, quando comparados aqueles de maior faixa etária.

A segunda variável de perfil analisada foram os níveis de escolaridade dos cooperados. As diferenças nas classificações médias dos escores foram estatisticamente significantes apenas para o indicador Ass7 $\left(X^{2}(7)=15,906, p=0,026\right)$. 
Para todas as demais variáveis as diferenças não foram estatisticamente significativas $(p>0,05)$ entre os diferentes níveis de escolaridade dos cooperados.

A análise post hoc revelou diferenças estatisticamente significativas nos escores do indicador Ass7 (Educação, formação e informação ao cooperado) entre os grupos Mestrado ou doutorado (postos médios $=42,11$ ) e Superior Incompleto (postos médios $=90,62)(p=0,038)$ mas não entre os demais grupos. É interessante perceber que os grupos de maior instrução (mestrado ou doutorado) classificaram com menor importância indicador referente a educação, formação e informação ao cooperado do que um grupo de menor instrução (superior incompleto).

A terceira variável de perfil analisada foram os níveis de renda familiar dos cooperados. As diferenças nas classificações médias dos escores foram estatisticamente significantes apenas para os indicadores Ass3 $\left(X^{2}(5)=15,241, p=\right.$ $0,009)$ e Ass7 $\left(X^{2}(5)=11,446, p=0,043\right)$.Para todas as variáveis as diferenças não foram estatisticamente significativas $(p>0,05)$ entre os diferentes níveis de renda familiar dos cooperados.

A análise post hoc revelou diferenças estatisticamente significativas nos escores dos seguintes indicadores:

- Ass3 entre os grupos $R \$ 964-R \$ 1.908$ (postos médios $=53,11$ ) e mais de $R \$ 7.632$ (postos médios $=93,56)(p=0,006)$ mas não entre os demais grupos;

- Ass7 entre os grupos $R \$ 1.908-R \$ 3.816$ (postos médios $=92,12$ ) e mais de $R \$ 7.632$ (postos médios $=63,58)(p=0,029)$ mas não entre os demais grupos.

Interessante notar que as diferenças aparecem entre os níveis extremos. Sendo que na a renda mais alta considera mais importante o indicador Ass3 (Menor custo das transações), enquanto o nível de renda mais baixo considera mais importante o indicador Ass7 (Educação, formação e informação ao cooperado).

A quarta variável de perfil analisada foi o tempo de associado dos cooperados. As diferenças nas classificações médias dos escores foram estatisticamente significantes apenas para o indicador Ass6 $\left(X^{2}(3)=12,127, p=0,007\right)$. Para todas as variáveis as diferenças não foram estatisticamente significativas $(p>0,05)$ entre os diferentes níveis de tempo de associado dos cooperados.

A análise post hoc revelou diferenças estatisticamente significativas nos escores entre os grupos "entre 3 e 4 anos" (postos médios $=59,42$ ) e mais de 5 anos (postos médios $=90,40)(p=0,006)$ mas não entre os demais grupos. Portanto, Ass6 
(Emancipação social e econômica do associado) foi mais bem avaliada por aqueles que são associados há mais tempo.

A sexta variável de perfil analisada foi o número de assembleias que o cooperado participou. As diferenças nas classificações médias dos escores foram estatisticamente significantes $(\mathrm{p}<0,05)$ apenas para os indicadores Fin5, Fin7, Fin8, Ass1, Ass9 e Ass12. Para todas as variáveis as diferenças não foram estatisticamente significativas $(p>0,05)$ entre os diferentes níveis de tempo de associado dos cooperados.

A análise post hoc revelou diferenças estatisticamente significativas nos escores dos seguintes indicadores:

- Fin5 entre os grupos "nunca participei" (postos médios = 71,30) e "mais de 5 assembleias" (postos médios $=109,75)(p=0,015)$ e também "1 assembleia" (postos médios $=56,56)$ e "mais de 5 assembleias" (postos médios $=109,75)(p=0,011)$ mas não entre os demais grupos;

- Fin7 entre os grupos "nunca participei" (postos médios = 69,29) e "mais de 5 assembleias" (postos médios $=105,38)(p=0,028)$;

- Fin8 entre os grupos "3 assembleias" (postos médios $=63,83$ ) e "mais de 5 assembleias" (postos médios $=110,41)(p=0,037)$ e também "2 assembleias" (postos médios $=65,81)$ e "mais de 5 assembleias" (postos médios $=110,41)(p=0,016)$ mas não entre os demais grupos;

- Ass1 entre os grupos "nunca participei" (postos médios = 70,75) e "mais de 5 assembleias" (postos médios $=107,66)(p=0,027)$ e "1 assembleia" (postos médios $=55,27)$ e "mais de 5 assembleias" (postos médios $=107,66)(p=0,015)$ mas não entre os demais grupos;

- Ass9 entre os grupos "nunca participei" (postos médios = 68,59) e "mais de 5 assembleias" (postos médios $=114,12)(p=0,002)$ e também "4 assembleias" (postos médios $=57,83)$ e "mais de 5 assembleias" (postos médios $=114,12)(p=$ 0,009) mas não entre os demais grupos;

- Ass12 entre os grupos "nunca participei" (postos médios = 74,71) e "mais de 5 assembleias" (postos médios $=109,28)(p=0,042)$ e também "4 assembleias" (postos médios $=60,46)$ e "mais de 5 assembleias" (postos médios $=109,28)(p=$ $0,033)$ mas não entre os demais grupos. 
Salienta-se que aqueles que menos participam das assembleias (nunca participaram ou participaram uma vez) demonstraram menor grau de importância para os indicadores Fin5 (Grau do endividamento financeiro), Fin7 (Resultado econômico), Ass1 (Retenção de cooperantes) do que aqueles que participaram de mais de 5 assembleias.

Aqueles que participaram de duas ou três assembleias também percebem menor grau de importância nos indicadores Fin8 (Capitalização).

Os grupos que nunca participaram ou participaram de quatro assembleias reconhecem menor valor em indicadores como Ass9 (Associados em assembleia geral ordinária (AGO) e Ass12 (Relevância do associado na tomada de decisão) do que aqueles que participaram de mais de 5 assembleias.

De maneira geral percebe-se que os participantes da amostra analisada cujas faixas etárias condizem a uma idade menor têm tendência de classificar os indicadores com menor grau de importância, quando comparados aqueles de maior faixa etária.

Também se pode notar que grupos de maior instrução (mestrado ou doutorado) classificaram com menor importância indicador referente a educação, formação e informação ao cooperado do que um grupo de menor instrução (superior incompleto).

Notou-se também que participantes de renda mais alta consideram mais importante o indicador Menor custo das transações, do que os de renda mais baixa, e esses consideram mais importante o indicador Educação, formação e informação ao cooperado do que os de renda mais alta.

Sendo assim, vê-se que quando considerado o perfil do associado (faixa etária, escolaridade, renda e participação em assembleias) para essa amostra, houve divergência de opiniões, principalmente no que tange a indicadores como Grau do endividamento financeiro, Resultado econômico, Retenção de cooperantes, Capitalização, Associados em assembleia geral ordinária, Relevância do associado na tomada de decisão, Custo das transações, Educação, formação e informação ao cooperado.

Portanto, pode-se dizer que em relação a essas variáveis existe divergência de opiniões entre os próprios cooperados, o que pode gerar conflitos de interesse. 


\subsection{HIPÓTESE 6}

Com o objetivo de testar a hipótese 6: Existe tendência dos cooperados priorizarem seus benefícios individuais e não coletivos nas cooperativas de crédito, um teste $\mathrm{t}$ dependente foi conduzido para determinar se há diferenças nas médias da importância atribuída pelo grupo dos cooperados aos ganhos coletivos ( édia $=5,650$, desvio padrão $=0,91355$, e erro padrão da média $=0,7410$ ) e individuais (média $=5,815$, desvio padrão $=0,6879$, e erro padrão da média $=0,558$ ).

As variáveis que mediram a importância para os ganhos coletivos são: Ganhos financeiros de todos os cooperados (enquanto grupo); Projetos Sociais Desenvolvidos; Preocupação com a comunidade; Geração de empregos; e Combate à exclusão social. E as que mediram ganhos individuais foram: Satisfação de cooperantes; Menor custo das transações; Ganhos financeiros de cada cooperado individualmente; Emancipação social e econômica do associado; Realização pessoal dos cooperados; Sobras ou faturamento por cooperado.

Inicialmente buscou-se investigar se os dados são normalmente distribuídos para cada um dos grupos. Conforme avaliado pelo teste de Kolmogorov-Smirnov, os dados não são distribuídos normalmente, $(p<0,05)$. No entanto, como a amostra total é composta por 152 observações, o teste t de amostras independentes é considerado "robusto" para violações da normalidade (KANG; HARRING, 2012; LAERD STATISTICS, 2015; SAWILOWSKY; BLAIR, 1992).

Considerando as médias encontradas os cooperados atribuem mais importância aos ganhos individuais do que aos ganhos coletivos, gerando uma diferença estatisticamente significativa de 0,16579 (IC 95\%, -0,28697 a -0,04461), t $(152)=-2,703, p<0,05, r=0,21)$.

Portanto, conclui-se que para a presente amostra, aceita-se a hipótese $\mathrm{H} 6$, de que existe uma tendência dos cooperados priorizarem seus benefícios individuais e não coletivos nas cooperativas de crédito.

\subsection{HIPÓTESE 7}

A fim de testar a hipótese 7: Há conflitos de interesses entre os membros do Conselho Fiscal e Administrativo em relação à Avaliação do Desempenho da Cooperativa de Crédito, um teste $t$ de amostras independentes foi executado para 
determinar em quais indicadores de cada uma das categorias os "Cooperados" e "Conselho Administrativo" apresentam níveis de percepção de importância diferentes. O bootstrapping foi empregado para gerar intervalos de confiança para a diferença entre as médias, sendo cada intervalo de confiança baseado em 10000 amostras de bootstrapping.

Investigou-se a normalidade da distribuição para cada um dos grupos por meio do teste de Kolmogorov-Smirnov. Para as distribuições não-normais, como a amostra total é composta por 52 observações, o teste $t$ de amostras independentes é considerado "robusto" para violações da normalidade (KANG; HARRING, 2012; LAERD STATISTICS, 2015; SAWILOWSKY; BLAIR, 1992). Já a homogeneidade das variâncias foi testada utilizando o teste de Levene. Caso a homogeneidade das variâncias for violada, então foi utilizado o Teste $t$ de Welch, que se mostra mais robusto quando há a violação da homogeneidade das variâncias somado a expressiva diferença no tamanho das amostras (tamanhos de grupo desiguais) (HOWELL, 2012; KOHR; GAMES, 1974).

De acordo com os resultados do teste Levene a homogeneidade das variâncias foi violada nos indicadores Fin1, Fin4, Fin11 e Fin13 ( $p<0,05)$, do módulo Financeiro, assim os resultados para o Teste $\mathrm{t}$ de Welch são encontrados nas linhas "Variâncias iguais não assumidas". Os demais indicadores apresentaram homogeneidade das variâncias $(p>0,05)$.

Por fim, houve uma diferença estatisticamente significativa entre Conselho Fiscal e Conselho Administrativo para os indicadores Fin1, Fin2, Fin7, Fin10, Fin12 e Fin13. As diferenças entre os grupos se mostraram estatisticamente significativas, pois $p<0,05$. Para os demais indicadores (Fin3, Fin4, Fin5, Fin6, Fin8, Fin9 e Fin11) não houve diferença estatisticamente significativa entre os grupos Conselho Administrativo e Cooperados ( $p>0,05)$.

A tabela 47 compila os resultados para o módulo Financeiro. 
Tabela 47 - Estatísticas dos grupos: categoria Financeiro

\begin{tabular}{|c|c|c|c|c|c|c|c|c|c|c|c|c|}
\hline & & & \multirow[b]{2}{*}{$\begin{array}{c}\begin{array}{c}\text { Conselho } \\
\text { Fiscal }^{\mathrm{a}}\end{array} \\
\text { Média } \\
\end{array}$} & \multirow[b]{2}{*}{$\begin{array}{c}\begin{array}{c}\text { Conselho } \\
\text { Administrativo }\end{array} \\
\text { Média }\end{array}$} & \multicolumn{2}{|c|}{$\begin{array}{l}\text { Teste de } \\
\text { Levene }\end{array}$} & \multicolumn{3}{|c|}{$\begin{array}{c}\text { teste-t para } \\
\text { Igualdade de Médias }\end{array}$} & \multicolumn{3}{|c|}{ Bootstrapc } \\
\hline & & & & & $\mathbf{F}$ & Sig. & $\mathbf{t}$ & gl & $\begin{array}{c}\text { Sig. } \\
\text { (bilateral) }\end{array}$ & $\begin{array}{c}\text { Diferença } \\
\text { média }\end{array}$ & $\begin{array}{l}\text { Interv } \\
\text { Confian } \\
\text { Inferior }\end{array}$ & $\begin{array}{l}\text { alo de } \\
\text { iça } 95 \% \\
\text { Inferior }\end{array}$ \\
\hline Crescimento & Variâncias & assumidas & 6,12 & 6,50 & 28,498 & ,000 & - & $-\quad 51$ & ,006 &,- 380 &,- 618 &,- 124 \\
\hline vendas & iguais & não & 6,12 & 6,50 & & & & - 43,900 & ,005 &,- 380 &,- 618 &,- 124 \\
\hline (Fin2) Retorno sobre & Variâncias & assumidas & 5,76 & 6,61 &, 748 & ,391 & - & $-\quad 51$ &, 000 &,- 847 & $-1,235$ &,- 468 \\
\hline investimento & iguais & não & 5,76 & 6,61 & & & & - 41,703 &, 000 &,- 847 & $-1,235$ &,- 468 \\
\hline (Fin3) Rentabilidade & Variâncias & assumidas & 6,36 & 6,46 & 2,170 &, 147 &,- 459 & 51 & ,648 &,- 104 &,- 474 & ,369 \\
\hline patrimônio líquido & iguais & não & 6,36 & 6,46 & & &,- 476 & 39,440 & ,636 &,- 104 &,- 474 & ,369 \\
\hline (Fin4) Capital em giro & Variâncias & assumidas & 6,00 & 6,32 & 16,194 & ,000 & - & $-\quad 51$ & ,109 &,- 321 &,- 687 & ,067 \\
\hline & iguais & não & 6,00 & 6,32 & & & & - 44,106 & ,100 &,- 321 &,- 687 & ,067 \\
\hline (Fin5) & Variâncias & assumidas & 5,96 & 6,25 & ,389 &, 536 & - & $-\quad 51$ & 177 &,- 290 &,- 725 & 115 \\
\hline endividamento financeiro & iguais & não & 5,96 & 6,25 & & & & $-43,376$ & ,186 &,- 290 &,- 725 & ,115 \\
\hline (Fin6) Margem bruta & Variâncias & assumidas & 5,72 & 6,07 & ,674 & ,416 & - & $-\quad 51$ & ,107 &,- 351 &,- 775 & ,070 \\
\hline & iguais & não & 5,72 & 6,07 & & & & $-47,419$ & 111 &,- 351 &,- 775 & 070 \\
\hline (Fin7) Resultado econômico & Variâncias & assumidas & 6,36 & 6,68 & ,331 &, 568 & - & $-\quad 51$ & ,020 &,- 319 &,- 565 &,- 054 \\
\hline & & não & 6,36 & 6,68 & & & & - 49,948 & ,020 &,- 319 &,- 565 &,- 054 \\
\hline (Fin8) Capitalização & Variâncias & assumidas & 6,16 & 6,29 & ,826 & ,368 &,- 711 & 151 & ,480 &,- 126 &,- 470 & ,221 \\
\hline & iguais & não & 6,16 & 6,29 & & &,- 713 & 50,803 & ,479 &,- 126 &,- 470 & ,221 \\
\hline (Fin9) Geração de rendas & Variâncias & assumidas & 6,00 & 6,25 & ,790 & ,378 & - & $-\quad 51$ & ,293 &,- 250 &,- 725 & ,221 \\
\hline & & não & 6,00 & 6,25 & & & & $-42,403$ & ,303 &,- 250 &,- 725 & ,221 \\
\hline (Fin10) Crescimento & Variâncias & assumidas & 6,48 & 5,96 & ,400 &, 530 & 2,566 & 51 &, 013 &, 516 & ,119 & ,910 \\
\hline aplicações totais & iguais & não & 6,48 & 5,96 & & & 2,572 & 50,722 & ,013 &, 516 & ,119 & ,910 \\
\hline (Fin11) Crescimento & Variâncias & assumidas & 6,00 & 6,21 & 14,760 & ,000 & - & $-\quad 51$ & ,249 &,- 214 &,- 563 &, 135 \\
\hline captações totais & iguais & não & 6,00 & 6,21 & & & & - 46,294 & ,238 &,- 214 &,- 563 & ,135 \\
\hline (Fin12) Equilíbrio & Variâncias & assumidas & 6,00 & 6,50 & ,625 & ,433 & - & $-\quad 51$ & ,038 &,- 500 &,- 969 &,- 039 \\
\hline orçamento & & não & 6,00 & 6,50 & & & & $-42,147$ &, 043 &,- 500 &,- 969 &,- 039 \\
\hline (Fin13) Nível & Variâncias & assumidas & 6,48 & 6,79 & 11,475 & ,001 & - & $-\quad 51$ & ,020 &,- 306 &,- 547 &,- 048 \\
\hline inadimplemento (NID) & iguais & não & 6,48 & 6,79 & & & & $-46,537$ & ,022 &,- 306 &,- 547 &,- 048 \\
\hline
\end{tabular}

a. $\mathrm{n}=25$

b. $n=28$

c. A menos que indicado de outra maneira, os resultados da bootstrap são baseados em 10000 amostras bootstrap

Fonte: autora. 
De acordo com os resultados do teste Levene a homogeneidade das variâncias foi violada nos indicadores Ass1, Ass3 e Ass8 ( $p<0,05)$, do módulo Associados, assim os resultados para o Teste t de Welch são encontrados nas linhas "Variâncias iguais não assumidas". Os demais indicadores apresentaram homogeneidade das variâncias $(p>0,05)$.

Por fim, houve uma diferença estatisticamente significativa entre Conselho Fiscal e Conselho Administrativo para os indicadores Ass4 e Ass7. As diferenças entre os grupos se mostraram estatisticamente significativas, pois $p<0,05$. Para os demais indicadores não houve diferença estatisticamente significativa entre os grupos Conselho Administrativo e Cooperados $(p>0,05)$.

A tabela 48 compila os resultados para o módulo Associados.

De acordo com os resultados do teste Levene a homogeneidade das variâncias foi violada apenas nos indicadores Pro4 e Pro7 $(p<0,05)$ do módulo Processos Internos, assim os resultados para o Teste t de Welch são encontrados nas linhas "Variâncias iguais não assumidas". Os demais indicadores apresentaram homogeneidade das variâncias $(p>0,05)$.

Por fim, houve uma diferença estatisticamente significativa entre Conselho Fiscal e Conselho Administrativo apenas para os indicadores Pro5 e Pro7. As diferenças entre os grupos se mostraram estatisticamente significativas, pois $p<0,05$. Para os demais indicadores não houve diferença estatisticamente significativa entre os grupos Conselho Administrativo e Cooperados ( $p>0,05)$.

A tabela 49 compila os resultados para o módulo Processos Internos. 
Tabela 48 - Estatísticas dos grupos: categoria Associado

\begin{tabular}{|c|c|c|c|c|c|c|c|c|c|c|c|}
\hline & & \multirow[b]{2}{*}{$\begin{array}{c}\text { Conselho } \\
\text { Fiscala }^{\text {Ciśdia }} \\
\text { Médie }\end{array}$} & \multirow[b]{2}{*}{$\begin{array}{c}\text { Conselho } \\
\text { Administrativo }^{\text {b }}\end{array}$} & \multicolumn{2}{|c|}{$\begin{array}{l}\text { Teste de } \\
\text { Levene }\end{array}$} & \multicolumn{3}{|c|}{$\begin{array}{c}\text { teste-t para } \\
\text { Igualdade de Médias }\end{array}$} & \multicolumn{3}{|c|}{ Bootstrapc } \\
\hline & & & & $\mathbf{F}$ & Sig. & $\mathbf{t}$ & gl & $\begin{array}{c}\text { Sig. } \\
\text { (bilateral) }\end{array}$ & $\begin{array}{c}\text { Diferença } \\
\text { média }\end{array}$ & $\begin{array}{l}\text { Interv } \\
\text { Confian } \\
\text { Inferior }\end{array}$ & $\begin{array}{l}\text { alo de } \\
\text { ça } 95 \% \\
\text { Inferior }\end{array}$ \\
\hline $\begin{array}{ll}\text { (Ass1) } & \text { Retenção }\end{array}$ & assumidas & 6,12 & 6,39 & 5,000 &, 030 & - & 51 &, 149 &,- 273 &,- 616 &, 090 \\
\hline cooperantes & não & 6,12 & 6,39 & & & & $-50,593$ & ,144 &,- 273 &,- 616 & ,090 \\
\hline (Ass2) Satisfação & assumidas & 6,48 & 6,54 & ,609 & ,439 &,- 371 & 51 & ,712 &,- 056 &,- 342 & 244 \\
\hline cooperantes & não & 6,48 & 6,54 & & &,- 373 & 50,998 & ,710 &,- 056 &,- 342 & ,244 \\
\hline (Ass3) Menor custo & assumidas & 6,24 & 6,43 & 8,392 & ,006 & - & 51 & 187 &,- 189 &,- 451 & ,086 \\
\hline transações & não & 6,24 & 6,43 & & & & 49,811 &, 181 &,- 189 &,- 451 & 086 \\
\hline (Ass4) Ganhos financeiros Variâncias & assumidas & 5,60 & 6,21 & ,019 & ,890 & - & 51 & ,002 &,- 614 &,- 997 &,- 254 \\
\hline de cada cooperado & não & 5,60 & 6,21 & & & & 49,943 & ,002 &,- 614 &,- 997 &,- 254 \\
\hline (Ass5) Ganhos financeiros & assumidas & 6,28 & & ,253 & ,617 &,- 234 & 51 & ,816 &,- 041 &,- 387 & ,308 \\
\hline de todos os cooperados iguais & não & 6,28 & 6,32 & & &,- 232 & 48,695 & ,817 &,- 041 &,- 387 & ,308 \\
\hline (Ass6) Emancipação social e Variâncias & assumidas & 5,76 & 6,04 & ,010 & ,921 & - & 51 & ,235 &,- 276 &,- 733 &, 180 \\
\hline econômica do associado iguais & não & 5,76 & 6,04 & & & & 50,425 & ,235 &,- 276 &,- 733 & 180 \\
\hline (Ass7) Educação, formação Variâncias & assumidas & 6,40 & 5,96 & ,002 & ,967 & 2,470 & 51 & 017 & ,436 & 108 &, 776 \\
\hline e informação ao cooperado iguais & não & 6 & 5 & & & 2,524 & 47,526 &, 015 & ,436 & 108 &, 776 \\
\hline (Ass8) Realização pessoal Variâncias & assumidas & 6,00 & 5,64 & 12,064 & ,001 & 1,280 & 51 & ,206 & ,357 &,- 158 & ,894 \\
\hline dos cooperados iguais & não & 6,00 & 5,64 & & & 1,318 & 44,042 & 194 &, 357 &,- 158 & ,894 \\
\hline (Ass9) Associados em Variâncias & assumidas & 6,12 & 6,46 & ,446 &, 507 & - & 51 & 140 &,- 344 &,- 819 &, 109 \\
\hline assembleia geral ordinária iguais & não & 6,12 & 6,46 & & & & 42,896 &, 149 &,- 344 &,- 819 & 109 \\
\hline (Ass10) Número associados Variâncias & assumidas & 6,6 & 6,61 &, 665 & ,418 & ,224 & 51 & ,823 & ,033 &,- 245 & ,319 \\
\hline ativos iguais & não & & 6,6 & & & ,226 & 50,953 & 822 & ,033 &,- 245 & ,319 \\
\hline (Ass11) Sobras ou Variâncias & assumidas & 6,28 & 6,04 & ,119 & ,732 & 1,157 & 51 &, 252 & ,244 &,- 170 &, 655 \\
\hline faturamento por cooperado iguais & não & 6,28 & 6,04 & & & 1,171 & 50,543 & 247 & 244 &,- 170 & 655 \\
\hline (Ass12) Relevância do Variâncias & assumidas & 6,12 & 6,14 &, 540 & ,466 &,- 086 & 51 & ,932 &,- 023 &,- 553 & ,493 \\
\hline associado na tomada de iguais & não & 6,12 & 6,14 & & &,- 085 & 47,292 & ,933 &,- 023 &,- 553 & ,493 \\
\hline
\end{tabular}

a. $\mathrm{n}=25$

b. $n=28$

c. A menos que indicado de outra maneira, os resultados da bootstrap são baseados em 10000 amostras bootstrap

Fonte: autora. 
Tabela 49 - Estatísticas dos grupos: categoria Processos Internos

\begin{tabular}{|c|c|c|c|c|c|c|c|c|c|c|c|}
\hline & & \multirow{3}{*}{$\begin{array}{c}\text { Conselho } \\
\text { Fiscal }^{\mathrm{a}}\end{array}$} & \multirow{3}{*}{$\begin{array}{c}\text { Conselho } \\
\text { Administrativo }^{\text {b }}\end{array}$} & \multicolumn{2}{|c|}{$\begin{array}{l}\text { Teste de } \\
\text { Levene }\end{array}$} & \multicolumn{3}{|c|}{$\begin{array}{c}\text { teste-t para } \\
\text { Igualdade de Médias }\end{array}$} & \multicolumn{3}{|c|}{ Bootstrap ${ }^{c}$} \\
\hline & & & & & & & & Sig. & Diferença & $\begin{array}{l}\text { Interva } \\
\text { Confian } \\
\end{array}$ & $\begin{array}{l}\text { alo de } \\
\text { ça } 95 \%\end{array}$ \\
\hline & & & & $\mathbf{F}$ & Sig. & $\mathbf{t}$ & gl & (bilateral) & média & Inferior & Inferior \\
\hline (Pro1) Lucratividade $\quad$ por Variâncias & assumidas & 5,52 & 5,71 & 117 & ,733 &,- 921 & 51 & ,361 &,- 194 &,- 613 & ,212 \\
\hline segmento-alvo & não & 5,52 & 5,71 & & &,- 928 & 50,995 & ,358 &,- 194 &,- 613 & ,212 \\
\hline (Pro2) Percentual de Variâncias & assumidas & 5,52 & 5,64 & 1,490 & ,228 &,- 439 & 51 & 662 &,- 123 &,- 639 & ,435 \\
\hline transações $\quad$ realizadas iguais & não & 5,52 & 5,64 & & &,- 452 & 44,280 & 653 &,- 123 &,- 639 & ,435 \\
\hline (Pro3) Projetos sociais Variâncias & assumidas & 6,16 & 6,00 & 1,167 & ,285 &, 698 & 51 & ,488 & 160 &,- 280 & ,614 \\
\hline desenvolvidos & não & 6,16 & 6,00 & & &, 701 & 50,908 & ,486 & 160 &,- 280 & ,614 \\
\hline (Pro4) Percentual & assumidas & 5,16 & 4,75 & 4,268 &, 044 & 1,285 & 51 & ,205 & ,410 &,- 189 & 1,028 \\
\hline trabalho extraordinário $\quad$ iguais & não & 5,16 & 4,75 & & & 1,323 & 43,699 & 193 & ,410 &,- 189 & 1,028 \\
\hline (Pro5) Desenvolvimento Variâncias & assumidas & 6,52 & 6,07 & ,320 &, 574 & 2,055 & 51 & ,045 & ,449 & ,033 & ,881 \\
\hline sustentável iguais & não & 6,52 & 6,07 & & & 2,076 & 50,772 & ,043 & ,449 & ,033 & ,881 \\
\hline de Variâncias & assumidas & 6,88 & 6,86 & ,234 & ,631 & 241 & 51 & 811 & ,023 &,- 162 & 211 \\
\hline Transparência & não & 6,88 & 6,86 & & & ,242 & 50,902 & 810 & ,023 &,- 162 & ,211 \\
\hline (Pro7) Perpetuação & assumidas & 6,36 & 6,75 & 10,619 & ,002 & - & 51 & , 018 &,- 390 &,- 716 &,- 071 \\
\hline instituição & não & 6,36 & 6,75 & & & & 39,601 & ,022 &,- 390 &,- 716 &,- 071 \\
\hline (Pro8) Preservação da Variâncias & assumidas & 6,36 & 6,36 & ,433 &, 514 & 015 & 51 & ,988 & ,003 &,- 363 &, 381 \\
\hline identidade organizacional $\quad$ iguais & não & 6,36 & 6,36 & & & ,015 & 49,925 & ,988 & ,003 &,- 363 &, 381 \\
\hline
\end{tabular}

a. $n=25$

b. $n=28$

c. A menos que indicado de outra maneira, os resultados da bootstrap são baseados em 10000 amostras bootstrap

Fonte: autora. 
De acordo com os resultados do teste Levene a homogeneidade das variâncias foi violada para os indicadores Apr1 e Apr2 $(p<0,05)$, do módulo Aprendizado e Crescimento assim os resultados para o Teste t de Welch são encontrados nas linhas "Variâncias iguais não assumidas". O indicador Apr3 apresentou homogeneidade das variâncias $(p>0,05)$.

Por fim, houve uma diferença estatisticamente significativa entre Conselho Fiscal (média $=6,16$, erro padrão $=0,160$ ) e Conselho Administrativo (média $=6,68$, erro padrão $=0,104$ ) apenas para o indicador Apr1. Esta diferença de -0,519 (Percentil $95 \%, I C[-0,903,-0,134])$ se mostrou estatisticamente significativa ( $t(41,799)=-2,721$, $p=0,009)$. Para os demais indicadores (Apr2 e apr3) não houve diferença estatisticamente significativa entre os grupos Conselho Administrativo e Cooperados $(p>0,05)$.

A tabela 50 compila os resultados para o módulo Aprendizado e Crescimento.

De acordo com os resultados do teste Levene a homogeneidade das variâncias foi violada nos indicadores Pes1, Pes5, Pes6 e Pes8 $(p<0,05)$, do módulo Pessoas e Inovação, assim os resultados para o Teste t de Welch são encontrados nas linhas "Variâncias iguais não assumidas". Os demais indicadores apresentaram homogeneidade das variâncias ( $p>0,05)$.

Por fim, houve uma diferença estatisticamente significativa entre Conselho Fiscal (média $=5,64$, erro padrão $=0,223$ ) e Conselho Administrativo (média $=6,14$, erro padrão $=0,123$ ) apenas para o indicador Pes2. Esta diferença de -0,503 (Percentil $95 \%, I C[-1,019,-0,037])$ se mostrou estatisticamente significativa $(t(51)=-2,034, p=$ 0,047). Todos os demais indicadores não apresentaram diferença estatisticamente significativa entre os grupos Conselho Fiscal e Conselho Administrativo ( $p>0,05)$.

A tabela 51 compila os resultados para o módulo Pessoas e Inovação. 
Tabela 50 - Estatísticas dos grupos: categoria Aprendizado e Crescimento

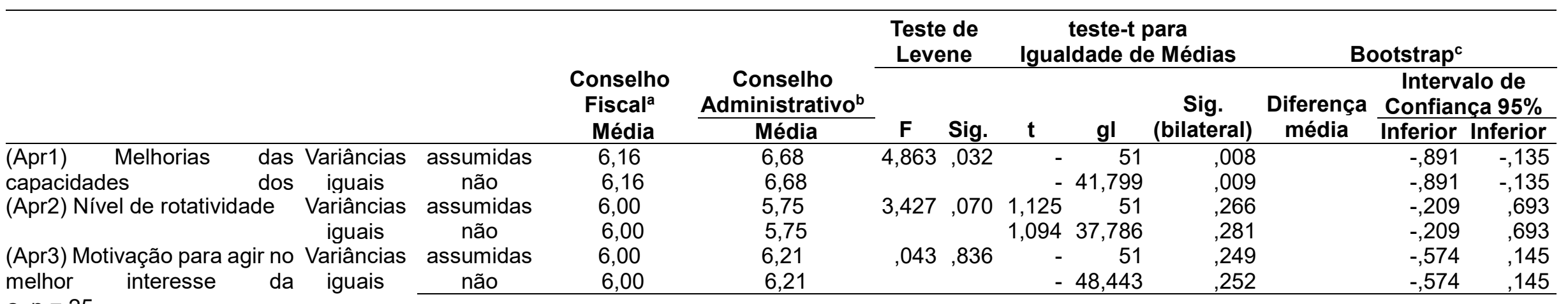

a. $\mathrm{n}=25$

b. $n=28$

c. A menos que indicado de outra maneira, os resultados da bootstrap são baseados em 10000 amostras bootstrap

Fonte: autora. 
Tabela 51 - Estatísticas dos grupos: categoria Pessoa e Inovação

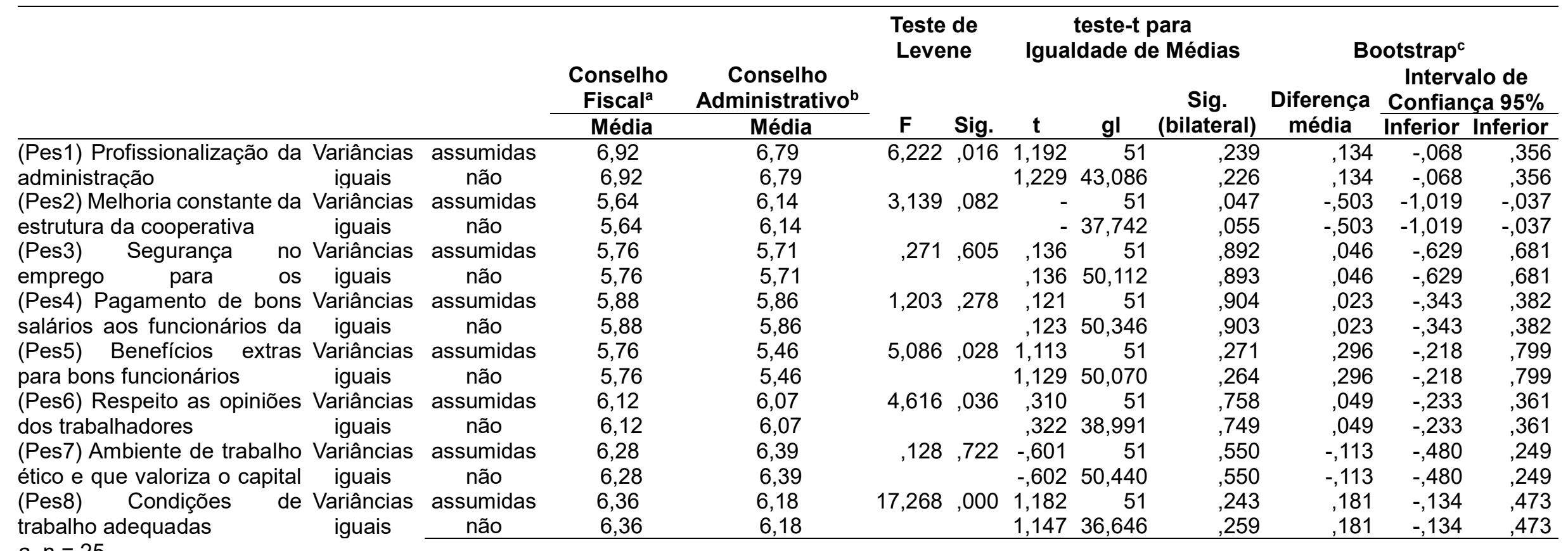

a. $n=25$

b. $n=28$

c. A menos que indicado de outra maneira, os resultados da bootstrap são baseados em 10000 amostras bootstrap

Fonte: autora. 
De acordo com os resultados do teste de Levene a homogeneidade das variâncias foi violada apenas nos indicadores Pri1 e Pri9 ( $p<0,05$ ), do módulo Princípios Cooperativistas, assim os resultados para o Teste $\mathrm{t}$ de Welch são encontrados nas linhas "Variâncias iguais não assumidas". Os demais indicadores apresentaram homogeneidade das variâncias $(p>0,05)$.

Por fim, houve uma diferença estatisticamente significativa entre Conselho Fiscal e Conselho Administrativo apenas para os indicadores Pri1, Pri2 e Pri7. As diferenças entre os grupos se mostraram estatisticamente significativas, pois $p<0,05$. Para os demais indicadores não houve diferença estatisticamente significativa entre os grupos Conselho Administrativo e Cooperados ( $p>0,05)$.

A tabela 52 compila os resultados para o módulo Princípios Cooperativistas.

Com o objetivo de investigar se os membros do Conselho Fiscal percebem maior importância nas diferentes categorias dos indicadores de desempenho em relação aos membros do Conselho Fiscal, aplicou-se o teste $t$ de amostras independentes para as médias.

Inicialmente buscou-se investigar se os dados são normalmente distribuídos para cada um dos grupos. Conforme avaliado pelo teste de Kolmogorov-Smirnov, a maioria dos dados não são distribuídos normalmente, $(p<0,05)$.

De acordo com os resultados do teste Levene a homogeneidade das variâncias foi violada $(p<0,05)$ apenas para as categorias de indicadores Aprendizado e Crescimento (Apr), assim os resultados para o Teste t de Welch são encontrados nas linhas "Variâncias iguais não assumidas". Já as demais categorias de indicadores apresentaram homogeneidade das variâncias $(p>0,05)$.

Por fim, houve uma diferença estatisticamente significativa entre Conselho Administrativo (média $=6,075$, erro padrão $=0,1051$ ) e Cooperados (média $=6,011$, erro padrão $=0,560$ ) apenas para a categoria de indicadores Pessoas e Inovação (Pes). Esta diferença de -0,268 (Percentil 95\%, IC [-0,512, -,0281]) se mostrou estatisticamente significativa ( $\mathrm{t}(51)=-2,170, \mathrm{p}=0,035)$. Para as demais categorias de indicadores não houve diferença estatisticamente significativa entre os grupos Conselho Fiscal e Conselho Administrativo e Cooperados ( $p>0,05)$.

A tabele 53 apresenta os resultados. 
Tabela 52 - Estatísticas dos grupos: categoria Princípios Cooperativistas

\begin{tabular}{|c|c|c|c|c|c|c|c|c|c|c|c|}
\hline & & \multirow[b]{2}{*}{$\begin{array}{c}\text { Conselho } \\
\text { Fiscal }^{\mathrm{a}} \\
\text { Média }^{-}\end{array}$} & \multirow[b]{2}{*}{$\begin{array}{c}\text { Conselho } \\
\text { Administrativo }^{b} \\
\text { Média }\end{array}$} & \multicolumn{2}{|c|}{$\begin{array}{l}\text { Teste de } \\
\text { Levene }\end{array}$} & \multicolumn{3}{|c|}{$\begin{array}{c}\text { teste-t para } \\
\text { Igualdade de Médias }\end{array}$} & \multicolumn{3}{|c|}{ Bootstrapc } \\
\hline & & & & $\mathbf{F}$ & Sig. & $\mathbf{t}$ & gl & $\begin{array}{c}\text { Sig. } \\
\text { (bilateral) }\end{array}$ & $\begin{array}{c}\text { Diferença } \\
\text { média }\end{array}$ & $\begin{array}{l}\text { Interv } \\
\text { Confian } \\
\text { Inferior }\end{array}$ & $\begin{array}{l}\text { alo de } \\
\text { ça } 95 \% \\
\text { Inferior }\end{array}$ \\
\hline princípios Variâncias & assumidas & 6,88 & 6,57 & 13,377 & ,001 & 1,915 & 51 & ,061 & ,309 & ,026 &, 629 \\
\hline cooperativistas & não & 6,88 & 6,57 & & & 1,990 & 38,285 & ,054 & ,309 &,- 037 & ,737 \\
\hline (Pri2) Democracia & assumidas & 6,64 & 6,29 & 1,183 & ,282 & 1,754 & 51 &, 085 & ,354 &,- 037 &, 737 \\
\hline igualdade & não & 6,64 & 6,29 & & & 1,763 & 50,956 & ,084 & ,354 &,- 090 & ,881 \\
\hline (Pri3) Solidariedade & assumidas & 6,40 & 6,00 & , 150 & ,700 & 1,602 & 51 & ,115 & ,400 &,- 090 & ,881 \\
\hline iguais & não & 6,40 & 6,00 & & & 1,610 & 50,952 &, 114 & ,400 &,- 290 & 691 \\
\hline (Pri4) Valores de ajuda Variâncias & assumidas & 6,00 & 5,82 & 3,442 & ,069 & 683 & 51 & ,498 & 179 &,- 290 & 691 \\
\hline mútua (preocupação com o iguais & não & 6,00 & 5,82 & & & ,700 & 46,061 & ,488 & 179 &,- 662 &, 521 \\
\hline (Pri5) Autonomia e a Variâncias & assumidas & 5,92 & 6,00 & ,060 & ,807 &,- 260 & 51 & ,796 &,- 080 &,- 662 &, 521 \\
\hline independência & não & 5,92 & 6,00 & & &,- 261 & 50,893 & ,795 &,- 080 &,- 053 & ,977 \\
\hline (Pri6) Adesão & assumidas & 6,64 & 6,21 & ,380 &, 541 & 1,587 & 51 & 119 & ,426 &,- 053 & ,977 \\
\hline voluntária iguais & não & 6,64 & 6,21 & & & 1,631 & 44,954 & 110 & ,426 &, 034 & ,756 \\
\hline (Pri7) Preocupação com a Variâncias & assumidas & 6,32 & 5,93 & 2,624 & ,111 & 2,105 & 51 &, 040 & ,391 & ,034 &, 756 \\
\hline comunidade iguais & não & 6,32 & 5,93 & & & 2,100 & 49,782 & ,041 & ,391 &,- 182 &, 550 \\
\hline (Pri8) Geração de empregos Variâncias & assumidas & 6,00 & 5,82 & ,000 & ,987 &, 944 & 51 & ,350 & 179 &,- 182 &, 550 \\
\hline iguais & não & 6,00 & 5,82 & & &, 941 & 49,571 & ,351 & 179 &,- 450 & ,431 \\
\hline (Pri9) Combate a exclusão Variâncias & assumidas & 6,00 & 6,00 & 9,703 & ,003 & ,000 & 51 & 1,000 & ,000 &,- 450 & ,431 \\
\hline social iguais & não & 6,00 & 6,00 & & &, 000 & 36,130 & 1,000 &, 000 & 026 & 629 \\
\hline
\end{tabular}

a. $n=25$

b. $n=28$

c. A menos que indicado de outra maneira, os resultados da bootstrap são baseados em 10000 amostras bootstrap

Fonte: autora. 
Tabela 53 - Bootstrap para Teste de amostras independentes

\begin{tabular}{|c|c|c|c|c|c|c|}
\hline & & \multirow[b]{3}{*}{ Diferença média } & \multicolumn{4}{|c|}{ Bootstrap ${ }^{a}$} \\
\hline & & & \multirow[b]{2}{*}{ Viés } & \multirow[b]{2}{*}{ Erro Padrão } & \multicolumn{2}{|c|}{ Intervalo de Confiança 95\% } \\
\hline & & & & & Inferior & Superior \\
\hline \multirow[t]{2}{*}{ Fin_média } & Variâncias iguais assumidas &,- 26862 &,- 00145 & ,12273 &,- 51202 &,- 02801 \\
\hline & Variâncias iguais não assumidas &,- 26862 &,- 00145 &, 12273 &,- 51202 &,- 02801 \\
\hline \multirow[t]{2}{*}{ Ass_média } & Variâncias iguais assumidas &,- 06221 &,- 00155 & ,13293 &,- 32434 & , 19951 \\
\hline & Variâncias iguais não assumidas &,- 06221 &,- 00155 & ,13293 &,- 32434 & 19951 \\
\hline \multirow[t]{2}{*}{ Pro_média } & Variâncias iguais assumidas & ,04214 &,- 00035 & 15817 &,- 25855 & ,36522 \\
\hline & Variâncias iguais não assumidas & ,04214 &,- 00035 &, 15817 &,- 25855 & ,36522 \\
\hline \multirow[t]{2}{*}{ Apr_média } & Variâncias iguais assumidas &,- 16104 &,- 00082 & , 16910 &,- 50273 & , 16343 \\
\hline & Variâncias iguais não assumidas &,- 16104 &,- 00082 & 16910 &,- 50273 & 16343 \\
\hline \multirow[t]{2}{*}{ Pes_média } & Variâncias iguais assumidas & ,01411 &,- 00150 &, 15111 &,- 28986 & ,31172 \\
\hline & Variâncias iguais não assumidas &, 01411 &,- 00150 &, 15111 &,- 28986 & ,31172 \\
\hline \multirow[t]{2}{*}{ Pri_média } & Variâncias iguais assumidas & ,23950 &,- 00103 & ,17305 &,- 09407 &, 58465 \\
\hline & Variâncias iguais não assumidas & ,23950 &,- 00103 &, 17305 &,- 09407 &, 58465 \\
\hline
\end{tabular}

a. A menos que indicado de outra maneira, os resultados da bootstrap são baseados em 1000 amostras bootstrap

Fonte: autora 
Sendo assim, há discordância de opiniões entre os conselheiros fiscais e administrativos:

- para 6 dos 13 indicadores financeiros, a saber: crescimento das vendas, retorno sobre o investimento, resultado econômico, crescimento aplicações totais, equilíbrio do orçamento e nível de inadimplemento.

- para apenas 2 dos 12 indicadores do módulo Associados, a saber: Ganhos financeiros de cada cooperado individualmente e Educação, formação e informação ao cooperado.

- para apenas 2 dos 8 indicadores do módulo Processos Internos, a saber: Desenvolvimento sustentável e Perpetuação da instituição.

- para apenas 1 dos 3 indicadores do módulo Aprendizado e Crescimento, a saber: melhorias das capacidades dos funcionários.

- para apenas 1 dos 8 indicadores do módulo Pessoas e inovação, a saber: Melhoria constante da estrutura da cooperativa.

- para apenas 3 dos 9 indicadores do módulo Princípios Cooperativistas, a saber: Cumpre princípios cooperativistas, Democracia e igualdade e Preocupação com a comunidade.

Nesse caso, pode-se dizer que os Conselheiros Administrativos e Fiscais classificam de maneira estatisticamente diferente 15 dos 53 indicadores avaliados por eles. Não se pode afirmar que os grupos têm opiniões discordantes e sim diferentes, portanto, sabe-se que para $28,30 \%$ dos indicadores eles dão grau de importância diferentes.

Percebeu-se a partir da análise das médias, que no geral os Conselheiros Fiscais atribuem maior valor aos indicadores do módulo "Financeiro" do que os Conselheiros Administrativos; e os Administrativos classificaram melhor os indicadores do módulo "Princípios Cooperativistas" do que os Conselheiros Fiscais.

Em suma, para os demais módulos, Conselheiros Fiscais avaliam melhor indicadores que remetem ao ganho financeiros de cada cooperado, perpetuação da instituição e melhoria das capacidades dos funcionários e da estrutura da cooperativa; enquanto os Conselheiros Administrativos avaliam melhor indicadores como educação, formação e informação ao cooperado e desenvolvimento sustentável.

Percebe-se, portanto, que os Conselheiros Administrativos tem tendência de priorizarem indicadores mais ideológicos e os Fiscais aqueles mais funcionalistas. Sendo assim, conclui-se que devido a esse cenário, os grupos poderão ter conflitos 
de interesse futuro, confirmando a hipótese 7 de que há conflitos de interesses entre os membros do Conselho Fiscal e Administrativo em relação à Avaliação de desempenho de Cooperativas de Crédito.

\subsection{HIPÓTESE 8}

A fim de testar a hipótese 8: Se os gestores das cooperativas de crédito tentam assegurar os princípios e valores cooperativos, então os gestores enfatizam a livre e aberta adesão dos membros, o caráter democrático da gestão e do controle cooperativos, a autonomia e a independência, a responsabilidade social e a preservação da identidade organizacional, verificou-se junto aos grupos envolvidos no estudo, a saber: "Cooperados", "Conselheiros Administrativos", "Conselheiros Fiscais" e "Gerentes", qual o grau de importância atribuem aos indicadores: cumpre princípios cooperativistas, democracia e igualdade, solidariedade, valores de ajuda mútua, autonomia e independência, adesão livre e voluntária, preocupação com a comunidade, geração de empregos, combate a exclusão social, projetos sociais desenvolvidos e preservação da identidade organizacional.

Dessa forma foi possível perceber se as opiniões dos participantes dos Conselhos Administrativos representam alto grau de importância a esses indicadores em comparação aos demais grupos participantes da pesquisa.

Na tabela 54 é possível observar os altos valores atribuídos pelos Conselheiros Administrativos e demais grupos para as variáveis referentes aos princípios e valores cooperativos. Os altos valores indicam que os mesmos percebem que as variáveis analisadas são entre muito importantes e extremamente importantes. 
Tabela 54 - Estatísticas Descritivas: Categoria das observações da amostra Conselho Fiscal

\begin{tabular}{|c|c|c|c|c|c|c|c|c|c|c|c|c|}
\hline \multirow[b]{2}{*}{ Indicadores } & \multicolumn{3}{|c|}{ Conselho Fiscala } & \multicolumn{3}{|c|}{ Conselho Administrativo ${ }^{b}$} & \multicolumn{3}{|c|}{ Cooperados $^{c}$} & \multicolumn{3}{|c|}{ Gerentes $^{d}$} \\
\hline & Média & $\begin{array}{l}\text { Desvio } \\
\text { Padrão }\end{array}$ & $\begin{array}{c}\text { Erro } \\
\text { Padrão } \\
\text { da } \\
\text { Média } \\
\end{array}$ & Média & $\begin{array}{l}\text { Desvio } \\
\text { Padrão }\end{array}$ & $\begin{array}{l}\text { Erro } \\
\text { Padrão } \\
\text { da Média }\end{array}$ & Média & $\begin{array}{l}\text { Desvio } \\
\text { Padrão }\end{array}$ & $\begin{array}{c}\text { Erro } \\
\text { Padrão } \\
\text { da Média }\end{array}$ & Média & $\begin{array}{l}\text { Desvio } \\
\text { Padrão }\end{array}$ & $\begin{array}{l}\text { Erro } \\
\text { Padrão } \\
\text { da Média }\end{array}$ \\
\hline (Pri1) Cumpre princípios cooperativistas & 6,88 & 0,332 & 0,066 & 6,57 & 0,742 & 0,14 & 5,49 & 1,496 & 0,121 & 6,75 & 0,503 & 0,052 \\
\hline (Pri2) Democracia e igualdade & 6,64 & 0,7 & 0,14 & 6,29 & 0,763 & 0,144 & 5,86 & 1,207 & 0,098 & 6,52 & 0,619 & 0,064 \\
\hline (Pri3) Solidariedade & 6,4 & 0,866 & 0,173 & 6 & 0,943 & 0,178 & 5,58 & 1,315 & 0,107 & 6,33 & 0,727 & 0,075 \\
\hline $\begin{array}{l}\text { (Pri4) Valores de ajuda mútua } \\
\text { (preocupação com o semelhante) }\end{array}$ & 6 & 0,707 & 0,141 & 5,82 & 1,124 & 0,212 & 5,64 & 1,159 & 0,094 & 6,48 & 0,669 & 0,069 \\
\hline (Pri5) Autonomia e a independência & 5,92 & 1,077 & 0,215 & 6 & 1,155 & 0,218 & 5,81 & 1,021 & 0,083 & 6,44 & 0,65 & 0,067 \\
\hline (Pri6) Adesão livre e voluntária & 6,64 & 0,7 & 0,14 & 6,21 & 1,166 & 0,22 & 5,59 & 1,153 & 0,094 & 6,59 & 0,647 & 0,067 \\
\hline (Pri7) Preocupação com a comunidade & 6,32 & 0,69 & 0,138 & 5,93 & 0,663 & 0,125 & 5,57 & 1,274 & 0,103 & 6,68 & 0,555 & 0,058 \\
\hline (Pri8) Geração de empregos & 6 & 0,707 & 0,141 & 5,82 & 0,67 & 0,127 & 6,02 & 1,058 & 0,086 & 6,46 & 0,669 & 0,069 \\
\hline (Pri9) Combate a exclusão social & 6 & 1 & 0,2 & 6 & 0,544 & 0,103 & 5,76 & 1,172 & 0,095 & 6,38 & 0,721 & 0,075 \\
\hline (Pro3) Projetos sociais desenvolvidos & 6,16 & 0,8 & 0,16 & 6 & 0,861 & 0,163 & 5,11 & 1,568 & 0,127 & 6,39 & 0,643 & 0,067 \\
\hline $\begin{array}{c}\text { (Pro8) Preservação da identidade } \\
\text { organizacional }\end{array}$ & 6,36 & 0,7 & 0,14 & 6,36 & 0,678 & 0,128 & 5,67 & 1,195 & 0,097 & 6,58 & 0,596 & 0,062 \\
\hline $\begin{array}{ll}\text { a. } & N=25 \\
\text { b. } & N=28 \\
\text { c. } & N=152 \\
\text { d. } & N=93\end{array}$ & & & & & & & & & & & & \\
\hline
\end{tabular}

Fonte: autore 
De forma complementar, um teste $\mathrm{H}$ de Kruskal-Wallis foi conduzido para determinar se havia diferenças nos escores da importância atribuída aos indicadores de desempenho para cooperativas Pri1, Pri2,Pri3, Pri4, Pri5, Pri6, Pri7, Pri8, Pri9, Pro3 e Pro8 entre os grupos "Conselho Administrativo", "Conselho Fiscal”, "Cooperados" e "Gerentes". As distribuições dos escores não foram semelhantes para todos os grupos, conforme avaliado pela inspeção visual dos boxplots.

As diferenças entre as classificações médias dos escores foram estatisticamente significantes entre os quatro grupos para todos os indicadores (conforme valores de $X^{2}$ (k - 1) e p-valor apresentados), indicando que a distribuição de pelo menos um grupo é diferente da distribuição de outro grupo.

Tabela 55 - Estatísticas do teste H de Kruskal-Wallis de amostras independentes

\begin{tabular}{|c|c|c|c|c|c|}
\hline & & \multicolumn{3}{|c|}{ Estatística } & \multirow[b]{2}{*}{ Sig. ${ }^{\mathrm{b}}$} \\
\hline & & $\mathrm{n}$ & $\begin{array}{c}\text { de teste } \\
\left(X^{2}\right)\end{array}$ & G.L. ${ }^{a}$ & \\
\hline (Pro3) Projetos sociais desenvolvidos & & 298 & 85,524 & 3 & 000 \\
\hline (Pro8) Preservação da identidade organizacional & & 298 & 26,256 & 3 & ,000 \\
\hline (Pri1) Cumpre princípios cooperativistas & & 298 & 26,089 & 3 & ,000 \\
\hline (Pri2) Democracia e igualdade & & 298 & 39,845 & 3 & 000 \\
\hline (Pri3) Solidariedade & & 298 & 24,687 & 3 & ,000 \\
\hline $\begin{array}{l}\text { (Pri4) Valores de ajuda mútua (preocupação } \\
\text { semelhante) }\end{array}$ & com o & 298 & 67,700 & 3 & ,000 \\
\hline (Pri5) Autonomia e a independência & & 298 & 67,759 & 3 & ,000 \\
\hline (Pri6) Adesão livre e voluntária & & 298 & 20,604 & 3 & ,000 \\
\hline (Pri7) Preocupação com a comunidade & & 298 & 20,146 & 3 & ,000 \\
\hline (Pri8) Geração de empregos & & 298 & 54,377 & 3 & ,000 \\
\hline (Pri9) Combate a exclusão social & & 298 & 51,310 & 3 & ,000 \\
\hline
\end{tabular}

a Graus de Liberdade

bSignificância Assintótica (teste bilateral)

Para descobrir quais grupos são diferentes de quais outros grupos foi executado um teste post hoc. No caso do teste de Kruskal-Wallis, foi executada e interpretada todas as comparações emparelhadas usando o procedimento de Dunn (1964) com um ajuste de Bonferroni. Valores de $p$ ajustados são apresentados. Os valores são postos médios, a menos que seja indicado o contrário. 
Tabela 56 - Post hoc: pairwise comparisonsa

\begin{tabular}{|c|c|c|c|c|c|c|}
\hline & $\begin{array}{c}\text { Coop } \\
x \\
\text { ConAdm }\end{array}$ & $\begin{array}{c}\text { Coop } \\
x \\
\text { Confis }\end{array}$ & $\begin{array}{l}\text { Coop } \\
x \\
\text { Gere }\end{array}$ & $\begin{array}{c}\text { ConAdm } \\
x \\
\text { ConFis }\end{array}$ & $\begin{array}{c}\text { ConAdm } \\
\text { x } \\
\text { Gere }\end{array}$ & $\begin{array}{c}\text { Gere } \\
x \\
\text { ConFis }\end{array}$ \\
\hline (Pri1) Cumpre princ. cooperativistas & ,000 &, 000 &, 000 & & & \\
\hline (Pri2) Democracia e igualdade & & ,001 &, 000 & & & \\
\hline (Pri3) Solidariedade & & ,005 & ,000 & & & \\
\hline (Pri4) Valores de ajuda mútua & & & ,000 & & ,012 & ,042 \\
\hline (Pri5) Autonomia e a independência & & & ,000 & & & \\
\hline (Pri6) Adesão livre e voluntária & ,014 & ,000 &, 000 & & & \\
\hline $\begin{array}{l}\text { (Pri7) Preocupação com } \\
\text { comunidade }\end{array}$ & & ,035 & ,000, & & ,000 & \\
\hline (Pri8) Geração de empregos & & & ,006 & & ,000 & ,039 \\
\hline (Pri9) Combate a exclusão social & & & ,000 & & & \\
\hline (Pro3) Projetos sociais desenvolvidos & ,037 & ,007 & ,000 & & & \\
\hline $\begin{array}{l}\text { (Pro8) Preservação da ident. } \\
\text { Organizacional }\end{array}$ & ,016 & 023 & 000 & & & \\
\hline
\end{tabular}

a. os valores apresentados se referem ao p-valor ajustado.

Esta análise post hoc revelou diferenças estatisticamente significativas nos escores entre os grupos Cooperados e Gerentes em todos os indicadores. De uma maneira geral, o grupo Cooperados apresenta diferenças estatisticamente significantes $(p<0,05)$ em 22 das 33 relações. Por sua vez, o Conselho Administrativo apresentou diferenças estatisticamente significantes com os Cooperados nos indicadores Pri1, Pri6, Pro3 e Pro8. Já na relação com os Gerentes, apresentou diferenças estatisticamente $(p<0,05)$ significativas nos indicadores Pri4, Pri7 e Pri8.

Sendo assim, pode-se dizer que os "Conselheiros Administrativos" participantes da amostra, percebem de forma geral alto grau de importância em relação aos indicadores referentes a valores e princípios cooperativistas.

Porém, considerando os indicadores com diferenças estatisticamente significativas, de forma geral os "Conselheiros Administrativos" percebem menos valor nos referidos indicadores do que "Gerentes", e mais valor do que "Cooperados". Em relação ao grupo "Conselheiros Fiscais" não houve diferença estatística significativa.

Sendo assim, pode-se aceitar a hipótese 8 de que se os gestores das cooperativas de crédito tentam assegurar os princípios e valores cooperativos, então os gestores enfatizam a livre e aberta adesão dos membros, o caráter democrático da gestão e do controle cooperativos, a autonomia e a independência, a responsabilidade social e a preservação da identidade organizacional, pois esses percebem alto grau de importância para os indicadores, apesar de gerentes perceberem mais valor. 


\subsubsection{OUTRAS ANÁLISES RELEVANTES}

Para responder a todos os objetivos traçados por esse trabalho, cabe ainda realizar algumas análises além daquelas geradas pelas hipóteses.

A primeira delas vem de encontro a responder o objetivo específico: relacionar as variáveis determinadas como importantes para avaliar desempenho de cooperativas de crédito sob o ponto de vista dos envolvidos considerando seu perfil.

A segunda delas busca conhecer a importância atribuída pelos diferentes grupos participantes da pesquisa para cada módulo.

A terceira delas busca "apontar as convergências e divergências de opiniões entre agentes e principal".

E a quarta busca "verificar se os princípios do cooperativismo são vistos como importantes pelos grupos, quando se trata da avaliação de desempenho de cooperativas de crédito".

A seguir as análises e discussões são apresentadas.

\subsection{VARIÁVEIS DETERMINADAS COMO IMPORTANTES PARA AVALIAR DESEMPENHO DE COOPERATIVAS DE CRÉDITO SOB O PONTO DE VISTA DOS ENVOLVIDOS CONSIDERANDO SEU PERFIL}

A fim de atender ao objetivo da pesquisa de relacionar as variáveis determinadas como importantes para avaliar desempenho de cooperativas de crédito sob o ponto de vista dos envolvidos considerando seu perfil, um teste $\mathrm{H}$ de KruskalWallis foi conduzido para determinar se havia diferenças nos escores da importância atribuída aos diferentes indicadores entre os níveis das variáveis que caracterizam o perfil dos gerentes e conselho administrativo.

Pode-se considerar que as distribuições dos escores não foram semelhantes para todos os grupos, conforme avaliado pela inspeção visual dos boxplots. Para descobrir quais grupos são diferentes de quais outros grupos foi executado um teste post hoc. No caso do teste de Kruskal-Wallis, foram executadas e interpretadas todas as comparações emparelhadas usando o procedimento de Dunn (1964) com um ajuste de Bonferroni. Valores de p ajustados são apresentados. Os valores são postos médios, a menos que seja indicado o contrário. 
A primeira variável de perfil analisada foram os níveis de idade dos gerentes. As diferenças não foram estatisticamente significativas $(p>0,05)$ entre os diferentes níveis de idade dos gerentes.

A segunda variável de perfil analisada foram os níveis de escolaridade dos gerentes. As diferenças não foram estatisticamente significativas $(p>0,05)$ entre os diferentes níveis de escolaridade dos gerentes, exceto para a variável Ass1 $\left(X^{2}(3)=10,735, p=0,013\right)$. No entanto, o teste post hoc verificou que não há diferenças estatisticamente significantes $(p<0,05)$ entre os níveis de escolaridade.

A terceira variável de perfil analisada foi o tempo que exerce a função de gerência. As diferenças nas classificações médias dos escores foram estatisticamente significantes apenas para os indicadores Pro1 $\left(X^{2}(3)=16,097, p=0,001\right)$ e Pes4 $\left(X^{2}(3)=10,735, p=0,013\right)$. Para todas as variáveis as diferenças não foram estatisticamente significativas $(p>0,05)$ entre os diferentes níveis de tempo de associado dos gerentes.

A análise post hoc revelou diferenças estatisticamente significativas nos escores dos indicadores:

- Pro1 entre os grupos "menos de 1 ano" (postos médios = 69,92) e mais de 5 anos (postos médios $=39,69)(p=0,001)$ mas não entre os demais grupos.

- Pes4 entre os grupos "menos de 1 ano" (postos médios $=64,58$ ) e mais de 5 anos (postos médios $=42,35)(p=0,015)$ mas não entre os demais grupos.

Sendo assim, pode-se dizer que a idade e escolaridade dos gerentes não influenciam na forma desse grupo avaliar desempenho de cooperativas de crédito. Por sua, vez, segundo as análises realizadas, o tempo de gerência influiu na avaliação de dois indicadores, a saber: Lucratividade por segmento-alvo e Pagamento de bons salários aos funcionários da cooperativa. Destaca-se que para ambos os indicadores, gerentes com menos de um ano de cargo avaliaram com maior grau de importância do que gerentes com mais de cinco anos de cargo.

Em relação aos Conselheiros Administrativos, a primeira variável de perfil analisada foram os níveis de idade. As diferenças nas classificações médias dos escores foram estatisticamente significantes apenas para o indicador Ass6 $\left(X^{2}(2)=6,335, p=0,042\right)$. Para todas as variáveis as diferenças não foram estatisticamente significativas $(p>0,05)$ entre os diferentes níveis de idade do Conselho Administrativo. 
A análise post hoc revelou diferenças estatisticamente significativas nos escores do indicador Ass6 entre os grupos "25-35 anos" (postos médios $=4,500$ ) e "acima de 50 anos" (postos médios $=6,294)(p=0,047)$ mas não entre os demais grupos. Sendo assim, destaca-se que o indicador Emancipação social e econômica do associado é avaliado com um grau maior de importância por conselheiros administrativos mais velhos.

A segunda variável de perfil analisada foram os níveis de escolaridade do Conselho Administrativo. As diferenças não foram estatisticamente significativas ( $p$ > $0,05)$ entre os diferentes níveis de escolaridade do Conselho Administrativo.

A terceira variável de perfil analisada foi a quantos mandatos ele exerce a função de conselheiro administrativo. As diferenças nas classificações médias dos escores foram estatisticamente significantes apenas para os seguintes indicadores: Ass6 $\left(X^{2}(3)=9,003, p=0,029\right)$; Ass8 $\left(X^{2}(3)=13,311, p=0,004\right)$; Pes3 $\left(X^{2}(3)=12,360, p\right.$ $=0,006)$; Pes4 $\left(X^{2}(3)=9,817, p=0,020\right)$; Pes5 $\left(X^{2}(3)=13,958, p=0,003\right)$; Pri3 $\left(X^{2}(3)=8,406, p=0,038\right)$; e Pri5 $\left(X^{2}(3)=8,324, p=0,040\right)$

Para todas as outras variáveis as diferenças não foram estatisticamente significativas $(p>0,05)$ entre os diferentes níveis de quantos mandatos ele exerce a função de conselheiro administrativo.

A análise post hoc revelou diferenças estatisticamente significativas nos escores dos indicadores:

- Ass 6 entre os grupos "1 mandato" (postos médios = 19,15) e "2 mandatos" ( postos médios 10,18$)(p=0,027)$ mas não entre os demais grupos.

- Ass 8 entre os grupos "1 mandato" (postos médios = 20,35) e "2 mandatos" (postos médios $=9,41)(p=0,004)$ mas não entre os demais grupos.

- Pes 3 entre os grupos "1 mandato" (postos médios = 20,04) e "2 mandatos" (postos médios $=9,36)(p=0,006)$ mas não entre os demais grupos.

- Pes 4 entre os grupos "1 mandato" (postos médios = 19,08) e "2 mandatos" (postos médios $=10,55)(p=0,032)$ mas não entre os demais grupos.

- Pes 5 entre os grupos "1 mandato" (postos médios = 20,19) e "2 mandatos" (postos médios $=9,09)(p=0,004)$ mas não entre os demais grupos.

- Pri 3 entre os grupos "1 mandato" (postos médios = 19,04) e "2 mandatos" (postos médios $=10,59)(p=0,049)$ mas não entre os demais grupos. 
- Pri 5 entre os grupos "1 mandato" (postos médios = 19,00) e "2 mandatos" (postos médios $=10,41)(p=0,040)$ mas não entre os demais grupos.

Em suma, os respondentes que atuam como conselheiros administrativos a apenas um mandato classificaram os indicadores Emancipação social e econômica do associado, Realização pessoal dos cooperados, Segurança no emprego para os trabalhadores da cooperativa, Pagamento de bons salários aos funcionários da cooperativa, Benefícios extras para bons funcionários, Solidariedade e Autonomia e a independência, com maior nível de importância do que aqueles que atuam a dois mandatos.

A fim de determinar se havia diferenças nos escores da importância atribuída aos diferentes indicadores entre os níveis das variáveis que caracterizam o perfil dos conselheiros fiscais, um teste $U$ de Mann-Whitney foi conduzido. Os grupos comparados foram dois níveis das variáveis Idade, Escolaridade e Número de mandatos que caracterizam o perfil do conselho fiscal.

Pode-se considerar que as distribuições dos escores não foram semelhantes para todos os grupos, conforme avaliado pela inspeção visual dos boxplots. O nível significância estatística utilizada foi o teste Exato (ExactSig) por conta do pequeno tamanho da amostra (DINNEEN; BLAKESLEY, 1973; FIELD, 2009).

A primeira variável de perfil analisada foram os grupos "25-35 anos" e "Acima de 50 anos" da variável idade do Conselho Fiscal. Em relação ao indicador Fin6 (Margem bruta), a importância atribuída pelo grupo de idade de "25-35 anos" (posto médio $=19,88)$ foi significativamente maior do que a importância atribuída pelo grupo de idade de "Acima de 50 anos" (posto médio = 9,76) $(U=13,000, z=-3,321, p=0,001)$.

Em relação ao indicador Pro2 (Percentual de transações realizadas através dos diversos canais), a importância atribuída pelo grupo de idade de "25-35 anos" (posto médio $=18,12$ ) foi significativamente maior do que a importância atribuída pelo grupo de idade de "Acima de 50 anos" (posto médio = 10,59) $(U=27,000, z=-2,441, p=$ 0,016). Para os demais indicadores as diferenças não foram estatisticamente significativas $(p>0,05)$.

Sendo assim, pode-se dizer que os conselheiros fiscais participantes da amostra que tem idade entre 25 e 35 anos avaliam melhor dois indicadores do que aqueles com idade superior a 50 anos. 
A segunda variável de perfil analisada foram os grupos "Especialização" e "Superior Completo" da variável escolaridade do Conselho Fiscal. As diferenças na importância atribuída pelos grupos "especialização" e "Superior completo" da variável escolaridade aos indicadores analisados não foram estatisticamente significativas ( $p$ > $0,05)$.

A terceira variável de perfil analisada foram os grupos "1 mandato" e "2 mandatos" da variável Número de Mandatos do Conselho Fiscal. Em relação ao indicador Fin6 (Margem bruta), a importância atribuída pelo grupo "1 mandato" (posto médio $=17,80$ ) foi significativamente maior do que a importância atribuída pelo grupo "2 mandatos" (posto médio $=9,80)(U=27,000, z=-2,760, p=0,007)$. Para os demais indicadores as diferenças não foram estatisticamente significativas $(p>0,05)$.

Em suma, os conselheiros fiscais participantes da amostra que tem idade entre 25 e 35 anos avaliam melhor dois indicadores do que aqueles com idade superior a 50 anos; e aqueles "1 mandato" avaliaram com maior importância um indicador do que pelo grupo "2 mandatos".

Para o grupo de cooperados, conforme já discutido pela hipótese 5 , tem-se que aqueles que menos participam das assembleias demonstraram menor grau de importância para alguns indicadores do que aqueles que participaram mais (para os indicadores: grau do endividamento financeiro, resultado econômico, retenção de cooperantes, capitalização, associados em assembleia geral ordinária e relevância do associado na tomada de decisão).

Os cooperados de menor faixa etária também classificam 0 indicador Solidariedade com menor grau de importância. Grupos de maior instrução (mestrado ou doutorado) classificaram com menor importância indicador referente à educação, formação e informação ao cooperado. Participantes de renda mais alta consideram mais importante o indicador Menor custo das transações, do que os de renda mais baixa, e esses consideram mais importante o indicador Educação, formação e informação ao cooperado do que os de renda mais alta.

Vê-se que de forma geral, as variáveis idade e escolaridade dos participantes da amostra pouco influenciam na percepção de importância dos indicadores em todos os grupos analisados. O que realmente pesa em relação às divergências de opinião é o quanto o participante é envolvido na cooperativa (denotado pelas variáveis: tempo de função, número de mandatos e participação em assembleias). 
Percebe-se que para Conselheiros Fiscais e Administrativos e Gerentes, aqueles que estão na função há menos tempo tem tendência a classificar melhor alguns indicadores do que aqueles que estão há mais tempo. O grupo que chama mais atenção é dos Conselheiros Administrativos, visto que os mais novos no cargo se preocupam mais com questões ideológicas e com o bem-estar de cooperados e colaboradores do que aqueles que estão a mais tempo na função.

Já para os cooperados, aqueles que menos participam da cooperativa (nunca foram a assembleias ou foram menos vezes) classificam com menor importância os indicadores, demonstrando menor preocupação com grau de endividamento, resultado econômico, capitalização, retenção de cooperantes, associados em assembleia geral e relevância do associado na tomada de decisão. Pode ser que não participem tanto de assembleias justamente pelo fato de não acreditem na necessidade de estarem presentes e na relevância de sua opinião, como destacado.

Portanto, pode-se dizer que considerando a perspectiva do perfil que trata do nível de envolvimento do grupo com a cooperativa, representado pelo tempo de função, número de mandatos e participação em assembleias, as variáveis determinadas como importantes para avaliar desempenho de cooperativas de crédito variam no que tange aos indicadores discutidos.

\subsection{IMPORTÂNCIA ATRIBUÍDA PELOS DIFERENTES GRUPOS PARTICIPANTES DA PESQUISA PARA CADA MÓDULO}

Um teste $\mathrm{H}$ de Kruskal-Wallis foi conduzido para determinar se havia diferenças nos escores da importância atribuída aos diferentes indicadores e módulos entre os quatro grupos de respondentes. Pode-se considerar que as distribuições dos escores não foram semelhantes para todos os grupos, conforme avaliado pela inspeção visual dos boxplots. Para descobrir quais grupos são diferentes de quais outros grupos foi executado um teste post hoc. No caso do teste de Kruskal-Wallis, foi executada e interpretada todas as comparações emparelhadas usando o procedimento de Dunn (1964) com um ajuste de Bonferroni.Valores de p ajustados são apresentados. Os valores são postos médios, a menos que seja indicado o contrário. 
As diferenças nas classificações médias dos escores foram estatisticamente significantes entre grupos da categoria de indicadores Financeiros $\left(X^{2}(3)=48,455, p<\right.$ 0,0005).

A análise post hoc revelou diferenças estatisticamente significantes nos escores dos grupos Cooperados (postos médios = 116,67) e Gerentes (postos médios $=187,08)$, sendo assim os gerentes atribuem maior importância a categoria Financeira do que os cooperados $p=0,000)$.

Também revelou diferenças estatisticamente significantes nos escores dos grupos Cooperados (postos médios $=116,67$ ) e Conselho Administrativo (postos médios $=196,80$ ), sendo assim o Conselho Administrativo atribui maior importância para a categoria Financeira do que os cooperados $(p=0,000)$.

As diferenças nas classificações médias dos escores foram estatisticamente significantes entre grupos da categoria de indicadores Associados $\left(X^{2}(3)=76,239, p<\right.$ 0,0005).

A análise post hoc revelou diferenças estatisticamente significantes nos escores dos grupos Cooperados (postos médios $=107,10$ ) e Conselho Fiscal (postos médios $=179,32$ ), sendo assim o Conselho Fiscal atribui maior importância a categoria Associado do que os cooperados $(p=0,001)$.

Também revelou diferenças estatisticamente significantes nos escores dos grupos Cooperados (postos médios $=107,10$ ) e Conselho Administrativo (postos médios = 191,36), sendo assim o Conselho Administrativo atribui maior importância a categoria Associado do que os cooperados ( $p=0,000)$.

Por fim, o teste post hoc revelou diferenças estatisticamente significantes nos escores dos grupos Cooperados (postos médios $=107,10$ ) e Gerentes (postos médios $=198,18)$, sendo assim os gerentes atribuem maior importância a categoria Associado do que os cooperados ( $p=0,000)$.

As diferenças nas classificações médias dos escores foram estatisticamente significantes entre grupos da categoria de indicadores Processos Internos $\left(X^{2}(3)=86,469, p<0,0005\right)$.

A análise post hoc revelou diferenças estatisticamente significantes nos escores dos grupos Cooperados (postos médios $=106,14$ ) e Conselho Fiscal (postos médios $=174,70)$, sendo assim o Conselho Fiscal atribui maior importância a categoria Processos Internos do que os cooperados ( $p=0,002)$. 
Também revelou diferenças estatisticamente significantes nos escores dos grupos Cooperados (postos médios $=106,14$ ) e Conselho Administrativo (postos médios $=170,29$ ), sendo assim o Conselho Administrativo atribui maior importância a categoria Processos Internos do que os cooperados $(p=0,001)$.

Por fim, o teste post hoc revelou diferenças estatisticamente significantes nos escores dos grupos Cooperados (postos médios $=106,14$ ) e Gerentes (postos médios $=207,33$ ), sendo assim os gerentes atribuem maior importância a categoria Processos Internos do que os cooperados $(p=0,000)$.

As diferenças nas classificações médias dos escores foram estatisticamente significantes entre grupos da categoria de indicadores Aprendizado e Crescimento $\left(X^{2}(3)=77,116, p<0,0005\right)$.

A análise post hoc revelou diferenças estatisticamente significantes nos escores dos grupos Cooperados (postos médios $=108,55$ ) e Conselho Fiscal (postos médios $=162,64$ ), sendo assim o Conselho Fiscal atribui maior importância a categoria Aprendizado e Crescimento do que os cooperados $(p=0,020)$.

Também revelou diferenças estatisticamente significantes nos escores dos grupos Cooperados (postos médios $=108,55$ ) e Conselho Administrativo (postos médios $=178,12$ ), sendo assim o Conselho Administrativo atribui maior importância a categoria Aprendizado e Crescimento do que os cooperados ( $p=0,000)$.

Por fim, o teste post hoc revelou diferenças estatisticamente significantes nos escores dos grupos Cooperados (postos médios $=108,55$ ) e Gerentes (postos médios $=204,28)$, sendo assim os gerentes atribuem maior importância a categoria Aprendizado e Crescimento do que os cooperados $(p=0,000)$.

As diferenças nas classificações médias dos escores foram estatisticamente significantes entre grupos da categoria de indicadores Pessoas e Inovação $\left(X^{2}(3)=15,727, p=0,001\right)$.

A análise post hoc revelou diferenças estatisticamente significantes nos escores dos grupos Cooperados (postos médios $=135,38$ ) e Gerentes (postos médios = 178,69), sendo assim os Gerentes atribuem maior importância a categoria Pessoas e Inovação do que os cooperados ( $p=0,001)$.

As diferenças nas classificações médias dos escores foram estatisticamente significantes entre grupos da categoria de indicadores Princípios Cooperativistas $\left(X^{2}(3)=67,565, p<0,0005\right)$. 
A análise post hoc revelou diferenças estatisticamente significantes nos escores dos grupos Cooperados (postos médios $=112,72$ ) e Conselho Fiscal (postos médios $=178,38$ ), sendo assim o Conselho Fiscal atribui maior importância a categoria Princípios Cooperativistas do que os cooperados $(p=0,002)$.

Também revelou diferenças estatisticamente significantes nos escores dos grupos Cooperados (postos médios $=112,72$ ) e Gerentes (postos médios $=203,63$ ), sendo assim os gerentes atribuem maior importância a categoria Princípios Cooperativistas do que os cooperados $(p=0,000)$.

Por fim, o teste post hoc revelou diferenças estatisticamente significantes nos escores dos grupos Gerentes (postos médios $=203,63$ ) e Conselho Administrativo (postos médios $=143,57$ ), sendo assim os gerentes atribuem maior importância a categoria Princípios Cooperativistas do que o Conselho Administrativo $(p=0,007)$.

A tabela 57 a seguir traz as médias de cada grupo para cada módulo: 
Tabela 57 - Médias de cada grupo por módulo

\begin{tabular}{ccccc}
\hline MÓDULO/GRUPO & Cooperados & Gerentes & $\begin{array}{c}\text { Conselheiros } \\
\text { Administrativos }\end{array}$ & $\begin{array}{c}\text { Conselheiros } \\
\text { Fiscais }\end{array}$ \\
\hline Financeiro & 5,645 & 6,307 & 6,376 & 6,108 \\
Associados & 5,603 & 6,285 & 6,323 & 6,17 \\
Processos Internos & 5,398 & 6,32 & 6,018 & 6,06 \\
Aprendizado e & 5,504 & 6,412 & 6,214 & 6,053 \\
Crescimento & 6,012 & 6,344 & 6,076 & 6,09 \\
Pessoas e Inovação & 5,703 & 6,515 & 6,072 & 6,311 \\
Princípios Cooperativistas & & &
\end{tabular}

Fonte: autora.

Em suma temos que o grupo de Cooperados atribui maior grau de importância ao módulo "Pessoas e Inovação", e menor importância a "Processos Internos", denotando que consideram mais relevantes aspectos diretamente relacionados ao bem-estar dos colaboradores e melhoria da estrutura da cooperativa do que ao desenvolvimento do trabalho e melhoria de processos.

Gerentes atribuíram maior valor a "Princípios cooperativistas" e menor a "Associados", revelando considerar mais importante aspectos diretamente relacionados ao atendimento de princípios cooperativistas e menos importante aqueles relacionados ao bem-estar dos associados.

Conselheiros administrativos atribuíram maior valor ao módulo "Financeiro" e menor ao módulo "Processos Internos", considerando mais importantes aspectos diretamente relacionados aos resultados financeiros da cooperativa e menos importantes aqueles relacionados ao desenvolvimento do trabalho e melhoria de processos.

E por fim, conselheiros administrativos, atribuíram maior grau de importância a "Princípios Cooperativistas" e menor a "Processos Internos", relevando maior preocupação no que tange ao atendimento de princípios cooperativistas, e menor preocupação referente ao desenvolvimento do trabalho e melhoria de processos.

A média mais alta dos indicadores "Financeiro" e "Associados" foi atribuída por Conselheiros Administrativos; e a média mais alta dos demais módulos foi atribuída por Gerentes. De maneira geral, o grupo que melhor classificou os módulos foi Gerentes, e que pior classificou foi o grupo de Cooperados. 


\subsection{CONVERGÊNCIAS E DIVERGÊNCIAS DE OPINIÕES ENTRE AGENTES E PRINCIPAL}

Um teste $t$ de amostras independentes foi executado para determinar em quais indicadores agentes e principais apresentam níveis de percepção de importância diferentes. Conforme avaliado pelo teste de Kolmogorov-Smirnov os dados de cada grupo não são distribuídos normalmente $(p<0,05)$ No entanto, como a amostra total é composta por 298 observações, o teste t de amostras independentes é considerado "robusto" para violações da normalidade (KANG; HARRING, 2012; LAERD STATISTICS, 2015; SAWILOWSKY; BLAIR, 1992).

A homogeneidade das variâncias foi testada utilizando o teste de Levene (tabela 59). Caso a homogeneidade das variâncias for violada, então foi utilizado o Teste $\mathrm{t}$ de Welch, que se mostra mais robusto quando há a violação da homogeneidade das variâncias somado a expressiva diferença no tamanho das amostras (tamanhos de grupo desiguais) (HOWELL, 2012; KOHR; GAMES, 1974).

Entende-se aqui que o "principal" da relação tratada nesse estudo é o cooperado, visto que esse é o dono da cooperativa, e delega poder aos agentes para que façam a gestão da mesma. Nesse sentido, se reconhece como os "agentes" da relação os conselheiros administrativos e fiscais e os gerentes.

Em relação aos resultados encontrados, estes estão dispostos na tabela 59, que denota que para 7 indicadores, dos 53 indicadores apresentados os grupos representados por "agente" e "principal" convergem de opinião. Para os demais 46 indicadores os dois grupos divergem de opinião.

Os indicadores cujas opiniões são significativamente parecidas são: Retorno sobre o investimento, Menor custo das transações, Ganhos financeiros de cada cooperado individualmente, Segurança no emprego para os trabalhadores da cooperativa, Pagamento de bons salários aos funcionários da cooperativa, Benefícios extras para bons funcionários e Condições de trabalho adequadas. As médias de cada grupo para cada indicador estão discriminadas na tabela 59. 
Tabela 58 - Médias para os indicadores onde houve convergência de opiniões entre os grupos

\begin{tabular}{lll}
\hline \multicolumn{1}{c}{ Indicador } & \multicolumn{1}{c}{ Grupo } & Média \\
\hline (Fin2) Retorno sobre o investimento & Fiscal & 5,760 \\
& Conselho Administrativo & 6,607 \\
& Cooperados & 5,974 \\
& Gerentes & 6,108 \\
\hline (Ass3) Menor custo das transações & Fiscal & 6,240 \\
& Conselho Administrativo & 6,429 \\
& Cooperados & 6,105 \\
& Gerentes & 6,043 \\
\hline (Ass4) Ganhos financeiros de cada & Fiscal & 5,600 \\
cooperado individualmente & Conselho Administrativo & 6,214 \\
& Cooperados & 5,724 \\
& Gerentes & 5,634 \\
\hline (Pes3) Segurança no emprego para & Fiscal & 5,760 \\
os trabalhadores da cooperativa & Conselho Administrativo & 5,714 \\
& Cooperados & 5,895 \\
& Gerentes & 6,118 \\
\hline (Pes4) Pagamento de bons salários & Fiscal & 5,880 \\
aos funcionários da cooperativa & Conselho Administrativo & 5,857 \\
& Cooperados & 5,901 \\
& Gerentes & 6,194 \\
\hline (Pes5) Benefícios extras para bons & Fiscal & 5,760 \\
funcionários & Conselho Administrativo & 5,464 \\
& Cooperados & 5,711 \\
& Gerentes & 5,763 \\
\hline (Pes8) Condições de trabalho & Fiscal & 6,360 \\
adequadas & Conselho Administrativo & 6,179 \\
& Cooperados & 6,342 \\
& Gerentes & 6,634 \\
\hline
\end{tabular}

Fonte: autora.

Dessa forma vê-se que os grupos de agente e principal concordam em relação às seguintes condições:

- A relação entre a quantidade de dinheiro ganho em um investimento e a quantidade de dinheiro investido, já que classificam o indicador "Retorno sobre o investimento" como moderadamente importante e muito importante.

- Custo das transações menores que outras instituições financeiras, já que classificam o indicador "Menor custo das transações" como muito importante.

- Preocupação com os ganhos financeiros do indivíduo, já que, no geral, classificam o indicador "Ganhos financeiros de cada cooperado individualmente" como moderadamente importante.

- Média de demissões, já que, no geral, classificam o indicador "Segurança no emprego para os trabalhadores da cooperativa" como moderadamente importante.

- Média salarial, já que, no geral, classificam o indicador "Pagamento de bons salários aos funcionários da cooperativa" como moderadamente importante. 
- Programa de benefícios para os colaboradores, já que classificam o indicador "Benefícios extras para os bons funcionários" como moderadamente importante.

- Ambiente de trabalho seguro e confortável, já que classificam o indicador "Condições de trabalho adequadas" como muito importante. 
Tabela 59 - Estatísticas dos grupos: todas as categorias

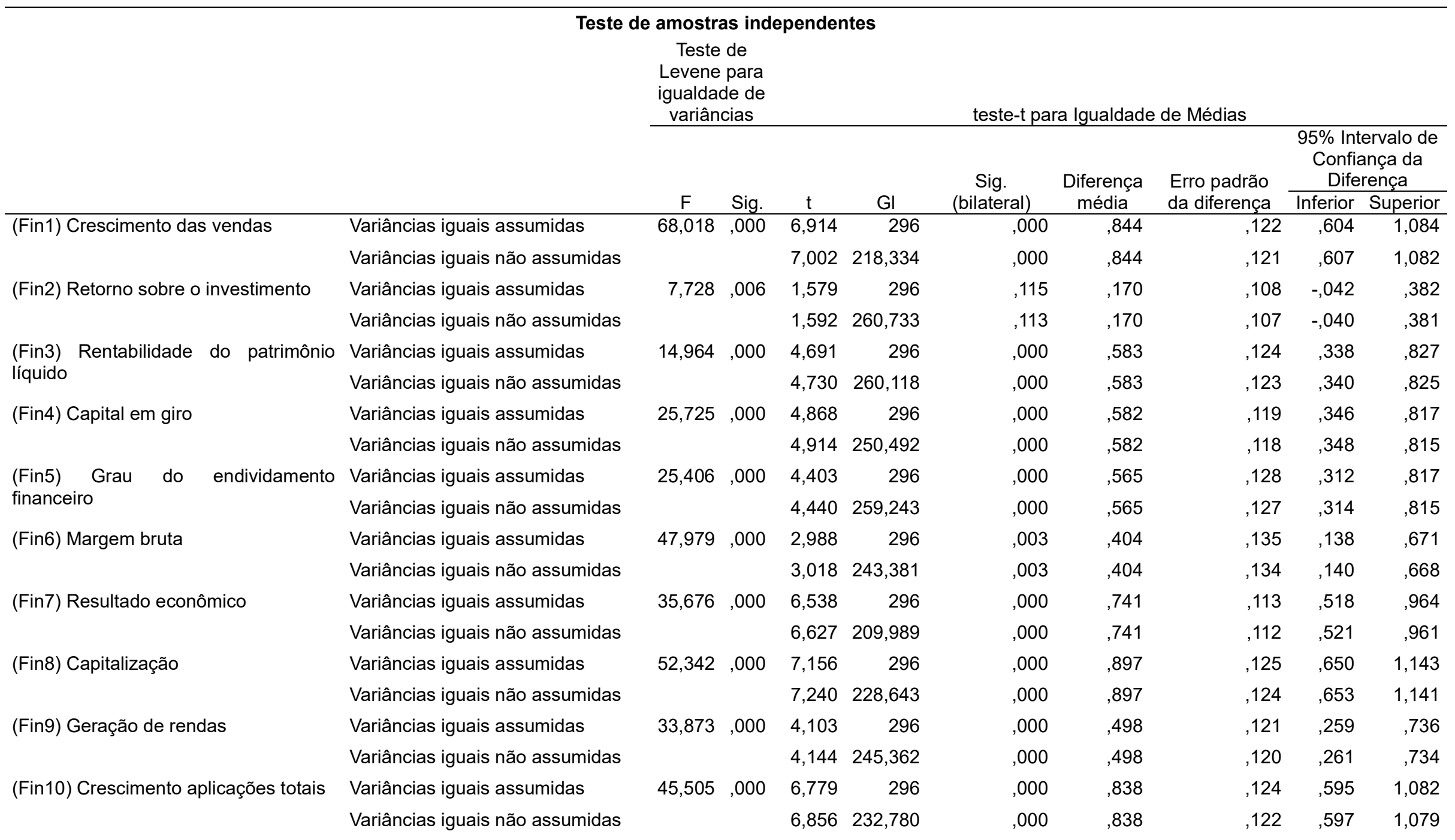


(Fin11) Crescimento captações totais

(Fin12) Equilíbrio do orçamento

(Fin13) Nível de inadimplemento (NID)

(Ass1) Retenção de cooperantes

(Ass2) Satisfação de cooperantes

(Ass3) Menor custo das transações

(Ass4) Ganhos financeiros de cada Variâncias iguais assumidas

cooperado individualmente

(Ass5) Ganhos financeiros de todos os Variâncias iguais assumidas

cooperados (enquanto grupo)

(Ass6) Emancipação social

(Ass7) Educação, formação informação ao cooperado

(Ass8) Realização pessoa

Variâncias iguais assumidas Variâncias iguais não assumidas Variâncias iguais assumidas Variâncias iguais não assumidas

ariâncias iguais assumidas

Variâncias iguais não assumidas

Variâncias iguais assumidas

Variâncias iguais não assumidas

Variâncias iguais assumidas

Variâncias iguais não assumidas

Variâncias iguais assumidas

iguais não assumidas

Variâncias iguais não assumidas

e Variâncias iguais assumidas

Variâncias iguais não assumidas

e Variâncias iguais assumidas

Variâncias iguais não assumidas

cooperados

dos Variâncias iguais assumidas

Variâncias iguais não assumidas

(Ass9) Associados em assembleia Variâncias iguais assumidas geral ordinária (AGO)

Variâncias iguais não assumidas

(Ass10) Número associados ativos

Variâncias iguais assumidas

Variâncias iguais não assumidas

(Ass11) Sobras ou faturamento por Variâncias iguais assumidas

cooperado

Variâncias iguais não assumidas

\begin{tabular}{|c|c|c|c|c|c|}
\hline \multirow[t]{2}{*}{57,324} & ,000 & 8,347 & 296 & ,000 & 1,010 \\
\hline & & 8,450 & 222,364 & ,000 & 1,010 \\
\hline \multirow[t]{2}{*}{12,351} & ,001 & 3,614 & 296 & ,000 & , 427 \\
\hline & & 3,649 & 248,370 & ,000 & , 427 \\
\hline \multirow[t]{2}{*}{65,592} & ,000 & 7,161 & 296 & ,000 & ,780 \\
\hline & & 7,273 & 190,376 & ,000 & ,780 \\
\hline \multirow[t]{2}{*}{55,384} & ,000 & 10,284 & 296 & ,000 & 1,316 \\
\hline & & 10,423 & 211,332 & ,000 & 1,316 \\
\hline \multirow[t]{2}{*}{43,729} & ,000 & 5,997 & 296 & ,000 & ,613 \\
\hline & & 6,078 & 210,986 & ,000 & ,613 \\
\hline \multirow[t]{2}{*}{17,844} & ,000 & ,438 & 296 & ,662 & ,045 \\
\hline & & ,441 & 269,412 & 659 & ,045 \\
\hline \multirow[t]{2}{*}{7,843} & ,005 & ,128 & 296 & ,899 & ,016 \\
\hline & & 128 & 290,582 & ,898 & ,016 \\
\hline \multirow[t]{2}{*}{23,384} & ,000 & 4,140 & 296 & ,000 & , 457 \\
\hline & & 4,178 & 251,287 & ,000 & ,457 \\
\hline \multirow[t]{2}{*}{22,867} & ,000 & 4,381 & 296 & ,000 & ,493 \\
\hline & & 4,412 & 268,697 & ,000 & ,493 \\
\hline \multirow[t]{2}{*}{12,217} & ,001 & 3,593 & 296 & ,000 & ,335 \\
\hline & & 3,619 & 269,692 & ,000 & ,335 \\
\hline \multirow[t]{2}{*}{,060 } & ,806 & 2,211 & 296 & ,028 & ,247 \\
\hline & & 2,212 & 295,999 & ,028 & ,247 \\
\hline \multirow[t]{2}{*}{26,579} & ,000 & 11,002 & 296 & ,000 & 1,600 \\
\hline & & 11,106 & 249,443 & ,000 & 1,600 \\
\hline \multirow[t]{2}{*}{47,413} & ,000 & 11,489 & 296 & ,000 & 1,318 \\
\hline & & 11,640 & 215,136 & ,000 & 1,318 \\
\hline \multirow[t]{2}{*}{58,342} & ,000 & 4,945 & 296 & ,000 & ,642 \\
\hline & & 5.001 & 2897 & 000 & 642 \\
\hline
\end{tabular}

, 121

1,245

, $118 \quad$,659

, 657

,109 , 566

107 , 568

,128 $1,064 \quad 1,567$

,126 1,067 1,564

, 102, 412 , 414

, 101 , 414

, $104 \quad-, 159 \quad 249$

,103 -, 248

, $126 \quad-, 231 \quad 263$

,125 -,263

674

,672

,113, 2715

,112, 273 , ,713

,093 , 518

,092, 153 , 517

, 112 , 468

, 112 , 027

,145 1,314 1,887

,144 1,317 1,884

,115 1,093 1,544

,113 1,095 1,542

, 898

, 896 
(Ass12) Relevância do associado na Variâncias iguais assumidas tomada de decisão

Variâncias iguais não assumidas

(Pro1) Lucratividade por segmento- Variâncias iguais assumidas alvo

Variâncias iguais não assumidas

(Pro2) Percentual de transações Variâncias iguais assumidas

realizadas através dos diversos canais Variâncias iguais não assumidas

(Pro3) Projetos sociais desenvolvidos Variâncias iguais assumidas

Variâncias iguais não assumidas

(Pro4) Percentual de trabalho Variâncias iguais assumidas extraordinário

Variâncias iguais não assumidas

(Pro5) Desenvolvimento sustentável

Variâncias iguais assumidas

Variâncias iguais não assumidas

(Pro6) Nível de Transparência

(Pro7) Perpetuação da instituição

Variâncias iguais assumidas

Variâncias iguais não assumidas

Variâncias iguais assumidas

Variâncias iguais não assumidas

(Pro8) Preservação da identidade Variâncias iguais assumidas organizacional

Variâncias iguais não assumidas

(Apr1) Melhorias das capacidades dos Variâncias iguais assumidas funcionários

(Apr2) Nível de rotatividade

Variâncias iguais não assumidas

Variâncias iguais assumidas

Variâncias iguais não assumidas

(Apr3) Motivação para agir no melhor Variâncias iguais assumidas interesse da cooperativa

(Pes1) Profissionalização administração

\begin{tabular}{rrrrrr}
13,924 &, 000 & 5,702 & 296 &, 000 &, 741 \\
22,635 & & 5,743 & 269,063 &, 000 &, 741 \\
& & 3,508 & 296 &, 001 &, 469 \\
25,347 &, 000 & 6,074 & 258,972 &, 000 &, 469 \\
& & 6,134 & 246,090 &, 000 &, 856 \\
53,869 &, 000 & 8,150 & 296 &, 000 &, 856 \\
& & 8,257 & 215,267 &, 000 & 1,162 \\
22,008 &, 000 & 4,936 & 296 &, 000 &, 808 \\
& & 4,972 & 267,846 &, 000 &, 808 \\
$57,041,000$ & 7,968 & 296 &, 000 & 1,073 \\
& & 8,076 & 210,841 &, 000 & 1,073 \\
99,193 &, 000 & 4,993 & 296 &, 000 &, 318 \\
& & 5,061 & 210,164 &, 000 &, 318 \\
62,523 &, 000 & 9,308 & 296 &, 000 & 1,039 \\
& & 9,419 & 226,506 &, 000 & 1,039 \\
26,648 &, 000 & 7,434 & 296 &, 000 &, 829 \\
& & 7,519 & 232,015 &, 000 &, 829 \\
56,826 &, 000 & 8,098 & 296 &, 000 &, 932 \\
& & 8,201 & 218,806 &, 000 &, 932 \\
36,426 &, 000 & 7,576 & 296 &, 000 & 1,017 \\
& & 7,652 & 244,538 &, 000 & 1,017 \\
6,013 & \multirow{2}{*}{, 015} & 4,383 & 296 &, 000 &, 476 \\
& & 4,402 & 287,141 &, 000 &, 476 \\
39,003 &, 000 & 5,137 & 296 &, 000 &, 450 \\
& & 5,190 & 241,253 &, 000 &, 450 \\
22,897 &, 000 & 2,605 & 296 &, 010 &, 277
\end{tabular}

\begin{tabular}{rrr}
, 130 &, 486 &, 997 \\
, 129 &, 487 &, 996 \\
, 134 &, 206 &, 732 \\
, 133 &, 208 &, 730 \\
, 141 &, 579 & 1,134 \\
, 140 &, 581 & 1,131 \\
& & \\
, 143 &, 882 & 1,443 \\
, 141 &, 885 & 1,440 \\
, 164 &, 486 & 1,131 \\
, 163 &, 488 & 1,129 \\
, 135 &, 808 & 1,339 \\
, 133 &, 811 & 1,335 \\
, 064 &, 193 &, 443 \\
, 063 &, 194 &, 442 \\
, 112 &, 819 & 1,259 \\
, 110 &, 822 & 1,257 \\
, 112 &, 610 & 1,048 \\
, 110 &, 612 & 1,046 \\
, 115 &, 705 & 1,158 \\
, 114 &, 708 & 1,156 \\
, 134 &, 753 & 1,281 \\
, 133 &, 755 & 1,279 \\
, 109 &, 262 &, 690 \\
, 108 &, 263 &, 689 \\
, 088 &, 278 &, 623 \\
, 087 &, 279 &, 621 \\
, 106 &, 068 & 486 \\
\hline & &
\end{tabular}


(Pes2) Melhoria constante da estrutura Variâncias iguais não assumidas da cooperativa

(Pes3) Segurança no emprego para os Variâncias iguais assumidas

trabalhadores da cooperativa Variâncias iguais não assumidas

(Pes4) Pagamento de bons salários Variâncias iguais assumidas aos funcionários da cooperativa

Variâncias iguais não assumidas

(Pes5) Benefícios extras para bons Variâncias iguais assumidas funcionários

Variâncias iguais não assumidas

(Pes6) Respeito as opiniões dos Variâncias iguais assumidas

trabalhadores

Variâncias iguais não assumidas

(Pes7) Ambiente de trabalho ético e Variâncias iguais assumidas

que valoriza o capital humano

Variâncias iguais não assumidas

(Pes8) Condições de trabalho Variâncias iguais assumidas

adequadas

(Pri1) Cumpre

cooperativistas

(Pri2) Democracia e igualdade

(Pri3) Solidariedade

Valores de ajuda mútua Variâncias iguais assumidas

(preocupação com o semelhante)

Variâncias iguais não assumidas

(Pri5) Autonomia e a independência

Variâncias iguais assumidas

Variâncias iguais não assumidas

(Pri6) Adesão livre e voluntária

Variâncias iguais assumidas

Variâncias iguais não assumidas

(Pri7) Preocupação com a comunidade Variâncias iguais assumidas

Variâncias iguais não assumidas

\begin{tabular}{|c|c|c|c|c|c|c|c|c|}
\hline & & 2,623 & 270,598 & , 009 & ,277 & , 106 & 069 & \\
\hline \multirow[t]{2}{*}{2,654} & ,104 & ,662 & 296 & ,509 & ,085 & 128 & -,167 & 37 \\
\hline & & 663 & 294,945 & ,508 & ,085 & 128 & -167 & \\
\hline \multirow[t]{2}{*}{13,437} & ,000 & 1,642 & 296 & 102 & 174 & 106 &,- 035 & \\
\hline & & 1,652 & 274,483 & 100 & 174 & 105 &,- 033 & \\
\hline \multirow[t]{2}{*}{2,318} & ,129 &,- 039 & 296 & ,969 &,- 005 & ,130 &,- 261 & \\
\hline & &,- 039 & 280,595 & 969 &,- 005 & 130 &,- 262 & \\
\hline \multirow[t]{2}{*}{6,001} & ,015 & 3,411 & 296 & ,001 & ,326 & ,096 & 138 & \\
\hline & & 3,435 & 270,392 & ,001 & ,326 & 095 & 139 & \\
\hline \multirow[t]{2}{*}{22,335} & ,000 & 4,330 & 296 & ,000 & ,436 & 101 & ,238 & \\
\hline & & 4,375 & 239,560 & ,000 & ,436 & 100, & 240 & \\
\hline \multirow[t]{2}{*}{18,567} & ,000 & 1,873 & 296 & ,062 & 158 & ,084 &,- 008 & \\
\hline & & 1,888 & 258,917 & ,060 & 158 & ,084 & -007 & \\
\hline \multirow[t]{2}{*}{97,860} & ,000 & 9,541 & 296 & ,000 & 1,253 & ,131 & ,994 & \\
\hline & & 9,691 & 190,922 & ,000 & 1,253 & ,129 & ,998 & \\
\hline \multirow[t]{2}{*}{22,485} & ,000 & 5,556 & 296 & ,000 & 631 & 114 & 408 & \\
\hline & & 5,616 & 237,246 & ,000 & 631 & 112 & 410 & \\
\hline \multirow[t]{2}{*}{28,699} & ,000 & 5,534 & 296 & ,000 & ,702 & 127 & 452 & \\
\hline & & 5,586 & 251,530 & ,000 & 702 & ,126 & 454 & \\
\hline \multirow[t]{2}{*}{10,936} & ,001 & 5,377 & 296 & ,000 & ,629 & 117 & ,399 & \\
\hline & & 5,413 & 273,407 & ,000 & ,629 & 116 & 400 & \\
\hline \multirow[t]{2}{*}{1,143} & 286 & 4,153 & 296 & ,000 & ,458 & 110 & 241 & \\
\hline & & 4,166 & 292,121 & ,000 & 458 & 110 & 242 & \\
\hline \multirow[t]{2}{*}{24,473} & ,000 & 8,139 & 296 & ,000 & ,935 & 115, & 709 & \\
\hline & & 8,198 & 267,935 & ,000 & ,935 & 114 & ,711 & \\
\hline \multirow[t]{2}{*}{41,255} & ,000 & 7,596 & 296 & ,000 & ,900 & ,119 & 667 & \\
\hline & & 7,684 & 229,821 & ,000 & ,900 & ,117 & 669 & \\
\hline
\end{tabular}


(Pri8) Geração de empregos

(Pri9) Combate a exclusão social

Fonte: autora.
Variâncias iguais assumidas

Variâncias iguais não assumidas

Variâncias iguais assumidas

Variâncias iguais não assumidas $\begin{array}{llll}6,589,011 & 2,281 & 296\end{array}$ $2,298 \quad 267,959$

$\begin{array}{llll}16,941,000 & 4,140 \quad 296\end{array}$

$4,174 \quad 260,926$
023

,241

,105

,033

, 1054

, 250

,114 252

448

,447

$\begin{array}{lllll}, 000 & \text {, 477 } & \text {, 115 } & \text {, 250 }\end{array}$

$\begin{array}{lllll}\text {,000 } & \text {, 252 }\end{array}$




\subsection{IMPORTÂNCIA DADA AOS PRINCÍPIOS DO COOPERATIVISMO PELOS GRUPOS, QUANDO SE TRATA DA AVALIAÇÃO DE DESEMPENHO DE COOPERATIVAS DE CRÉDITO}

Para compreender a importância dada aos princípios do cooperativismo pelos grupos, quando se trata da avaliação de desempenho de cooperativas de crédito, optouse por tomar como base as análises do item 5.3.4.3 dessa sessão.

As discussões do item 5.3.4.3 geraram a tabela 57, que esclarece que o grupo de Gerentes (média $=6,515$ ) é o que melhor avaliou o módulo, seguido por Conselheiros Fiscais (média = 6,311), Administrativos (média = 6,072) e Cooperados (média = 5,703).

Em comparação a todos os módulos, o módulo "Princípios Cooperativistas" é considerado por dois grupos (Gerentes e Conselheiros Fiscais) como o de maior grau de importância. Por sua vez, cooperados atribuem a segunda média maior a esse grupo (ficando atrás apenas do módulo Pessoas e Inovação) e Conselheiros Administrativos a quinta média maior (ficando a frente apenas do módulo Processos Internos). Sendo assim, nenhum grupo o considerou como o módulo menos importante.

Em suma, no geral o módulo que contempla os Princípios Cooperativistas foi muito bem avaliado pelos respondentes, ocupando posição de destaque em relação aos demais módulos nas análises de 3 (três) dos 4 (quatro) grupos participantes da pesquisa.

\subsection{ENTREVISTA COM COOPERATIVA E ANÁLISE DOCUMENTAL}

Com base na entrevista realizada com o Gestor de planejamento estratégico da cooperativa participante dessa fase da pesquisa, foi possível entender que a instituição utiliza o Balanced Score Card (BSC) para efetuar a avaliação de desempenho da organização.

Utilizam todas as dimensões do modelo, porém fizeram adaptações na perspectiva do cliente. Essa foi subdividida em três: associado; atuação em segmento e atuação geográfica. Isso porque, facilita o entendimento em relação ao público da cooperativa, já que não fazia sentido falar em cliente, sendo que se trabalha com associado.

Utilizam um software onde cadastraram todos os objetivos da cooperativa, e os indicadores de cada um deles. A partir dessa ferramenta de gestão da estratégia todos os indicadores tem suas metas traçadas e acompanhadas mensalmente.

O modelo aprimorado do BSC possui quatro módulos: Econômico, Clientes, Processos e Tecnologia e Aprendizado e Crescimento. 
Dentre de cada uma dessas perspectivas existem os chamados objetivos da cooperativa e seus respectivos indicadores, a partir dos quais se aferem se os objetivos estão sendo atingidos.

A perspectiva "Econômica" possui 5 (cinco) objetivos e 8 (oito) indicadores; a perspectiva "Cliente" é subdividida em 3 (três), a saber "Associado" com 2 (dois) objetivos e 6 (seis) indicadores, "Atuação em Segmento" com 3 (três) objetivos e 5 (cinco) indicadores e "Atuação Geográfica" com 3 (três) objetivos e 6 (seis indicadores). Por sua vez, a perspectiva "Processos e Tecnologia" possui 3 (três) objetivos e 6 (seis) indicadores; e a perspectiva "Aprendizado e Crescimento" possui 3 (três) objetivos e 6 (seis) indicadores.

O quadro 13 a seguir exprime todas as perspectivas, seus respectivos objetivos e indicadores:

Quadro 13 - Objetivos da cooperativa e seus indicadores

\begin{tabular}{|l|l|l|l|}
\hline \multicolumn{1}{|c|}{ Perspectiva } & \multicolumn{1}{|c|}{ Objetivo } & \multicolumn{1}{|c|}{ Indicador } & \multicolumn{1}{|c|}{ Unidade } \\
\hline Perspectiva Econômica & $\begin{array}{l}\text { Aumentar a base de } \\
\text { associados }\end{array}$ & Associados correntistas & quantidade \\
\hline Perspectiva Econômica & $\begin{array}{l}\text { Assegurar níveis adequados } \\
\text { de patrimônio }\end{array}$ & $\begin{array}{l}\text { Margem de capital / } \\
\text { RWA }\end{array}$ & percentual \\
\hline Perspectiva Econômica & $\begin{array}{l}\text { Assegurar níveis adequados } \\
\text { de patrimônio }\end{array}$ & Patrimônio Líquido & milhões de R\$ \\
\hline Perspectiva Econômica & Ampliar os ativos & Ativos totais & bilhões de R\$ \\
\hline Perspectiva Econômica & Gerir a liquidez & Índice de Liquidez & índice \\
\hline Perspectiva Econômica & Garantir a eficácia econômica & $\begin{array}{l}\text { Agências com resultado } \\
\text { positivo }\end{array}$ & percentual \\
\hline Perspectiva Econômica & $\begin{array}{l}\text { Garantir a eficácia econômica } \\
\text { líquida }\end{array}$ & $\begin{array}{l}\text { Índice de lucratividade } \\
\text { lidarcentual }\end{array}$ \\
\hline Perspectiva Econômica & Garantir a eficácia econômica & $\begin{array}{l}\text { Retorno sobre o PL } \\
\text { (\%CDI) }\end{array}$ & percentual \\
\hline $\begin{array}{l}\text { Perspectiva do Cliente } \\
\text { (Associado) }\end{array}$ & $\begin{array}{l}\text { Exercer os princípios do } \\
\text { cooperativismo }\end{array}$ & $\begin{array}{l}\text { Participação } \\
\text { assembleias }\end{array}$ & nercentual \\
\hline $\begin{array}{l}\text { Perspectiva do Cliente } \\
\text { (Associado) }\end{array}$ & $\begin{array}{l}\text { Exercer os princípios do do } \\
\text { cooperativismo }\end{array}$ & $\begin{array}{l}\text { Cidades com União Faz } \\
\text { a Vida }\end{array}$ & quantidade \\
\hline $\begin{array}{l}\text { Perspectiva do Cliente } \\
\text { (Associado) }\end{array}$ & $\begin{array}{l}\text { Ser a principal IF do } \\
\text { associado }\end{array}$ & Associados ativos & percentual \\
\hline $\begin{array}{l}\text { Perspectiva do Cliente } \\
\text { (Associado) }\end{array}$ & $\begin{array}{l}\text { Ser a principal IF do } \\
\text { associado }\end{array}$ & $\begin{array}{l}\text { Retenção } \\
\text { associados }\end{array}$ & percentual \\
\hline $\begin{array}{l}\text { Perspectiva do Cliente } \\
\text { (Associado) }\end{array}$ & $\begin{array}{l}\text { Ser a principal IF do } \\
\text { associado }\end{array}$ & $\begin{array}{l}\text { Índice de soluções por } \\
\text { associado - ISA }\end{array}$ & índice \\
\hline $\begin{array}{l}\text { Perspectiva do Cliente } \\
\text { (Associado) }\end{array}$ & $\begin{array}{l}\text { Ser a principal IF do } \\
\text { associado }\end{array}$ & Índice de cobertura & percentual \\
\hline $\begin{array}{l}\text { Perspectiva do Cliente } \\
\text { (Atuação em Segmento) }\end{array}$ & $\begin{array}{l}\text { Satisfazer as necessidades } \\
\text { dos associados }\end{array}$ & $\begin{array}{l}\text { Net Promoter Score - } \\
\text { NPS }\end{array}$ & percentual \\
\hline
\end{tabular}




\begin{tabular}{|c|c|c|c|}
\hline $\begin{array}{l}\text { Perspectiva do Cliente } \\
\text { (Atuação em Segmento) }\end{array}$ & $\begin{array}{l}\text { Ter portfólios adequados aos } \\
\text { segmentos estratégicos }\end{array}$ & ISAPF & índice \\
\hline $\begin{array}{l}\text { Perspectiva do Cliente } \\
\text { (Atuação em Segmento) }\end{array}$ & $\begin{array}{l}\text { Ter portfólios adequados aos } \\
\text { segmentos estratégicos }\end{array}$ & ISA PF Agro & índice \\
\hline $\begin{array}{l}\text { Perspectiva do Cliente } \\
\text { (Atuação em Segmento) }\end{array}$ & $\begin{array}{l}\text { Ter portfólios adequados aos } \\
\text { segmentos estratégicos }\end{array}$ & ISAPJ & índice \\
\hline $\begin{array}{l}\text { Perspectiva do Cliente } \\
\text { (Atuação em Segmento) }\end{array}$ & $\begin{array}{l}\text { Atuar com foco em } \\
\text { segmentos de menor risco }\end{array}$ & Concessão para BBM & percentual \\
\hline $\begin{array}{l}\text { Perspectiva do Cliente } \\
\text { (Atuação Geográfica) }\end{array}$ & $\begin{array}{l}\text { Ampliar participação de } \\
\text { mercado }\end{array}$ & Market share crédito & percentual \\
\hline $\begin{array}{l}\text { Perspectiva do Cliente } \\
\text { (Atuação Geográfica) }\end{array}$ & $\begin{array}{l}\text { Ampliar participação de } \\
\text { mercado }\end{array}$ & Market share depósitos & percentual \\
\hline $\begin{array}{l}\text { Perspectiva do Cliente } \\
\text { (Atuação Geográfica) }\end{array}$ & $\begin{array}{l}\text { Ampliar participação de } \\
\text { mercado }\end{array}$ & Número de agências & quantidade \\
\hline $\begin{array}{l}\text { Perspectiva do Cliente } \\
\text { (Atuação Geográfica) }\end{array}$ & $\begin{array}{l}\text { Expandir para municípios de } \\
\text { alto potencial }\end{array}$ & \begin{tabular}{|lcc} 
Novas agências & em \\
cidades & de & alto \\
potencial & & \\
\end{tabular} & percentual \\
\hline $\begin{array}{l}\text { Perspectiva do Cliente } \\
\text { (Atuação Geográfica) }\end{array}$ & Cobrir toda a área de atuação & Market share empresas & percentual \\
\hline $\begin{array}{l}\text { Perspectiva do Cliente } \\
\text { (Atuação Geográfica) }\end{array}$ & Cobrir toda a área de atuação & Market share PEA & percentual \\
\hline $\begin{array}{l}\text { Perspectiva Processos e } \\
\text { Tecnologia }\end{array}$ & $\begin{array}{l}\text { Aumentar a eficácia dos } \\
\text { processos }\end{array}$ & Índice de Eficiência & Percentual \\
\hline $\begin{array}{l}\text { Perspectiva Processos e } \\
\text { Tecnologia }\end{array}$ & $\begin{array}{l}\text { Aumentar a eficácia dos } \\
\text { processos }\end{array}$ & $\begin{array}{l}\text { Transações nos canais } \\
\text { alternativos }\end{array}$ & Percentual \\
\hline $\begin{array}{l}\text { Perspectiva Processos e } \\
\text { Tecnologia }\end{array}$ & $\begin{array}{l}\text { Ter canais adequados aos } \\
\text { segmentos estratégicos }\end{array}$ & $\begin{array}{l}\text { Pesquisa de satisfação } \\
\text { com os canais }\end{array}$ & Nota de $0-10$ \\
\hline $\begin{array}{l}\text { Perspectiva Processos e } \\
\text { Tecnologia }\end{array}$ & $\begin{array}{l}\text { Ter canais adequados aos } \\
\text { segmentos estratégicos }\end{array}$ & $\begin{array}{l}\text { Transações nos canais } \\
\text { digitais }\end{array}$ & Percentual \\
\hline $\begin{array}{l}\text { Perspectiva Processos e } \\
\text { Tecnologia }\end{array}$ & Melhorar o ciclo de crédito & Over 90 - C.A. & Percentual \\
\hline $\begin{array}{l}\text { Perspectiva Processos e } \\
\text { Tecnologia }\end{array}$ & Melhorar o ciclo de crédito & $\begin{array}{l}\text { Concessões } \\
\text { Automáticas }\end{array}$ & Percentual \\
\hline $\begin{array}{l}\text { Perspectiva Aprendizado } \\
\text { e Crescimento }\end{array}$ & $\begin{array}{l}\text { Elevar o bem estar do } \\
\text { colaborador e a satisfação } \\
\text { organizacional }\end{array}$ & $\begin{array}{l}\text { Pesquisa de clima e } \\
\text { engajamento }\end{array}$ & Índice \\
\hline $\begin{array}{l}\text { Perspectiva Aprendizado } \\
\text { e Crescimento }\end{array}$ & $\begin{array}{l}\text { Elevar o bem estar do } \\
\text { colaborador e a satisfação } \\
\text { organizacional }\end{array}$ & $\begin{array}{l}\text { Estar entre as melhores } \\
\text { empresas }\end{array}$ & Classificação \\
\hline $\begin{array}{l}\text { Perspectiva Aprendizado } \\
\text { e Crescimento }\end{array}$ & $\begin{array}{l}\text { Desenvolver competências } \\
\text { por meio da Educação } \\
\text { Corporativa }\end{array}$ & $\begin{array}{l}\text { Colaboradores } \\
\text { capacitados na Escola } \\
\text { de Talentos }\end{array}$ & Nota de $0-10$ \\
\hline $\begin{array}{l}\text { Perspectiva Aprendizado } \\
\text { e Crescimento }\end{array}$ & $\begin{array}{l}\text { Desenvolver competências } \\
\text { por meio da Educação } \\
\text { Corporativa }\end{array}$ & \begin{tabular}{|l|} 
Colaboradores \\
capacitados na \\
Academia de Liderança
\end{tabular} & Nota de $0-10$ \\
\hline
\end{tabular}


\begin{tabular}{|l|l|l|l|}
$\begin{array}{l}\text { Perspectiva Aprendizado } \\
\text { e Crescimento }\end{array}$ & $\begin{array}{l}\text { Desenvolver competências } \\
\text { por meio da Educação } \\
\text { Corporativa }\end{array}$ & $\begin{array}{l}\text { Colaboradores com } \\
\text { desempenho acima da } \\
\text { meta }\end{array}$ & Percentual \\
\hline $\begin{array}{l}\text { Perspectiva Aprendizado } \\
\text { e Crescimento }\end{array}$ & $\begin{array}{l}\text { Criar uma cultura } \\
\text { cooperativista que dê forma e e } \\
\text { ritmo }\end{array}$ & $\begin{array}{l}\text { Colaboradores } \\
\text { capacitados } \\
\text { Cooperativismo em }\end{array}$ & Nota de 0 - 10 \\
\hline
\end{tabular}

Fonte: Cooperativa participante.

Destaca-se que os "Princípios Cooperativistas" são tratados no instrumento de avaliação de desempenho da cooperativa a partir da perspectiva "Associado" e "Aprendizado e Crescimento".

O entrevistado esclareceu que os módulos e indicadores do modelo da cooperativa tem o mesmo peso dentro do modelo, não havendo distinção entre os mesmos. Isso porque, no primeiro modelo elaborado tentaram propor essa distinção, porém não chegaram à conclusão de qual indicador teria mais relevância e por isso resolveram considerar o peso igual para todos os indicadores.

Os módulos e indicadores começaram a ser estipulados em 2015, com a ajuda da Fundação Dom Cabral, quando foi feito o primeiro mapa estratégico da cooperativa. Porém, o mesmo gerava inconsistência porque continha a perspectiva "Cliente" e a fala da cooperativa é "Associado". Para acabar com essa inconsistência fez-se um desdobramento do módulo "Cliente", que passou a contemplar os "Associados".

A nova modelagem foi proposta pela equipe de planejamento da cooperativa e por um professor da Fundação Dom Cabral. Os indicadores foram estabelecidos por eles, pela alta administração e as áreas responsáveis. As metas de cada objetivo são variáveis e são revistas anualmente.

Destaca-se que os cooperados, os gerentes e os conselheiros não participaram da confecção do instrumento de avaliação de desempenho da cooperativa. Os gerentes de agência participaram somente da construção do plano de ação, ou seja, quais ações seriam tomadas para atingir os objetivos do modelo.

Salienta-se que atualmente a equipe responsável pelo monitoramento e avaliação do desempenho da cooperativa é formada por 3 (três) pessoas, que monitoram o BSC.

O entrevistado destacou ainda que outras cooperativas singulares utilizam planilha de Excel e mapa estratégico para monitorar seu desempenho. Portanto, não há um modelo específico de acompanhamento disseminado a todas as cooperativas do sistema. 


\subsection{A PROPOSIÇÃO DE UM MODELO DE AVALIAÇÃO DE DESEMPENHO PARA COOPERATIVAS DE CRÉDITO VISANDO A DIMINUIÇÃO DOS CONFLITOS DE AGÊNCIA}

O presente modelo de avaliação de desempenho de cooperativas de crédito visa, conforme proposto por Vilela, Nagano e Merlo (2007):

1. Identificar os problemas que alteram o que havia sido planejado pela organização, com o intuito de corrigir e evitar que aconteça novamente;

2. Aproximar o máximo possível os resultados obtidos com os esperados;

3. Verificar se as estratégias e políticas se enquadram no contexto real que a empresa está inserida;

4. Verificar se a estrutura organizacional e processual da cooperativa é condizente com seus objetivos;

5. Criar condições para otimização dos processos diretivos e decisórios da cooperativa;

6. Propiciar um ambiente de relações interpessoais adequado e;

7. Fornecer informações gerenciais periódicas a fim de que haja agilidade na intervenção no desempenho da avaliação do modelo de gestão da cooperativa.

Para tanto, é necessário que o modelo seja global, já que deve conter todas as dimensões; histórico, por contemplar o desempenho ao longo dos anos; possibilitar o comparativo com outras empresas e setores; possuir uma relação de causa/efeito, ou seja, relacionar as áreas e; antecipação, focar nas causas e não apenas nos efeitos (CORRÊA, 1986). Além disso, deve balancear medidas financeiras e não financeiras; fazer a identificação dos fatores críticos de sucesso e ligá-los aos objetivos estratégicos a fim de considerar que eles são a base para a construção do valor da empresa (ZILBER; FISCHMANN, 2002).

Para a sua proposição parte-se do princípio de que os modelos aplicados às empresas tradicionais baseadas na maximização do lucro não podem ser aplicados diretamente nas cooperativas de crédito, visto que essas devem maximizar os interesses dos seus membros (SMITH; CARGILL; MEYER, 1981).

Isso porque, cooperativas são alternativas econômicas emancipatórias, cujos princípios não se baseiam na economia capitalista, pois tal sistema produz desigualdade de recursos e poder, relações de concorrência (baseadas no benefício 
pessoal e não na solidariedade), e exploração de recursos naturais de forma insustentável (SANTOS, 2002).

Ao contrário disso, a cooperativa propõe alternativas baseadas em iniciativas coletivas, geralmente plasmadas em empresas e organizações econômicas populares de propriedade e gestão solidária que tentam contrariar, por um lado, a separação entre capital e trabalho e, por outro, a necessidade de recorrer à ajuda estatal (SANTOS, 2008, p. 47-48). Sendo uma forma de desenvolvimento alternativo, baseado na igualdade e cidadania, que preza pela inclusão dos marginalizados na produção e nos seus resultados.

Nesse sentido, o cooperativismo é considerado uma alternativa mais sustentável, igualitária e solidária para o desenvolvimento da economia e da sociedade em que vivemos, prezando pela semi-periferia e periferia, ao propor projetos de desenvolvimento comunitário e respeito pela diversidade. Sua implantação visa garantir que as minorias sejam incluídas no contexto econômico e social, e que o sistema contemple a coletividade e não mais a individualidade, como vem fazendo o capitalismo, que não integra todos à economia (SINGER, 2002).

Portanto, a cooperativa surge como um meio de unir forças individuais para alcançar resultados coletivos, num ambiente econômico-social altamente competitivo (BECKER, 1996, p. 69).

Para tanto, a gestão das cooperativas deve procurar assegurar os princípios e valores cooperativos, que distinguem as sociedades cooperativas das demais organizações econômicas voltadas para o mercado. Para tanto, é necessário que se enfatizem a livre e aberta adesão dos membros, o caráter democrático da gestão e do controle cooperativos, a autonomia e a independência, a responsabilidade social. Isso contribui para a preservação da identidade organizacional e, ao mesmo tempo, promove cooperativas sólidas, competitivas, transparentes e confiáveis (OCB, 2016).

Um adequado modelo de avaliação de desempenho para cooperativas de crédito pode auxiliar na definição do planejamento estratégico e na correção e adequação da gestão da instituição, para que a cooperativa seja fiel aos seus propósitos.

Isso porque identificando tais indicadores de desempenho, esses poderão ser utilizados para medir o processo ou seus resultados, além de sinalizar possíveis desvios de rota nos planos traçados, bem como contribuindo para a melhoria na eficiência dos processos de trabalho. Com isso, pretende-se ajudar os gestores de 
Cooperativas de Crédito a melhorar o desempenho das suas organizações, possibilitando maior chance de atendimento aos objetivos traçados no momento de fundação da cooperativa.

Fazendo uso de um adequado modelo de avaliação de desempenho, as cooperativas de crédito podem ainda buscar garantir que os conflitos agência sejam minimizados.

Justifica-se seu uso para esse fim já que os conflitos de agência ocorrem devido ao fato de agente e principal terem interesses distintos e serem maximizadores de sua própria utilidade. Sendo essa uma boa motivação para acreditar que o agente nem sempre agirá de acordo com os melhores interesses do principal (JENSEN, MECKLING, 1976; COSTAMARQUES E CONDE, 2000; GODOY E MARCON, 2006). Segundo Morgan (2002), na prática, os agentes se preocupam com a própria riqueza, com os benefícios indiretos, com a segurança no emprego, e com aspectos extraorganização.

Em suma, os problemas de agência ocorrem devido a conflitos de interesse entre agente e principal, pois segundo a teoria, esses dois grupos não têm objetivos comuns.

Sendo papel do modelo de avaliação de desempenho de cooperativas de crédito buscar, entre outros, aproximar o máximo possível os resultados obtidos daqueles esperados (VILELA; NAGANO; MERLO, 2007), cabe a ele portanto, garantir que todos os envolvidos nesse processo estejam engajados na mesma causa, ou seja, cabe a ele também se preocupar em minimizar os conflitos de agência.

E é justamente essa a ideologia do cooperativismo, como já citado anteriormente por Becker (1996): unir forças individuais para alcançar resultados coletivos, num ambiente econômico-social altamente competitivo. Sendo assim, no cooperativismo não deveria existir conflitos de agência, pois todos os envolvidos deveriam ter a consciência de que estão ali com a finalidade comum de ajudar uns aos outros a atingirem seus objetivos pessoais a partir do alcance dos objetivos do grupo.

Conclui-se então que o que causa os problemas de agência em cooperativas de crédito é justamente a falta de praticar os princípios e fundamentos do cooperativismo. Isso porque, os problemas de agência são causados principalmente por questões como individualidade e oportunismo, características essas antagônicas ao cooperativismo. 
Portanto o que falta para as cooperativas de crédito e provavelmente para as cooperativas de modo geral, é conscientizar mais os grupos envolvidos sobre o objeto de existência de uma cooperativa e sobre a necessidade de se pensar e agir coletivamente e de maneira associativa.

Nesse sentido, o modelo de avaliação de desempenho de cooperativas de crédito aqui proposto parte da ideia de que os conflitos de agência podem ser minimizados a partir da conscientização de agente e principal acerca da necessidade de cooperar e respeitar os princípios cooperativistas.

Assim sendo, apresenta-se o cerne do modelo (figura 11), composto pelo objetivo da cooperativa de crédito de incluir as minorias no contexto econômico e social, e permeado pela necessidade de respeito aos princípios cooperativistas, ou seja, pela necessidade de incutir sempre mais nos agente e principal a ideologia cooperativista. Isso porque, essas são organizações diferentes das tradicionais mercantis, e por isso apresentam a necessidade de uma forma de gestão também distinta, baseada em princípios cooperativistas (KOTZ, 2007).

Figura 11 - Cerne do Modelo de Avaliação de Desempenho de Cooperativas de Crédito

Fonte: autora.

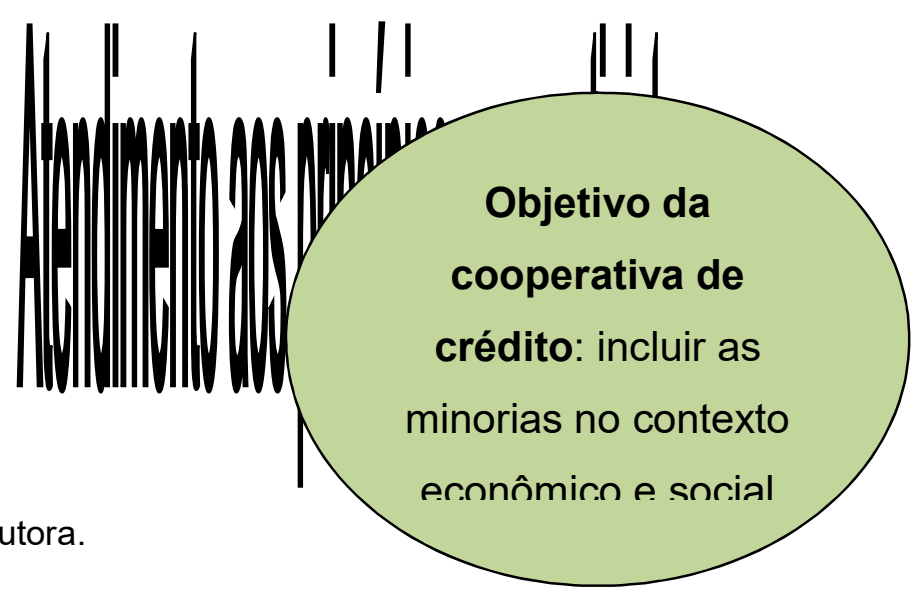

Portanto, permeando o objetivo da cooperativa tem-se o módulo "Princípios cooperativistas", que visa o respeito aos ideais do cooperativismo, aqui representado pelos indicadores: cumpre princípios cooperativistas, democracia e igualdade, solidariedade, valores de ajuda mútua, autonomia e independência, adesão livre e voluntária, preocupação com a comunidade, geração de empregos e combate a exclusão social. 
Conforme a discussão baseada nos dados empíricos coletados nessa pesquisa vê-se que os ideais cooperativistas são considerados como muito relevantes por todos os grupos participantes da amostra.

Esse é um cenário favorável a implantação de um modelo de avaliação de desempenho cujo cerne é os princípios cooperativistas, visto que os grupos envolvidos em cooperativas de crédito (agente e principal) estão inseridos em um sistema econômico capitalista, que fomenta o individualismo, o ganho em cima dos outros indivíduos, entre outras características discordantes em relação ao cooperativismo, e apesar disso reconhecem a importância de se pensar e agir cooperativamente.

Estabelecida a necessidade de programar um módulo baseado em princípios cooperativistas, como citado acima, agora parte-se para a discussão do seguinte cenário: as cooperativas de crédito são instituições associativas que operam em um ambiente capitalista e extremamente competitivo.

Portanto, para que a cooperativa de crédito alcance seu objetivo de incluir as minorias no contexto econômico e social do mundo capitalista, ao qual está envolta, é imprescindível que essa seja competitiva nesse mercado. Sendo assim, deve prezar por ser tão eficiente quanto uma empresa mercantil tradicional.

Como já ressaltado por Birck (2005), as cooperativas são instituições inseridas no sistema capitalista de produção, e que precisam sobreviver em consonância com ele, devendo ser economicamente eficientes para continuar atuando no mercado e poder trazer benefícios para seus associados.

Sendo assim, precisam ser competitivas tanto quanto um empreendimento convencional. O ideal é que sejam eficientes quanto ao seu objetivo (que é emancipar social e economicamente seu cooperado), e ao mesmo tempo competitivas em um mercado capitalista, necessitando utilizar estratégias como: enxugar custos, buscar escala de produção, compatibilizar agilidade na tomada de decisões democráticas, buscar a modernidade na gestão, ser inovadoras e compatibilizar atividades.

Ao conseguirem responder as problemáticas organizacionais e de gestão, poderão ao mesmo tempo aproveitar oportunidades empresariais que se abrem no mercado, para que assim cresçam e permaneçam atingindo sua finalidade sócioeconômica.

Um empreendimento cooperativo deve permanecer vigilante quanto ao seu desempenho social, político, educacional e financeiro, pois assim poderá atingir sua 
finalidade, satisfazendo cooperados e mantendo-se competitivo (PINHO, 1986; OLIVEIRA JUNIOR, 1996; BARROS; MORAES, 2015; KAPLAN; NORTON, 2004).

Em resumo, a organização cooperativista de crédito deve implementar módulos em seu modelo de avaliação de desempenho que a monitorem em relação ao mercado capitalista, assim como uma instituição financeira não cooperativa.

Esses módulos aqui propostos são fruto das investigações teóricas e empíricas realizadas ao longo desse trabalho. Destaca-se que considerando o exemplo do modelo utilizado pela cooperativa entrevistada na fase empírica dessa investigação, contempla todos os elementos do Balanced Score Card, fazendo ajustes que se adéqüem ao que foi discutido ao longo da pesquisa.

Sendo assim, um dos módulos do modelo apresentado é o financeiro, cuja importância é salientada por Bialoskorski Neto (2005) ao colocar sobre a necessidade de monitorar o desempenho econômico e financeiro de cooperativas, a fim de manter a sobrevivência dessas organizações que possuem como ponto crítico a maximização de resultados financeiros aos associados.

Lazzarini et al. (1999) atrelam o sucesso financeiro de cooperativas aos ganhos sociais ao concluírem que ao classificar as cooperativas através de variáveis econômicas, explica-se melhor seu desempenho do que ao se comparar com o uso de variáveis sociais.

Dessa forma é reforçada pelos autores a importância de se acompanhar o desenvolvimento econômico das cooperativas, a fim de caracterizar o próprio desempenho social. Em suma, no sentido de doutrina, o cooperativismo tem por objeto a correção do social pelo econômico (COSTA, 2007).

Considerando os indicadores validados por essa pesquisa, bem como os presentes no modelo da cooperativa entrevistada, propõe-se que o módulo financeiro contemple: crescimento das vendas, retorno sobre o investimento, rentabilidade do patrimônio líquido, capital em giro, grau de endividamento financeiro, margem bruta, resultado econômico, capitalização, geração de rendas, crescimento das aplicações totais, crescimento das captações totais, equilíbrio do orçamento, nível de inadimplemento, patrimônio líquido, ativos totais, liquidez, eficácia econômica das agências.

Outro módulo é o Associados, que da mesma forma que o Balanced Score Card, busca traduzir em objetivos e metas as expectativas do associado. 
Ele é representado pelos indicadores validados por essa pesquisa, bem como os presentes no modelo da cooperativa entrevistada, a saber: retenção de cooperantes, satisfação de cooperantes, menor custo das transações, ganhos financeiros de cada cooperado individualmente, ganhos financeiros de todos os cooperados enquanto grupo, emancipação social e econômica do associado, educação, formação e informação do cooperado, realização pessoal dos cooperados, associados em assembleia geral, número de associados ativos, sobras ou faturamento por cooperado, relevância do associado na tomada de decisão, índice de soluções por associado, índice de cobertura, participação de mercado e número de municípios atendidos.

O outro módulo é Processos Internos, que busca melhoria de processos internos a partir da identificação de processos críticos que são indispensáveis para alcançar os objetivos da cooperativa, a saber: lucratividade por segmento-alvo, percentual de transações realizadas através dos diversos canais, projetos sociais desenvolvidos, percentual de trabalho extraordinário, desenvolvimento sustentável, nível de transparência, perpetuação da instituição, preservação da identidade organizacional.

O módulo Pessoas e Inovação foi readaptado do modelo validado em campo e unido ao módulo Aprendizado e Crescimento, devido às semelhanças de propósito dos indicadores.

Esse diz respeito às forças que vão levar a cooperativa a criar a infra-estrutura necessária para alcançar os objetivos definidos nas outras perspectivas. Para tanto remete a idéia de Capital Intelectual, do modelo Skandia Navigator, composto pelo capital humano e estrutural, esse último devendo estar sempre atento às inovações tecnológicas do setor.

Os indicadores que atendem esse módulo são: melhorias das capacidades dos colaboradores, motivação para agir no melhor interesse da cooperativa e nível de rotatividade, profissionalização da administração, melhoria constante da estrutura, segurança no emprego para os trabalhadores da cooperativa, pagamento de bons salários aos funcionários da cooperativa, benefícios extra para bons funcionários, respeito às opiniões dos trabalhadores, ambiente ético e que valoriza o capital humano e condições de trabalho adequadas.

A figura 12 representa o Modelo de Avaliação de Desempenho de Cooperativas de Crédito, composto por cinco módulos: Financeiro, Associados, Pessoas e inovação, 
Processos Internos e Princípios Cooperativistas, que interagindo de forma permanente devem buscar um objetivo comum: incluir as minorias no contexto econômico e social.

Figura 12 - O modelo de avaliação de Desempenho de Cooperativas de Crédito

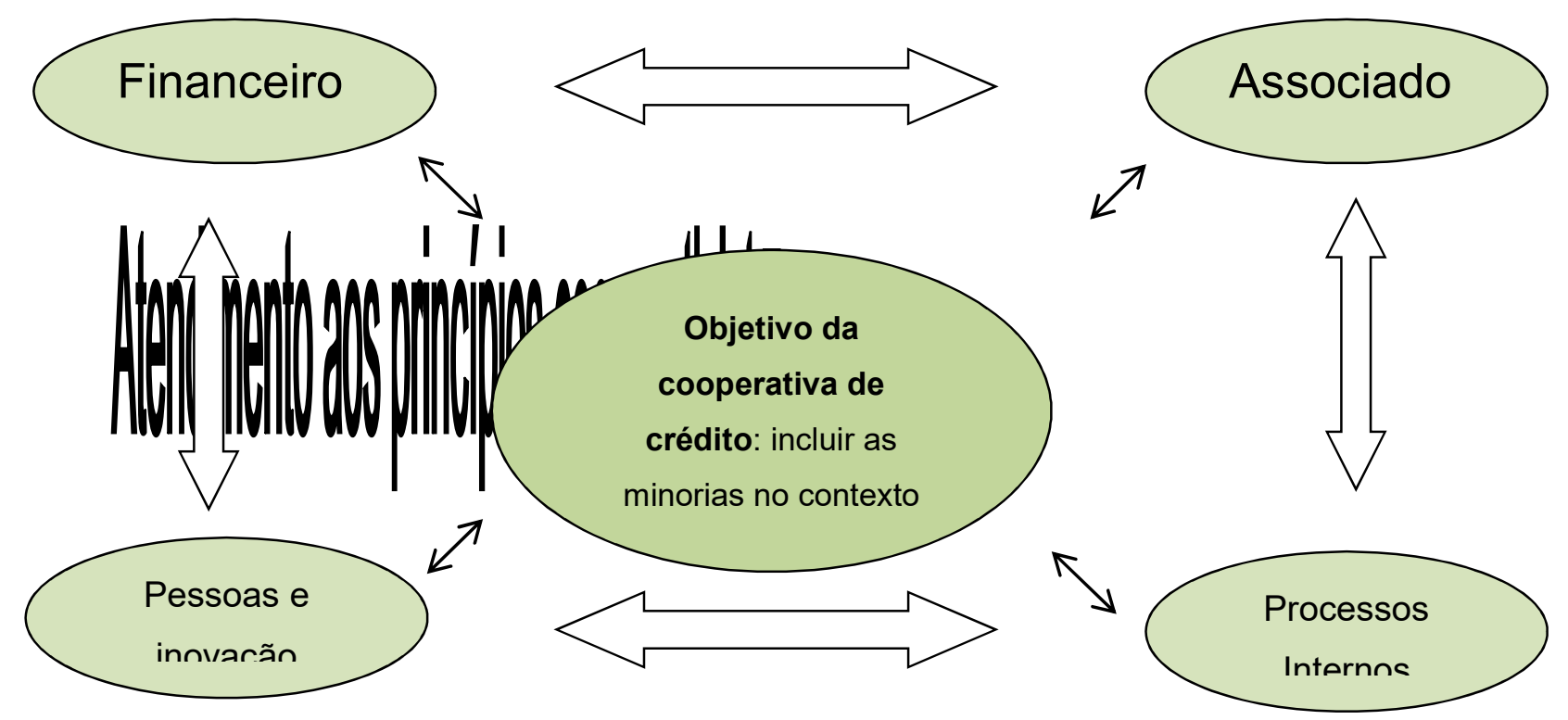

Fonte: autora.

Salienta-se que com o modelo de avaliação de desempenho em mãos, cabe às cooperativas de crédito estabelecer os níveis de desempenho que serão aceitos em uma escala ordinal e identificar as diferenças de atratividades (mensuração) entre os níveis de desempenho, utilizando uma escala cardinal (GALLON; ENSSLIN; ENSSLIN, 2011).

Seus indicadores de desempenho devem ser avaliados de forma constante, visto que eles devem refletir as mudanças ocorridas na organização, já que essa vive em um ambiente complexo e altamente mutável.

É importante relembrar que embora se busque um modelo global, um agrupamento de indicadores sempre será o reflexo de uma visão parcial e contextual da organização (PACE, 2009). 


\section{CONSIDERAÇÕES FINAIS}

O objetivo geral do presente trabalho foi analisar a percepção de desempenho de cooperativas de crédito sob a ótica da Teoria da Agência. Para tanto, tomou-se mão dos seguintes objetivos específicos: identificar indicadores de avaliação desempenho que sejam pertinentes a cooperativas de crédito; compreender quais aspectos influenciam na avaliação de desempenho de cooperativas de crédito na visão de cada grupo envolvido; relacionar as variáveis determinadas como importantes para avaliar desempenho de cooperativas de crédito sob o ponto de vista dos envolvidos considerando seu perfil; verificar se os princípios do cooperativismo são tidos como importantes quando se trata da avaliação de desempenho de cooperativas de crédito; apontar as divergências e convergências de opiniões de agentes e principal; sugerir um Modelo de Avaliação de Desempenho de Cooperativas de Crédito que diminua os conflitos de agência; e entender a influência da Teoria da Agência na gestão do desempenho de cooperativas de crédito

Buscando responder o primeiro objetivo específico: identificar indicadores de avaliação desempenho que sejam pertinentes a cooperativas de crédito; fez-se uma varredura nos trabalhos já apresentados sobre a temática e temáticas correlatas a avaliação de desempenho de cooperativas. Com isso foi possível gerar uma lista inicial de indicadores, que posteriormente foi levada ao crivo da metodologia Delphi e validade de face e conteúdo.

A nova lista de indicadores, já validada, foi submetida a uma pesquisa empírica junto a quatro públicos envolvidos nas atividades de cooperativas de crédito: cooperados, gerentes, conselheiros administrativos e fiscais.

Com isso foi possivel responder os seguintes objetivos específicos: quais aspectos influenciam na avaliação de desempenho de cooperativas de crédito na visão de cada grupo envolvido; apontar as divergências e convergências de opiniões de agentes e principal; relacionar as variáveis determinadas como importantes para avaliar desempenho de cooperativas de crédito sob o ponto de vista dos envolvidos considerando seu perfil; entender a influência da Teoria da Agência na gestão do desempenho de cooperativas de crédito; verificar se os princípios do cooperativismo são tidos como importantes quando se trata da avaliação de desempenho de cooperativas de crédito. 
Em relação especificamente ao objetivo que investigava quais aspectos influenciam na avaliação de desempenho de cooperativas de crédito na visão de cada grupo envolvido; concluiu-se que:

Os Conselheiros Fiscais participantes da amostra

- Classificaram como indicadores mais relevantes em relação ao módulo “Financeiro", no que tange a avaliação de desempenho de cooperativas de crédito: Crescimento das Aplicações totais, Nível de inadimplemento e Rentabilidade do patrimônio líquido, dessa forma demonstram acreditar que a cooperativa deve priorizar avaliar o desempenho financeiro em relação à quantia aplicada no período, ao grau de risco das operações e acerca do prejuízo ou sobra da cooperativa. Os fatores que alcançaram menor pontuação foram Margem bruta e Retorno sobre o investimento, demonstrando menor preocupação acerca da porcentagem de lucro de cada venda e da relação entre a quantidade de dinheiro ganho e investido.

- Em relação aos indicadores do módulo "Associados", avaliaram com maior grau de importância: Número de associados ativos e Satisfação de cooperantes, o que demonstra maior preocupação com a número total de cooperados que utilizam os serviços da cooperativa e satisfação dos mesmos. Os fatores que alcançaram menor pontuação foram Ganhos financeiros de cada cooperado individualmente, e Emancipação social e econômica do associado, o que expressa menor preocupação com ganhos financeiros do indivíduo e satisfação das necessidades humanas de forma geral.

○ Em relação aos indicadores do módulo "Processos Internos", atribuíram maior valor a Nível de transparência e Desenvolvimento Sustentável, demonstrando maior preocupação com a manutenção da transparência das informações, e com a atenção ao capital humano, econômico e ambiental. Por outro lado, atribuíram menor valor a Percentual de trabalho extraordinário, que condiz às horas extras realizadas.

- Em relação aos indicadores do módulo "Aprendizado e Crescimento", atribuíram maior grau de importância para o indicador Melhoria das capacidades dos funcionários, e menor grau de importância para Nível de rotatividade e Motivação para agir no melhor interesse da cooperativa, denotando preocupação com a necessidade de o colaborador participar de cursos e eventos de capacitação, e menor preocupação com o número de desligamentos de colaboradores e motivação para agir conforme se espera do colaborador. 
○ Entendem que os indicadores do módulo "Pessoas e Inovação", mais relevantes são: Profissionalização da administração, Condições de trabalho adequadas e Ambiente de trabalho ético e que valoriza o capital humano, ressaltando a importância da capacitação dos colaboradores, e do oferecimento de um ambiente seguro, confortável e respeitoso para os funcionários. E como menos relevantes: Melhoria constante da estrutura da cooperativa, Segurança no emprego para os trabalhadores da cooperativa e Benefícios extra para bons funcionários, demonstrando menor preocupação no que tange a programas de benefícios para colaboradores, número de demissões e desenvolvimento de tecnologias, processos e estrutura física.

- Em relação aos indicadores do módulo "Princípios Cooperativistas", classificaram com maior grau de importância Democracia e igualdade, e Cumpre os princípios cooperativistas, demonstrando maior preocupação no que tange a direito a voto de mesmo peso, e ao respeito aos princípios cooperativistas. O classificado com menor grau de importância Autonomia e independência.

Os Conselheiros Administrativos participantes da amostra

- Demonstraram maior preocupação com os indicadores Nível de inadimplemento, Resultado econômico, no que tange ao módulo "Financeiro". Dessa forma enfatizam aspectos voltados ao grau de risco das operações e aos prejuízos e sobras da cooperativa. E menor preocupação com os indicadores Crescimento das captações totais e Margem Bruta, o que demonstra menor preocupação em relação à porcentagem de lucro de cada venda, e comparação entre a quantia captada no período atual e anterior.

- Em relação ao módulo "Associados", julgaram com maior grau de importância: Número de associados ativos e Satisfação de cooperantes, o que indica maior preocupação no que tange ao número total de cooperados que utilizam os serviços da cooperativa e satisfação dos mesmos. E com menor importância Realização pessoal dos cooperados.

○ Em relação aos indicadores do módulo "Processos Internos", atribuíram maior valor a Nível de transparência e Perpetuação da instituição; e menor valor a Percentual de trabalho extraordinário. Dessa forma demonstram maior preocupação com a transparência de informações e decisões, bem como com a condição da cooperativa continuar existindo; e menor preocupação com o número de horas extras realizadas. 
- Atribuíram maior valor a Melhoria nas capacidades dos funcionários, e menor a Nível de rotatividade, no que tange ao módulo "Aprendizado e Crescimento", demonstrando maior preocupação com número de cursos e eventos de capacitação aplicados a funcionários e menor preocupação com número de desligamentos de colaboradores da instituição.

○ Em relação os indicadores do módulo "Pessoas e inovação", percebem maior grau de importância nos indicadores: Profissionalização da administração e Ambiente de trabalho ético e que valoriza o capital humano, ressaltando a importância da capacitação dos colaboradores, e do oferecimento de um ambiente respeitoso para os funcionários. E menor grau para Benefícios extra para bons funcionários e Segurança no emprego para os trabalhadores da cooperativa, demonstrando menor preocupação no que tange a programas de benefícios para colaboradores, número de demissões.

○ Por fim, no módulo "Princípios Cooperativistas" avaliaram melhor os indicadores Cumpre princípios cooperativistas e Democracia e igualdade, denotando maior preocupação com o respeito aos princípios cooperativistas, e com o direito a voto de mesmo peso dos cooperados. E avaliaram com menor importância os indicadores Valores de ajuda mútua (preocupação com o semelhante) e Geração de empregos, aparentando menor preocupação com o semelhante e número de empregos gerados.

Os Cooperados participantes da amostra

- Atribuíram maior valor aos indicadores Equilíbrio do orçamento, Nível de inadimplemento e Retorno sobre 0 investimento (módulo "Financeiro"), demonstrando dessa forma acreditar que a cooperativa deve priorizar avaliar o desempenho em relação a: se os ganhos foram maiores que os gastos, grau de risco das operações de crédito e sob a relação de entre a quantidade de dinheiro ganho em um investimento e a quantidade de dinheiro investido. E menor importância foram Crescimento das aplicações totais, Capitalização e Crescimento das vendas, evidenciando menor preocupação com questões como quantia aplicada, relação entre capital próprio e total, e volume de vendas.

- Acerca do módulo "Associados", entendem que os indicadores Educação, formação e informação do associado e Menor custo das transações tem maior relevância, se importando mais com entrega de menores taxas e cuidados com a educação, formação e informação do cooperado. Os fatores que alcançaram menor 
pontuação foram Associados em Assembleia Geral Ordinária, Retenção de cooperados e Número de associados ativos, importando-se menos com questões voltadas ao número de associados, bem como sua participação nas operações e assembleias.

- Em relação aos indicadores do módulo "Processos Internos", atribuíram maior valor a Nível de transparência, Preservação da identidade organizacional e Perpetuação da instituição; e menor valor a Percentual de trabalho extraordinário, Percentual de transações realizados nos diversos canais e Projetos sociais desenvolvidos.

○ No módulo “Aprendizado e Crescimento", consideram mais relevante o indicador Melhoria nas capacidades dos funcionários e menos importante Nível de rotatividade, considerando a importâncias de cursos e eventos de capacitação e menos importante o número de desligamentos de colaboradores.

○ Em relação ao módulo "Pessoas e Inovação" entendem como mais relevantes indicadores como: Condições de trabalho adequadas Profissionalização da administração, e Ambiente ético e que valoriza o capital humano, ressaltando a importância da capacitação dos colaboradores, e do oferecimento de um ambiente respeitoso para os funcionários. E como menos relevantes pontuaram Benefícios extra para os bons funcionários, Segurança no emprego e Pagamentos de bons salários aos funcionários, demonstrando menor preocupação no que tange a programas de benefícios para colaboradores, número de demissões e média salarial.

- E por fim, em relação ao módulo "Princípios Cooperativistas" atribuíram maior pontuação a Geração de empregos, Democracia e igualdade e Combate a exclusão social, demonstrando maior preocupação com número de empregos gerados, medidas que proporcionem equidade social e diminuição da pobreza, e direito a voto de mesmo peso. E avaliaram com menor importância Cumpre os princípios cooperativistas, Preocupação com a comunidade, e Solidariedade, demonstrando menor preocupação em relação ao respeito aos princípios cooperativistas, com o bem-estar e evolução da comunidade e compromisso com as pessoas.

Os Gerentes participantes da amostra

- Avaliaram que os indicadores Rentabilidade do Patrimônio Líquido, Resultado Econômico, Equilíbrio do Orçamento e Nível de Inadimplemento, pertencentes ao módulo "Financeiro", como sendo mais relevantes no que tange à avaliação de desempenho do módulo financeiro de cooperativas de crédito. Dessa 
forma dão mais importância a aspectos como: quantia de sobras ou prejuízo da cooperativa, se ganhos foram maiores que gastos e em relação ao grau de risco das operações financeiras. Já em relação aos indicadores com menor importância atribuída pelos gerentes, temos: Margem bruta e Geração de rendas, levando a crer que vêem como menos relevantes questões como porcentagem de lucro com cada venda e quanto se gerou de rendimento e a quantia gasta para isso.

- Em relação aos indicadores do módulo “Associados”, perceberem maior importância nos indicadores Satisfação de cooperantes, Educação, formação e informação ao cooperado, Retenção de cooperantes e Número de associados ativos, o que evidencia maior preocupação com número de associados participantes da cooperativa, bem como com o conforto, segurança, produtos e serviços oferecidos, e com a promoção de sua educação, formação e informação. E menor importância reconhecem indicador Ganhos financeiros de cada cooperado individualmente.

- Por sua vez, acerca dos indicadores do módulo "Processos Internos" atribuíram maior valor a Nível de transparência e Perpetuação da instituição, e menor valor a Percentual de trabalho extraordinário e Lucratividade por segmento-alvo.

- Em relação aos indicadores do módulo "Aprendizado e Crescimento", atribuem maior valor a Melhoria das capacidades dos funcionários e menor a Nível de rotatividade.

- Por sua vez, acerca do módulo "Pessoas e Inovação” demonstraram maior preocupação com os indicadores Profissionalização da administração, Ambiente de trabalho ético e que valoriza o capital humano e Condições de trabalho adequadas, ressaltando a importância da capacitação dos colaboradores, e do oferecimento de um ambiente seguro, confortável e respeitoso para os funcionários. E menor preocupação com o indicador Benefícios extras para os bons funcionários.

- No módulo “Princípios Cooperativistas” classificaram com maior grau de importância Cumpre os princípios cooperativistas e Preocupação com a comunidade, exprimindo maior preocupação com o respeito aos princípios cooperativistas e com o bem-estar e evolução da comunidade a qual a cooperativa está inserida. E com menor importância Solidariedade e Combate a exclusão social, denotando menor importância com o compromisso entre as pessoas e com medidas que proporcionem equidade social e diminuição da pobreza.

Em suma, Conselheiros Fiscais são mais influenciados por questões que envolvem o grau de risco das operações, o prejuízo ou sobra da cooperativa, o número 
total de cooperados que utilizam os serviços da cooperativa e satisfação dos mesmos, a manutenção da transparência das informações, com a atenção ao capital humano, econômico e ambiental, a necessidade de o colaborador participar de cursos e eventos de capacitação, capacitação dos colaboradores, oferecimento de um ambiente seguro, confortável e respeitoso para os funcionários, o direito a voto de mesmo peso, e o respeito aos princípios cooperativistas.

Por sua vez, os Conselheiros Administrativos são mais influenciados por aspectos voltados ao grau de risco das operações, aos prejuízos e sobras da cooperativa, ao número total de cooperados que utilizam os serviços da cooperativa e satisfação dos mesmos, a transparência de informações e decisões, bem como com a condição da cooperativa continuar existindo, o número de cursos e eventos de capacitação aplicados a funcionários, capacitação dos colaboradores, o oferecimento de um ambiente respeitoso para os funcionários, o respeito aos princípios cooperativistas, e com o direito a voto de mesmo peso dos cooperados.

Já os Cooperados são mais influenciados por questões que envolvem maiores ganhos do que gastos; grau de risco das operações de crédito; relação de entre a quantidade de dinheiro ganho em um investimento; quantidade de dinheiro investido; entrega de menores taxas; cuidados com a educação, formação e informação do cooperado; nível de transparência; preservação da identidade organizacional; perpetuação da instituição; capacitação dos colaboradores; oferecimento de um ambiente respeitoso para os funcionários; número de empregos gerados; medidas que proporcionem equidade social e diminuição da pobreza; garantia de direito a voto de mesmo peso.

E por fim, os gerentes são mais influenciados por aspectos voltados a quantia de sobras ou prejuízo da cooperativa; se ganhos foram maiores que gastos; grau de risco das operações financeiras; número de associados participantes da cooperativa; conforto, segurança, produtos e serviços oferecidos; promoção de sua educação, formação e informação do associado; nível de transparência; perpetuação da instituição; melhoria das capacidades dos funcionários; nível de rotatividade; capacitação dos colaboradores, oferecimento de um ambiente seguro, confortável e respeitoso para os funcionários; respeito aos princípios cooperativistas; preocupação com o bem-estar e evolução da comunidade a qual a cooperativa está inserida.

Em relação ao objetivo de relacionar as variáveis determinadas como importantes para avaliar desempenho de cooperativas de crédito sob o ponto 
de vista dos envolvidos considerando seu perfil, conclui-se que de forma geral, as variáveis idade e escolaridade dos participantes da amostra pouco influenciam na percepção de importância dos indicadores em todos os grupos analisados. O que realmente pesa em relação às divergências de opinião é o quanto o participante é envolvido na cooperativa (denotado pelas variáveis: tempo de função, número de mandatos e participação em assembleias).

Percebe-se que para Conselheiros Fiscais e Administrativos e Gerentes, aqueles que estão na função há menos tempo tem tendência a classificar melhor alguns indicadores do que aqueles que estão há mais tempo. O grupo que chama mais atenção é dos Conselheiros Administrativos, visto que os mais novos no cargo se preocupam mais com questões ideológicas e com o bem-estar de cooperados e colaboradores do que aqueles que estão a mais tempo na função.

Já para os cooperados, aqueles que menos participam da cooperativa (nunca foram a assembleias ou foram menos vezes) classificam com menor importância os indicadores, demonstrando menor preocupação com grau de endividamento, resultado econômico, capitalização, retenção de cooperantes, associados em assembleia geral e relevância do associado na tomada de decisão. Pode ser que não participem tanto de assembleias justamente pelo fato de não acreditem na necessidade de estarem presentes e na relevância de sua opinião, como destacado.

Portanto, pode-se dizer que considerando a perspectiva do perfil que trata do nível de envolvimento do grupo com a cooperativa, representado pelo tempo de função, número de mandatos e participação em assembleias, as variáveis determinadas como importantes para avaliar desempenho de cooperativas de crédito variam no que tange aos indicadores discutidos.

A fim de responder ao objetivo proposto de: verificar se os princípios do cooperativismo são tidos como importantes quando se trata da avaliação de desempenho de cooperativas de crédito, analisa-se os resultados obtidos por meio da hipótese 8: "Conselheiros Administrativos" participantes da amostra, percebem de forma geral alto grau de importância em relação aos indicadores referentes a valores e princípios cooperativistas, visto que suas médias de respostas para os referidos indicadores

Porém, considerando os indicadores com diferenças estatisticamente significativas, de forma geral os "Conselheiros Administrativos" percebem menos valor 
nos referidos indicadores do que "Gerentes", e mais valor do que "Cooperados". Em relação ao grupo "Conselheiros Fiscais" não houve diferença estatística significativa.

Sendo assim, entende-se que se os gestores das cooperativas de crédito tentam assegurar os princípios e valores cooperativos, já que enfatizam a livre e aberta adesão dos membros, o caráter democrático da gestão e do controle cooperativos, a autonomia e a independência, a responsabilidade social e a preservação da identidade organizacional, pois esses percebem alto grau de importância para os indicadores, apesar de gerentes perceberem mais valor.

A respeito do objetivo: apontar as divergências e convergências de opiniões de agentes e principal a investigação conclui que para 7 indicadores, dos 53 indicadores apresentados os grupos representados por "agente" e "principal" convergem de opinião. Para os demais 46 indicadores os dois grupos divergem de opinião.

Os indicadores cujas opiniões são significativamente parecidas são: Retorno sobre o investimento, Menor custo das transações, Ganhos financeiros de cada cooperado individualmente, Segurança no emprego para os trabalhadores da cooperativa, Pagamento de bons salários aos funcionários da cooperativa, Benefícios extras para bons funcionários e Condições de trabalho adequadas.

A fim de sugerir um Modelo de Avaliação de Desempenho de Cooperativas de Crédito que diminua os conflitos de agência, buscou-se complementar a bagagem de discussão acerca de indicadores relevantes para a avaliação de desempenho de cooperativas de crédito com uma entrevista com o responsável por essa atividade dentro de uma das cooperativas participantes do estudo. Com isso, foi possível conhecer como se dá a avaliação de desempenho dentro da mesma e unir isso ao que foi obtido com as pesquisas realizadas a fim de propor o modelo.

O modelo é formado por cinco módulos (Financeiro, Pessoas e inovação, Processos Internos, Associados e Princípios Cooperativistas), e centrado no objetivo da cooperativa de incluir as minorias no contexto econômico e social. Nesse sentido, todos os módulos interagem a fim de alcançar esse objetivo.

O grande diferencial do modelo proposto é o fato desse colocar como cerne do seu funcionamento o respeito aos princípios cooperativistas, com a intenção de minimizar os conflitos de agência.

Isso porque entende-se que os conflitos de agência ocorrem devido a divergências de interesse entre agente e principal, pois segundo a teoria, esses dois 
grupos não têm objetivos comuns, visto que buscam maximizar suas próprias utilidades.

Porém, no cooperativismo não deveriam existir conflitos de agência, pois todos os envolvidos deveriam ter a consciência de que estão ali com a finalidade comum de ajudar uns aos outros a atingirem seus objetivos pessoais a partir do alcance dos objetivos do grupo.

Então, parte-se do princípio que a causa dos problemas de agência em cooperativas de crédito é justamente a falta de praticar os princípios e fundamentos do cooperativismo. Isso porque, os problemas de agência são causados principalmente por questões como individualidade e oportunismo, características essas antagônicas ao cooperativismo.

Portanto o que falta para as cooperativas de crédito e provavelmente para as cooperativas de modo geral, é conscientizar mais os grupos envolvidos sobre o objeto de existência de uma cooperativa e sobre a necessidade de se pensar e agir coletivamente e de maneira associativa.

Nesse sentido, o modelo de avaliação de desempenho de cooperativas de crédito proposto parte da idéia de que os conflitos de agência podem ser minimizados a partir da conscientização de agente e principal acerca da necessidade de cooperar e respeitar os princípios cooperativistas.

Concluindo, entende-se que a influência da Teoria da Agência na gestão do desempenho de cooperativas de crédito existe, visto que, como discutido, para vários indicadores foi possível reconhecer divergências de opiniões, que podem futuramente levar a conflitos de agência. Nesse sentido, sugere-se um modelo de avaliação de desempenho focado em resolver dentre outros, os possíveis conflitos de agência. 


\section{REFERÊNCIAS}

ALBUQUERQUE, S. F. Indicadores para avaliação de desempenho das Cooperativas de Crédito. 2010. Disponível em: http://www.dfcooperativo.coop.br/conteudo.jsp?idnoticia=291\&idarea=20. Acesso em 03 de fev. de 2016.

ALVES, V. S. Desempenho Econômico-Financeiro de Cooperativas de Crédito: uma Abordagem Regional no Pós-Marco Regulatório Brasileiro de 2003. Dissertação (Mestrado em Administração). Fundação Universidade Federal de Rondônia, Porto Velho, Rondônia, 2010.

ALVES, Z. M. M. B.; SILVA, M. H. G. F. D. Análise qualitativa de dados de entrevista: uma proposta. Paidéia. n. 2. Ribeirão Preto. Fev./Jul. 1992.

AMESS, K.; HOWCROFT, B. Corporate governance structures and the comparative advantage of Credit Unions. Corporate Governance: an International Review; v. 9, n.1, p. 59-65, Jan. 2001.

ANDRADE, A.; ROSSETTI, J. P. Governança corporativa: fundamentos, desenvolvimento e tendências. 3.ed. São Paulo: Atlas, 2007

ANDRIESSEN, D.; TISSEN, R. Weightless Wealth: find your real value in a future of intangible assets, Financial Times and Prentice. Hall: London, 2000.

ARRUDA, G. S.; MADRUGA, S. R.; FREITAS JUNIOR, N. I. A governança corporativa e a teoria da agência em consonância com a controladoria. Revista de Administração da UFSM, v. 1, n. 1, art. 5, p. 71-84, 2008.

BANCO CENTRAL DO BRASIL (BACEN). Relação das Instituições em Funcionamento no País - 2018. Brasília, 2018.

BARROS, M. G. MORAES, M. B. C. Análise dos Determinantes de Desempenho em Cooperativas de Crédito no Brasil: Um Estudo com Base no Desempenho Financeiro e Operacional em Benefício ao Cooperado. XV Congresso da USP de Controladoria e Contabilidade. São Paulo, jul, 2015.

BASTOS, R. L. Ciências Humanas e Complexidades: projetos, métodos e técnicas de pesquisa. Juiz de Fora: EDUFJF, 1999.

BATISTA, L. E.; ESCUDER, M. M. L.; PEREIRA, J. C. R. A cor da morte: causas de óbito segundo características de raça no Estado de São Paulo, 1999 a 2001. Revista de Saúde Pública, v. 38, n. 5, p. 630-636, 2004.

BEBER, S. J. N.; RIBEIRO, J. L. D.; KLIEMANN NETO, F. L. Análise das causas do fracasso em implantações de BSC. Revista Produção on line, v. 6, n. 2, 2006.

BECKER, D. F. Competitividade: um novo padrão de regulação e ou normalização. Estudo \& Debate. Lajeado, v. 3, n. 1, p. 69-84, 1996. 
BECHT, M. BOLTON, P.; ROELL, A. Corporate governance and control. New York: ECGI, 2002.

BERTO, R. M. V. S.; NAKANO, D. N. A produção científica nos anais do encontro nacional de engenharia de produção: um levantamento de métodos e tipos de pesquisa. Produção, v. 9, n. 2, p. 65-76, 2000.

BERTUOL, R; CANÇADO, A. C.; SOUZA, M. F. A. A Prática dos Princípios Cooperativistas: um estudo de caso no Tocantins. AOS - Amazônia, Organizações e Sustentabilidade. v. 1, n.2, ago./dez. 2012.

BIALOSKORSKI NETO, S. Agribusiness cooperativo: economia, doutrina e estratégias de gestão. Piracicaba, 1994. 179 f. Dissertação (Mestrado em Economia Aplicada) - Escola Superior de Agricultura "Luiz de Queiroz", Piracicaba, 1994.

BIALOSKORSKI NETO, S. Aspectos econômicos das cooperativas. Belo Horizonte: Mandamentos, 2006.

BIALOSKORSKI NETO, S. Cooperativas agropecuárias no estado de São Paulo: uma análise da evolução na década de 90 . Informações Econômicas, São Paulo, v. 35, p. 1-11, 2005.

BIALOSKORSKI NETO, S.; NAGANO, M. S.; MORAES, M. B. da C. Eficiência econômica de cooperativas agropecuárias: um modelo de análise utilizando-se redes neurais. Anais... XL Congresso Brasileiro de Economia e Sociologia Rural. Passo Fundo. 2002.

BIALOSKORSKI NETO, S.; NAGANO, M. S.; MORAES, M. B. C. Utilização de redes neurais artificiais para avaliação sócio-econômica: uma aplicação em cooperativas. Revista de Administração (USP), São Paulo, v. 4, n. 1, p. 59-68, 2006.

BIALOSKORSKI NETO, S. ; BARROSO, M. F. G. ; REZENDE, A. J. . Governança corporativa e sistemas gerenciais: um ensaio utilizando-se da ótica da teoria de agency. In: V Encontro de Pesquisadores Latino-americano de Cooperativismo, 2008, Ribeirão Preto. Anais... Ribeirão Preto : FEA-RP USP, 2008.

BIRCHALL, J.; SIMMONS, R. What motivates members to participate in co-operative and mutual businesses? Annals of Public \& Cooperative Economics, v. 75, n. 3, p. 465-95, Sept. 2004.

BIRCHALL, J. The international co-operative movement. Manchester: Manchester University Press, 1997.

BIRCK, L. G. Agronegócio Cooperativo: A Inserção Econômica da Cooperativa Agroindustrial Lar. Toledo, 2005, 108 p. Dissertação (Mestrado em Desenvolvimento Regional e Agronegócio) - Programa de Pós-Graduação em 
Desenvolvimento Regional e Agronegócio, Universidade Estadual do Oeste do Paraná, Toledo, 2005.

BITITCI, U. S.; CARRIE, A. S. MACDEVITT, L.; TURNER, T. Integrated Performance Measurement Systems: a reference model. In: SCHONSLEBEN, P.; BUCHEL, A. (Org.). Organising the Extended Enterprise. London: Chapmam \& Hall, 1998a.

BITITCI, U. S.; CARRIE, A. S.; TURNER, T.; LUTZ, S. Integrated Performance Measurement Systems: imprementation case studies. In.: BITITCI, U. S.; CARRIE, A. S. (Org.). Strategic Management of the Manufacturing Valeu Chain. Norwell: Kluwer Academic Publichers, 1998b.

BOLFARINE, H.; SANDOVAL, M. C. Introdução à Inferência Estatística. São Paulo: SBM, 2000.

BOURGUIGNON, A.; MALLERET, V.; NORREKLIT, H. The American Balanced Scorecard versus the French Tableau de Bord: The Ideological Dimension. Management Accounting Research, v. 15, n. 2, pp. 107-134, 2004.

BORGES, R. C.; BENEDICTO, G. C.; CARVALHO, F. M. Avaliação de Desempenho Econômico-Financeiro de Cooperativas de Crédito de Livre Admissão de Minas Gerais por meio da Análise Fatorial das Demonstrações Contábeis. XIV Congresso de Controladoria e Contabilidade da USP. São Paulo, 2014.

BORTOLUZZI, S. C.; ENSSLIN, S.R.; ENSSLIN, L. Avaliação de desempenho multicritério como apoio à gestão de empresas: aplicação em uma empresa de serviços. Gest. Prod., São Carlos, v. 18, n. 3, p. 633-650, 2011.

BRANCH, B., BAKER, C. Chapter 11: Overcoming Credit Union GovernanceProblems. IN WESTLEY, Glenn D., BRANCH, Brian (org.). Safe money: building effective credit unions in Latin America. Washington: InterAmerican Development Bank and World Council of Credit Unions, 2000.

BRASIL, Lei nº 5.764, de dezembro de 1971.

BRESSAN, V. G. F.; BRAGA, M. J.; BRESSAN, A. A. Avaliação financeira das cooperativas de crédito rural do estado de Minas Gerais. O.R. \& A. Revista de Administração da UFLA - v.5 - n.2 - julho/dezembro 2003.

BRESSAN, V. G. F.; BRAGA, M. J.; BRESSAN, A. Al. Análise da dominação de membros tomadores ou poupadores de recursos nas cooperativas de crédito mineiras. Economia Aplicada, v. 16, n. 2, p. 339-59, 2012.

BRESSAN, V. G. F.; BRAGA, M. J.; BRESSAN, A. A. Eficiência e Economia de Escala em Cooperativas de Crédito: uma Abordagem de Fronteira Estocástica de Custo com Dados em Painel. Scientific and Applied Accounting. v.3, n.3, p.335-352, 2010.

BRESSAN, V. G. F.; BRAGA, M. J.; BRESSAN, A. A.; RESENDE-FILHO, M. A. O Seguro Depósito Induz ao Risco Moral nas Cooperativas de Crédito Brasileiras? 
Um Estudo com Dados em Painel. Revista Brasileira de Economia. v. 66 n. 2 / p. 167-185 Abr-Jun 2012.

BRESSAN, V. G. S.; BRAGA, M. J.; BRESSAN, A. A.; RESENDE FILHO, M. A. Uma Aplicação do Sistema PEARLS às Cooperativas de Crédito Brasileiras. Revista de Administração (FEA-USP), v. 46, p. 258-274, 2011.

BRESSAN, V. G. S. Seguro depósito e moral Hazard nas cooperativas de crédito brasileiras. 2009. $371 \mathrm{f}$. Tese (Doutorado em Economia Aplicada)-Universidade Federal de Viçosa, Viçosa, 2009.

BUCHELE, R. B. How to Evaluate a Firm. California Management Review, v. 5, n. 5, 1962.

BUCHELE, R. B. Políticas administrativas para empresas em crescimento. São Paulo: Atlas, 1971.

BUSK, G. K.; BROWN, R. M.; KILLOUGH, L. N. Components and relative weights in utilization of dashboard systems like the Balanced Scorecard. The British Accounting Review, v. 35, 2003.

CANÇADO, A. C. Autogestão em cooperativas populares: os desafios da práticas. 2004. 134 f. (Mestrado em Administração) - Universidade Federal da Bahia, Salvador, 2004

CANÇADO, A. C.; SOUZA, M. F. A.; PEREIRA Os princípios cooperativistas e a identidade do movimento cooperativista em xeque. Revista de Gestão e Organizações Cooperativas - RGC. Santa Maria, v. 1, n. 2, 2014.

CANNEL, C. F.; KAHN, R. L. Coleta de dados por entrevista. In: FESTINGER, L. \& KATZ, D. A pesquisa da psicologia social. Rio de Janeiro: EFGV, 1974.

CAÑETE,I. Humanização: Desafio da Empresa Moderna. 2.ed. São Paulo: Ícone, 2001.

CARVALHO, F. L.; BIALOSKORSKI NETO, S. Indicadores de Avaliação de Desempenho em Cooperativas Agropecuárias: Um Estudo em Cooperativas Paulistas. V Encontro de Pesquisadores Latino-americanos de Cooperativismo. Ribeirão Preto, São Paulo, 2008.

CATELLI, A.; GUERREIRO, R.; PEREIRA, C. A. Avaliação de resultados e desempenhos em instituições financeiras. In.: CATELLI, A. (Coord.). Controladoria. São Paulo: Atlas, 1999. p. 385-411.

CAVALCANTI, H. W. V.; LYRA, M. M. Metodologia do índice de exclusão/inclusão socioambiental da cidade do Recife. 2006. Disponível em http://www.fundaj.gov.br/geral/observanordeste/livro\%20MUR/ContracapaSumriolntrodu--o\%20MUR.pdf. Acesso em: jul. 2017. 
CLARK, T. Theories of Corporate Governance: the theoretical foundations. New York: Routledge, 2004.

CONSELHO FEDERAL DE EDUCAÇÃO. Parecer n. 3.491/77, Relator: Conselheiro Newton Lins Buarque Sucupira. Conceito de necessidades sociais e critérios de sua aplicação. Fórum, Rio de Janeiro, jan/mar 1978.

COOK, M. L. The future of U.S. agricultural cooperatives: a neo-institutional approach. American Journal of Agricultural Economics, v. 77, p. 1153-1159, Dec. 1995.

COOK, M. L.; CHADDAD, F. R.; ILIOPOULOS, C. Governance models in food production and distribution: evolution and role of mutual vertical integration. In: Annual Conference of the International Society for New Institutional Economics Aassociation. Tucson: ISNIE, 2004.

COSTA, D. R. M. ; BIALOSKORSKI NETO, S. Assimetria de informação no cooperativismo agropecuário brasileiro: origem, implicações e soluções. In: XLII Congresso da Sociedade Brasileira de Economia e Sociologia Rural, 2004, Cuiabá, Anais... Cuiabá : 2004.

COSTA, L. S. O cooperativismo: uma breve reflexão teórica. Ciências Sociais em Perspectiva. Volume 06, N. 11, 2. sem. de 2007.

CO-OPERATIVES OF THE AMERICAS. Co-operative Identity, Principles and Values. Co-operatives of the Americas. c2001-2015. Disponível em: $<$ http://www.aciamericas.coop/Co-operative-Identitiy-Principles-4484>. Acesso em: 28 abr. 2016.

CORRÊA, H. L.; HOURNEAX JÚNIOR, F. Sistemas de mensuração e avaliação de desempenho organizacional: estudo de casos no setor químico no Brasil. Revista Contabilidade \& Finanças (Online), v. 19, p. 50-64, 2008.

CORRÊA, H. L. O "Estado da Arte" da Avaliação de Empresas Estatais. Tese (Doutorado em Administração). Faculdade de Economia, Administração e Contabilidade - Universidade de São Paulo, São Paulo, 1986.

COSTAMARQUES, M.C.C.; CONDE, M.F. Teoria da sinalização e da agência. CROC - Revisores e Empresas, jul./set. 2000.

CRANDALL, R. E. Keys to better performance measurement. Industrial Management. Vol. 44, Jan/Feb. 2002.

CRESWELL, J. W. Projeto de pesquisa: métodos qualitativos, quantitativos e misto. $2^{\mathrm{a}}$ Ed. Porto Alegre: Artmed, 2007.

CROSS, K. F.; LYNCH, R. L. The SMART Way to Define and Sustain Success. National Productivity Review, v. 8, n. 1, p. 23-33, 1988.

CUEVAS, C. E., FISCHER, K. Cooperative financial institutions: issues in governance, regulation, and supervision. Washington: The World Bank, 2006. 
CUNHA, J. A. C. Avaliação de desempenho e eficiência em organizações de saúde: um estudo em hospitais filantrópicos. Tese (Doutorado). Faculdade de Economia, Administração e Contabilidade - Universidade de São Paulo, São Paulo, 2011.

CURI, F. M. B. Cooperativas de Serviços Médicos domo Sócias de Outros Tipos Societários. Revista da Faculdade de Direito da Universidade Federal do Paraná. v. 43. Curitiba, 2005.

CRÚZIO, H. O. Por que as cooperativas agropecuárias e agroindustriais brasileiras estão falindo? RAE, v.39, n.2, 1999.

DAFT, R. L.; MARCIC, D. Understanding Management Versailes. Thomson-SouthWestern, 2004.

DEVELLIS, R. F. Scale development: Theory and applications. 2 ed. Thousand Oaks, CA: Sage Publications, 2003.

DINNEEN, L. C.; BLAKESLEY, B. C. Algorithm AS 62: A Generator for the Sampling Distribution of the Mann- Whitney U Statistic. Journal of the Royal Statistical Society, v. 22, n. 2, p. 269-273, 1973. Disponível em: <https://www.jstor.org/stable/pdf/2346934.pdf>

DIXON, J.R., NANNI, A.J.; VOLLMANN, T.E. The New Performance Challenge: Measuring Operations for World Class Competition, Dow Jones/lrwin, Homewood, IL. 1990.

DRUCKER, P. F. The pratice of Management. HarperCollins, 2010.

DRUCKER, P. F. Prática de Administração de Empresas. $3^{a}$ Ed. Rio de Janeiro: Fundação de Cultura, 1968.

DUNN, O. J. Multiple comparisons using rank sums. Technometrics, v. 6, p. 241-252, 1964.

EDVINSSON, L. Developing Intellectual Capital at Skandia. Long Range Planning, USA, p.366-373, jun. 1997.

EDVINSSON O, L.; MALONE, M. S. Capital Intelectual: descobrindo o valor real de sua empresa pela identificação de seus valores internos. São Paulo: Makron Books, 1988.

EGGERTSSON, T. Economic behavior and institutions. Cambridge: Cambridge University, 1995.

EPSTEIN, M. J.; MANZONI, J. The Balanced Scorecard and Tabelau de Bord: Translating Strategy Action. Management Accouting, v. 79, n. 2, ago, 1997. 
EVANS, J. R.; MATHUR, A. The value of online survey. Internet Research, v. 15, n. 2, p. 195-219, 2005.

FAN, C.; ZHANG, D.; ZHANG, C.-H. On Sample Size of the Kruskal-Wallis Test with Application to a Mouse Peritoneal Cavity. Biometrics, v. 67, n. 1, p. 213-224, 2011.

FARIAS, C. G. B. A controladoria no contexto do sistema de gestão econômica (GECON) - uma abordagem para instituições financeiras. 1998. 171 p. Dissertação (Mestrado em Controladoria e Contabilidade) - Universidade de São Paulo, São Paulo.

FAVALLI, R. T. Governança corporativa e análise do desempenho de cooperativas de crédito no Brasil. Dissertação (Mestrado em Ciências Econômicas). Universidade Estadual de Campinas, Campinas, SP, 2010.

FÁVERO, L. P. L.; MARTINS, G. A.; LIMA, G. A. S. F. Associação entre Níveis de Governança, Indicadores Contábeis e Setor: uma análise sob as perspectivas da Anacor e da Homals. Revista de Informação Contábil. Vol. 1, no 2, p. 1-17, outdez/2007.

FERGUSON, A.A. Managing Without Managers: Crisis and Resolution in a Collective Bakery. In: M. BURAWOY; BURTON, A.; FERGUSON, A., FOX, K. J. (coords.), Ethnography Unbound. Berkeley, University of California Press, p. 108-132, 1991.

FERREIRA, M. A. M.; GOLÇALVES, R. M. L.; BRAGA, M. J. Investigação do desempenho das cooperativas de crédito de Minas Gerais por meio da Análise Envoltória de Dados (DEA). Economia aplicada, São Paulo, v. 11, n. 3, p. 425445, Jul/set 2007.

FIELD, A. Descobrindo a estatística usando o SPSS. 2. ed. Porto Alegre: Bookman, 2009.

FIELD, A. Discovering Statistics Using IBM SPSS Statistics. 4. ed. Thousand Oaks: Sage, 2013.

FINTECH. Revista ÉPOCA Negócios. Disponível em: https://epocanegocios.globo.com/Dinheiro/noticia/2016/01/o-fenomeno-fintechnova-leva-de-startups-que-invadiram-o-sistema-financeiro.html. Acesso em jun. 2018.

FLICK, U. Uma introdução à pesquisa qualitativa. 2. ed. Porto Alegre: Bookman, 2004.

FONTES FILHO, J. R.; VENTURA, E. C. F.; OLIVEIRA, M. J. Governança e participação no contexto das cooperativas de crédito. FACES Revista de Administração, Belo Horizonte. p. 48-63, 2008. 
FONTES FILHO, J. R. Governança organizacional aplicada ao setor público, VIII Congreso Internacional del CLAD sobre la Reforma del Estado y de la Administración Pública, Panamá, Out. 2003.

FORSTH, B.; ROTHGEB, J.; WILLIS, D. Does Pretesting Make a Difference? In: Presser, J.M.; Rothgeb, M. P.; Lessler, J. T.; Martin, E.; Martin, J.; Singer, E. (Orgs). Methods for Testing and Evaluting Survey Questionnaires. New York (Estados Unidos): Wiley \& Sons, 2004.

FORZA, C. Survey research in operations management: a process-based perspective. International Journal of Operations and Production Management, v. 22, n, 2, p. 152-194, 2002.

FUNDAÇÃO NACIONAL DA QUALIDADE. Disponível em: $<$ http://www.fnq.org.br/avalie-se/metodologia-meg/modelo-de-excelencia-dagestao. Acesso em: 19 set.2015.

FROST, B. Performance metrics: the new strategic discipline. Strategy and Leadership. Vol. 27, May/Jun. 1999.

GALLON, A. V.; ENSSLIN, S. R.; ENSSLIN, L. Avaliação de desempenho organizacional em incubadoras de empresas por meio da Metodologia Multicritério de Apoio à Decisão Construtivista (MCDA-C): a experiência do MIDI tecnológico. Revista de Administração e Inovação, v. 8, p. 37-63, 2011.

GENOVEZ, P. C. Território e desigualdades: análise espacial intra-urbana no estudo da dinâmica de exclusão/inclusão social no espaço urbano em São José dos Campos. Dissertação (Mestrado em Sensoriamento Remoto). Instituto Nacional de Pesquisas Espaciais, São José dos Campos, 2005.

GHALAYINI, A. M.; NOBLE, J. S. The Changing Basis of Performance Measurement. International Journal of Operations \& Production Management, v. 16, n. 8, p. 63-80, 1996.

GIÃO, P. R.; GOMIDES, A.; PICCHIONI, C. N.; CORREA, H. L. , OLIVEIRA JUNIOR, M. M.;OLIVEIRA JUNIOR, M. M. Modelo Sigma Sustentabilidade Flexível: Uma Contribuição Rumo a Organizações Sustentáveis. FACEF Pesquisa, v. 13, n. 2, 2010.

GIL, A. C. Como elaborar projetos de pesquisa. 4.ed. São Paulo: Atlas, 2010.

GIL, A.C. Métodos e Técnicas de Pesquisa Social. São Paulo: Atlas, 2006.

GUIMARÃES, R. G. A presença dos cinco capitais no Índice de Sustentabilidade Empresarial (ISE). Dissertação (Mestrado). Universidade de São Paulo, São Paulo, 2013.

GUSE, J. C.; LEITE, M.; SILVA, T. P.; GOLLO, V. Desempenho Econômico Financeiro das Maiores Cooperativas de Crédito Brasileiras. XI Simpósio de Excelência em Gestão e Tecnologia. Resende, Rio de Janeiro, 2014. 
GODOY, P.; MARCON, R. Teoria da Agência e os conflitos organizacionais: a influência das transferências e das promoções nos custos de agência em uma instituição bancária. Revista de Administração Mackenzie, v. 7, n. 4, p. 168210, 2006.

GOMES, R. Análise e interpretação de dados de pesquisa qualitativa. In: MINAYO, M. C. S. Pesquisa social: teoria, método e criatividade. Petrópolis, RJ: Vozes, 2008.

GONÇALVES, M. R. G. A utopia cooperativista regulada pelo direito: crítica para uma filosofia jurídica transmoderna. 2006. 205p. Dissertação (Mestrado em Direito) - Setor de Ciência Jurídica, Universidade Federal do Paraná, Coritiba, 2006.

HAIR JR, J. F.; BABIN, B.; MONEY, A.H.; SAMOUEL, P. Fundamentos de métodos de pesquisa em administração. Porto Alegre: Bookman, 2005.

HAIR, J. F.; ANDERSON, R. E.; TATHAM, R. L.; BLACK, W. C. Análise multivariada de dados. 5. ed. Porto Alegre: Bookman, 2005.

HALACHMI, A. Performance measurement is only one way of managing performance. International Journal of Productivity and Performance Management, Vol. 54, 2005.

HANSMANN, H. Cooperative firms in theory and practice. The Finnish Journal of Business Economics, v. 4, p. 387-403, 1999.

HAUSER, J.; KATZ, G. Metrics: you are what you measure! European Management Journal. v. 16, n. 5, p. 517-528, 1998.

HENDRIKSEN, E. S.; VAN BREDA, M. F. Teoria da contabilidade. Tradução Antonio Zoratto Sanvicente. São Paulo: Atlas, 1999.

HOURNEAUX JR, F. Avaliação de Desempenho Organizacional: Estudo de Casos de Empresas do Setor Químico. Dissertação (Mestrado em Administração) Faculdade de Economia, Administração e Contabilidade. Universidade de são Paulo, São Paulo, 2005.

HOURNEAUX JR., F.; CARNEIRO-DA-CUNHA, J. A; CORRÊA, H. L. Performance measurement and management systems: different usages in Brazilian manufacturing companies. Managerial Auditing Journal, 2017.

HOWELL, D. C. Statistical Methods for Psychology. Vermont: Cengage Learning, 2012.

HRONEC, S. M. Sinais vitais: usando medidas de desempenho da qualidade, tempo e custo para traçar a rota para o futuro de sua empresa. São Paulo: Makron Books, 1994.

HUBNER, B. T.; TIECKER, S. S.; UTZIG, M. J. S.; MAGRO, C. B. D.; DITTADI, J. R.; LAVARDA, C. E. F. Proposta de Indicadores de Performance sob a Perspectiva 
do Balanced Scorecard: O Caso de uma Cooperativa de Crédito. Revista Catarinense da Ciência Contábil - CRCSC - Florianópolis, v. 11, n. 31, p. 922, dez./mar. 2012.

INTERNATIONAL CO-OPERATIVE ALLIANCE. What is a co-operative? COOP. 2005a. Disponível em: <http://ica.coop/en/what-co-operative>. Acesso em: 28 abr. 2016.

INTERNATIONAL CO-OPERATIVE ALLIANCE. What is a co-operative? COOP. 2005b. Disponível em: <http://ica.coop/en/what-co-operative>. Acesso em: 10 jul. 2015.

JACKSON, P. M. Measures for success in the public sector. London: The Public Finance Foundation, 1995.

JAEGER, F. S. O Cooperativismo como Fator de Inclusão Econômico-Social na Lei 5764/71. Centro Universitário Univates, Lajeado, 2005.

JANSSON, T.; STAUFFENBERG, D.; KENYON, N.; BADIOLA, M. C. Performance indicators for microfinance institutions: technical guide. 2003.

JANUÁRIO, S.; MENDES, M. M.; FERREIRA, H.; SAMAGAIO, F.; RODRIGUES, E. V. A pobreza e a exclusão social: teorias, conceitos e políticas sociais em Portugal. A Sociologia: Revista da Universidade de Letras da Universidade do Porto, v. 9. 1999.

JENSEN, M.C.; MECKLING.W.H. Theory of the firm: Managerial behavior, agency costs and ownership structure. Journal of Financial Economics. Volume 3, Issue 4, October 1976, Pages 305-360

KANG, Y.; HARRING, J. R. Investigating the Impact of Non-Normality, Effect Size, and Sample Size on Two-Group Comparison Procedures: An Empirical Study. In: Presented at the Annual Meeting of the American Educational Research Association (AERA). 2012, Anais...2012. p. 29

KAYO, E. K.; FAMA, R. Teoria da agência e crescimento: evidências empíricas dos efeitos positivos e negativos do endividamento. Caderno de Pesquisas em Administração, 1997.

KAPLAN, R. S.; NORTON, D. P. Mapas estratégicos - Balanced Scorecard: convertendo ativos intangíveis em resultados tangíveis. Rio de Janeiro: Elsevier, 2004.

KAPLAN, R. S.; NORTON, D. P. A estratégia em ação: Balanced Scorecard. 5. Ed. Rio de Janeiro: Campus, 1997.

KAPLAN, R. S.; NORTON, D. P. Organização orientada para a estratégia: como as empresas que adotam o balanced scorecard prosperam no novo ambiente de negócios. Rio de Janeiro: Campus, 2000. 
KENNERLEY, M.; NEELY, A. Performance Measurement Frameworks: a Review. In: NEELY, A. (Org). Busineess Performance Measurement. Theory and Pratice. Cambridge: Cambrigde University Press, 2002.

KLINE, R. B. Principles and practice of structural equation modeling. 2 ed. New York: Guildford, 2005

KOHR, R. L.; GAMES, P. A. Robustness of the analysis of variance, the Welch procedure and a Box procedure to heterogeneous variances. The Journal of Experimental Education, v. 43, n. 1, p. 61-69, 1974.

KOTZ, E. J. Competição num mercado globalizado $X$ fidelidade aos princípios cooperativistas - o caso Sicredi RS. Dissertação (mestrado). Universidade do Vale do Rio dos Sinos - Unisinos. 2007.

KRAHNEN, J. P.; SCHMIDT, R. H. On the theory of credit cooperatives: equity and onlending in a multi-tier system: poverty oriented banking. 1997.

KRAVCHUCK, R. S.; SCHACK, R. W. Designing effective performance-measurement systems under the Government Performance and Results Act of 1993. Public Administration Review, Whashington, v. 56, jul/ago, 1996.

LAERD STATISTICS. Independent-samples t-test using SPSS Statistics. Statistical tutorials and software guides. Laerd Statistics. 2015. Disponível em: $<$ https://statistics.laerd.com/premium/spss/istt/independent-t-test-in-spss24.php>. Acesso em: 27 jul. 2018.

LAZZARINI, S. G.; BIALOSKORSKI NETO, S.; CHADDAD, F. R. Decisões financeiras em cooperativas: fontes de ineficiências e possíveis soluções. Gestão da Produção, São Carlos, v. 6, n. 3, p. 257-268, 1999.

LEBAS, M. J. Performance Measurement and Performance Management. International Journal of Production Economics, v. 41, n. 1, p. 23-35, 1995.

LIMA, R. E. Conflitos de agência nas cooperativas de crédito brasileiras. Tese (Doutorado). Universidade Federal de Minas Gerais. Centro de Pós-Graduação e Pesquisas em Administração, Belo Horizonte, 2014.

LINSTONE, H.A.; TUROFF, M. Introduction. In: Linstone, M.; Turoff, M. (Orgs). The Delphi Method. Techniques and Applications. Reading (Estados Unidos): Addison-Wesley, 1975.

LODI, J. B. Administração por objetivos. São Paulo: Pioneira, 1974.

LOUREIRO, M. R. Cooperativas agrícolas e capitalismo no Brasil. São Paulo: Cortez, 1981.

LUIJSTERBURG, J.; HAM, M. V.; BROUWERS, E.; SMITS, M. Towards Performance Indicators for the Health Care Sector. 21th Bled e Conference e Collaboration: 
Overcoming Boundaries Through Multi-Channel Interaction. Bled, Slovenia, June, 2008.

MACEDO-SOARES, T. D. A.; RATTON, C. Medição de Desempenho e Estratégias Orientadas para o Cliente. RAE, Revista de Administração de Empresas, São Paulo, v. 39, n. 4, p. 46-59, out./dez. 1999.

MARCONI, M. A.; LAKATOS, E.M. Fundamentos de metodologia científica. 5. ed. - São Paulo : Atlas 2003.

MARINHO, S. V.; SELIG, P. M. Utilização do conceito de gestão estratégica de custos dentro do Balanced Scorecard. In: Congresso Brasileiro de Custos, Recife, Anais. Recife: UFPE, 2000.

MARTINDELL, J. The Scientific Appraisal of Management. A Study of the Business Practices of the Well Managed Companies. New York: Harper, 1950.

MARTINEZ, A. L. Agency theory na pesquisa contábil. In: Encontro da Associação Nacional de Programas de Pós-graduação em Contabilidade. Foz do Iguaçu: ANPAD, 1998.

MARTIN, N. C.; SANTOS, L. R.; DIAS FILHO, J. M. Governança empresarial, riscos e controles internos: A emergência de um novo modelo de controladoria. Revista Contabilidade \& Finanças. São Paulo. v. 34, n. 1, p. 7-22, janeiro/abril de 2004.

MARTINO, J, P. Technological forecasting for decision making. 3. Ed. New York: Mc Graw-Hill Inc, 1993.

MARTINS, V. G.; GIRÃO, L. F. A. P.; SILA E FILHO, A. C.C.; ARAÚJO, A. O. A Utilização de Modelos de Avaliação de Desempenho Sob a Perspectiva do Gecon e do Balanced Scorecard: Estudo de Caso em uma Central de Cooperativas de Crédito. Revista Evidenciação Contábil \& Finanças. João Pessoa, v.1, n. 1, p. 99-117, jan./jun. 2013.

MATHEWS, P. Sample size calculations: Practical methods for engineers and scientists. Fairport Harbor: Mathews Malnar and Bailey, 2010.

MEHO, L. E-mail interviewing in qualitative research: a methodological discussion. Journal of the American Society For Information Science And Technology, v. 57, n. 10 , p. $1284-1295,2006$.

MEINEN, E.; DOMINGUES, J. N.; DOMINGUES, J. A. S. (Org.). Cooperativas de crédito no direito brasileiro. Porto Alegre: Sagra Luzzatto, 2002.

MENDES, A. P. S. Teoria da agência aplicada à análise de relações entre os participantes dos processos de cooperação tecnológica universidadeempresa. Tese (Doutorado em Administração) - Faculdade de Economia, Administração e Contabilidade, São Paulo, 2001. 260 f. 
MENEGÁRIO, A. H. Emprego de indicadores sócio econômico na avaliação financeira de cooperativas agropecuárias. 2000, 121 f. Dissertação (Mestrado em Ciências) - Escola Superior de Agricultura Luiz de Queiroz, Universidade de São Paulo, Piracicaba, 2000.

MEURER, S; MARCON, R. Desempenho de Cooperativas: O Caso de uma Cooperativa de Crédito Rural. Organizações Rurais \& Agroindustriais, Lavras, v. 9, n. 3, p. 334-348, 2007.

MEYRICK, J. The Delphi Method and Health Research, v. 103, n.1, 2003.

MONTEIRO, E. S. R. B.; CANÇADO, A. C.; OLIVEIRA, V. A. R.; RIGO, A. S. Prática dos Princípios Cooperativistas: um Estudo de Caso na Cooperativa Adalzisa Moniz em Cabo Verde. IV Encontro Nacional de Pesquisadores em Gestão Social - IV ENAPEGS. Lavras, 2010.

MORGAN, G. Imagens da organização. 2. Ed. São Paulo: Atlas, 2002.

MUCCILLO NETO, J. Avaliação de desempenho de instituições financeiras. Revista de Administração, São Paulo, v. 28, n. 3, p. 13-21, jul/set 1993.

MUNARETTO, L. F. Avaliação de desempenho organizacional em cooperativas de eletrificação: um estudo sobre o uso de indicadores de desempenho. Faculdade de Economia, Administração e Contabilidade - Universidade de São Paulo, São Paulo, 2013. 293 p.

MUNARETTO, L. F.; CORREAA, H. L.; CUNHA, J. A. C. Um estudo sobre as características do método Delphi e de grupo focal, como técnicas na obtenção de dados em pesquisas exploratórias. Rev. Adm. UFSM, Santa Maria, v. 6, n. 1, p. 09-24, jan./mar. 2013.

MURCIA, F. D.-R. Fatores determinantes do nível de disclosure voluntário de companhias abertas no Brasil. 2009. 182 f.Tese (doutorado em Ciências Contábeis)—Universidade São Paulo (FEA-USP), São Paulo, 2009

NASCIMENTO, A.M.; BIANCHI, M. Um estudo sobre o papel da controladoria no processo de redução de conflitos de agência e governança corporativa. In: Congresso USP de Controladoria e Contabilidade. Universidade de São Paulo: São Paulo, 2005.

NASCIMENTO, F. R. Cooperativa como alternativa de mudança: uma abordagem normativa. Rio de Janeiro: Forense, 2000, 209 p.

NASCIMENTO, J. R.; GIRIOLI,L. S.; BIALOSKORSKI NETO S.; RIBEIRO, E. M. S. Uma Análise do Desempenho das Cooperativas de Crédito Rural Brasileiras Segundo Modelo DEA - Análise Envoltória de Dados. XXII Congresso Brasileiro de Custos. Foz do Iguaçu, 2015.

NEELY, A. Measuring business performance: why, what and how. London: Economists Books, 1998. 
NETTO, F. S. Medição de Desempenho Organizacional: um estudo das vantagens e desvantagens dos principais sistemas sob as óticas teóricas-acadêmicas e de práticas de mercado. In: XXXI Encontro da ANPAD, Rio de Janeiro, 2007.

NIVEN, P. R. Balanced Scorecard passo-a-passo: elevando o desempenho e mantendo resultados. Rio de Janeiro: Qualitymark, 2005.

NORREKLITU, $\mathrm{H}$. The balance on the balanced scorecard-a critical analysis of some of its assumptions. Management Accounting Research, 2000.

ODIORNE, G. S. Gestão por objetivos: um sistema de direção. Lisboa: Clássica, 1970.

OLIVEIRA, D. A. Educação básica: gestão do trabalho e da pobreza. Petrópolis, RJ: Vozes, 2000.

OLIVEIRA, D. P. R. Manual de gestão das cooperativas. São Paulo: Atlas, 2001.

OLIVEIRA, E. W. M.; YAMAMOTO, I.; CORREAA, H. L. O papel do modelo de avaliação de desempenho organizacional como sistema de medição para permitir o alinhamento entre a estratégia de negócio e operação para uma instituição de ensino superior. VII Encontro de Estudos em Estratégia da ANPAD, jun. 2015.

OLIVEIRA JÚNIOR, C. R. A avaliação da eficiência empresarial cooperativa. Curitiba: OCEPAR, 1996.

OLIVEIRA JUNIOR, C. C. Avaliação de eficiência empresarial das cooperativas. Série Cooperativismo. Paraná: OCEPAR, 1991.

OLIVEIRA, J. R. O comprometimento do cooperado com a cooperativa. Dissertação (Mestrado em Engenharia de Produção), Universidade Federal de Santa Maria, Santa Maria, 2007.

ORGANIZAÇÃO DAS COOPERATIVAS BRASILEIRAS. 2015. Disponível em: http://www.ocb.org.br/site/ramos/credito_numeros.asp. Acesso em: jul. 2015.

ORGANIZAÇÃO DAS COOPERATIVAS BRASILEIRAS. Relatório OCB 2013. 2014. Disponível em: <http://relatorioocb2013.brasilcooperativo.coop.br/wpcontent/uploads/2014/04/relatorio_gestao_OCB_2013.pdf>. Acesso em: 26 abr. 2016.

PACE, E. S. U. Metodologias de avaliação de desempenho com a criação de valor como contribuição ao planejamento das organizações sem fins lucrativos. Tese (Doutorado) - Universidade de São Paulo. São Paulo, 2009.

PADULA, M; ARAÚJO, Z. A. S. Governança corporativa e relações públicas em cooperativas: verdade ou mito. In: V Encontro de Pesquisadores Latinoamericanos de Cooperativismo, 2008, Ribeirão Preto. Anais... Ribeirão Preto: USP-RP, 2008. CD-ROM. 
PAGANO, M.; GAUVREAU, K. Testes de hipóteses. In: Pagano M, Gauvreau K (Orgs.). Princípios de bioestatística. São Paulo: Editora Pioneira Thomson Learning; 2004. p. 209-31.

PAGNUSSATT, A., Guia do Cooperativismo de Crédito: organização, governança e políticas corporativas. Porto Alegre: Ed. Sagra Luzzatto, 2004.

PARMENTER, D. Key performance indicators, Chartered Accountants. Journal of New Zealand, pp60-71, Oct. 1991.

PATIN, J. R. P.; McNIEL, D. W. Member group orientation of credit uinions and total member benefits. Review of Social Economy, v. 49, n. 1, p. 37-61, 1991.

PEREIRA, A. C. Contribuição a análise e estruturação das demonstrações financeiras das sociedades cooperativas brasileiras. Cadernos de Estudos, n. 10, mar. 2004.

PEREIRA, M. J. A.; SOUZA, A. B. Cooperativismo Ou Capitalismo Disfarçado? Uma Breve Análise Das Cooperativas Agrícolas Em Roraima. Revista de Administração de Roraima - RARR. Ed.3, V. 1, Boa Vista, 2013.

PIKE, S.; FERNSTROM, L.; ROSS, G. Intellectual capital: Management approach in ICS Ltd. Journal of Intellectual Capital, Vol. 6, 2005.

PINHO, D.B. A empresa cooperativa: análise social, financeira e contábil. São Paulo: Coopercultura, 1986. 80p.

PINHO, D. B. Economia e cooperativismo. São Paulo: Saraiva, 1977.

PINHO, D. B. Manual do Cooperativismo. São Paulo: CNPq/BNCC, 1982, 101 p.

PINHO, D. B.; FALHARES, V. M. A. (Org.) . O Cooperativismo de Crédito no Brasil - do século XX ao século XXI - edição comemorativa. 1ª. ed. São Paulo: Confebrás - editores associados, 2004.

PONTES, D. R. Configurações Contemporâneas do cooperativismo brasileiro: da economia ao direito. Dissertação (Mestrado em Direito) - Setor de Ciência Jurídica, Universidade Federal do Paraná, Curitiba, 2004.

PORTAL COOPERATIVISMO DO BRASIL. ESTATÍSTICAS DO COOPERATIVISMO EM 2012. 2015.2 Disponível em: <http://www.cooperativismodobrasil.com.br/estatistica.htm>.

PORTAL DO COOPERATIVISMO FINANCEIRO. Dados consolidados dos Sistemas Cooperativos. [c2016]. Disponível em: $<$ http://cooperativismodecredito.coop.br/cenario-mundial/cenariobrasileiro/dados-consolidados-dos-sistemas-cooperativos/>.

PORTAL DO COOPERATIVISMO FINANCEIRO. Instituições Financeiras Cooperativas cresceram em 16\% o volume de depósitos em 2015. $2015 a$. 
Disponível em: <http://cooperativismodecredito.coop.br/2016/04/instituicoesfinanceiras-cooperativas-cresceram-em-16-o-volume-de-depositos-em-2015/>. Acesso em: 25 abr. 2016.

PORTAL DO COOPERATIVISMO FINANCEIRO. Maiores cooperativas financeiras do Brasil - base dez/2014. 2015b. Disponível em: <http://cooperativismodecredito.coop.br/2015/03/maiores-cooperativasfinanceiras-do-brasil-2014/>. Acesso em: 25 abr. 2016.

PORTAL DO COOPERATIVISMO FINANCEIROS. Conselho de Administração de Cooperativas de Crédito. 2018. Disponível em: http://cooperativismodecredito.coop.br/legislacao-e-gestao/conselho-deadministracao/. Acesso em: jul. 2018.

PORTO, W. S. Avaliação de Desempenho de Cooperativas de Crédito Rural Baseada no uso do Balanced Scorecard. Florianópolis, 2002. 80f. Dissertação (Mestrado em Engenharia de Produção) - Programa de Pós-graduação em Engenharia de Produção. UFSC, 2002.

PRATT, J.W.; ZECKHAUSER, R. Principals and agents: the structure of business. Harvard Business School Press, 1985. p. 241.

PRESSER, S.; COUPER, M. P.; LESSLER, J. T.; MARTIN, E.; ROTHGEB, J. M.; SINGER, E. Methods for Testing and Evaluating Survey Questions. Public Opinion Quarterly, v. 68, n. 1, pp. 109-130, 2004.

PREVIDELLO, A.; DUTRA, I. Elementos de Economia. Bauru: Jalovi, 1973.

QUEIROZ, M. I. P. Relatos orais: do "indizível ao "dizível". Ciência e Cultura, São Paulo, 1987.

QUIROGA, M. D. P. S.; BRESSAN, V. G. F.; BRAGA, M. J. Avaliação financeira das cooperativas de crédito mútuo do estado de Minas Gerais. Revista de Ciências Empresariais da UNIPAR. V. 6, n. 1, 2005.

RESENDE, J. F. Balanced Scorecard e a Gestão do Capital Intelectual. Rio de Janeiro: Campus, 2003.

RESENDE, J. F. Indicadores de Desempenho para as Gráficas de Pequeno Porte da Região Metropolitana de Belo Horizonte. Dissertação (Mestrado em Engenharia de Produção). Universidade Federal de Santa Catarina, Florianópolis, 2003.

ROCHA, P. R. Z. Métodos de avaliação de ativos intangíveis e capital intelectual: análise das competências individuais. Dissertação (Mestrado). Programa de Pós-graduação em Engenharia e Gestão do Conhecimento. Universidade Federal de Santa Catarina. Florianópolis, 2012.

RODRIGUES. R. A segunda onda do cooperativismo. In: PINHO, D. B.; FALHARES, V. M. A. (Org.). O Cooperativismo de Crédito no Brasil - do século XX ao século 
XXI - edição comemorativa. $1^{\text {a }}$. ed. São Paulo: Confebrás - editores associados, 2004.

ROSA JUNIOR, A. X. Modelo de Tableau de Bord de Gestão para Empresas Brasileiras com Base na Contabilidade em Atividades. Dissertação (Mestrado). Programa de Pós-Graduação em Engenharia de Produção, Universidade Federal de Santa Catarina, Florianópolis, SC. 2003.

RUMMLER, G. A.; BRACHE, Alan P. Melhores desempenhos das empresas. São Paulo: Makron Books, 1994.

RYAN, T. P. Sample size determination and power. Hoboken: Wiley, 2013.

SACKMAN, H. Summary Evaluation of Delphi. Policy Analysis, v. 1,. N.4, 0. 693-718, 1975.

SANTOS, B. Produzir para Viver: os caminhos da produção não-capitalista. Rio de Janeiro: Civilização Brasileira, 2002.

SANTOS, H. S. A análise econômica e financeira da empresa cooperativa. In: PINHO, D. B (Org.). Empresa cooperativa: análise social, financeira e contábil. São Paulo: Coopercultura, 1986. p. 19-36.

SANTOS, G. M.; STECCA, J. P.; MUNARETTO, L. F.; FALLER, L. P.; CORREAA, H. L. Avaliação de Desempenho Organizacional: uma proposta de modelo para empresas do setor de móveis planejados. V Encontro de Estudos em Estratégia da ANPAD. Porto Alegre, 2011.

SANTOS, M. Por uma outra globalização: do pensamento único à consciência universal. Brasília: Record, 2008.

SANTOS, S. D. Práticas de Governança e Desempenho Financeiro em Cooperativas de Crédito. Dissertação (Mestrado em Controladoria e Contabilidade). Universidade de São Paulo, São Paulo, 2016.

SARUBBI, F. M.; DIAS, J. L. P. C.; CORREA, H. L. Sistemas de Mensuração e Avaliação de Desempenho Organizacional: estudo de casos no setor de revistas segmentadas. In: XIII Semead, set. 2010.

SAWILOWSKY, S. S.; BLAIR, R. C. A More Realistic Look at the Robustness and Type II Error Properties of the $t$ Test to Departures From Population Normality. Psychological Bulletin, v. 111, n. 2, p. 352-360, 1992.

SCHRÖEDER, C. S. (2005). Critérios e indicadores de desempenho para sistemas de treinamento corporativo virtual: um modelo para medir resultados. Dissertação (Mestrado) - Universidade Federal do Rio Grande do Sul, Escola de Administração, Programa de Pós Graduação em Administração, $214 \mathrm{f}$. 
SCHNEIDER, J. O. O Cooperativismo e a promoção do desenvolvimento sustentável. Extensão Rural, v.8, n.01, p.63-98. 2001.

SEGATTO-MENDES, A. P.; CARVALHO ROCHA, K. Contribuições da teoria de agência ao estudo dos processos de cooperação tecnológica universidadeempresa. Revista de Administração - RAUSP, vol. 40, núm. 2, abr/jun, 2005.

SEN, A. K. Desenvolvimento como liberdade. São Paulo: Companhia de Letras, 2000.

SERRA, F.; TORRES, M. C.; TORRES, A. P. Administração Estratégica. 4. ed. Florianópolis: Editora Insular, 2009

SESCOOP. Panorama do cooperativismo brasileiro - ano 2011. Brasilia: OCB, $2012 . \quad$ Disponível em: <http://www.ocb.org.br/gerenciador/ba/arquivos/panorama_do_cooperativismo_ brasileiro__2011.pdf>. Acesso em: 24 abr. 2016.

SICOOB. Apresentação. 2018. Disponível em: http://www.sicoob.com.br/osicoob/apresentacao. Acesso em: maio/2018.

SICREDI. Sobre o Sicredi. 2018. Disponível em: https://www.sicredi.com.br/html/conheca-o-sicredi/quemsomos/?utm_source=menu_topo\&utm_medium=topo_site\&utm_campaign=que m_somos. Acesso em: maio/2018.

SIEBERT, C. F.; SIEBERT, D. C. Data Analysis with Small Samples and Nonnormal Data: Nonparametrics and Other Strategies. Oxford University Press, 2017.

SIGMA. The Sigma Guidelines toolkit: Susteinability scorecard. 2003. Disponível em: HTTP://www.projectsigma.co.uk/. Acesso em 20 de maio de 2015.

SILVA FILHO, G. T. Avaliação de desempenho em cooperativas de crédito: uma aplicação do modelo de gestão econômica - GECON. Organizações Rurais e Agroindustriais, Lavras, v. 4, n. 1, 2002.

SILVA, J.P. Gestão e análise de risco de crédito. 2. ed. São Paulo: Atlas, 1998.

SILVA, S.S.; SOUZA, A.R.; LEITE, E.T. Conflito de Agência em Organizações Cooperativas: um Ensaio Teórico. Organizações Rurais \& Agroindustriais, Lavras, v. 13, n. 1, p. 63-76, 2011.

SINK, D.S. e TUTTLE, T.C. Planejamento e Medição para a Performance. Rio de Janeiro, Qualitymark Editora, 1993

SINGER, P. A recente ressurreição da economia solidária no Brasil. SANTOS, B. S. (org.) Produzir para viver: os caminhos da produção não capitalista. Rio de Janeiro: Civilização Brasileira, 2002. 
SISTEMA OCB. Agenda Institucional do Cooperativismo. Brasilia: OCB, 2015. Disponível em: <http://www.brasilcooperativo.coop.br/GERENCIADOR/ba/arquivos/agenda_ins titucional_do_cooperativismo_2015.pdf>. Acesso em: 25 abr. 2016.

SOARES, M. M.; VENTURA, E. C. F. Governança Cooperativa: as funções estratégicas e executivas em cooperativas de crédito no Brasil. In: V Encontro de Pesquisadores Latino-americanos de Cooperativismo, 2008, Ribeirão Preto. Anais... Ribeirão Preto: USP-RP, 2008. CD-ROM.

SOUSA, D. N.; PINHO, J. B.; AMODEO, N. B. P.; MILAGRES, C. S. F. A comunicação como ferramenta da educação cooperativista. Revista de Extensão e Estudos Rurais, v. 2, n. 1, 2014.

SPOSATI, A. Mapa da exclusão/inclusão social da cidade de São Paulo. São Paulo, EDUC, 1996, $141 \mathrm{p}$.

STEWART, T. A. Capital intelectual: a nova vantagem competitiva das empresas. 11. ed. Rio de Janeiro: Campus, 1998.

THORPE, R.; BEASLEY, T. The Characteristics of Performance Management Research. Implications and Challenges. International Journal of Productivity and Performance Management, v. 53, n. 4. P. 334-344, 2004.

UNITED NATIONS. About the International Year of Cooperatives. United Nations. 2012. Disponível em: <http://social.un.org/coopsyear/about-iyc.html>. Acesso em: 28 abr. 2016.

VASCONCELOS, A. F. Felicidade no Ambiente de Trabalho: exame e proposição de algumas variáveis críticas. Revista REAd, ed. 37 Vol. 10 No.1, 2004.

VERBO COOPERAR. Infográficos. [c2016]. Disponível em: <http://www.verbocooperar.com.br/index.php/infograficos/>. Acesso em: 25 abr. 2016.

VERGARA, S.C. Métodos de Pesquisa em Administração. $3^{a}$ Ed. São Paulo: Atlas, 2008.

VIEIRA, S. S. DA C. Avaliação de programas de educação continuada: análise da percepção do aluno e do seu modelo de decisão para escolha de programas de especialização para executivos no Brasil. ANOVA-Test.t, 2009.

VILELA, D. L.; NAGANO, M. S.; MERLO, E. M. Aplicação da Análise Envoltória de Dados em Cooperativas de Crédito Rural. RAC, 2a. Edição Especial 2007: 99120.

WARRACK, B. J., SINHA, M. N. e BAWDEN, G. A performance measurement framework for inspection effectiveness at the system level. Annual Quality Congress Proceedings. 2001. 
WESTLEY, G. D., BRANCH, B. (Org.). Safe money: building effective credit unions in Latin America. Washington: Inter-American Development Bank and World Council of Credit Unions, 2000.

WHITLARK, D. B.; SMITH, S. M. Using correspondence analysis to map relationships. Marketing Research, v. 13, n. 3, p. 22-27, out./2001.

WILLIAMSON, O. E. Corporate finance and corporate governance. Journal of Finance, v. 43, n. 3, July 1988.

WRIGHT, J. T. C.; GIOVINAZZO, R. A. Delphi - uma ferramenta de apoio ao planejamento prospectivo. Caderno de Pesquisas em administração, São Paulo, v. 01, $\mathrm{n}^{\circ} 12,2^{\circ}$ trim./2000.

YAMADA, C. Y.; BIALOSKORSKI NETO, S. Indicadores e Avaliação de Desempenho de Cooperativas de Crédito Rural. XVIII SIICUSP, São Paulo, 2010.

YENIYURT, S. A literature review and integrative performance measurement framework for multinational companies. Marketing Intelligence \& Planning. v. 21, n.3, 2003.

YOKOMIZO, C. A. Avaliação de Desempenho Organizacional: um Estudo Exploratório em Empresas Brasileiras de Desenvolvimento de Softwares. Dissertação (Mestrado em Administração). Faculdade de Economia, Administração e Contabilidade - Universidade de São Paulo. São Paulo, 2009.

ZYLBERSZTAJN, D. Quatro estratégias fundamentais para cooperativas agrícolas. In: BRAGA, M. J.; REIS, B. S. (Orgs.). Agronegócio cooperativo: reestruturação e estratégias. Viçosa, MG: UFV, 2002.

ZILBER, M. A.; FISCHMANN, A. A. Competitividade e a importância de indicadores de desempenho: utilização de um modelo de tendência. In: Encontro Da Associação Nacional Dos Programas De Pós-Graduação Em Administração. Anais.Salvador: ANPAD, 2002. 


\section{APÊNDICES}

APÊNDICE 1 - ROTEIRO DE VALIDAÇÃO DOS INDICADORES PARA O MODELO DE AVALIAÇÃO DE DESEMPENHO DE COOPERATIVAS DE CRÉDITO (METODOLOGIA DELPHI)

Essa pesquisa tem como objetivo validar as variáveis relevantes para a avaliação de desempenho de Cooperativas de Crédito.

1. Faça um breve resumo de qual sua experiência profissional com Cooperativas de Crédito.

2. Conforme sua opinião assinale com " $x$ " o grau de importância para cada um dos indicadores a seguir na avaliação de desempenho das Cooperativas de Crédito (sendo nível 1 o menor grau de importância e nível 5 o maior).

\begin{tabular}{|c|c|c|c|c|c|c|c|c|c|}
\hline $\begin{array}{l}\text { Tipo de } \\
\text { indicador }\end{array}$ & Indicador & Significado & $\begin{array}{l}\text { Não } \\
\text { é } \\
\text { impor- } \\
\text { tante }\end{array}$ & $\begin{array}{l}\text { Baixa } \\
\text { impor- } \\
\text { tância }\end{array}$ & $\begin{array}{l}\text { Um pouco } \\
\text { importante }\end{array}$ & $\begin{array}{l}\text { Neu- } \\
\text { tro }\end{array}$ & $\begin{array}{l}\text { Moderada- } \\
\text { mente } \\
\text { importante }\end{array}$ & $\begin{array}{l}\text { Muito } \\
\text { impor- } \\
\text { tante }\end{array}$ & $\begin{array}{l}\text { Extrema- } \\
\text { mente } \\
\text { importante }\end{array}$ \\
\hline \multicolumn{10}{|c|}{ FINANCEIRO } \\
\hline & $\begin{array}{l}\text { Crescimento das } \\
\text { Vendas }\end{array}$ & $\begin{array}{l}\text { Apura se o volume de vendas } \\
\text { de um período para o outro foi } \\
\text { maior ou menor }\end{array}$ & 1() & 2() & 3() & 4() & 5() & 6() & $7(\quad)$ \\
\hline & $\begin{array}{l}\text { Retorno sobre } \quad 0 \\
\text { Investimento }\end{array}$ & $\begin{array}{l}\text { Relação entre a quantidade de } \\
\text { dinheiro ganho em um } \\
\text { investimento e a quantidade de } \\
\text { dinheiro investido }\end{array}$ & 1() & 2() & 3() & 4() & 5() & 6() & 7() \\
\hline
\end{tabular}




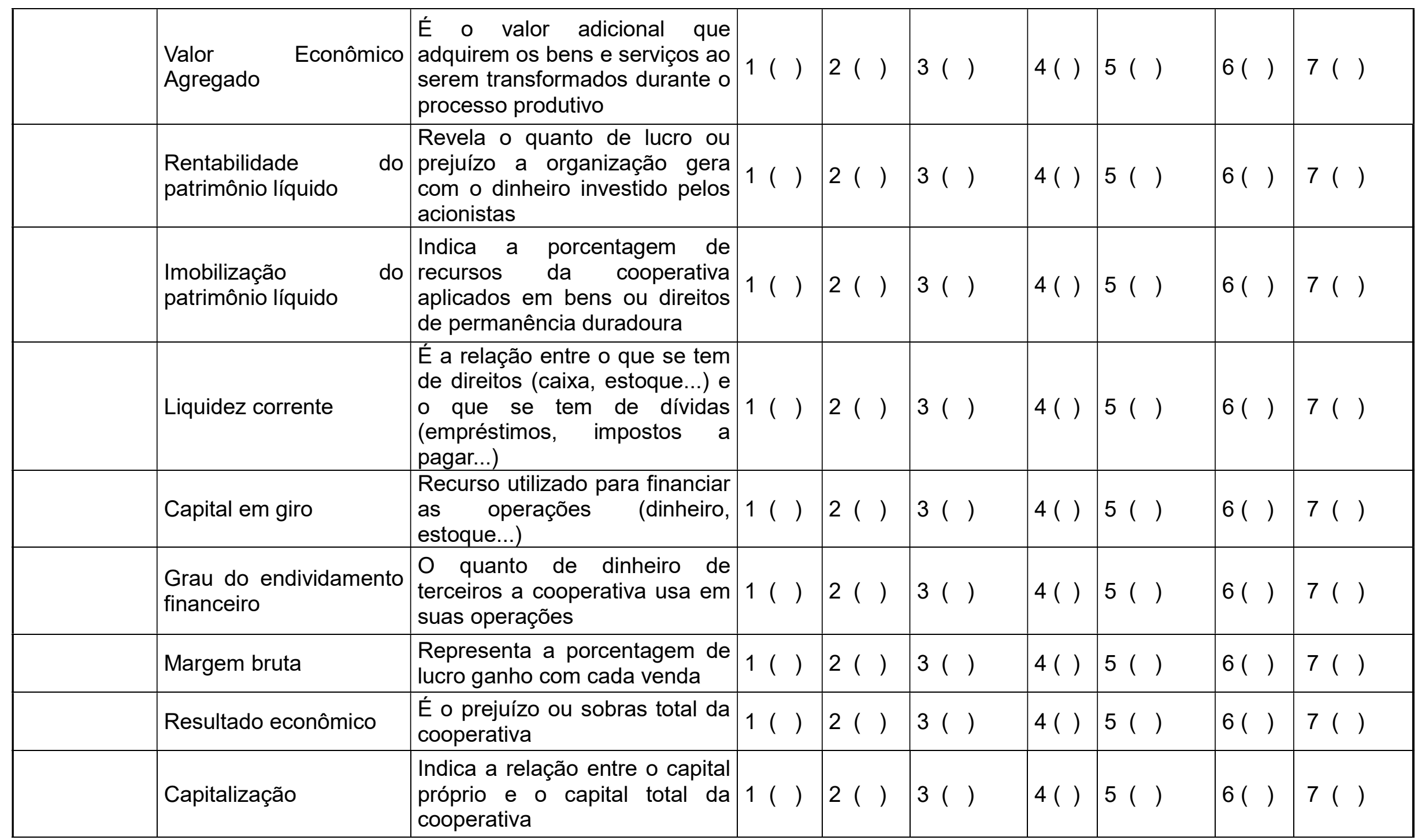




\begin{tabular}{|c|c|c|c|c|c|c|c|c|}
\hline Alavancagem & 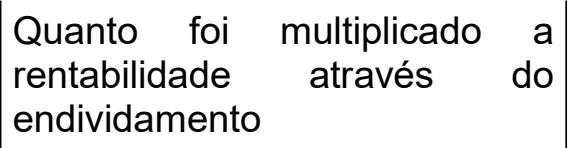 & 1() & 2() & 3() & 4() & 5() & 6() & 7() \\
\hline Cobertura voluntária & 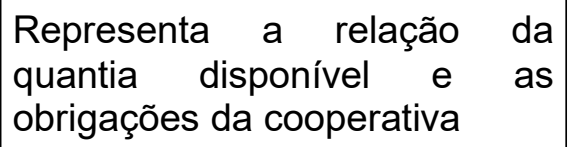 & 1() & 2() & 3() & 4() & 5() & $6(\quad)$ & 7() \\
\hline Volume de crédito & $\begin{array}{l}\text { Representa a relação entre o } \\
\text { número de operações de crédito } \\
\text { e o total de patrimônio líquido }\end{array}$ & $1(\quad)$ & 2() & 3() & 4() & 5() & $6(\quad)$ & 7() \\
\hline Geração de rendas & $\begin{array}{l}\text { Relação do quanto se gerou de } \\
\text { rendimento e a quantia utilizada } \\
\text { para isso }\end{array}$ & 1() & 2() & 3() & 4() & 5() & $6(\quad)$ & 7() \\
\hline $\begin{array}{l}\text { Crescimento aplicações } \\
\text { totais }\end{array}$ & $\begin{array}{l}\text { Comparação da quantia que foi } \\
\text { aplicada pela cooperativa no } \\
\text { período atual com o período } \\
\text { anterior }\end{array}$ & 1() & 2() & 3() & $4($ ) & 5() & 6() & 7() \\
\hline $\begin{array}{l}\text { Crescimento captações } \\
\text { totais }\end{array}$ & $\begin{array}{l}\text { Comparação da quantia que foi } \\
\text { captada pela cooperativa no } \\
\text { período atual com o período } \\
\text { anterior }\end{array}$ & 1() & 2() & 3() & 4() & 5() & 6() & 7() \\
\hline $\begin{array}{l}\text { Crescimento receita } \\
\text { operacional }\end{array}$ & $\begin{array}{l}\text { Se os ganhos foram maiores no } \\
\text { período atual que no período } \\
\text { anterior }\end{array}$ & 1() & 2() & 3() & 4() & 5() & $6(\quad)$ & 7() \\
\hline Equilíbrio do orçamento & $\begin{array}{l}\text { Se os ganhos foram maiores } \\
\text { que os gastos }\end{array}$ & $1(\quad)$ & 2() & 3() & 4() & 5() & $6(）$ & 7() \\
\hline $\begin{array}{l}\text { Independência } \\
\text { Financeira }\end{array}$ & $\begin{array}{l}\text { Medida composta pela } \\
\text { diferença entre os juros que } \\
\text { cobram por financiamentos e } \\
\text { juros pagos a depósitos }\end{array}$ & 1() & 2() & 3() & 4() & 5() & 6() & 7() \\
\hline
\end{tabular}




\begin{tabular}{|c|c|c|c|c|c|c|c|c|c|}
\hline & $\begin{array}{l}\text { Faturamento por } \\
\text { Funcionário }\end{array}$ & \begin{tabular}{|l|} 
É o faturamento dividido pelo \\
total de funcionários
\end{tabular} & 1() & 2() & 3() & 4() & 5() & 6() & 7() \\
\hline & $\begin{array}{l}\text { Nível de } \\
\text { inadimplemento (NID) }\end{array}$ & $\begin{array}{l}\text { Demonstra o grau de risco das } \\
\text { operações de crédito }\end{array}$ & 1() & 2() & 3() & 4() & 5() & $6(）$ & 7() \\
\hline & $\begin{array}{l}\text { Receitas dos créditos } \\
\text { (REC) }\end{array}$ & $\begin{array}{l}\text { Demonstra } \quad \text { o r retorno } \\
\text { proporcionado pelas operações } \\
\text { de crédito }\end{array}$ & $1(\quad)$ & 2() & 3() & 4() & 5() & 6() & 7() \\
\hline \multicolumn{10}{|l|}{ ASSOCIADO } \\
\hline & \begin{tabular}{|l|}
$\begin{array}{l}\text { Retenção } \\
\text { cooperantes }\end{array}$ \\
\end{tabular} & $\begin{array}{l}\text { Número de associados atual } \\
\text { subtraído pelo número anterior } \\
\text { de } \\
\text { cooperantes }\end{array}$ & $1(\quad)$ & 2() & 3() & 4() & 5() & $6(）$ & 7() \\
\hline & $\begin{array}{l}\text { Satisfação } \\
\text { cooperantes }\end{array}$ & 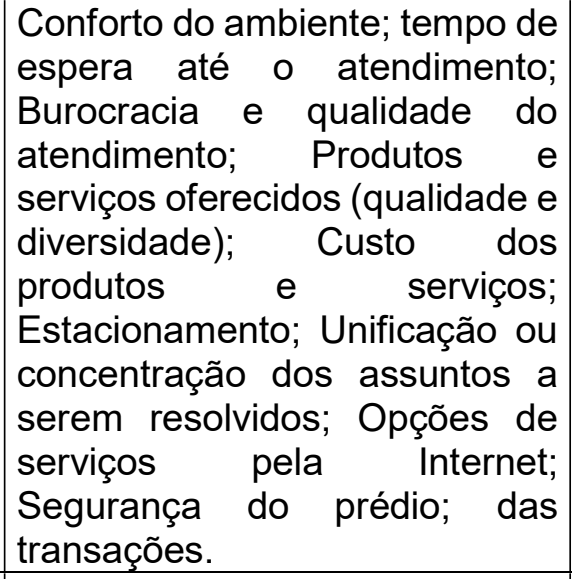 & $1(\quad)$ & 2() & 3() & 4() & 5() & $6(\quad)$ & 7() \\
\hline & \begin{tabular}{|lr} 
Associados & em \\
Assembleia & Geral \\
Ordinária (AGO) & \\
\end{tabular} & $\begin{array}{l}\text { Número de associados } \\
\text { participantes das AGO }\end{array}$ & 1() & $2(\quad)$ & 3() & 4() & $5(）$ & $6(）$ & 7() \\
\hline & $\begin{array}{l}\text { Número Associados } \\
\text { Ativos }\end{array}$ & $\begin{array}{l}\text { Número total de cooperados } \\
\text { que utilizam os serviços da } \\
\text { cooperativa }\end{array}$ & 1() & 2() & 3() & 4() & 5() & 6() & 7() \\
\hline
\end{tabular}




\begin{tabular}{|c|c|c|c|c|c|c|c|c|c|}
\hline & $\begin{array}{l}\text { Sobras ou faturamento } \\
\text { por cooperado }\end{array}$ & $\begin{array}{l}\text { Valor das sobras distribuídas } \\
\text { dividido pelo número de } \\
\text { associados }\end{array}$ & 1() & 2() & 3() & 4() & 5() & $6(\quad)$ & 7() \\
\hline & $\begin{array}{l}\text { Capital integralizado por } \\
\text { associado }\end{array}$ & $\begin{array}{l}\text { Valor médio integralizado por } \\
\text { cada associado }\end{array}$ & 1() & 2() & 3() & 4() & 5() & $6(）$ & 7() \\
\hline \multicolumn{10}{|c|}{ PROCESSOS INTERNOS } \\
\hline & $\begin{array}{l}\text { Lucratividade } \quad \text { por } \\
\text { segmento-alvo }\end{array}$ & $\begin{array}{l}\text { Percentual de sobras de cada } \\
\text { segmento de serviço oferecido } \\
\text { pela cooperativa }\end{array}$ & 1() & 2() & 3() & 4() & 5() & $6(\quad)$ & 7() \\
\hline & \begin{tabular}{|lr} 
Percentual & de \\
transações & realizadas \\
através & dos \\
diversos canais & (caixas \\
eletrônicos, & caixas \\
convencionais, & ou \\
auxiliadas & por \\
computador) &
\end{tabular} & 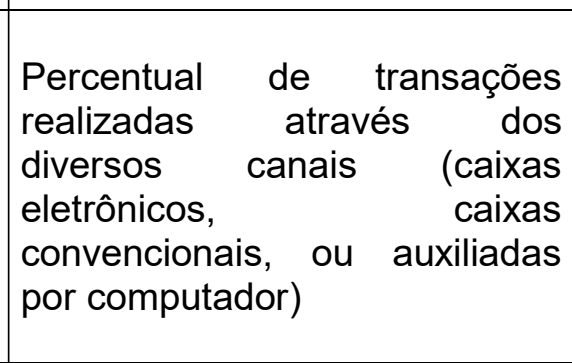 & $1(\quad)$ & 2() & 3() & 4() & 5() & 6() & 7() \\
\hline & $\begin{array}{ll}\begin{array}{l}\text { Projetos } \\
\text { desenvolvidos }\end{array} & \text { sociais } \\
\end{array}$ & $\begin{array}{l}\text { Número de projetos sociais } \\
\text { desenvolvidos }\end{array}$ & 1() & 2() & 3() & 4() & 5() & $6(）$ & 7() \\
\hline & $\begin{array}{l}\text { Percentual de trabalho } \\
\text { extraordinário }\end{array}$ & $\begin{array}{l}\text { Quantidade de horas extras } \\
\text { realizadas }\end{array}$ & 1() & 2() & 3() & 4() & 5() & 6() & 7() \\
\hline & $\begin{array}{|lr|}\text { Número } & \text { de } \\
\text { consumidores por ponto } \\
\text { de } & \text { atendimento } \\
\text { próprio } & \\
\end{array}$ & $\begin{array}{l}\text { Número de consumidores de } \\
\text { dividido pelo número de pontos } \\
\text { de } \\
\text { atendimento }\end{array}$ & $1(\quad)$ & 2() & 3() & 4() & 5() & $6(）$ & 7() \\
\hline & $\begin{array}{l}\text { Desenvolvimento } \\
\text { sustentável }\end{array}$ & $\begin{array}{l}\text { Atenção ao capital humano } \\
\text { envolvido, à sustentabilidade } \\
\text { econômica do negócio e } \\
\text { preservação do meio ambiente. }\end{array}$ & $1(\quad)$ & 2() & 3() & 4() & 5() & 6() & 7() \\
\hline
\end{tabular}




\begin{tabular}{|c|c|c|c|c|c|c|c|c|}
\hline \begin{tabular}{|l} 
Volume de \\
oferecidos \\
demanda satisfatória
\end{tabular} & 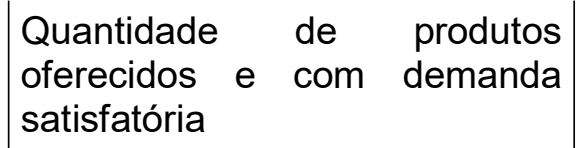 & 1() & 2() & 3() & $4($ ) & 5() & $6(）$ & 7() \\
\hline $\begin{array}{l}\text { Quantidade } \quad \text { de } \\
\text { estagiários }\end{array}$ & Número de estagiários & 1() & 2() & 3() & 4() & 5() & $6(）$ & 7() \\
\hline \multicolumn{9}{|l|}{ APRENDIZADO e CRESCIMENTO } \\
\hline $\begin{array}{|lr|}\text { Melhorias } & \text { das } \\
\text { capacidades } & \text { dos } \\
\text { funcionários } & \\
\text { (conhecimento do } & \text { dolaborador para dar as } \\
\text { informações corretas) } \\
\end{array}$ & $\begin{array}{l}\text { Número de cursos e eventos de } \\
\text { capacitação aplicados aos } \\
\text { funcionários }\end{array}$ & 1() & 2() & 3() & 4() & $5(）$ & $6(\quad)$ & 7() \\
\hline Nível de rotatividade & $\begin{array}{l}\text { Número de desligamentos de } \\
\text { funcionários da cooperativa }\end{array}$ & 1() & 2() & 3() & 4() & 5() & $6(\quad)$ & 7() \\
\hline \begin{tabular}{l|l} 
Motivação para agir no \\
melhor interesse da \\
cooperativa
\end{tabular} & Pesquisas motivacionais & 1() & 2() & 3() & 4() & 5() & $6(）$ & 7() \\
\hline \multicolumn{9}{|l|}{ PESSOAS E INOVAÇÃO } \\
\hline $\begin{array}{l}\text { Idade média dos } \\
\text { colaboradores }\end{array}$ & $\begin{array}{|ll|}\begin{array}{l}\text { Somatório das idades dos } \\
\text { colaboradores dividido pelo } \\
\text { número de colaboradores }\end{array} \\
\end{array}$ & 1() & 2() & 3() & 4() & 5() & $6(）$ & 7() \\
\hline $\begin{array}{l}\text { Profissionalização da } \\
\text { administração }\end{array}$ & \begin{tabular}{|lccc|} 
Número & de & \multicolumn{2}{c|}{ treinamentos, } \\
cursos e eventos & que os \\
funcionários & e & gestores \\
participam & & \\
\end{tabular} & $1(\quad)$ & 2() & 3() & 4() & 5() & $6(）$ & 7() \\
\hline $\begin{array}{l}\text { Melhoria constante da } \\
\text { estrutura }\end{array}$ & $\begin{array}{l}\text { Melhorias em sistemas } \\
\text { informação, concepção } \\
\text { novos produtos e serviços }\end{array}$ & 1() & 2() & 3() & 4() & 5() & $6(）$ & 7() \\
\hline
\end{tabular}




\begin{tabular}{|c|c|c|c|c|c|c|c|c|}
\hline $\begin{array}{l}\text { Nível de satisfação dos } \\
\text { colaboradores }\end{array}$ & $\begin{array}{l}\text { Pesquisa de satisfação com os } \\
\text { funcionários }\end{array}$ & 1() & 2() & 3() & 4() & 5() & $6(）$ & 7() \\
\hline \begin{tabular}{|lr} 
Percentual & de \\
colaboradores & com \\
cursos & de \\
especialização, & \\
mestrado e doutorado \\
\end{tabular} & $\begin{array}{l}\text { Quantidade de especialistas, } \\
\text { mestres e doutores dividida pelo } \\
\text { total de funcionários } \times 100\end{array}$ & 1() & 2() & 3() & 4() & 5() & 6() & 7() \\
\hline $\begin{array}{l}\text { Número de acidentes de } \\
\text { trabalho }\end{array}$ & $\begin{array}{l}\text { Somatório dos acidentes de } \\
\text { trabalho no período }\end{array}$ & 1() & 2() & 3() & 4() & 5() & 6() & 7() \\
\hline
\end{tabular}

3. Descreva, conforme sua experiência, quais outros indicadores você julga serem importantes para a avaliação de desempenho das Cooperativas de Crédito. 
APÊNDICE 2 - ROTEIRO DE VALIDAÇÃO DOS INDICADORES PARA O MODELO DE AVALIAÇÃO DE DESEMPENHO DE COOPERATIVAS DE CRÉDITO (VALIDADE DE FACE E CONTEÚDO)

Prezado, a seguir temos uma lista de indicadores de avaliação de desempenho de Cooperativas de Crédito. Peço que apreciem e posteriormente respondam a ficha de avaliação anexa.

\begin{tabular}{|c|c|}
\hline Indicador & Descrição \\
\hline \multicolumn{2}{|l|}{ FINANCEIRO } \\
\hline CRESCIMENTO DAS VENDAS & Apura se o volume de vendas de um período para o outro foi maior ou menor \\
\hline RETORNO SOBRE O INVESTIMENTO & $\begin{array}{l}\text { Relação entre a quantidade de dinheiro ganho em um investimento e a quantidade de dinheiro } \\
\text { investido }\end{array}$ \\
\hline RENTABILIDADE DO PATRIMÔNIO LÍQUIDO & $\begin{array}{c}\text { Revela o quanto de lucro ou prejuízo a organização gera com o dinheiro investido pelos } \\
\text { acionistas }\end{array}$ \\
\hline CAPITAL EM GIRO & Recurso utilizado para financiar as operações (dinheiro, estoque...) \\
\hline GRAU DO ENDIVIDAMENTO FINANCEIRO & O quanto de dinheiro de terceiros a cooperativa usa em suas operações \\
\hline MARGEM BRUTA & Representa a porcentagem de lucro ganho com cada venda \\
\hline RESULTADO ECONÔMICO & É o prejuízo ou sobras total da cooperativa \\
\hline CAPITALIZAÇÃO & Indica a relação entre o capital próprio e o capital total da cooperativa \\
\hline GERAÇÃO DE RENDAS & Relação do quanto se gerou de rendimento e a quantia utilizada para isso \\
\hline CRESCIMENTO APLICAÇÕES TOTAIS & $\begin{array}{l}\text { Comparação da quantia que foi aplicada pela cooperativa no período atual com o período } \\
\text { anterior }\end{array}$ \\
\hline CRESCIMENTO CAPTAÇÕES TOTAIS & Comparação da quantia que foi captada pela cooperativa no período atual com o período anterior \\
\hline EQUILÍBRIO DO ORÇAMENTO & Se os ganhos foram maiores que os gastos \\
\hline NÍVEL DE INADIMPLEMENTO (NID) & Demonstra o grau de risco das operações de crédito \\
\hline \multicolumn{2}{|l|}{ ASSOCIADOS } \\
\hline RETENÇÃO DE COOPERANTES & Número de associados atual subtraído pelo número anterior de cooperantes \\
\hline
\end{tabular}




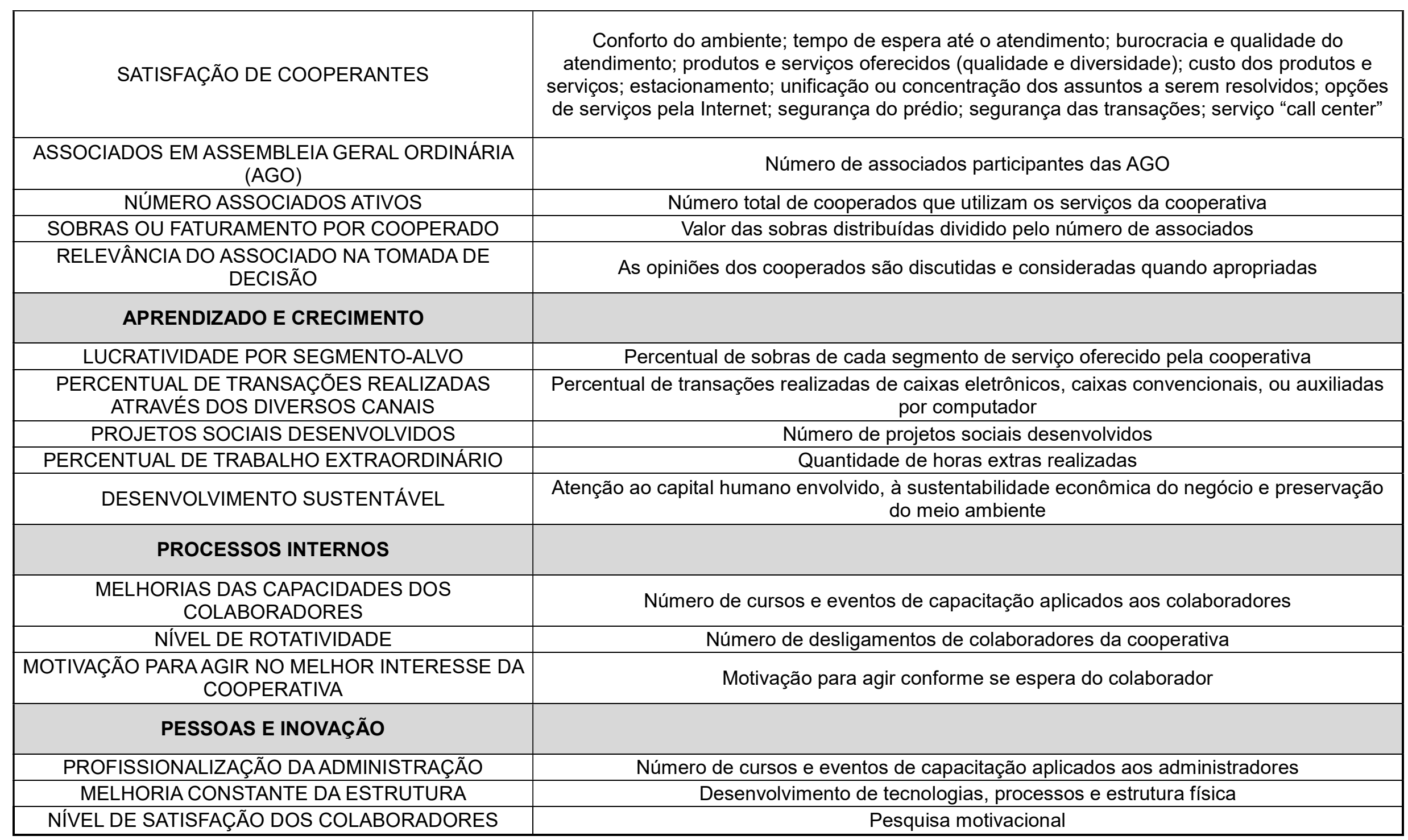


FICHA DE AVALIAÇÃO DE FACE E CONTEÚDO DO INSTRUMENTO DE PESQUISA

Prezado,

Após a leitura do Questionário de Pesquisa, assinale abaixo a alternativa que demonstra sua percepção em relação ao questionário e justifique as assertivas se achar necessário.

Agradeço a contribuição e estou à disposição para quaisquer esclarecimentos.

Atenciosamente,

Elizabeth Moçato Pimentel

Doutoranda FEA/USP

(47) 99131-3101/elizabeth.mocato@usp.br

1- Tempo utilizado para responder o instrumento de pesquisa: minutos.

2- O questionário apresentou dificuldade de leitura: ( ) sim ( ) não Justificativa:

3- As questões foram compreendidas: ( ) sim ( ) não Justificativa:

4- Apresentação adequada do questionário: ( ) sim ( ) não Justificativa:

5- Existe presença de erros tipográficos: ( ) sim ( ) não Justificativa:

6- A fonte da leitura do questionário é adequada: ( ) sim ( ) não Justificativa:

7- Clareza das questões com suas respectivas opções de respostas:

( ) $\operatorname{sim}$ ( ) não Justificativa:

8- Os conceitos se aplicam adequadamente a avaliação de desempenho para cooperativas de crédito? ( ) sim ( ) não Justificativa:

9 - Você sugere a inclusão ou exclusão de algum indicador? ( ) $\operatorname{sim}($ ) não Qual:

10 - Há repetição de indicadores e demais conteúdos? （） sim （ ） não Quais:

11 -Avaliação final do questionário:

( ) ótimo ( ) bom ( ) regular ( ) irregular

12 - Sugestões e críticas do questionário de pesquisa: 


\section{APÊNDICE 3 - QUESTIONÁRIO COOPERADOS}

Esse questionário faz parte da coleta de dados da Tese de Doutorado de Elizabeth Moçato Pimentel, da Universidade de São Paulo (USP), e pretende conhecer qual o grau de importância os associados de cooperativas de crédito atribuem para determinados indicadores de desempenho de cooperativas de crédito.

“Indicadores de desempenho são medidas usadas para acompanhar, controlar e comunicar os resultados de atividades da cooperativa".

A seguir temos algumas perguntas a respeito do seu perfil. E após, uma lista de indicadores de desempenho de cooperativas de crédito para você avaliar.

\section{Traçando o perfil do cooperado:}

1- Sua idade:

2- Sua conta é:
( ) Pessoa física
( ) Pessoa jurídica

3- Escolaridade:
( ) ENSINO FUNDAMENTAL (1 $\left.{ }^{\circ} \mathrm{GRAU}\right)$ INCOMPLETO
( ) ENSINO FUNDAMENTAL (1 $\left.{ }^{\circ} \mathrm{GRAU}\right)$ COMPLETO
( ) ENSINO MÉDIO (2० GRAU) INCOMPLETO
( ) ENSINO MÉDIO (2० GRAU) COMPLETO 
（ ） SUPERIOR INCOMPLETO

( ) SUPERIOR COMPLETO

( ) ESPECIALIZAÇÃO

( ) MESTRADO OU DOUTORADO

4- Renda familiar:
( ) ATÉ R \$954,00
( ) DE R\$ 954,00 A,R \$ 1.908,00
( ) DE R\$1908,00 A R \$ 3.816,00
( ) DE R\$ 3.816,00 A R $\$ 5.724,00$
（） DE R\$ 5.724,00 A R\$ 7.632,00
( ) MAIS DE R\$ 7.632,00

5- Há quanto tempo é associado dessa cooperativa:

ANO (S) E MÊSES

6- Já participou de quantas Assembleias:

7- Serviços que consome na cooperativa (pode marcar mais de um) :
( ) CÂMBIO
( ) CARTÕES
( ) CERTIFICADOS DIGITAIS 

( ) CONTA-CORRENTE
( ) CONSÓRCIOS
( ) EMPRÉSTIMOS
( ) INVESTIMENTOS (POUPANÇA E OUTROS)
( ) PAGAMENTOS
( ) PREVIDÊNCIA
( ) RECEBIMENTOS
( ) SEGUROS
( ) MÁQUINA DE CARTÕES

8- Você já trabalhou ou trabalha em cooperativa de crédito?
( ) SIM
( ) NÃO

9- Por qual razão se associou a uma cooperativa de crédito?

Considerando sua visão, qual o grau de importância você daria para cada um dos indicadores abaixo, se você precisasse avaliar o desempenho de uma cooperativa de crédito. 


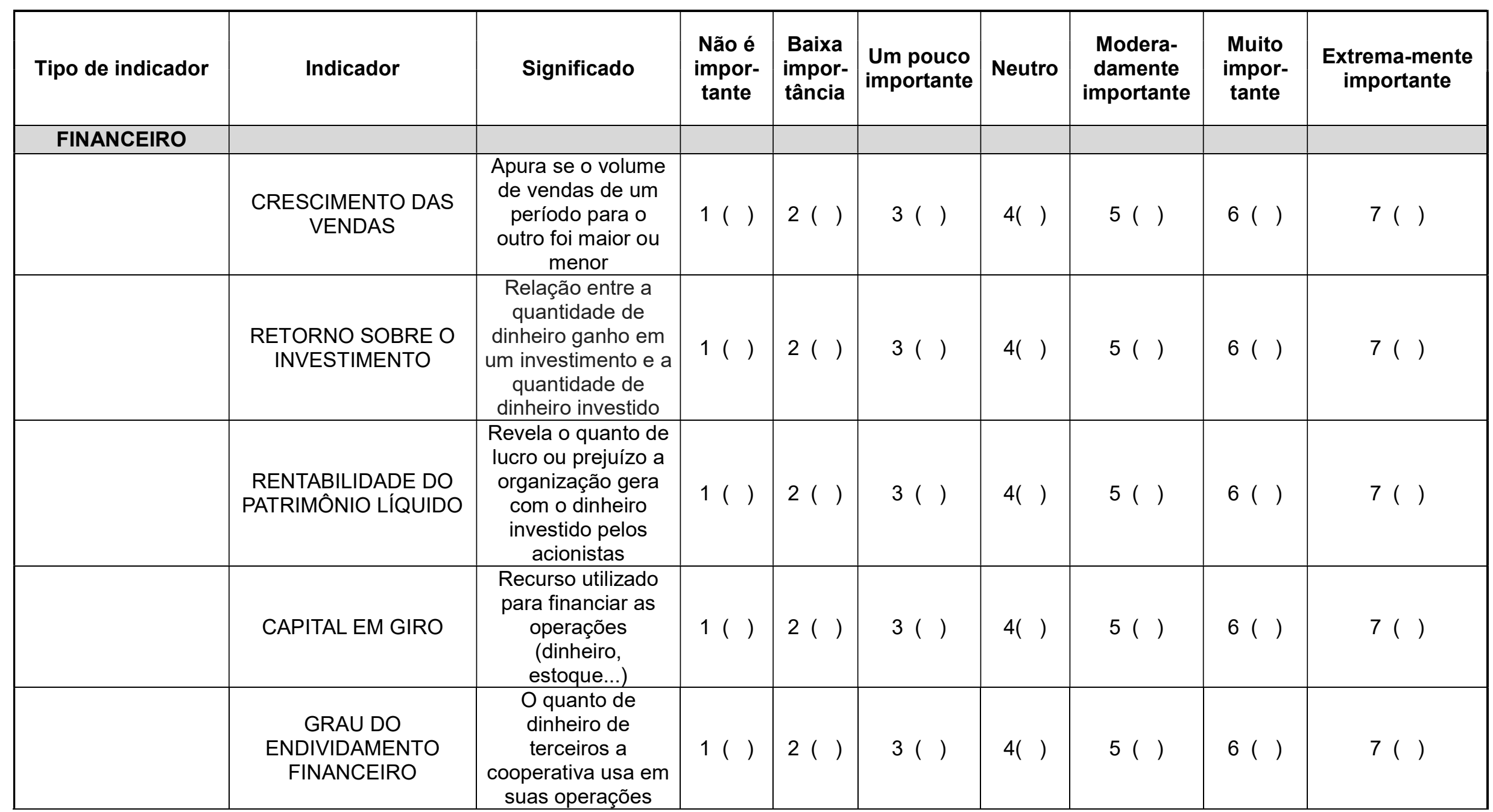




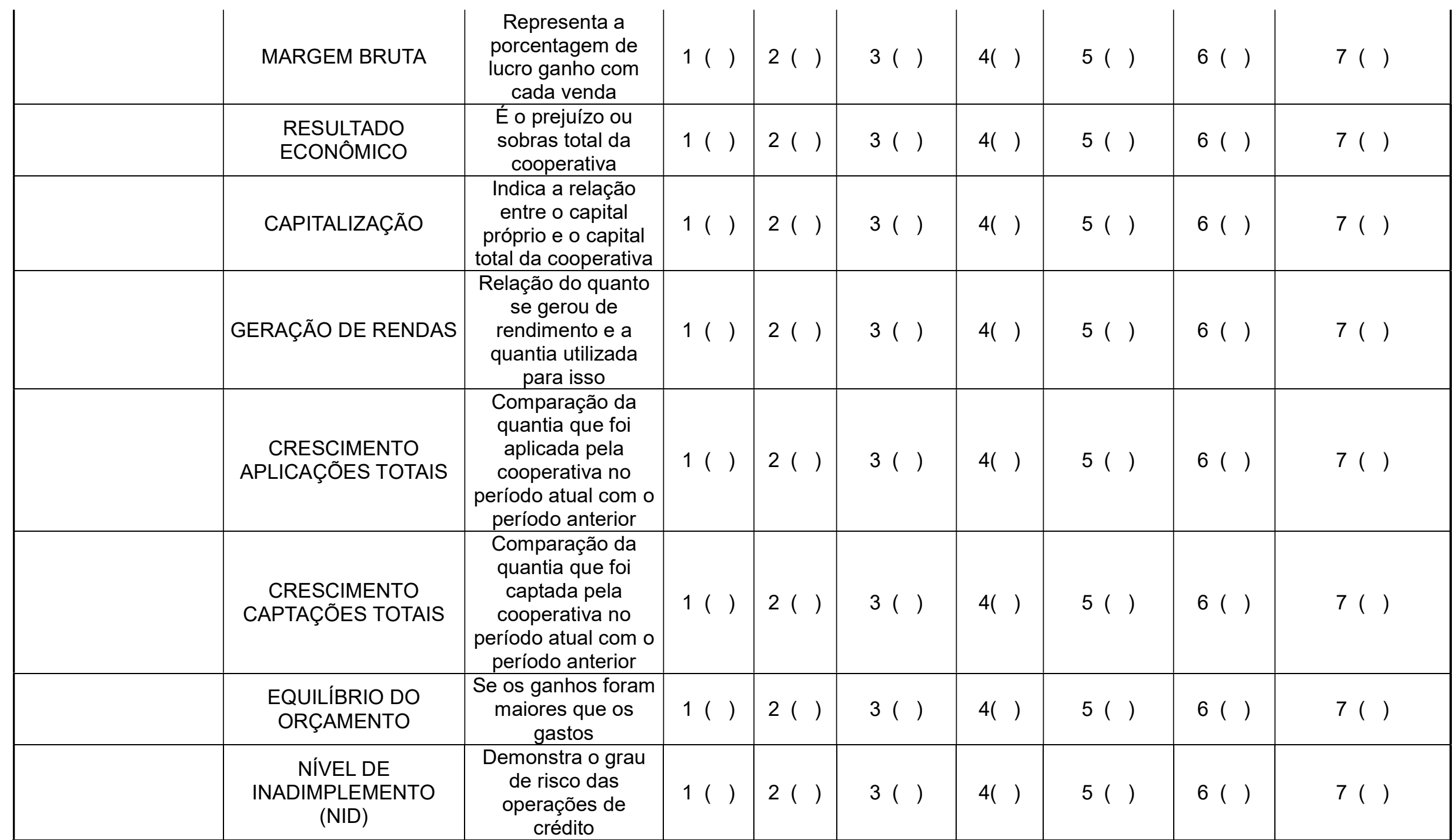




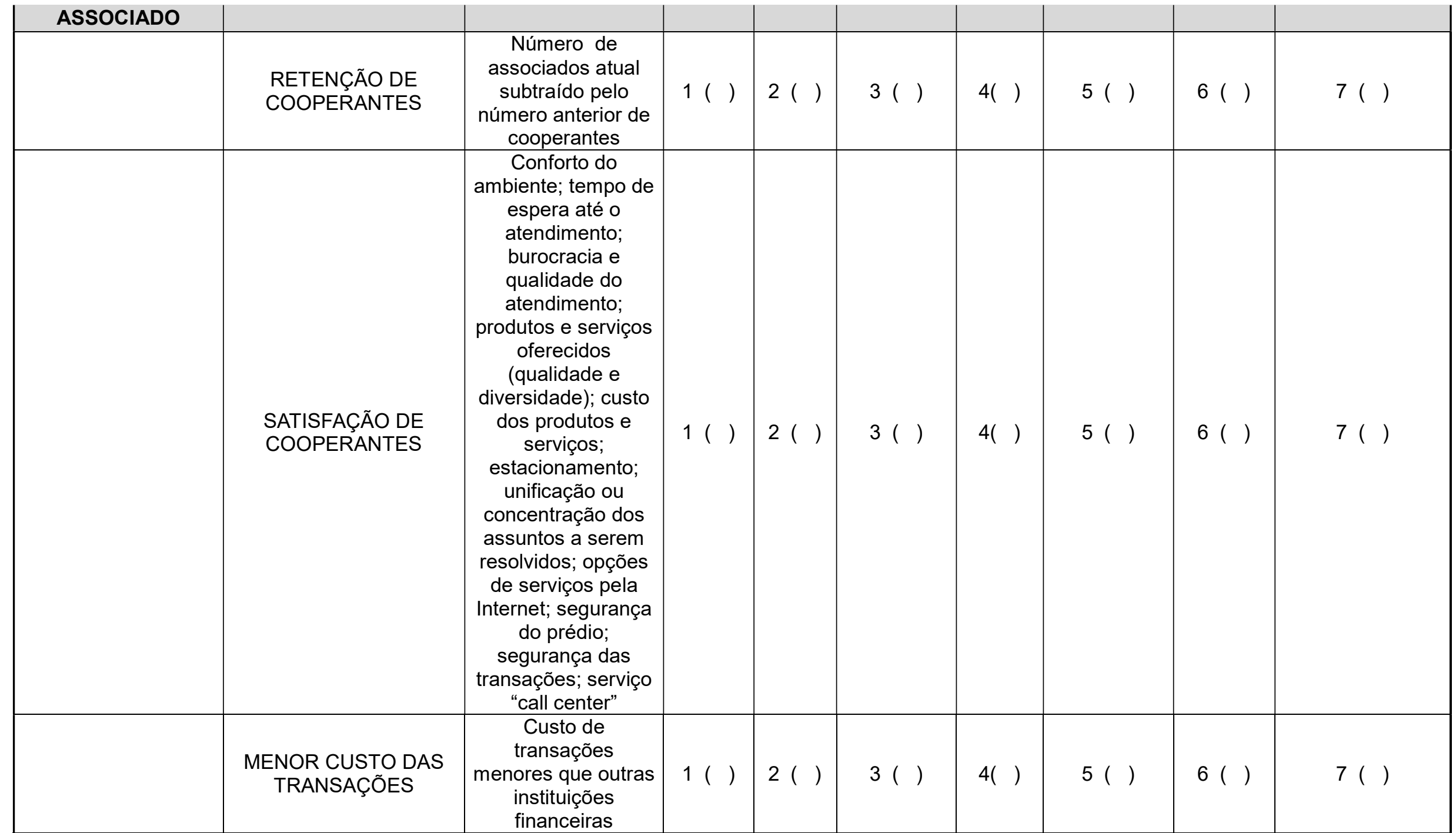




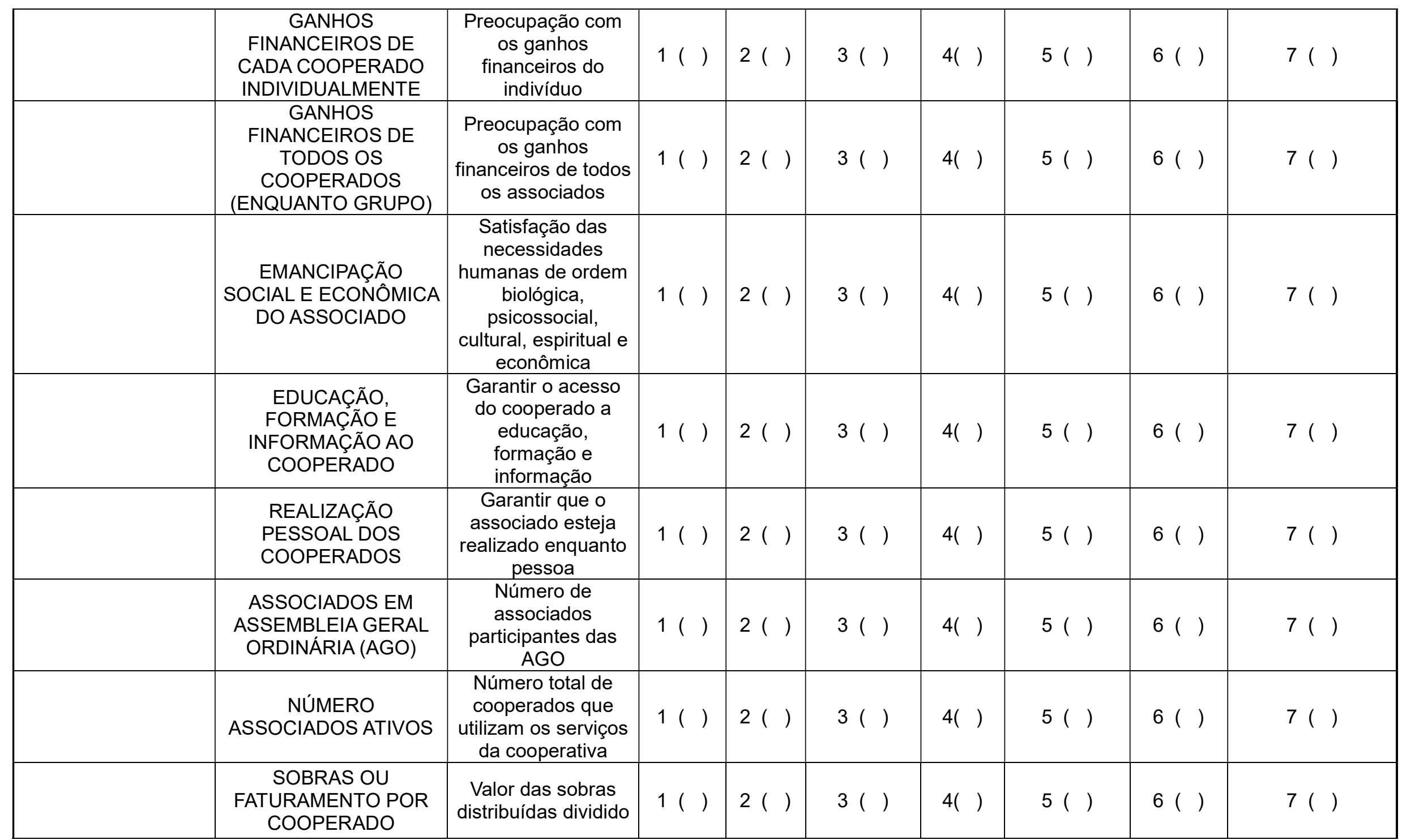




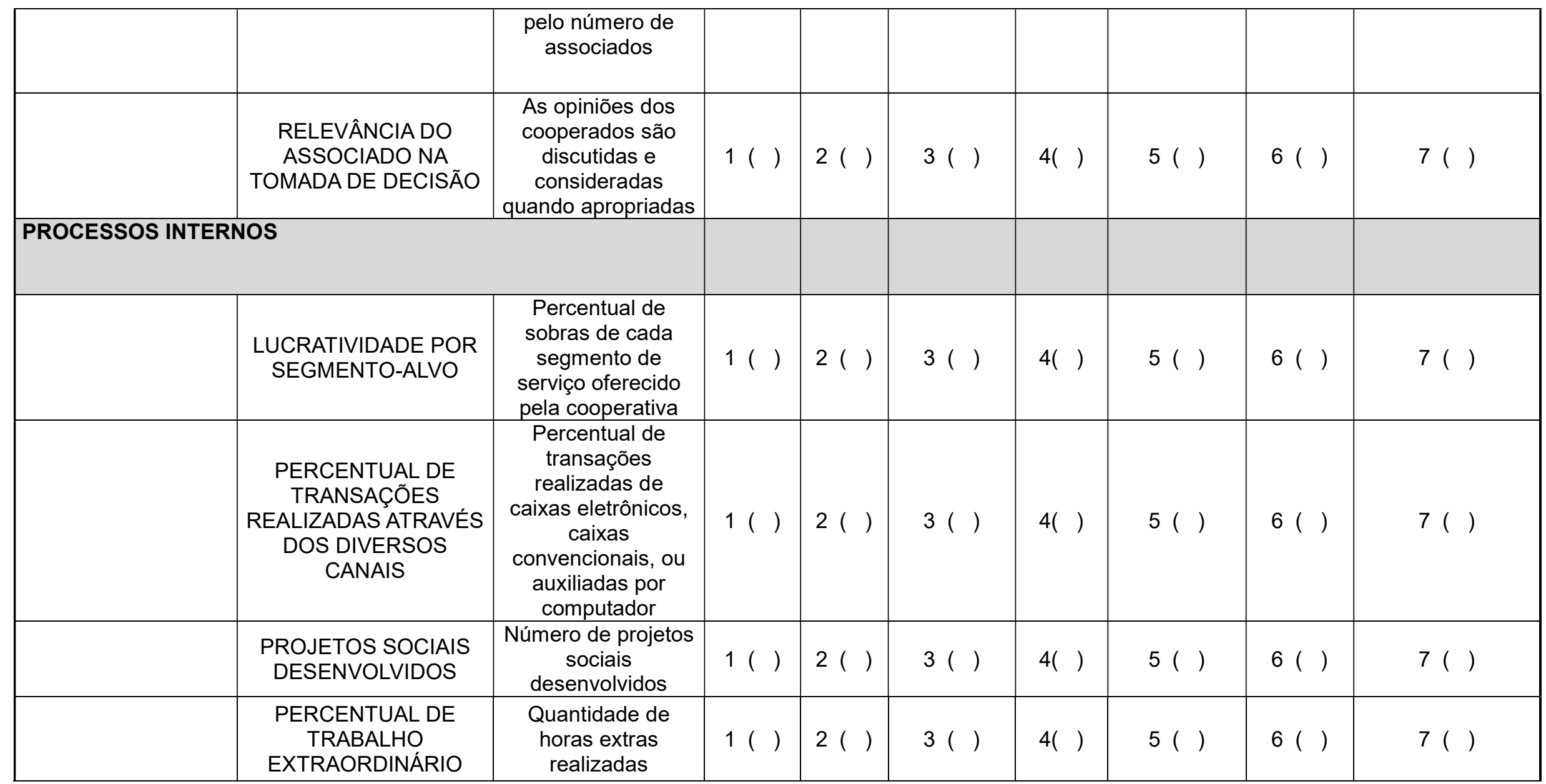




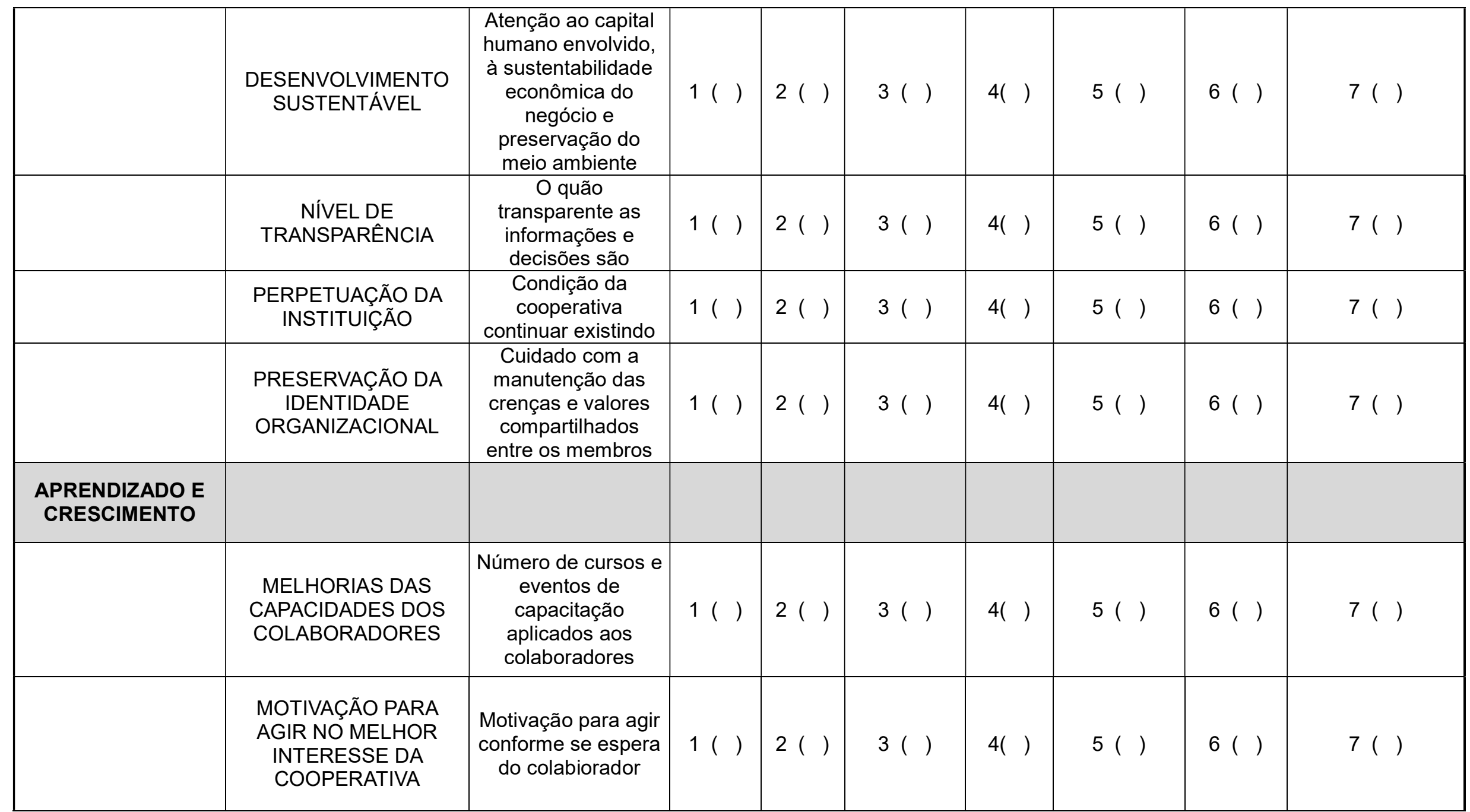




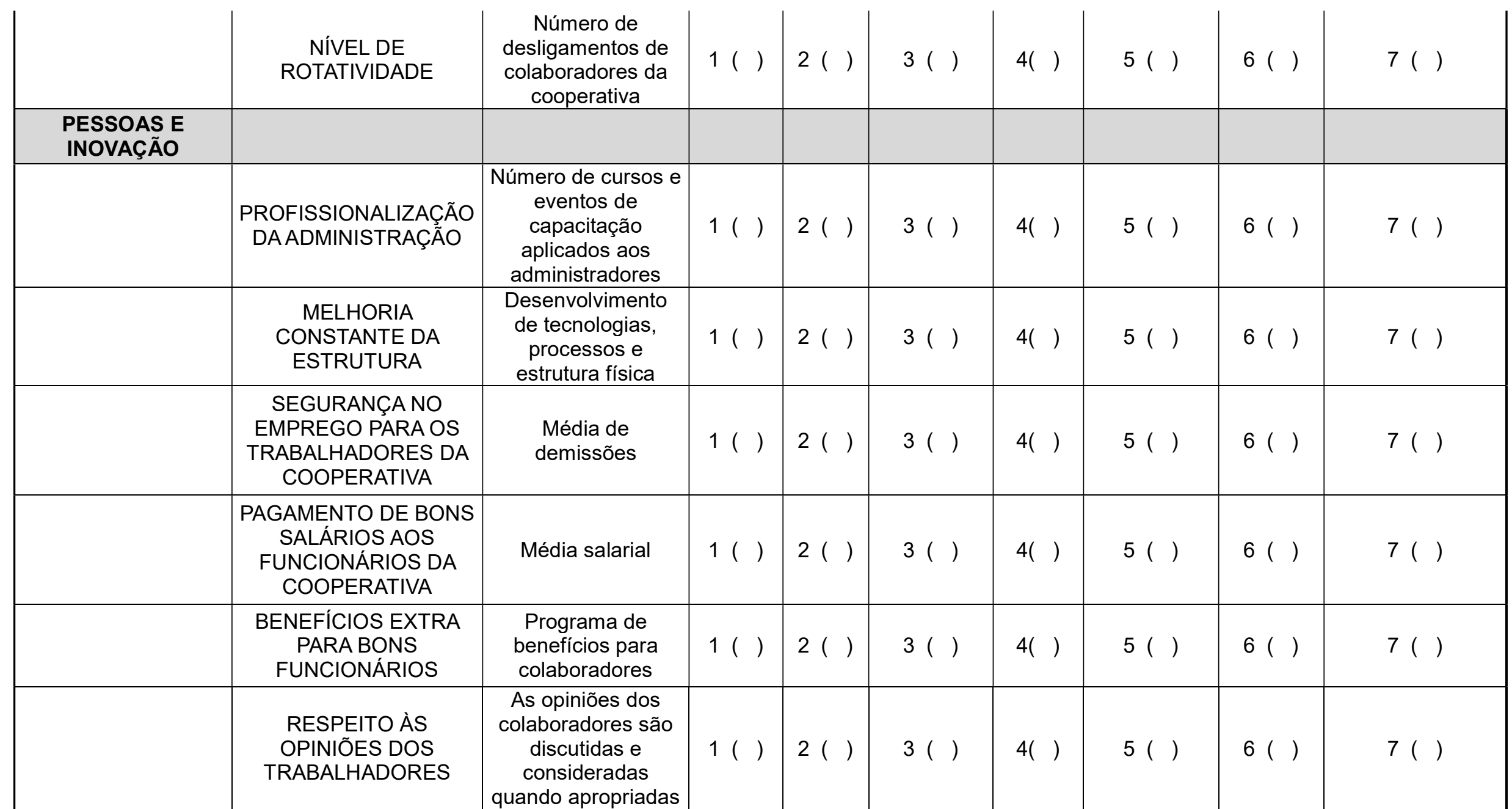




\begin{tabular}{|c|c|c|c|c|c|c|c|c|c|}
\hline & $\begin{array}{l}\text { AMBIENTE ÉTICO E } \\
\text { QUE VALORIZA O } \\
\text { CAPITAL HUMANO }\end{array}$ & $\begin{array}{l}\text { Ações em } \\
\text { conformidade com } \\
\text { princípios morais e } \\
\text { respeitosas com o } \\
\text { colaborador }\end{array}$ & 1() & 2() & 3() & $4(\quad)$ & 5() & 6() & 7() \\
\hline \multicolumn{10}{|l|}{$\begin{array}{c}\text { PRINCÍPIOS } \\
\text { COOPERATIVISTAS }\end{array}$} \\
\hline & $\begin{array}{l}\text { DEMOCRACIAE } \\
\text { IGUALDADE }\end{array}$ & $\begin{array}{l}\text { Direito a voto de } \\
\text { mesmo peso para } \\
\text { todos os } \\
\text { cooperados }\end{array}$ & 1() & 2() & 3() & $4(\quad)$ & 5() & 6() & 7() \\
\hline & SOLIDARIEDADE & $\begin{array}{c}\text { Compromisso pelo } \\
\text { qual as pessoas se } \\
\text { obrigam umas às } \\
\text { outras e cada uma } \\
\text { delas a todas. }\end{array}$ & 1() & 2() & 3() & $4(\quad)$ & 5() & 6() & 7() \\
\hline & $\begin{array}{l}\text { AUTONOMIAE } \\
\text { INDEPENDÊNCIA }\end{array}$ & $\begin{array}{l}\text { Preocupação com a } \\
\text { autonomia e } \\
\text { independência do } \\
\text { associado }\end{array}$ & 1() & 2() & 3() & $4(\quad)$ & 5() & 6() & 7() \\
\hline & $\begin{array}{l}\text { ADESÃO LIVRE E } \\
\text { VOLUNTÁRIA }\end{array}$ & $\begin{array}{l}\text { O acesso é livre a } \\
\text { quem queira } \\
\text { cooperar }\end{array}$ & 1() & 2() & 3() & 4() & 5() & 6() & 7() \\
\hline
\end{tabular}




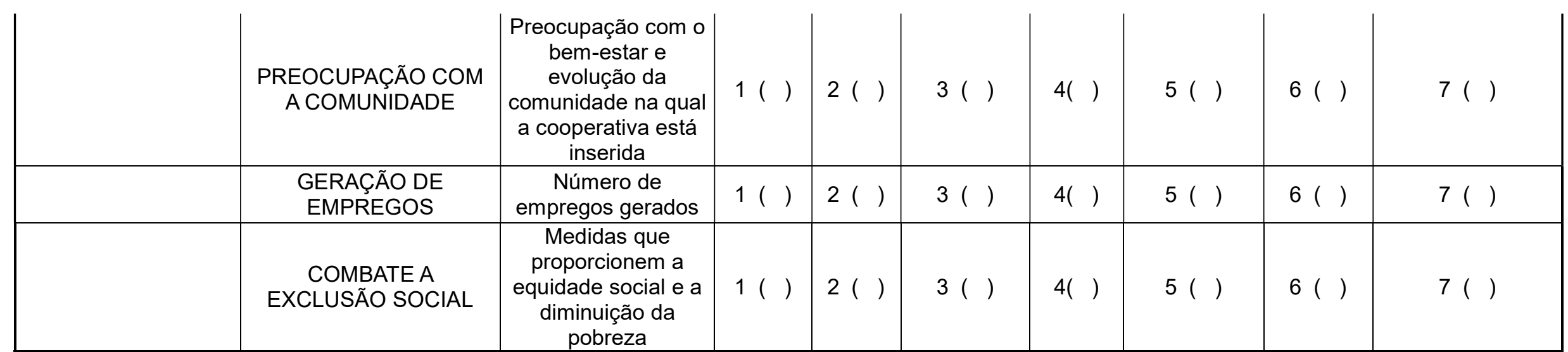




\section{APÊNDICE 4 - QUESTIONÁRIO GERENTES}

Esse questionário faz parte da coleta de dados da Tese de Doutorado de Elizabeth Moçato Pimentel, da Universidade de São Paulo (USP), e pretende conhecer qual o grau de importância os Gerentes de cooperativas de crédito atribuem para determinados indicadores de desempenho.

“Indicadores de desempenho são medidas usadas para acompanhar, controlar e comunicar os resultados de atividades da cooperativa".

A seguir temos algumas perguntas a respeito do seu perfil. E após, uma lista de indicadores de desempenho de cooperativas de crédito.

Traçando o perfil do:

1- A qual gerencia pertence:
( ) Pessoa Física
( ) Geral
( ) Pessoa Jurídica

2- Sua idade: 
3- Escolaridade:

( ) ENSINO FUNDAMENTAL (1 $\left.{ }^{\circ} \mathrm{GRAU}\right)$ INCOMPLETO

( ) ENSINO FUNDAMENTAL (10 GRAU) COMPLETO

( ) ENSINO MÉDIO (2० GRAU) INCOMPLETO

( ) ENSINO MÉDIO (2० GRAU) COMPLETO

( ) SUPERIOR INCOMPLETO

( ) SUPERIOR COMPLETO

( ) ESPECIALIZAÇÃO

( ) MESTRADO OU DOUTORADO

4- É gerente a quanto tempo: anos e meses.

5- Vejo que meu cargo tem como principal objetivo assegurar que:

Considerando sua visão, qual o grau de importância você daria para cada um dos indicadores abaixo, se você precisasse avaliar o desempenho de uma cooperativa de crédito. 


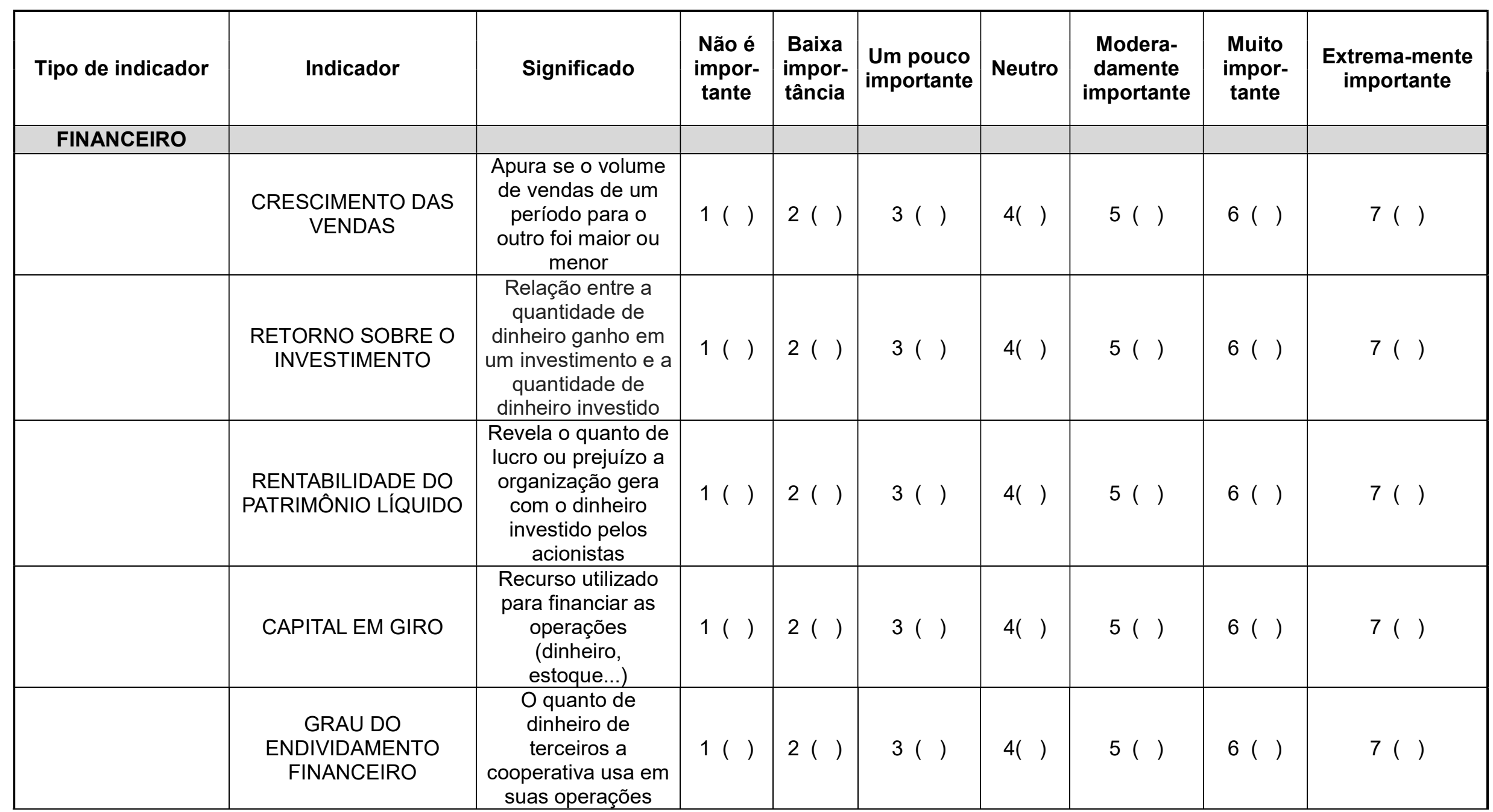




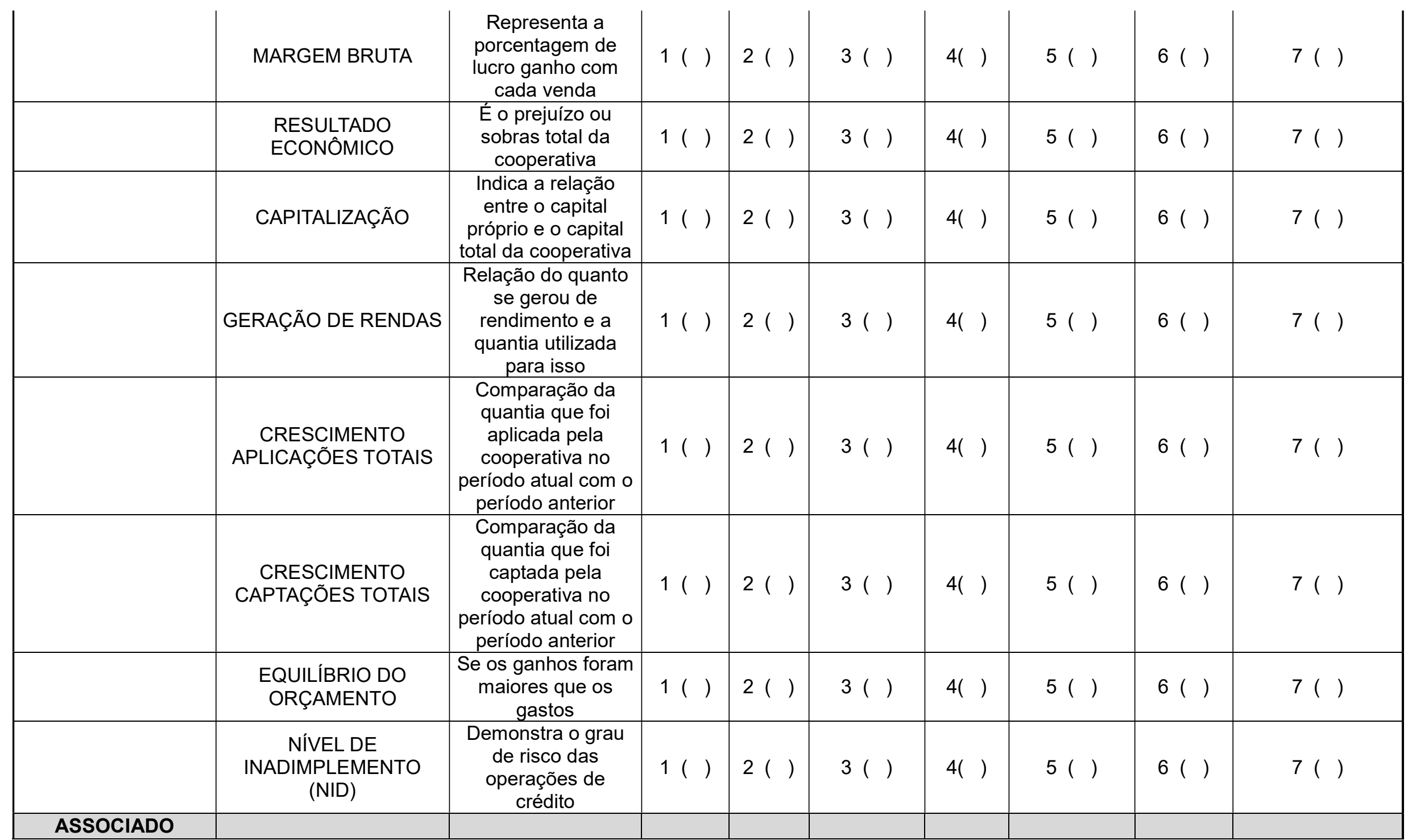




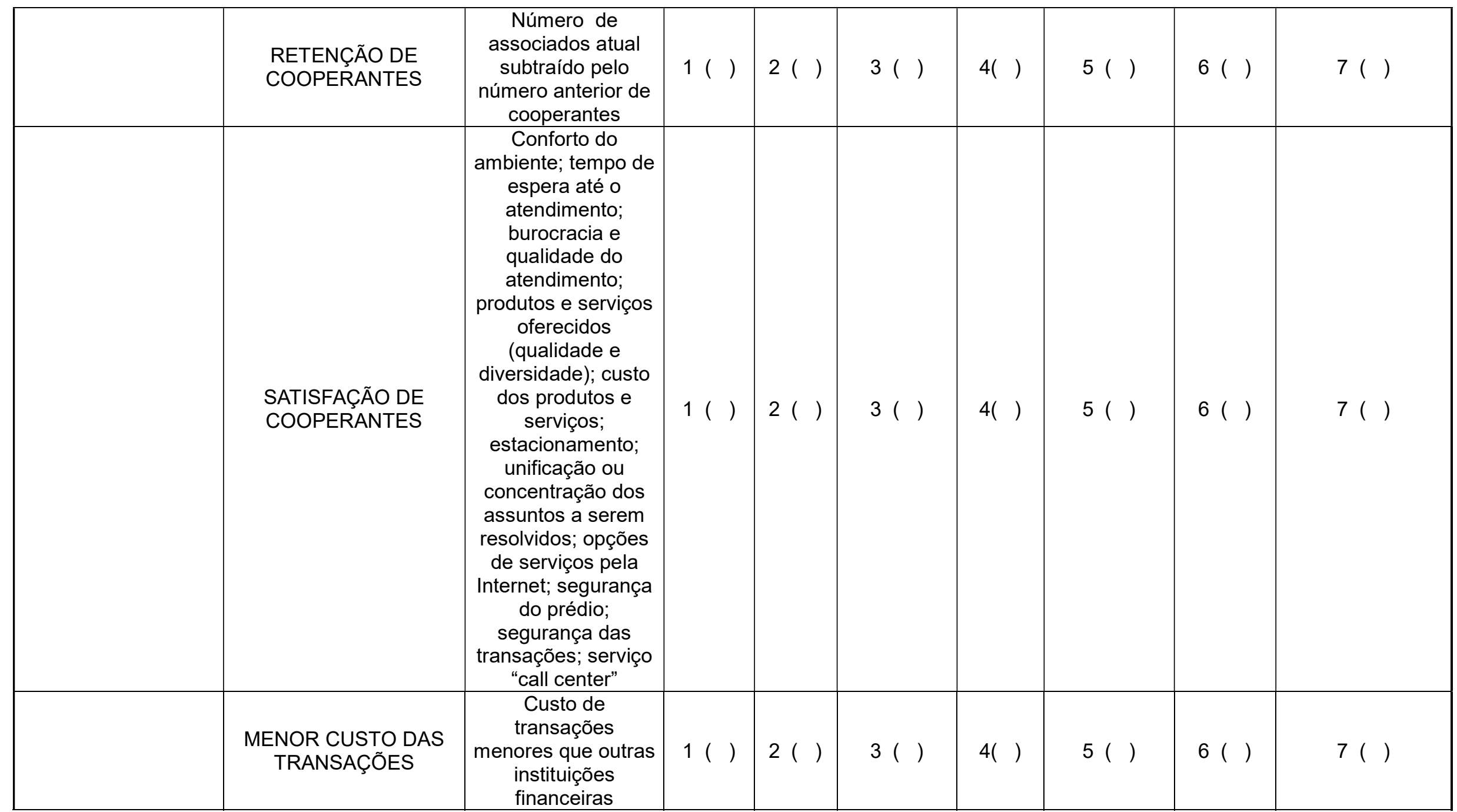




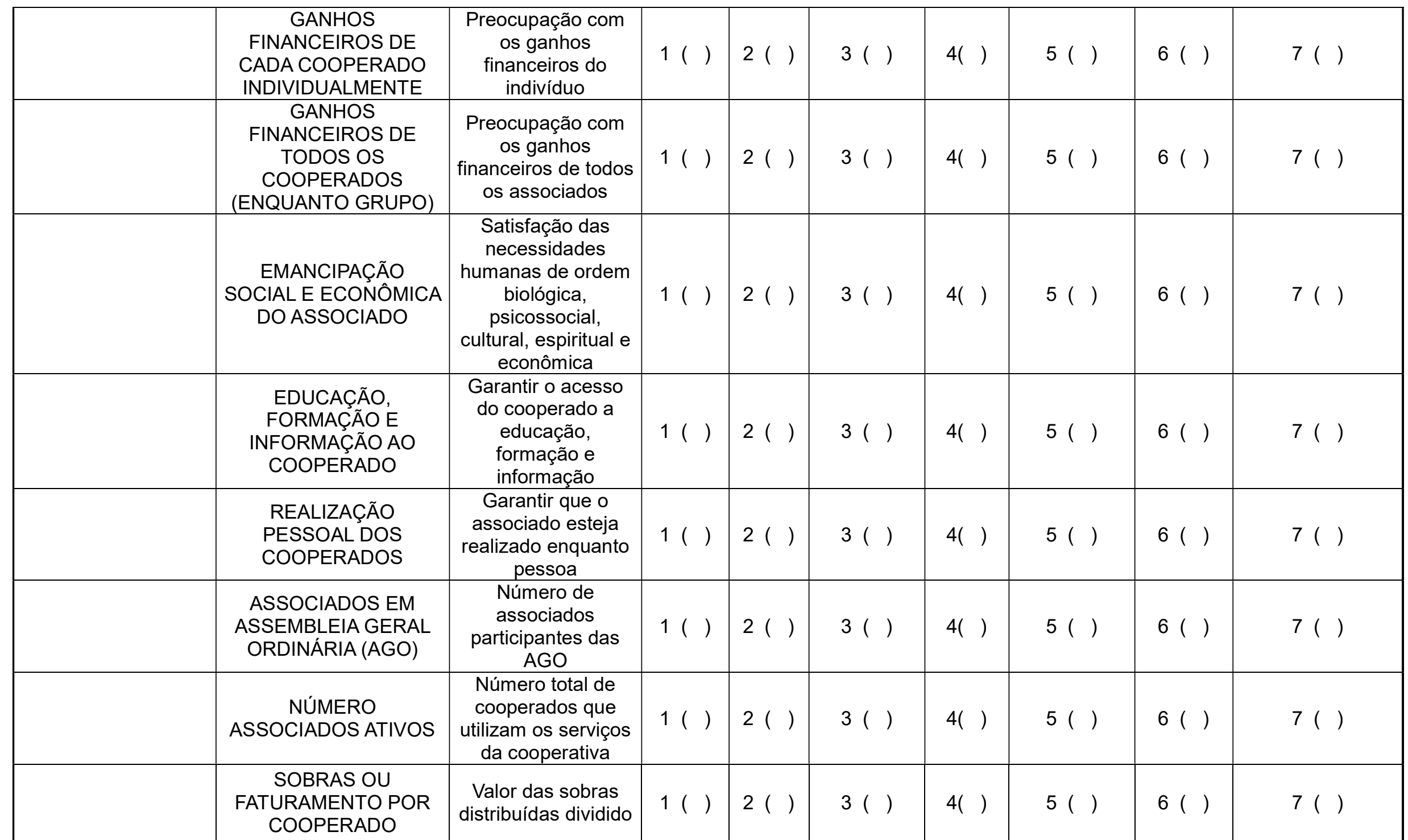




\begin{tabular}{|c|c|c|c|c|c|c|c|c|c|}
\hline & & $\begin{array}{l}\text { pelo número de } \\
\text { associados }\end{array}$ & & & & & & & \\
\hline & $\begin{array}{c}\text { RELEVÂNCIA DO } \\
\text { ASSOCIADO NA } \\
\text { TOMADA DE DECISÃO }\end{array}$ & $\begin{array}{c}\text { As opiniões dos } \\
\text { cooperados são } \\
\text { discutidas e } \\
\text { consideradas } \\
\text { quando apropriadas }\end{array}$ & 1() & 2() & 3() & $4(\quad)$ & 5() & 6() & 7() \\
\hline \multicolumn{10}{|l|}{$\begin{array}{l}\text { PROCESSOS } \\
\text { INTERNOS }\end{array}$} \\
\hline & $\begin{array}{c}\text { PERCENTUAL DE } \\
\text { TRANSAÇÕES } \\
\text { REALIZADAS ATRAVÉS } \\
\text { DOS DIVERSOS } \\
\text { CANAIS }\end{array}$ & $\begin{array}{l}\text { Percentual de } \\
\text { transações } \\
\text { realizadas de } \\
\text { caixas eletrônicos, } \\
\text { caixas } \\
\text { convencionais, ou } \\
\text { auxiliadas por } \\
\text { computador }\end{array}$ & 1() & 2() & 3() & $4(\quad)$ & 5() & 6() & 7() \\
\hline & $\begin{array}{l}\text { PERCENTUAL DE } \\
\text { TRABALHO } \\
\text { EXTRAORDINÁRIO }\end{array}$ & $\begin{array}{l}\text { Quantidade de } \\
\text { horas extras } \\
\text { realizadas }\end{array}$ & 1() & 2() & 3() & $4(\quad)$ & 5() & 6() & 7() \\
\hline & $\begin{array}{l}\text { DESENVOLVIMENTO } \\
\text { SUSTENTÁVEL }\end{array}$ & $\begin{array}{c}\text { Atenção ao capital } \\
\text { humano envolvido, } \\
\text { à sustentabilidade } \\
\text { econômica do } \\
\text { negócio e }\end{array}$ & 1() & 2() & 3() & $4(\quad)$ & 5() & 6() & 7() \\
\hline
\end{tabular}




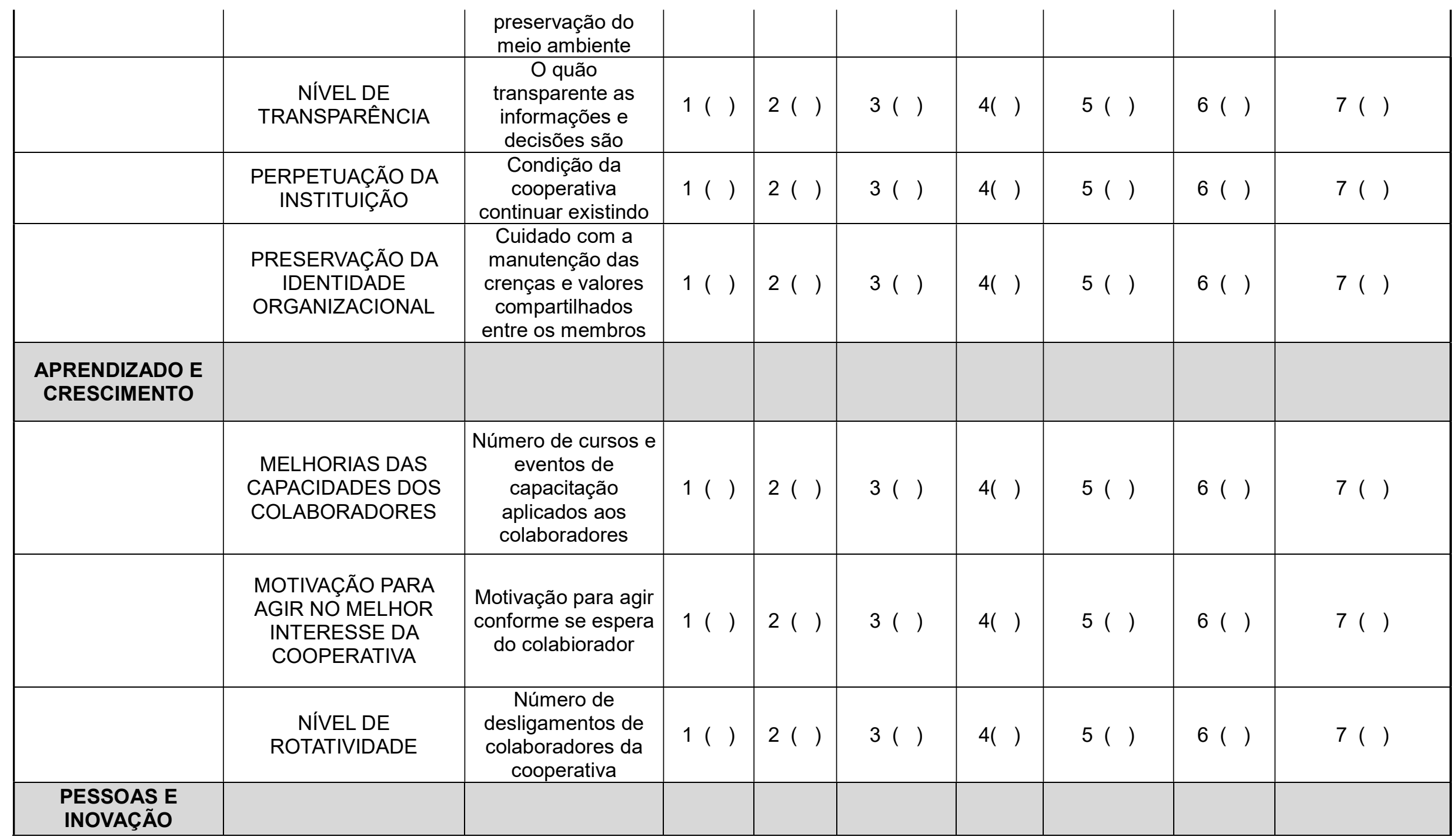




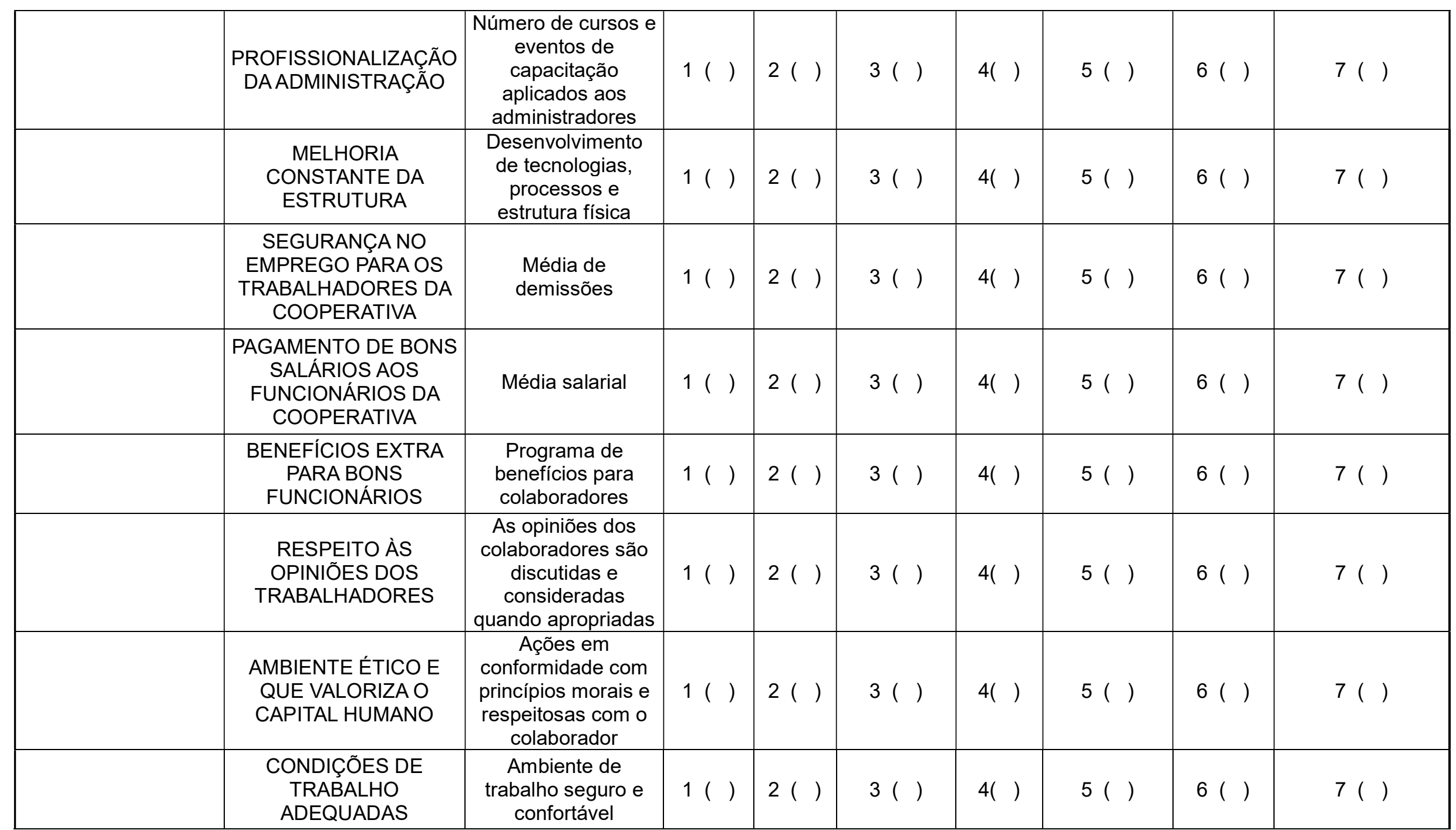




\begin{tabular}{|c|c|c|c|c|c|c|c|c|c|}
\hline \multicolumn{10}{|l|}{$\begin{array}{c}\text { PRINCÍPIOS } \\
\text { COOPERATIVISTAS }\end{array}$} \\
\hline & $\begin{array}{l}\text { CUMPRE PRINCÍPIOS } \\
\text { COOPERATIVISTAS }\end{array}$ & $\begin{array}{l}\text { Respeita os princípios } \\
\text { cooperativistas }\end{array}$ & 1() & 2() & 3() & 4() & 5() & 6() & 7() \\
\hline & SOLIDARIEDADE & $\begin{array}{l}\text { Compromisso pelo } \\
\text { qual as pessoas se } \\
\text { obrigam umas às } \\
\text { outras e cada uma } \\
\text { delas a todas. }\end{array}$ & 1() & 2() & 3() & 4() & 5() & 6() & 7() \\
\hline & $\begin{array}{c}\text { VALORES DE AJUDA } \\
\text { MÚTUA }\end{array}$ & $\begin{array}{l}\text { Preocupação com o } \\
\text { semelhante }\end{array}$ & 1() & 2() & 3() & 4() & 5() & 6() & 7() \\
\hline & $\begin{array}{l}\text { AUTONOMIA E } \\
\text { INDEPENDÊNCIA }\end{array}$ & $\begin{array}{l}\text { Preocupação com a } \\
\text { autonomia e } \\
\text { independência do } \\
\text { associado }\end{array}$ & 1() & 2() & 3() & 4() & 5() & 6() & 7() \\
\hline & $\begin{array}{l}\text { GERAÇÃO DE } \\
\text { EMPREGOS }\end{array}$ & $\begin{array}{l}\text { Número de empregos } \\
\text { gerados }\end{array}$ & $1($ ) & 2() & 3() & 4() & 5() & 6() & 7() \\
\hline & $\begin{array}{l}\text { COMBATE A EXCLUSÃO } \\
\text { SOCIAL }\end{array}$ & $\begin{array}{c}\text { Medidas que } \\
\text { proporcionem a } \\
\text { equidade social e a } \\
\text { diminuição da } \\
\text { pobreza }\end{array}$ & 1() & 2() & 3() & 4() & 5() & 6() & 7() \\
\hline
\end{tabular}




\section{APÊNDICE 5 - QUESTIONÁRIO MEMBROS DOS CONSELHOS ADMINISTRATIVO E FISCAL}

Esse questionário faz parte da coleta de dados da Tese de Doutorado de Elizabeth Moçato Pimentel, da Universidade de São Paulo (USP), e pretende conhecer qual o grau de importância os Conselhos Fiscal e Administrativo de cooperativas de crédito atribuem para determinados indicadores de desempenho.

"Indicadores de desempenho são medidas usadas para acompanhar, controlar e comunicar os resultados de atividades da cooperativa".

A seguir temos algumas perguntas a respeito do seu perfil. E após, uma lista de indicadores de desempenho de cooperativas de crédito. Traçando o perfil do membro do conselho:

1- A qual conselho pertence:
( ) Fiscal
( ) Administrativo

2- Sua idade:

3- Escolaridade:

( ) MESTRADO OU DOUTORADO
( ) ENSINO FUNDAMENTAL (1० GRAU) INCOMPLETO
( ) ENSINO FUNDAMENTAL (1 ${ }^{\circ} \mathrm{GRAU}$ ) COMPLETO
( ) ENSINO MÉDIO (2० GRAU) INCOMPLETO
( ) ENSINO MÉDIO (2० GRAU) COMPLETO
( ) SUPERIOR INCOMPLETO
( ) SUPERIOR COMPLETO
( ) ESPECIALIZAÇÃO 
4- Participa desse Conselho a quantos mandatos:

5- Vejo que o Conselho que participo tem como principal objetivo assegurar que:

Considerando sua visão, qual o grau de importância você daria para cada um dos indicadores abaixo, se você precisasse avaliar o desempenho de uma cooperativa de crédito.

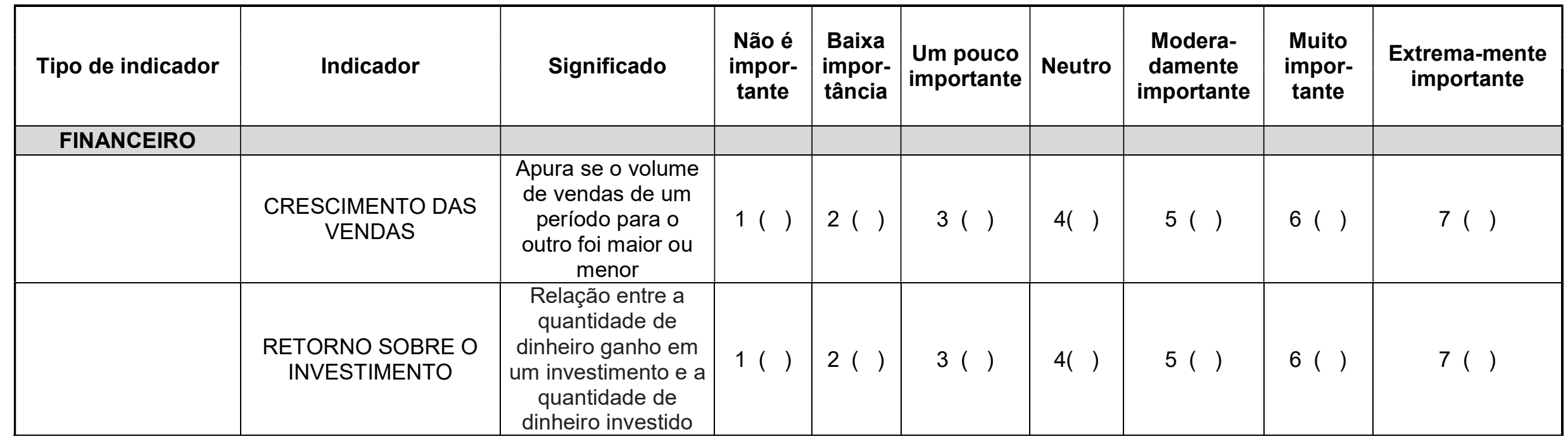




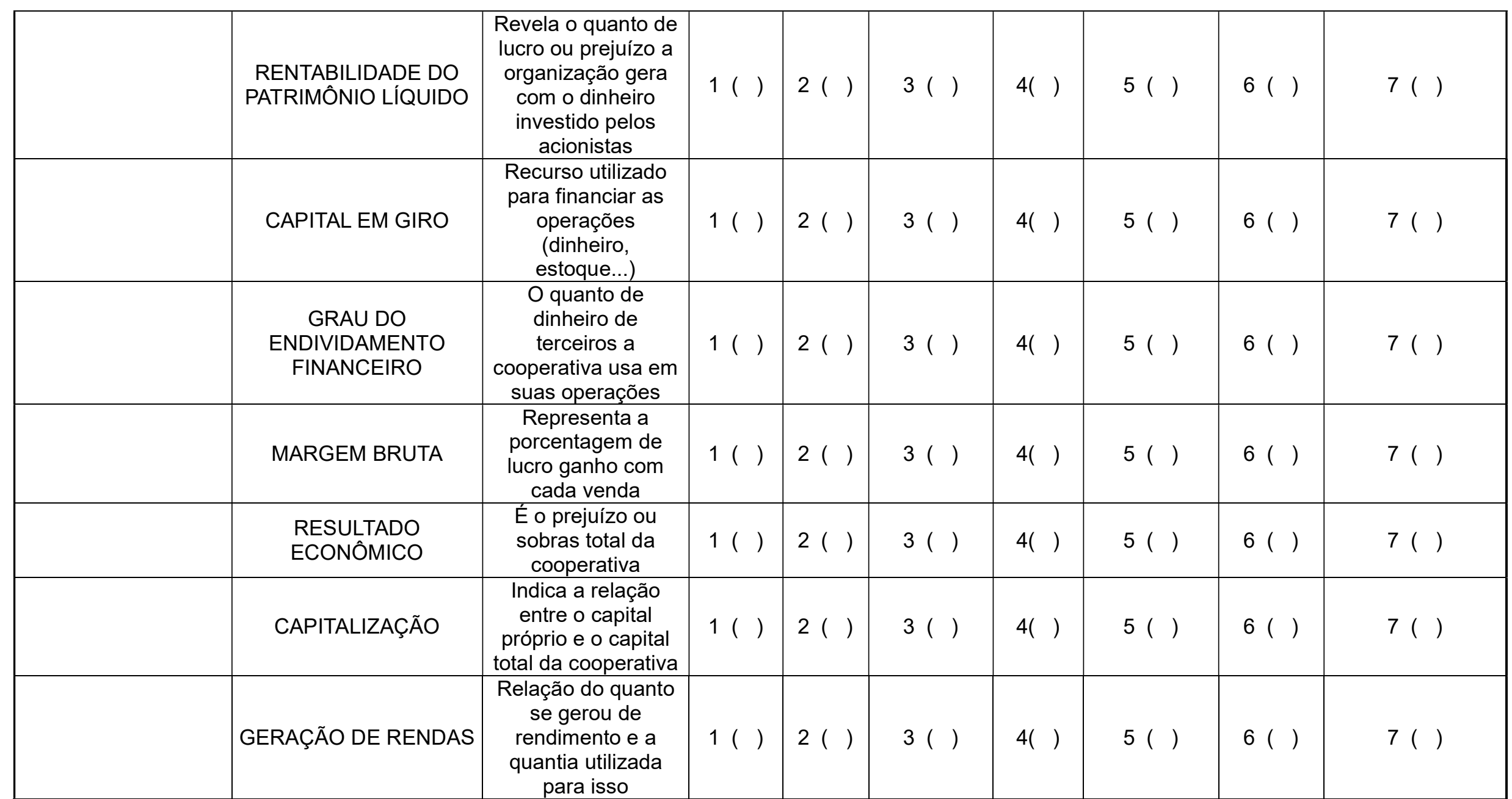




\begin{tabular}{|c|c|c|c|c|c|c|c|c|c|}
\hline & $\begin{array}{c}\text { CRESCIMENTO } \\
\text { APLICAÇÕES TOTAIS }\end{array}$ & $\begin{array}{c}\text { Comparação da } \\
\text { quantia que foi } \\
\text { aplicada pela } \\
\text { cooperativa no } \\
\text { período atual com o } \\
\text { período anterior }\end{array}$ & 1() & 2() & 3() & $4(\quad)$ & 5() & 6() & 7() \\
\hline & $\begin{array}{c}\text { CRESCIMENTO } \\
\text { CAPTAÇÕES TOTAIS }\end{array}$ & $\begin{array}{l}\text { Comparação da } \\
\text { quantia que foi } \\
\text { captada pela } \\
\text { cooperativa no } \\
\text { período atual com o } \\
\text { período anterior }\end{array}$ & 1() & 2() & 3() & $4(\quad)$ & 5() & 6() & 7() \\
\hline & $\begin{array}{l}\text { EQUILÍBRIO DO } \\
\text { ORÇAMENTO }\end{array}$ & $\begin{array}{l}\text { Se os ganhos foram } \\
\text { maiores que os } \\
\text { gastos }\end{array}$ & 1() & 2() & 3() & $4(\quad)$ & 5() & 6() & 7() \\
\hline & $\begin{array}{c}\text { NÍVEL DE } \\
\text { INADIMPLEMENTO } \\
\text { (NID) }\end{array}$ & $\begin{array}{l}\text { Demonstra o grau } \\
\text { de risco das } \\
\text { operações de } \\
\text { crédito } \\
\end{array}$ & 1() & 2() & 3() & $4(\quad)$ & 5() & 6() & 7() \\
\hline \multicolumn{10}{|l|}{ ASSOCIADO } \\
\hline
\end{tabular}




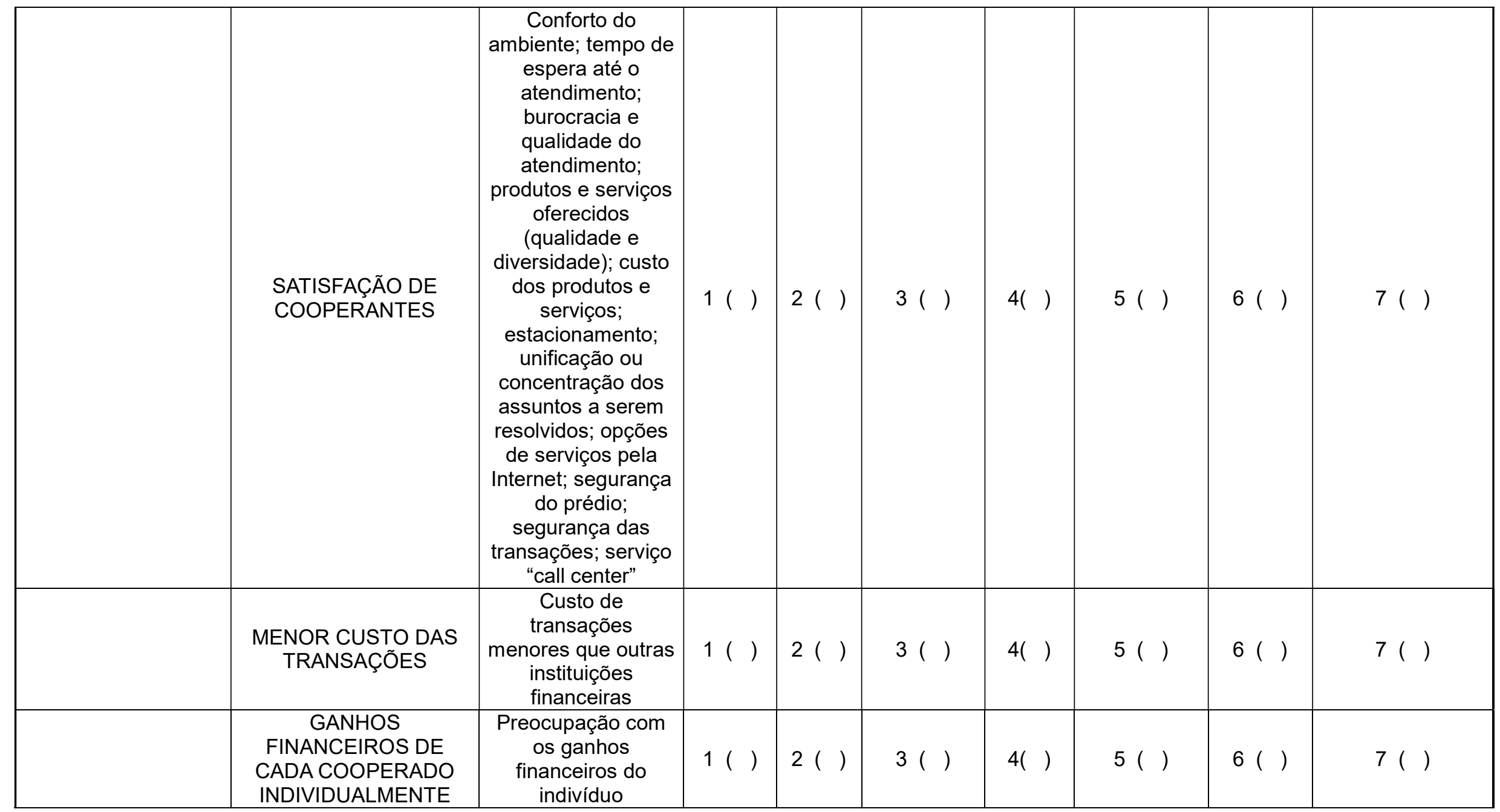




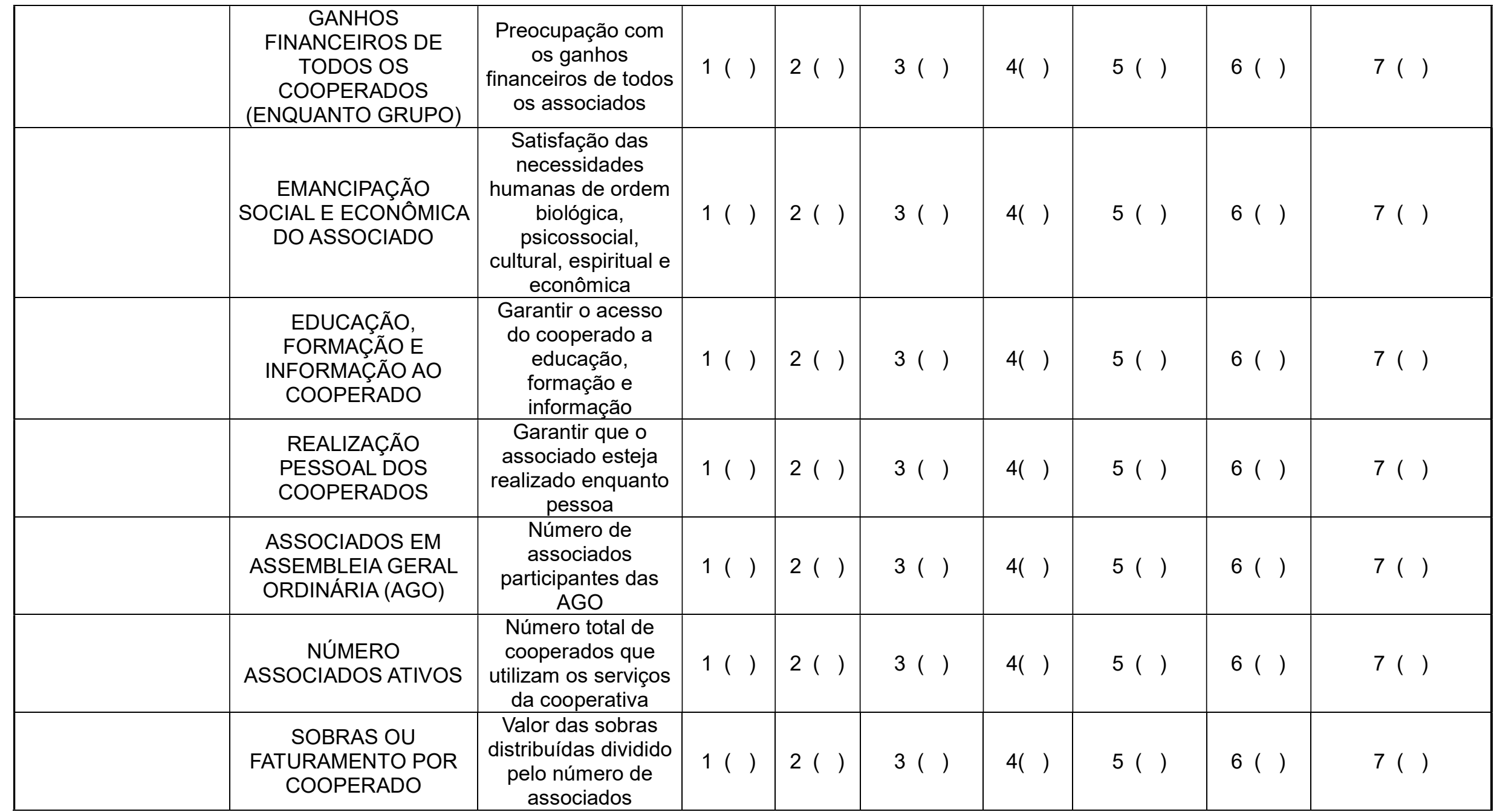




\begin{tabular}{|c|c|c|c|c|c|c|c|c|c|}
\hline & $\begin{array}{c}\text { RELEVÂNCIA DO } \\
\text { ASSOCIADO NA } \\
\text { TOMADA DE DECISÃO }\end{array}$ & $\begin{array}{l}\text { As opiniões dos } \\
\text { cooperados são } \\
\text { discutidas e } \\
\text { consideradas } \\
\text { quando apropriadas }\end{array}$ & 1() & 2() & 3() & $4(\quad)$ & $5(）$ & 6() & 7() \\
\hline \multicolumn{10}{|l|}{$\begin{array}{l}\text { PROCESSOS } \\
\text { INTERNOS }\end{array}$} \\
\hline & $\begin{array}{l}\text { LUCRATIVIDADE POR } \\
\text { SEGMENTO-ALVO }\end{array}$ & $\begin{array}{l}\text { Percentual de } \\
\text { sobras de cada } \\
\text { segmento de } \\
\text { serviço oferecido } \\
\text { pela cooperativa }\end{array}$ & 1() & 2() & 3() & $4(\quad)$ & 5() & 6() & 7() \\
\hline & $\begin{array}{c}\text { PERCENTUAL DE } \\
\text { TRANSAÇÕES } \\
\text { REALIZADAS ATRAVÉS } \\
\text { DOS DIVERSOS } \\
\text { CANAIS }\end{array}$ & $\begin{array}{c}\text { Percentual de } \\
\text { transações } \\
\text { realizadas de } \\
\text { caixas eletrônicos, } \\
\text { caixas } \\
\text { convencionais, ou } \\
\text { auxiliadas por } \\
\text { computador }\end{array}$ & 1() & 2() & 3() & $4(\quad)$ & $5(）$ & 6() & 7() \\
\hline & $\begin{array}{l}\text { PROJETOS SOCIAIS } \\
\text { DESENVOLVIDOS }\end{array}$ & $\begin{array}{c}\text { Número de projetos } \\
\text { sociais } \\
\text { desenvolvidos }\end{array}$ & 1() & 2() & 3() & $4(\quad)$ & 5() & 6() & 7() \\
\hline & $\begin{array}{l}\text { PERCENTUAL DE } \\
\text { TRABALHO } \\
\text { EXTRAORDINÁRIO }\end{array}$ & $\begin{array}{c}\text { Quantidade de } \\
\text { horas extras } \\
\text { realizadas }\end{array}$ & 1() & 2() & 3() & $4(\quad)$ & 5() & 6() & $7($ ) \\
\hline & $\begin{array}{l}\text { DESENVOLVIMENTO } \\
\text { SUSTENTÁVEL }\end{array}$ & $\begin{array}{l}\text { Atenção ao capital } \\
\text { humano envolvido, } \\
\text { à sustentabilidade } \\
\text { econômica do } \\
\text { negócio e } \\
\text { preservação do } \\
\text { meio ambiente }\end{array}$ & 1() & 2() & 3() & $4(\quad)$ & 5() & 6() & $7($ ) \\
\hline
\end{tabular}




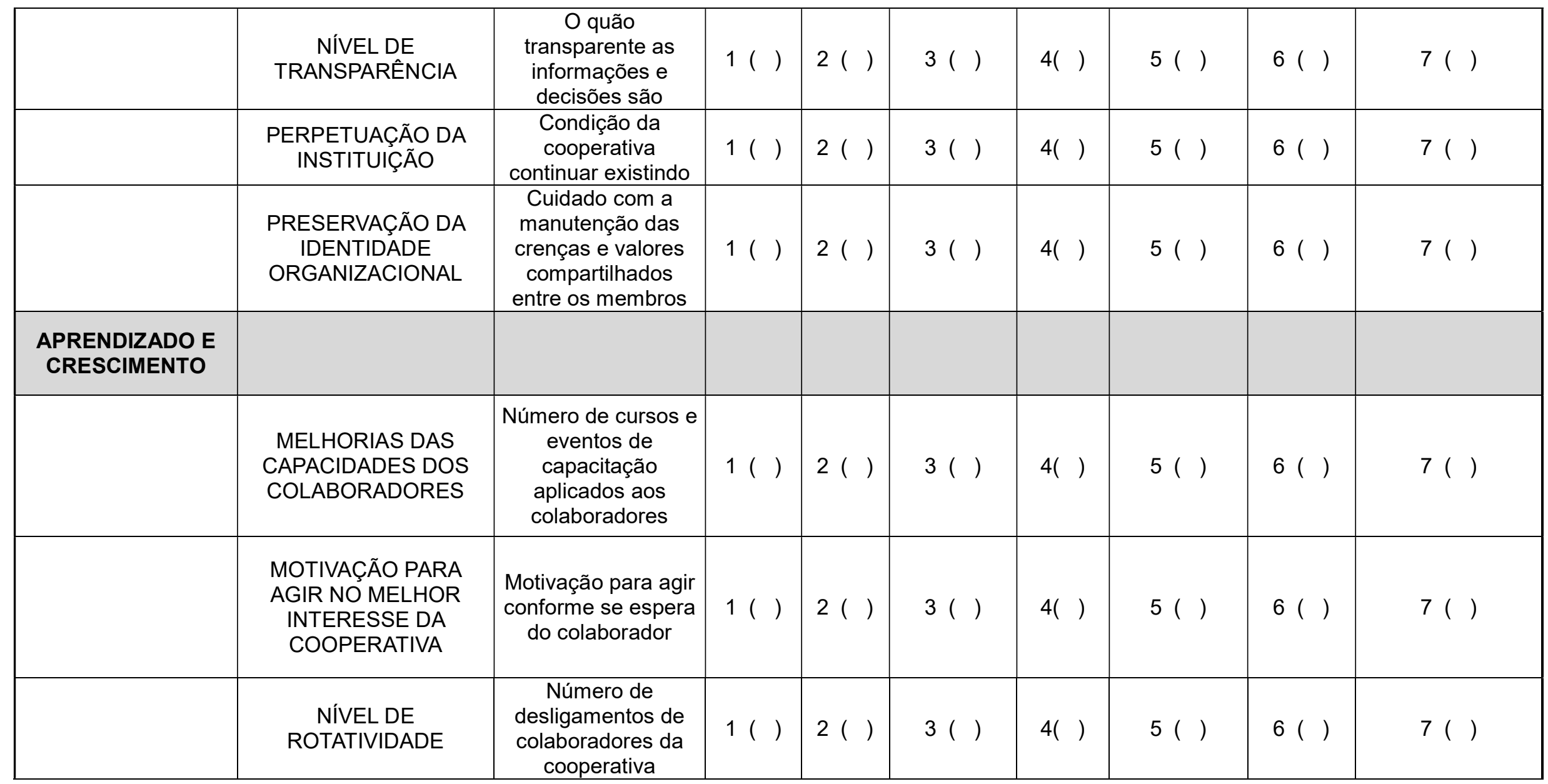




\begin{tabular}{|c|c|c|c|c|c|c|c|c|c|}
\hline $\begin{array}{l}\text { PESSOAS E } \\
\text { INOVAÇÃO }\end{array}$ & & & & & & & & & \\
\hline & $\begin{array}{c}\text { MELHORIA CONSTANTE } \\
\text { DA ESTRUTURA }\end{array}$ & $\begin{array}{c}\text { Desenvolvimento de } \\
\text { tecnologias, } \\
\text { processos e estrutura } \\
\text { física } \\
\end{array}$ & $1($ ) & 2() & 3() & 4() & 5() & 6() & 7() \\
\hline & $\begin{array}{l}\text { PAGAMENTO DE BONS } \\
\text { SALÁRIOS AOS } \\
\text { FUNCIONÁRIOS DA } \\
\text { COOPERATIVA }\end{array}$ & Média salarial & $1($ ) & 2() & 3( & $4(\quad)$ & 5() & 6() & 7() \\
\hline & $\begin{array}{c}\text { AMBIENTE ÉTICO E QUE } \\
\text { VALORIZA O CAPITAL } \\
\text { HUMANO }\end{array}$ & $\begin{array}{c}\text { Ações em } \\
\text { conformidade com } \\
\text { princípios morais e } \\
\text { respeitosas com o } \\
\text { colaborador } \\
\end{array}$ & $1($ ) & 2() & 3() & 4() & 5() & $6($ ) & 7() \\
\hline & $\begin{array}{c}\text { CONDIÇÕES DE } \\
\text { TRABALHO ADEQUADAS }\end{array}$ & $\begin{array}{l}\text { Ambiente de trabalho } \\
\text { seguro e confortável }\end{array}$ & $1($ ) & 2() & 3() & 4() & 5() & 6() & 7() \\
\hline
\end{tabular}




\begin{tabular}{|c|c|c|c|c|c|c|c|c|c|}
\hline $\begin{array}{c}\text { PRINCíPIOS } \\
\text { COOPERATIVISTAS }\end{array}$ & & & & & & & & & \\
\hline & $\begin{array}{c}\text { CUMPRE PRINCÍPIOS } \\
\text { COOPERATIVISTAS }\end{array}$ & $\begin{array}{c}\text { Respeita os princípios } \\
\text { cooperativistas }\end{array}$ & $1($ ) & 2() & 3() & 4() & $5($ ) & 6() & 7() \\
\hline & $\begin{array}{l}\text { DEMOCRACIAE } \\
\text { IGUALDADE }\end{array}$ & $\begin{array}{l}\text { Direito a voto de } \\
\text { mesmo peso para } \\
\text { todos os cooperados }\end{array}$ & $1($ ) & 2() & 3() & 4() & $5($ ) & 6() & 7() \\
\hline & SOLIDARIEDADE & $\begin{array}{l}\text { Compromisso pelo } \\
\text { qual as pessoas se } \\
\text { obrigam umas às } \\
\text { outras e cada uma } \\
\text { delas a todas. } \\
\end{array}$ & $1($ ) & 2() & 3() & $4(\quad)$ & $5($ ) & 6() & 7() \\
\hline & $\begin{array}{l}\text { VALORES DE AJUDA } \\
\text { MÚTUA }\end{array}$ & $\begin{array}{l}\text { Preocupação com o } \\
\text { semelhante }\end{array}$ & $1($ ) & 2() & 3() & 4() & $5($ ) & 6() & 7() \\
\hline & $\begin{array}{l}\text { AUTONOMIA E } \\
\text { INDEPENDÊNCIA }\end{array}$ & $\begin{array}{l}\text { Preocupação com a } \\
\text { autonomia e } \\
\text { independência do } \\
\text { associado }\end{array}$ & $1($ ) & 2() & 3() & 4() & $5($ ) & 6() & 7() \\
\hline & $\begin{array}{l}\text { GERAÇÃO DE } \\
\text { EMPREGOS }\end{array}$ & $\begin{array}{l}\text { Número de empregos } \\
\text { gerados }\end{array}$ & $1($ ) & 2() & 3() & 4() & $5($ ) & 6() & 7() \\
\hline & $\begin{array}{c}\text { COMBATE A EXCLUSÃO } \\
\text { SOCIAL }\end{array}$ & $\begin{array}{c}\text { Medidas que } \\
\text { proporcionem a } \\
\text { equidade social e a } \\
\text { diminuição da } \\
\text { pobreza }\end{array}$ & $1($ ) & 2() & 3() & 4() & $5($ ) & 6() & 7() \\
\hline
\end{tabular}




\section{APÊNDICE 6 - INSTRUMENTO SEMI-ESTRUTURADO DE COLETA DE DADOS VIA ENTREVISTA COM COOPERATIVA SINGULAR}

1. Qual seu cargo na cooperativa e qual a responsabilidade dele?

2. Como é feito o processo de avaliação de desempenho da cooperativa? Existe um modelo de avaliação?

3. Quais os indicadores são considerados?

4. Quem estipulou os indicadores a serem avaliados?

5. De que forma o cooperado, os gerentes e os conselheiros participam do processo de avaliação de desempenho da cooperativa? Eles ajudaram a escolher os indicadores que são considerados importantes para a avaliação do desempenho?

6. Quem é a equipe responsável por esse processo?

7. Os princípios cooperativistas são considerados nosso processo de avaliação de desempenho?

8. É estipulado peso para cada módulo e indicador?

9. Outras cooperativas singulares do sistema também avaliam desempenho assim? Ou cada uma tem seu próprio sistema de avaliação? 
APÊNDICE 7 - COEFICIENTE ALFA DE CRONBACH GERAL DO INSTRUMENTO

\begin{tabular}{rrrr}
\hline Alfa de Cronbach & base em itens padronizados & N de itens \\
\hline, 962 &, 961 & 53 \\
\hline
\end{tabular}

\begin{tabular}{|c|c|c|}
\hline & $\begin{array}{l}\text { Correlação de } \\
\text { item total } \\
\text { corrigida }\end{array}$ & $\begin{array}{c}\text { Alfa de } \\
\text { Cronbach se o } \\
\text { item for excluído }\end{array}$ \\
\hline (Fin1) Crescimento das vendas & ,490 & 961 \\
\hline (Fin2) Retorno sobre o investimento & ,315 & ,962 \\
\hline (Fin3) Rentabilidade do patrimônio líquido & 429 & ,962 \\
\hline (Fin4) Capital em giro &, 521 & ,961 \\
\hline (Fin5) Grau do endividamento financeiro &, 588 & ,961 \\
\hline (Fin6) Margem bruta & ,562 & ,961 \\
\hline (Fin7) Resultado econômico & ,537 & ,961 \\
\hline (Fin8) Capitalização & 618 & ,961 \\
\hline (Fin9) Geração de rendas & ,589 & ,961 \\
\hline (Fin10) Crescimento aplicações totais & ,628 & ,961 \\
\hline (Fin11) Crescimento captações totais & 666 & 961 \\
\hline (Fin12) Equilíbrio do orçamento & ,507 & 961 \\
\hline (Fin13) Nível de inadimplemento (NID) & ,546 & 961 \\
\hline (Ass1) Retenção de cooperantes & 624 & 961 \\
\hline (Ass2) Satisfação de cooperantes &, 550 & ,961 \\
\hline (Ass3) Menor custo das transações & 227 & 962 \\
\hline (Ass4) Ganhos financeiros de cada cooperado individualmente & ,279 & ,962 \\
\hline $\begin{array}{l}\text { (Ass5) Ganhos financeiros de todos os cooperados (enquanto } \\
\text { grupo) }\end{array}$ & ,491 & ,961 \\
\hline (Ass6) Emancipação social e econômica do associado & ,585 & 961 \\
\hline (Ass7) Educação, formação e informação ao cooperado & 476 & 961 \\
\hline (Ass8) Realização pessoal dos cooperados & ,517 & 961 \\
\hline (Ass9) Associados em assembleia geral ordinária (AGO) & ,718 & ,960 \\
\hline (Ass10) Número associados ativos & 677 & ,961 \\
\hline (Ass11) Sobras ou faturamento por cooperado & ,559 & 961 \\
\hline (Ass12) Relevância do associado na tomada de decisão & ,644 & ,961 \\
\hline (Pro1) Lucratividade por segmento-alvo &, 597 & ,961 \\
\hline $\begin{array}{l}\text { (Pro2) Percentual de transações realizadas através dos diversos } \\
\text { canais }\end{array}$ & ,625 & 961 \\
\hline (Pro3) Projetos sociais desenvolvidos & ,712 & 960 \\
\hline (Pro4) Percentual de trabalho extraordinário & 616 & 961 \\
\hline (Pro5) Desenvolvimento sustentável & ,715 & ,960 \\
\hline (Pro6) Nível de Transparência & 431 & ,962 \\
\hline (Pro7) Perpetuação da instituição & ,592 & 961 \\
\hline (Pro8) Preservação da identidade organizacional & ,613 & ,961 \\
\hline (Apr1) Melhorias das capacidades dos funcionários & ,695 & ,961 \\
\hline (Apr2) Nível de rotatividade & ,597 & 961 \\
\hline (Apr3) Motivação para agir no melhor interesse da cooperativa & 436 & 962 \\
\hline (Pes1) Profissionalização da administração & 485 & 961 \\
\hline (Pes2) Melhoria constante da estrutura da cooperativa & 418 & 962 \\
\hline $\begin{array}{l}\text { (Pes3) Segurança no emprego para os trabalhadores da } \\
\text { cooperativa }\end{array}$ &, 503 & ,961 \\
\hline $\begin{array}{l}\text { (Pes4) Pagamento de bons salários aos funcionários da } \\
\text { cooperativa }\end{array}$ & ,513 & ,961 \\
\hline (Pes5) Benefícios extras para bons funcionários & ,326 & ,962 \\
\hline
\end{tabular}


(Pes6) Respeito as opiniões dos trabalhadores $\quad$,546 ,961

(Pes7) Ambiente de trabalho ético e que valoriza o capital ,961

humano

(Pes8) Condições de trabalho adequadas $\quad$,454 ,961

(Pri1) Cumpre princípios cooperativistas $\quad, 710 \quad 960$

$\begin{array}{lll}\text { (Pri2) Democracia e igualdade } & , 652 \quad, 961\end{array}$

(Pri3) Solidariedade $\quad$,693 ,961

(Pri4) Valores de ajuda mútua (preocupação com o semelhante) , 961

(Pri5) Autonomia e a independência $\quad, 560 \quad, 961$

(Pri6) Adesão livre e voluntária $\quad$,556 , 961

(Pri7) Preocupação com a comunidade $\quad, 667 \quad, 961$

(Pri8) Geração de empregos $\quad$,553 ,961

\begin{tabular}{lrr} 
(Pri9) Combate a exclusão social &, 589 &, 961 \\
\hline
\end{tabular} 